\title{
Final Report of Comprehensive Testing Program for Concrete at Elevated Temperatures
}

\author{
C. B. Oland \\ D. J. Naus
}

G. C. Robinson

\section{MASTER}

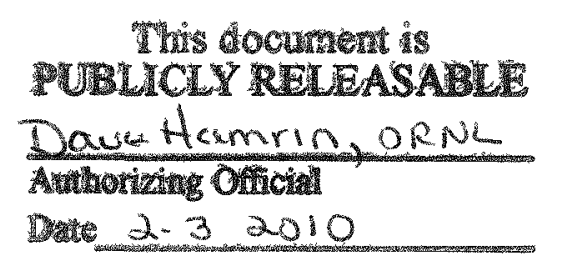

\section{DPERATED BY}

UNION CABBDE CORPOBATION FOR THE UUTEO STATES DEPATTMENT OF ENERGY 
Printed in the United States of America. Available from the Department of Energy

Technical Information Center

P.O. Box 62, Oak Ridge, Tennessee 37830

Thrs report was prepared as an account of work sponsored by an agency of the Unted States Government. Nether the United States Government nor any agency thereof, nor any of their employees, makes any warranty, express or implied, or assumes any legal hability or responsibility for the accuracy. completeness, or usefulness of any information, apparatus, product, or process disclosed, or represents that its use would not infrnge privaty owned rights. Reterence herein to any spectic commercial product, process, or senvice by trade name, trademark. manufacturer, or otherwise, does not necessarily constitute or imply its andorsement, recommendation, or favoring by the United States Goverment or any agency thereof. The views and opinons of authors axpressed heren do not necessarly state or reflect those of the Unted States coverment or any agency thereos 


\section{DISCLAIMER}

This report was prepared as an account of work sponsored by an agency of the United States Government. Neither the United States Government nor any agency Thereof, nor any of their employees, makes any warranty, express or implied, or assumes any legal liability or responsibility for the accuracy, completeness, or usefulness of any information, apparatus, product, or process disclosed, or represents that its use would not infringe privately owned rights. Reference herein to any specific commercial product, process, or service by trade name, trademark, manufacturer, or otherwise does not necessarily constitute or imply its endorsement, recommendation, or favoring by the United States Government or any agency thereof. The views and opinions of authors expressed herein do not necessarily state or reflect those of the United States Government or any agency thereof. 


\section{DISCLAIMER}

Portions of this document may be illegible in electronic image products. Images are produced from the best available original document. 
ORNL/BRP-80/5

lom ted-Distribution

Contract No. W-7405-eng-26

Engineering Technology Division

CLINCH RIVER BREEDER REACTOR PLANT PROJECT

(189a No. BHO12)

Milestone $\mathrm{G}-1$

FINAL REPORT OF COMPREHENSIVE TESTING PROGRAM

FOR CONCRETE AT ELEVATED TEMPERATURES

C. B. Oland D. J. Naus

G. C. Robinson

Date Published: October 1980

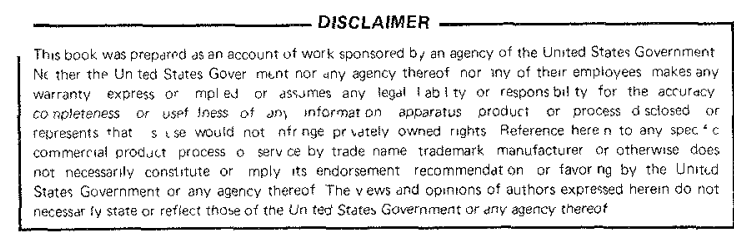

Prepared by the

OAK RIDGE NATIONAL LABORATORY

Oak Ridge, Tennessee 37830

operated by

UNION CARBIDE CORPORATION

for the

DEPARTMENT OF ENERGY

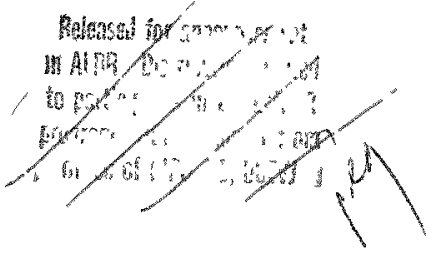


-

$\bullet$ 


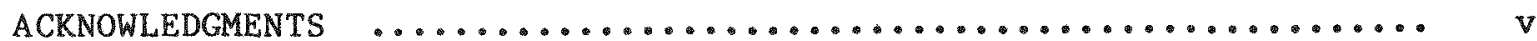

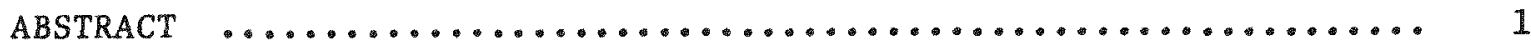

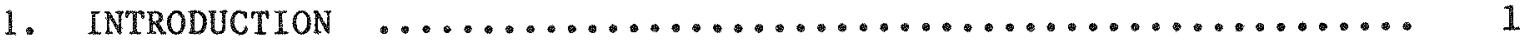

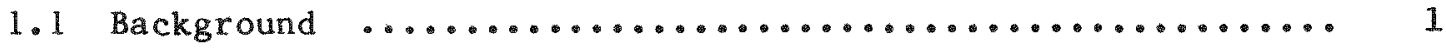

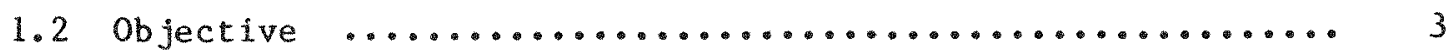

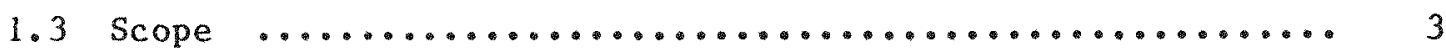

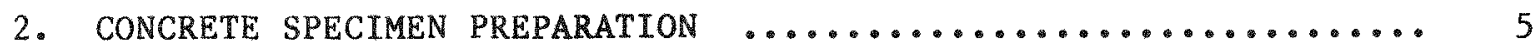

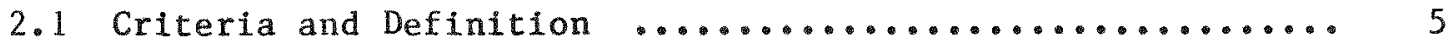

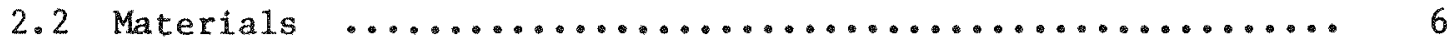

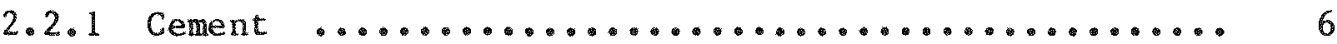

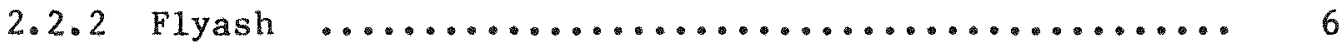

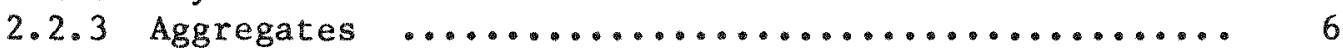

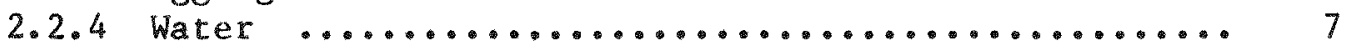

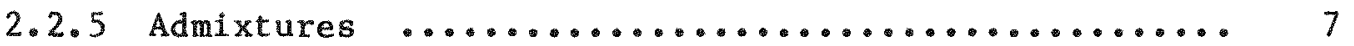

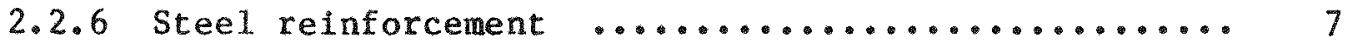

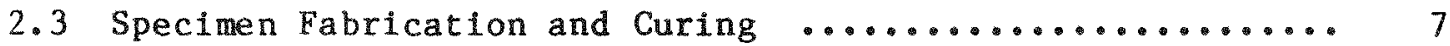

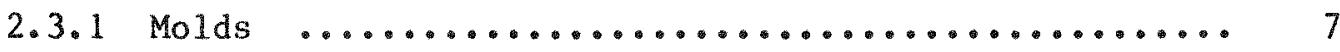

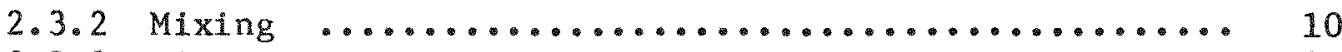

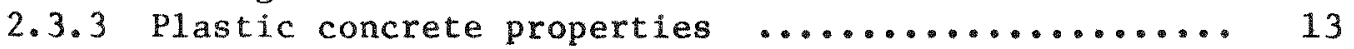

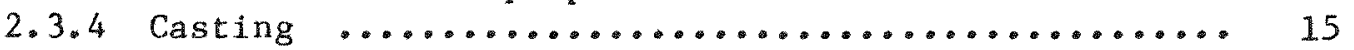

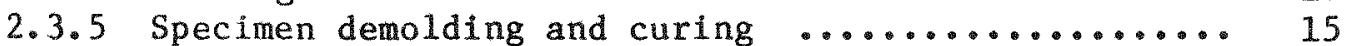

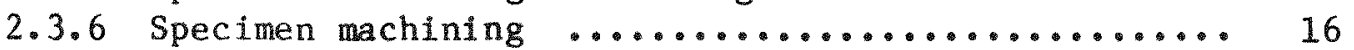

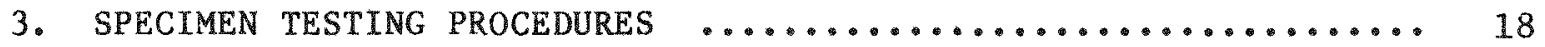

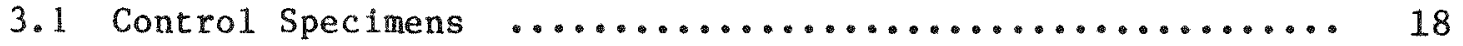

3.2 Unconfined Compression Test Specimens $\ldots . . . \ldots \ldots \ldots \ldots . . . . .20$

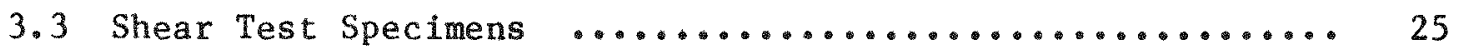

3.4 Bond Pull-out Test Specimens ..................... 29

3.5 Sustained Load Test Specimens ................... 36

4. SPECIMEN TEST RESULTS ........................... 42

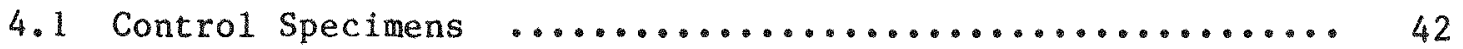

4.2 Unconfined Compression Test Specimens .............. 42

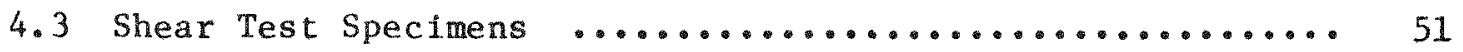

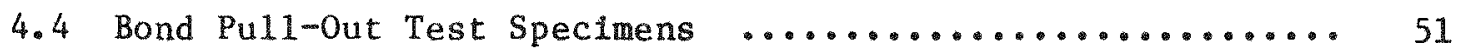

4.5 Sustained Load Test Specimens $\ldots . \ldots \ldots \ldots \ldots \ldots \ldots \ldots \ldots \ldots . \ldots \ldots$ 


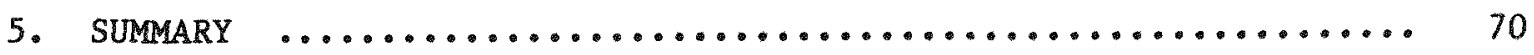

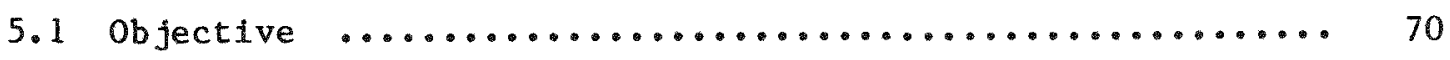

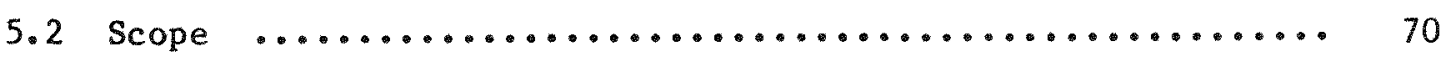

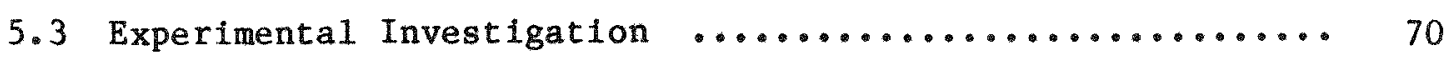

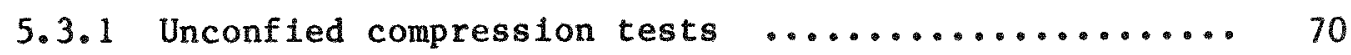

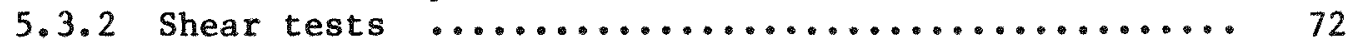

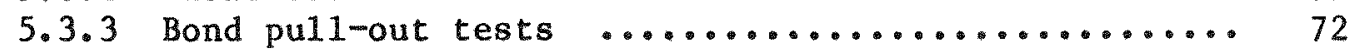

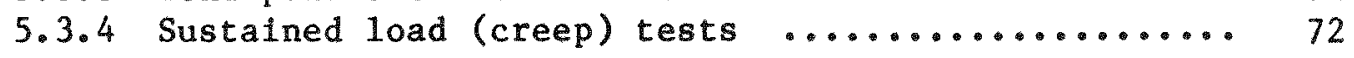

APPENDIX A. CONCRETE MIX DATA (BATCH NUMBERS 1 TO 21) ......... 75

APPENDIX B. CONTROL SPECIMEN UNCONFINED COMPRESSION STRESS-STRAIN

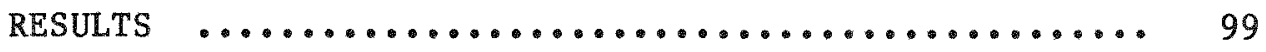

APPENDIX C. ELEVATED TEMPERATURE SPECIMEN'S TEMPERATURE HISTORY AND UNCONF INED COMPRESSION STRESSS-STRAIN RESULTS $\quad \ldots . .139$

APPENDIX D. SHEAR SPECIMEN'S TEMPERATURE HISTORY _............. 195

APPENDIX E. CONCRETE-REBAR BOND STRESS VERSUS SLIP DATA ........ 209

APPENDIX F. SUSTAINED LOAD SPECIMEN'S LOAD, STRAIN, AND TEMPERA-

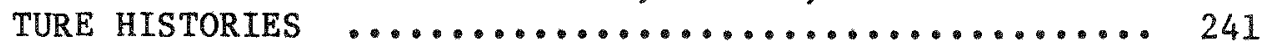




\section{ACKNOWLEDGMENTS}

The planning and execution of this investigation required the assistance and cooperation of numerous people at the $\mathrm{Y}-12$ Plant and the Solid Mechanics Section of the Engineering Technology Division of Oak Ridge National Laboratory. The authors are indebted to these people for their cooperation and concern for the success of the investigation. A note of appreciation is due T. M. Cate, J. R. Dougan, and J. P. Callahan who made substantial contributions during various phases of the program. A special

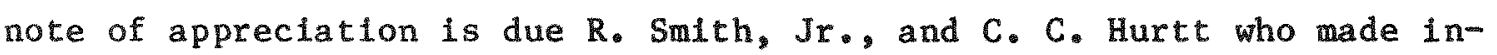
valuable contributions to the test program. 
FINAL REPORT OF COMPREHENSIVE TESTING PROGRAM FOR CONCRETE AT ELEVATED TEMPERATURES

\author{
C. B. Oland D. J. Naus \\ G. C. Robinson
}

\begin{abstract}
In a Liquid-Metal Fast Breeder Reactor (LMFBR), concrete temperatures in excess of normal code limits can result from postulated large sodium spills in lined, inert, and air-filled equipment cells. Elevated temperature concrete property data, which may provide a basis for the design and evaluation of such postulated accident conditions, are quite limited. Thus, data need to be developed, commensurate with LMFBR plant applications, for critical physical and mechanical concrete properties under prototypic thermal accident conditions.

The objective of this program was to define the variations in physical (thermal) and mechanical (strength) properties of limestone aggregate concrete and 11ghtweight insulating concrete exposed to elevated temperatures that could occur as a result of a postulated large sodium spill in a lined LMFBR equipment cel1. To meet this objective, five test series were conducted: (1) unconfined compression, (2) shear, (3) rebar bond, (4) sustained loading (creep), and (5) thermal properties. Mechanical property results are presented for concretes subjected to temperature up to $621^{\circ} \mathrm{C}\left(1150^{\circ} \mathrm{F}\right)$. Thermal property test results were conducted under a subcontract with the University of California at Berkeley (ORNL Sub. No. 7464) and thus will be published as a separate report.

Keywords: concrete, elevated temperature, stress, strain, compressive strength, shear strength, creep, rebar bond.
\end{abstract}

\title{
1. INTRODUCTION
}

\subsection{Background}

In a Liquid-Metal Fast Breeder Reactor (LMFBR), concrete temperatures in excess of normal code limits can result from postulated large sodium spills in lined, inert, and air-filled equipment cells (class 8 accident). ${ }^{1}$ Elevated concrete temperatures can also occur in these structures as a result of a Thermal Margin Beyond the Design Base (TMBDB) accident (a class 9 core disruptive accident). Elevated temperature concrete 
property data, which may provide a basis for the design and evaluation of such postulated accident conditions, are quite limited. In addition, the available data are not representative of actual conditions; they address a limited number of parameters and exhibit variations resulting from (1) differing materials and mixes, (2) cure periods, (3) specimen sizes, (4) load conditions during heating, (5) moisture migration states, (6) thermal stabilization durations, and (7) temperature conditions. Thus, data need to be developed, commensurate with LMFBR plant applications, for critical physical and mechanical concrete properties under prototypic thermal accident conditions.

An interim elevated temperature concrete testing program was conducted at the Oak Ridge National Laboratory (ORNL) in early 1976. The program objective was to provide data to confirm the proposed Burns and Roe, Inc., elevated temperature concrete design relationships as a part of the TMBDB design for the Clinch River Breeder Reactor Plant (CRBRP) equipment cells. In that test program, uniaxial compression tests were conducted on limestone aggregate structural concrete $[27.57 \mathrm{MPa}$ (4000 psi) nominal compressive strength] test cylinders* $[0.15 \mathrm{~m}$ diam by $0.30 \mathrm{~m}$ ( $6 \mathrm{in.} \mathrm{diam} \mathrm{by} 12 \mathrm{in.}$ )] which had been subjected to temperatures of either $176.7,371.1,565.6$, or $760^{\circ} \mathrm{C}\left(350,700,1050,1400^{\circ} \mathrm{F}\right)$ for $14 \mathrm{~d}$. The tests were conducted under two moisture migration states, open-hot and closed-cold, to establish the concrete's upper- and lower-bound response, respectively, to sustained elevated temperature exposure. In the open-hot tests, specimens were permitted to lose moisture freely to simulate the response of a concrete element during a thermal accident in which the element is either vented or has free atmospheric communication. In the closed-cold tests, the specimens were heated in a closed-moisture migration environment which restricted the moisture release from the specimen; this test simulated a concrete element's response to a thermal accident in which the element is located within an unvented region or within a massive concrete structure. Specimens in the open-hot test

\footnotetext{
${ }^{*}$ Cylinders were obtained from an ongoing Tennessee Valley Authority project and varied in age from 263 to $587 \mathrm{~d}$ at the test time. As a result, the control cylinders varied somewhat in batch strength, even though they were continuously molst-cured.
} 
series were tested at temperature, and those in the closed-cold test series were permitted to slowly cool to room temperature before testing. Compressive strength and modulus of elasticity values from the control cylinders, obtained from the same batches as the test cylinders, were then used as a reference to evaluate the residual compressive strength and residual modulus of elasticity for the elevated temperature test specimens. Results of this test program are summarized in Ref. 2.

While confirming the design relationships developed by Burns and Roe, Inc.,$^{3}$ the results of the interim testing program did not sufficiently define all the physical (thermal) and mechanical (strength) properties of concrete utilized in the structural design and thermal accident analysis. Accordingly, a more comprehensive testing program ${ }^{4}$ was developed based on Ref. 1 .

\subsection{Objective}

The objective of the overall testing program is to define the variations in the physical (thermal) and mechanical (strength) properties of limestone aggregate concrete and 1ightweight insulating concrete exposed to elevated temperatures that could occur as a result of a postulated large sodium spill in a lined LMFBR equipment cell.

\subsection{Scope}

To meet the present objective, four mechanical (strength) test series were conducted: (1) unconfined compression, (2) shear, (3) rebar bond, and (4) sustained loading (creep). The physical (thermal) properties tests for coefficients of thermal expansion, diffusivity, and conductivity, were conducted under a subcontract with the University of California at Berkeley and $w i 11$ be presented in a separate report.

Unconfined compressive tests were conducted on limestone aggregate and lightweight aggregate concretes for the open-hot condition at a specified series of discrete temperatures up to $621^{\circ} \mathrm{C}\left(1150^{\circ} \mathrm{F}\right)$ for periods of exposure of either 14 or $28 \mathrm{~d}$. The effects of the elevated temperature exposure were determined on unconfined compressive strength, modulus of elasticity, moisture and weight 1oss, and Poisson's ratio. 
Shear tests were conducted using S-shaped, paralleleplped specimens fabricated from limestone aggregate concrete. The spectmens were tested in the open-hot condition at thermal stablilization temperatures up to $621^{\circ} \mathrm{C}\left(1150^{\circ} \mathrm{F}\right)$ for periods of exposure of $14 \mathrm{~d}$. The relative effects of the elevated temperature exposure on shear strength were determined.

Rebar bond pul1-out tests were conducted using specimens consisting of a No. 11 reinforcing bar, embedded vertically in a $0.31-m\left(12-i n_{*}\right)$ limestone aggregate concrete cube. After thermal stabilization for $14 \mathrm{~d}$ at temperatures up to $621^{\circ} \mathrm{C}\left(1150^{\circ} \mathrm{F}\right)$, the specimens were tested in the open-hot condition to determine the relative effect of the elevated temperature exposure on the concrete-rebar slip behavior.

Creep tests of limestone aggregate concrete cylindrical specimens $0.15 \mathrm{~m}$ diam by $0.30 \mathrm{~m}$ ( $6 \mathrm{in}$. diam by $12 \mathrm{in}$ ) were conducted for sustained loads, representing up to $50 \%$ of the 28 -d reference design compressive strength of the concrete. During these loadings, which had maximum durations of two months, the specimens were exposed to thermal stabilization temperatures up to $537.8^{\circ} \mathrm{C}\left(1000^{\circ} \mathrm{F}\right)$ to determine the effect of these load combinations on the specimens' deformational behavior. 


\section{CONCRETE SPECIMEN PREPARATION}

\subsection{Criteria and Definition}

Specimens were cast from elther a structural limestone aggregate concrete or an insulating aggregate concrete. The structural concrete specimens were fabricated from crushed limestone aggregates supplied by CRBRP Project Office from the proposed quarry site; the insulating concrete specimens were fabricated from a commercially avallable, lightweight, perlite aggregate. In excess of 300 specimens were fabricated, cured, and tested in this program. In addition to the actual test specimens, this number includes batch control and apparatus calibration specimens. Individual test specimens were identified throughout the investigation by a unique letter-number combination which is described in Table 1.

Table 1. Spectmen Identification scheme

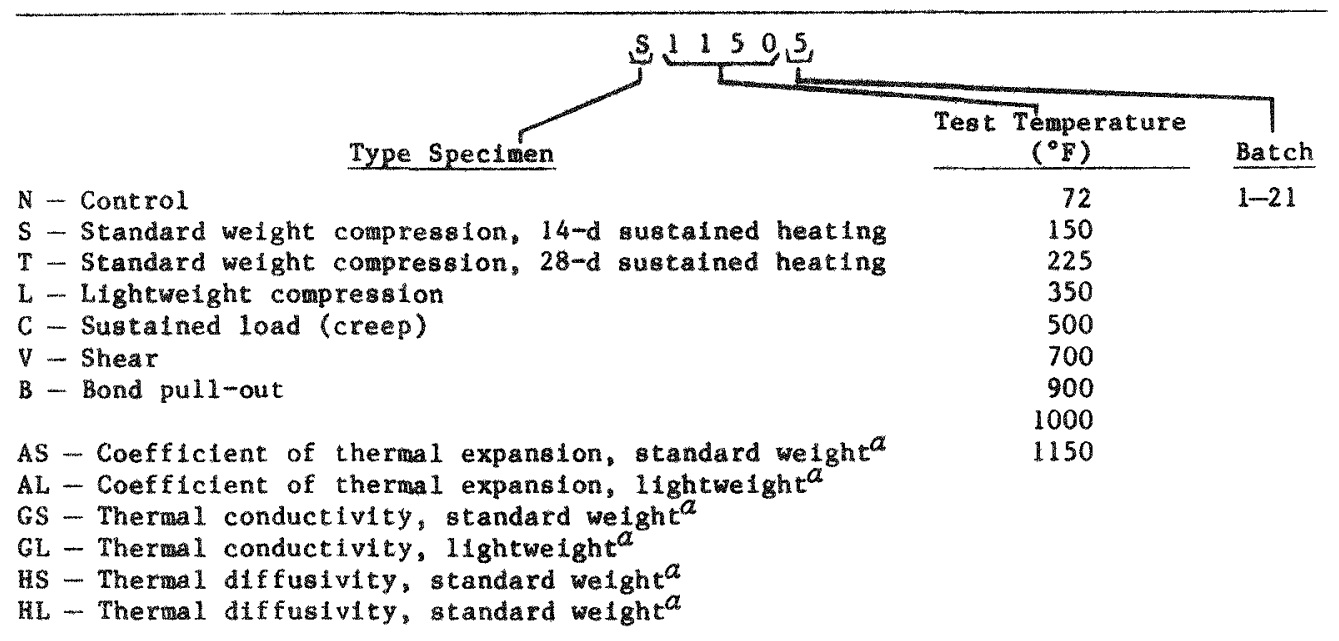

Examples

\begin{tabular}{|c|c|c|c|c|}
\hline Designation & Type Specimen & & $\begin{array}{c}\text { Test Temperature } \\
\left({ }^{\circ} \mathbb{E}\right)\end{array}$ & Batch \\
\hline $\begin{array}{l}\$ 1501 \\
L 22511\end{array}$ & $\begin{array}{l}\text { Standard wht compression } \\
\text { Lightwelght compression }\end{array}$ & $\begin{array}{l}14-d \\
14-d\end{array}$ & $\begin{array}{l}\text { sustained heating at } 150^{\circ} \mathrm{F} \\
\text { sustained heating at } 225^{\circ} \mathrm{F}\end{array}$ & $\begin{array}{r}1 \\
11\end{array}$ \\
\hline V50013 & Shear & & 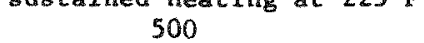 & $\begin{array}{l}11 \\
13\end{array}$ \\
\hline B70015 & Bond pul1-out & & 700 & 15 \\
\hline C100010 & Sustained load & & 1000 & 10 \\
\hline
\end{tabular}

\footnotetext{
a Test propertles on these specimens will be provided in a separate report.
} 


\subsection{Materials}

\subsubsection{Cement}

Cement conforming to the requirements of ANSI/ASTM C 150-78a for Type II portland cement was used throughout the investigation. The cement was obtained in a single lot and stored in barrels in the laboratory for use throughout the investigation.

\subsubsection{F1yash}

The flyash used in the investigation was obtained from a local source and comformed with the requirements of ANSI/ASTM C 618-78 for class F flyash.

\subsubsection{Aggregates}

Two types of aggregates were required for the investigation: crushed limestone and perlite. The crushed limestone was obtained from a test hole of the proposed on-site CRBRP quarry and was supplied by the CRBRP Project office. The perlite aggregate used in the insulating concrete mixes was obtained from a commercial supplier. The fine aggregate was also a product of the crushed limestone and conformed to ANSI/ASTM C $33-78$.

Upon receipt from the test hole, the coarse limestone aggregates were washed to remove deleterious substances. All of the limestone aggregates were then oven-dried at $110 \pm 5^{\circ} \mathrm{C}\left(230 \pm 9^{\circ} \mathrm{F}\right)$ for at least $16 \mathrm{~h}$, separated into individual sieve sizes, and stored in barrels in the laboratory for recombining at the time of mixing. The aggregates were tested for specific gravity and absorption in accordance with ANSI/ASTM C 127-77 and ANSI/ASTM C 128-73 requirements. The bulk specific gravity for the fine and the coarse aggregates was 2.80. The absorption of the fine aggregates was $0.563 \%$, and the absorption of the coarse aggregates was $0.450 \%$.

The perlite aggregate was tested in accordance with ANSI/ASTM C $332-77 \mathrm{a}$. The loose unit weight of the perlite was $120 \mathrm{~kg} / \mathrm{m}^{3}(7.491 \mathrm{~b} /$ $\mathrm{ft}^{3}$ ), and it had a fineness modulus of 2.66 . The material satisfied the requirements of a Group I lightweight aggregate. 


\section{2 .4 Water}

The water used for all batches was from the laboratory tap water supply. The water was potable.

\subsubsection{Admixtures}

A commercially available air-entraining agent, conforming to ANSI/ ASTM C 260-77, was used in both the standard weight and lightweight insulating concrete mixes.

A commercially available water-reducing agent, conforming to ANSI/ ASTM C 494-79, was used in the standard weight concrete mixes.

\subsubsection{Stee1 reinforcement}

Number 11 reinforcing bar, conforming to ANSI/ASTM 615-78 requirements for grade 60 steel, was used for the bond pul1-out tests. Results of measurements made to check conformance with this specification are presented in Table 2.

\subsection{Specimen Fabrication and Curing}

\subsubsection{Molds}

Three types of steel molds were used to cast the specimens. Standard $0.15-\mathrm{m}$-diam by $0.30-\mathrm{m}$ (6-in.-diam by 12-in.) cylinder molds were used for the control, compression, sustained load, and thermal properties test specimens. Thermocouple insert openings were cast into all specimens except those for control and the thermal conductivity tests. The molds and reinforcement* for the shear specimens are shown in Fig. 1. Nominal overal1 dimensions of the shear specimens were $0.14 \times 0.14 \times 0.30 \mathrm{~m}(5.5 \times 5.5$ $\times 12$ in.). Nominal overall dimenstons of the bond pull-out specimens were $0.30 \times 0.30 \times 0.30 \mathrm{~m}(12 \times 12 \times 12 \mathrm{in.})$. A No. 11 reinforcing bar, which had been sandblasted to remove loose surface rust, was positioned in the

\footnotetext{
*Reinforcing steel was contalned in the specimens to resist bending moments which develop in the upper and lower cantilever portions of the specimens.
} 
Table 2. Bond pul1-out reinforcing bar measurements

\begin{tabular}{|c|c|c|c|c|c|c|c|c|c|}
\hline \multirow{2}{*}{ Measurement } & \multicolumn{8}{|c|}{ Bar designation ${ }^{a}$} & \multirow{2}{*}{$\begin{array}{l}\text { ASTM A } 615-78 \\
\text { requirements }\end{array}$} \\
\hline & 72 & 150 & 225 & 350 & 500 & 700 & 900 & 1150 & \\
\hline $\begin{array}{l}\text { Inclined angle, } \\
\text { deg }\end{array}$ & 90 & 90 & 90 & 90 & 90 & 90 & 90 & 90 & $70-90^{b}$ \\
\hline $\begin{array}{l}\text { Average spacing, } \\
\mathrm{cm}(\text { in.) }\end{array}$ & $\begin{array}{c}2.999 \\
(0.905)\end{array}$ & $\begin{array}{c}2.289 \\
(0.901)\end{array}$ & $\begin{array}{l}2.263 \\
(0.891)\end{array}$ & $\begin{array}{c}2.286 \\
(0.900)\end{array}$ & $\begin{array}{c}2.276 \\
(0.896)\end{array}$ & $\begin{array}{c}2.230 \\
(0.878)\end{array}$ & $\begin{array}{c}2.253 \\
(0.887)\end{array}$ & $\begin{array}{c}2.334 \\
(0.919)\end{array}$ & $\begin{array}{l}2.507 \max \\
(0.987)^{m}\end{array}$ \\
\hline $\begin{array}{l}\text { Average helght, } \\
\mathrm{cm}(\text { in.) }\end{array}$ & $\begin{array}{c}0.198 \\
(0.078)\end{array}$ & $\begin{array}{c}0.213 \\
(0.084)\end{array}$ & $\begin{array}{c}0.213 \\
(0.084)\end{array}$ & $\begin{array}{c}0.213 \\
(0.084)\end{array}$ & $\begin{array}{c}0.226 \\
(0.089)\end{array}$ & $\begin{array}{c}0.226 \\
(0.084)\end{array}$ & $\begin{array}{c}0.213 \\
(0.084)\end{array}$ & $\begin{array}{c}0.198 \\
(0.078)\end{array}$ & $\begin{array}{l}0.180 \mathrm{~min} \\
(0.071)\end{array}$ \\
\hline Gap, cm (in.) & $\begin{array}{c}0.396 \\
(0.156)\end{array}$ & $\begin{array}{c}0.396 \\
(0.156)\end{array}$ & $\begin{array}{c}0.396 \\
(0.156)\end{array}$ & $\begin{array}{c}0.396 \\
(0.156)\end{array}$ & $\begin{array}{c}0.396 \\
(0.156)\end{array}$ & $\begin{array}{c}0.125 \\
(0.125)\end{array}$ & $\begin{array}{c}0.125 \\
(0.125)\end{array}$ & $\begin{array}{c}0.125 \\
(0.125)\end{array}$ & $\begin{array}{l}1.372 \max \\
(0.540)^{-1}\end{array}$ \\
\hline $\begin{array}{l}\text { Unit weight, } \\
\mathrm{kg} / \mathrm{m}(1 \mathrm{~b} / \mathrm{ft})\end{array}$ & $\begin{array}{c}7.620 \\
(5.120)\end{array}$ & $\begin{array}{c}7.570 \\
(5.090)\end{array}$ & $\begin{array}{c}7.680 \\
(5.160)\end{array}$ & $\begin{array}{c}7.660 \\
(5.150)\end{array}$ & $\begin{array}{c}7.630 \\
(5.130)\end{array}$ & $\begin{array}{l}7.620 \\
(5.120)\end{array}$ & $\begin{array}{l}7.590 \\
(5.100)\end{array}$ & $\begin{array}{c}7.630 \\
(5.130)\end{array}$ & $\begin{array}{l}7.907 \text { nom } \\
(5.313)\end{array}$ \\
\hline
\end{tabular}

$a_{\text {No. }} 11 ;$ ASTM A615 grade 60 .

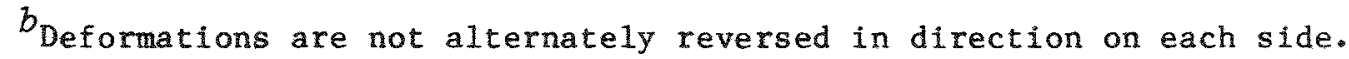




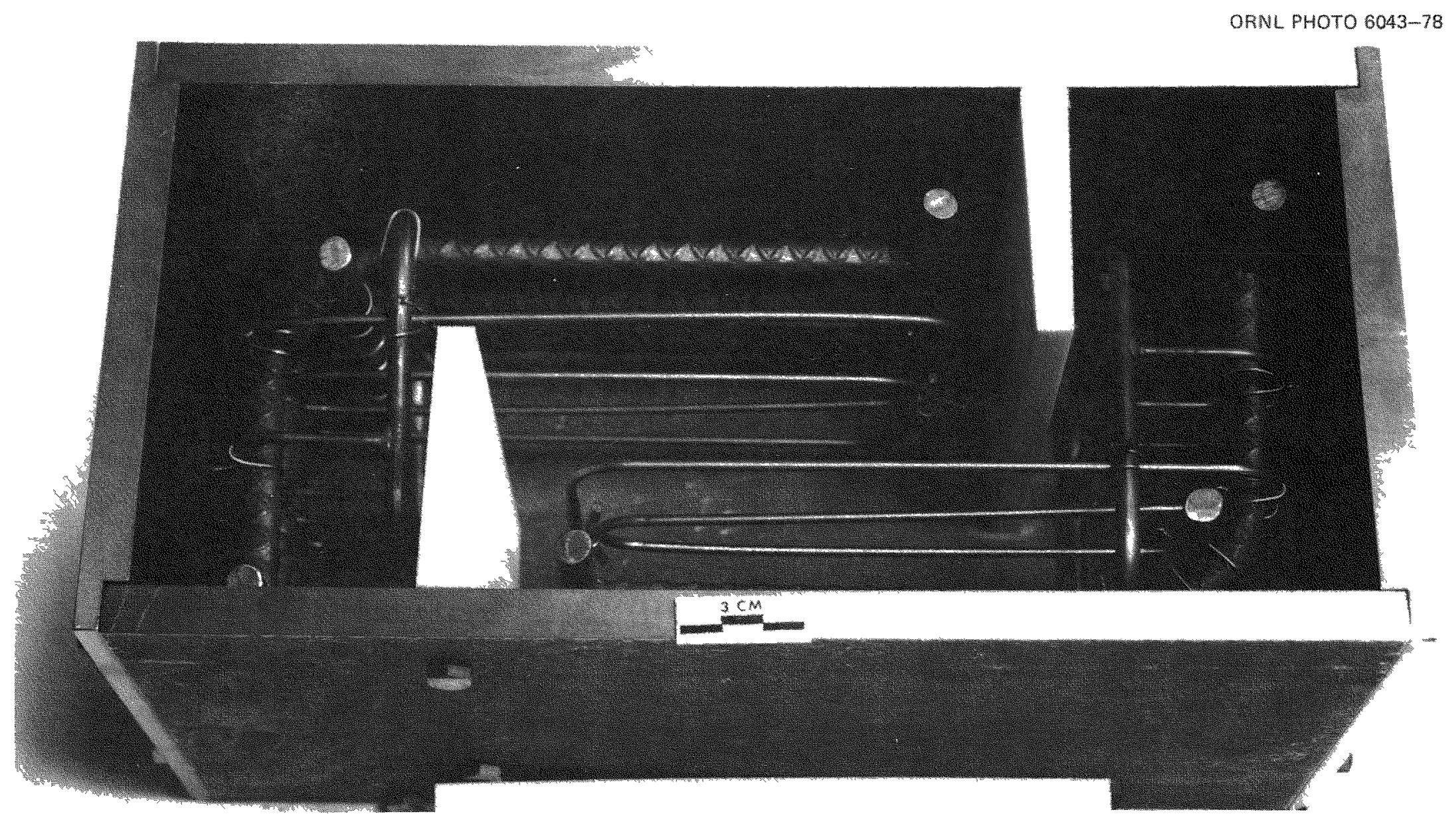

Fig. 1. Shear specimen reinforcement and mold. 
center of each mold. Thermocouples were also positioned in the mold before casting. A set of bond pull-out specimen molds prior to casting is shown in Fig. 2. Form release was applied to all molds the day before specimen casting. Care was taken to prevent the release agent from contacting the reinforcing bar in either the shear or bond pul1-out molds.

\subsubsection{Mixing}

Two types of concrete were specified for this program: standard weight, limestone aggregate concrete and a lightweight, perlite, insulating aggregate concrete. The mix proportions and required properties for each type of concrete are shown in Table 3 .

Twenty-one batches of concrete were prepared from which a total of 318 specimens were cast. The batch data summaries for each of the 16 batches of standard weight concrete and each of the five batches of 1ightweight insulating concrete are shown in Tables A.1 through A.21 (Appendix A). The laboratory temperature, relative humidity at the time of casting, and the individual test specimens which were cast from each batch are also noted in these tables.

Two different mixers were used to mix concrete for the testing program. A bladder type Omni-mixer with a $0.2-\mathrm{m}^{3}\left(7-\mathrm{ft}^{3}\right)$ maximum capacity was used for the standard weight concrete. A paddle-type, conventional mortar mixer was used for the lightweight insulating concrete.*

Standard weight concrete. The following procedure was performed for each batch of standard weight concrete. Steps 1 through 4 were performed on the day before casting, and steps 5 through 11 were performed on the day the specimens were cast.

1. Mixer was prewet, and excess water was permitted to drain.

2. Aggregates were placed in mixer.

3. Approximately one-half of the mix water was added to the mixer.

4. Mixer was covered and operated for $3 \mathrm{~min}$.

\footnotetext{
*The mixing action in the Omni-mixer, being quite vigorous, had a tendency to drive the air from the 1ightweight concrete mixes. The net result was a mix with too high a unit weight and too low an air content.
} 


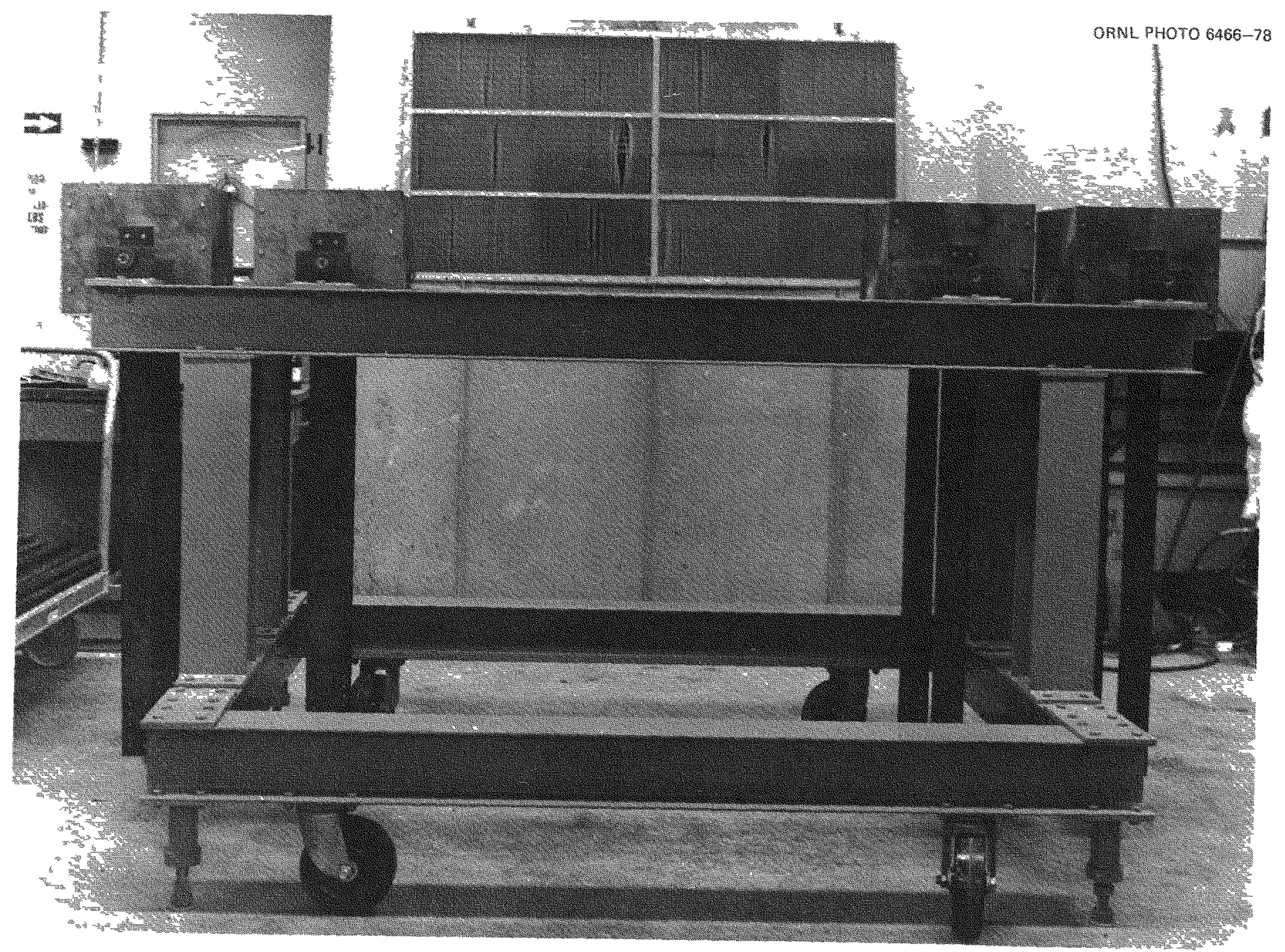

Fig. 2. Bond pul1-out specimen molds. 
Table 3. Concrete mix criteria

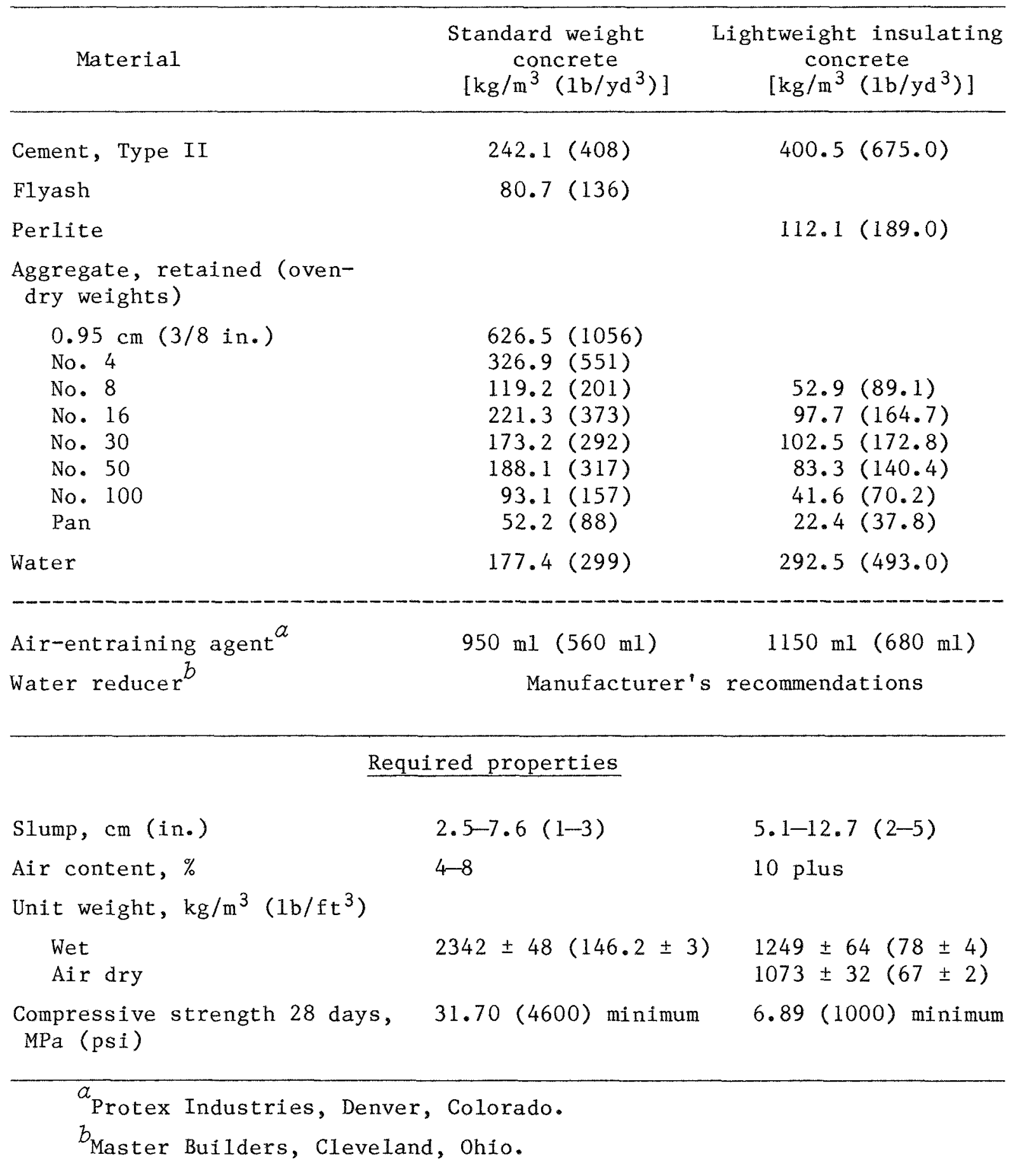


5. Cement, flyash, admixtures, and all but $2.3 \mathrm{~kg}$ ( $5 \mathrm{lb}$ ) of water were added to mixer.

6. Mixer was operated for $3 \mathrm{~min}$.

7. Slump was determined during a 3 -min rest.

8. Remaining water was added.

9. Mixer was operated for 2 min.

10. Contents were discharged into prewet container.

11. Slump, unit weight, air content, laboratory temperature, concrete temperature, and laboratory relative humidity were determined and recorded.

Lightweight insulating concrete. The following procedure was performed on the day of casting for each of the five batches of lightweight insulating concrete.

1. Mixer was prewet, and excess water was permitted to drain.

2. Aggregates were placed in mixer.

3. Approximately one-half of the mix water was added to the mixer.

4. The mixer was operated for approximately $5 \mathrm{~min}$.

5. Cement, admixtures, and all but $4.5 \mathrm{~kg}(10 \mathrm{lb})$ of water were added to the mixer.

6. Mixer was operated for $3 \mathrm{~min}$.

7. Slump was determined.

8. If required to adjust the slump to the desired value of approximately $127 \mathrm{~mm}$ ( $5 \mathrm{in.}$ ), water was added and the ingredients were remixed for 1 min. Slump was then redetermined.

9. Contents of mixer were discharged into prewet container and total water recorded.

10. Slump, unit weight, air content, laboratory temperature, concrete temperature, and laboratory relative humidity were determined and recorded.

\subsubsection{Plastic concrete properties}

Slump. The slump for each batch of concrete was determined in accordance with ANSI/ASTM C 143-78 (Table 4). 
Table 4. Plastic concrete properties

\begin{tabular}{|c|c|c|c|c|c|c|c|}
\hline Batch & $\begin{array}{l}\text { Type of } \\
\text { concrete }\end{array}$ & $\begin{array}{c}\text { Slump } \\
{\left[\operatorname{mm}\left(\mathrm{in}_{0}\right)\right]}\end{array}$ & $\begin{array}{l}\text { Air } \\
\text { content } \\
(\%)\end{array}$ & $\begin{array}{r}\text { Unit } \\
{\left[\mathrm{kg} / \mathrm{m}^{3}\right.}\end{array}$ & $\begin{array}{l}\text { weight } \\
\left.\left(1 \mathrm{~b} / \mathrm{ft} \mathrm{t}^{3}\right)\right]\end{array}$ & $\begin{array}{c}\text { Yield } \\
{\left[\mathrm{m}^{3}\left(\mathrm{ft}^{3}\right)\right]}\end{array}$ & $\begin{array}{l}\text { Concrete } \\
\text { temperature } \\
{\left[{ }^{\circ} \mathrm{C}\left({ }^{\circ} \mathrm{F}\right)\right]}\end{array}$ \\
\hline 1 & $\mathrm{~S}$ & $51(2.00)$ & 6.2 & 2336 & $6(146)$ & $0.172(6.06)$ & $28(83)$ \\
\hline 2 & $\mathrm{~s}$ & $38(1.50)$ & 4.5 & 2400 & $0(150)$ & $0.167(5.90)$ & $32(89)$ \\
\hline 3 & $\mathrm{~s}$ & $64(2.50)$ & 6.5 & 2342 & $2(146)$ & $0.114(4.03)$ & $21(70)$ \\
\hline 4 & $\mathrm{~s}$ & $44(1.75)$ & 4.7 & 2368 & $8(148)$ & $0.169(5.98)$ & $26(79)$ \\
\hline 5 & S & $45(1.75)$ & 4.5 & 2374 & $4(148)$ & $0.169(5.96)$ & 31 (88) \\
\hline 6 & $\mathrm{~s}$ & $45(1.75)$ & 4.6 & 2387 & $(149)$ & $0.168(5.93)$ & $30(86)$ \\
\hline 7 & $\mathrm{~s}$ & $29(1.13)$ & 4.7 & 2409 & $9(150)$ & $0.139(4.90)$ & $27(80)$ \\
\hline 8 & L & $159(6.25)$ & 17.0 & 1290 & $0(81)$ & $0.158(5.59)$ & $25(77)$ \\
\hline 9 & $s$ & $38(1.50)$ & 4.7 & 2416 & $5(151)$ & $0.166(5.86)$ & $28(83)$ \\
\hline 10 & $\mathrm{~s}$ & $38(1.50)$ & 4.0 & 2425 & $5(151)$ & $0.165(5.84)$ & $29(84)$ \\
\hline 11 & L & $114(4.50)$ & 19.0 & 1250 & $0(78)$ & $0.161(5.70)$ & $14(58)$ \\
\hline 12 & $s$ & $45(1.75)$ & 4.0 & 2406 & $6(150)$ & $0.167(5.89)$ & $28(83)$ \\
\hline 13 & $\mathrm{~s}$ & $41(1.63)$ & 4.3 & 2400 & $0(150)$ & $0.139(4.92)$ & $26(79)$ \\
\hline 14 & $\mathrm{~L}$ & $127(5.00)$ & 17.5 & 1240 & $0(77)$ & $0.163(5.77)$ & $23(73)$ \\
\hline 15 & $s$ & $45(1.75)$ & 4.3 & 2393 & $3(149)$ & $0.168(5.92)$ & $29(85)$ \\
\hline 16 & S & $38(1.50)$ & 4.0 & 2425 & $5(151)$ & $0.179(6.33)$ & $29(84)$ \\
\hline 17 & $\mathrm{~L}$ & $178(7.00)$ & 16.5 & 1340 & $0(84)$ & $0.150(5.31)$ & $27(81)$ \\
\hline 18 & $s$ & $32(1.25)$ & 4.0 & 2441 & 1 (152) & $0.164(5.80)$ & $27(80)$ \\
\hline 19 & S & $54(2.13)$ & 7.1 & 2348 & $8(147)$ & $0.168(6.00)$ & $26(79)$ \\
\hline 20 & $s$ & $48(1.88)$ & 3.8 & 2409 & $(150)$ & $0.166(5.88)$ & 31 (87) \\
\hline 21 & L & $127(5.00)$ & 15.0 & 1340 & o (84) & $0.186(6.64)$ & $27(81)$ \\
\hline
\end{tabular}

$a_{S}=$ standard weight limestone aggregate concrete; $L=1$ ightweight perlite aggregate concrete. 
Air content. The air content of the standard weight concrete was determined for each batch at the time of casting, using the procedures described in ANSI/ASTM C 231-78 for a Type B meter (Table 4).

The air content for the lightweight insulating concrete was determined for each batch at the time of casting, using the procedure described in ANSI/ASTM C 173-78 (Table 4).

Unit weight and yield. A $0.007-\mathrm{m}^{3}\left(0.25-\mathrm{ft}^{3}\right)$ measuring bowl was used to determine the wet-unit weight for each concrete batch. Entrapped air voids were removed from the standard weight concretes by external vibration. No vibration was used for the 1ightweight aggregate batches. Yield for each batch was then determined by dividing the sum of the batch material weights by the measured unit welght. These determinations were in accordance with ANSI/ASTM C 138-77 requirements. Unit weight and yield for each batch are present in Table 4.

\section{3 .4 Casting}

Concrete was placed into the molds in three approximately equal volumes. Consolidation of each layer of standard weight concrete was performed by means of either internal vibration (bond pull-out specimens) or external vibration (control, compression, shear, and creep specimens). The lightweight insulating concrete was not mechanically consolidated, but care was taken to ensure that the entrapped air at the mold-specimen interface was removed. Approximately 2 to $4 \mathrm{~h}$ after casting, the control specimens, which were used for reference value determinations, were capped with a neat portland cement paste in accordance with ASNI/ASTM C617-76. At this time, other test specimens were given a final troweling and covered with moist paper towels and plastic sheets to minimize moisture loss.

\subsubsection{Specimen demolding and curing}

Specimens were usually demolded between 24 and $48 \mathrm{~h}$ after casting, marked with a specimen identification number, and submerged in galvanized steel tanks which contained a saturated limewater solution. Standard weight concrete specimens remained in the curing tank until they were removed at 28 or $60 \mathrm{~d}$ for control tests, or until heating was initiated when 
the specimens were 60 to $90 \mathrm{~d}$ old. Lightweight, insulating concrete, control specimens used for air-dry density determinations were removed from the curing tank $7 \mathrm{~d}$ after casting and placed into a chamber which maintained an environment of $24 \pm 2^{\circ} \mathrm{C}\left(75 \pm 3^{\circ} \mathrm{F}\right)$ and $50 \pm 10 \%$ relative humidity. Twenty-eight days after casting, the remaining lightweight concrete specimens in a batch were removed from the curing tank; except for the control specimens scheduled to be tested at an age of $28 \mathrm{~d}$, all others were placed in the environmental chamber. The lightweight concrete specimens remained in the controlled environment chamber until heating was initiated when the specimens were between 60 to $90 \mathrm{~d}$ old.

\subsubsection{Specimen machining}

To ensure that the loaded surfaces of the test specimens were flat, the ends of the cylindrical specimens were machined.* This procedure was performed on each compression and sustained load specimen during the moist-cure period. The specimens remained in the saturated 1 imewater until they were placed in a lathe. During the machining process, water was sprayed on the specimens to keep them moist (Fig. 3). After machining, the specimens were checked for flatness and then resubmerged in the saturated limewater to continue moist-curing.

\footnotetext{
*Conventional methods (capping), such as noted in ANSI/ASTM Method C 617-76, could not be used to ensure that the cylindrical test specimens met the requirements for flatness and planeness because of a desire to eliminate any possible effects of the capping materials on test results.
} 
ENDS OF THE SPECIMENS WERE MACHINED TO ASTM DESIGNATION C39-72 TOLERANCES FOR FLATNESS AND PARALLELISM

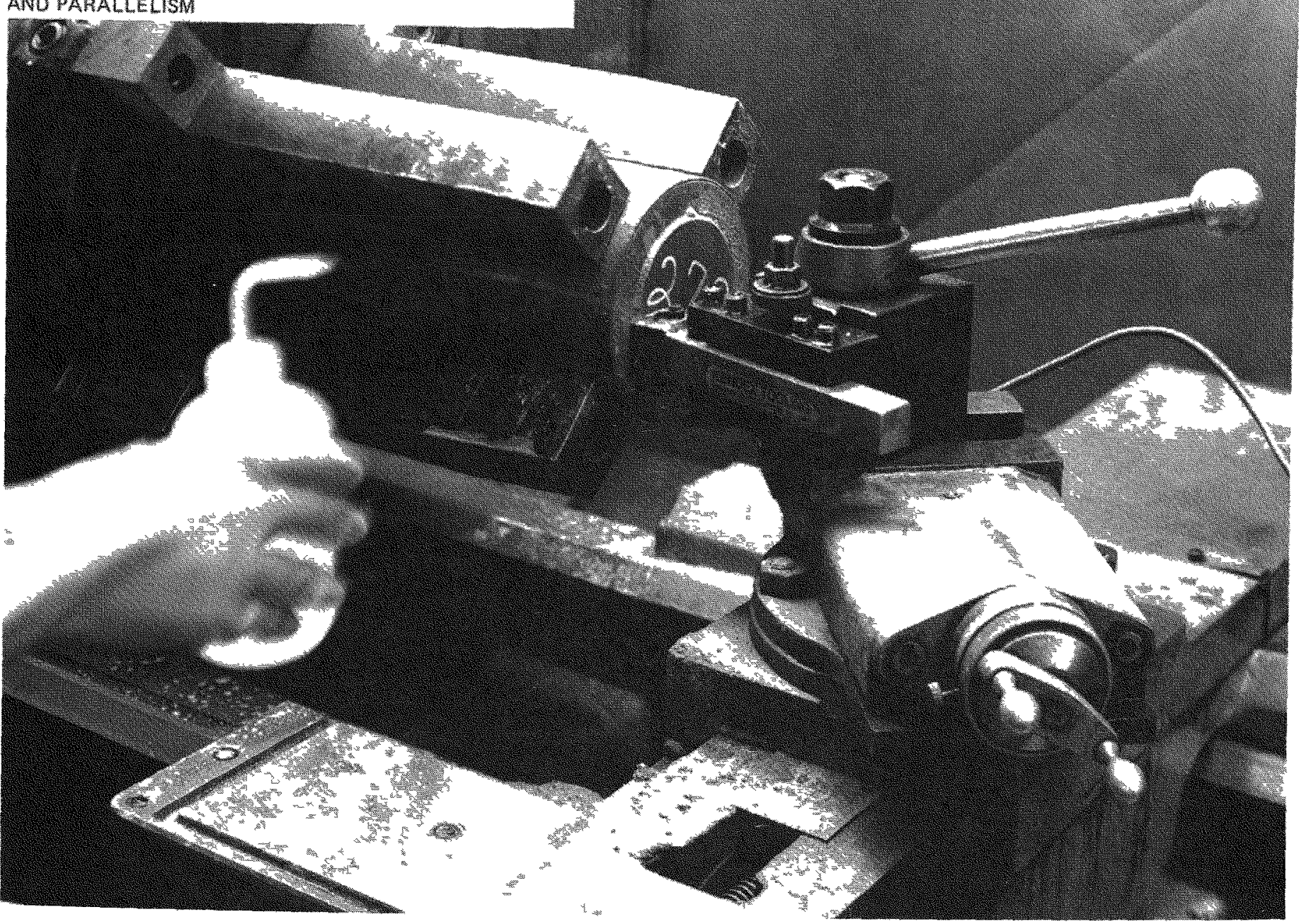

Fig. 3. Machining compression and sustained load test specimens. 


\section{SPECIMEN TESTING PROCEDURES}

\section{1 Control Specimens}

Control specimens cast from each batch of standard weight concrete were tested to determine reference compressive strength, modulus of elasticity, and Poisson's ratio values. These tests were performed at $28 \mathrm{~d}$ on three cylinders from each of the 16 batches of standard weight concrete. Sixty-day tests were also performed on three control specimens from batches 1, 5, 10, and 13 .

Two sets of three control specimens were cast from each of the five batches of lightweight insulating concrete. Three of these specimens were tested at $28 \mathrm{~d}$ to determine reference compressive strength, modulus of elasticity, and Poisson's ratio; the remaining three specimens were tested to determine air-dry density values. No control tests were performed at $60 \mathrm{~d}$ for the lightweight insulating concretes.

The instrumentation for testing control specimens in compression conformed to ASTM C 469-65 requirements (Table 5). Just before testing, each control specimen was removed from the curing water, and an average midheight diameter was determined. The compressometer-extensometer assembly (Fig. 4) was attached to each specimen, which was then centered on the loading platen of the testing machine. The two direct current displacement transducers (DCDTs) were calibrated by adjusting the gain of the $X-Y-Y$ recorder to appropriate displacement units as input by reference micrometers built into the compressometer-extensometer apparatus. A shunt resistor, internally contained in the amplifier for the pressure transducer, was used to calibrate the testing machine load transducer output. Displacement and the load calibrations were shown on the recorder sheet. Specimens were then loaded at a rate less than $0.34 \mathrm{MPa} / \mathrm{s}$ ( $50 \mathrm{psi} / \mathrm{s}$ ) to their ultimate load capacity (maximum load on testing machine dial), while a continuous plot of load vs displacement data was recorded. Testing was terminated at the inception of concrete crushing.

The air-dry density of lightweight insulating concrete was determined using the apparatus described in Table 5. Twenty-eight days after casting, each specimen was removed from the environmental chamber, 


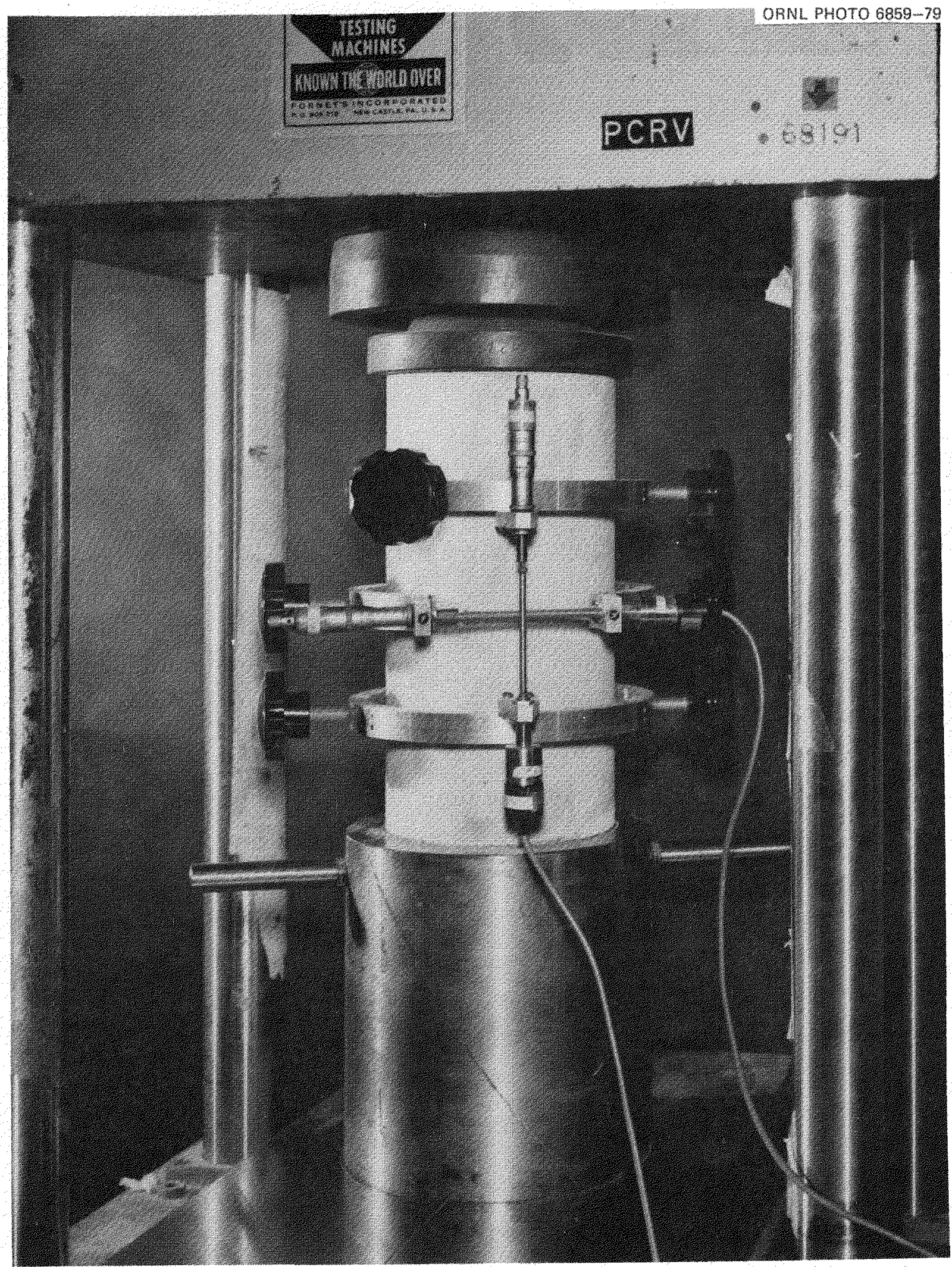

Fig. 4. Control specimen with instrumentation. 
Table 5. Control specimen testing apparatus

\begin{tabular}{|c|c|}
\hline Instrument & Discussion \\
\hline \multicolumn{2}{|c|}{ Compression tests } \\
\hline Compressometer-extensometer & $\begin{array}{l}\text { Axial and transverse displacement measure- } \\
\text { ments }\end{array}$ \\
\hline Forney testing machine & Load application to specimens \\
\hline $\begin{array}{l}\text { Direct current displacement } \\
\text { transducers (DCDTs) }\end{array}$ & Displacement indicators \\
\hline Micrometers & $\begin{array}{l}\text { DCDT calibration and specimen diameter } \\
\text { measurements }\end{array}$ \\
\hline Power supply (direct current) & DCDT excitation \\
\hline Signal conditioning & $\begin{array}{l}\text { Pressure transducer on Forney testing ma- } \\
\text { chine }\end{array}$ \\
\hline$X-Y-Z$ recorder & Displacement vs load data plots \\
\hline Digital voltmeter & DCDT output indicator \\
\hline \multicolumn{2}{|c|}{ Air-dry density tests } \\
\hline Scale & Specimen weight measurements \\
\hline Micrometers & Specimen length and diameter measurements \\
\hline
\end{tabular}

weighed, measured three times to obtain the average specimen length, and measured six times to obtain the average specimen diameter. The specimen volume was computed and the air-dry density determined by dividing the specimen weight by its volume.

\subsection{Unconfined Compression Test Specimens}

Unconfined compression tests were conducted in concurrence with ANSI/ASTM C 39-72 (compressive strength of cylindrical concrete specimens) using cylindrical test specimens $0.30 \mathrm{~m}$ by $0.15 \mathrm{~m}$ diam (12 in. by 6 in. diam). These specimens were fabricated from both the standard weight and lightweight insulating concretes and were cast according to 
procedures previously described. The objective of the tests was to determine the effects of elvated temperature exposure on unconfined compressive strength, modulus of elasticity, stress-strain relationships, moisture and weight $10 \mathrm{ss}$, and Poisson's ratio. Temperature levels of interest were $22.2,65.6,107.2,176.7,260,371.1,482.2$, and $621.1^{\circ} \mathrm{C}$ $\left(72,150,225,350,500,700,900\right.$, and $\left.1150^{\circ} \mathrm{F}\right) *^{*}$ Specimen testing was initiated 60 to $90 \mathrm{~d}$ after casting, using the following procedure.

1. Standard weight test specimens were removed from the curing tank, weighed to obtain a saturated surface dry weight, permitted to air-dry for 4 to $6 \mathrm{~h}$ and then inserted into their appropriate compression test furnace-platen assembly. (Lightweight, insulating concrete specimens were removed from the environmental chamber, weighed, and placed directly into the appropriate compression test furnace-platen assembly.)

2. Through an opening in the test furnace, a thermocouple was inserted into a precast hole in the specimen and secured with a hightemperature adhesive. This step was repeated for each specimen in the batch.

3. Alarm and temperature controller thermocouples were installed in each furnace assembly, so that the ends were in contact with the specimen surface. Thermocouples were then attached to the appropriate controller, alarm, and recorder lead wires.

4. Upper compression platens were centrally located on top of each test specimen, and Kaowool insulation was used to fill the voids between the upper compression platens and furnace assembly.

5. On the day following completion of items 1 through 4 , heat-up of the specimens was initiated at the specified rate of $17^{\circ} \mathrm{C} / \mathrm{h}\left(30^{\circ} \mathrm{F} / \mathrm{h}\right)$ using a programmable temperature control system. Figure 5 presents the compression furnace assemblies during heat-up.

6. When a specimen reached its scheduled thermal stabilization temperature (day zero), the appropriate temperature controller was switched to the local mode of operation. The set point was adjusted so that the

\footnotetext{
*The $621.1^{\circ} \mathrm{C}\left(1150^{\circ} \mathrm{F}\right)$ exposure was not considered for the lightweight insulating concrete. ${ }^{1}$
} 


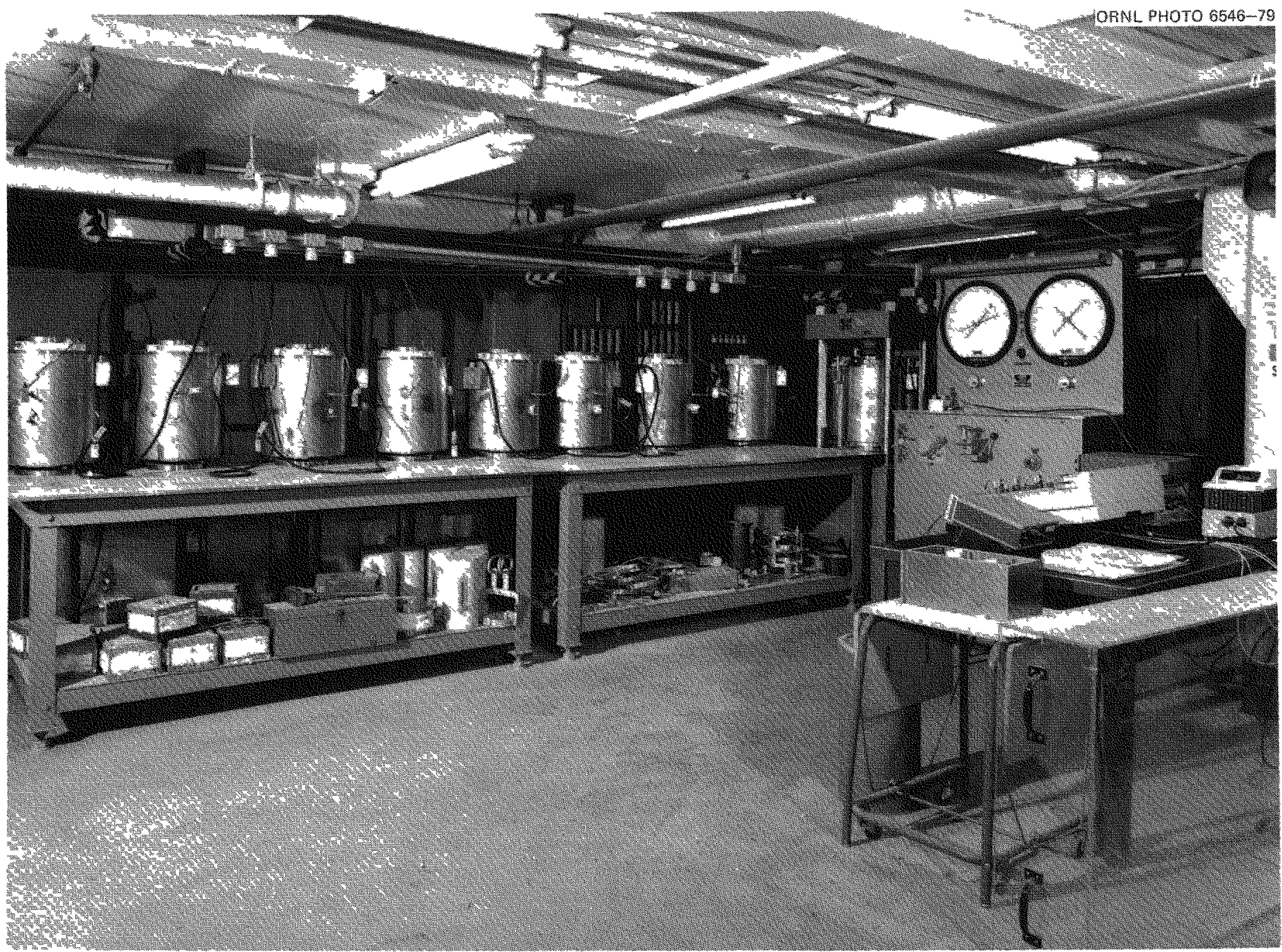

Fig. 5. Compression test furnaces during heat-up. 
test temperature remained stationary $\left[11^{\circ} \mathrm{C}\left(20^{\circ} \mathrm{F}\right)\right.$ maximum deviation permitted] for the scheduled thermal stablization period.

7. At the conclusion of the prescribed 14-d (or 28-d) thermal stabilization period, the furnace circuit breaker was open-circuited, the thermocouple leads were disconnected, and the compression test compressometer was attached. The specimen was then transferred to the compression testing machine and centered on the lower loading platen. The thermocouple leads were reconnected, the circuit breaker was closed, and the specimen was permitted to return to its thermal stablization temperature. During the 5-min transfer operation, the test specimen was not allowed to $\operatorname{cool}$ more than $11^{\circ} \mathrm{C}\left(20^{\circ} \mathrm{F}\right)$ before being reconnected with the heating element power source. A closeup of a specimen in the testing machine is shown in Fig. 6.

8. After the specimen returned to its thermal stabilization temperature, the testing machine load transducer output was zeroed, and the excitation of the X-channeI (Ioad) axis of the X-Y1-Y2 recorder was adjusted, so that a shunt calibration resistor produced a calibrated signal output. The calibrated load output signal was noted on the recorder paper.

9. The DCDT that monitored cylinder length changes was calibrated, by adjustment of the Y1-channel axis of the $\mathrm{X}-\mathrm{Y} 1-\mathrm{Y} 2$ recorder, to produce a signal output for a known displacement; the displacement was input by a precalibrated micrometer built into the compressometer apparatus. Calibrated displacement output was noted on the recorder paper.

10. The DCDT that monitored cylinder diameter changes was calibrated, by adjustment of the excitation of the Y2-channel axis of the $\mathrm{X}-\mathrm{Y} 1-\mathrm{Y} 2$ recorder, to produce a signal output for a known displacement, the displacement was input by a precalibrated micrometer built into the test fixture. Calibrated displacement output was noted on the recorder paper. (This step was omitted for the lightweight insulating concrete specimens.)

11. The specimen number, test furnace number, thermal stabilization temperature, test date, and scales for the $\mathrm{X}, \mathrm{Y} 1$, and $\mathrm{Y} 2$ axes were noted on the recorder paper.

12. Load was applied to the specimen at a rate of $0.34 \mathrm{MPa} / \mathrm{s}$ (50 psi/s) or less, until the maximum load was reached at the inception of 


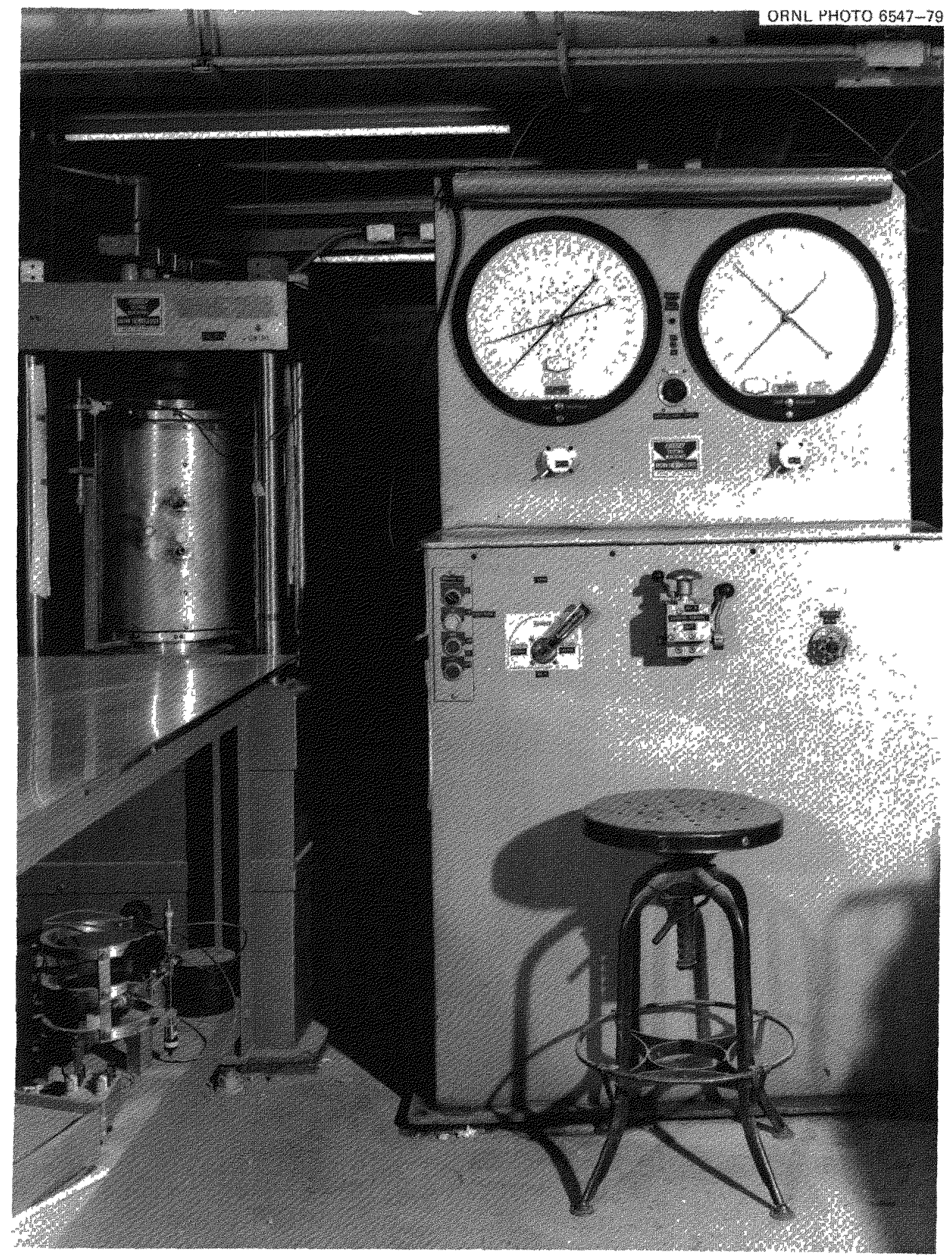

Fig. 6. Compression fixture in machine prior to test. 
concrete crushing; at this point, loading was stopped. Load vs displacement data were recorded during the entire loading history. As read from the testing machine dial, the maximum load applied was noted and marked on the recorder paper.

13. The furnace circuit breaker was open-circuited, all external oven connections were disconnected, and the furnace was removed from the testing machine. The upper loading platen was then removed, and the specimen was taken from the furnace and placed on a scale to obtain an oven-dry weight. The oven-dry weight was noted on the recorder paper.

14. This procedure was repeated for each specimen of the test series.

\subsection{Shear Test Specimens}

Shear is the action of two equal and opposite parallel forces applied in planes a short distance apart. Shear stresses cannot exist without accompanying tensile and compressive stresses. Pure shear can be applied only through torsion of a cylindrical specimen. Since concrete is weaker in tension than shear, failure in torsion invariably occurs in diagonal tension. Tests to determine shearing strength directly are inconclusive because of the effects of bending, friction, cutting, or lateral restraint imposed by the test apparatus. Some investigators have concluded that the shear strength of concrete is 20 to $30 \%$ greater than the tensile strength ( $\sim 12 \%$ the compressive strength), while others have determined the shear strength to be several times the tensile strength ( 50 to $90 \%$ the compressive strength). 5

Since no standard test was avallable for measuring the shear strength of concrete, an S-shaped, parallelepiped specimen was used (Fig. 7). Test specimens having similar geometries were tested and reported. 6 Although a specimen does have a predesignated shear plane, specimen failure will include effects due to tensile loading. Test results only provide a means for evaluating the relative effects of elevated temperature exposure on the shear strength of concrete.

The S-shape, parallelepiped test specimens were cast from standard weight concrete using procedures previously described. The test objective 
ORNL-DWG 78-6175
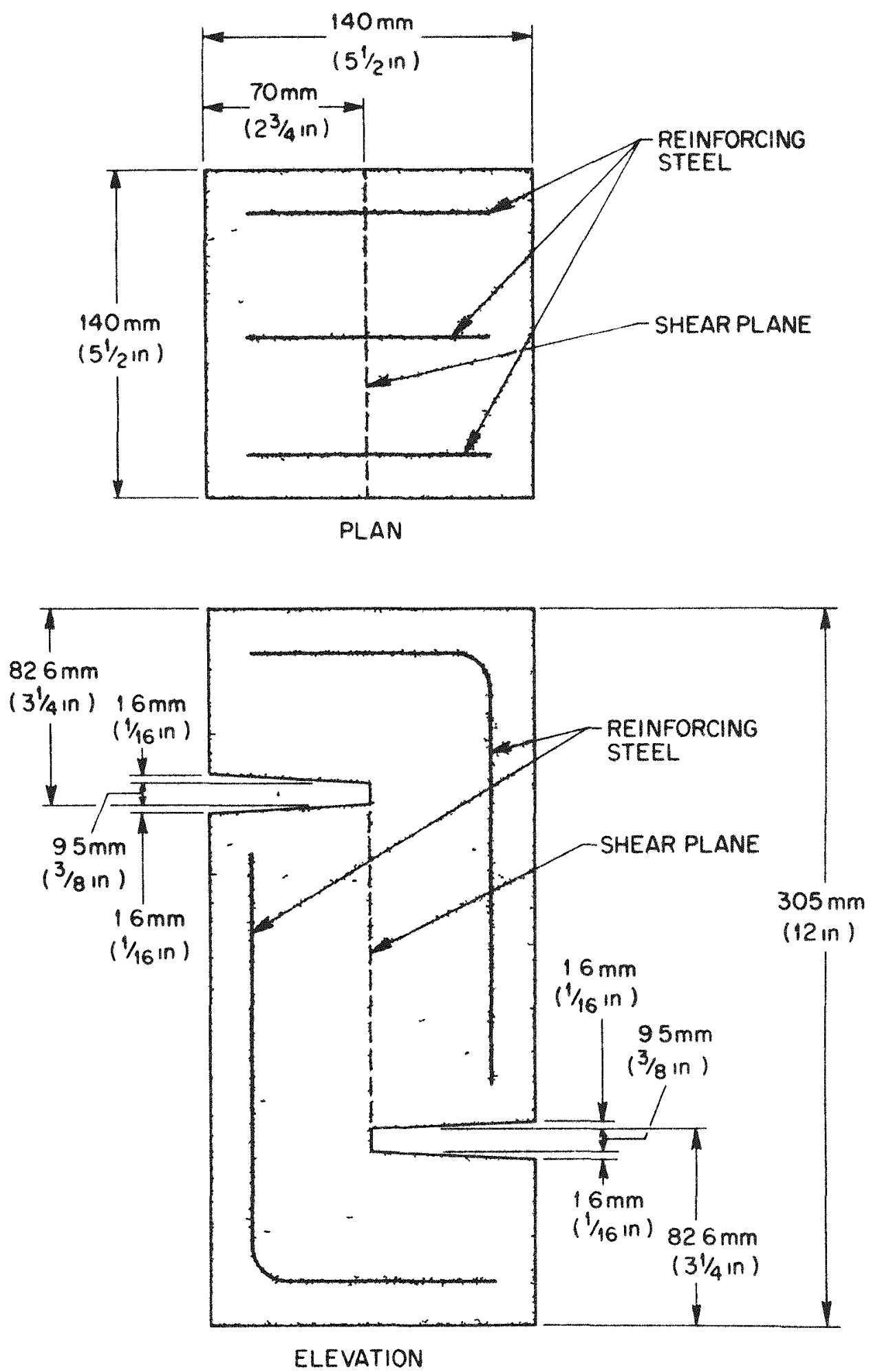

Fig. 7. S-shaped parallepiped shear test specimen. 
was to determine the effects of elevated temperature exposure on the shear strength of a limestone aggregate concrete. Temperatures of interest were $22.2,65.6,107.2,176.7,260,371.1,482.2$, and $621.1^{\circ} \mathrm{C}(72,150,225$, $350,500,700,900$, and $\left.1150^{\circ} \mathrm{F}\right)$. Testing of the specimens was initiated 60 to $90 \mathrm{~d}$ after casting using the following procedure:

1. Specimens were removed from the curing tank and weighed to obtain a saturated surface dry weight. The width $b$ and depth $d$ of the shear test section were measured. The specimen was then permitted to air-dry for 4 to $6 \mathrm{~h}$.

2. Controller and recorder thermocouples were inserted into a precast hole in the specimen and secured with a high-temperature adhesive, which was permitted to cure overnight.

3. The following day, each specimen was placed in its appropriate shear test furnace-platen assembly; extreme care was taken to ensure that the specimen was properly centered on its lower loading platen.

4. Controller, recorder, and alarm (positioned on oven interior wal1) thermocouples were attached to the appropriate lead wires.

5. Upper compression platens were centrally located on top of each test specimen, and Kaowool insulation was used to fill voids between the upper loading platens and furnace assemblies.

6. Heat-up of specimens was initiated at the specified rate of $17^{\circ} \mathrm{C} / \mathrm{h}\left(30^{\circ} \mathrm{F} / \mathrm{h}\right)$ using a programmable control system. Figure 8 presents the shear furnace assemblies during heat-up.

7. When a specimen reached its scheduled thermal stabilization temperature (day zero), the appropriate temperature controller was switched to the local mode of operation, and the set point was adjusted so that the temperature remained stationary $\left[11^{\circ} \mathrm{C}\left(20^{\circ} \mathrm{F}\right)\right.$ maximum deviation permitted].

8. At the conclusion of the 14-d thermal stabilization period, the furnace circuit breaker for the specimen to be tested was open-circuited, the thermocouple leads were disconnected, and the specimen was transferred to the compression testing machine and centered on the lower loading platen. The thermocouple leads were reconnected, the circuit breaker was closed, and the specimen was permitted to return to its thermal stabilization temperature. During the 5-min transfer operation, the specimen was 


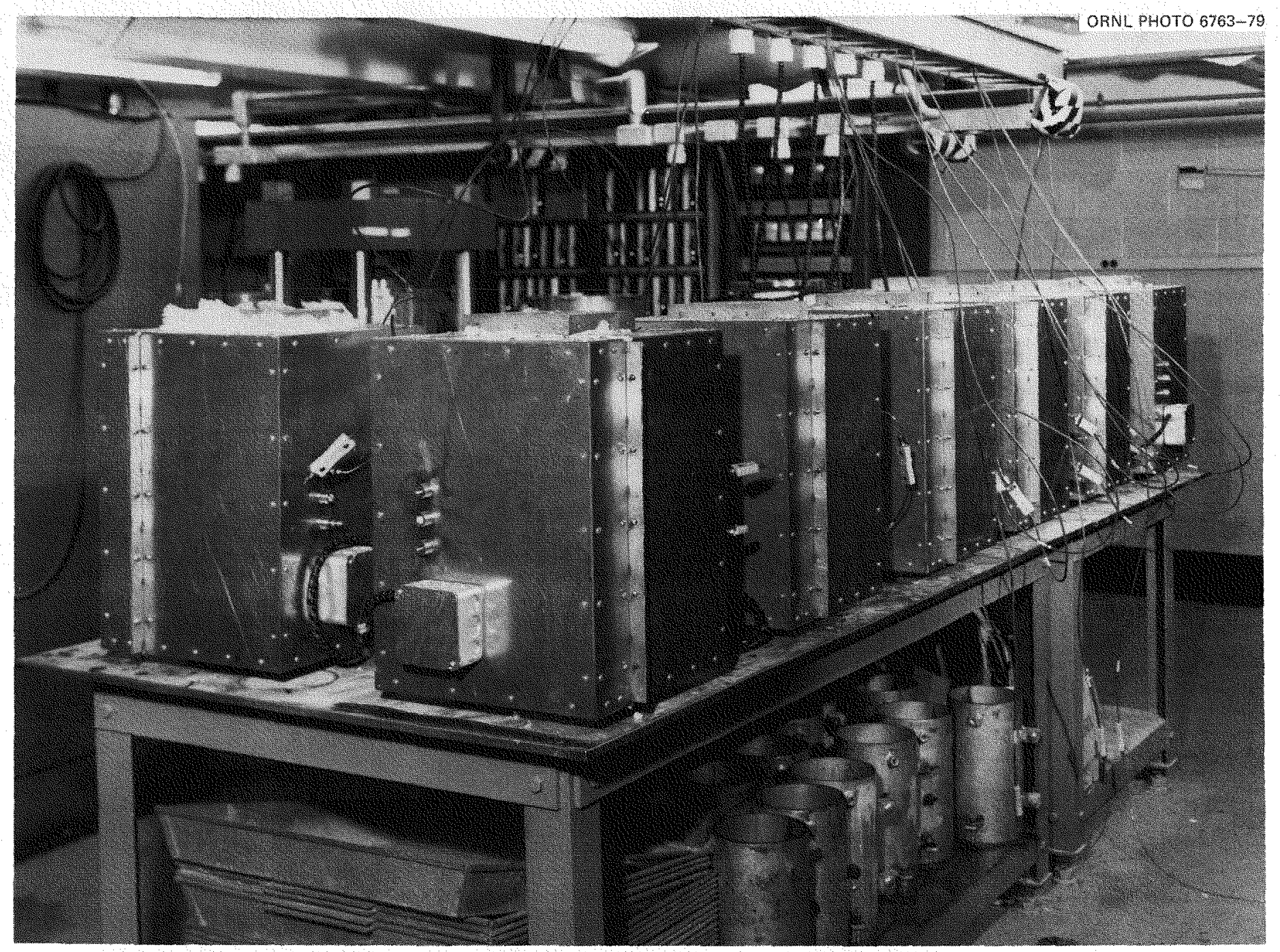

Fig. 8. Shear test furnaces during heat-up. 
not permitted to $\operatorname{coo} 1$ more than $11^{\circ} \mathrm{C}\left(20^{\circ} \mathrm{F}\right)$ before being reconnected with the heating element power source.

9. After the specimen returned to its designated thermal stabilization temperature, the testing machine load transducer output was zeroed, and the excitation of the Y1-channel (load) axis of the X-Y1-Y2 recorder was adjusted, so that a shunt calibration resistor produced a known signal output. The calibrated load output signal was noted on the recorder paper.

10. The $X$-channel axis of the $X-Y 1-Y 2$ recorder was set for a time base of $1970 \mathrm{~s} / \mathrm{m}(50 \mathrm{~s} / \mathrm{in}$.) of travel, so that a specimen loading rate could be established. The specimen number, test furnace number, thermal stabilization temperature, test date, and scales for the $X$ and $Y 1$ axes were noted on the recorder paper.

11. Load was applied to the specimen at a rate of $6.67 \mathrm{kN} / \mathrm{s}(1500$ $1 \mathrm{~b} / \mathrm{s}$ ) or less, until the maximum load was reached, and the load started to decrease; at this point, loading was stopped. Load vs time data were recorded during the entire loading history. As read from the testing machine dial, the maximum load applied Vu was noted and marked on the recorder paper.

12. The furnace circuit breaker was then open-circuited, all external oven connections were disconnected, and the furnace was removed from the testing machine. The upper loading platen was removed, and the specimen was taken from the furnace and placed on a scale to obtain an oven-dry weight. The oven-dry weight was noted on the recorder paper.

13. This procedure was repeated for each specimen of the test series.

14. The ultimate average shear stress Uu was then determined for each specimen using the following formula:

$$
\mathrm{Uu}=\frac{\mathrm{Vu}}{\mathrm{bd}}
$$

\subsection{Bond Pul1-Out Test Specimens}

The bond pu11-out tests were conducted using $0.30-\mathrm{m}\left(12-\mathrm{in}_{0}\right)$ standard weight concrete cubes containing No. 11 reinforcing bars of ANSI/ASTM A 615-78 grade 60 steel, which were embedded vertically in the concrete 
cubes. Figure 9 presents a bond pull-out test specimen before enclosure in the furnace. The objective of the test series was to determine the effect of elevated temperatures on the bond developed between the concrete and stee1. Temperatures of interest were 22.2, 65.6, 107.2, 176.7, 260, $371.1,482.2$, and $621.1^{\circ} \mathrm{C}\left(72,150,225,350,500,700,900\right.$, and $\left.1150^{\circ} \mathrm{F}\right)$. The test procedure developed for evaluating temperature effects is a modification of ANSI/ASTM C 234-71, Comparing Concretes on the Basis of the Bond Developed with Reinforcing Steel. Testing of the specimens was initiated 60 to $90 \mathrm{~d}$ after casting, using the following procedure:

1. The test specimen was removed from the curing tank when it was between 60 to $90 \mathrm{~d}$ old and placed into the loading frame. A $0.005-\mathrm{m}$ (0.19-in.) gap was provided between the specimen and lower test frame support platen to allow specimen venting during heat-up.

2. A displacement tranducer test fixture was attached to the test specimen such that the distance from the set screws of the fixture to the concrete surface was $0.46 \mathrm{~m}$ (18 $\mathrm{in}$.).

3. Controller and recorder thermocouples were placed in a precast hole in the specimen and secured with an elevated temperature adhesive. 4. On the following day, the furnace was assembled around the specimen, and specimen thermocouples were connected to their appropriate lead wires. Thermocouple positioning relative to the test specimen is shown in Fig. 10. Two additional thermocouples were attached to the furnace shell. and used as an over-temperature alarm sensor and as a readout for the furnace shell temperature. As a consequence of modifications, ${ }^{7}$ the thermocouple positioning was not consistent throughout the test series. Table 6 presents a listing of thermocouple positioning which was used for each concrete batch.

5. Specimen heat-up was initiated at the specified rate of $17^{\circ} \mathrm{C} / \mathrm{h}$ $\left(30^{\circ} \mathrm{F} / \mathrm{h}\right)$ using a programmable temperature control system. Figure 11 presents the bond pull-out furnace assembly during heat-up.

6. When the specimen reached a temperature of $177^{\circ} \mathrm{C}\left(350^{\circ} \mathrm{F}\right)$, the temperature was stabilized for $6 \mathrm{~h}$ to permit excess moisture to be driven from the test articles. After this period, insulation was installed between the furnace and insulating platens, and heating was resumed at the 


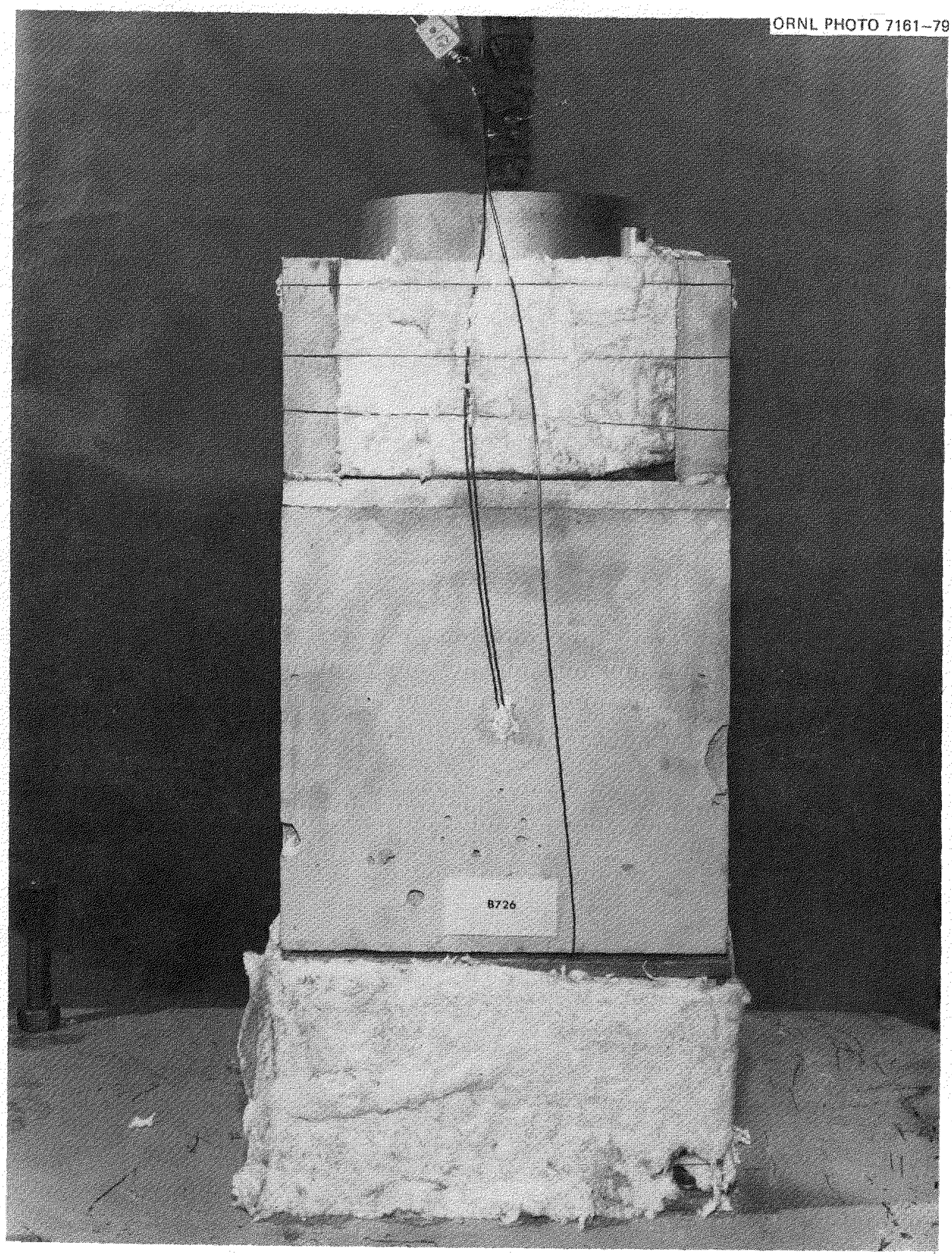

Fig. 9. Bond pull-out test specimen prior to placement in furnace. 


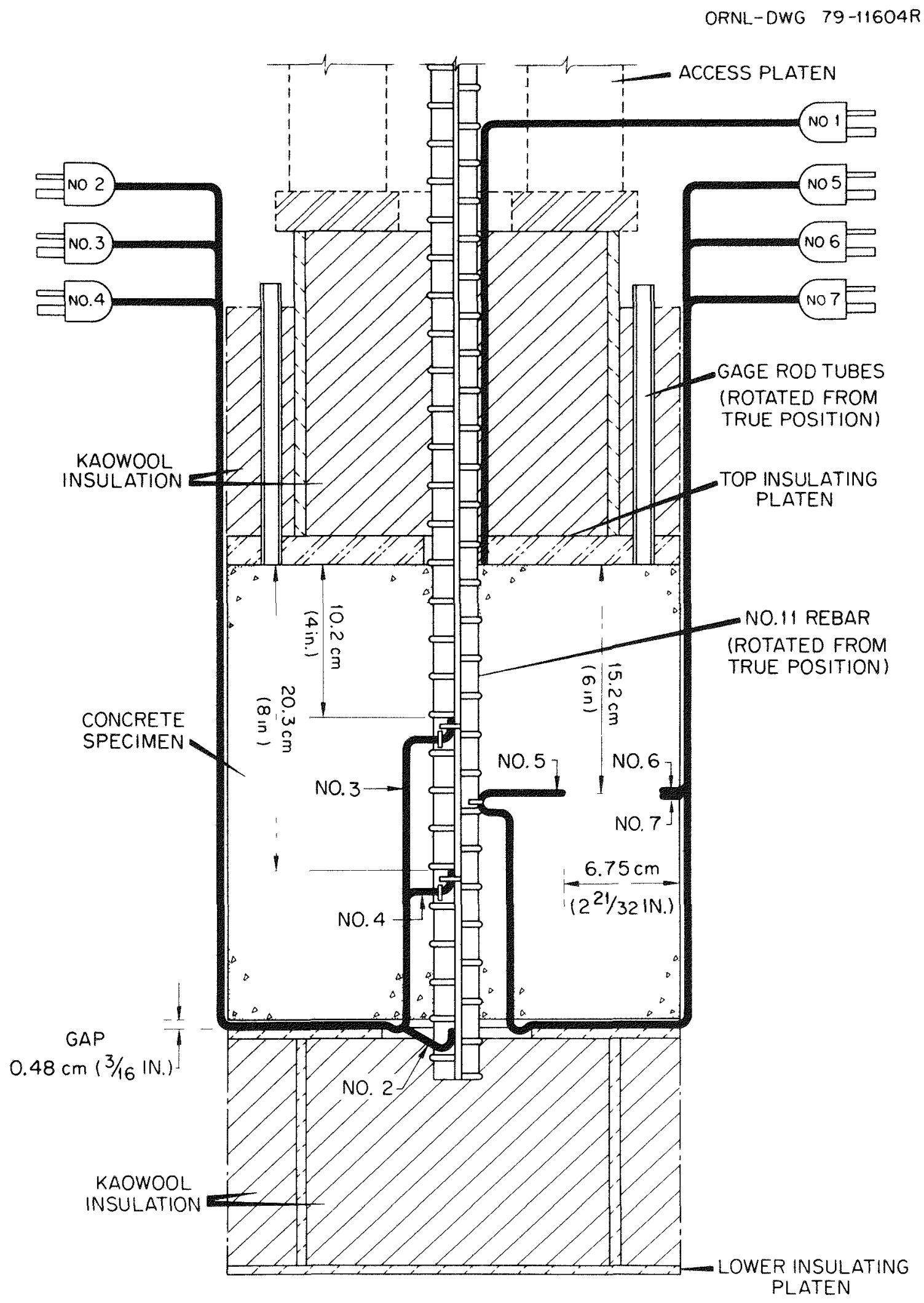

Fig. 10. Thermocouple locations in bond pul1-out specimens. 


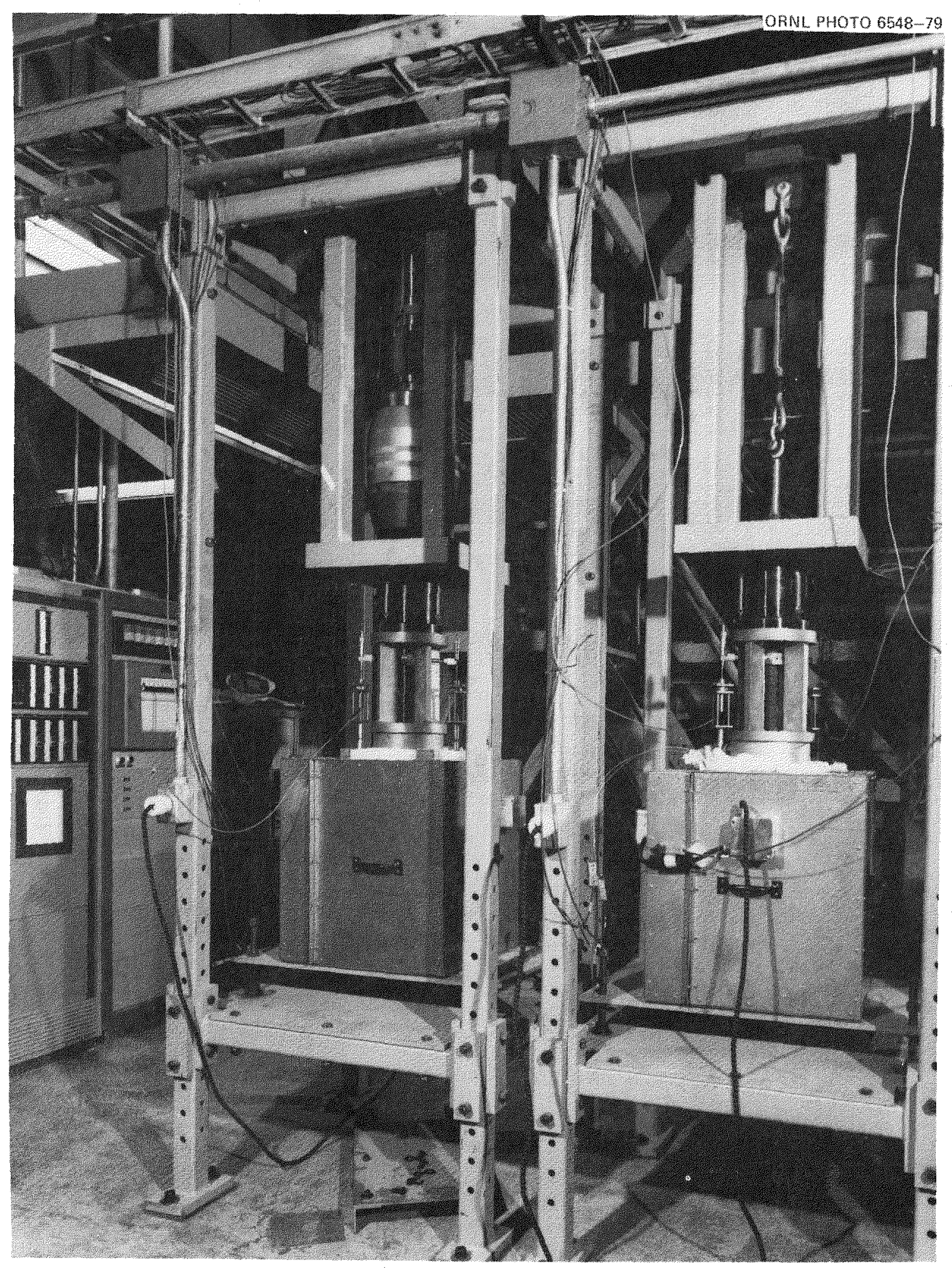

Fig. 11. Bond pul1-out furnaces during heat-up. 
Table 6. Bond pull-out test thermocouple listing

\begin{tabular}{cll}
\hline Thermocouple ${ }^{a}$ & \multicolumn{1}{c}{ Location } & $\begin{array}{c}\text { Applicable concrete } \\
\text { batch }\end{array}$ \\
\hline 1 & Top of specimen at rebar & $6,9,12,15,18-20$ \\
2 & Bottom of specimen at rebar & $6,9,12,15,18-20$ \\
3 & Upper third of rebar & 12,15 \\
4 & Lower third of rebar & 12,15 \\
5 & Midpoint of concrete & 12,15 \\
6 & Specimen surface (recorder) & $2,4,6,9,12,15,18-20$ \\
9 & Specimen surface (controller) & $2,4,6,9,12,15,18-20$ \\
9 & Furnace shel1 (alarm) & $2,4,6,9,12,15,18-20$
\end{tabular}

$a_{\text {Number }}$ as identified in Fig. 10.

rate of $17^{\circ} \mathrm{C} / \mathrm{h}\left(30^{\circ} \mathrm{F} / \mathrm{h}\right)$, until the desired thermal stabilization temperature was reached. [This step was omitted for specimens having a thermal stabilization temperature less than $\left.177^{\circ} \mathrm{C}\left(350^{\circ} \mathrm{F}\right)\right]$.

7. When a specimen reached its scheduled thermal stabilization temperature (day zero), the appropriate temperature controller was switched to the local mode of operation, and the set point was adjusted so that the test temperature remained stationary $\left[11^{\circ} \mathrm{C}\left(20^{\circ} \mathrm{F}\right)\right.$ maximum deviation permitted].

8. At the conclusion of the 14-d thermal stabilization period, the load cell contained in the test system was calibrated using a shunt resistor, which was sized to produce a known output (calibrated load). The gain on the $\mathrm{X}$-axis of the $\mathrm{X}-\mathrm{Y} 1-\mathrm{Y} 2$ recorder was adjusted so that this output corresponded to $1.75 \mathrm{MN} / \mathrm{m}$ (10 kips/in.) of recorder paper. The load calibration was shown on the recorder paper.

9. The reinforcing bar was gripped by the electrohydraulic servovalve test system, and a preload of 0.89 to $4.45 \mathrm{kN}(200$ to $1000 \mathrm{lb}$ ) was applied to the specimen. Figure 12 presents a schematic of the bond pul1out test rig. 


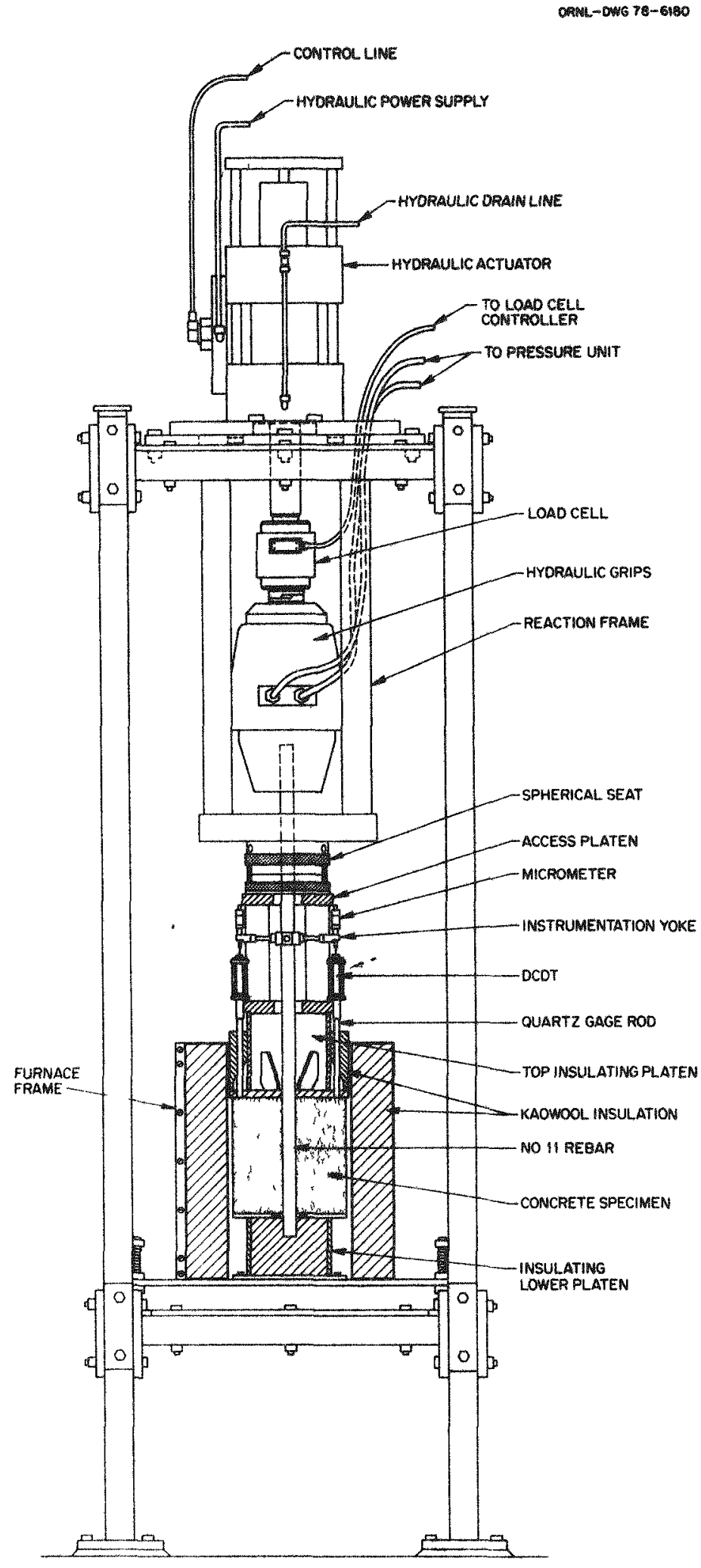

Fig. 12. Bond pull-out test fixture schematic. 
10. The two DCDTs measuring gross rebar deformation with respect to the concrete cube were calibrated, by adjustment of the excitation of the Y1- and Y2-channel of the X-Y1-Y2 recorder, to produce a signal output for a known displacement; the displacement was input by precalibrated micrometers built into the test apparatus. Calibrated displacement outputs were noted on the recorder paper.

11. The specimen identification number and test date were noted on the recorder paper.

12. Load was applied to the specimen at a rate of $0.35 \mathrm{MPa} / \mathrm{s}$ (50 psi/s) or less, until the rebar yielded, the concrete failed, or a load of $445 \mathrm{kN}(100,000 \mathrm{1b})$ was reached. A continuous record of load vs displacement data was obtained during the test.

13. The furnace circuit breaker was open-circuited, al1 external oven connections were disconnected, and the specimen was permitted to cool to ambient temperature. Upon cooling, the furnace was removed, and the specimen was examined for cracking or unusual modes of fallure.

14. This procedure was repeated for each specimen of the test serles.

\section{5 Sustained Load Test Specimens}

Sustained load (creep) tests were conducted on limestone aggregate concrete cylindrical specimens $0.15 \mathrm{~m} \mathrm{diam}$ by $0.30 \mathrm{~m}$ (6 in. by $12 \mathrm{in.}$ ). The objective of the tests was to determine the deformational behavior of a limestone aggregate concrete under sustained loading at elevated temperature. Temperatures of interest were $65.6,107.2,260$, and $537.8^{\circ} \mathrm{C}$ $\left(150,225,500,1000^{\circ} \mathrm{F}\right)$. Sustained loads represented either $20 \%$ (260 and $537.8^{\circ} \mathrm{C}$ exposure) or $50 \%\left(65.6,107.2\right.$, and $537.8^{\circ} \mathrm{C}$ exposure) of the reference design, 28-d, unconfined, ultimate compressive strength of $31.72 \mathrm{MPa}$ (4600 psi). Testing of the specimens was initiaed 60 to $90 \mathrm{~d}$ after casting using the following procedure:

1. Standard weight test specimens were removed from the curing tank, weighed to obtain a saturated surface dry weight, and permitted to afr-dry for 4 to $6 \mathrm{~h}$. 
2. Thermocouples for the alarm and controller were inserted into a precast hole in the specimen and secured with an elevated temperature adhesive.

3. The load cell was calibrated using a shunt resistor sized to produce a known output (calibrated load) for a given excitation. The strip chart recorder was adjusted so that a 44.5-kN (10,000-1b) load corresponded to a $0.025-\mathrm{m}(1-\mathrm{in}$.$) movement of the recorder stylus, and the$ load calibration was noted.

4. Lead weights were added to the bucket of the creep test loading rig, which had been designed to conform to the basic requirements of ANSI/ ASTM C 512-76 (Fig. 13). The total welght added to the bucket of a particular test rig (mechanical advantage of 16:1) was such that it imposed a specimen loading of either 20 or $50 \%$ of the $28-\mathrm{d}$, concrete, reference design, compressive strength of $31.72 \mathrm{MPa}$ (4600 psi).

5. On the day following operation of steps 1 through 4 , the specimen was placed into the loading rig, and between $2.2 \mathrm{kN}(5001 \mathrm{~b})$ and $8.90 \mathrm{kN}$ (2000 1b) of preloading was applied.

6. The furnace was placed around the specimen. The controller, recorder, and alarm thermocouples were attached to the appropriate lead wires, and the displacement transducer test fixture was attached to determine total end-to-end specimen length changes. Figure 14 presents a close-up of the furnace and displacement transducer test fixture in place.

7. The DCDT in the displacement transducer test fixture was calibrated, by adjustment of the transducer amplifier gain, to produce a signal output for a known displacement; the displacement was input by a precalibrated micrometer built into the test apparatus. Displacement transducer calibration was noted.

8. The chart speed of the strip chart recorder was set to 0.051 $\mathrm{m} / \mathrm{min}(2 \mathrm{in} . / \mathrm{min}$ ). The hydraulic jack was operated to adjust the weight bucket's vertical position and to transfer complete deadweight loading to the specimen. The collar of the hydraulic jack was locked, and the hydraulic oll pressure was vented. The times when the load was transferred and when the specimen reached the desired load were noted on the strip chart recorder paper. Chart speed was then changed to $0.025 \mathrm{~m} / \mathrm{h}$ (1 in./h). 

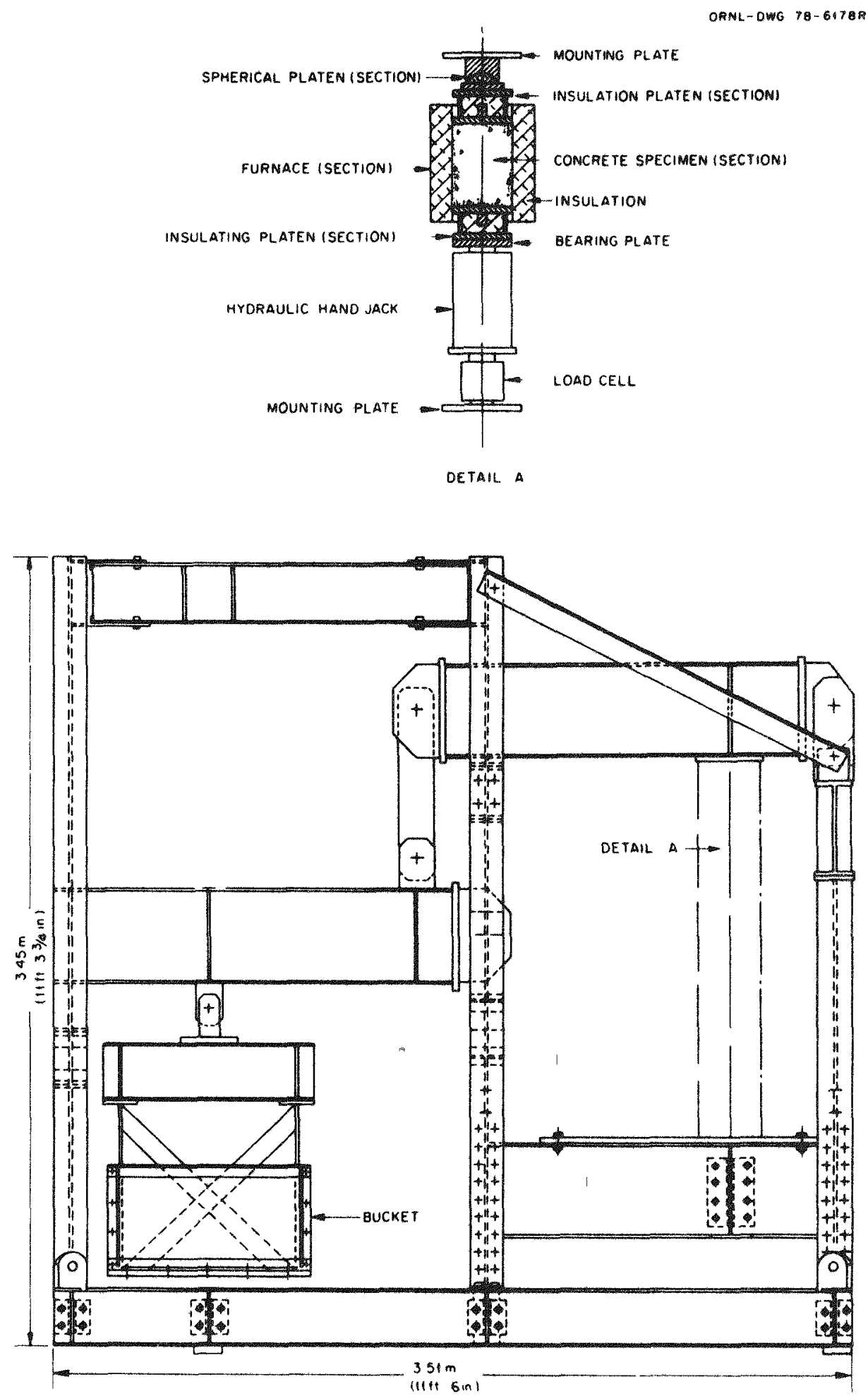

Fig. 13. Sustained load test fixture schematic. 


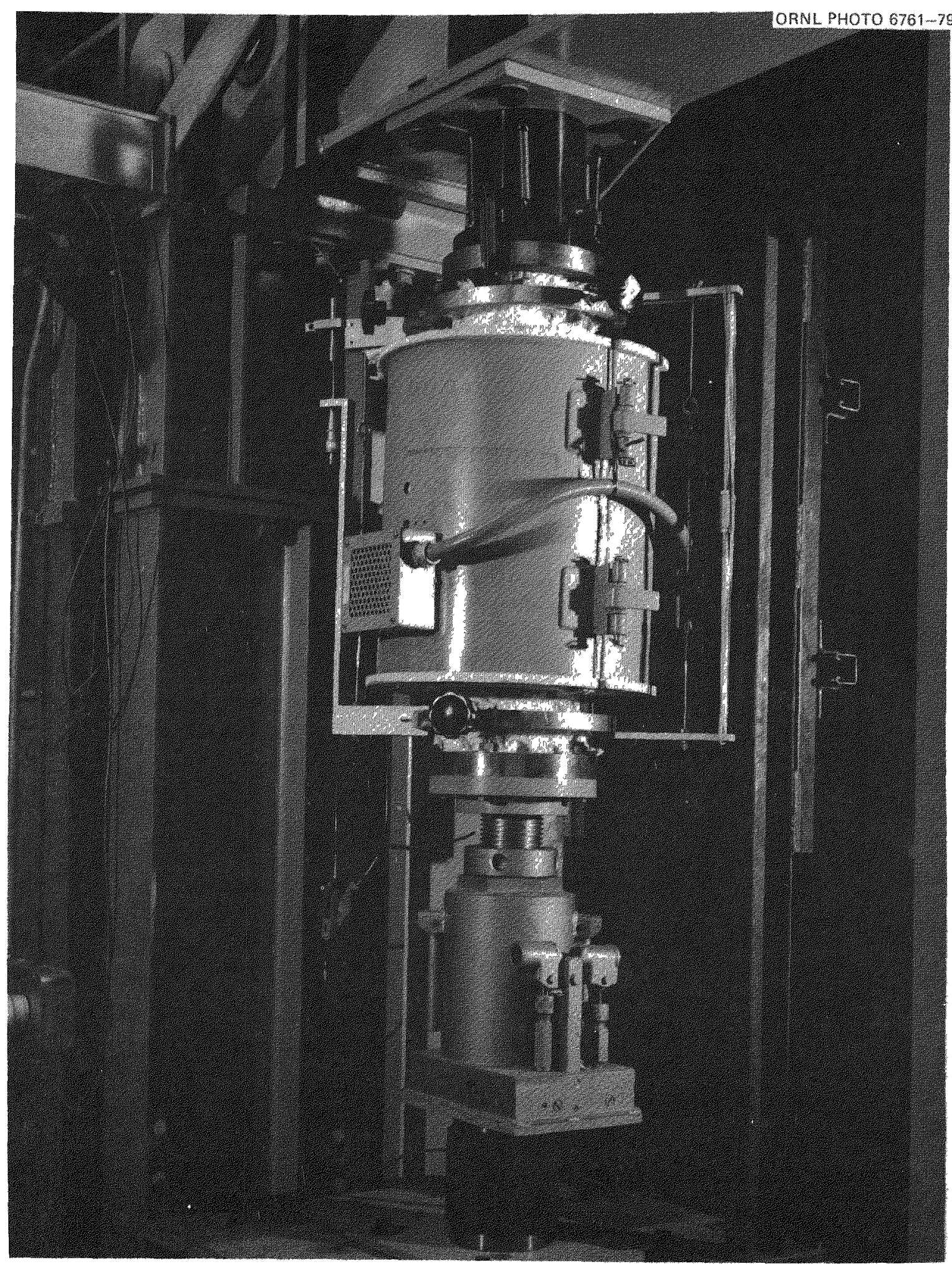

Fig. 14. Close-up of furnace and displacement transducer for sustained load tests. 
9. Specimen heat-up was initiated at the specified rate of $17^{\circ} \mathrm{C} / \mathrm{h}$ $\left(30^{\circ} \mathrm{F} / \mathrm{h}\right)$ using a programmable control system. Figure 15 presents an overall view of the creep rig test fixture during specimen heat-up.

10. When a specimen reached its scheduled thermal stabilization temperature (day zero), the appropriate temperature controller was switched to the local mode of operation, and the set point was adjusted so that the test temperature remained stationary $\left[11^{\circ} \mathrm{C}\left(20^{\circ} \mathrm{F}\right)\right.$ maximum deviation permitted].

11. At the end of the 60-d testing period, the specimen was permitted to cool slowly to ambient temperature. Load and specimen length changes and temperatures were monitored continuously throughout the heat-up, thermal stabilization, and cooling phases. Upon cooling, the furnace was removed, the specimen was examined, any abnormalities were noted, and an oven-dry weight was obtained.

12. This procedure was repeated for each specimen of the test series. Table 7 presents a summary of specimen load-temperature combinations which were investigated.

Table 7. Sustained load test parameter summary for limestone aggregate concrete

\begin{tabular}{|c|c|c|}
\hline $\begin{array}{l}\text { Creep test } \\
\text { rig }\end{array}$ & $\begin{array}{c}\text { Thermal stabilization } \\
\text { temperature } \\
{\left[{ }^{\circ} \mathrm{C}\left({ }^{\circ} \mathrm{F}\right)\right]}\end{array}$ & $\begin{array}{l}\text { Sustained stress } \\
(\% 28-d \text { reference } \\
\text { strength })^{a}\end{array}$ \\
\hline 1 & $260(500)$ & 50 \\
\hline 2 & $107.2(225)$ & 50 \\
\hline 3 & $537.8(1000)$ & 20 \\
\hline 4 & $260(500)$ & 20 \\
\hline 5 & $65.6(150)$ & 50 \\
\hline
\end{tabular}




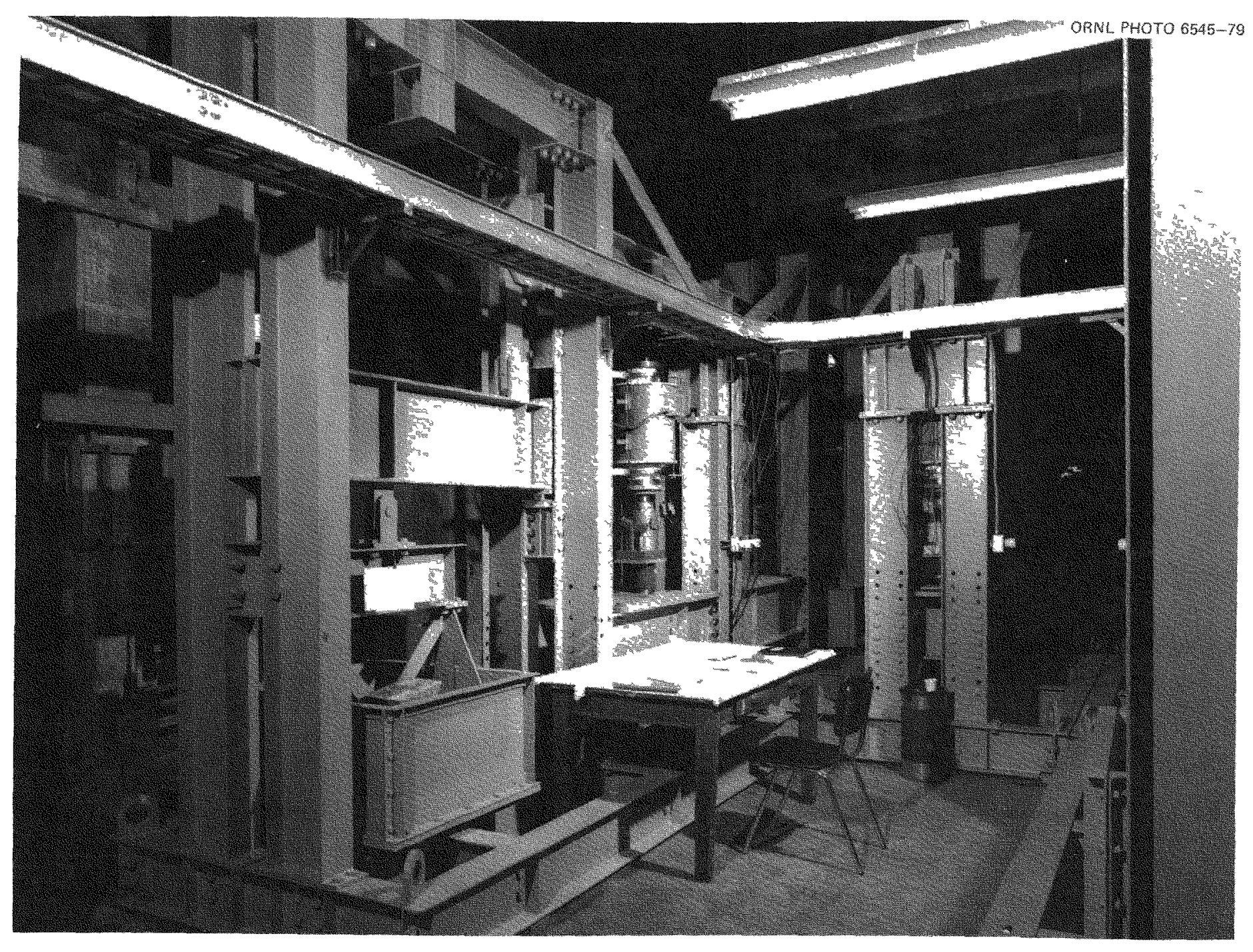

Fig. 15. Sustained load test rig during specimen heat-up. 


\section{SPECIMEN TEST RESULTS}

\subsection{Control Specimens}

Control specimens were tested for 21 batches (16 standard weight concrete, 5 lightweight concrete) using procedures previously described. Average values for compressive strength, modulus of elasticity, Poisson's ratio, microstrain at ultimate stress, and air-dry density (1ightweight concrete only) are summarized in Table 8. Figures B.1 through B.75 (Appendix B) present stress-strain curves for each control specimen tested.

\subsection{Unconfined Compression Test Specimens}

Open-hot unconfined compression tests were conducted at a concrete age of $62 \pm 2 \mathrm{~d}$ on 3 batches $(1,3$, and 5 ) of standard weight and 4 batches $(8,11,14$, and 17) of lightweight concretes, after they had been subjected to a specified series of discrete thermal stabilization temperatures for either 14- or 28-d (standard weight concretes only) exposures. Test results for the standard weight and lightweight concretes are summarized in Tables 9 and 10 respectively.* The effect of thermal stabilization temperature on ultimate compressive strength and modulus of elasticity, as a function of 28-d control reference values, is present in Figs. 16 through 17 and 18 through 19 for the standard weight and lightweight concretes respectively. Figures 20 and 21 present the effect of thermal stabilization temperture on strength and modulus respectively of the standard weight concrete as a function of 60-d control reference values. $^{\dagger}$ Figures 22 through 23 and 24 through 25 present the microstrain at ultimate strength and percent weight loss, as a function of thermal stabilization temperature, for the standard weight and lightweight concrete respectively. The effect of thermal stabilization temperature of the standard weight concretes on Poisson's ratio is presented in Fig. 26.

\footnotetext{
*Stress-strain curves and temperature history during the thermal stabilization period for each standard weight and each lightweight concrete test specimen are contained in Appendix $C$.

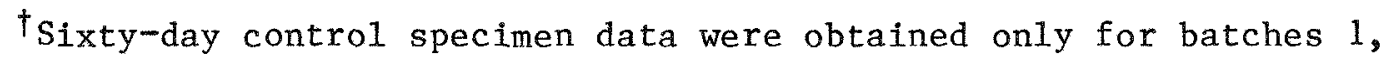
5,10 , and 13 .
} 
Table 8. Summary of control specimen test results (28-d values)

\begin{tabular}{|c|c|c|c|c|c|c|}
\hline Batch & $\begin{array}{l}\text { Type of } \\
\text { specimens } \\
\text { cast }\end{array}$ & $\begin{array}{l}\text { Average } \\
\text { compressive } \\
\text { strength } \\
{[\mathrm{MPa}(\mathrm{psi})]}\end{array}$ & $\begin{array}{c}\text { Average modulus } \\
\text { of elasticity } \\
{[\mathrm{GPa} \text { (ksi)] }}\end{array}$ & $\begin{array}{l}\text { Average } \\
\text { Poisson's } \\
\text { ratio }\end{array}$ & $\begin{array}{l}\text { Microstrain } \\
\text { at ultinate } \\
\text { stress }\end{array}$ & $\begin{array}{l}\text { Air-dry density } \\
{\left[\mathrm{kg} / \mathrm{m}^{3}\left(1 \mathrm{~b} / \mathrm{ft}^{3}\right)\right]^{b}}\end{array}$ \\
\hline 1 & $S, T, C$ & $28.90(4190)$ & $29.60(4300)$ & 0.21 & 1640 & \\
\hline 2 & $B$ & $35.00(5080)$ & $31.10(4500)$ & 0.20 & 1720 & \\
\hline 3 & $\mathrm{~S}, \mathrm{~T}$ & $26.50(3840)$ & $26.90(3900)$ & 0.20 & 1740 & \\
\hline 4 & $B$ & $32.00(4640)$ & $28.60(4150)$ & 0.21 & 1950 & \\
\hline 5 & $\mathrm{~S}, \mathrm{~T}, \mathrm{C}$ & $37.15(5390)$ & $33.20(4800)$ & 0.22 & 1880 & \\
\hline 6 & $\mathrm{~B}$ & $35.30(5120)$ & $32.70(4750)$ & 0.22 & 1840 & \\
\hline 7 & $V$ & $36.75(5330)$ & $35.10(5100)$ & 0.22 & 1830 & \\
\hline 8 & $\mathbf{L}$ & $8.95(1300)$ & $6.20 \quad(900)$ & 0.20 & 2270 & $1220(76.0)$ \\
\hline 9 & B & $37.05(5370)$ & $33.10(4800)$ & 0.21 & 1890 & \\
\hline 10 & $\mathrm{~V}, \mathrm{C}$ & $37.15(5390)$ & $32.80(4750)$ & 0.22 & 1970 & \\
\hline 11 & $\mathrm{~L}$ & $9.00(1310)$ & $5.40 \quad(800)$ & 0.19 & 2670 & $1150(72.1)$ \\
\hline 12 & $B$ & $34.10(4940)$ & $32.90(4750)$ & 0.21 & 1750 & \\
\hline 13 & $\mathrm{~V}$ & $36.05(5230)$ & $32.80(4750)$ & 0.21 & 1950 & \\
\hline 14 & $\mathbf{L}$ & $8.95(1300)$ & $5.60 \quad(800)$ & 0.21 & 2570 & $1160(72.5)$ \\
\hline 15 & $B$ & $35.65(5170)$ & $34.20(4950)$ & 0.23 & 1860 & \\
\hline 16 & $A S, G S, H S$ & $37.90(5500)$ & $34.50(5000)$ & 0.23 & 1880 & \\
\hline 17 & $\mathrm{~L}$ & $11.65(1700)$ & $7.50(1050)$ & 0.21 & 2750 & $1280(80.0)$ \\
\hline 18 & B & $37.00(5370)$ & $32.40(4700)$ & 0.21 & 1940 & \\
\hline $19^{\circ}$ & B & $31.40(4550)$ & $30.30(4400)$ & 0.22 & 1800 & \\
\hline 20 & B & $34.60(5020)$ & $34.60(5000)$ & 0.23 & 1860 & \\
\hline 21 & $A L, G L, H L$ & $11.00(1600)$ & $6.90(1000)$ & 0.20 & 2360 & $1290(80.4)$ \\
\hline
\end{tabular}

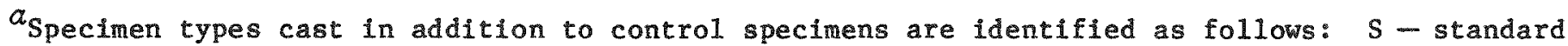
welght compression, 14-d heat soak; T - standard welght compression, 28-d heat soak; L - lightwelght compression; $C$ - sustained load (creep); $V$ - shear; B - bond pul1-out; AS - coefficient of thermal expansion, standard weight; AL - coeffecient of thermal expansion, Iightweight; GS - thermal conductivity, standard weight; GL - thermal conductivity, lightweight; HS - thermal diffusivity, standard weight; and HL - thermal diffusivity, lightweight.

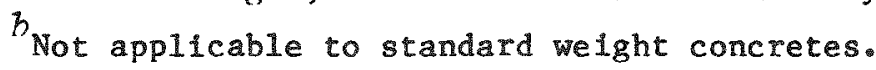

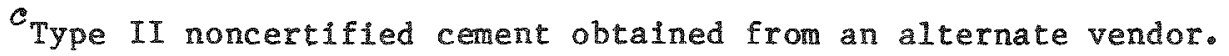


Table 9. Standard weight concrete unconfined compression test result surnmary

Thermal stabllization intiated at an age of $62 \pm 2 d$

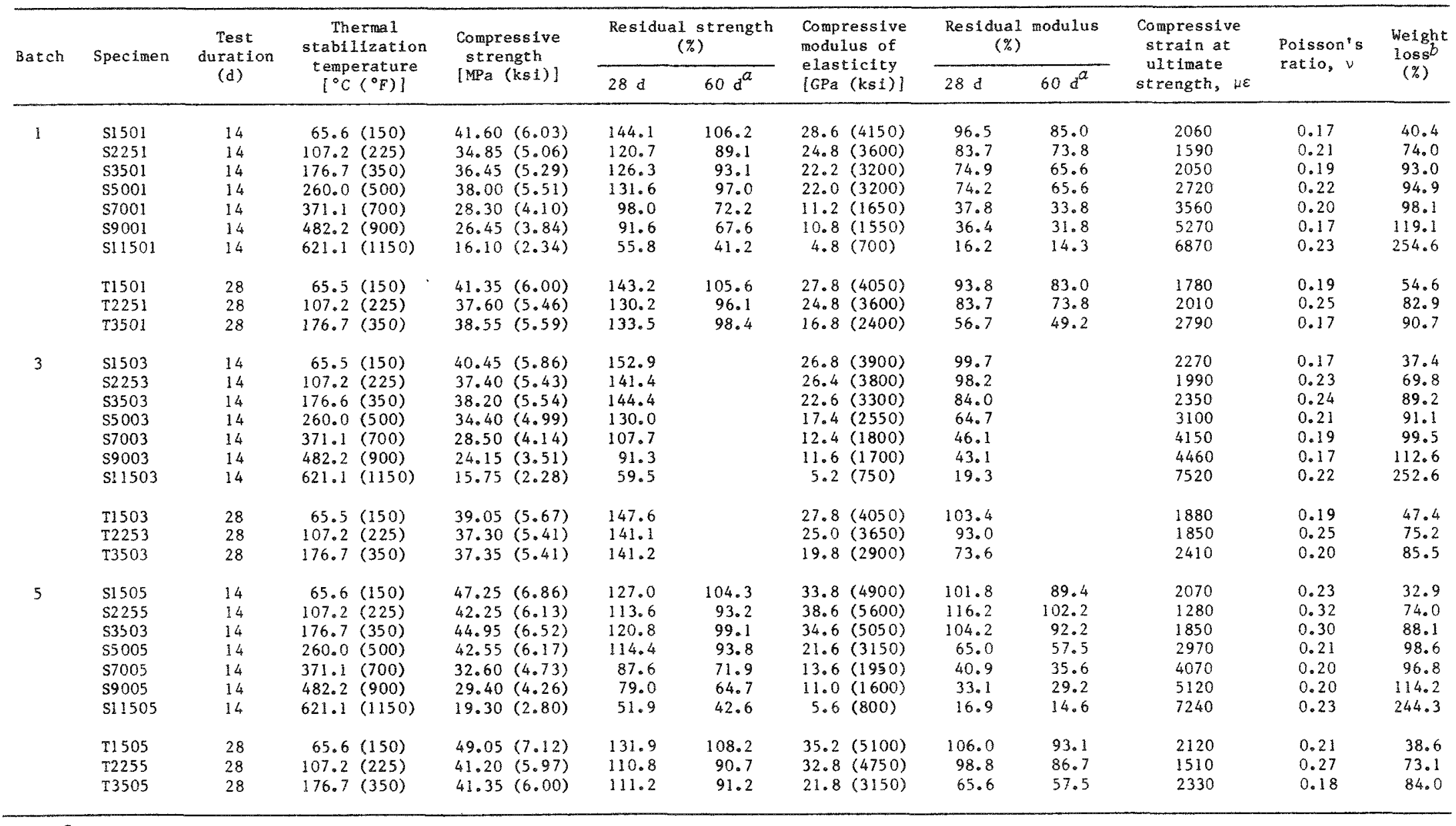

a Data avallable for batches 1 and 5 only.

$b_{\text {Percent weight }}$ loss $=\left(\right.$ WSSD $\left._{\text {- WOD }}\right) /$ W $_{\mathrm{T}} \times 100 \%$, where $\mathrm{W}_{S S D}$ is saturated surface dry weight of specimen just prior to heat-up, wOD is specimen weight at test conclusion, and $W_{T}$ is total weight of water contained in specimen at times of tixing (specimen volume times wet-unit welght times mixwater weight divided by total weight of mix material). 
Table 10. Lightweight concrete unconfined compression test result summary

14-d thermal stabilization period

\begin{tabular}{|c|c|c|c|c|c|c|c|c|}
\hline Batch & Specimen & $\begin{array}{c}\text { Thermal } \\
\text { stabilization } \\
\text { temperature } \\
{\left[{ }^{\circ} \mathrm{C}\left({ }^{\circ} \mathrm{F}\right)\right]}\end{array}$ & $\begin{array}{c}\text { Compressive } \\
\text { strength } \\
{[\mathrm{MPa}(\mathrm{ksi})]}\end{array}$ & $\begin{array}{l}\text { Strength } \\
\text { retention } b \\
(\%)\end{array}$ & $\begin{array}{l}\text { Compressive } \\
\text { modulus of } \\
\text { elasticity } \\
{[G P a(k s i)]}\end{array}$ & $\begin{array}{l}\text { Residual } \\
\text { modulus } b \\
(\%)\end{array}$ & $\begin{array}{l}\text { Compressive } \\
\text { strain at } \\
\text { ultimate } \\
\text { strength, we }\end{array}$ & $\begin{array}{l}\text { Welght } \\
\text { loss } c \\
(\%)\end{array}$ \\
\hline 8 & $\begin{array}{l}\text { L } 1508 \\
\text { L2258 } \\
\text { L3508 } \\
\text { L5008 } \\
\text { L7008 } \\
\text { L9008 }\end{array}$ & $\begin{array}{r}65.6(150) \\
107.2(225) \\
176.7(350) \\
260.0(500) \\
371.1(700) \\
482.2(900)\end{array}$ & $\begin{array}{r}10.15(1.47) \\
10.45(1.51) \\
9.95(1.44) \\
9.95(1.38) \\
7.35(1.06) \\
7.75(1.13)\end{array}$ & $\begin{array}{r}114.7 \\
118.1 \\
112.5 \\
108.0 \\
83.1 \\
87.6\end{array}$ & $\begin{array}{l}5.0(700) \\
4.4(650) \\
3.6(550) \\
3.0(400) \\
2.4(350) \\
2.0(300)\end{array}$ & $\begin{array}{l}82.1 \\
72.3 \\
59.1 \\
49.3 \\
39.4 \\
32.9\end{array}$ & $\begin{array}{l}2570 \\
2830 \\
3280 \\
4070 \\
4080 \\
5080\end{array}$ & $\begin{array}{r}42.7 \\
69.9 \\
81.6 \\
90.0 \\
99.6 \\
117.3\end{array}$ \\
\hline 11 & $\begin{array}{l}\text { L15011 } \\
\text { L22511 } \\
\text { L35011 } \\
\text { L50011 } \\
\text { L70011 } \\
\text { L90011 }\end{array}$ & $\begin{aligned} 65.6 & (150) \\
107.2 & (225) \\
176.7 & (350) \\
260.0 & (500) \\
371.1 & (700) \\
482.2 & (900)\end{aligned}$ & $\begin{array}{l}9.70(1.41) \\
9.50(1.38) \\
8.80(1.28) \\
9.15(1.33) \\
7.30(1.06) \\
6.85(0.99)\end{array}$ & $\begin{array}{r}107.5 \\
105.3 \\
97.5 \\
101.4 \\
80.9 \\
75.9\end{array}$ & $\begin{array}{l}5.0(700) \\
3.6(500) \\
3.6(550) \\
2.8(400) \\
2.6(350) \\
2.0(300)\end{array}$ & $\begin{array}{l}92.6 \\
66.7 \\
66.7 \\
51.9 \\
48.2 \\
37.0\end{array}$ & $\begin{array}{l}2390 \\
3110 \\
2820 \\
4100 \\
3970 \\
4100\end{array}$ & $\begin{array}{r}51.5 \\
69.9 \\
82.6 \\
85.8 \\
94.4 \\
112.8\end{array}$ \\
\hline 14 & $\begin{array}{l}\text { L15014 } \\
\text { L22514 } \\
\text { L35014 } \\
\text { L50014 } \\
L 70014 \\
\text { L90014 }\end{array}$ & $\begin{aligned} 65.6 & (150) \\
107.2 & (225) \\
176.7 & (350) \\
260.0 & (500) \\
371.1 & (700) \\
482.2 & (900)\end{aligned}$ & $\begin{array}{l}9.25(1.34) \\
8.90(1.29) \\
8.85(1.29) \\
8.05(1.17) \\
6.75(0.98) \\
6.90(1.00)\end{array}$ & $\begin{array}{r}103.0 \\
99.1 \\
98.6 \\
89.7 \\
75.2 \\
76.9\end{array}$ & $\begin{array}{l}4.2(600) \\
3.4(500) \\
3.6(500) \\
2.8(400) \\
2.0(300) \\
1.8(250)\end{array}$ & $\begin{array}{l}74.6 \\
60.4 \\
63.9 \\
49.7 \\
35.5 \\
32.0\end{array}$ & $\begin{array}{l}2550 \\
2990 \\
3100 \\
3550 \\
4170 \\
5000\end{array}$ & $\begin{array}{r}43.8 \\
75.0 \\
78.2 \\
91.7 \\
98.7 \\
107.4\end{array}$ \\
\hline 17 & $\begin{array}{l}\text { L15017 } \\
\text { L22517 } \\
\text { L35017 } \\
\text { L50017 } \\
\text { L70017 } \\
\text { L90017 }\end{array}$ & 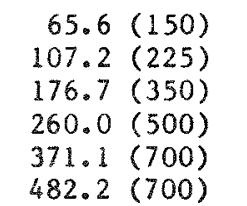 & $\begin{array}{r}11.65(1.69) \\
11.80(1.71) \\
11.65(1.69) \\
10.20(1.48) \\
8.85(1.28) \\
8.55(1.24)\end{array}$ & $\begin{array}{r}99.8 \\
101.1 \\
99.8 \\
87.4 \\
75.8 \\
73.2\end{array}$ & $\begin{array}{ll}5.8 & (850) \\
4.6 & (650) \\
4.2 & (600) \\
3.2 & (450) \\
2.8 & (400) \\
2.4 & (350)\end{array}$ & $\begin{array}{l}80.3 \\
63.7 \\
58.1 \\
44.3 \\
38.7 \\
33.2\end{array}$ & $\begin{array}{l}2260 \\
2920 \\
3300 \\
4030 \\
4430 \\
4480\end{array}$ & $\begin{array}{r}55.2 \\
78.2 \\
89.9 \\
99.6 \\
105.7 \\
100.7\end{array}$ \\
\hline
\end{tabular}

Heat-up infitated at an age of $62 \pm 2 \mathrm{~d}$.

$b_{\text {Relative to } 28-d \text { value. }}$

$c_{\text {Percent weight loss }}=\left(W_{A D}-W_{O D}\right) /\left[W_{T}-\left(W_{S S D}-W_{A D}\right)\right] \times 100 \%$, where $W_{A D}$ is air-dry weight of specimen at initiation of thermal stabilization test. $W_{O D}$ is oven-dry weight of specimen at test conclusion, $W_{T}$ is total weight of water contained in specimen at time of mixing (specimen volume times wet-unit weight times mix-water weight divided by total weight of mix materials, and WSSD is saturated surface weight of specimen. WSSD - WAD is weight of water lost due to air-drying. 
CRBR MIGH TEMPERATURE CONCRETE TESTS

EFFECT OF TEMPERATURE ON COMPRESSIVE STRENGTH

STANDARD WEIGHT CONCRETE - 14 DAY SUSTAINED HEATING

TEMPERATURE (F)

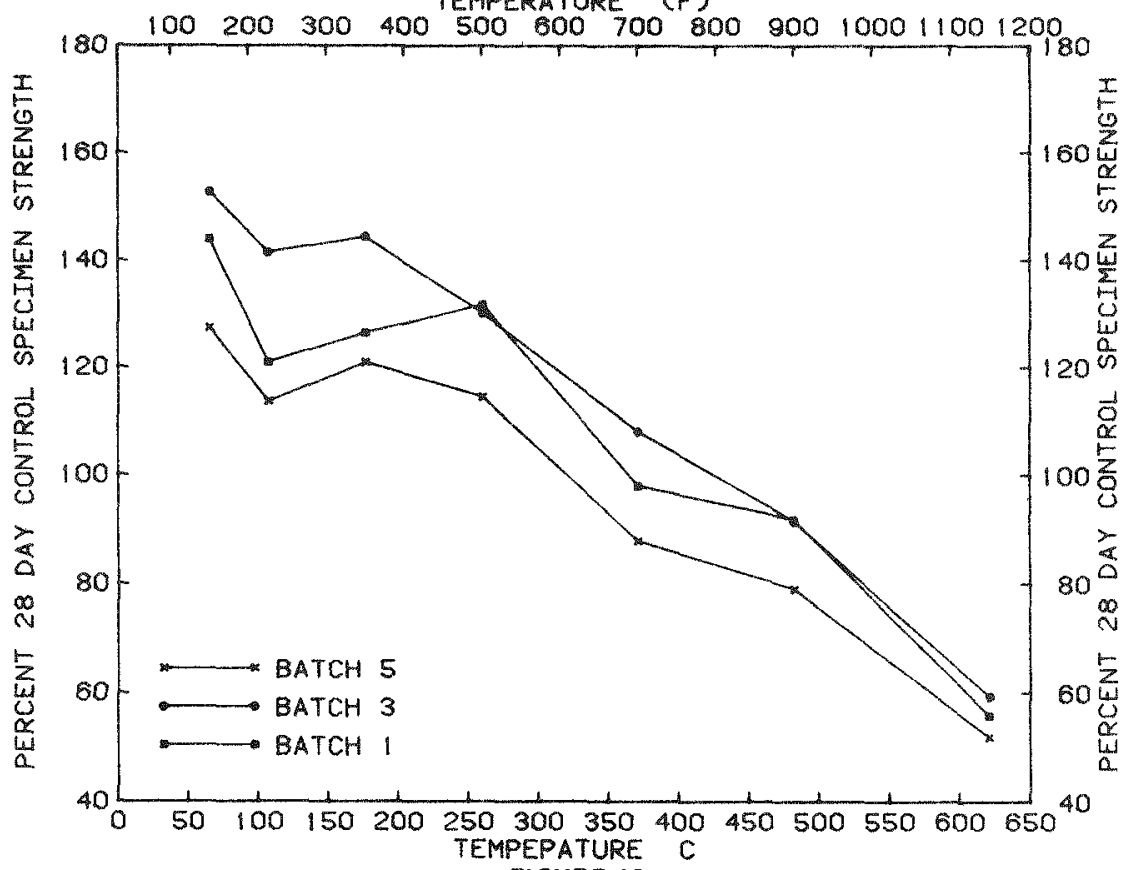

FIGUAE 16

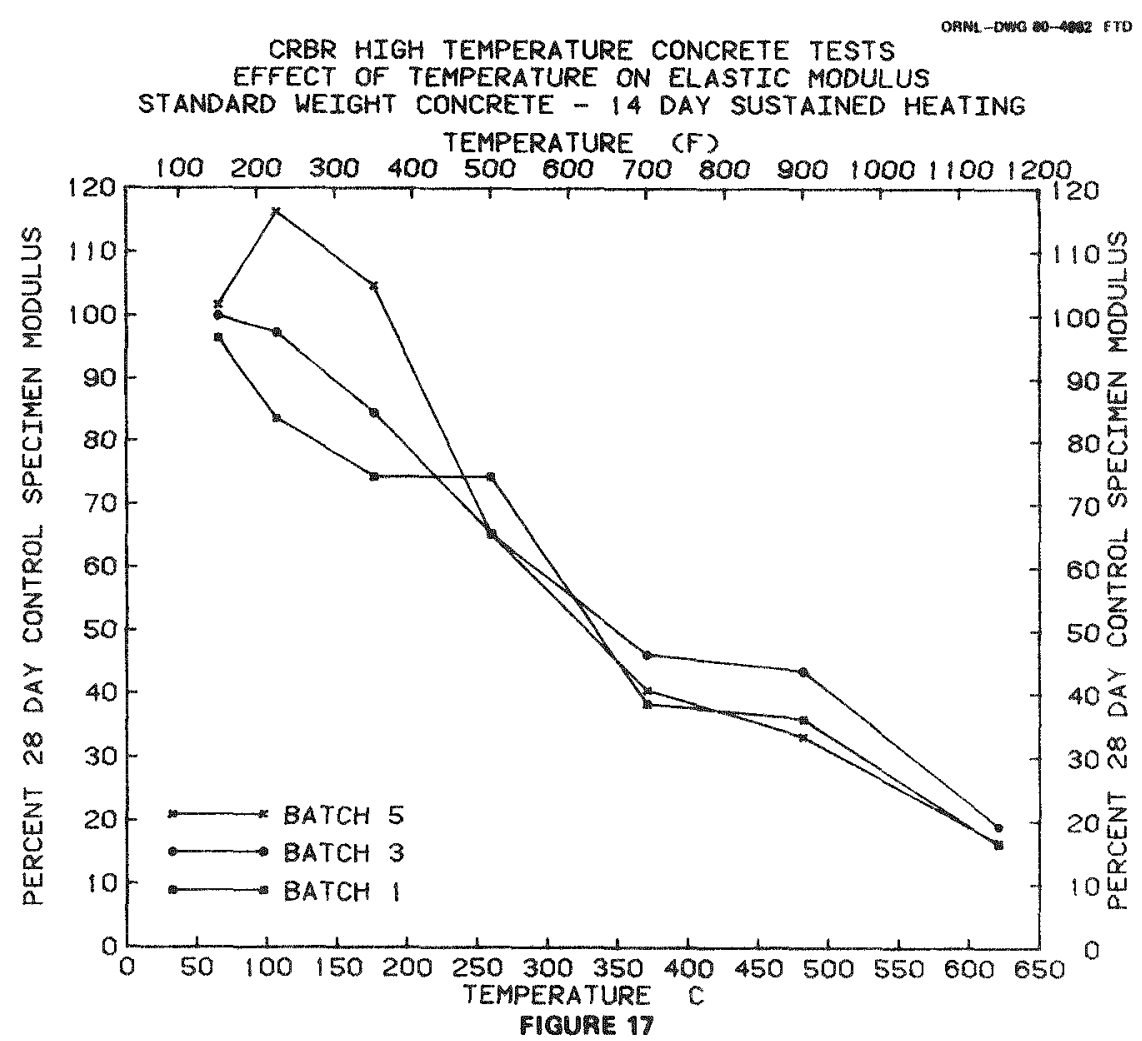


CRBR HIGH TEMPERATURE CONCRETE TESTS

ORa4L- E70 EFFECT OF TEMPERATURE ON COMPRESSIVE STRENGTH LIGHTWEIGHT CONCRETE - 14 DAY SUSTAINED HEATING
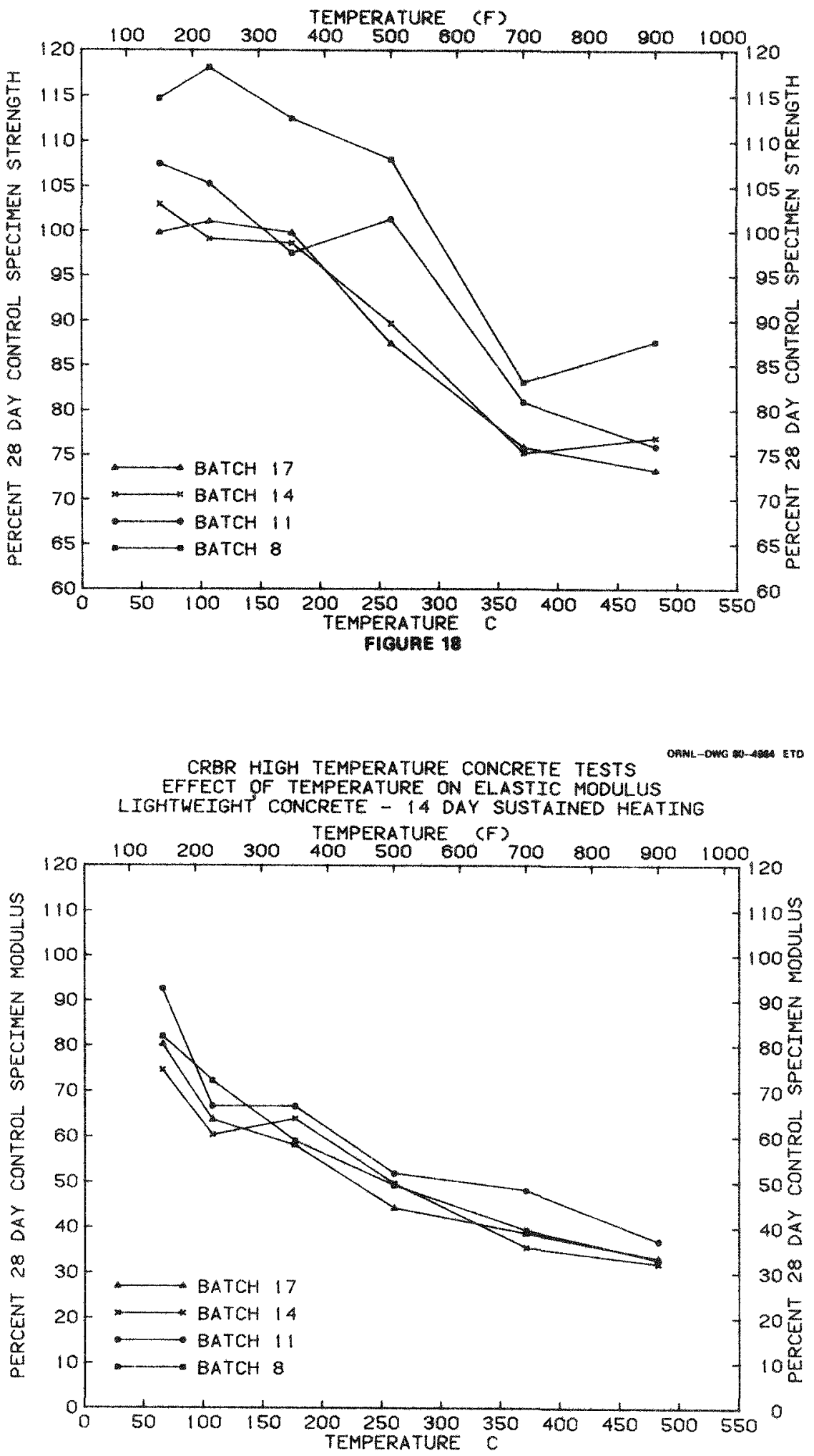

FIGUAE IS 


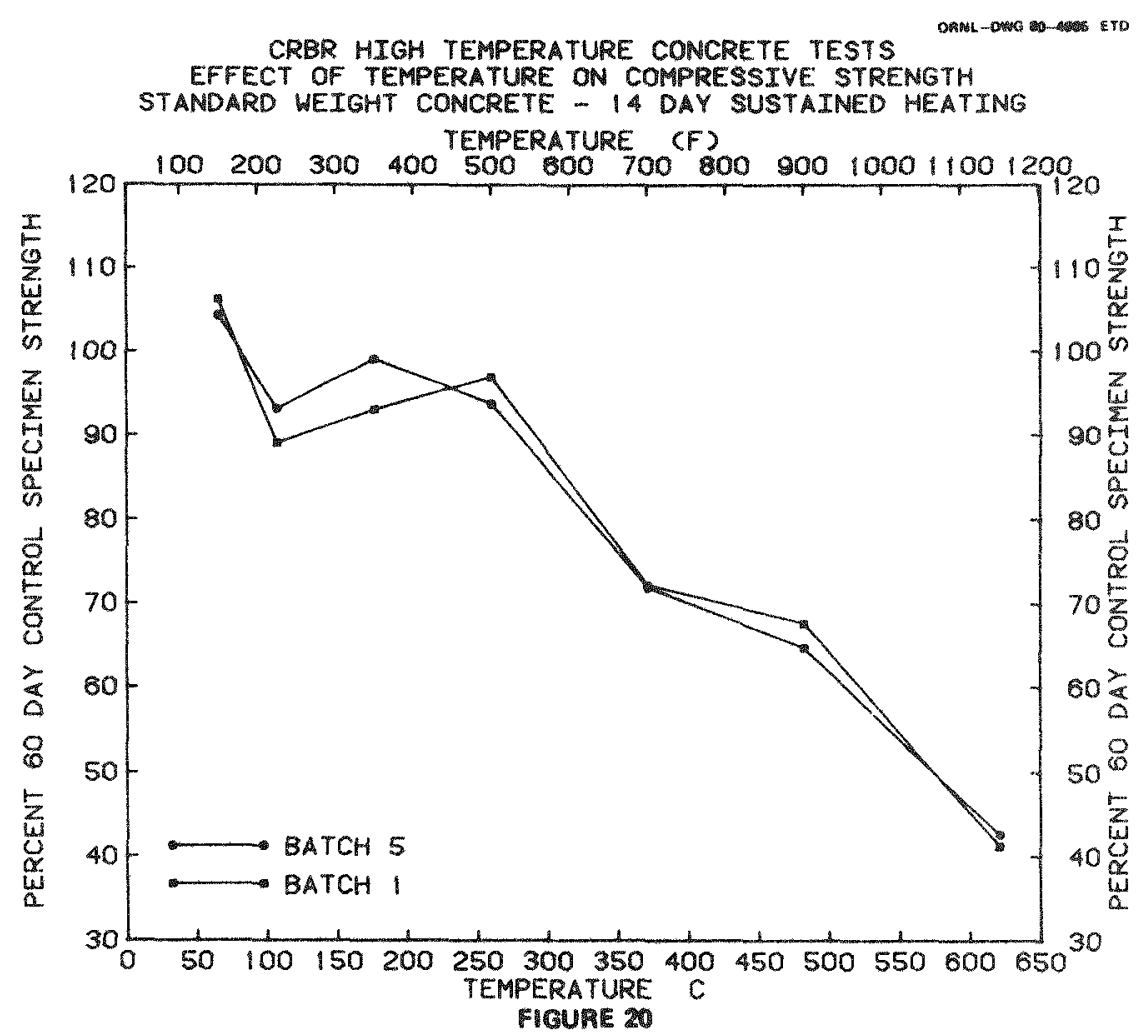

CRBR HIGH TEMPERATURE CONCRETE TESTS

EFFECT OF TEMPERATURE ON ELASTIC MODULUS

STANDARD WEIGHT CONCRETE - I DAY SUSTAINED HEATING

TEMPERATURE (F)

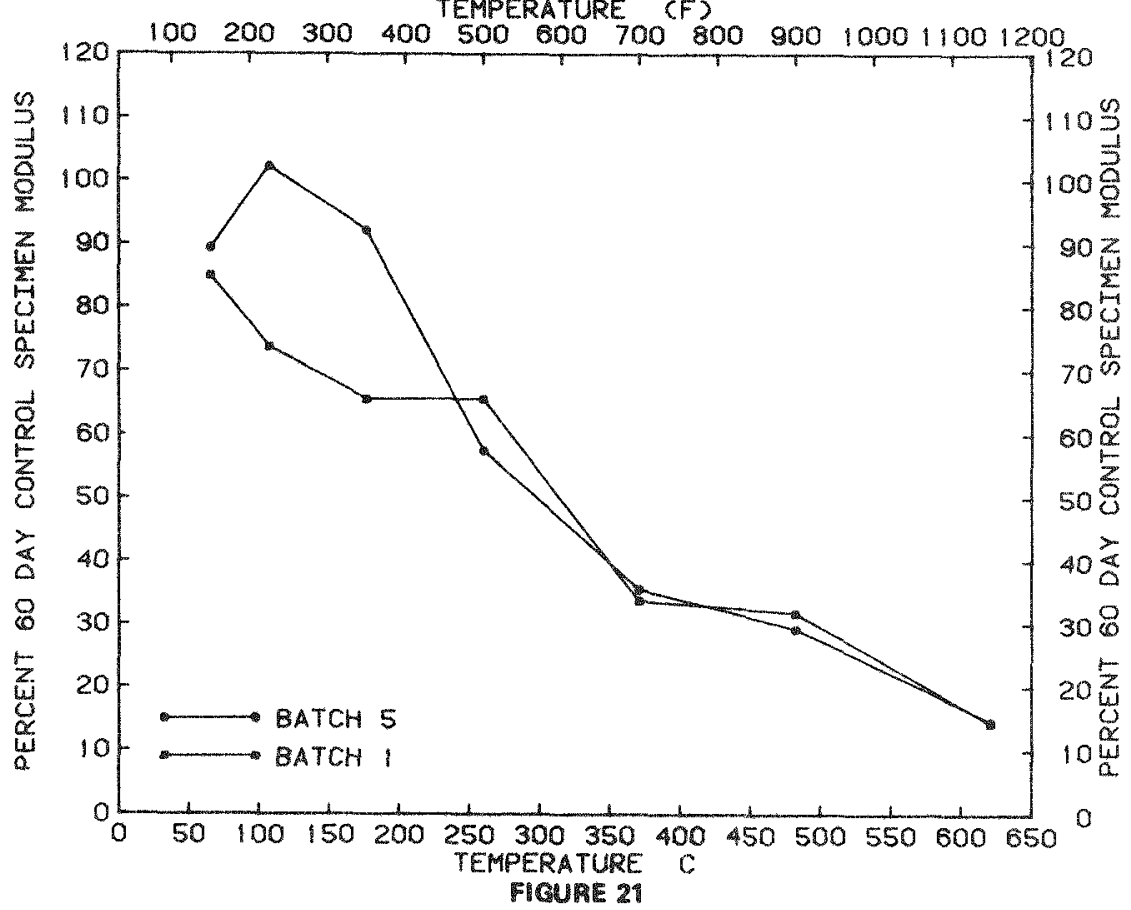




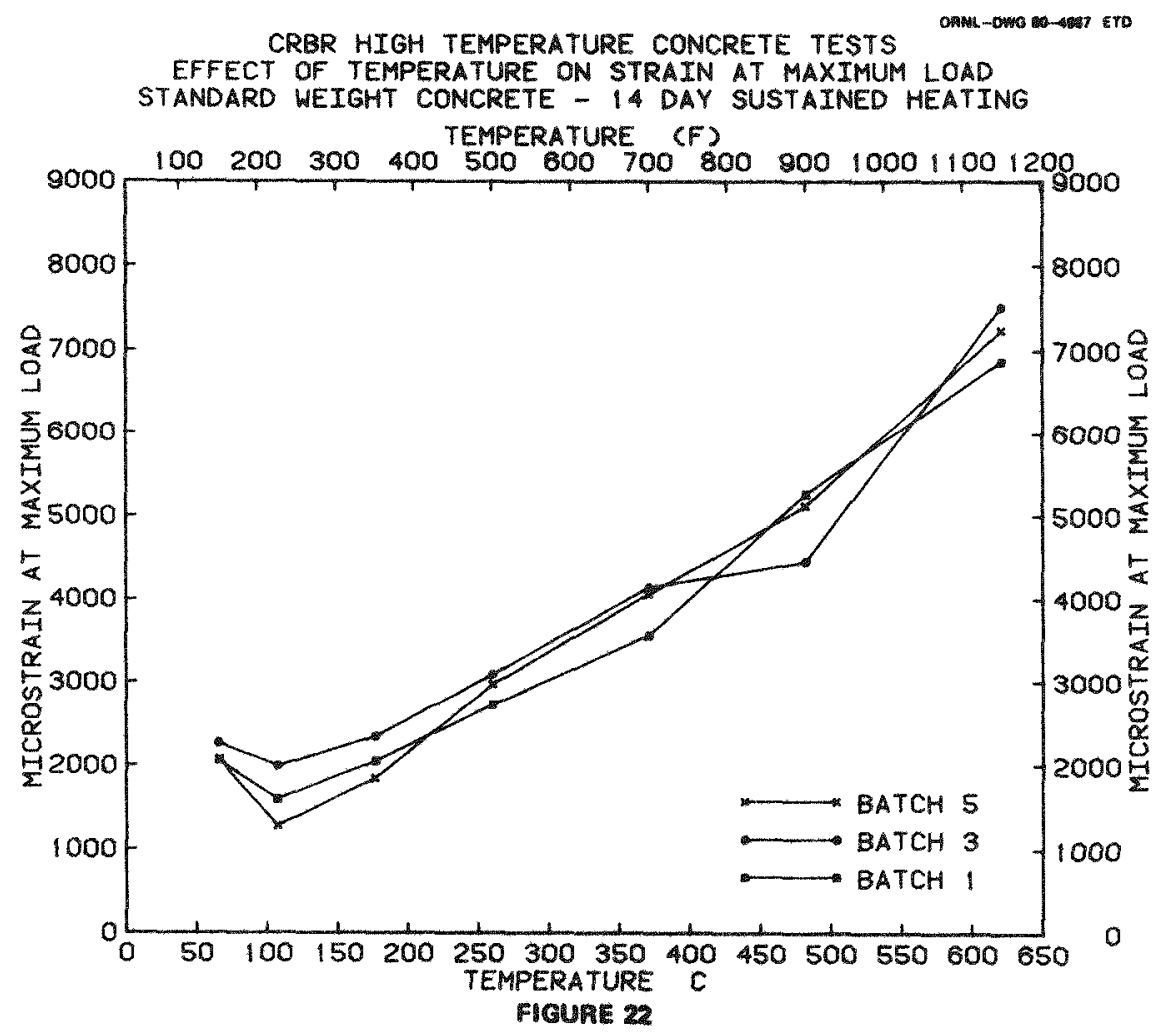

CRBR HIGH TEMPERATURE CONCRETE TESTS

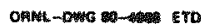

EFFECT OF TEMPERATURE ON WEIGNT LOSS

STANDARD WEIGHT CONCRETE - 14 DAY SUSTAINED HEATING

TEMPERATURE (F)

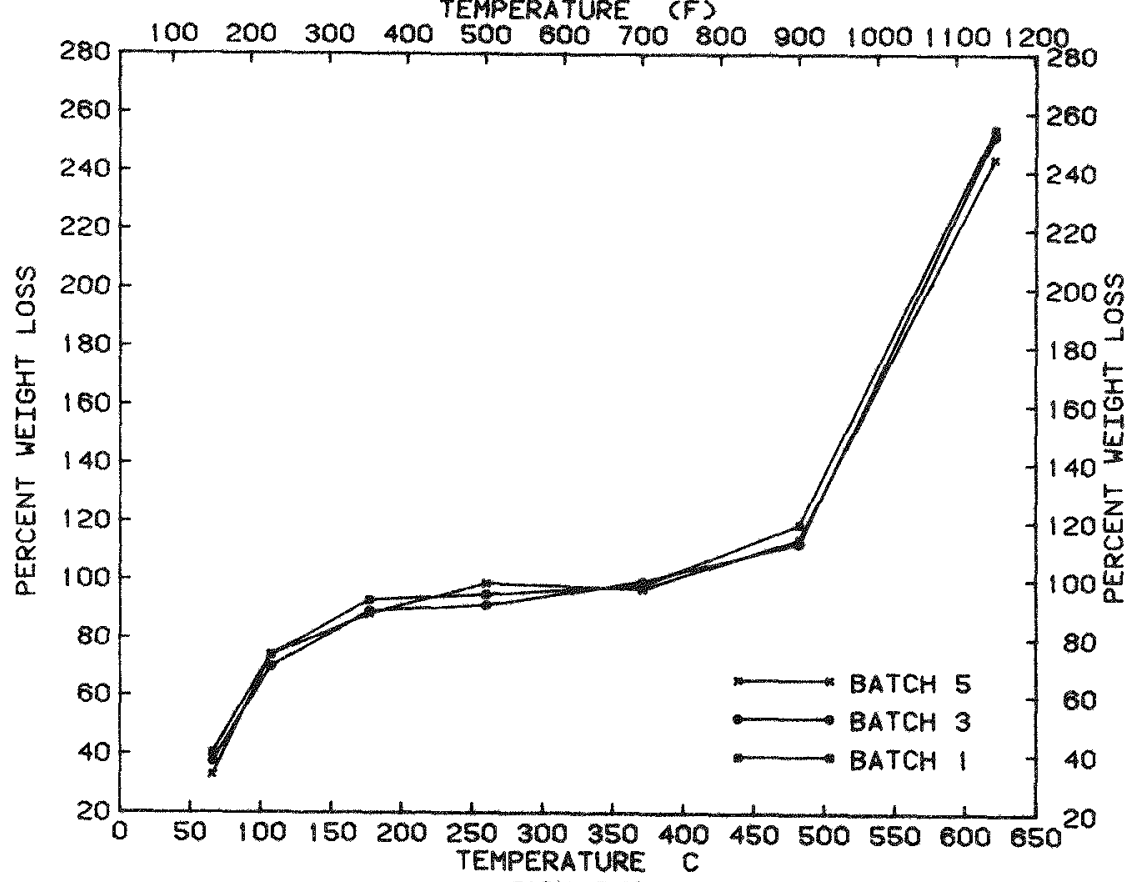

FIGUAE 22 
CRBR HIGH TEMPERATURE CONCRETE TESTS
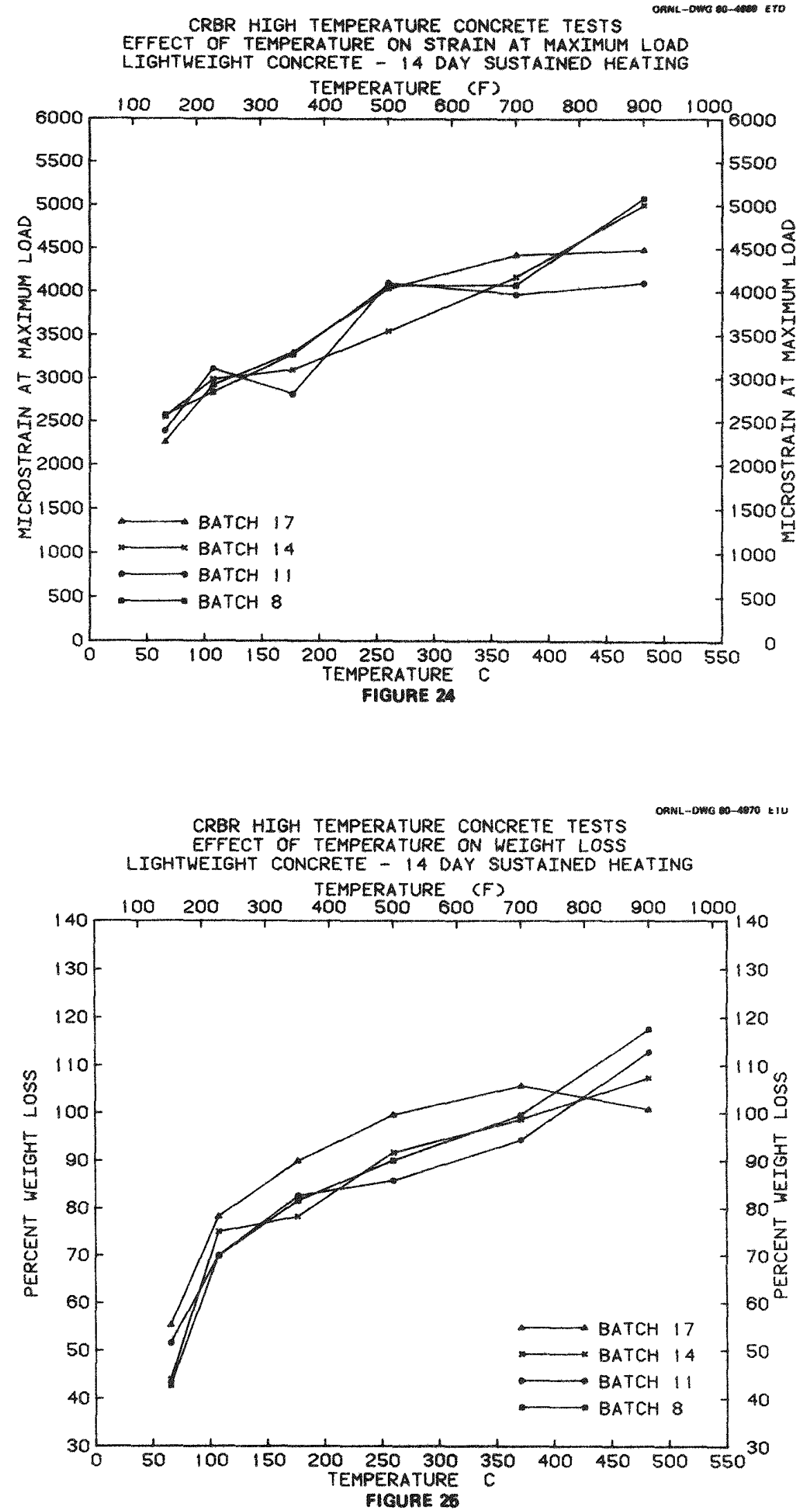


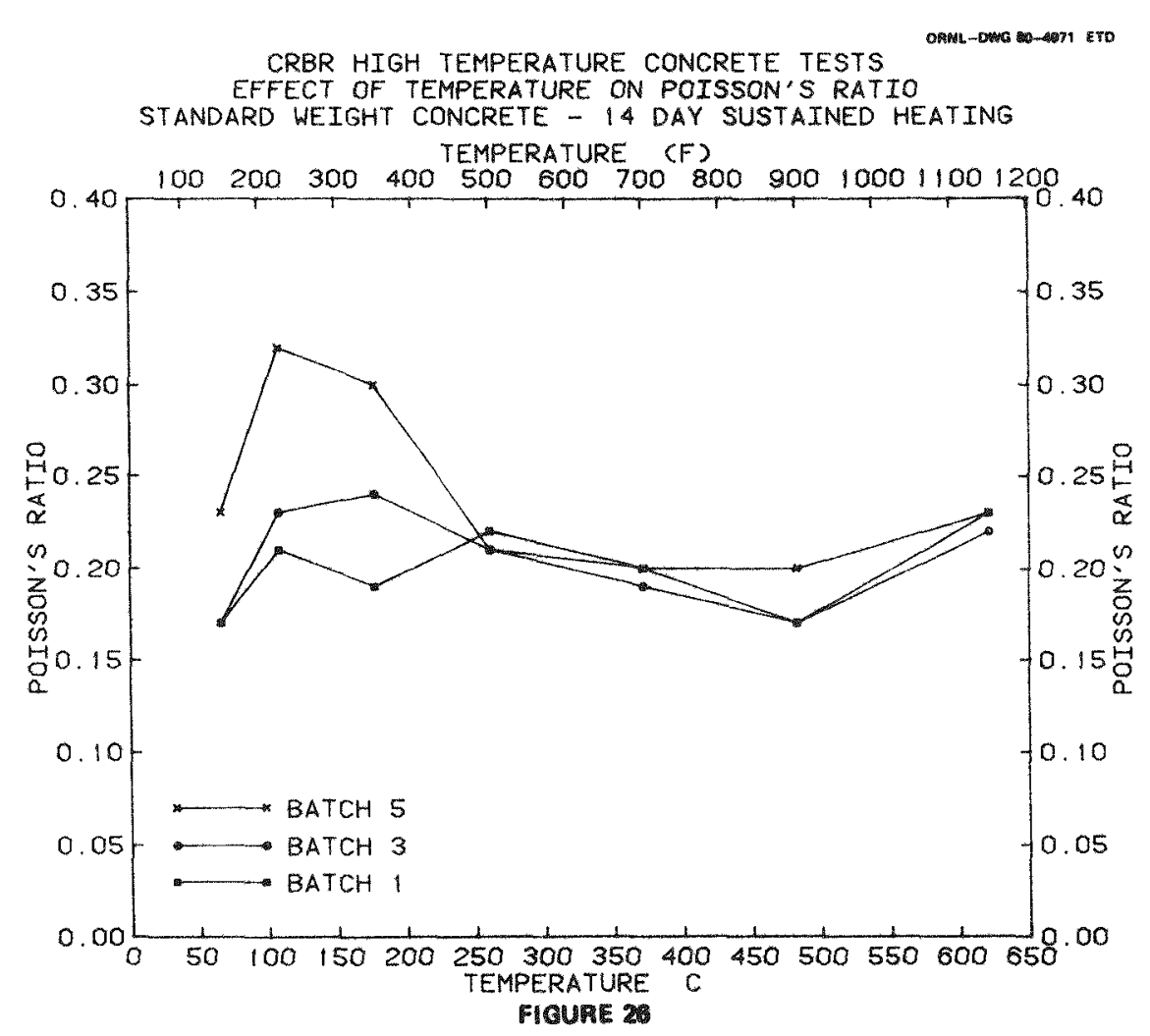

\subsection{Shear Test Specimens}

Results obtained for the shear strength tests conducted using Sshaped, parallelepiped, standard weight, concrete specimens which were $62 \pm 2 \mathrm{~d}$ old at heat-up are summarized in Table 11 . Figure 27 shows the effect of thermal stabilization temperature on shear strength as a function of the room temperature reference value. Curves presenting each shear specimen's temperature history (except for room temperature specimens) during the heat-up and thermal stabilization period are contained in Appendix $D$.

\subsection{Bond Pul1-Out Test Specimens}

Specimens were tested at each thermal stabilization temperature of interest. Tables 12 through 19 present pertinent data grouped according to thermal stabilization temperature (including specimen age at start of heat-up). To provide an indication of temperature distribution within 
Table 11. Standard weight concrete shear test result sumary

$14-\mathrm{d}$ thermal stabilization period ${ }^{\alpha}$

\begin{tabular}{|c|c|c|c|c|c|c|}
\hline Batch & Spectmen & $\begin{array}{c}\text { Therm } 1 \\
\text { stabilization } \\
\text { temperature } \\
{\left[{ }^{\circ} \mathrm{C}\left({ }^{\circ} \mathrm{F}\right)\right]}\end{array}$ & $\begin{array}{c}\text { Shear plane } \\
\text { wdth, } \\
{[\mathrm{m}(1 \mathrm{n} .)]}\end{array}$ & $\begin{array}{l}\text { Shed plane } \\
\text { wldch, d } \\
\text { [a }(1 \mathrm{n} .) !\end{array}$ & $\begin{array}{c}\text { Shear plane } \\
\left.\left.\text { area, } \frac{A}{2}\right)\right] \\
{\left[\operatorname{me}^{2}\left(i n \cdot{ }^{2}\right)\right]}\end{array}$ & $\begin{array}{l}\text { Average ultimate } \\
\text { shear stress, U } \\
\qquad \text { MPa (ksi)] }\end{array}$ \\
\hline 7 & $\begin{array}{l}V 727 \\
V 1507 \\
V 2257 \\
V 3507 \\
V 5007 \\
V 7007 \\
V 9007 \\
V 11507\end{array}$ & $\begin{array}{c}22.2(72) \\
65.6(150) \\
107.2(225) \\
176.7(350) \\
260.0(500) \\
371.1(700) \\
482.2(900) \\
621.1(1150)\end{array}$ & 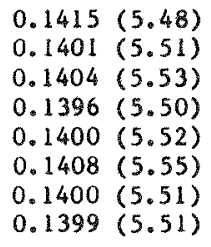 & 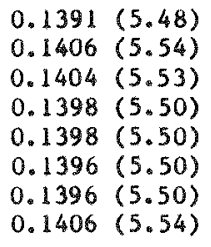 & $\begin{array}{ll}0.0197 & (30.50) \\
0.0197 & (30.53) \\
0.0197 & (30.57) \\
0.0195 & (30.25) \\
0.0196 & (30.36) \\
0.0197 & (30.48) \\
0.0195 & (30.31) \\
0.0197 & (30.49)\end{array}$ & 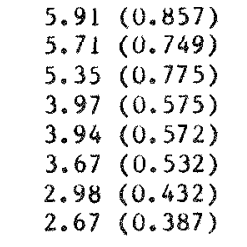 \\
\hline 10 & $\begin{array}{l}\text { V7210 } \\
V 15010 \\
v 22510 \\
\text { V35010 } \\
V 50010 \\
V 70010 \\
V 90010 \\
V 115010\end{array}$ & $\begin{array}{cl}22.2 & (72) \\
65.6 & (150) \\
107.2 & (225) \\
176.7 & (350) \\
260.0 & (500) \\
371.1 & (700) \\
482.2 & (900) \\
621.1 & (1150)\end{array}$ & $\begin{array}{l}0.1405(5.53) \\
0.1409(5.55) \\
0.1409(5.55) \\
0.1403(5.52) \\
0.1413(5.56) \\
0.1413(5.56) \\
0.1417(5.58) \\
0.1409(5.55)\end{array}$ & 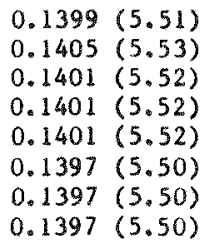 & $\begin{array}{ll}0.0197 & (30.47) \\
0.0198 & (30.68) \\
0.0197 & (30.60) \\
0.0197 & (30.47) \\
0.0198 & (30.68) \\
0.0197 & (30.60) \\
0.0198 & (30.68) \\
0.0197 & (30.51)\end{array}$ & $\begin{array}{l}5.34 \\
5.82(0.775) \\
3.92(0.844) \\
3.99(0.569) \\
3.93(0.578) \\
3.34(0.484) \\
3.21(0.466) \\
2.51(0.364)\end{array}$ \\
\hline 13 & $\begin{array}{l}V 7213 \\
V 15013 \\
V 22513 \\
V 35013 \\
V 50013 \\
V 70013 \\
V 90013 \\
V 115013\end{array}$ & $\begin{aligned} 22.2 & (72) \\
65.6 & (150) \\
107.2 & (225) \\
176.7 & (350) \\
260.0 & (500) \\
371.1 & (700) \\
482.2 & (900) \\
621.1 & (1150)\end{aligned}$ & $\begin{array}{ll}0.1409 & (5.55) \\
0.1404 & (5.53) \\
0.1409 & (5.55) \\
0.1409 & (5.55) \\
0.1404 & (5.53) \\
0.1413 & (5.56) \\
0.1404 & (5.53) \\
0.1404 & (5.53)\end{array}$ & 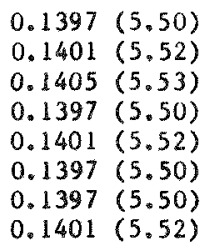 & $\begin{array}{ll}0.0197 & (30.51) \\
0.0197 & (30.51) \\
0.0198 & (30.68) \\
0.0197 & (30.51) \\
0.0197 & (30.51) \\
0.0197 & (30.60) \\
0.0196 & (30.42) \\
0.0197 & (30.51)\end{array}$ & $\begin{array}{ll}5.51 & (0.800) \\
5.42 & (0.787) \\
5.17 & (0.750) \\
4.72 & (0.685) \\
3.89 & (0.564) \\
3.33 & (0.484) \\
3.38 & (0.490) \\
3.28 & (0.475)\end{array}$ \\
\hline
\end{tabular}

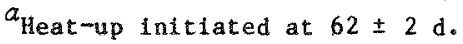

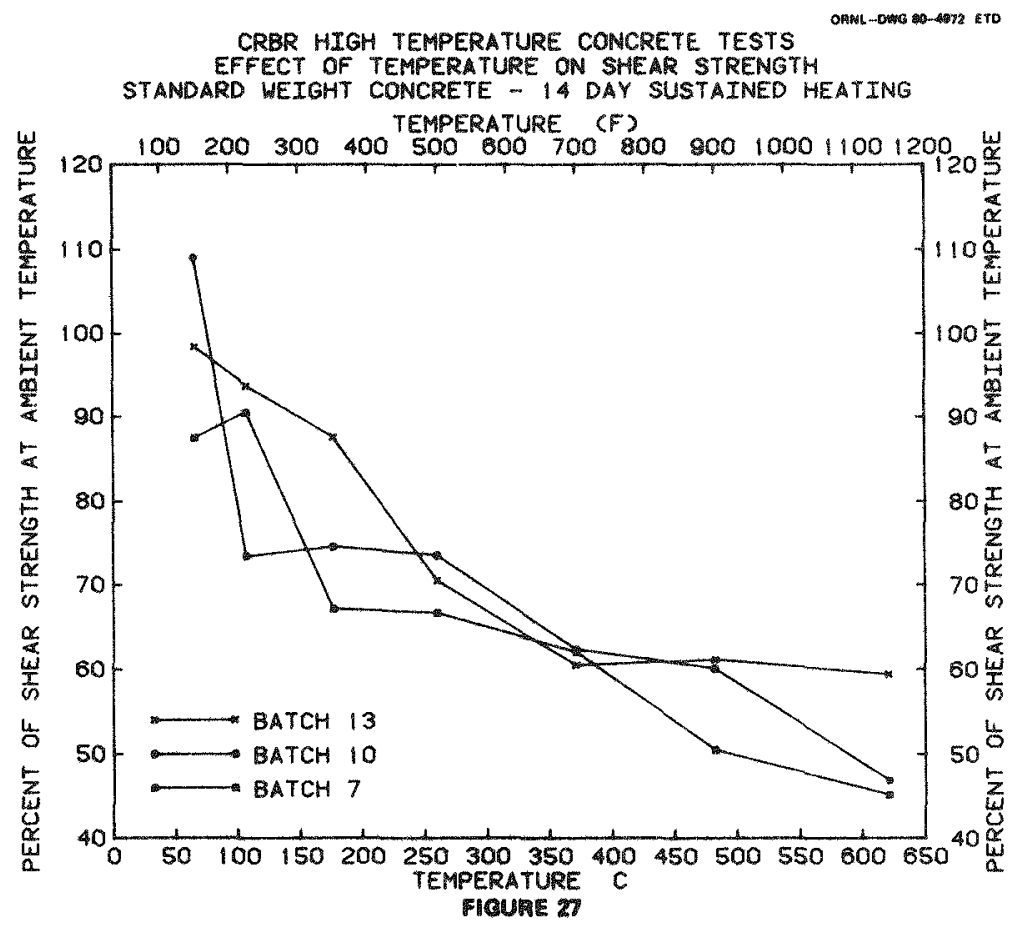


Table 12. Bond pul1-out data

$22^{\circ} \mathrm{C}\left(72^{\circ} \mathrm{F}\right)$ specimens

\begin{tabular}{|c|c|c|c|c|}
\hline \multirow{2}{*}{ Data } & \multicolumn{4}{|c|}{ Specimen identification number } \\
\hline & B7 22 & B726 & $B 7212$ & B7218 \\
\hline Specimen type & Test & Test & Test & Calibration \\
\hline Batch & 2 & 6 & 12 & 18 \\
\hline 28-d strength, $\mathrm{MPa}$ (psi) & $35.03(5080)$ & $35.30(5120)$ & $34.06(4940)$ & $37.02(5370)$ \\
\hline Testing frame & 1 & 1 & 1 & 1 \\
\hline \multicolumn{5}{|l|}{ Specimen age, d } \\
\hline $\begin{array}{l}\text { At end of moist-cure } \\
\text { At start of heat-up } \\
\text { At end of heat-up } \\
\text { At loading }\end{array}$ & $\begin{array}{l}61 \\
62 \\
62 \\
76\end{array}$ & $\begin{array}{l}62 \\
63 \\
63 \\
77\end{array}$ & $\begin{array}{l}68 \\
69 \\
69 \\
83\end{array}$ & $\begin{array}{l}62 \\
63 \\
63 \\
77\end{array}$ \\
\hline \multicolumn{5}{|l|}{ Temperature, ${ }^{\circ} \mathrm{C}\left({ }^{\circ} \mathrm{F}\right)^{a}$} \\
\hline $\begin{array}{l}\text { Specimen (the rmocouple } 6 \text { ) } \\
\text { Thermocouple } 1 \\
\text { Thermocouple } 2 \\
\text { Thermocouple } 3 \\
\text { Thermocouple } 4 \\
\text { Thermocouple } 5\end{array}$ & Ambient & $\begin{array}{l}\text { Ambient } \\
\text { Ambient } \\
\text { Ambient }\end{array}$ & $\begin{array}{l}\text { Ambient } \\
\text { Ambient } \\
\text { Ambient } \\
\text { Ambient } \\
\text { Ambient } \\
\text { Ambient }\end{array}$ & $\begin{array}{l}\text { Ambient } \\
\text { Ambient } \\
\text { Ambient }\end{array}$ \\
\hline Failure mode $b$ & $\mathrm{P}$ & $\mathbf{Y}$ & $\mathrm{T}$ & $T+Y$ \\
\hline
\end{tabular}

$a_{\text {Thermocouple positioning defined in Fig. } 10 .}$

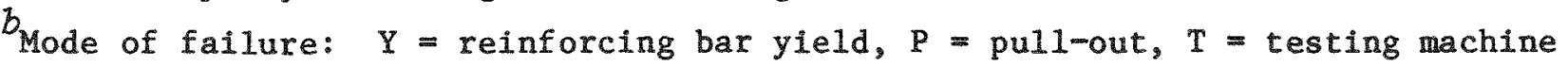
capacity reached [445 kN (100 kips)]. 
Table 13. Bond pul1-out data $66^{\circ} \mathrm{C}\left(150^{\circ} \mathrm{F}\right)$ specimens

\begin{tabular}{|c|c|c|c|c|}
\hline \multirow{2}{*}{ Data } & \multicolumn{4}{|c|}{ Specimen identification number } \\
\hline & B1504 & B1509 & B15015 & B15019 \\
\hline Specimen type & Test & Test & Test & Calibration \\
\hline Batch & 4 & 9 & 15 & 19 \\
\hline 28-d strength, $\mathrm{MPa}$ (psi) & $32.06(4650)$ & $37.02(5370)$ & $35.65(5170)$ & $31.37(4450)$ \\
\hline Testing frame & 1 & 1 & 1 & 1 \\
\hline \multicolumn{5}{|l|}{ Specimen age, $d$} \\
\hline $\begin{array}{l}\text { At end of moist-cure } \\
\text { At start of heat-up } \\
\text { At end of heat-up } \\
\text { At loading }\end{array}$ & $\begin{array}{l}63 \\
64 \\
64 \\
78\end{array}$ & $\begin{array}{l}61 \\
62 \\
62 \\
76\end{array}$ & $\begin{array}{l}61 \\
62 \\
62 \\
76\end{array}$ & $\begin{array}{l}61 \\
62 \\
62 \\
76\end{array}$ \\
\hline \multicolumn{5}{|l|}{ Temperature, ${ }^{\circ} \mathrm{C}\left({ }^{\circ} \mathrm{F}\right)^{a}$} \\
\hline $\begin{array}{l}\text { Specimen (thermocouple } 6 \text { ) } \\
\text { Thermocouple } 1 \\
\text { Thermocouple } 2 \\
\text { Thermocouple } 3 \\
\text { Thermocouple } 4 \\
\text { Thermocouple } 5\end{array}$ & $66(150)$ & $\begin{array}{l}66(150) \\
54(130) \\
60(140)\end{array}$ & $\begin{array}{l}66(150) \\
57(134) \\
60(140) \\
59(139) \\
60(140) \\
61(142)\end{array}$ & $\begin{array}{ll}66 & (150) \\
56 & (133) \\
61 & (141)\end{array}$ \\
\hline Failure mode ${ }^{b}$ & $\mathrm{Y}$ & $\mathrm{Y}$ & $\mathrm{T}$ & $T+Y$ \\
\hline
\end{tabular}

$a_{\text {Thermocouple positioning defined in Fig. } 10 .}$

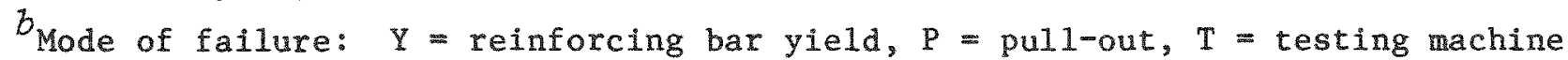
capacity reached [445 kN (100 kips)]. 
Table 14. Bond pull-out data

$107^{\circ} \mathrm{C}\left(225^{\circ} \mathrm{F}\right)$ specimens

\begin{tabular}{|c|c|c|c|c|}
\hline \multirow{2}{*}{ Data } & \multicolumn{4}{|c|}{ Specimen identification number } \\
\hline & B2252 & B2256 & B22512 & B22518 \\
\hline Specimen type & Test & Test & Test & Calibration \\
\hline Batch & 2 & 6 & 12 & 18 \\
\hline 28-d strength, MPa (psi) & $35.30(5080)$ & $35.30(5120)$ & $34.06(4940)$ & $37.02(5370)$ \\
\hline Testing frame & 3 & 3 & 3 & 3 \\
\hline \multicolumn{5}{|l|}{ Specimen age, $d$} \\
\hline $\begin{array}{l}\text { At end of moist-cure } \\
\text { At start of heat-up } \\
\text { At end of heat-up } \\
\text { At loading }\end{array}$ & $\begin{array}{l}68 \\
69 \\
69 \\
83\end{array}$ & $\begin{array}{l}69 \\
70 \\
70 \\
84\end{array}$ & $\begin{array}{l}74 \\
75 \\
75 \\
89\end{array}$ & $\begin{array}{l}64 \\
65 \\
65 \\
79\end{array}$ \\
\hline \multicolumn{5}{|l|}{ Temperature, ${ }^{\circ} \mathrm{C}\left({ }^{\circ} \mathrm{F}\right)^{a}$} \\
\hline $\begin{array}{l}\text { Specimen (thermocouple 6) } \\
\text { Thermocouple } 1 \\
\text { Thermocouple } 2 \\
\text { Thermocouple } 3 \\
\text { Thermocouple } 4 \\
\text { Thermocouple } 5\end{array}$ & $107(225)$ & $\begin{array}{l}107(225) \\
85(185) \\
93(200)\end{array}$ & $\begin{array}{l}107(225) \\
87(188) \\
93(200) \\
99(210) \\
99(210) \\
102(215)\end{array}$ & $\begin{array}{l}107(225) \\
93(200) \\
99(210)\end{array}$ \\
\hline Failure mode $b$ & $Y$ & $\mathbf{P}$ & $\mathrm{Y}$ & $Y$ \\
\hline
\end{tabular}

$a_{\text {Thermocouple positioning defined in Fig. } 10 .}$

$b$ Mode of fallure: $\mathrm{Y}=$ reinforcing bax yield, $\mathrm{P}=$ pull-out, $\mathrm{T}=$ testing machine capacity reached [445 kN (100 kips)]. 
Table 15. Bond pul1-out data

$177^{\circ} \mathrm{C}\left(350^{\circ} \mathrm{F}\right)$ specimens

\begin{tabular}{|c|c|c|c|c|c|}
\hline \multirow{2}{*}{ Data } & \multicolumn{5}{|c|}{ Specimen identification number } \\
\hline & B 3504 & B3509 & B35015 & $B 35020^{\circ}$ & B35019 \\
\hline Specimen type & Test & Test & Test & Replacement & Calibration \\
\hline Batch & 4 & 9 & 15 & 20 & 19 \\
\hline 28-d strength, MPa (psi) & $32.06(4650)$ & $37.02(5370)$ & $35.65(5170)$ & $34.61(5020)$ & $31.37(4450)$ \\
\hline Testing frame & 3 & 3 & 3 & 3 & 3 \\
\hline \multicolumn{6}{|l|}{ Specimen age, $d$} \\
\hline $\begin{array}{l}\text { At end of moist-cure } \\
\text { At start of heat-up } \\
\text { At end of heat-up } \\
\text { At loading }\end{array}$ & $\begin{array}{l}69 \\
70 \\
70^{b} \\
90\end{array}$ & $\begin{array}{l}68 \\
69 \\
69 \\
83\end{array}$ & $\begin{array}{l}68 \\
69 \\
69 \\
83^{c}\end{array}$ & $\begin{array}{l}76 \\
77 \\
77 \\
91\end{array}$ & $\begin{array}{l}68 \\
69 \\
69 \\
83\end{array}$ \\
\hline \multicolumn{6}{|l|}{ Temperature, ${ }^{\circ} \mathrm{C}\left({ }^{\circ} \mathrm{F}\right)^{d}$} \\
\hline $\begin{array}{l}\text { Specimen (thermocouple } 6 \text { ) } \\
\text { Thermocouple } 1 \\
\text { Thermocouple } 2 \\
\text { Thermocouple } 3 \\
\text { Thermocouple } 4 \\
\text { Thermocouple } 5\end{array}$ & $\begin{array}{l}621(1150)^{e} \\
456(853) f \\
483(901) f\end{array}$ & $\begin{array}{l}177(350) \\
141(285) \\
149(300)\end{array}$ & 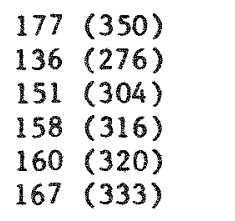 & $\begin{array}{l}177(350) \\
134(274) \\
147\end{array}$ & 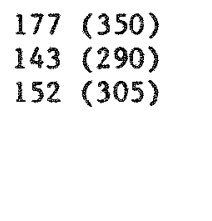 \\
\hline Fallure mode $g$ & $Y$ & $\mathrm{Y}$ & & $\mathbf{Y}$ & $\mathbf{Y}$ \\
\hline
\end{tabular}

$a_{\text {Bar cut from different rebar than } B 35019 .}$

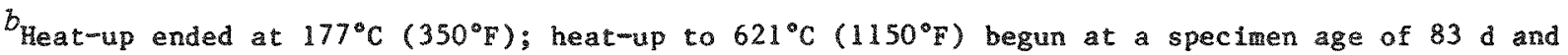
ended at $85 \mathrm{~d}$.

"No test data due to testing equipment fallure.

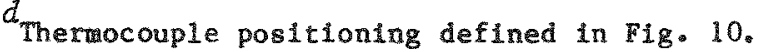

Specimen tested at $621^{\circ} \mathrm{C}\left(1150^{\circ} \mathrm{F}\right)$.

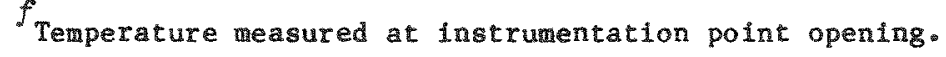

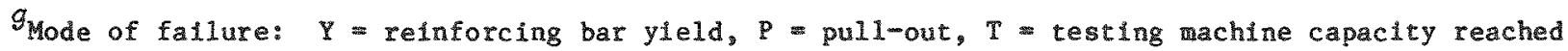
$[445 \mathrm{kN}(100 \mathrm{kips})]$. 
Table 16. Bond pul1-out data

$260^{\circ} \mathrm{C}\left(500^{\circ} \mathrm{F}\right)$ specimens

\begin{tabular}{|c|c|c|c|c|}
\hline \multirow{2}{*}{ Data } & \multicolumn{4}{|c|}{ Specimen identification number } \\
\hline & B5002 & B5006 & B 50012 & B 50018 \\
\hline Specimen type & Test & Test & Test & Calibration \\
\hline Batch & 2 & 6 & 12 & 18 \\
\hline 28-d strength, MPa (psi) & $35.03(5080)$ & $35.30(5120)$ & $34.06(4940)$ & $37.02(5370)$ \\
\hline Testing frame & 4 & 4 & 4 & 4 \\
\hline \multicolumn{5}{|l|}{ Specimen age, d } \\
\hline $\begin{array}{l}\text { At end of moist-cure } \\
\text { At start of heat-up } \\
\text { At end of heat-up } \\
\text { At loading }\end{array}$ & $\begin{array}{l}70 \\
71 \\
72 \\
86\end{array}$ & $\begin{array}{l}70 \\
71 \\
72 \\
86\end{array}$ & $\begin{array}{l}75 \\
76 \\
77 \\
91\end{array}$ & $\begin{array}{l}69 \\
70 \\
71 \\
85\end{array}$ \\
\hline \multicolumn{5}{|l|}{ Temperature, ${ }^{\circ} \mathrm{C}\left({ }^{\circ} \mathrm{F}\right)^{a}$} \\
\hline $\begin{array}{l}\text { Specimen (thermocouple } 6 \text { ) } \\
\text { Thermocouple } 1 \\
\text { Thermocouple } 2 \\
\text { Thermocouple } 3 \\
\text { Thermocouple } 4 \\
\text { Thermocouple } 5\end{array}$ & $260(500)$ & $\begin{array}{ll}260 & (500) \\
270 & (405) \\
217 & (422)\end{array}$ & $\begin{array}{l}260(500) \\
204(400) \\
214(418) \\
229(445) \\
229(445) \\
244(471)\end{array}$ & $\begin{array}{ll}260 & (500) \\
213 & (415) \\
216 & (420)\end{array}$ \\
\hline Fallure mode $e^{b}$ & $Y$ & $T+Y$ & $Y$ & $Y$ \\
\hline
\end{tabular}


Table 17. Bond pul1-out data

$371^{\circ} \mathrm{C}\left(700^{\circ} \mathrm{F}\right)$ specimens

\begin{tabular}{|c|c|c|c|c|c|}
\hline \multirow{2}{*}{ Data } & \multicolumn{5}{|c|}{ Specimen identification number } \\
\hline & B7004 & B7009 & $B 70015$ & $B 70020^{a}$ & $B 70019$ \\
\hline Specimen type & Test & Test & Test & Replacement & Calibration \\
\hline Batch & 4 & 9 & 15 & 20 & 19 \\
\hline 28-d strength, $M P_{a}$ (psi) & $32.06(4650)$ & $37.02(5370)$ & $35.65(5170)$ & $34.61(5020)$ & $31.37(4450)$ \\
\hline Testing frame & 4 & 4 & 4 & 4 & 4 \\
\hline \multicolumn{6}{|l|}{ Specimen age, d } \\
\hline $\begin{array}{l}\text { At end of moist-cure } \\
\text { At start of heat-up } \\
\text { At end of heat-up } \\
\text { At loading }\end{array}$ & $\begin{array}{l}64 \\
65 \\
66^{b} \\
\text { Not tested }\end{array}$ & $\begin{array}{l}69 \\
70 \\
71 \\
85\end{array}$ & $\begin{array}{l}69 \\
71 \\
72 \\
86\end{array}$ & $\begin{array}{l}76 \\
77 \\
78 \\
92\end{array}$ & $\begin{array}{l}68 \\
69 \\
70 \\
84\end{array}$ \\
\hline \multicolumn{6}{|l|}{ Temperature, ${ }^{\circ} \mathrm{C}\left({ }^{\circ} \mathrm{F}\right)^{\circ}$} \\
\hline $\begin{array}{l}\text { Specimen (the rmocouple 6) } \\
\text { Thermocouple } 1 \\
\text { Thermocouple } 2 \\
\text { Thermocouple } 3 \\
\text { Thermocouple } 4 \\
\text { Thermocouple } 5\end{array}$ & & $\begin{array}{ll}371(700) \\
271(520) \\
299(570)\end{array}$ & $\begin{array}{ll}371 & (700) \\
279 & (535) \\
297 & (567) \\
317 & (602) \\
317 & (602) \\
338 & (640)\end{array}$ & $\begin{array}{ll}371(700) \\
271(520) \\
293(560)\end{array}$ & $\begin{array}{l}371(700) \\
287(548) \\
295(563)\end{array}$ \\
\hline Failure mode $e^{d}$ & & $\mathbf{Y}$ & $\mathrm{Y}$ & $\mathrm{Y}$ & Y \\
\hline $\begin{array}{l}{ }^{a} \text { Same bar used to cast } \\
b_{\text {Specimen could not be }} \\
c_{\text {Thermocouple positionir }} \\
d_{\text {Mode of failure: }} \quad= \\
445 \mathrm{kN}(100 \mathrm{kips})] .\end{array}$ & $\begin{array}{l}04 . \\
\text { ted to } 371^{\circ} \mathrm{C}\end{array}$ & $\begin{array}{l}\left.00^{\circ} \mathrm{F}\right) \\
10 \\
\text { e1d, } \dot{P}=\end{array}$ & 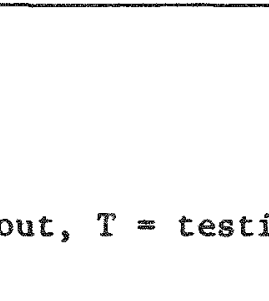 & - & hed \\
\hline
\end{tabular}


Table 18. Bond pul1-out data

$482^{\circ} \mathrm{C}\left(900^{\circ} \mathrm{F}\right)$ specimens

\begin{tabular}{|c|c|c|c|c|}
\hline \multirow{2}{*}{ Data } & \multicolumn{4}{|c|}{ Specimen identification number } \\
\hline & $\mathrm{B} 9002^{a}$ & B9006 & B90012 & 890019 \\
\hline Specimen type & Test & Test & Test & Calibration \\
\hline Batch & 2 & 6 & 12 & 19 \\
\hline 28-d strength, $\mathrm{MPa}$ (psi) & $35.03(5080)$ & $35.30(5120)$ & $34.06(4940)$ & $31.37(4550)$ \\
\hline Testing frame & 2 & 2 & 2 & 2 \\
\hline \multicolumn{5}{|l|}{ Specímen age, d } \\
\hline $\begin{array}{l}\text { At end of moist-cure } \\
\text { At start of heat-up } \\
\text { At end of heat-up } \\
\text { At loading }\end{array}$ & $\begin{array}{l}62 \\
63 \\
64 \\
78\end{array}$ & $\begin{array}{l}63 \\
64 \\
65 \\
79\end{array}$ & $\begin{array}{l}69 \\
70 \\
71 \\
85\end{array}$ & $\begin{array}{l}61 \\
62 \\
64 \\
78\end{array}$ \\
\hline \multicolumn{5}{|l|}{ Temperature, ${ }^{\circ} \mathrm{C}\left({ }^{\circ} \mathrm{F}\right)^{b}$} \\
\hline $\begin{array}{l}\text { Specimen (thermocouple 6) } \\
\text { Thermocouple } 1 \\
\text { Thermocouple } 2 \\
\text { Thermocouple } 3 \\
\text { Thermocouple } 4 \\
\text { Thermocouple } 5\end{array}$ & $482(900)$ & $\begin{array}{l}482(900) \\
369(697) \\
387(728)\end{array}$ & $\begin{array}{l}482(900) \\
349(660) \\
360(680) \\
392(737) \\
388(730) \\
431(808)\end{array}$ & $\begin{array}{l}482(900) \\
366(690) \\
362(683)\end{array}$ \\
\hline Failure mode $e^{c}$ & $\mathbf{Y}$ & $Y$ & $T+Y$ & $\Psi$ \\
\hline
\end{tabular}

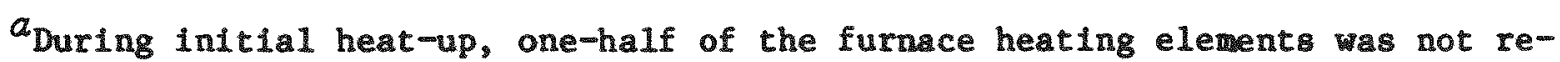
sponding. Thus, at a temperature of $148^{\circ} 9 \mathrm{C}\left(300^{\circ} \mathrm{F}\right)$, the heating was stopped, and the specimen was permitted to cool to ambient. The furnace was then repaired, and the specimen was reheated to its thermal stabilization temperature at the prescribed rate.

$b_{\text {Thermocouple positioning defined in Fig. } 10 .}$

Mode of failure: $Y=$ relnforcing bar yield, $P=$ pull-out, $T=$ testing machine capacity reached [445 kN (100 kips)]. 
Table 19. Bond pul1-out data

$621^{\circ} \mathrm{C}\left(1150^{\circ} \mathrm{F}\right)$ specimens

\begin{tabular}{|c|c|c|c|c|c|}
\hline \multirow{2}{*}{ Data } & \multicolumn{5}{|c|}{ Specimen identification number } \\
\hline & B11504 & $B 11509$ & $B 115015$ & $\mathrm{~B} 115020^{a}$ & B115020CAL \\
\hline Specimen type & Test & Test & Test & Replacement & Calibration \\
\hline Batch & 4 & 9 & 15 & 20 & 20 \\
\hline 28-d strength, $\mathrm{MPa}(\mathrm{ps} 1)$ & $32.06(4650)$ & $37.02(5370)$ & $35.65(5170)$ & $34.61(5020)$ & $34.61(5020)$ \\
\hline Testing frame & 2 & 2 & 2 & 1 & 2 \\
\hline \multicolumn{6}{|l|}{ Specimen age, d } \\
\hline $\begin{array}{l}\text { At end of molst-cure } \\
\text { At start of heat-up } \\
\text { At end of heat-up } \\
\text { At loading }\end{array}$ & $\begin{array}{l}70 \\
71 \\
71^{\circ} \\
\text { Not tested }\end{array}$ & $\begin{array}{l}62 \\
63 \\
65 \\
79\end{array}$ & $\begin{array}{l}61 \\
62 \\
64 \\
78\end{array}$ & $\begin{array}{l}68 \\
77^{b} \\
79 \\
93\end{array}$ & $\begin{array}{l}69 \\
70 \\
72 \\
86\end{array}$ \\
\hline \multicolumn{6}{|l|}{ Temperature, ${ }^{\circ} \mathrm{C}\left({ }^{\circ} \mathrm{F}\right)^{d}$} \\
\hline $\begin{array}{l}\text { Specimen (thermocouple } 6 \text { ) } \\
\text { Thermocouple } 1 \\
\text { Thermocouple } 2 \\
\text { Thermocouple } 3 \\
\text { Thermocouple } 4 \\
\text { Thermocouple } 5\end{array}$ & & $\begin{array}{l}621(1150) \\
443(830) \\
460(860)\end{array}$ & $\begin{array}{l}621(1150) \\
444(831) \\
446(835) \\
485(905) \\
485(905) \\
530(986)\end{array}$ & $\begin{array}{l}621(1150) \\
425(797) \\
460(860)\end{array}$ & $\begin{array}{ll}621 & (1150) \\
458 & (856) \\
463 & (866)\end{array}$ \\
\hline Fallure mode $e^{e}$ & & $\Psi$ & $\mathbf{P}$ & $\mathbf{Y}$ & $Y$ \\
\hline
\end{tabular}

a Same bar used to cast B11504.

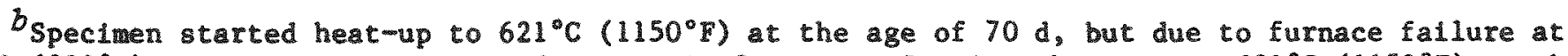
$482^{\circ} \mathrm{C}\left(900^{\circ} \mathrm{F}\right)$, heat-up was terminated to repair furnace. Specimen heat-up to $621^{\circ} \mathrm{C}\left(1150^{\circ} \mathrm{F}\right)$ was begun again at specimen age of $77 \mathrm{~d}$.

${ }^{\circ}$ Specimen could not be heated to $621^{\circ} \mathrm{C}\left(1150^{\circ} \mathrm{F}\right)$.

$d_{\text {Thermocouple positioning defined in Fig. } 10 .}$

Mode of fallure: $Y$ - reinforcing bar yield, $P=$ pull-out, $T=$ testing machine capacity reached $[445 \mathrm{kN}(100 \mathrm{klps})]$. 
the specimens during the thermal stabllization perfod, outputs obtained from thermocouples positioned at different locations in the test specimens are also noted in these tables, as well as any specimen abnormal1tips which occurred. Average bond stress vs discrete slip* values $[0$ to $0.254 \mathrm{~mm}$ (0 to $0.010 \mathrm{in}$ ) ) for each test temperaturet are presented in Table 20. Figures 28 and 29 present average bond stress vs slip curves for temperature ranges of amblent to $260^{\circ} \mathrm{C}\left(500^{\circ} \mathrm{F}\right)$ and $260^{\circ} \mathrm{C}\left(500^{\circ} \mathrm{F}\right)$ to $621.1^{\circ} \mathrm{C}\left(1150^{\circ} \mathrm{F}\right)$ respectively. Appendix E contains bond stress vs slip curves and temperature history ${ }^{\dagger}$ for each specimen (except for room temperature specimens) during the thermal stabilization period. The last data point in each figure represents termination of the test due to rebar yielding, rebar pull-out or the testing machine limit capacity being reached. Specimen failure modes are noted in Tables 12 through 19.

\subsection{Sustained Load Test Specimens}

Sustained load tests were conducted according to the parameters listed in Table 7. Fifteen speclmens, cast from three concrete batches (1, 5, and 10), were tested at a concrete age of $62 \pm 2 \mathrm{~d}$. Testing criteria for each specimen are presented in Table 21. Continuous recordings of temperature, load, and end-to-end displacement were obtained for each

* Since the specimens were contained within furnaces and the modulus of elasticity of the steel rebars varied with temperature, the procedure described in ANSI/ASTM C 234-71 for measuring slip of the rebar could not be used directly for the test series. Thus, eight calibration specimens cast from concrete batches 18 through 20 (one for each test temperature of interest) were tested. The heating, instrumentation, and test procedures followed were similar to the regular test series, except the rebars were restrained from slipping at the surface of the concrete. The difference between the test data in which the rebar could slip through the concrete and that in which the rebar was restrained was the slip of the reinforcing steel relative to the concrete.

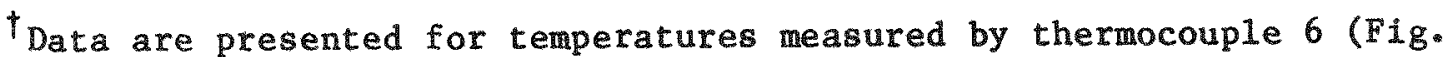
10), which is near the specimen surface. Actual rebar-concrete interface temperature, which is lower than the specimen surface temperature, can be obtained from the thermocouple data presented in Tables 12 through 19. 
Table 20. Bond stress vs slip data sumary

\begin{tabular}{|c|c|c|c|c|c|c|c|c|}
\hline \multirow{3}{*}{$\begin{array}{l}\text { Slip interval } \\
\text { [mm (in.)] }\end{array}$} & \multicolumn{8}{|c|}{ Bond stress $[\mathrm{MPa}(\mathrm{psi})]$} \\
\hline & \multicolumn{8}{|c|}{ Thermal stabilization temperature $\left[{ }^{\circ} \mathrm{C}\left({ }^{\circ} \mathrm{F}\right)\right]^{a}$} \\
\hline & $22.2(72)$ & $65.6(150)$ & $107.2(225)$ & $176.7(350)$ & $260(500)$ & $371.1(700)$ & $482.2(900)$ & $621.1(1150)$ \\
\hline $0(0)$ & $0(0)$ & $0(0)$ & $0(0)$ & $0(0)$ & $0(0)$ & $0(0)$ & $0(0)$ & $0(0)$ \\
\hline $0.025(0.001)$ & $2.05(297)$ & $1.90(276)$ & $1.90(276)$ & $2.08(302)$ & $1.62(234)$ & $0.61(89)$ & $0.52(75)$ & $0.39(56)$ \\
\hline $0.051(0.002)$ & $2.99(434)$ & $2.93(424)$ & $3.05(442)$ & $3.12(453)$ & $2.65(384)$ & $1.16(168)$ & $1.04(151)$ & $0.74(107)$ \\
\hline $0.076(0.003)$ & $3.89(564)$ & $3.87(561)$ & $4.00(580)$ & $3.90(565)$ & $3.48(505)$ & $1.66(240)$ & $1.57(228)$ & $1.07(155)$ \\
\hline $0.102(0.004)$ & $4.80(696)$ & $4.78(694)$ & $4.83(701)$ & $4.57(663)$ & $4.23(614)$ & $2.13(309)$ & $2.10(304)$ & $1.39(201)$ \\
\hline $0.127(0.005)$ & $5.76(836)$ & $5.67(823)$ & $5.61(814)$ & $5.24(760)$ & $4.96(719)$ & $2.61(379)$ & $2.61(379)$ & $1.69(245)$ \\
\hline $0.152(0.006)$ & $6.76(980)$ & $6.55(950)$ & $6.36(922)$ & $5.91(857)$ & $5.68(824)$ & $3.11(450)$ & $3.12(453)$ & $2.00(290)$ \\
\hline $0.178(0.007)$ & $7.73(1122)$ & $7.40(1074)$ & $7.08(1027)$ & $6.63(962)$ & $6.39(927)$ & $3.62(525)$ & $3.63(526)$ & $2.30(333)$ \\
\hline $0.203(0.008)$ & $8.66(1256)$ & $8.25(1197)$ & $7.79(1130)$ & $7.43(1078)$ & $7.08(1027)$ & $4.17(604)$ & $4.11(597)$ & $2.59(376)$ \\
\hline $0.229(0.009)$ & $9.52(1381)$ & $9.11(1322)$ & $8.52(1236)$ & $8.29(1203)$ & $7.75(1124)$ & $4.75(689)$ & $4.61(668)$ & $2.89(419)$ \\
\hline $0.254(0.010)$ & $10.29(1492)$ & $9.94(1441)$ & $9.24(1340)$ & $9.29(1348)$ & $8.41(1219)$ & $5.35(776)$ & $5.10(740)$ & $3.19(462)$ \\
\hline
\end{tabular}

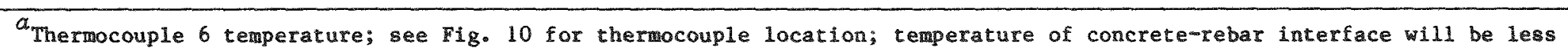
than these values. 

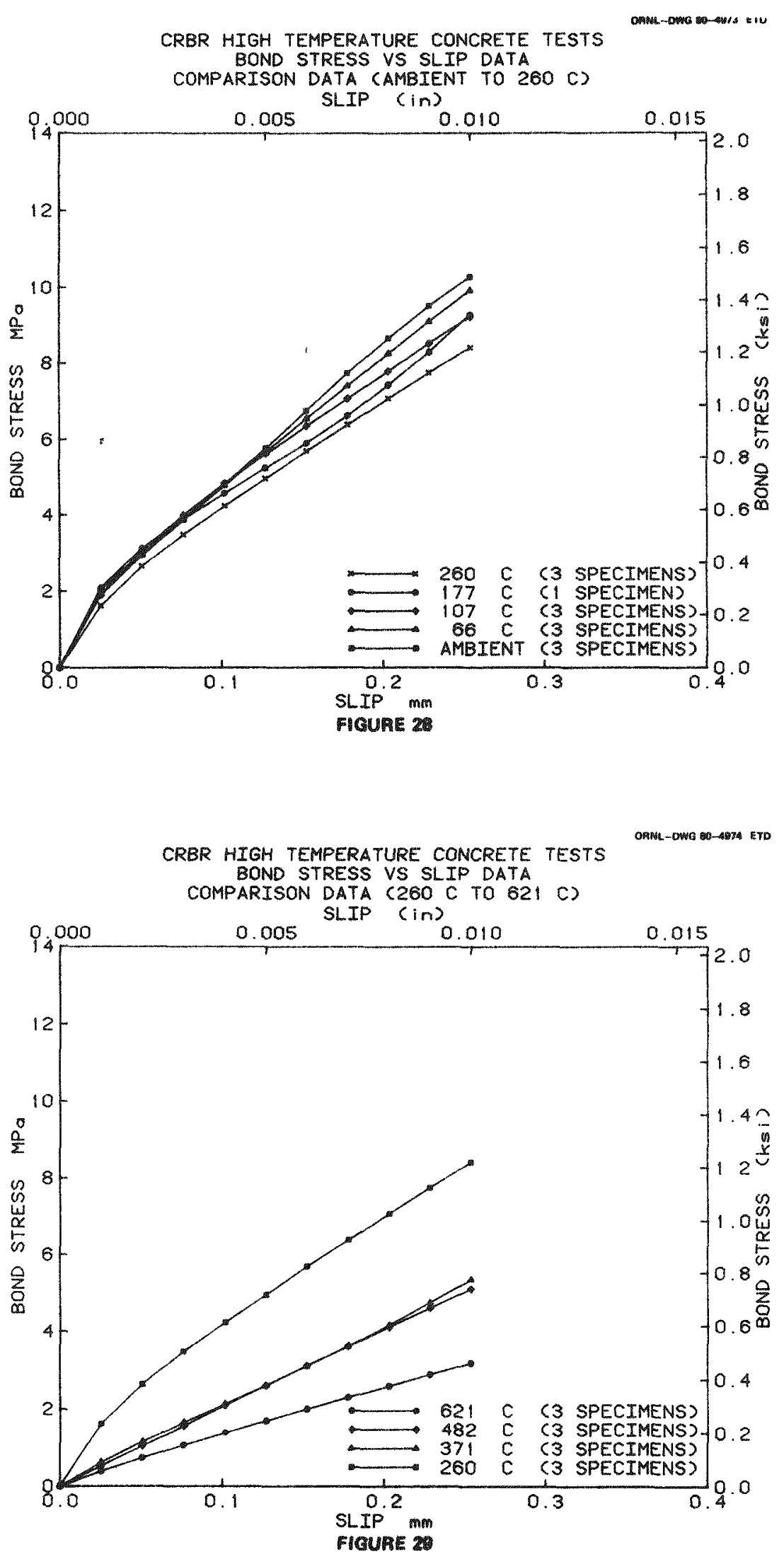
Table 21. Sustalned load test criteria

\begin{tabular}{lcccc}
\hline $\begin{array}{c}\text { Specimen } \\
\text { identification }\end{array}$ & $\begin{array}{c}\text { Concrete } \\
\text { batch }\end{array}$ & $\begin{array}{c}\text { Creep } \\
\text { test } \\
\text { rig }\end{array}$ & $\begin{array}{c}\text { Nomina1 therma } \\
\text { stabilization } \\
\text { temperature } \\
{\left[{ }^{\circ} \text { C }\left({ }^{\circ} \mathrm{F}\right)\right]}\end{array}$ & $\begin{array}{c}\text { Nominal } \\
\text { sustained } \\
\text { load } \\
{[\mathrm{kN} \text { (kips)] }}\end{array}$ \\
\hline C1501 & 1 & 5 & $65.6(150)$ & $290(65)$ \\
C2251 & 1 & 2 & $107.2(225)$ & $290(65)$ \\
C5001.2 & 1 & 4 & $260.0(500)$ & $120(26)$ \\
C5001.5 & 1 & 1 & $260.0(500)$ & $290(65)$ \\
C10001 & 1 & 3 & $537.8(1000)$ & $120(26)$ \\
& & 5 & $65.6(150)$ & $290(65)$ \\
C1505 & 5 & 5 & $107.2(225)$ & $290(65)$ \\
C2255 & 5 & 2 & $260.0(500)$ & $120(26)$ \\
C5005.2 & 5 & 4 & $260.0(500)$ & $290(65)$ \\
C5005.5 & 5 & 1 & $537.8(1000)$ & $120(26)$ \\
C10005 & 5 & 3 & & \\
& & 5 & $65.6(150)$ & $290(65)$ \\
C15010 & 10 & 5 & $107.2(225)$ & $290(65)$ \\
C22510 & 10 & 2 & $260.0(500)$ & $120(26)$ \\
C50010.2 & 10 & 4 & $260.0(500)$ & $290(65)$ \\
C50010.5 & 10 & 1 & $537.8(1000)$ & $120(26)$ \\
C100010 & 10 & 3 & & \\
\hline
\end{tabular}

$a_{\text {Reference }} 4$ limits maximum variations in specified test temperatures and loads to $\pm 11^{\circ} \mathrm{C}\left(20^{\circ} \mathrm{F}\right)$ and $\pm 9 \mathrm{kN}(2 \mathrm{kips}) \mathrm{re}-$ spectively.

specimen throughout the 60-d test duration (Table 22). Figures 30 through 32 present plots of microstrain* vs time for concrete batches 1, 5, and 10, respectively, and Figs. 33 through 37 present microstrain* vs time for specimens tested at the same thermal stablilzation temperature and sustained load leve1. Data obtained during cool-down of the specimens to ambient are also presented. Microstrain, load, and temperature histories for each specimen are contained in Appendix $F$.

*Microstrain values were determined by dividing the specimen axial displacement by gage length. Units of microstrain are $10^{-6} \mathrm{~m} / \mathrm{m}(\mathrm{in} . / \mathrm{in}$.$) .$ Positive microstrain values represent an increase in specimen length, and negative values represent a decrease in specimen length. These values are relative to specimen lengths determined just before the initiation of loading and heating. 
Table 22. Sustained load specimen test data

\begin{tabular}{|c|c|c|c|c|c|c|c|c|}
\hline \multirow[t]{2}{*}{$\begin{array}{c}\text { Specimen } \\
\text { identification }\end{array}$} & \multirow{2}{*}{$\begin{array}{c}\text { Specimen } \\
\text { length } \\
{[m \text { (in.)] }}\end{array}$} & \multirow{2}{*}{$\begin{array}{l}\text { Specimen } \\
\text { diameter } \\
{[\min (i n .)]}\end{array}$} & \multirow{2}{*}{$\begin{array}{c}\text { SSD } \\
\text { weight } \\
{[\mathrm{kg}(1 \mathrm{~b})]}\end{array}$} & \multirow{2}{*}{$\begin{array}{l}\text { Oven-dry } \\
\text { weight } \\
{[\mathrm{kg} \mathrm{(1b)]}}\end{array}$} & \multirow{2}{*}{$\begin{array}{l}\text { Weight } \\
\operatorname{loss} \\
(\%)\end{array}$} & \multirow{2}{*}{$\begin{array}{l}\text { Average specimen } \\
\text { sustained load } \\
{[k N \text { (kips)] }}\end{array}$} & \multicolumn{2}{|c|}{$\begin{array}{c}\text { Sustained stress } \\
\text { of batch strength } \\
(\%)\end{array}$} \\
\hline & & & & & & & $28 d$ & $60 \mathrm{~d}$ \\
\hline $\begin{array}{l}\mathrm{C} 1501 \\
\mathrm{C} 1505 \\
\mathrm{C} 15010 \\
\mathrm{C} 2251 \\
\mathrm{C} 2255 \\
\mathrm{C} 22510 \\
\mathrm{C} 5001.2 \\
\mathrm{C} 5005.2 \\
\mathrm{C} 50010.2 \\
\mathrm{C} 5001.5 \\
\mathrm{C} 5005.5 \\
\mathrm{C} 50010.5 \\
\mathrm{C} 10001 \\
\mathrm{C} 10005 \\
\mathrm{C} 100010\end{array}$ & $\begin{array}{l}302.2(11.89) \\
300.2(11.82) \\
299.9(11.81) \\
301.4(11.87) \\
303.7(11.96) \\
299.9(11.81) \\
300.2(11.82) \\
303.8(11.96) \\
299.9(11.81) \\
303.8(11.96) \\
303.7(11.96) \\
299.9(11.81) \\
301.9(11.89) \\
303.3(11.94) \\
299.6(11.80)\end{array}$ & $\begin{array}{l}153.1(6.03) \\
153.0(6.02) \\
153.5(6.04) \\
153.5(6.04) \\
153.0(6.02) \\
153.0(6.02) \\
153.0(6.02) \\
153.1(6.03) \\
153.3(6.04) \\
153.4(6.04) \\
153.2(6.03) \\
153.7(6.05) \\
153.7(6.05) \\
153.5(6.04) \\
153.2(6.03)\end{array}$ & $\begin{array}{ll}13.29 & (29.3) \\
13.21 & (29.1) \\
13.45 & (29.7) \\
13.34 & (29.4) \\
13.47 & (29.7) \\
13.50 & (29.8) \\
13.09 & (29.9) \\
13.34 & (29.4) \\
13.52 & (29.8) \\
13.36 & (29.5) \\
13.52 & (29.8) \\
13.56 & (29.9) \\
13.37 & (29.5) \\
13.52 & (29.8) \\
13.50 & (29.8)\end{array}$ & $\begin{array}{ll}12.75 & (28.1) \\
12.71 & (28.0) \\
13.01 & (28.7) \\
12.53 & (27.6) \\
12.69 & (28.0) \\
12.76 & (28.1) \\
12.21 & (26.9) \\
12.42 & (27.4) \\
12.61 & (27.8) \\
12.43 & (27.4) \\
12.61 & (27.8) \\
12.66 & (27.9) \\
11.93 & (26.3) \\
12.01 & (26.5) \\
11.97 & (26.4)\end{array}$ & $\begin{array}{l}55.8 \\
51.2 \\
43.5 \\
82.4 \\
78.5 \\
74.3 \\
91.1 \\
92.7 \\
89.2 \\
94.5 \\
91.4 \\
89.2 \\
146.1 \\
150.9 \\
152.3\end{array}$ & $\begin{array}{ll}278.4 & (62.6) \\
286.1 & (64.3) \\
287.3 & (64.6) \\
287.6 & (64.7) \\
288.7 & (64.9) \\
286.3 & (64.4) \\
114.4 & (25.7) \\
120.7 & (27.1) \\
116.9 & (26.3) \\
286.7 & (64.5) \\
289.3 & (65.0) \\
293.6 & (66.0) \\
120.3 & (27.0) \\
120.4 & (27.1) \\
120.3 & (27.0)\end{array}$ & $\begin{array}{l}54 \\
42 \\
42 \\
54 \\
42 \\
42 \\
22 \\
18 \\
17 \\
54 \\
42 \\
43 \\
22 \\
17 \\
18\end{array}$ & $\begin{array}{l}40 \\
34 \\
31 \\
40 \\
35 \\
31 \\
16 \\
14 \\
13 \\
40 \\
35 \\
32 \\
17 \\
14 \\
13\end{array}$ \\
\hline
\end{tabular}

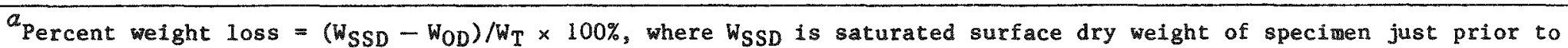
heat-up, WOD is specimen weight at conclusion of sustained load test, and WT is total weight of water contained in specimen at time of mixing (specimen volume times wet-unit weight times mix-water weight divided by total weight of mix materials). 

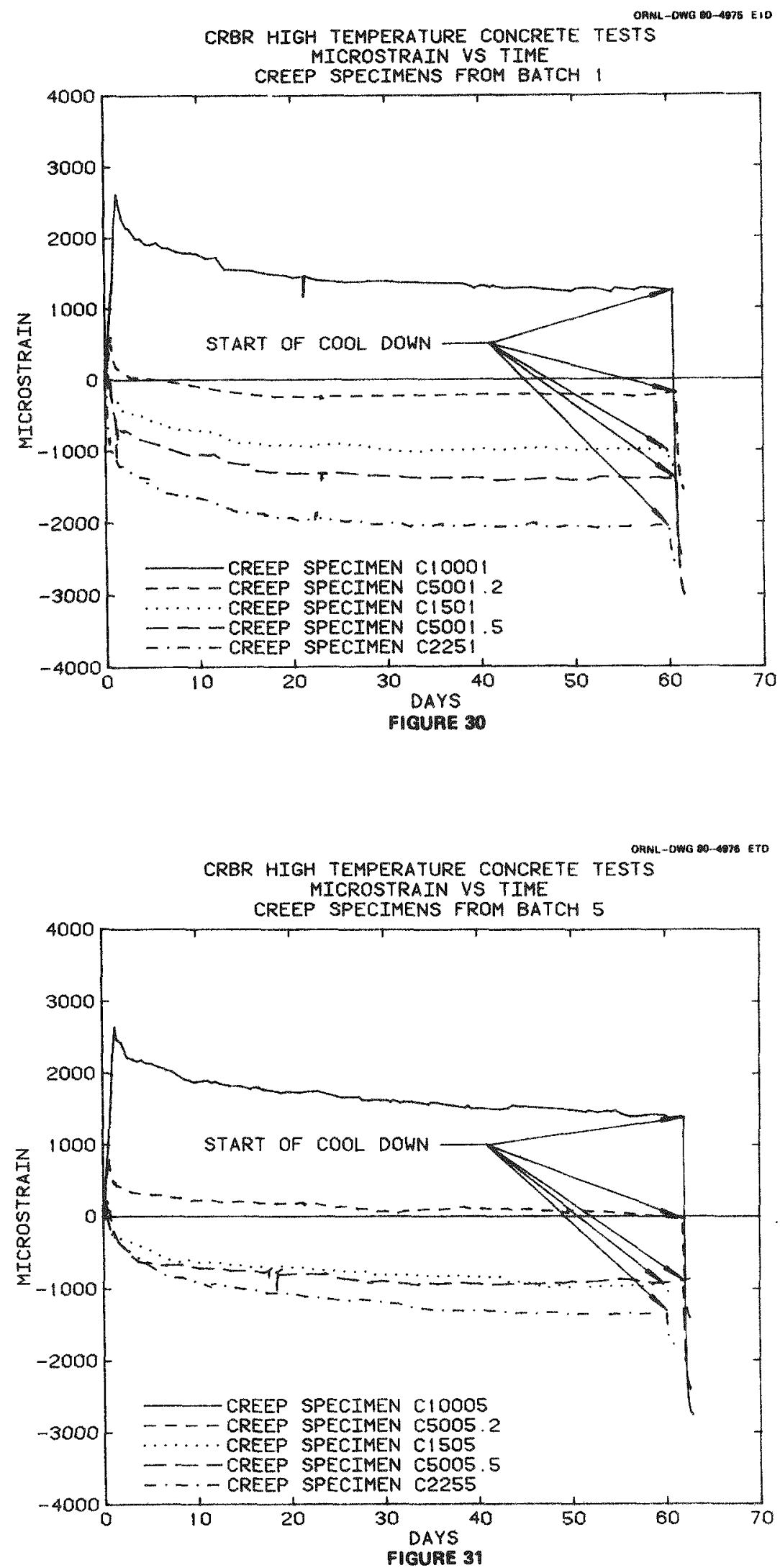

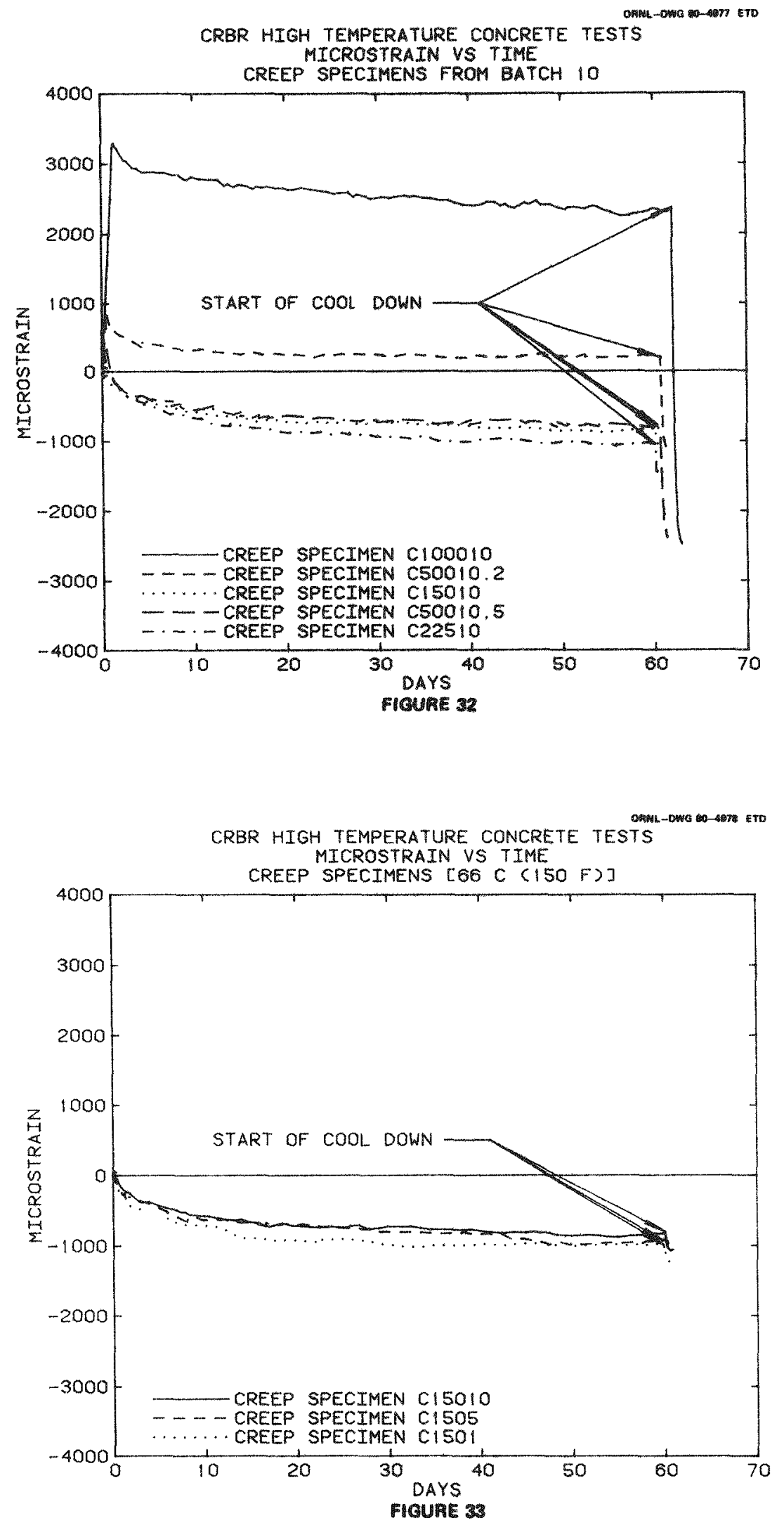

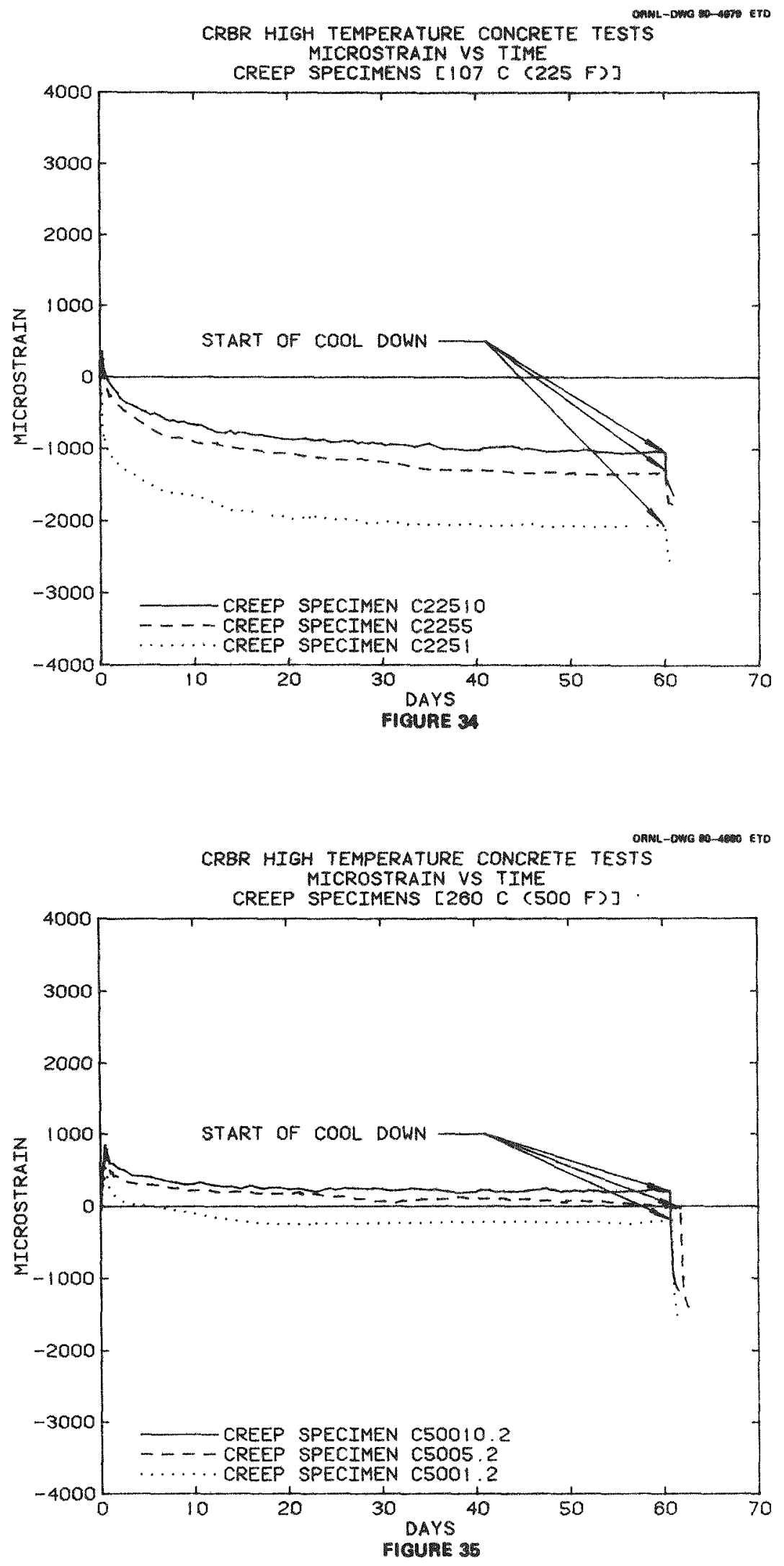

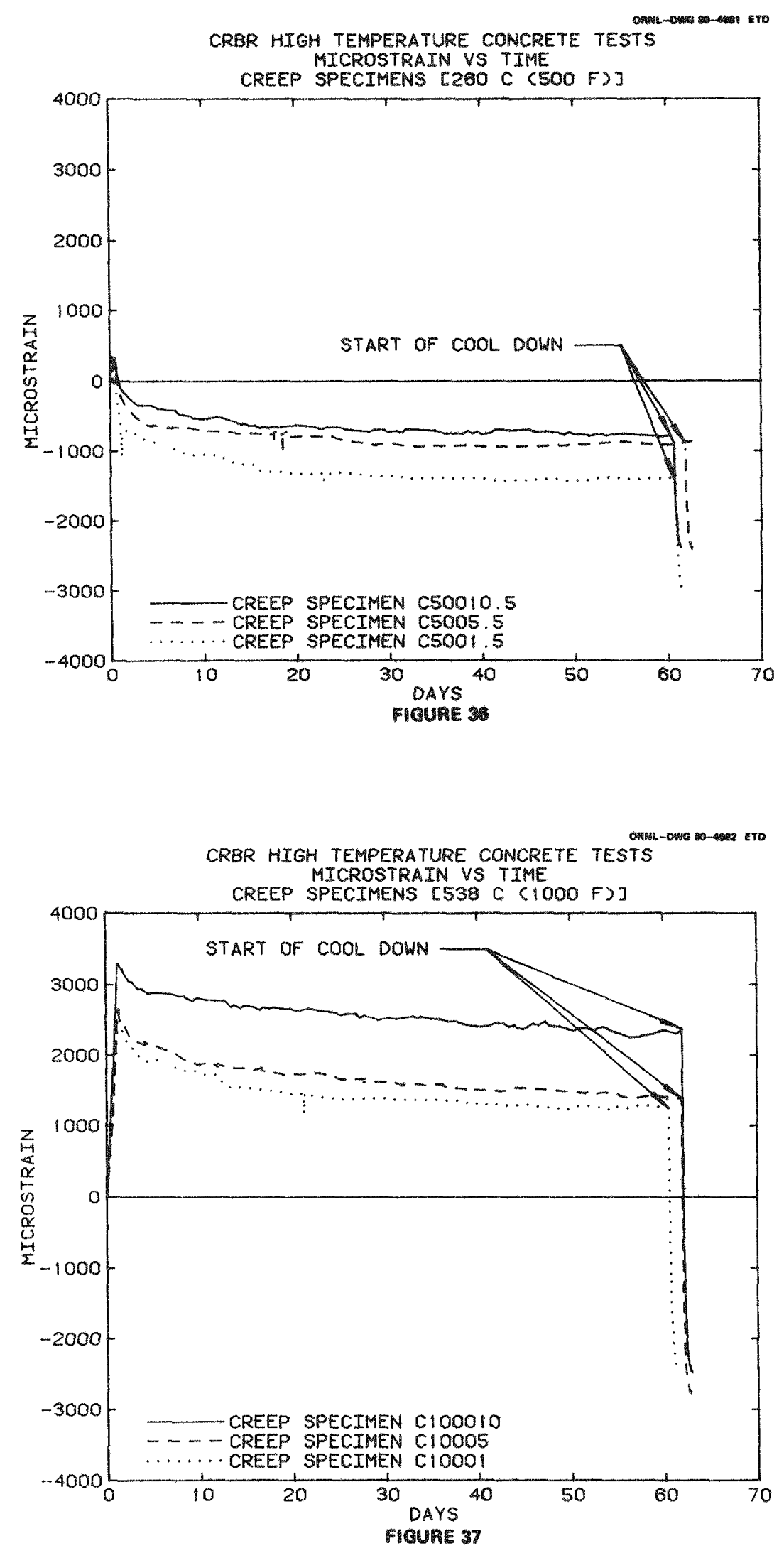


\section{SUMMARY}

\subsection{Objective}

The objective of this testing program was to define the variations in mechanical (strength) properties of limestone aggregate concrete and lightweight insulating concrete exposed to elevated temperatures that could occur as a result of a postulated large sodium spill in a lined LMFBR equipment cell.

\subsection{Scope}

To meet the present objective, four test series were conducted: (1) unconfined compression, (2) shear, (3) rebar bond, and (4) sustained loading (creep).

\subsection{Experimental Investigation}

\subsubsection{Unconfined compression tests}

Unconfined compression tests were conducted on cylindrical test specimens $0.30 \mathrm{~m}$ by $0.15 \mathrm{~m}$ diam (12 $\mathrm{in}$. by $6 \mathrm{ln}$, diam) fabricated from both the standard weight and 11ghtweight insulating concretes. These tests were conducted to determine the effects of elevated temperature exposure on the material's mechanical properties. The specimens were subjected to thermal stabilization temperatures ranging from ambient to $621.1^{\circ} \mathrm{C}\left(1500^{\circ} \mathrm{F}\right)$ for periods of elther 14 or $28 \mathrm{~d}$. Ultimate compressive strength, stress-strain behavior, modulus of elasticity, and moisture and weight loss were determined for each specimen. Poisson's ratio values were also determined for the standard welght concrete specimens.

Results obtained for the standard welght concretes indicate that the ultimate compressive strengths for temperature exposures of $371.1^{\circ} \mathrm{C}$ $\left(700^{\circ} \mathrm{F}\right)$ or less were generally greater that the $28-\mathrm{d}$, room temperature, moisture, molst-cured reference values. For exposure temperatures greater than $371^{\circ} \mathrm{C}\left(700^{\circ} \mathrm{F}\right)$, the compressive strength decreased steadily with increasing temperature. In relation to 28 -d reference control specimens, 
the modulus of elasticity exhibited a tendency to steadily decrease as the exposure temperature increased. In relation to the $60-\mathrm{d}$, room temperature, molst-cured, reference values, the residual strength and modulus of e lacticity after temperture exposures were less than the corresponding 28-d control values. However, this tendency was expected because of the specimen's continued strength gain in going from a 28- to a 60 -d cure period. In relation to the $60-d$ control values, the residual strengths did not show a significant decrease until the thermal stabilization temperature exceeded $260^{\circ} \mathrm{C}\left(500^{\circ} \mathrm{F}\right)$. Residual modulus of elasticity values decreased steadily with temperature exposure in relation to 60 -d control specimen values. Compressive strains at ultimate strength increased as the exposure temperature increased; that is, the specimens became more ductile with increasing exposure temperature. Weight loss also increased as the exposure temperature increased, with the most significant increase occurring when the temperature increased from $482.2^{\circ} \mathrm{C}\left(900^{\circ} \mathrm{F}\right)$ to $621.1^{\circ} \mathrm{C}$ $\left(1150^{\circ} \mathrm{F}\right)$. No definite trend was observed for the effect of exposure temperature on Poisson's ratio.

The lightweight insulating concrete specimens exhibited an apparent increase in compressive strength in relation to $28-\mathrm{d}$, room temperature, cured specimens for exposure temperatures of up to approximately $260^{\circ} \mathrm{C}$ $\left(500^{\circ} \mathrm{F}\right) .^{*}$ For higher exposure temperatures, the ultimate strength continued to decrease as the temperature increased. The modulus of elasticity, compressive strain at ultimate strength, and weight loss for the lightweight concrete showed trends for the effects of exposure temperature similar to those exhibited by the standard weight specimens. Poisson's ratio data were not obtained from the 1 ightweight concrete specimens.

*The apparent increase in strength properties with an exposure temperature of up to $260^{\circ} \mathrm{C}\left(500^{\circ} \mathrm{F}\right)$ is somewhat exaggerated; the values at temperature were obtained from 74-d old specimens, while the reference values were obtained from 28-d old specimens. Results indicate that strength gain due to additional hydration more than affects the strength loss due to temperature exposure up to $260^{\circ} \mathrm{F}\left(500^{\circ} \mathrm{F}\right)$; however, above $260^{\circ} \mathrm{C}$ $\left(500^{\circ} \mathrm{F}\right)$ the temperature effects are more significant than those due to continued hydration. 


\subsubsection{Shear tests}

S-shape, parallelepiped specimens were used to determine the effects of elevated temperature exposure on the shear strength (Sect. 3.3) of Iimestone aggregate concrete. Specimens were subjected to thermal stabilization at temperatures up to $621.1^{\circ} \mathrm{C}\left(1150^{\circ} \mathrm{F}\right)$ for $14 \mathrm{~d}$. Results obtained indicate that the shear strength was inversely proportional to the exposure temperature.

\subsubsection{Bond pul1-out tests}

Bond pul1-out tests were conducted using $0.30-\mathrm{m}\left(12-\mathrm{n}_{0}\right)$ standard weight concrete cubes containing No. 11 reinforcing bars, which were embedded vertically. The tests were conducted to determine the effect of exposure temperature on the concrete-rebar load-slip behavior. The spectmens were exposed to thermal stabilization temperatures ${ }^{*}$ up to $621.1^{\circ} \mathrm{C}$ $\left(1150^{\circ} \mathrm{F}\right)$ for $14 \mathrm{~d}$ prior to testing. The results indicate a tendency for the concrete-rebar slip to increase, at a specified bond stress, as the thermal stabilization temperature increases.

\subsubsection{Sustained load (creep) tests}

Sustained load tests were conducted on limestone aggregate cylindrical specimens $0.30 \mathrm{~m}$ by $0.15 \mathrm{~m}$ diam $(12 \mathrm{in}$. by $6 \mathrm{in}$. diam). The objective of the tests was to determine the deformational behavior of a limestone aggregate concrete under sustained loading at elevated temperature. Specimens were loaded at room temperature to either 20 or $50 \%$ of their reference design, 28-d unconfined, ultimate compressive strength of 31.72 MPa (4600 psi) and then exposed to thermal stabilization temperatures up to $537.8^{\circ} \mathrm{C}\left(1000^{\circ} \mathrm{F}\right)$ for $60 \mathrm{~d}$. Specimen length changes resulted from loadings, thermal expansion, modulus reduction with temperatures, and moisture loss (shrinkage). Specimen behavior within each concrete batch was consistent, but specimens from different concrete batches, tested at the same

\footnotetext{
*Data are presented for temperatures measured by thermocouple 6 (Fig. 10), which is near the specimen surface. Actual rebar-concrete interface temperature, which is lower than the specimen surface temperature, can be obtained from the thermocouple data presented in Tables 12 through 19.
} 
combination of temperature and load, exhibited somewhat differing displacement histories. Displacement differences were due to the ratio of applied load to specimen strength changing slightly from batch to batch a.d tie infcrostrain data being a function of the following material variations which were influenced by temperature exposure: modulus of elasticity, shrinkage, thermal expansion, creep, and compressive strength. No specimens falled under these combinations of load and temperature. 


\section{RE TERENCES}

1. Burns and Roe, Inc., A Comprehensive Testing Program for Conerete at Elevated Temperatures, DRS 27.13 (Rev.6), approved by EN:RPS:79-019 dated January 23, 1979, recelved by ORNL Apri1 10, 1980.

2. J. P. Callahan et al., "Unlaxial Compressive Strength of Concrete for Temperatures Reaching 1033 K, "Nucl. Eng. Des. 45, 439 (1978).

3. G. Freskakis et a1., "Strength Properties of Concrete at Elevated Temperatures," ASCE preprint 3594, Civ. Eng. Nucl. Power 1 (Apri1 1979).

4. C. B. Oland et al., Plan for the Determination of Mechanical and Therm mal Properties of Concretes to Temperatures of $621^{\circ} \mathrm{C}\left(1150^{\circ} \mathrm{F}\right)$, ORNL/ TM-6234 (September 1978).

5. G. E. Troxell et al., Composition and Properties of Concrete, 2d ed., McGraw-Hi11, New York, 1968.

6. J. A. Hofbeck et al., "Shear Transfer in Reinforced Concrete," Proc. Am. Coner. Inst. J. 66(2), 119 (February 1969).

7. Letter, D. R. Riley, Assistant Director for Engineering of CRBRP Project, to J. M. Corum, Manager of High Temperature Structural Design Program for LMFBR at ORNL, dated Apr11 18, 1979, Subject: Revised Bond Pull-Out Testing Procedure for DRS 27.13. 
Appendix A

CONCRETE MIX DATA (BATCH NUMBERS 1 TO 21) 
76
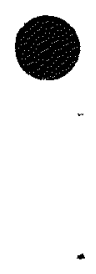

-

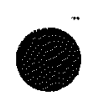


Table. A.1. Batch 1 standard welght concrete data sumary ${ }^{a}$

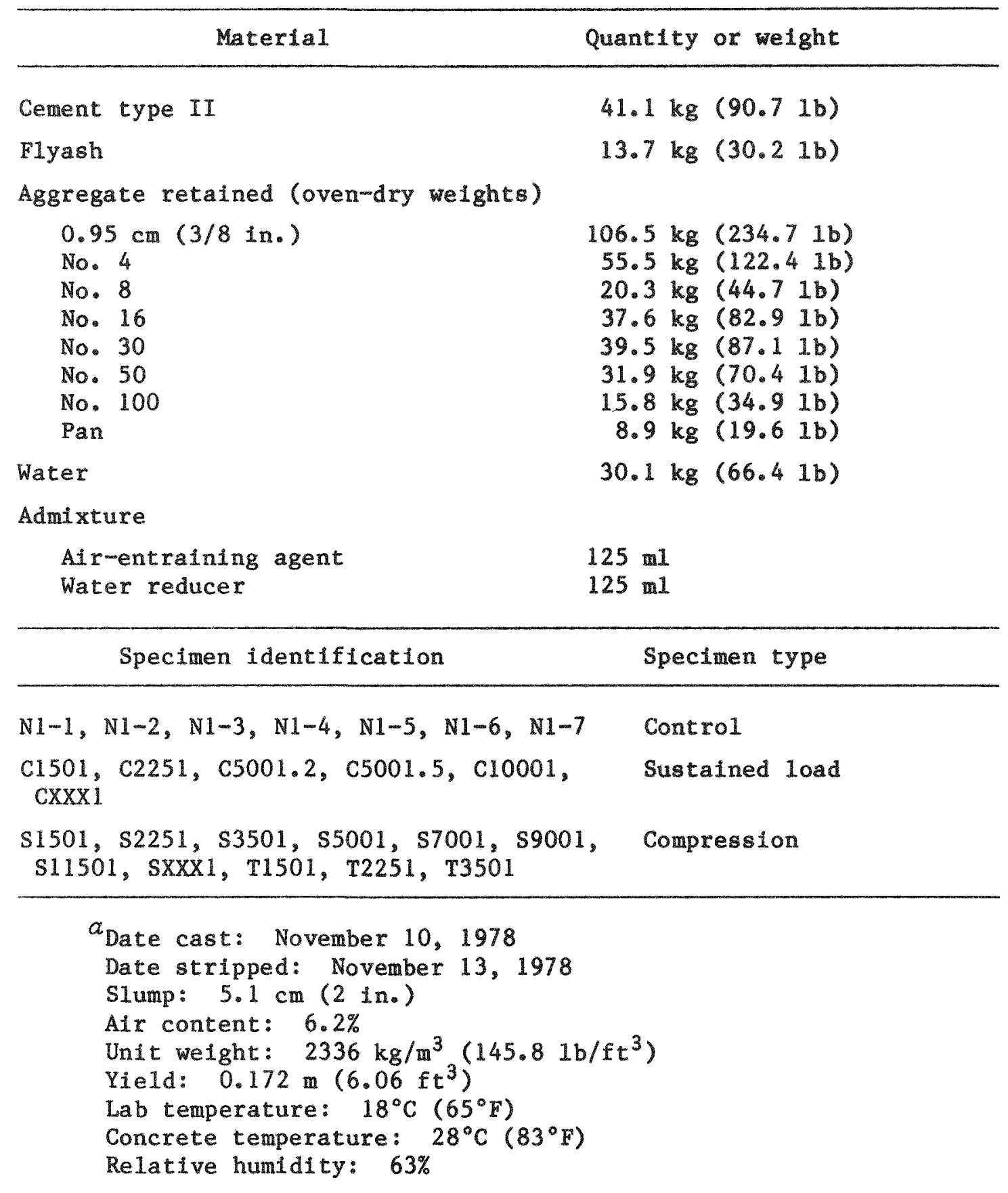


Table. A.2. Batch 2 standard weight concrete data sumary ${ }^{a}$

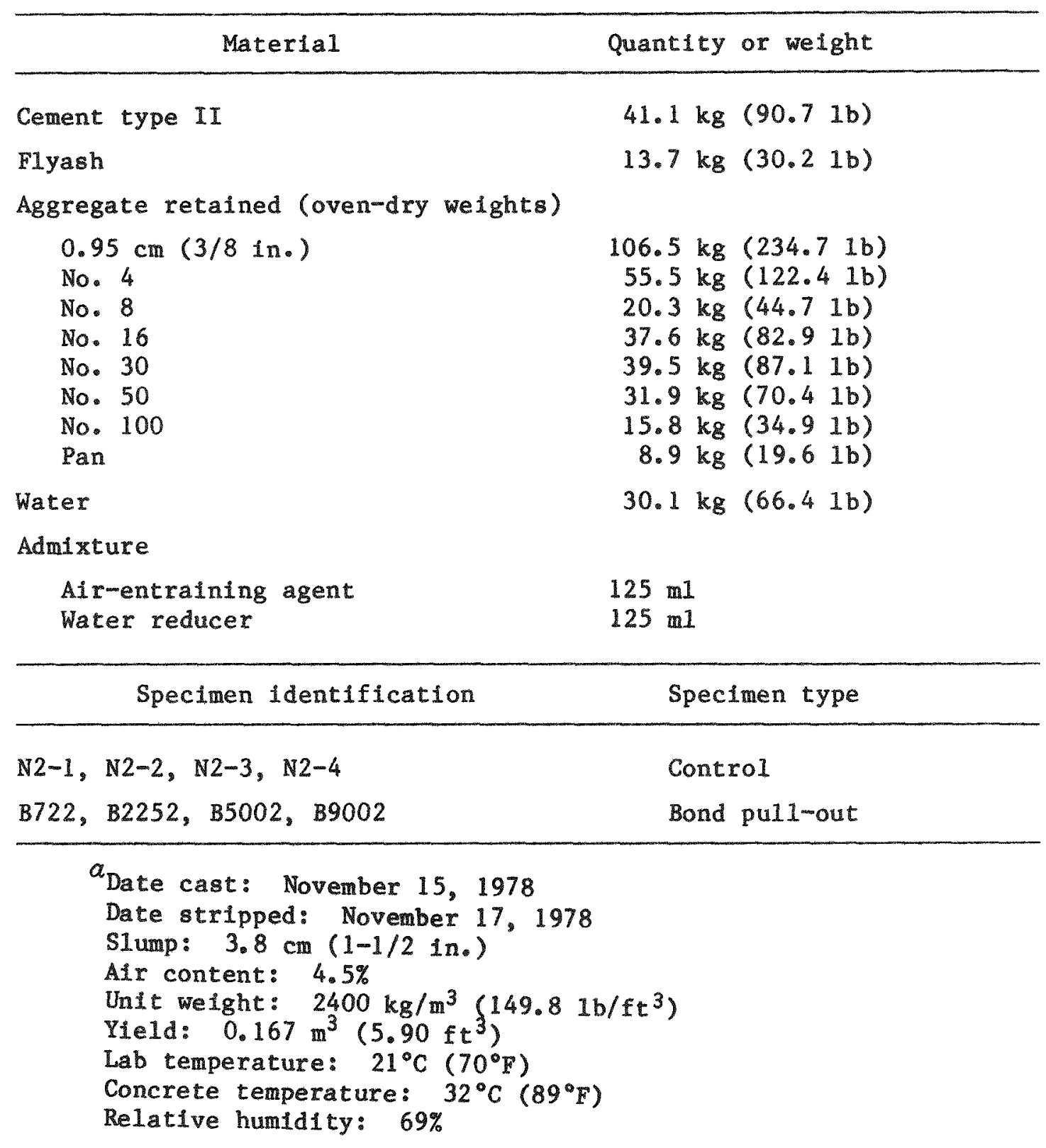


Table. A.3. Batch 3 standard welght concrete data summary $a$

\begin{tabular}{|c|c|}
\hline Material & Quantity or weight \\
\hline Cement type II & $27.4 \mathrm{~kg}(60.4 \mathrm{lb})$ \\
\hline Flyash & $9.1 \mathrm{~kg}(20.1 \mathrm{lb})$ \\
\hline \multicolumn{2}{|c|}{ Aggregate retalned (oven-dry weights) } \\
\hline $\begin{array}{l}0.95 \mathrm{~cm}(3 / 8 \mathrm{in.}) \\
\text { No. } 4 \\
\text { No. } 8 \\
\text { No. } 16 \\
\text { No. } 30 \\
\text { No. } 50 \\
\text { No. } 100 \\
\text { Pan }\end{array}$ & $\begin{array}{r}70.1 \mathrm{~kg}(156.4 \mathrm{lb}) \\
37.0 \mathrm{~kg}(81.6 \mathrm{lb}) \\
13.5 \mathrm{~kg}(29.8 \mathrm{lb}) \\
25.1 \mathrm{~kg}(55.3 \mathrm{lb}) \\
26.4 \mathrm{~kg}(58.1 \mathrm{lb}) \\
21.3 \mathrm{~kg}(47.01 \mathrm{~b}) \\
10.6 \mathrm{~kg}(23.31 \mathrm{~b}) \\
5.9 \mathrm{~kg}(13.01 \mathrm{~b})\end{array}$ \\
\hline Water & $20.1 \mathrm{~kg}(44.31 \mathrm{~b})$ \\
\hline \multicolumn{2}{|l|}{ Admixture } \\
\hline $\begin{array}{l}\text { Air-entraining agent } \\
\text { Watex reducer }\end{array}$ & $\begin{array}{l}85 \mathrm{ml} \\
85 \mathrm{ml}\end{array}$ \\
\hline Specimen identification & Specimen type \\
\hline $\begin{array}{l}\text { N3-1, N3-2, N3-3, N3-4, } \\
\text { S1503, S2253, S3503, S5003, S700 } \\
\text { S11503, SXXX3, T1503, T2253, T3 }\end{array}$ & Compression \\
\hline \multicolumn{2}{|c|}{$\begin{array}{l}a_{\text {Date cast: December } 12,1978} \\
\text { Date stripped: December } 14,1978 \\
\text { Slump: } 6.4 \mathrm{~cm}(2-1 / 2 \mathrm{in}) \\
\text { Air content: } 6.5 \% \\
\text { Unit weight: } 2342 \mathrm{~kg} / \mathrm{m}^{3}\left(146.21 \mathrm{~b} / \mathrm{ft}^{3}\right) \\
\text { Yield: } 0.114 \mathrm{~m}^{3}\left(4.03 \mathrm{ft}^{3}\right) \\
\text { Lab temperature: } 14^{\circ} \mathrm{C}\left(58^{\circ} \mathrm{F}\right) \\
\text { Concrete temperature: } 21^{\circ} \mathrm{C}\left(70^{\circ} \mathrm{F}\right) \\
\text { Relative humidity: } 45 \%\end{array}$} \\
\hline
\end{tabular}


Table. A.4. Batch 4 standard welght concrete data summary

\begin{tabular}{|c|c|}
\hline Material & Quantity or weight \\
\hline Cement type II & $41.1 \mathrm{~kg}(90.71 \mathrm{~b})$ \\
\hline Flyash & $13.7 \mathrm{~kg}(30.2 \mathrm{lb})$ \\
\hline \multicolumn{2}{|c|}{ Aggregate retained (oven-dry weights) } \\
\hline $\begin{array}{l}0.95 \mathrm{~cm}(3 / 8 \mathrm{in}) \\
\text { No. } 4 \\
\text { No. } 8 \\
\text { No. } 16 \\
\text { No. } 30 \\
\text { No. } 50 \\
\text { No. } 100 \\
\text { Pan }\end{array}$ & $\begin{array}{r}106.5 \mathrm{~kg}(234.7 \mathrm{lb}) \\
55.5 \mathrm{~kg}(122.4 \mathrm{lb}) \\
20.3 \mathrm{~kg}(44.7 \mathrm{lb}) \\
37.6 \mathrm{~kg}(82.9 \mathrm{lb}) \\
39.5 \mathrm{~kg}(87.1 \mathrm{lb}) \\
31.9 \mathrm{~kg}(70.4 \mathrm{lb}) \\
15.8 \mathrm{~kg}(34.9 \mathrm{Ib}) \\
8.9 \mathrm{~kg}(19.61 \mathrm{~b})\end{array}$ \\
\hline Water & $30.1 \mathrm{~kg}(66.4 \mathrm{lb})$ \\
\hline \multicolumn{2}{|l|}{ Admixture } \\
\hline $\begin{array}{l}\text { Air-entraining agent } \\
\text { Water reducer }\end{array}$ & $\begin{array}{l}125 \mathrm{ml} \\
125 \mathrm{ml}\end{array}$ \\
\hline Specimen identification & Specimen type \\
\hline $\begin{array}{l}\text { N4-1, N4-2, N4-3, N4-4 } \\
\text { B1504, B3504, B7004, B1 } 1504\end{array}$ & $\begin{array}{l}\text { Control } \\
\text { Bond pul1-out }\end{array}$ \\
\hline \multicolumn{2}{|c|}{$\begin{array}{l}a_{\text {Date cast: December } 19,1979} \\
\text { Date stripped: December } 21,1979 \\
\text { Slump: } 4.4 \mathrm{~cm}(1-3 / 4 \mathrm{in} .) \\
\text { Air content: } 4.7 \% \\
\text { Unit weight: } 2368 \mathrm{~kg} / \mathrm{m}^{3}\left(147.81 \mathrm{~b} / \mathrm{ft}^{3}\right) \\
\text { Yield: } 0.169 \mathrm{~m}^{3}\left(5.98 \mathrm{ft}^{3}\right) \\
\text { Lab temperature: } 18^{\circ} \mathrm{C}\left(65^{\circ} \mathrm{F}\right) \\
\text { Concrete temperature: } 26^{\circ} \mathrm{C}\left(79^{\circ} \mathrm{F}\right) \\
\text { Relative humidity: } 44 \%\end{array}$} \\
\hline
\end{tabular}


Table. A.5. Batch 5 standard weight concrete data summary ${ }^{a}$

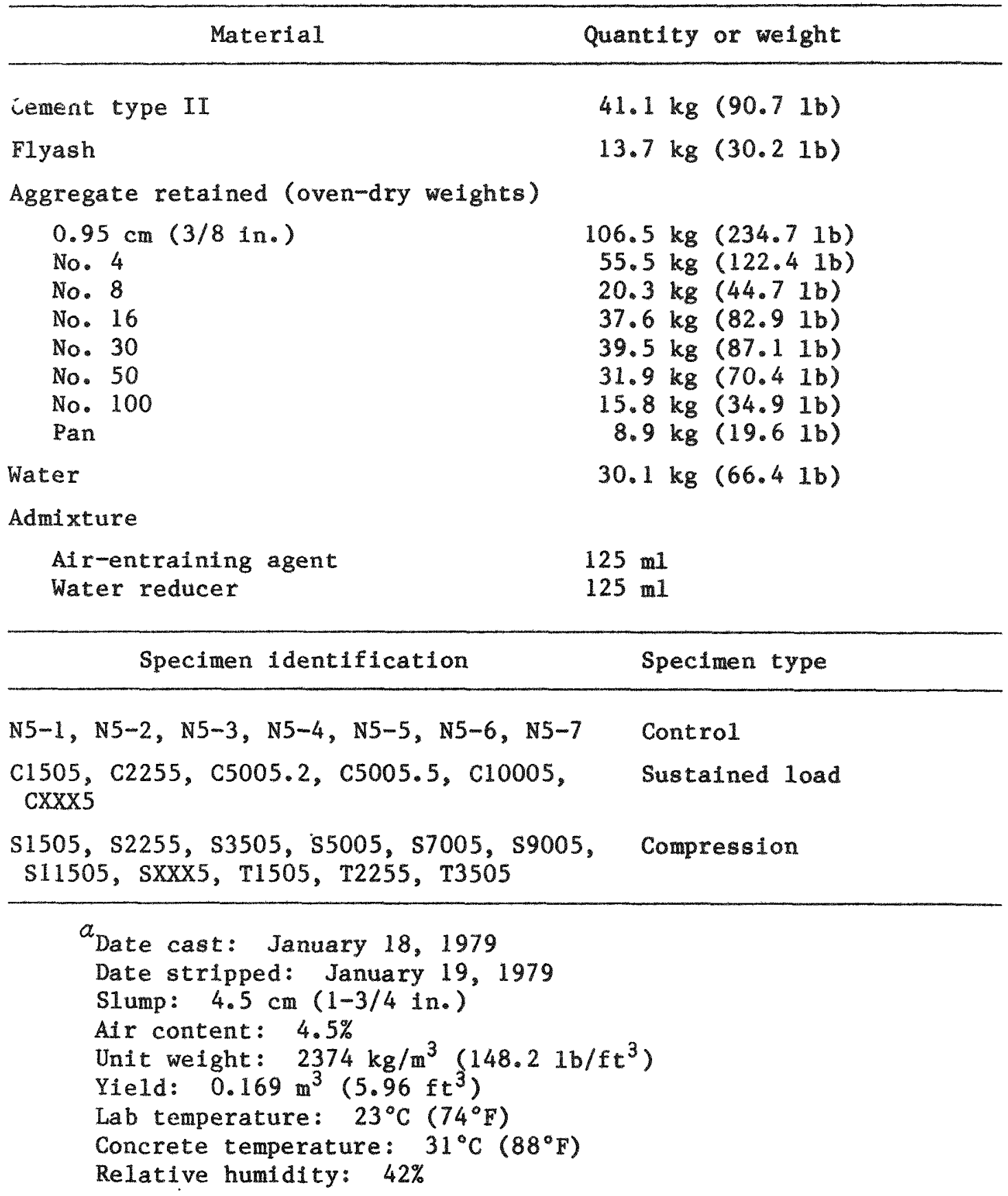


Table. A.6. Batch 6 standard welght concrete data summary ${ }^{a}$

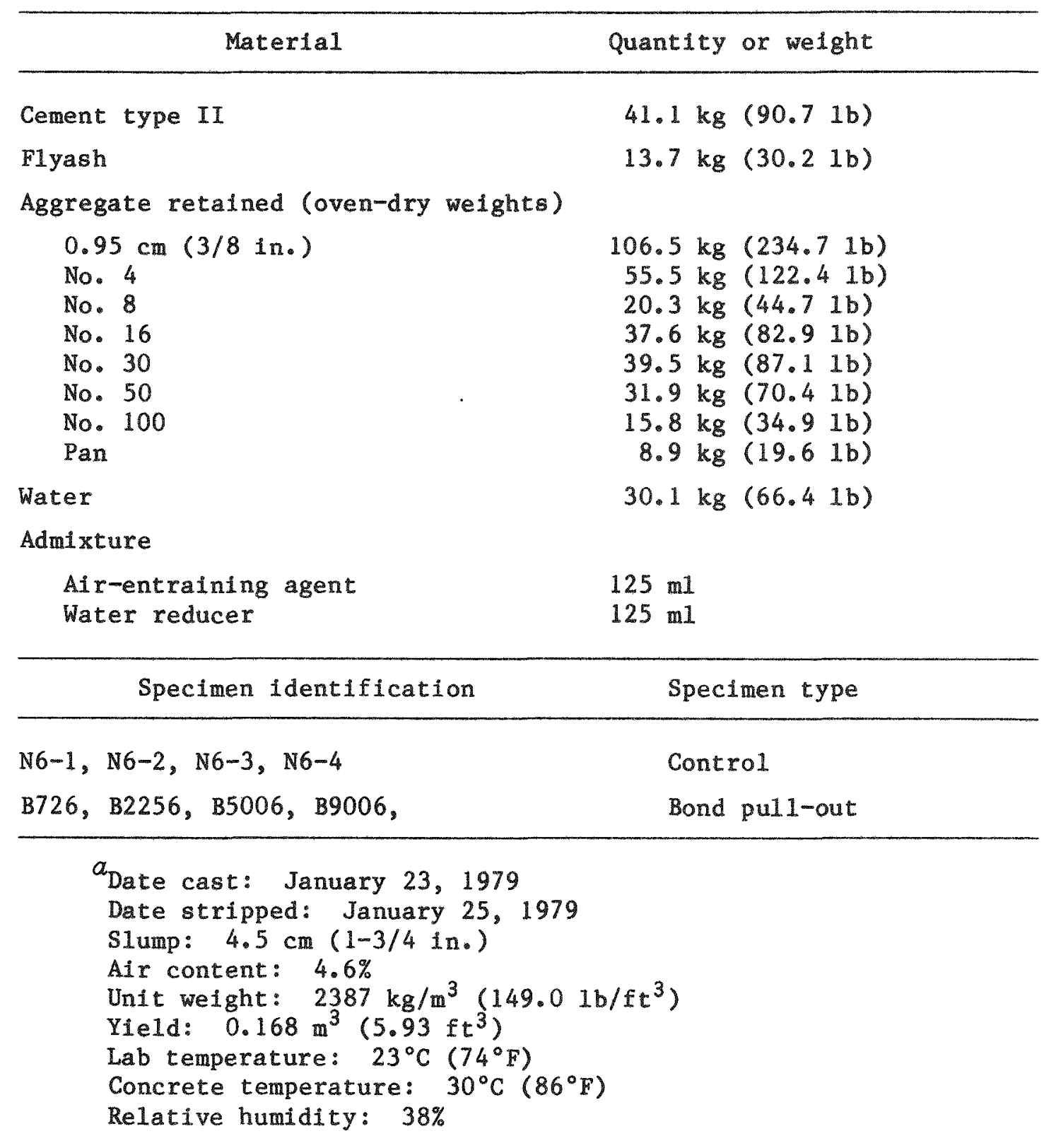


Table. A.7. Batch 7 standard weight concrete data summary ${ }^{a}$

\begin{tabular}{|c|c|}
\hline Material & Quantity or weight \\
\hline Cement type II & $34.3 \mathrm{~kg}(75.6 \mathrm{lb})$ \\
\hline Flyash & $11.4 \mathrm{~kg}(25.21 \mathrm{~b})$ \\
\hline \multicolumn{2}{|l|}{ Aggregate retalned (oven-dry weights) } \\
\hline $\begin{array}{l}0.95 \mathrm{~cm}(3 / 8 \mathrm{in.}) \\
\text { No. } 4 \\
\text { No. } 8 \\
\text { No. } 16 \\
\text { No. } 30 \\
\text { No. } 50 \\
\text { No. } 100 \\
\text { Pan }\end{array}$ & $\begin{array}{l}88.7 \mathrm{~kg}(195.61 \mathrm{~b}) \\
46.3 \mathrm{~kg}(102.01 \mathrm{~b}) \\
16.9 \mathrm{~kg}(37.2 \mathrm{lb}) \\
31.3 \mathrm{~kg}(69.1 \mathrm{lb}) \\
32.9 \mathrm{~kg}(72.61 \mathrm{~b}) \\
26.6 \mathrm{~kg}(58.7 \mathrm{lb}) \\
13.2 \mathrm{~kg}(29.11 \mathrm{~b}) \\
7.4 \mathrm{~kg}(16.31 \mathrm{~b})\end{array}$ \\
\hline Water & $25.1 \mathrm{~kg}(55.41 \mathrm{~b})$ \\
\hline \multicolumn{2}{|l|}{ Admixture } \\
\hline $\begin{array}{l}\text { Air-entraining agent } \\
\text { Water reducer }\end{array}$ & $\begin{array}{l}104 \mathrm{ml} \\
104 \mathrm{~m} 1\end{array}$ \\
\hline Specimen identification & Specimen type \\
\hline $\begin{array}{l}\text { N7-1, N7-2, N7-3, N7-4, N7-5, N7-6, N7-7 } \\
\text { V727, V1507, V2257, V3507, V5007, V7007, } \\
\text { V9007, V11507 }\end{array}$ & $\begin{array}{l}\text { Control } \\
\text { Shear }\end{array}$ \\
\hline $\begin{array}{l}\text { a Date cast: February 6, } 1979 \\
\text { Date stripped: February } 8,1979 \\
\text { S1ump: } 2.9 \mathrm{~cm}(1-1 / 8 \mathrm{in}) \\
\text { Air content: } 4.7 \% \\
\text { Unit weight: } 2409 \mathrm{~kg} / \mathrm{m}^{3}(150.4 \mathrm{lb} / \\
\text { Yield: } 0.139 \mathrm{~m}^{3}\left(4.90 \mathrm{ft}^{3}\right) \\
\text { Lab temperature: } 21^{\circ} \mathrm{C}\left(69^{\circ} \mathrm{F}\right) \\
\text { Concrete temperature: } 27^{\circ} \mathrm{C}\left(80^{\circ} \mathrm{F}\right) \\
\text { Relative humidity: } 39 \%\end{array}$ & $\left.f t^{3}\right)$ \\
\hline
\end{tabular}


Table. A.8. Batch 8 lightweight Insulating concrete data sumary ${ }^{\alpha}$

\begin{tabular}{lr}
\hline \multicolumn{1}{c}{ Material } & Quantity or weight \\
\hline Cement type II & $68.0 \mathrm{~kg}(150.01 \mathrm{~b})$ \\
Perlite & $19.1 \mathrm{~kg}(42.01 \mathrm{~b})$ \\
Aggregate retained (oven-dry weights) & \\
No. 8 & $9.0 \mathrm{~kg}(19.81 \mathrm{~b})$ \\
No. 16 & $16.6 \mathrm{~kg}(36.61 \mathrm{~b})$ \\
No. 30 & $17.4 \mathrm{~kg}(38.41 \mathrm{~b})$ \\
No. 50 & $14.2 \mathrm{~kg}(31.21 \mathrm{~b})$ \\
No. 100 & $7.1 \mathrm{~kg}(15.61 \mathrm{~b})$ \\
Pan & $3.8 \mathrm{~kg}(8.41 \mathrm{~b})$ \\
Water & $49.7 \mathrm{~kg}(109.61 \mathrm{~b})$ \\
Admixture & \\
Air-entraining agent & $150 \mathrm{ml}$ \\
\hline
\end{tabular}

N8-1, N8-2, N8-3, N8-4, N8-5, N8-6, N8-7, Contro 1 $\mathrm{N} 8-8, \mathrm{~N} 8-9, \mathrm{~N} 8-10$

L1508, L2258, L3508, L5008, L7008, L9008, Compression LX8, LXX8, LXXX8

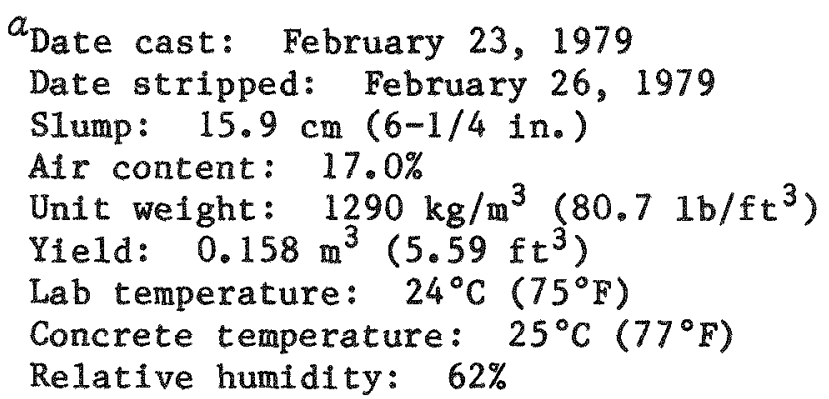


Table. A.9. Batch 9 standard weight concrete data summary ${ }^{a}$

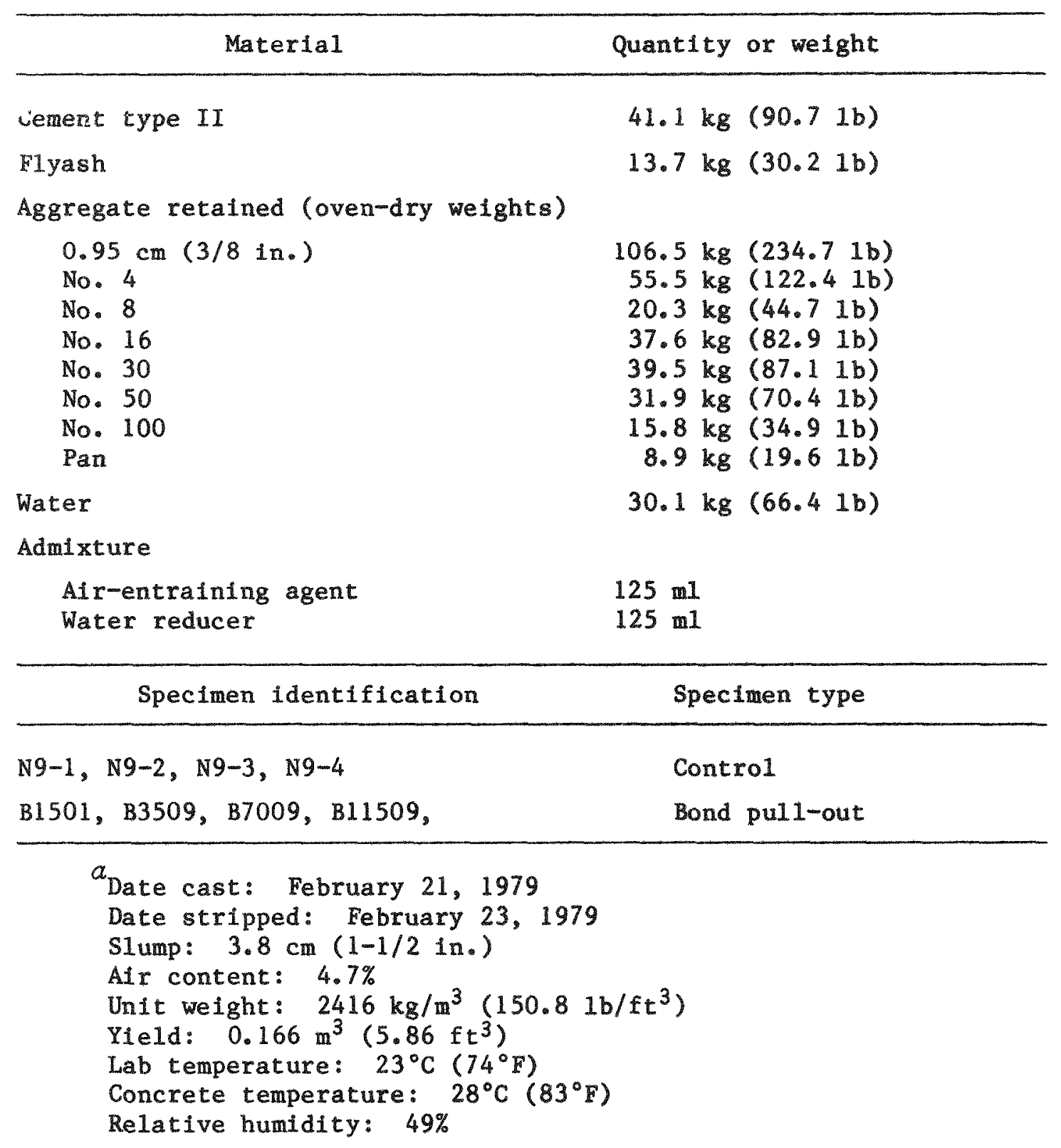


Table. A.10. Batch 10 standard welght concrete data summary ${ }^{a}$

\begin{tabular}{|c|c|}
\hline Material & Quantity or weight \\
\hline Cement type II & $41.1 \mathrm{~kg}(90.7 \mathrm{lb})$ \\
\hline Flyash & $13.7 \mathrm{~kg}(30.2 \mathrm{lb})$ \\
\hline \multicolumn{2}{|l|}{ Aggregate retained (oven-dry weights) } \\
\hline $\begin{array}{l}0.95 \mathrm{~cm}(3 / 8 \mathrm{in.}) \\
\text { No. } 4 \\
\text { No. } 8 \\
\text { No. } 16 \\
\text { No. } 30 \\
\text { No. } 50 \\
\text { No. } 100 \\
\text { Pan }\end{array}$ & $\begin{array}{r}106.5 \mathrm{~kg}(234.7 \mathrm{lb}) \\
55.5 \mathrm{~kg}(122.4 \mathrm{lb}) \\
20.3 \mathrm{~kg}(44.7 \mathrm{lb}) \\
37.6 \mathrm{~kg}(82.9 \mathrm{lb}) \\
39.5 \mathrm{~kg}(87.1 \mathrm{lb}) \\
31.9 \mathrm{~kg}(70.4 \mathrm{lb}) \\
15.8 \mathrm{~kg}(34.9 \mathrm{lb}) \\
8.9 \mathrm{~kg}(19.6 \mathrm{lb})\end{array}$ \\
\hline Water & $30.1 \mathrm{~kg}(66.4 \mathrm{lb})$ \\
\hline \multicolumn{2}{|l|}{ Admixture } \\
\hline $\begin{array}{l}\text { Air-entraining agent } \\
\text { Water reducer }\end{array}$ & $\begin{array}{l}125 \mathrm{~m} 1 \\
125 \mathrm{~m} 1\end{array}$ \\
\hline Specimen identification & Specimen type \\
\hline $\begin{array}{l}\text { N10-1, N10-2, N10-3, N10-4, N10-5, } \\
\text { N10-6, N10-7 }\end{array}$ & Control \\
\hline $\begin{array}{l}\mathrm{C} 15010, \mathrm{C} 22510, \mathrm{C} 50010.2, \mathrm{C} 50010.5 \\
\mathrm{C} 101110, \mathrm{CXXX10}\end{array}$ & Sustained load \\
\hline $\begin{array}{l}\mathrm{V} 7201, \mathrm{~V} 15010, \mathrm{~V} 22510, \mathrm{~V} 35010, \mathrm{~V} 55010, \\
\mathrm{~V} 70010, \mathrm{~V} 90010, \mathrm{~V} 115010\end{array}$ & Shear \\
\hline $\begin{array}{l}a_{\text {Date cast: March } 20,1979} \\
\text { Date stripped: March } 21,1979 \\
\text { Slump: } 3.8 \mathrm{~cm}(1-1 / 2 \mathrm{in} .) \\
\text { Air content: } 4.0 \% \\
\text { Unit weight: } 2425 \mathrm{~kg} / \mathrm{m}^{3}(151.4 \\
\text { Yield: } 0.165, \mathrm{~m}^{3}\left(5.84 \mathrm{ft}^{3}\right) \\
\text { Lab temperature: } 22^{\circ} \mathrm{C}\left(71^{\circ} \mathrm{F}\right) \\
\text { Concrete temperature: } 29^{\circ} \mathrm{C}\left(84^{\circ}\right. \\
\text { Relative humidity: } 61 \%\end{array}$ & $\begin{array}{l}\left.1 \mathrm{~b} / \mathrm{ft}^{3}\right) \\
\text { F) }\end{array}$ \\
\hline
\end{tabular}


Table. A.11. Batch 11 11ghtweight insulating concrete data summary $a$

\begin{tabular}{|c|c|}
\hline Material & Quant1ty or we1ght \\
\hline Cement type II & $68.0 \mathrm{~kg}(150.0 \mathrm{lb})$ \\
\hline Perlite & $19.1 \mathrm{~kg}(42.01 \mathrm{~b})$ \\
\hline \multicolumn{2}{|l|}{ Aggregate retained (oven-dry welghts) } \\
\hline $\begin{array}{l}\text { No. } 8 \\
\text { No. } 16 \\
\text { No. } 30 \\
\text { No. } 50 \\
\text { No. } 100 \\
\text { Pan }\end{array}$ & $\begin{array}{r}9.0 \mathrm{~kg}(19.8 \mathrm{lb}) \\
16.6 \mathrm{~kg}(36.6 \mathrm{lb}) \\
17.4 \mathrm{~kg}(38.4 \mathrm{lb}) \\
14.2 \mathrm{~kg}(31.2 \mathrm{lb}) \\
7.1 \mathrm{~kg}(15.61 \mathrm{~b}) \\
3.8 \mathrm{~kg}(8.4 \mathrm{lb})\end{array}$ \\
\hline Water & $47.4 \mathrm{~kg}(104.6 \mathrm{lb})$ \\
\hline \multicolumn{2}{|l|}{ Admixture } \\
\hline Air-entraining agent & $150 \mathrm{ml}$ \\
\hline Specimen identification & Specimen type \\
\hline $\begin{array}{l}\text { N11-1, N11-2, N11-3, N11-4, N11-5, N11-6 } \\
\text { N11-7, N11-8, N11-9, N11-10 }\end{array}$ & Contro1 \\
\hline $\begin{array}{l}\text { L15011, L22511, L35011, L50011, L70011, } \\
\text { L90011, LX11, LXX11, LXXX11 }\end{array}$ & Compression \\
\hline $\begin{array}{l}a_{\text {Date cast: March } 16,1979} \\
\text { Date stripped: March } 19,1979 \\
\text { Slump: } 11.4 \mathrm{~cm}(4-1 / 2 \mathrm{in} .) \\
\text { Alr content: } 19.0 \% \\
\text { Wet unit weight: } 1250 \mathrm{~kg} / \mathrm{m}^{3}(78.3 \\
\text { Yleld: } 0.161 \mathrm{~m}^{3}\left(5.70 \mathrm{ft}^{3}\right) \\
\text { Lab temperature: } 16^{\circ} \mathrm{C}\left(61^{\circ} \mathrm{F}\right) \\
\text { Concrete temperature: } 14^{\circ} \mathrm{C}\left(58^{\circ} \mathrm{F}\right) \\
\text { Relative humidity: } 40 \%\end{array}$ & $\left.1 \mathrm{~b} / \mathrm{ft} \mathrm{t}^{3}\right)$ \\
\hline
\end{tabular}


Table. A.12. Batch 12 standard welght concrete data summarya

\begin{tabular}{|c|c|}
\hline Material & Quantity or weight \\
\hline Cement type II & $41.1 \mathrm{~kg}(90.7 \mathrm{1b})$ \\
\hline F1yash & $13.7 \mathrm{~kg}(30.2 \mathrm{1b})$ \\
\hline \multicolumn{2}{|c|}{ Aggregate retained (oven-dry welghts) } \\
\hline $\begin{array}{l}0.95 \mathrm{~cm}(3 / 8 \mathrm{in} .) \\
\text { No. } 4 \\
\text { No. } 8 \\
\text { No. } 16 \\
\text { No. } 30 \\
\text { No. } 50 \\
\text { No. } 100 \\
\text { Pan }\end{array}$ & $\begin{array}{r}106.5 \mathrm{~kg}(234.7 \mathrm{lb}) \\
55.5 \mathrm{~kg}(122.4 \mathrm{Ib}) \\
20.3 \mathrm{~kg}(44.71 \mathrm{~b}) \\
37.6 \mathrm{~kg}(82.9 \mathrm{lb}) \\
39.5 \mathrm{~kg}(87.1 \mathrm{lb}) \\
31.9 \mathrm{~kg}(70.4 \mathrm{lb}) \\
15.8 \mathrm{~kg}(34.9 \mathrm{Ib}) \\
8.9 \mathrm{~kg}(19.6 \mathrm{Ib})\end{array}$ \\
\hline Water & $30.1 \mathrm{~kg}(66.41 \mathrm{~b})$ \\
\hline \multicolumn{2}{|l|}{ Admixture } \\
\hline $\begin{array}{l}\text { Air-entraining agent } \\
\text { Water reducer }\end{array}$ & $\begin{array}{l}125 \mathrm{ml} \\
125 \mathrm{ml}\end{array}$ \\
\hline Specimen identification & Specimen type \\
\hline $\begin{array}{l}\text { N12-1, } \mathrm{N} 12-2, \mathrm{~N} 12-3, \mathrm{~N} 12-4 \\
\mathrm{~B} 7212, \mathrm{~B} 22512, \mathrm{~B} 50012, \mathrm{~B} 90012\end{array}$ & Control \\
\hline $\begin{array}{l}a_{\text {Date cast: March } 22,197} \\
\text { Date stripped: March } 26, \\
\text { Slump: } 4.5 \mathrm{~cm}(1-3 / 4 \mathrm{in} \\
\text { Air content: } 4.0 \% \\
\text { Unit weight: } 2406 \mathrm{~kg} / \mathrm{m}^{3} \\
\text { Yield: } 0.167 \mathrm{~m}^{3}(5.89 \mathrm{ft} \\
\text { Lab temperature: } 23^{\circ} \mathrm{C}(7 \\
\text { Concrete temperature: } 28 \\
\text { Relative humidity: } 56 \%\end{array}$ & $\begin{array}{l}\left.1 b / f t^{3}\right) \\
\text { F) }\end{array}$ \\
\hline
\end{tabular}


Table. A.13. Batch 13 standard weight concrete data summary ${ }^{a}$

\begin{tabular}{lc}
\hline \multicolumn{1}{c}{ Material } & Quantity or weight \\
\hline Cement type II & $34.3 \mathrm{~kg}(75.61 \mathrm{~b})$ \\
F1yash & $11.4 \mathrm{~kg}(25.21 \mathrm{~b})$ \\
Aggregate retained (oven-dry weights) & \\
0.95 cm (3/8 in.) & $88.7 \mathrm{~kg}(195.6 \mathrm{lb})$ \\
No. 4 & $46.3 \mathrm{~kg}(102.01 \mathrm{~b})$ \\
No. 8 & $16.9 \mathrm{~kg}(37.21 \mathrm{~b})$ \\
No. 16 & $31.3 \mathrm{~kg}(69.1 \mathrm{~b})$ \\
No. 30 & $32.9 \mathrm{~kg}(72.61 \mathrm{~b})$ \\
No. 50 & $26.6 \mathrm{~kg}(58.7 \mathrm{lb})$ \\
No. 100 & $13.2 \mathrm{~kg}(29.1 \mathrm{ib})$ \\
Pan & $7.4 \mathrm{~kg}(16.31 \mathrm{~b})$ \\
Water & $25.1 \mathrm{~kg}(55.41 \mathrm{~b})$ \\
Admixture & $104 \mathrm{ml}$ \\
Air-entraining agent & $104 \mathrm{ml}$ \\
Water reducer & Specimen type \\
\hline
\end{tabular}

N13-1, N13-2, N13-3, N13-4, N13-5, Control N13-6, N13-7

V7213, V15013, V22513, V35013, V50013, Shear V70013, V90013, V115013

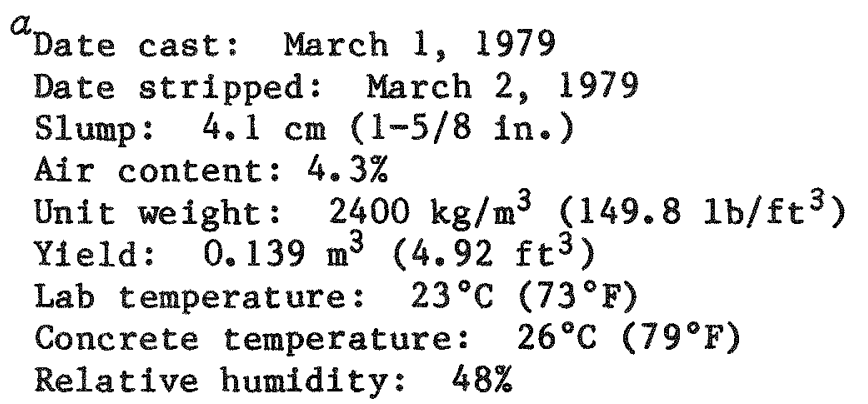


Table. A.14. Batch 14 lightweight insulating concrete data summary ${ }^{\alpha}$

\begin{tabular}{|c|c|}
\hline Material & Quantity or weight \\
\hline Cement type II & $68.0 \mathrm{~kg}(150.01 \mathrm{~b})$ \\
\hline Perlite & $19.1 \mathrm{~kg}(42.01 \mathrm{~b})$ \\
\hline \multicolumn{2}{|l|}{ Aggregate retained (oven-dry weights) } \\
\hline $\begin{array}{l}\text { No. } 8 \\
\text { No. } 16 \\
\text { No. } 30 \\
\text { No. } 50 \\
\text { No. } 100 \\
\text { Pan }\end{array}$ & $\begin{array}{r}9.0 \mathrm{~kg}(19.8 \mathrm{lb}) \\
16.6 \mathrm{~kg}(36.6 \mathrm{lb}) \\
17.4 \mathrm{~kg}(38.41 \mathrm{~b}) \\
14.2 \mathrm{~kg}(31.21 \mathrm{~b}) \\
7.1 \mathrm{~kg}(15.61 \mathrm{~b}) \\
3.8 \mathrm{~kg}(8.41 \mathrm{~b})\end{array}$ \\
\hline Water & $47.4 \mathrm{~kg}(104.5 \mathrm{lb})$ \\
\hline \multicolumn{2}{|l|}{ Admixture } \\
\hline Air-entraining agent & $150 \mathrm{ml}$ \\
\hline Specimen identification & Specimen type \\
\hline $\begin{array}{l}\mathrm{N} 14-1, \mathrm{~N} 14-2, \mathrm{~N} 14-3, \mathrm{~N} 14-4, \mathrm{~N} 14-5, \\
\mathrm{~N} 14-6, \mathrm{~N} 14-7, \mathrm{M} 14-8, \mathrm{~N} 14-9, \mathrm{~N} 14-10\end{array}$ & Control \\
\hline $\begin{array}{l}\text { L15014, L22514, L35014, L50014, L70014, } \\
\text { L90014, LX14, LXX14, LXXX14, LXXXXX14 }\end{array}$ & Compression \\
\hline $\begin{array}{l}\text { ade cast: Apri1 6, } 1979 \\
\text { Date stripped: Apri1 9, } 1979 \\
\text { Slump: } 12.7 \mathrm{~cm}(5 \mathrm{in} .) \\
\text { Air content: } 17.5 \% \\
\text { Wet unit weight: } 1240 \mathrm{~kg} / \mathrm{m}^{3}(77.4 \\
\text { Yield: } 0.163 \mathrm{~m}^{3}\left(5.77 \mathrm{ft}^{3}\right) \\
\text { Lab temperature: } 21^{\circ} \mathrm{C}\left(70^{\circ} \mathrm{F}\right) \\
\text { Concrete temperature: } 23^{\circ} \mathrm{C}\left(73^{\circ} \mathrm{F}\right) \\
\text { Relative humidity: } 44 \%\end{array}$ & $\left.1 \mathrm{~b} / \mathrm{ft}^{3}\right)$ \\
\hline
\end{tabular}


Table. A.15. Batch 15 standard weight concrete data summary ${ }^{a}$

\begin{tabular}{|c|c|}
\hline Material & Quantity or weight \\
\hline Cemert type II & $41.1 \mathrm{~kg}(90.71 \mathrm{~b})$ \\
\hline F1yash & $13.7 \mathrm{~kg}(30.2 \mathrm{lb})$ \\
\hline \multicolumn{2}{|l|}{ Aggregate retained (oven-dry weights) } \\
\hline $\begin{array}{l}0.95 \mathrm{~cm}(3 / 8 \mathrm{in} .) \\
\text { No. } 4 \\
\text { No. } 8 \\
\text { No. } 16 \\
\text { No. } 30 \\
\text { No. } 50 \\
\text { No. } 100 \\
\text { Pan }\end{array}$ & $\begin{array}{r}106.5 \mathrm{~kg}(234.7 \mathrm{lb}) \\
55.5 \mathrm{~kg}(122.4 \mathrm{lb}) \\
20.3 \mathrm{~kg}(44.7 \mathrm{lb}) \\
37.6 \mathrm{~kg}(82.9 \mathrm{lb}) \\
39.5 \mathrm{~kg}(87.1 \mathrm{lb}) \\
31.9 \mathrm{~kg}(70.4 \mathrm{lb}) \\
15.8 \mathrm{~kg}(34.9 \mathrm{lb}) \\
8.9 \mathrm{~kg}(19.6 \mathrm{lb})\end{array}$ \\
\hline Water & $30.1 \mathrm{~kg}(66.41 \mathrm{~b})$ \\
\hline \multicolumn{2}{|l|}{ Admixture } \\
\hline $\begin{array}{l}\text { Air-entraining agent } \\
\text { Water reducer }\end{array}$ & $\begin{array}{l}125 \mathrm{ml} \\
125 \mathrm{ml}\end{array}$ \\
\hline Specimen identification & Specimen type \\
\hline $\begin{array}{l}\text { N15-1, N15-2, N15-3, N15-4 } \\
\text { B15015, B35015, B70015, N115015 }\end{array}$ & $\begin{array}{l}\text { Control } \\
\text { Bond pull-out }\end{array}$ \\
\hline $\begin{array}{l}a_{\text {Date cast: April } 25,1979} \\
\text { Date stripped: Apri1 27, } 1979 \\
\text { Slump: } 4.5 \mathrm{~cm}(1-3 / 4 \mathrm{in} .) \\
\text { Air content: } 4.3 \% \\
\text { Unit weight: } 2393 \mathrm{~kg} / \mathrm{m}^{3}(149.4 \\
\text { Yield: } 0.168 \mathrm{~m}^{3}\left(5.92 \mathrm{ft}^{3}\right) \\
\text { Lab temperature: } 26^{\circ} \mathrm{C}\left(79^{\circ} \mathrm{F}\right) \\
\text { Concrete temperature: } 29^{\circ} \mathrm{C}\left(85^{\circ}\right. \\
\text { Relative humidity: } 54 \%\end{array}$ & $\begin{array}{l}\left.1 \mathrm{~b} / \mathrm{ft}^{3}\right) \\
\left.{ }^{\circ} \mathrm{F}\right)\end{array}$ \\
\hline
\end{tabular}


Table. A.16. Batch 16 standard weight concrete data summary ${ }^{a}$

\begin{tabular}{|c|c|}
\hline Material & Quantity or welght \\
\hline Cement type II & $44.6 \mathrm{~kg}(98.7 \mathrm{Ib})$ \\
\hline Flyash & $14.8 \mathrm{~kg}(32.7 \mathrm{lb})$ \\
\hline \multicolumn{2}{|l|}{ Aggregate retained (oven-dry weights) } \\
\hline $\begin{array}{l}0.95 \mathrm{~cm}(3 / 8 \mathrm{in} .) \\
\text { No. } 4 \\
\text { No. } 8 \\
\text { No. } 16 \\
\text { No. } 30 \\
\text { No. } 50 \\
\text { No. } 100 \\
\text { Pan }\end{array}$ & $\begin{array}{r}115.4 \mathrm{~kg}(254.3 \mathrm{lb}) \\
60.2 \mathrm{~kg}(132.6 \mathrm{lb}) \\
22.0 \mathrm{~kg}(48.4 \mathrm{Ib}) \\
40.7 \mathrm{~kg}(89.8 \mathrm{Ib}) \\
42.8 \mathrm{~kg}(94.4 \mathrm{lb}) \\
34.6 \mathrm{~kg}(76.3 \mathrm{lb}) \\
17.2 \mathrm{~kg}(37.8 \mathrm{lb}) \\
9.6 \mathrm{~kg}(21.2 \mathrm{lb})\end{array}$ \\
\hline Water & $32.6 \mathrm{~kg}(17.91 \mathrm{~b})$ \\
\hline \multicolumn{2}{|l|}{ Admi xture } \\
\hline $\begin{array}{l}\text { Air-entraining agent } \\
\text { Water reducer }\end{array}$ & $\begin{array}{l}135 \mathrm{~m} 1 \\
135 \mathrm{~m} 1\end{array}$ \\
\hline Specimen identification & Specimen type \\
\hline $\mathrm{N} 16-1, \mathrm{~N} 16-2, \mathrm{~N} 16-3, \mathrm{~N} 16-4$ & Control \\
\hline GS16-1, GS16-2, GS16-3, GS16-4, & Thermal conductivity \\
\hline AS 16-1, AS16-2, AS16-3, AS16-4, AS16-5, & $\begin{array}{l}\text { Coefficient of thermal } \\
\text { expansion }\end{array}$ \\
\hline $\begin{array}{l}\text { HS 16-1, HS16-2, HS16-3, HS16-4, HS16-5, } \\
\text { HS 16-6, HS16-7, HS16-8, HS16-9, } \\
\text { HS 16-10, HS 16-1 }, \text { HS } 16-12 \text {, HS } 16-13\end{array}$ & Thermal diffusivity \\
\hline $\begin{array}{l}\text { a Date cast: July } 10,1979 \\
\text { Date stripped: July } 12,1979 \\
\text { Slump: } 3.8 \mathrm{~cm}(1-1 / 2 \mathrm{in}) \\
\text { Air content: } 4.0 \% \\
\text { Unit weight: } 2425 \mathrm{~kg} / \mathrm{m}^{3}(151.41 \\
\text { Yield: } 0.179 \mathrm{~m}^{3}\left(6.33 \mathrm{ft}^{3}\right) \\
\text { Lab temperature: } 25^{\circ} \mathrm{C}\left(77^{\circ} \mathrm{F}\right) \\
\text { Concrete temperature: } 29^{\circ} \mathrm{C}\left(84^{\circ} \mathrm{F}\right. \\
\text { Relative humidity: } 66 \%\end{array}$ & $\begin{array}{l}\left.1 \mathrm{~b} / \mathrm{f} \mathrm{t}^{3}\right) \\
\text { F) }\end{array}$ \\
\hline
\end{tabular}


Table. A.17. Batch 17 1ightweight insulating concrete data summary ${ }^{a}$

\begin{tabular}{|c|c|}
\hline Material & Quant1ty or weight \\
\hline Samer: type II & $68.0 \mathrm{~kg}(150.0 \mathrm{lb})$ \\
\hline Perlite & $19.1 \mathrm{~kg}(42.0 \mathrm{lb})$ \\
\hline \multicolumn{2}{|l|}{ Aggregate retalned (oven-dry weights) } \\
\hline $\begin{array}{l}\text { No. } 8 \\
\text { No. } 16 \\
\text { No. } 30 \\
\text { No. } 50 \\
\text { No. } 100 \\
\text { Pan }\end{array}$ & $\begin{array}{r}9.0 \mathrm{~kg}(19.8 \mathrm{lb}) \\
16.6 \mathrm{~kg}(36.6 \mathrm{1b}) \\
17.4 \mathrm{~kg}(38.4 \mathrm{1b}) \\
14.2 \mathrm{~kg}(31.2 \mathrm{1b}) \\
7.1 \mathrm{~kg}(15.6 \mathrm{lb}) \\
3.8 \mathrm{~kg}(8.41 \mathrm{~b})\end{array}$ \\
\hline Water & $46.5 \mathrm{~kg}(102.51 \mathrm{~b})$ \\
\hline \multicolumn{2}{|l|}{ Admixture } \\
\hline Air-entraining agent & $150 \mathrm{ml}$ \\
\hline Specimen identification & Specimen type \\
\hline $\begin{array}{l}\text { N17-1, N17-2, N17-3, N17-4, N17-5, } \\
\text { N17-6, N17-7, N17-8, N17-9, N17-10 }\end{array}$ & Control \\
\hline $\begin{array}{l}\text { L15017, L22517, L35017, L50017, L70017, } \\
\text { L90017, LX17, LXX17, LXXX17, LXXXX17 }\end{array}$ & Compression \\
\hline $\begin{array}{l}\text { a Date cast: April } 27,1979 \\
\text { Date stripped: April } 30,1979 \\
\text { Slump: } 17.8 \mathrm{~cm}(7 \mathrm{in} .) \\
\text { Air content: } 16.5 \% \\
\text { Unit weight: } 1340 \mathrm{~kg} / \mathrm{m}^{3}\left(83.71 \mathrm{~b} / \mathrm{f}^{3}\right. \\
\text { Yield: } 0.150 \mathrm{~m}^{3}\left(5.31 \mathrm{ft}^{3}\right) \\
\text { Lab temperature: } 22^{\circ} \mathrm{C}\left(71^{\circ} \mathrm{F}\right) \\
\text { Concrete temperature: } 27^{\circ} \mathrm{C}\left(81^{\circ} \mathrm{F}\right) \\
\text { Relative humidity: } 48 \%\end{array}$ & $\left.f t^{3}\right)$ \\
\hline
\end{tabular}


Table. A.18. Batch 18 standard welght concrete data summary ${ }^{a}$

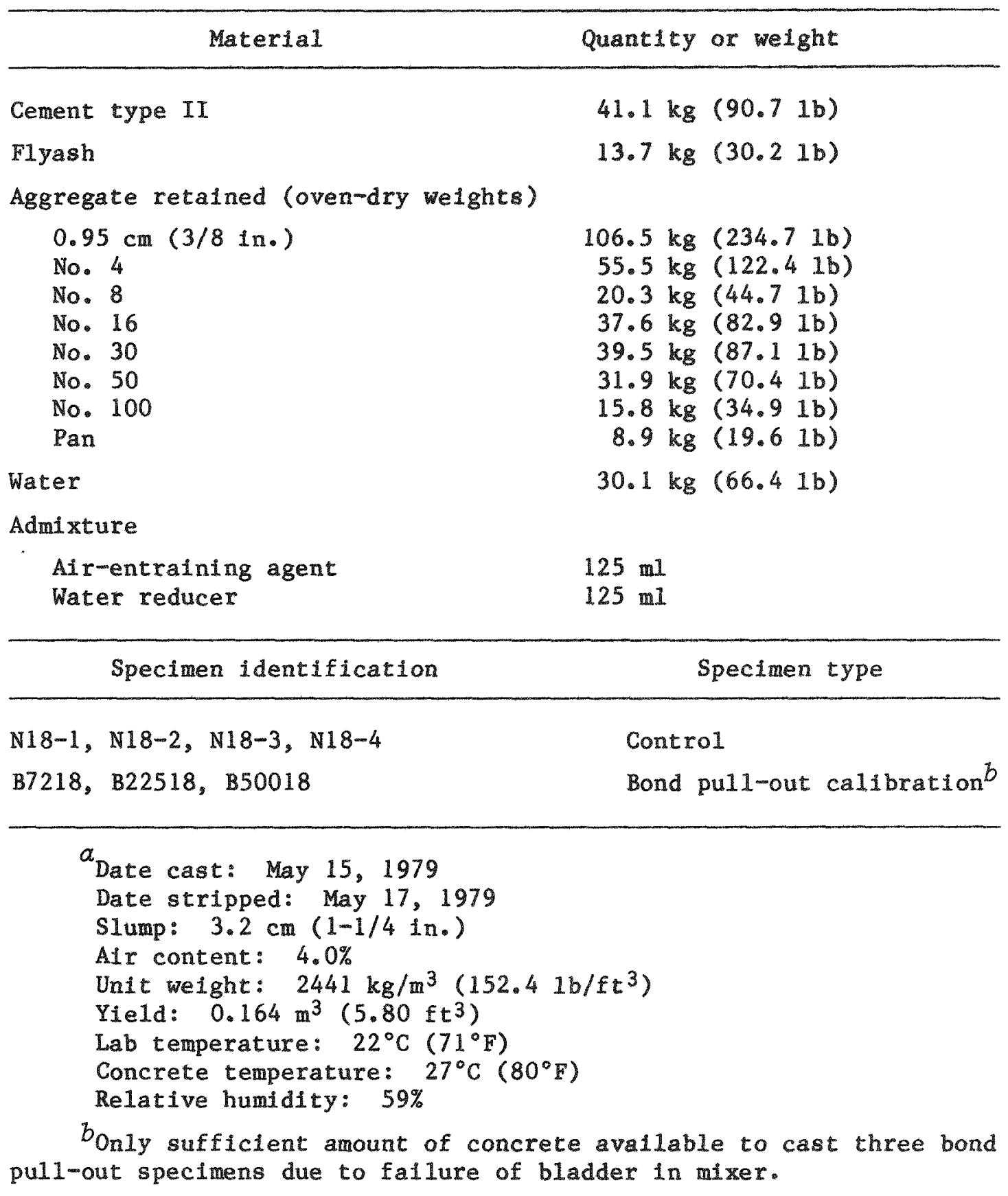


Table. A.19. Batch 19 standard weight concrete data sumary ${ }^{a}$

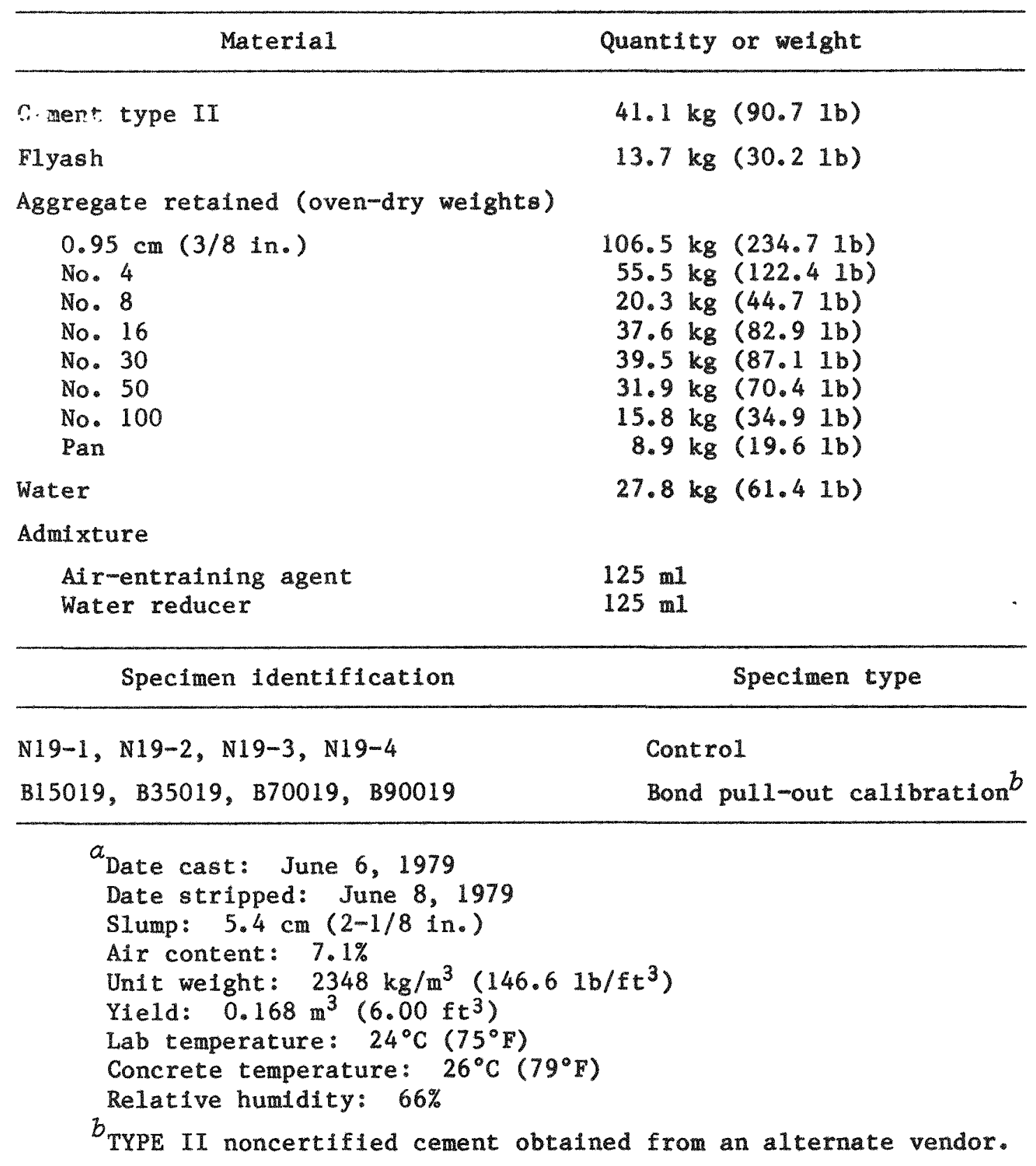


Table. A.20. Batch 20 standard weight concrete data summary ${ }^{a}$

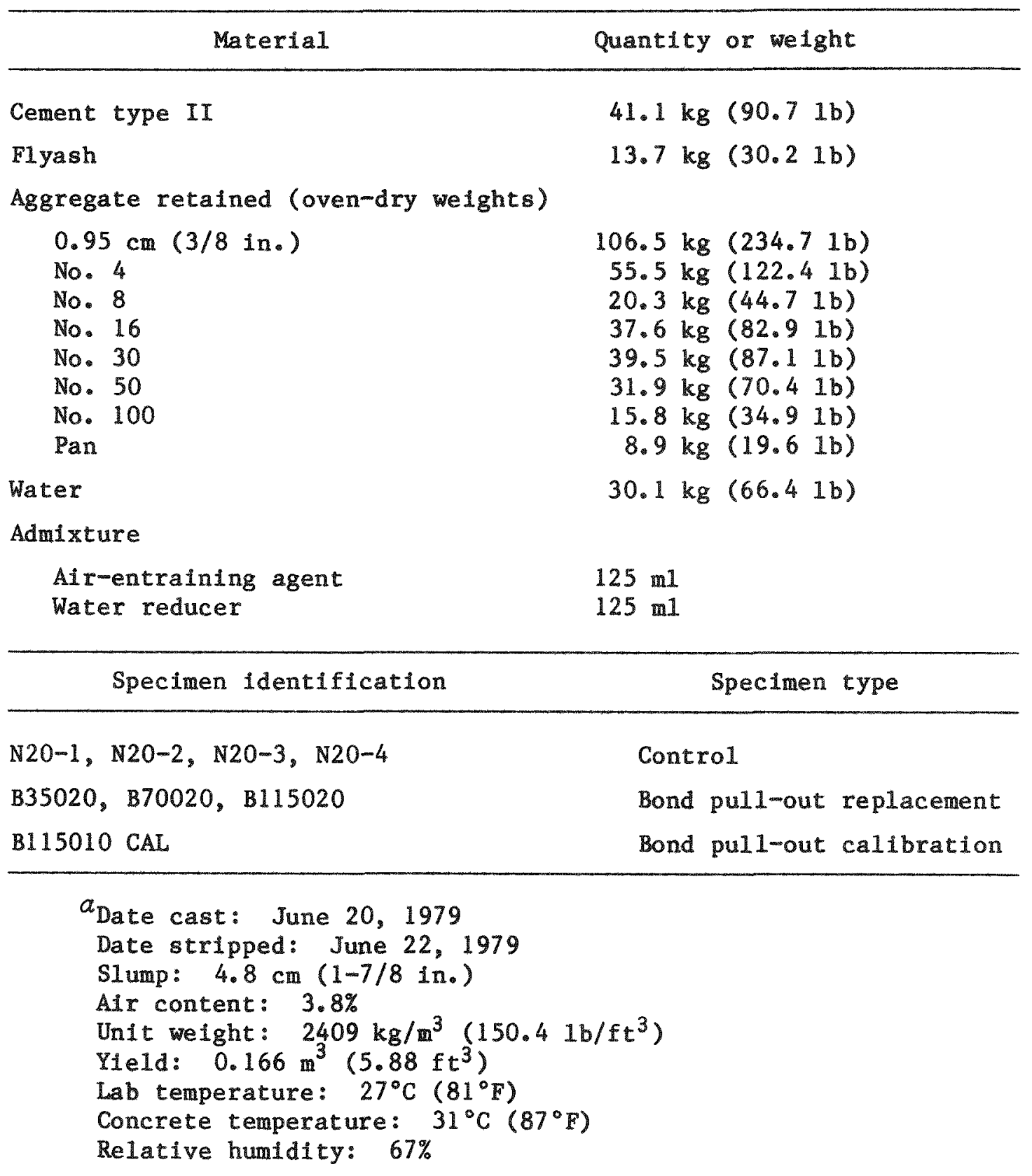


Table. A.21. Batch 21 1ightweight Insulating concrete data summary

\begin{tabular}{|c|c|}
\hline Material & Quantity or weight \\
\hline werr.. type II & $85.0 \mathrm{~kg}(187.5 \mathrm{lb})$ \\
\hline Perlite & $23.8 \mathrm{~kg}(52.51 \mathrm{~b})$ \\
\hline \multicolumn{2}{|l|}{ Aggregate retalned (oven-dry welghts) } \\
\hline $\begin{array}{l}\text { No. } 8 \\
\text { No. } 16 \\
\text { No. } 30 \\
\text { No. } 50 \\
\text { No. } 100 \\
\text { Pan }\end{array}$ & $\begin{aligned} 11.3 \mathrm{~kg} & (24.8 \mathrm{Ib}) \\
20.8 \mathrm{~kg} & (45.81 \mathrm{~b}) \\
21.8 \mathrm{~kg} & (48.01 \mathrm{~b}) \\
17.7 \mathrm{~kg} & (39.01 \mathrm{~b}) \\
3.6 \mathrm{~kg} & (8.01 \mathrm{~b}) \\
10.0 \mathrm{~kg} & (22.01 \mathrm{~b})\end{aligned}$ \\
\hline Water & $59.0 \mathrm{~kg}(130.01 \mathrm{~b})$ \\
\hline \multicolumn{2}{|l|}{ Admixture } \\
\hline Air-entraining agent & $188 \mathrm{ml}$ \\
\hline Specimen identification & Specimen type \\
\hline $\begin{array}{l}\mathrm{N} 21-1, \mathrm{~N} 21-2, \mathrm{~N} 21-3, \mathrm{~N} 21-4, \mathrm{~N} 21-5, \\
\mathrm{~N} 21-6, \mathrm{~N} 21-7\end{array}$ & Control \\
\hline GL21-1, GL21-2, GL21-3, GL21-4, GL21-5 & Thermal conductivity \\
\hline AL21-1, AL21-2, AL21-3, AL21-4, AL21-5 & $\begin{array}{l}\text { Coefficient of thermal } \\
\text { expansion }\end{array}$ \\
\hline $\begin{array}{l}\text { HL2 } 1-1, \text { HL21-2, HL21-3, HL21-4, HL21-5 } \\
\text { HL21-6, HL21-7, HL21-8, HL2 } 1-9 \text {, } \\
\text { HL21-10, HL21-1 , HL21-12, HL21-13 }\end{array}$ & Thermal diffusivity \\
\hline $\begin{array}{l}\text { ate cast: August 9, } 1979 \\
\text { Date stripped: August } 13,1979 \\
\text { Slump: } 12.7 \mathrm{~cm}(5 \mathrm{In} .) \\
\text { Alt content: } 15.0 \% \\
\text { Wet unit weight: } 1340 \mathrm{~kg} / \mathrm{m}^{3} \quad(83.9 \\
\text { Yield: } 0.186 \mathrm{~m}^{3}\left(6.64 \mathrm{ft}^{3}\right) \\
\text { Lab temperature: } 29^{\circ} \mathrm{C}\left(85^{\circ} \mathrm{F}\right) \\
\text { Concrete temperature: } 27^{\circ} \mathrm{C}\left(81^{\circ} \mathrm{F}\right) \\
\text { Relative humidity: } 70 \%\end{array}$ & $\left.1 \mathrm{~b} / \mathrm{ft} \mathrm{t}^{3}\right)$ \\
\hline
\end{tabular}


-

- 
Appendix B

CONTROL SPECIMEN UNCONEINED COMPRESSION STRESS-STRAIN RESULTS 
-

- 


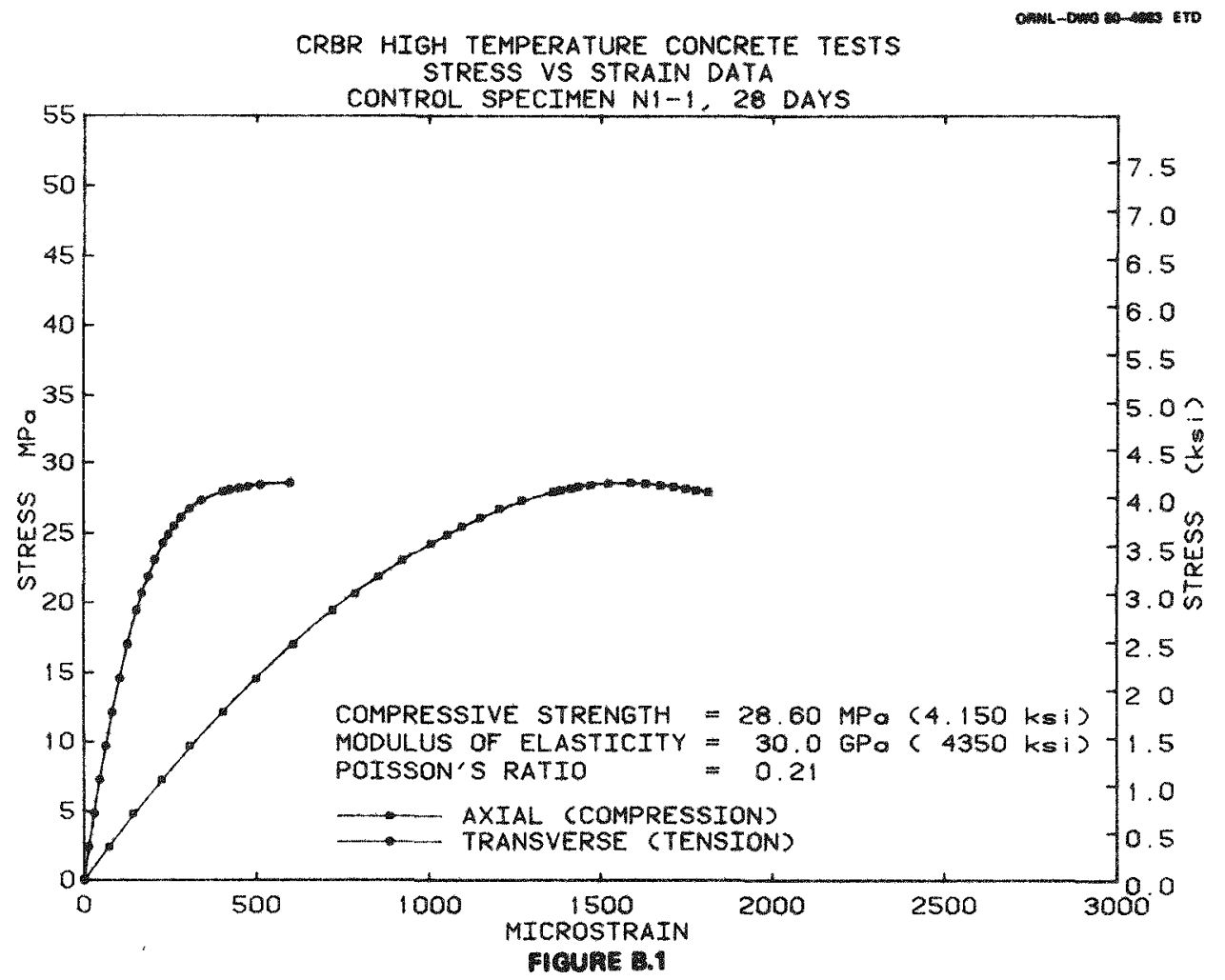

CRBR HIGH TEMPERATURE CONCRETE TESTS

STRESS VS STRAIN DATA

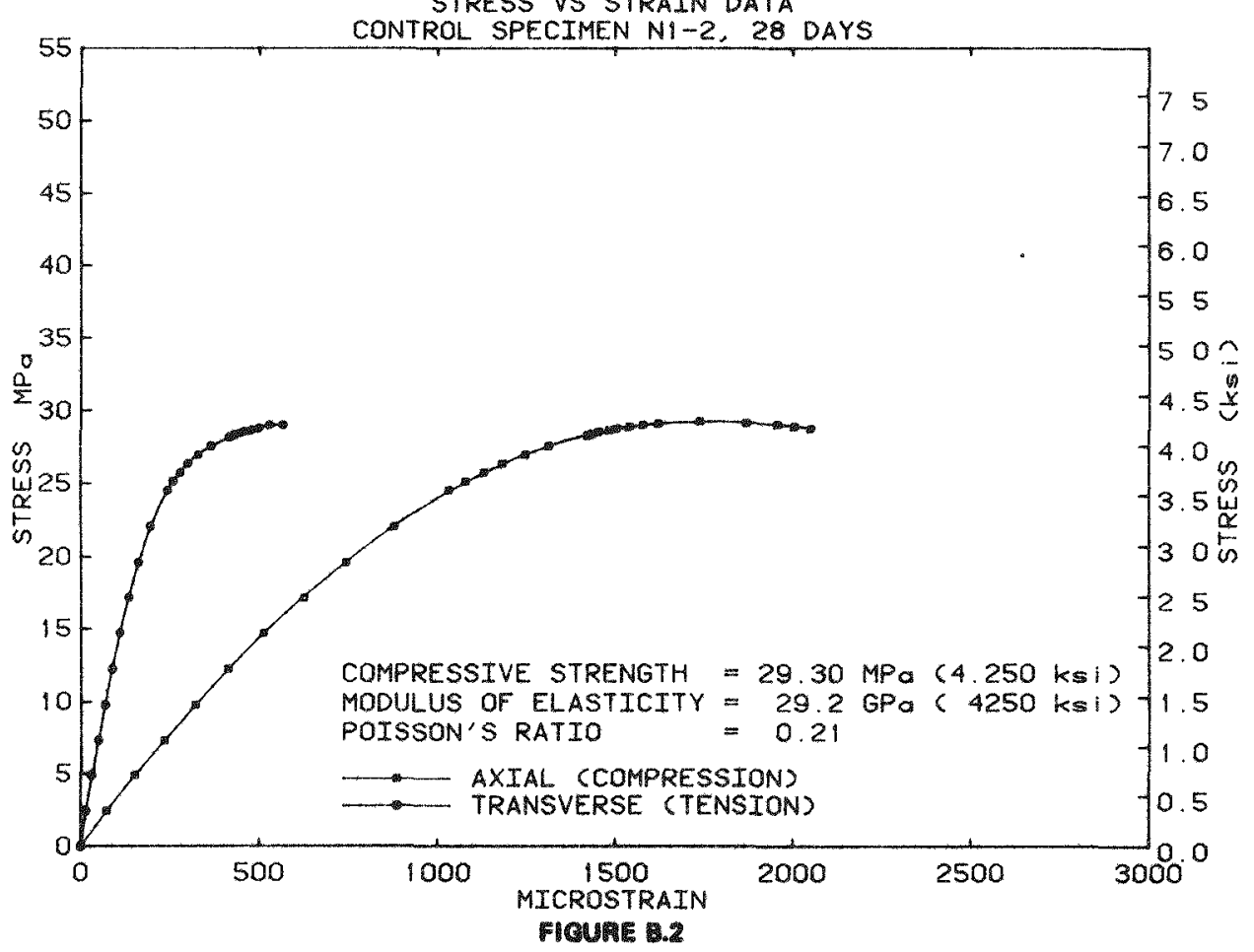




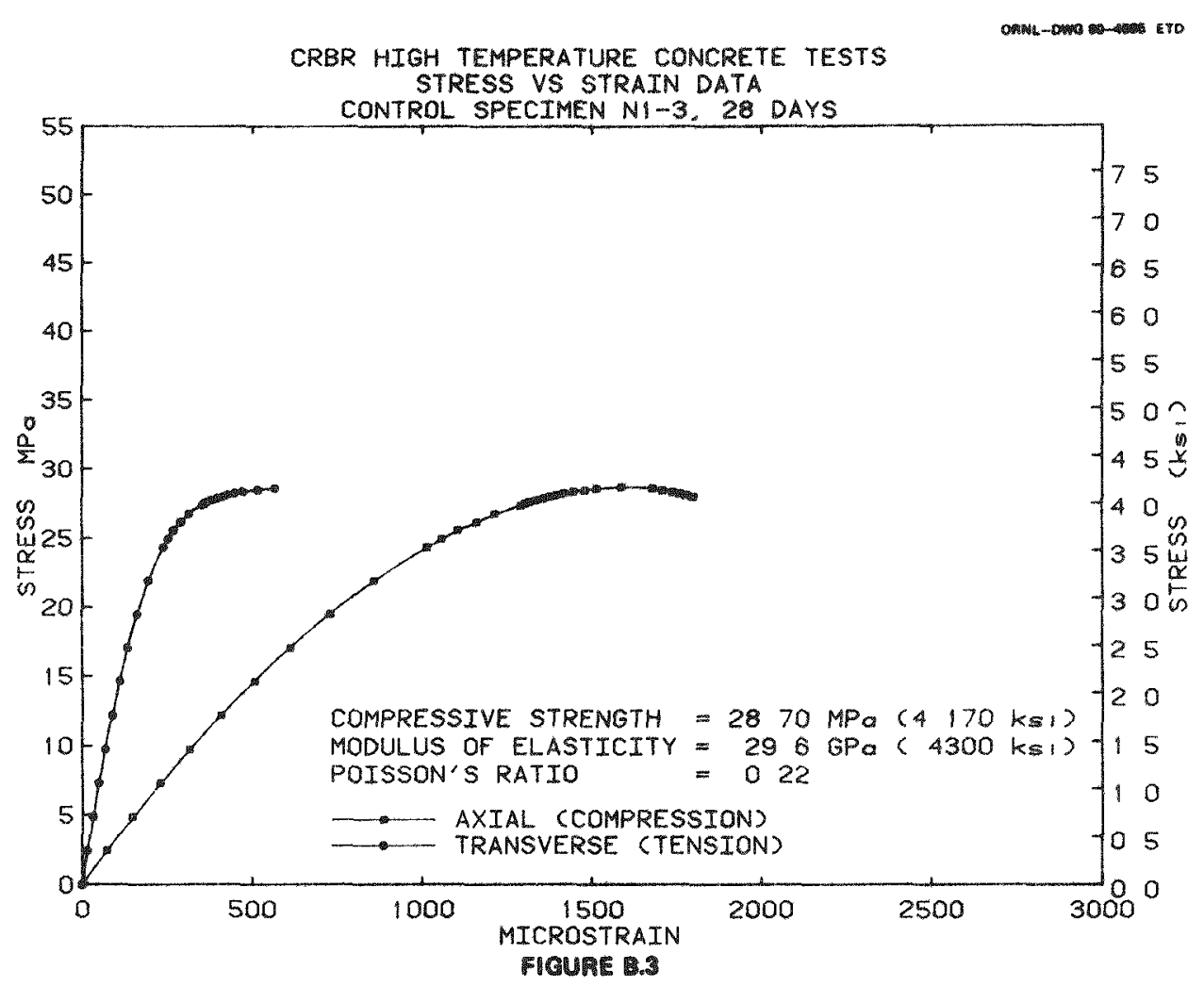

CRBR HIGH TEMPERATURE CONCRETE TESTS

STRESS VS STRAIN DATA

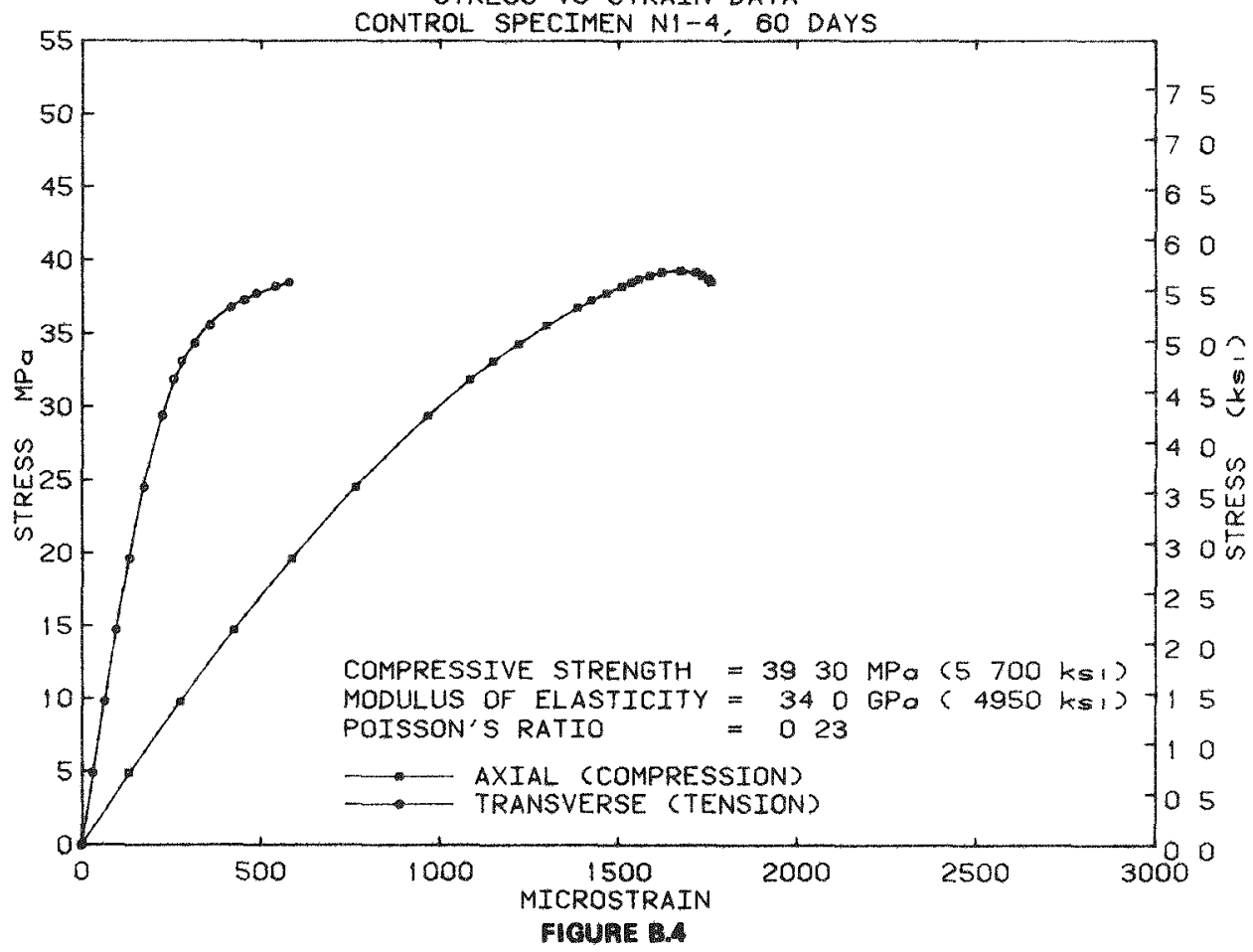


CRBR HIGH TEMPERATURE CONCRETE TESTS

OANL-D ETO STRESS VS STRAIN DATA

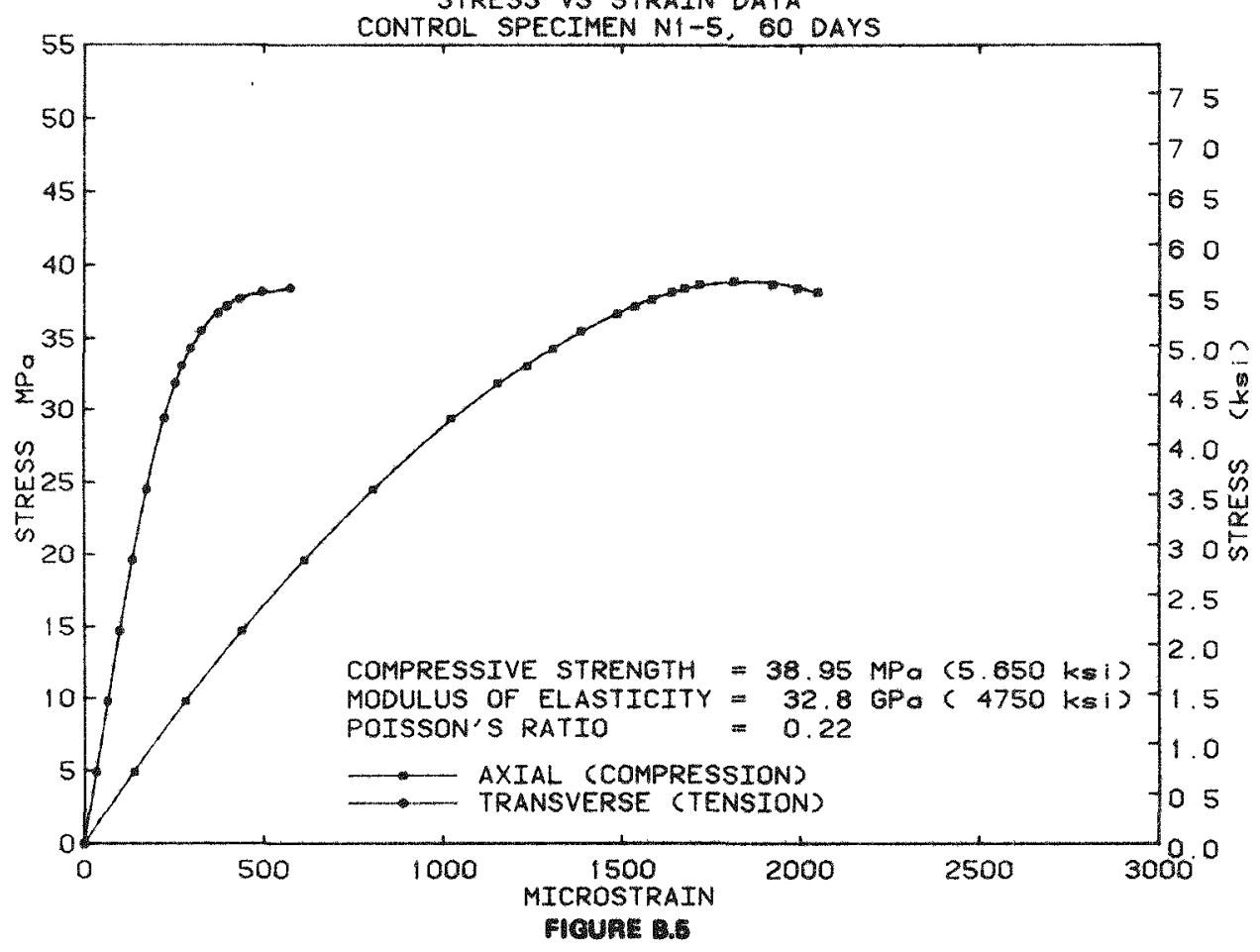

CRBR HIGH TEMPERATURE CONCRETE TESTS

OFMER -DWG STRESS VS STRAIN DATA

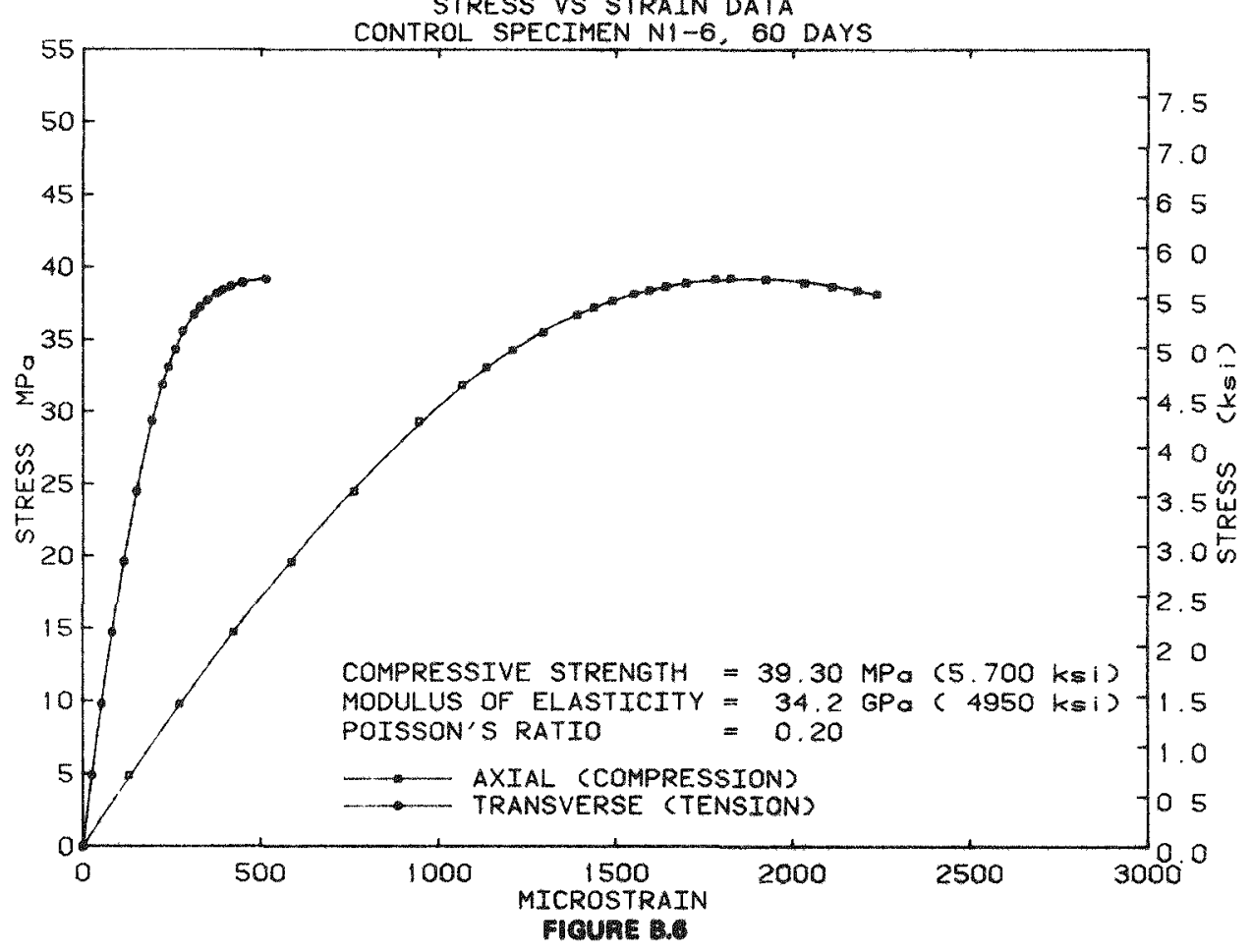




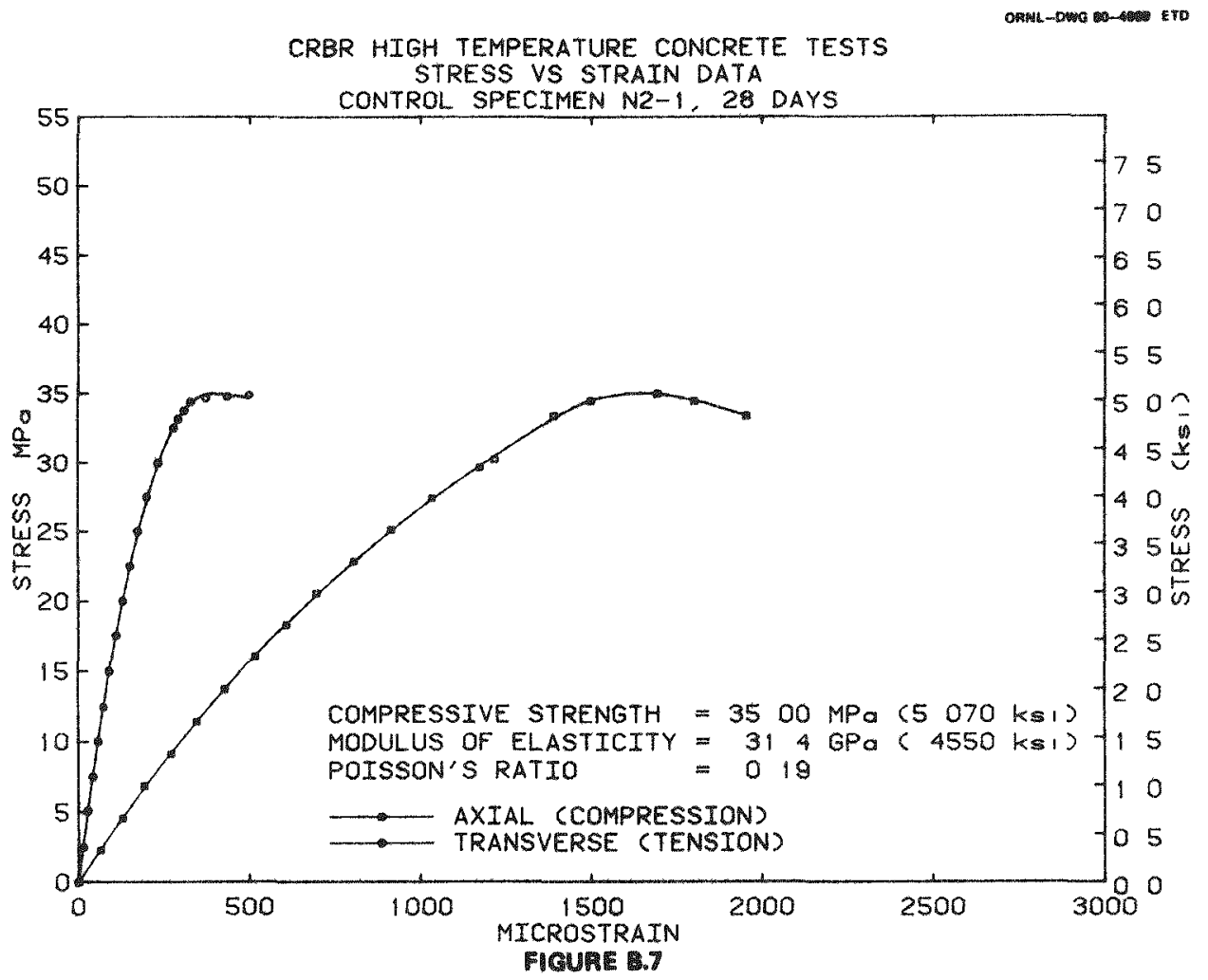

ORALLO ETB

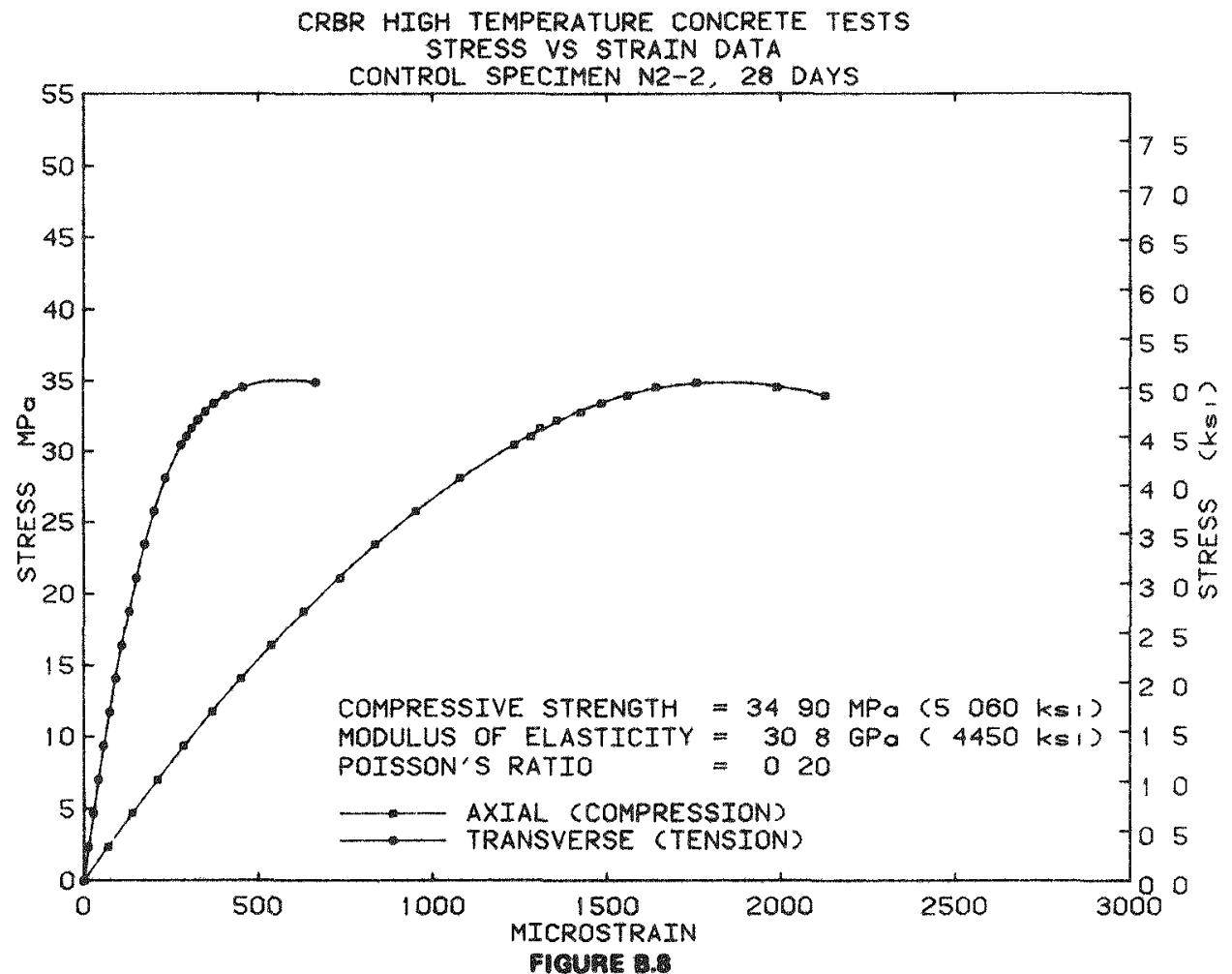




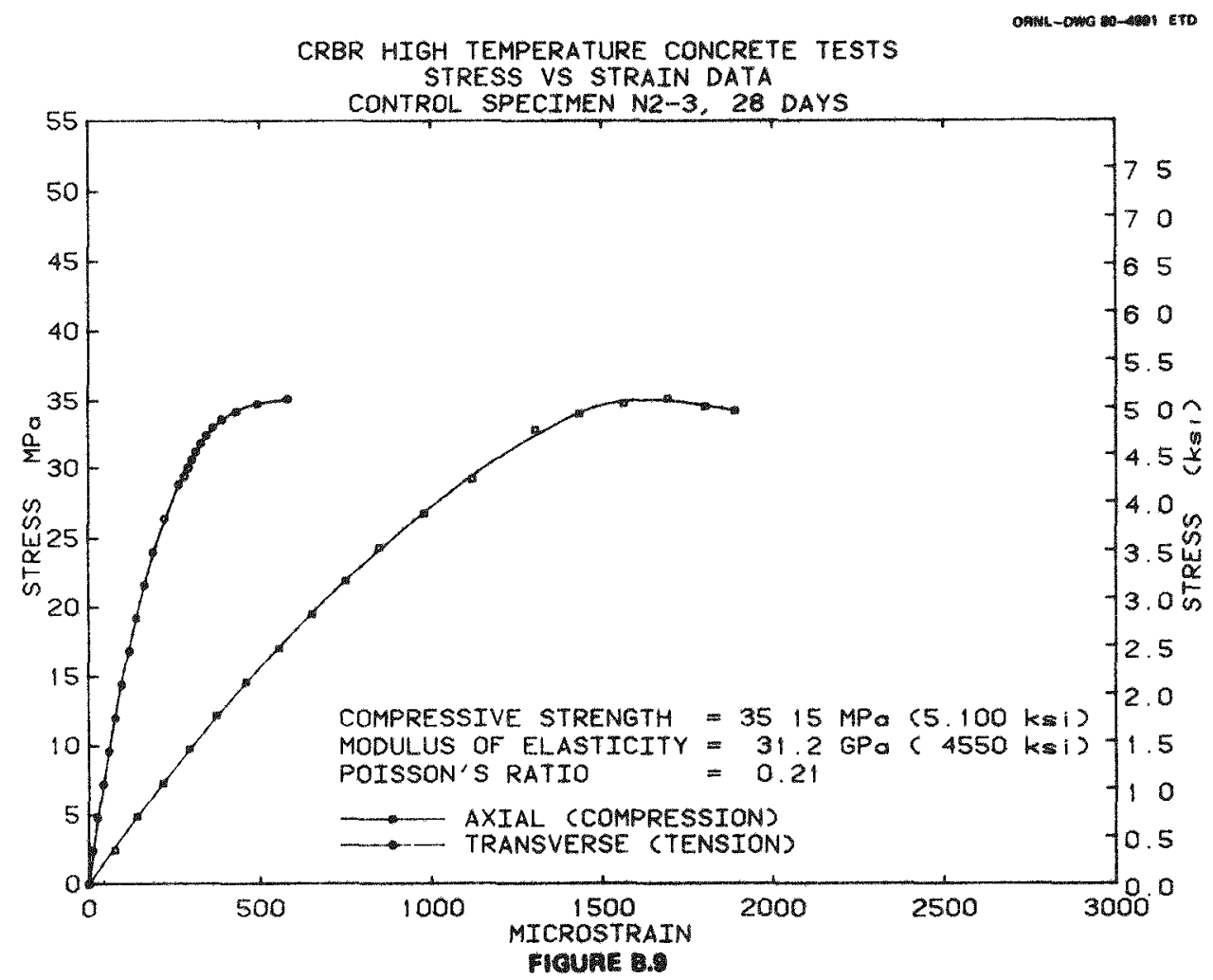

CRBR HIGH TEMPERATURE CONCRETE TESTS

ORNL-DWG MOSR ETO STRESS VS STRAIN DATA

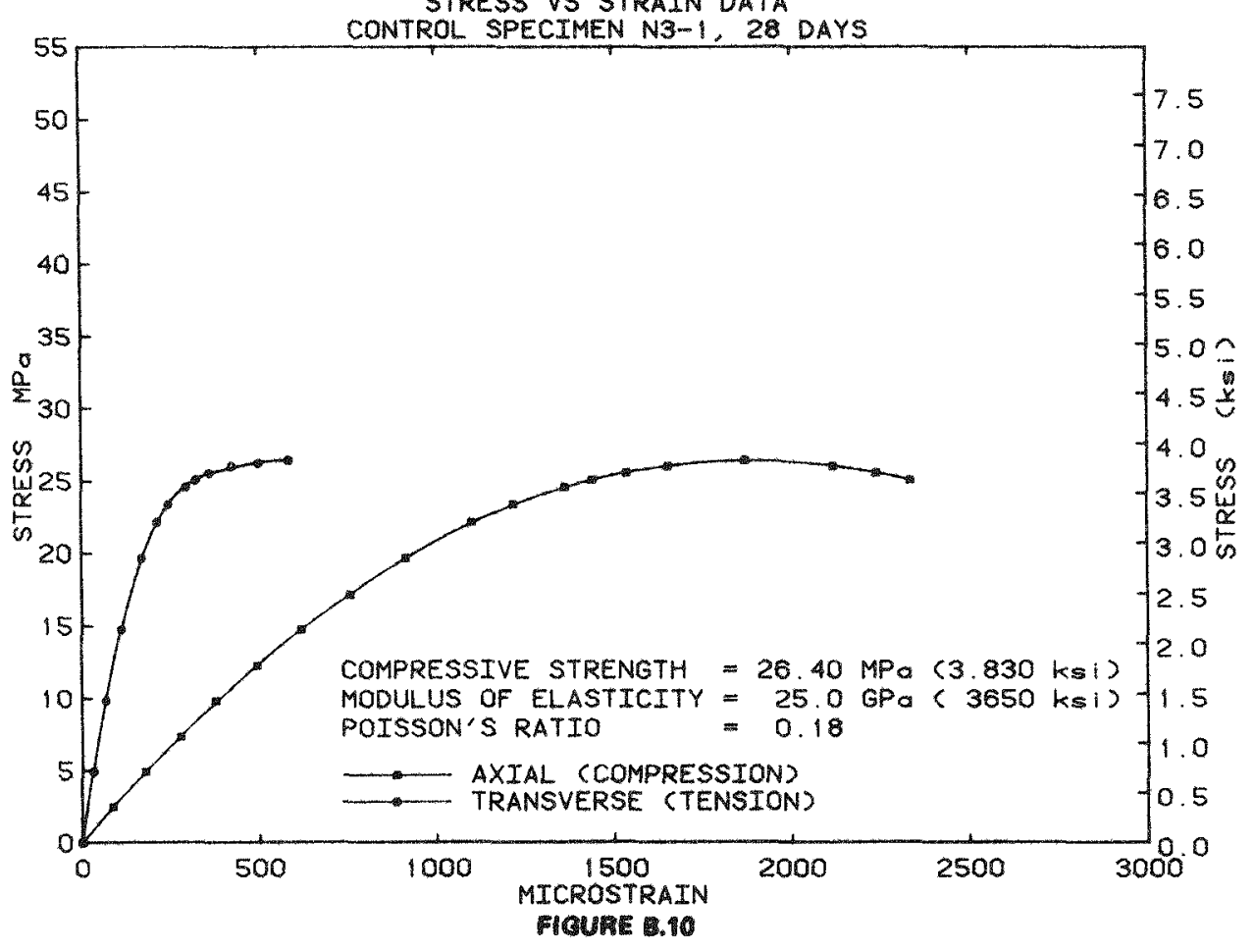




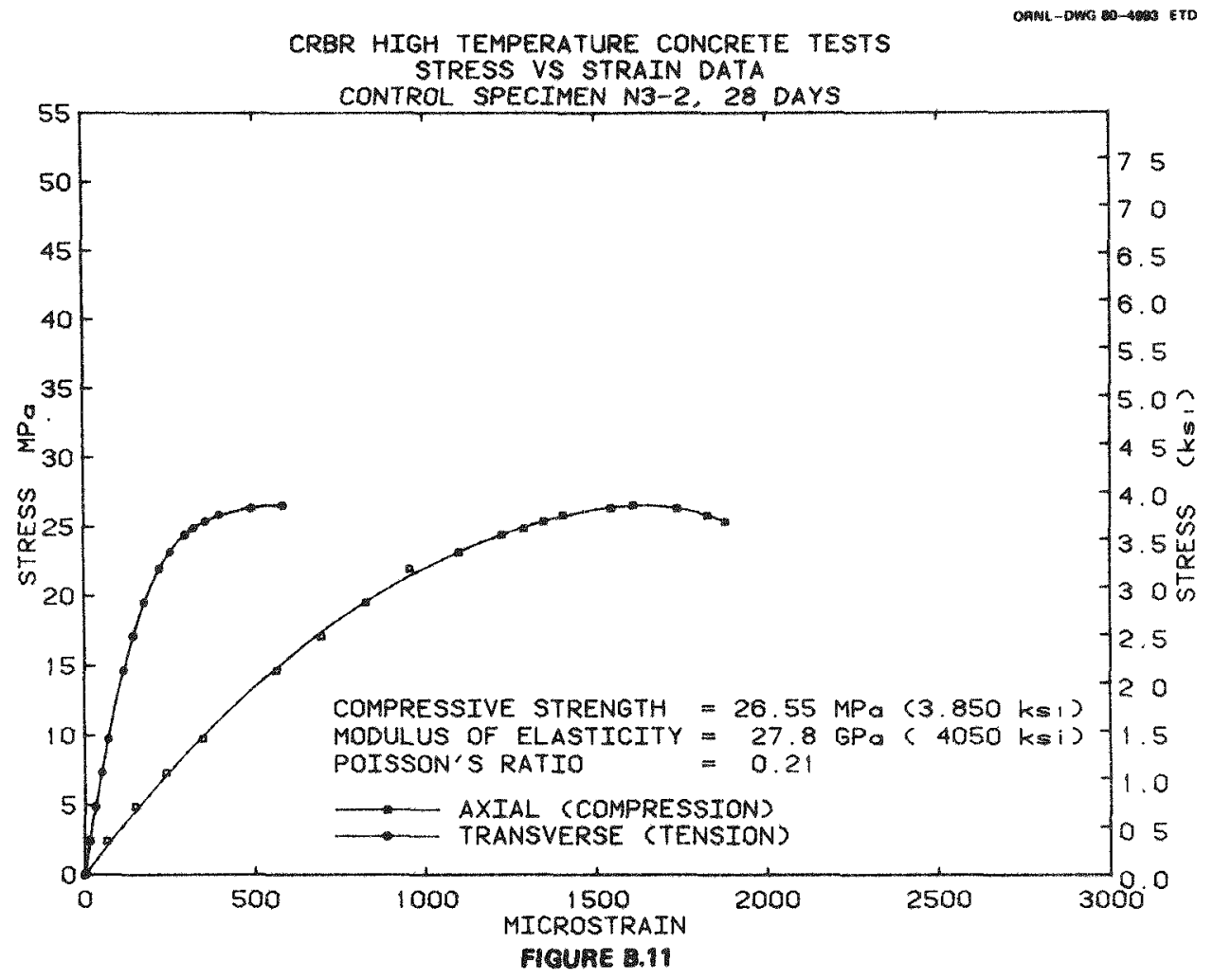

ONPA-DG

CRBR HIGH TEMPERATURE CONCRETE TESTS STRESS VS STRAIN DATA

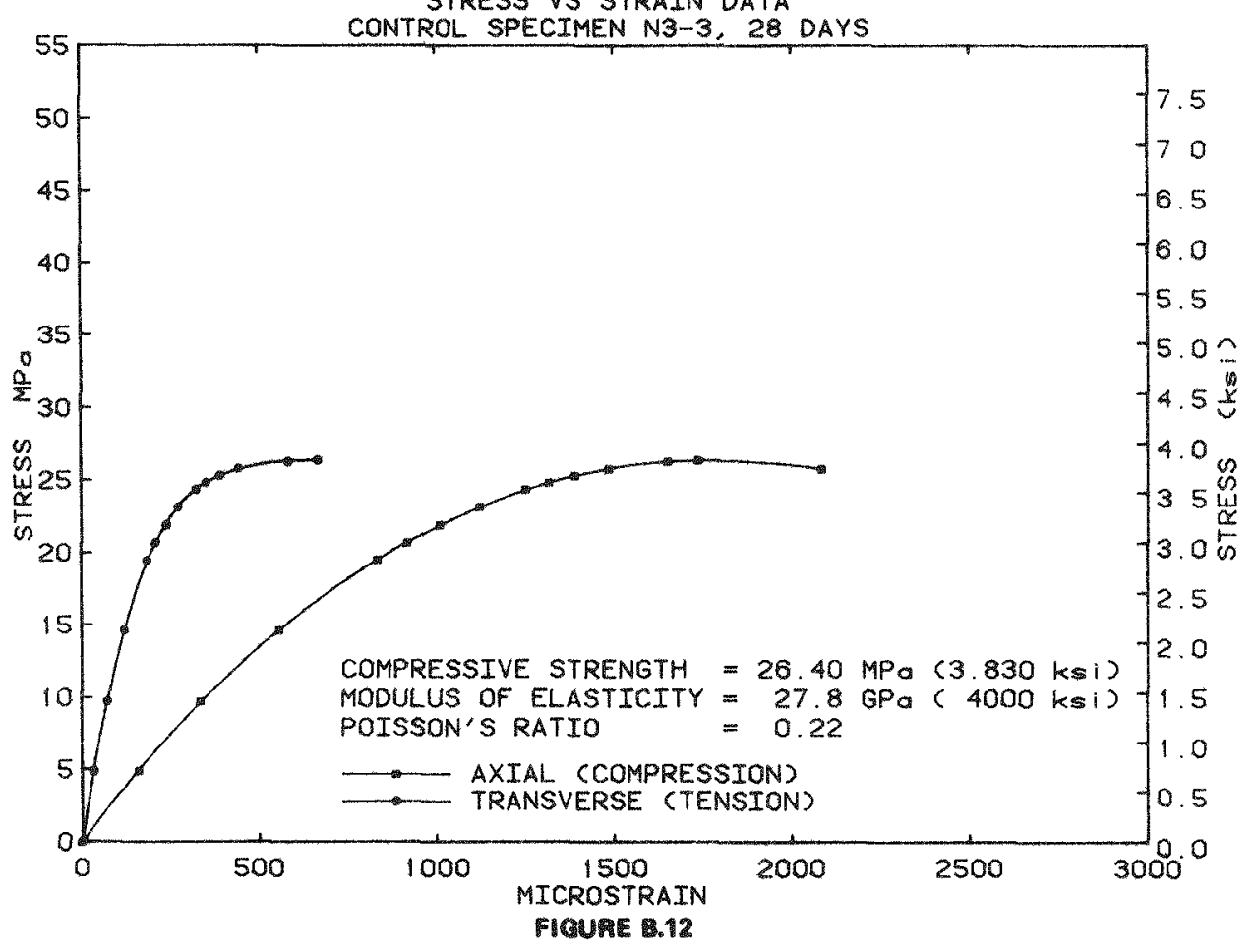


CRBR HIGH TEMPERATURE CONCRETE TESTS

OANL-DWC ETO STRESS VS STRAIN DATA

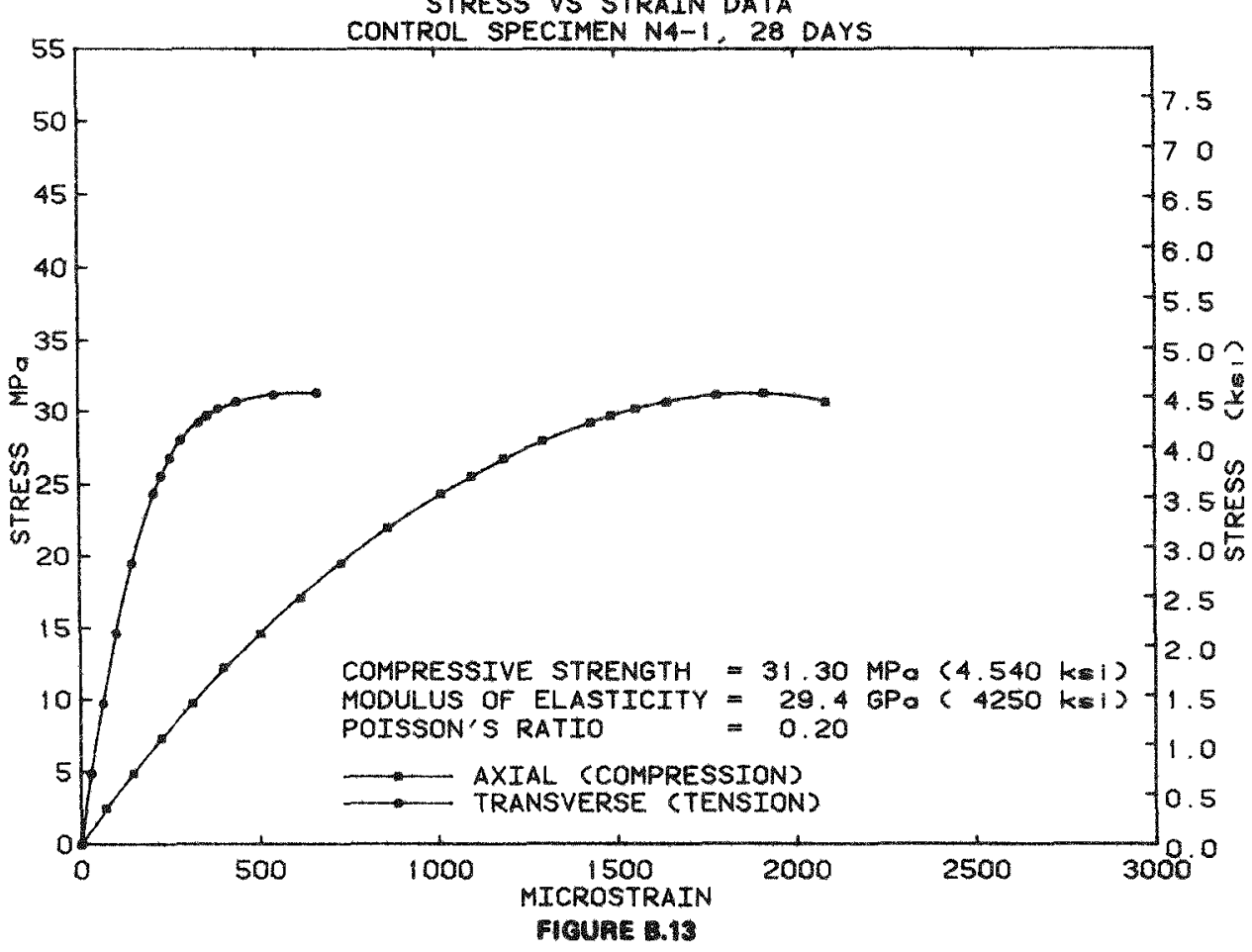

OAML-DW ETO

CRBR HIGH TEMPERATURE CONCRETE TESTS

STRESS VS STRAIN DATA

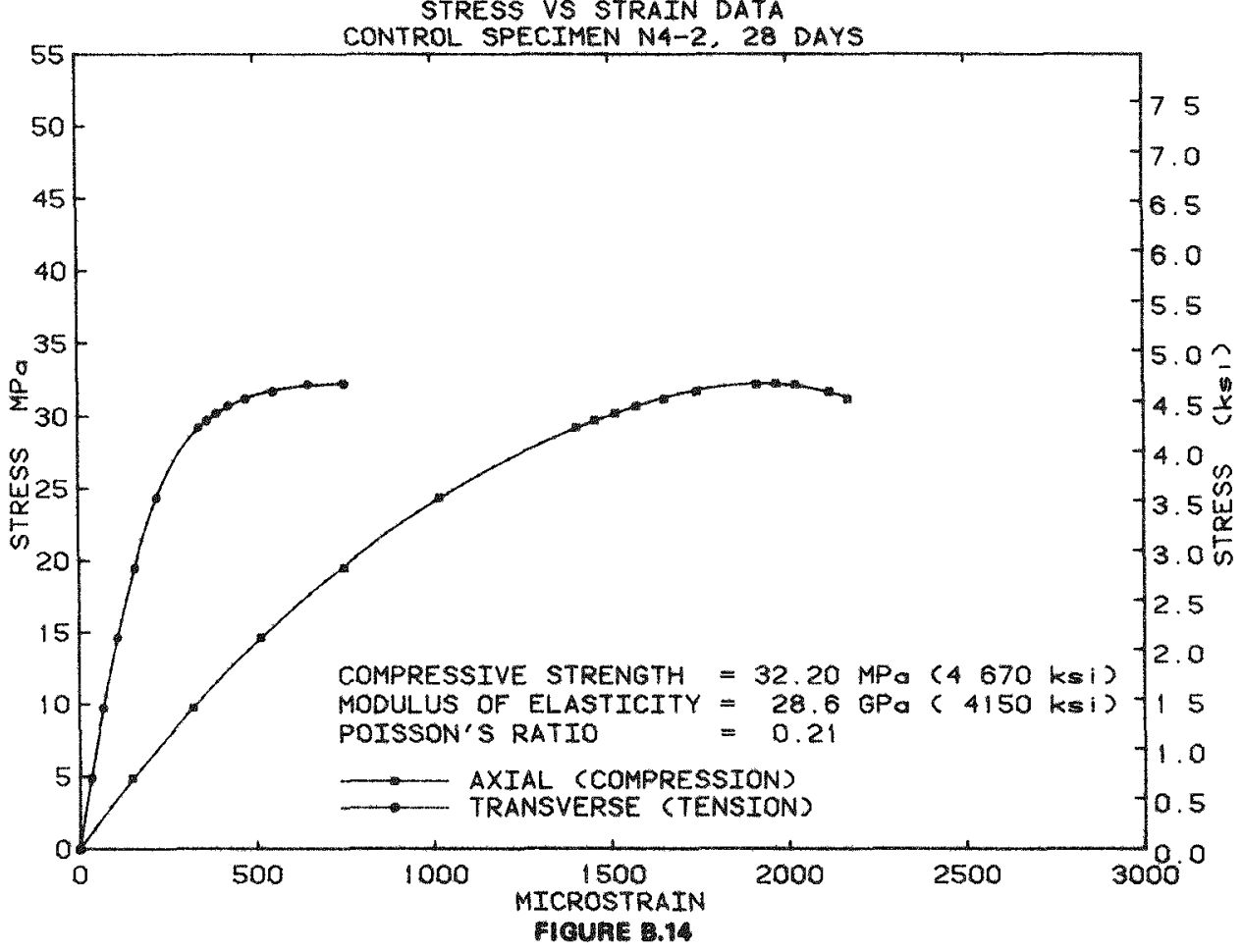




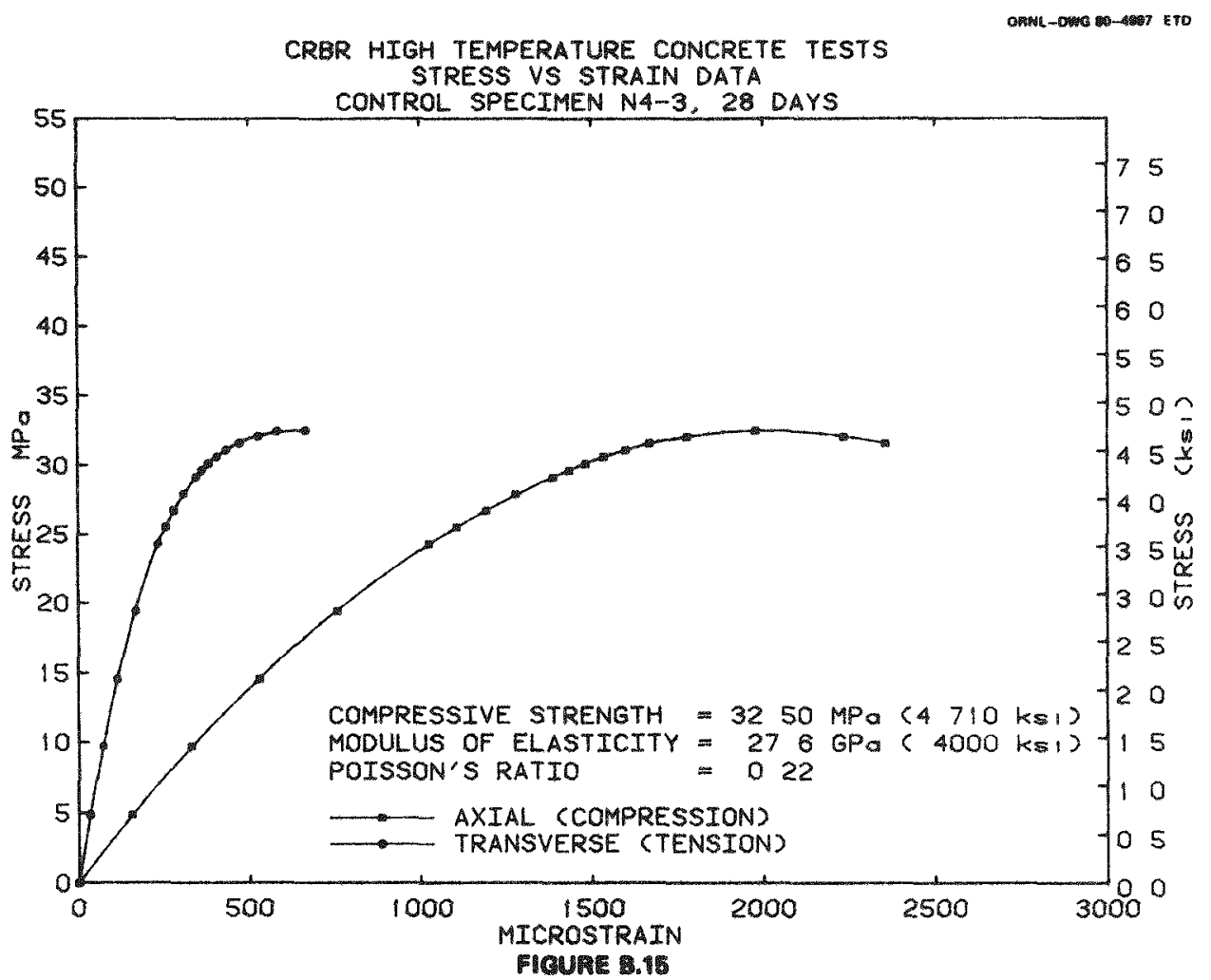

CRBR HIGH TEMPERATURE CONCRETE TESTS

OFNLL-DWG

STRESS VS STRATN DATA

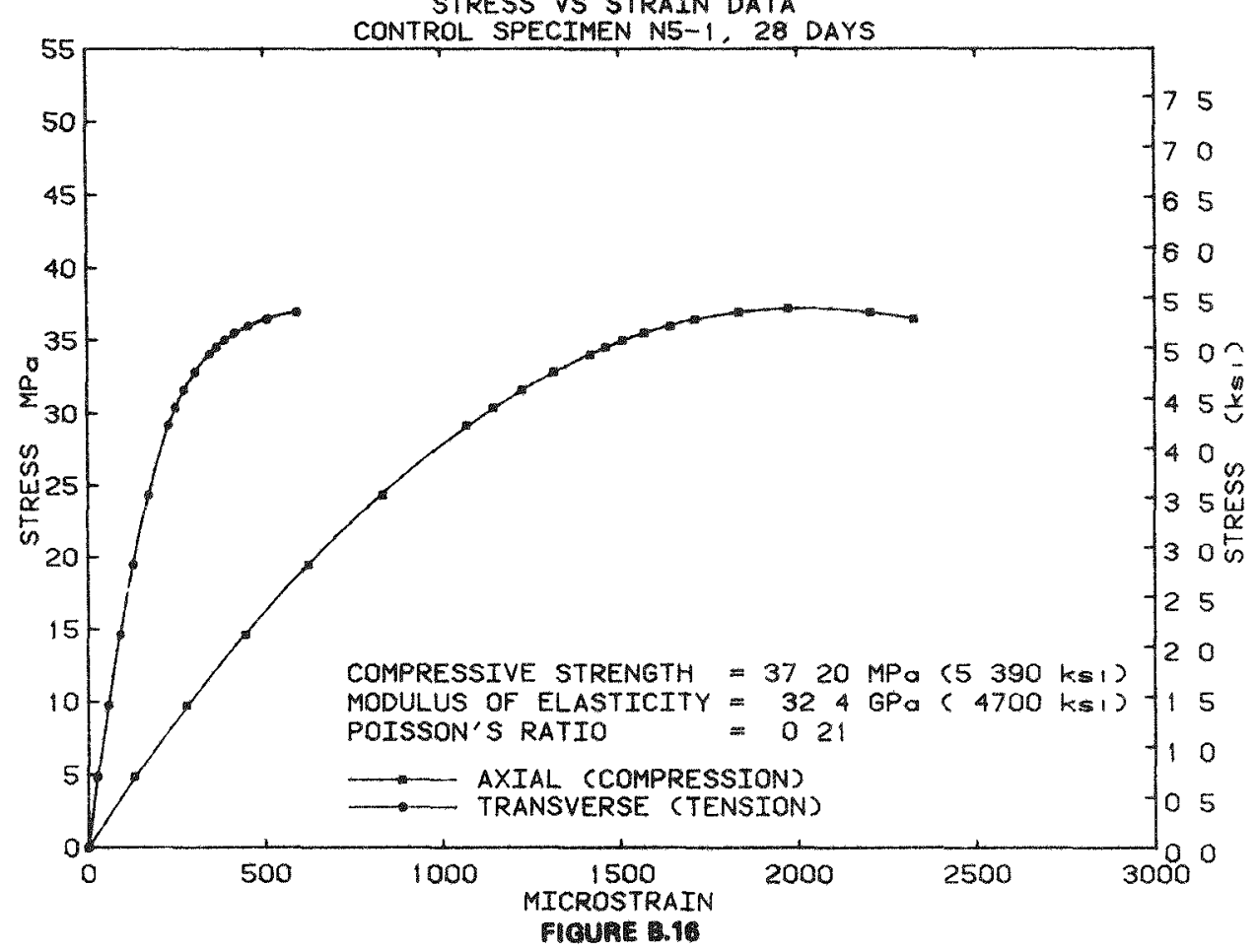



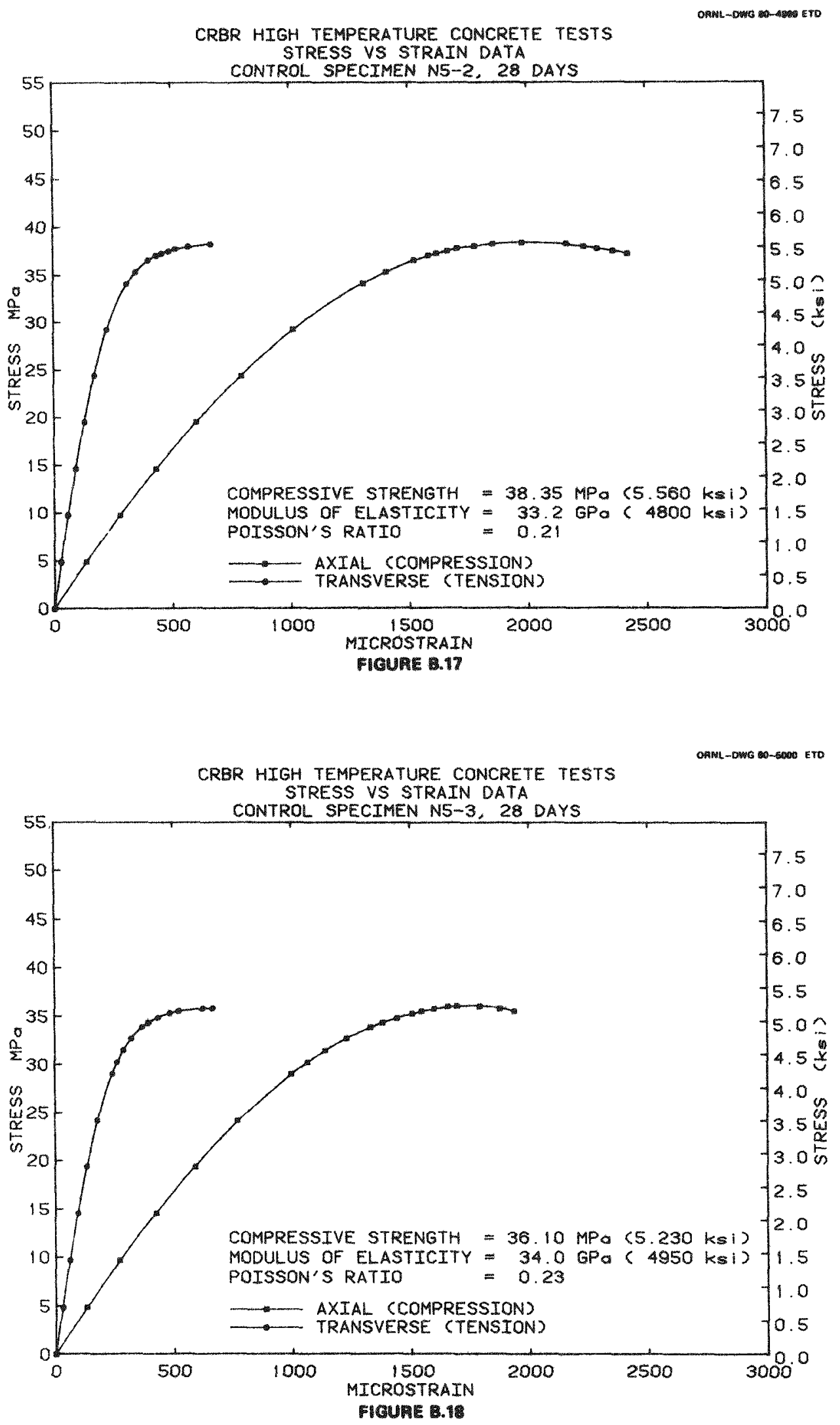
CRBR HIGH TEMPERATURE CONCRETE TESTS

ORALT-D STRESS VS STRATN DATA

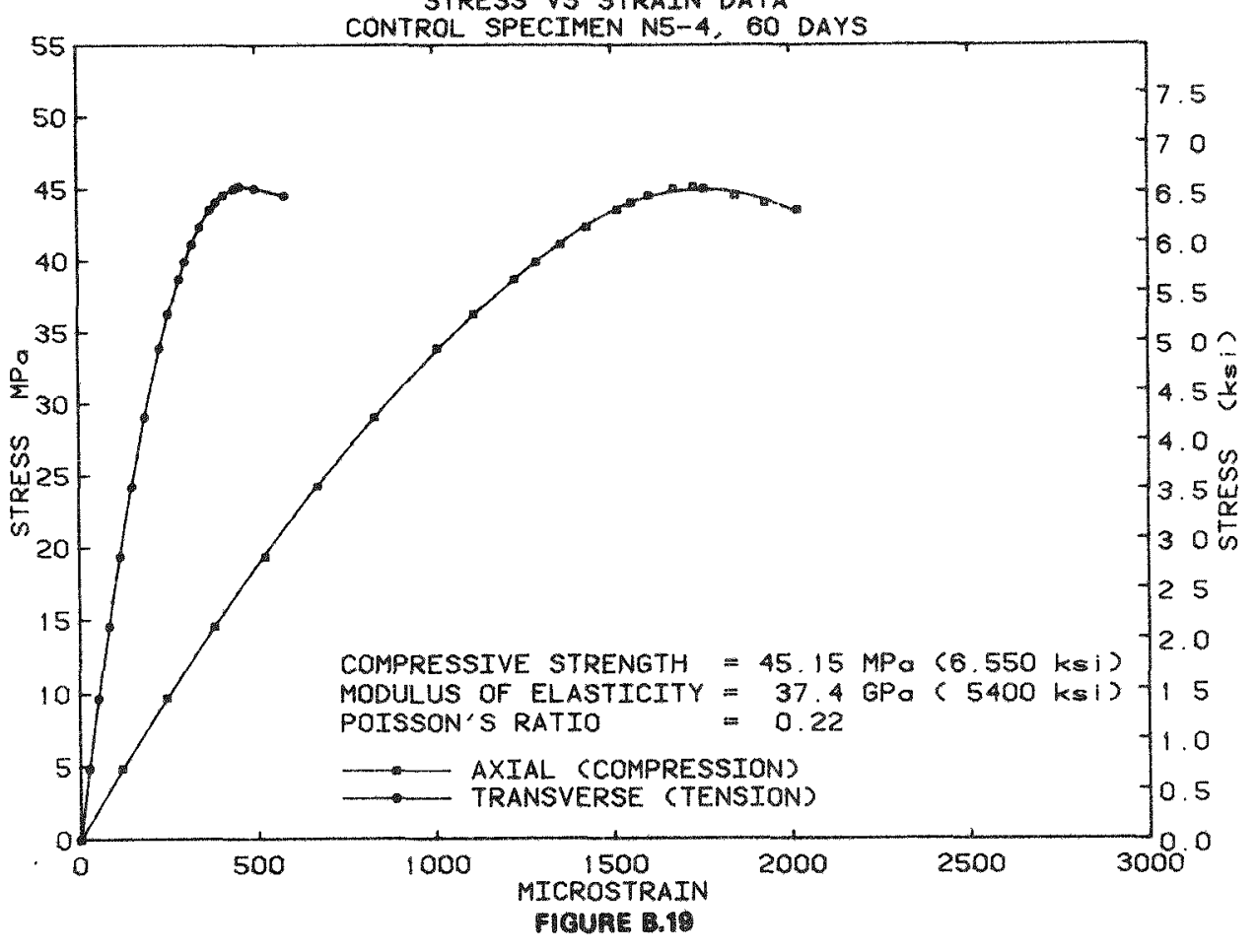

Oคคน - - D

CRBR HIGH TEMPERATURE CONCRETE TESTS STRESS VS STRAIN DATA

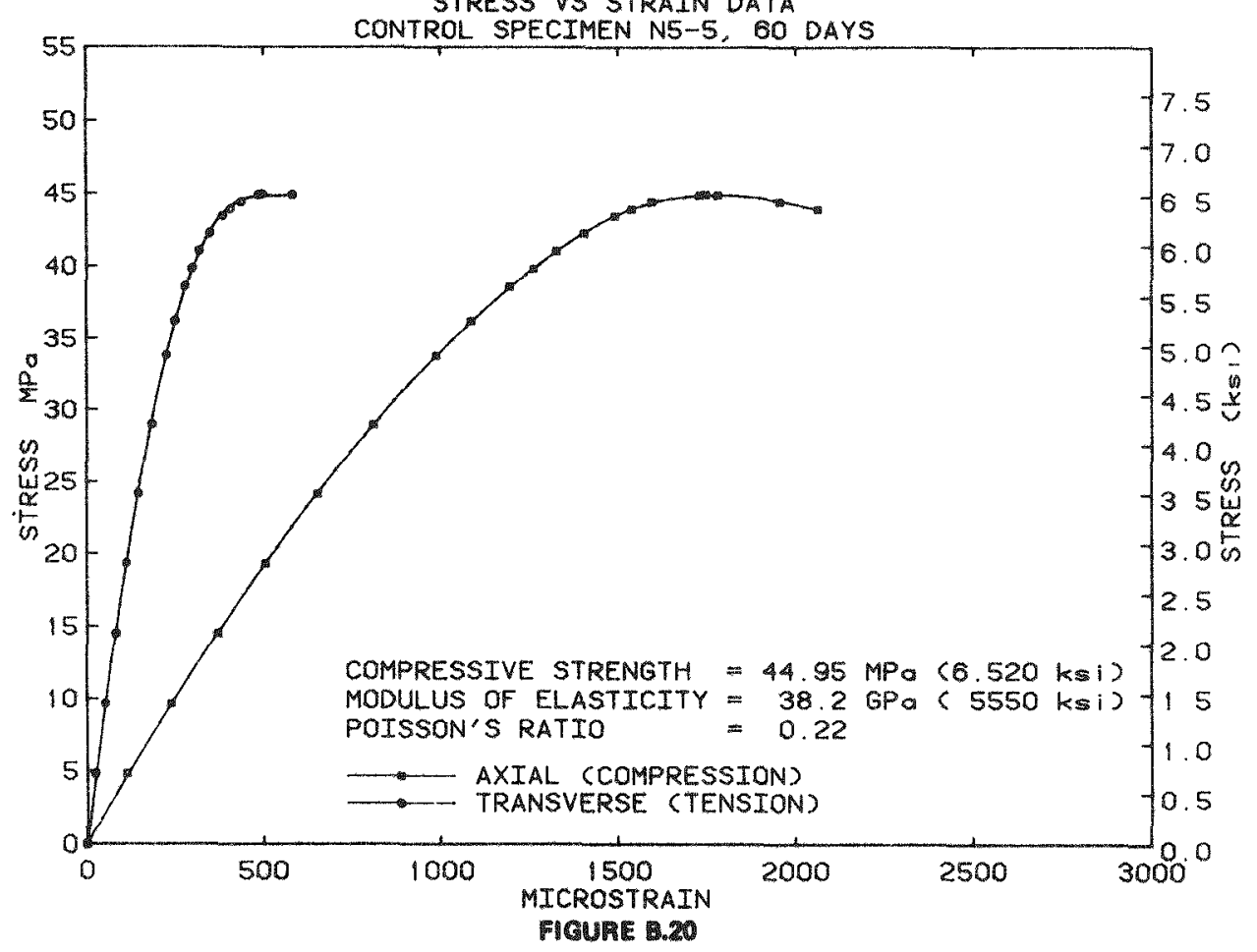


CRBR HIGH TEMPERATURE CONCRETE TESTS

OANL-O ETO

STRESS VS STRAIN DATA

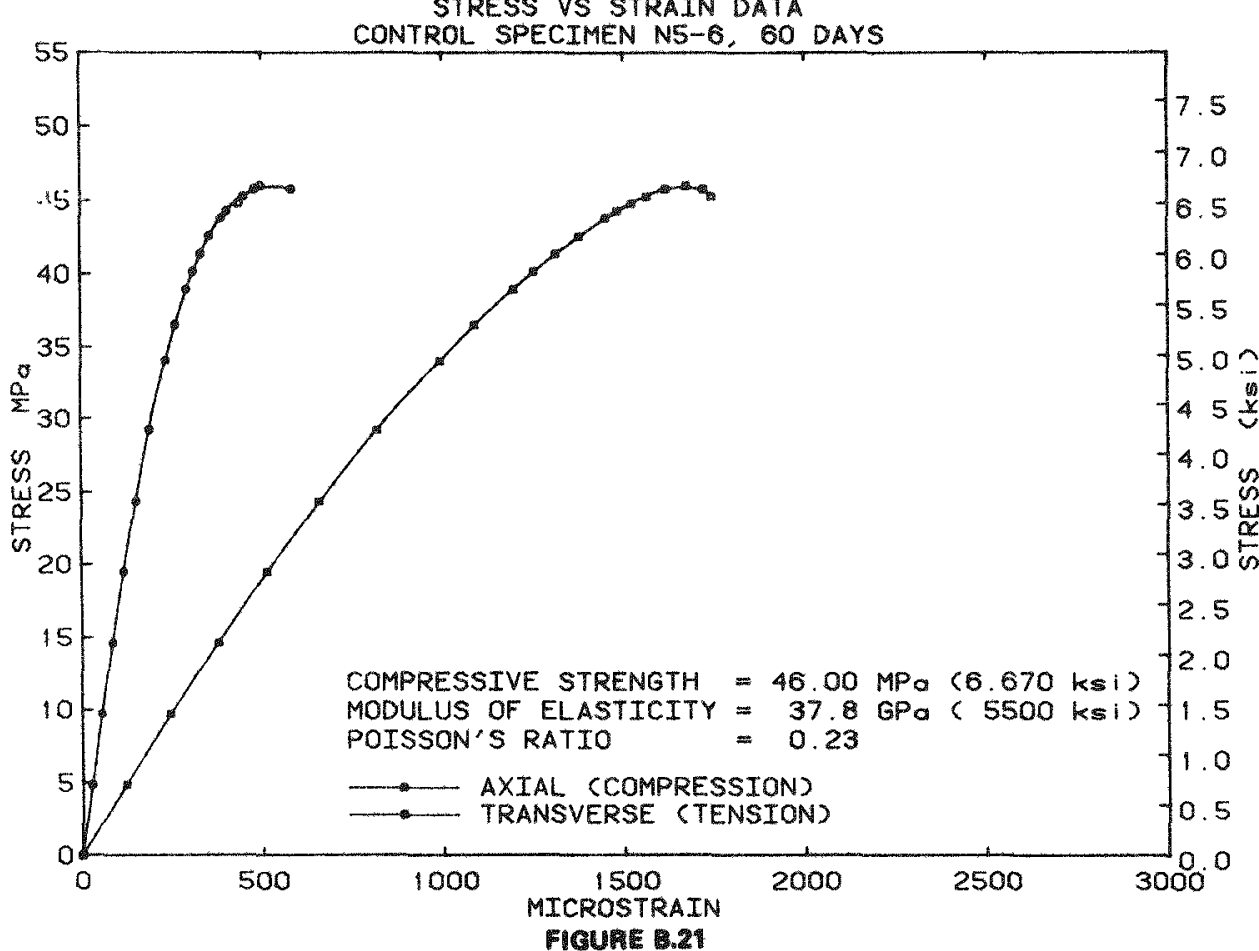

OPNL-OWG

CRBR HIGH TEMPERATURE CONCRETE TESTS STRESS VS STRAIN DATA

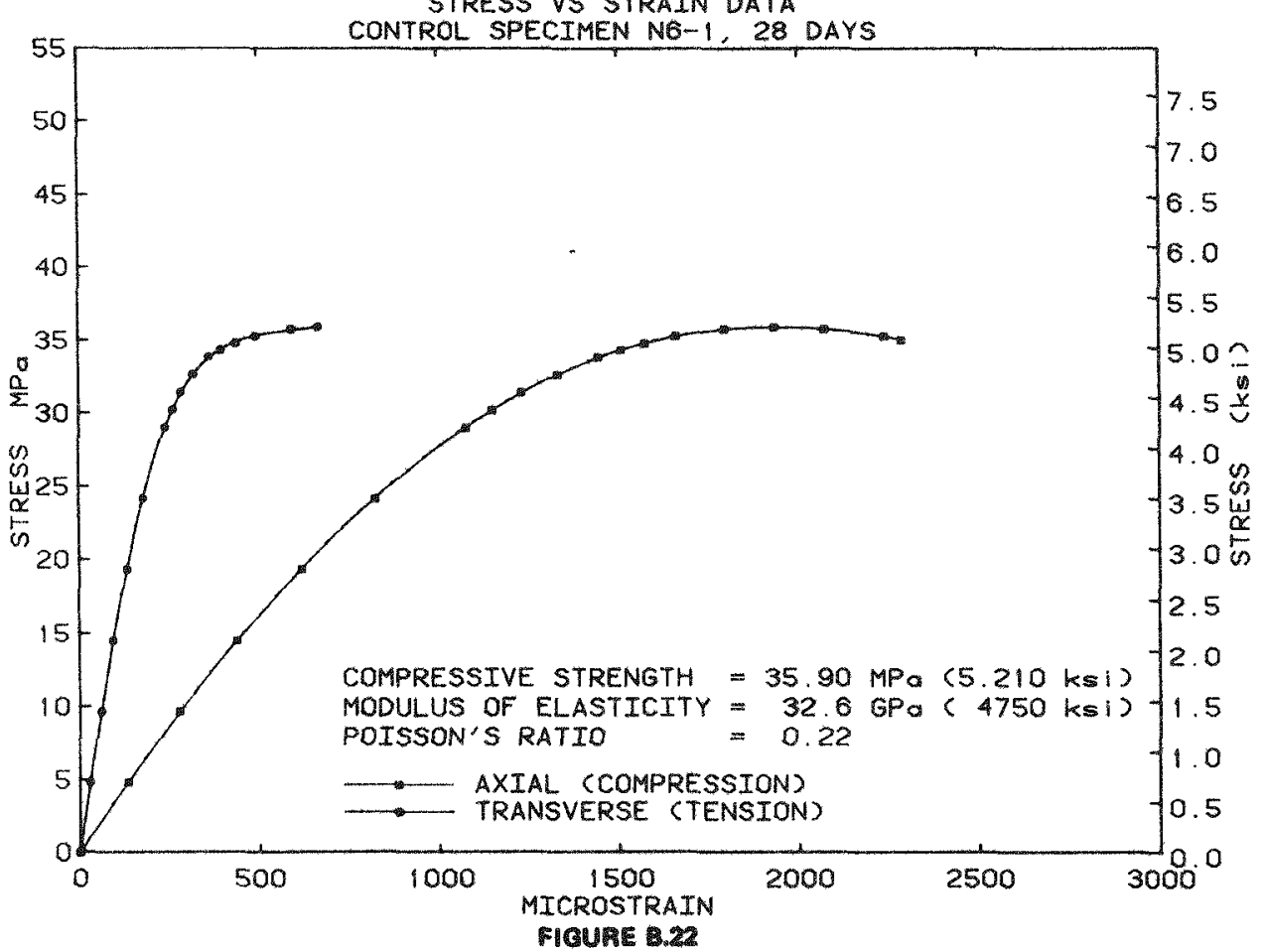


CRBR HIGH TEMPERATURE CONCRETE TESTS

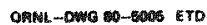
STRESS VS STRATN DATA

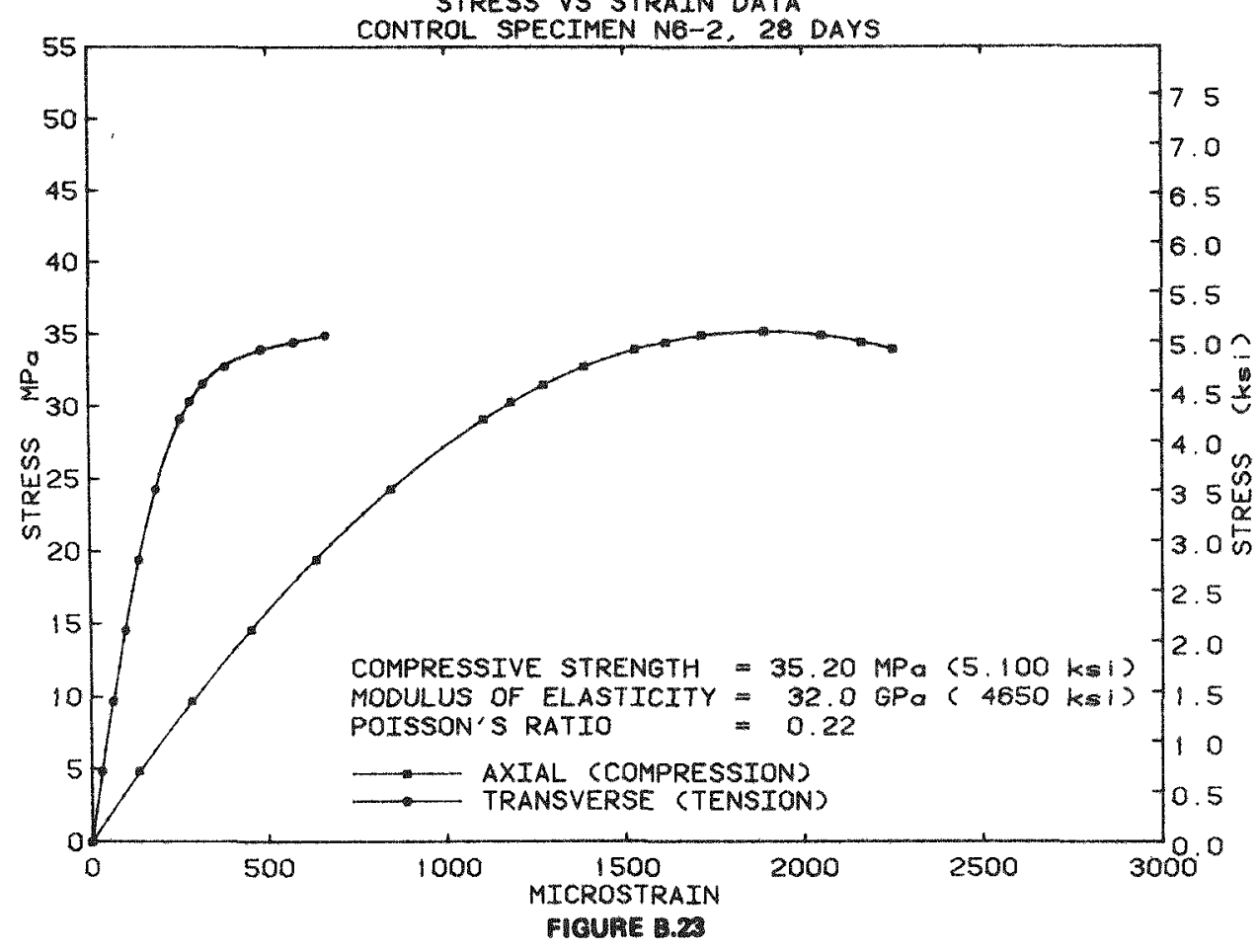

ORNLLOWG ETD

CRBR HIGH TEMPERATURE CONCRETE TESTS STRESS VS STRAIN DATA

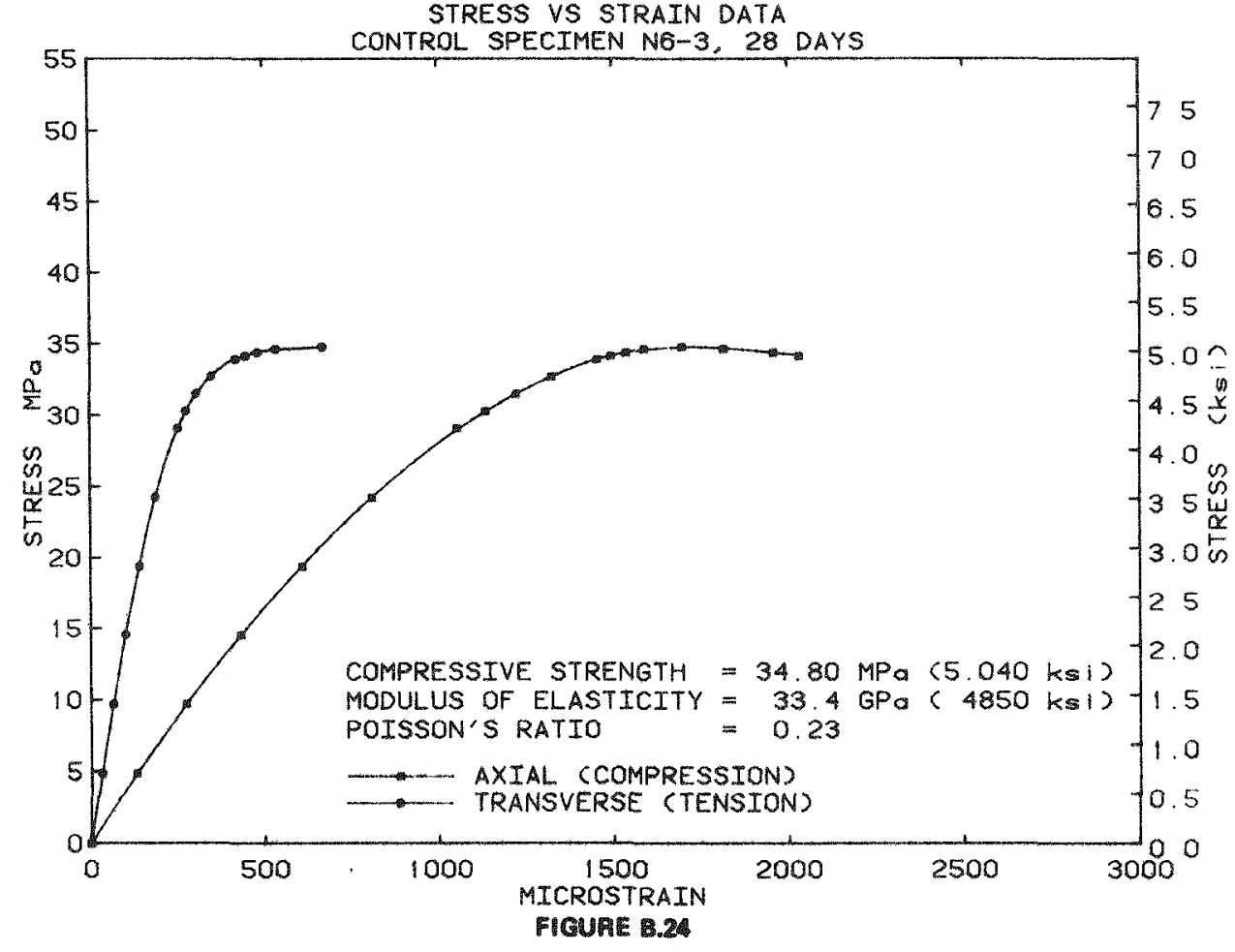


CRBR MIGH TEMPERATURE CONCRETE TESTS STRESS VS STRAIN DATA

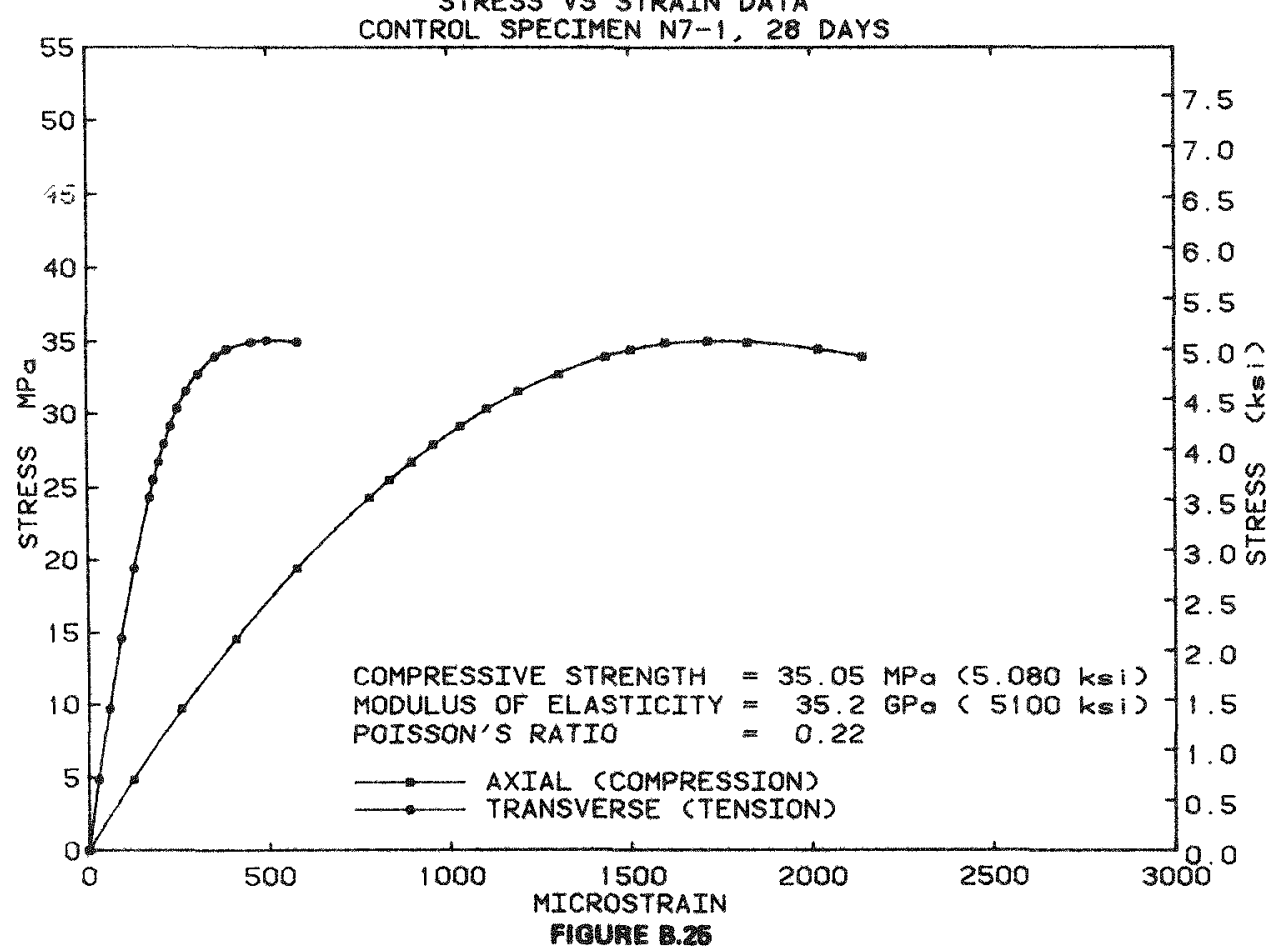

ORNL-DWO OO-5000 ETO

CRBR HIGH TEMPERATURE CONCRETE TESTS STRESS VS STRAIN DATA

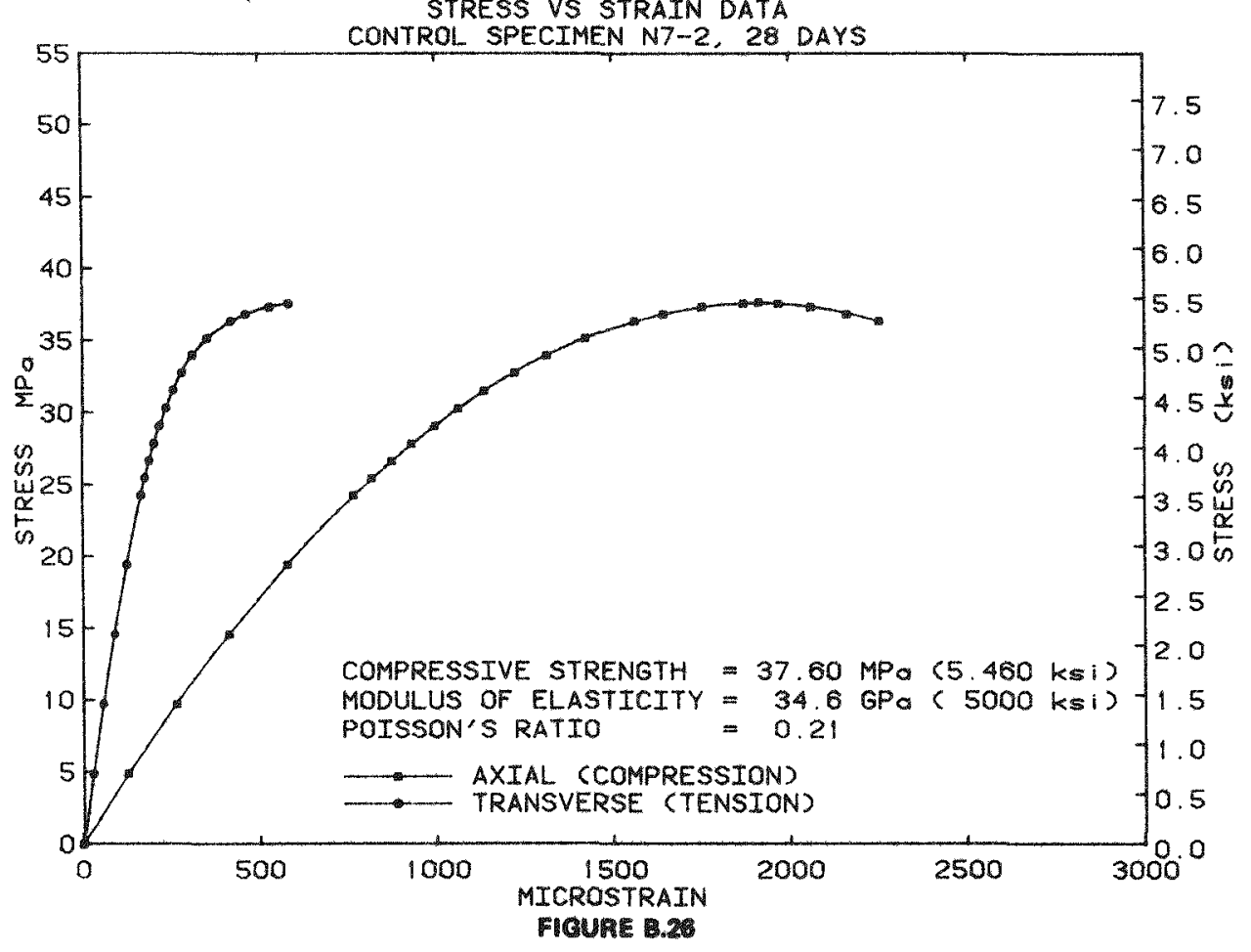




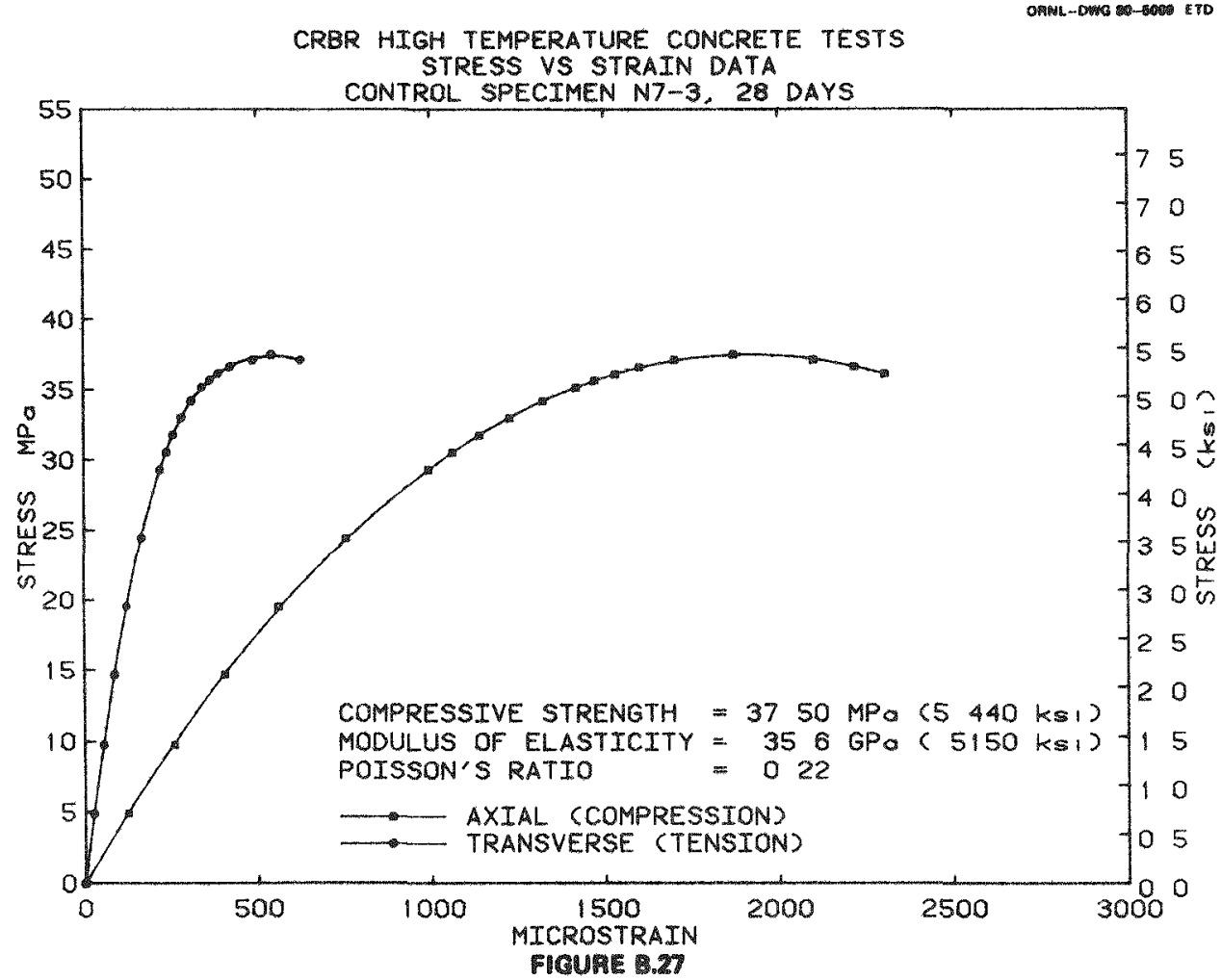

ORAL -

CRBR HIGH TEMPERATURE CONCRETE TESTS

STRESS VS STRAIN DATA

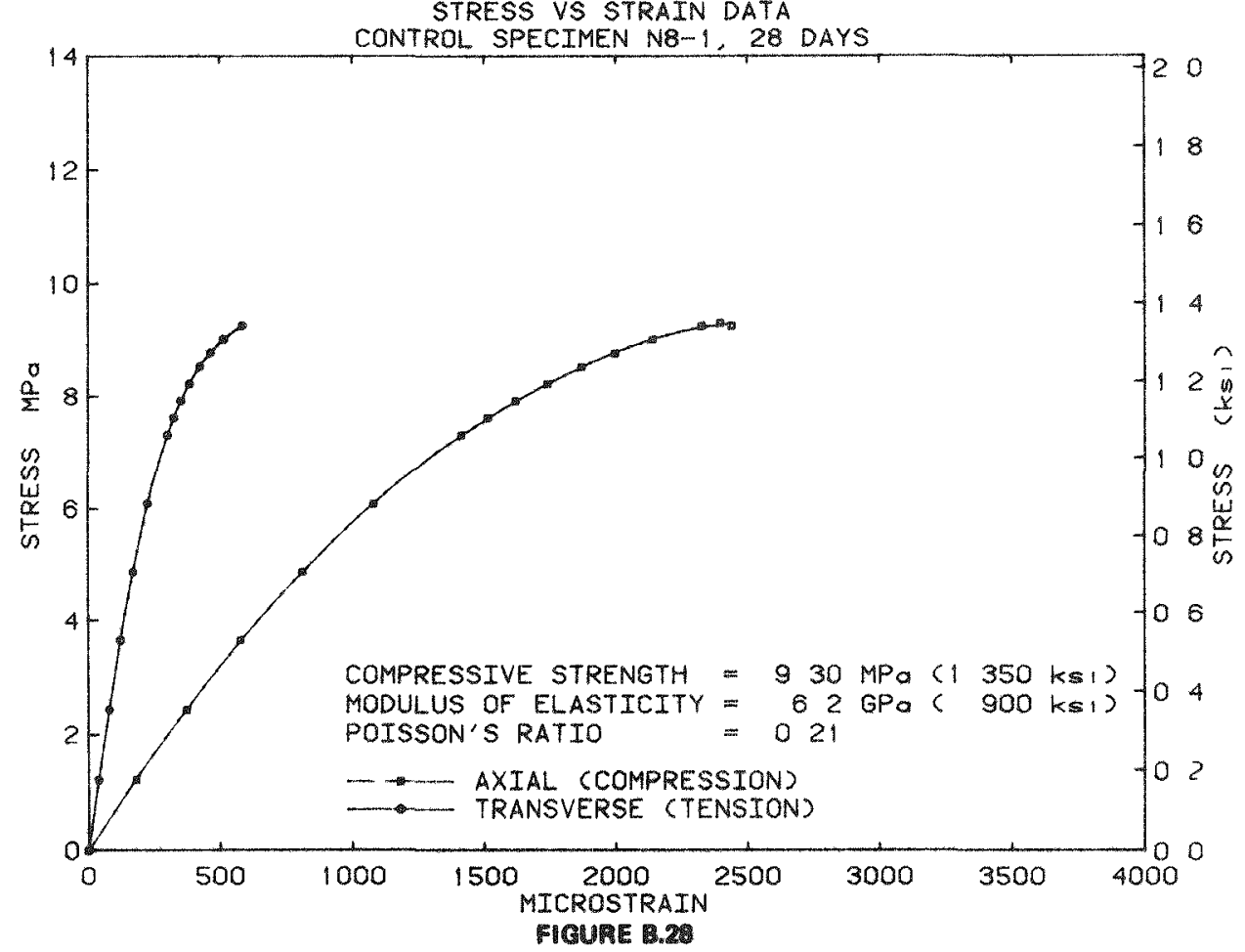


CRBR HIGH TEMPERATURE CONCRETE TESTS

STRESS VS STRAIN DATA

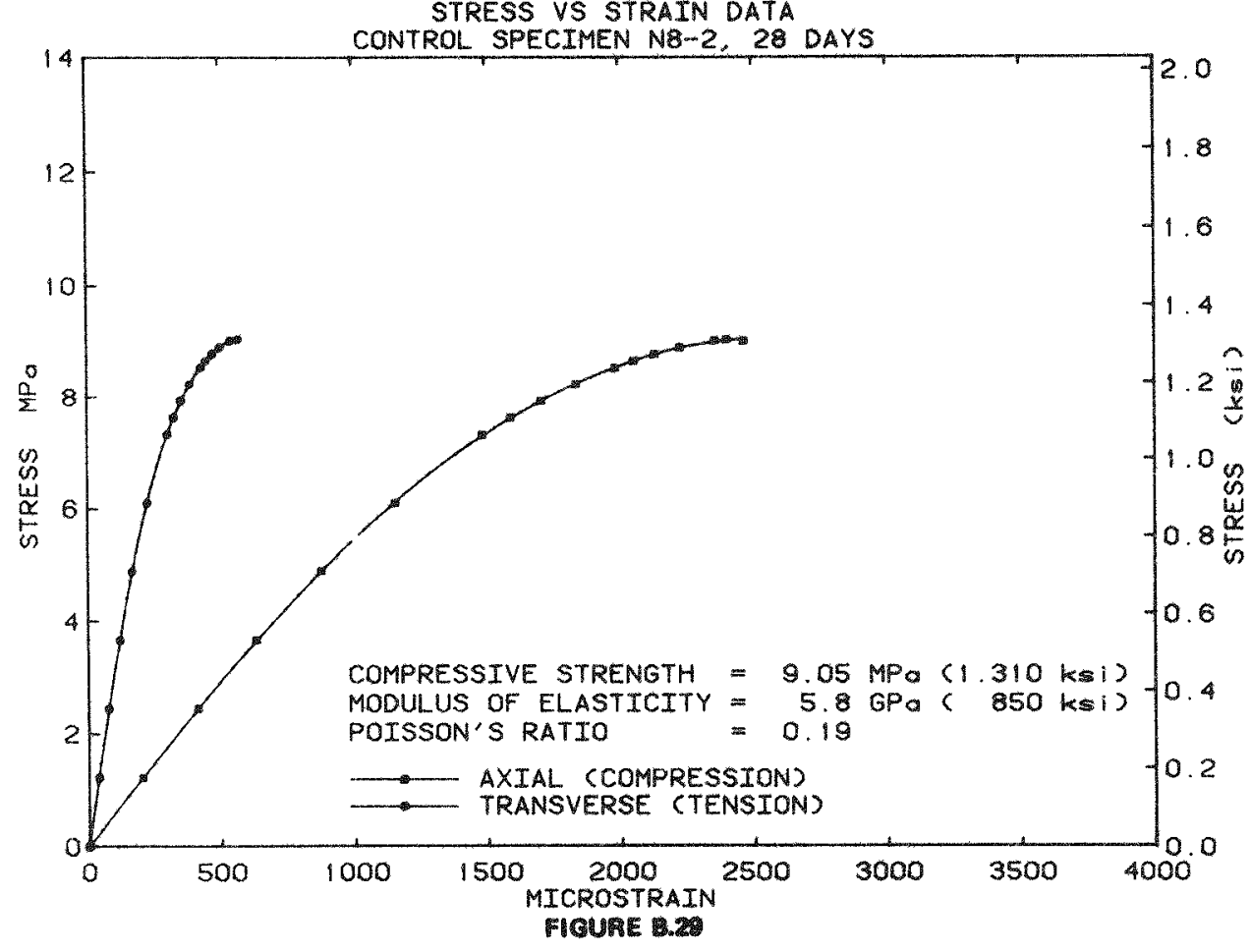

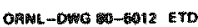

CRBR HIGH TEMPERATURE CONCRETE TESTS STRESS VS STRAIN DATA

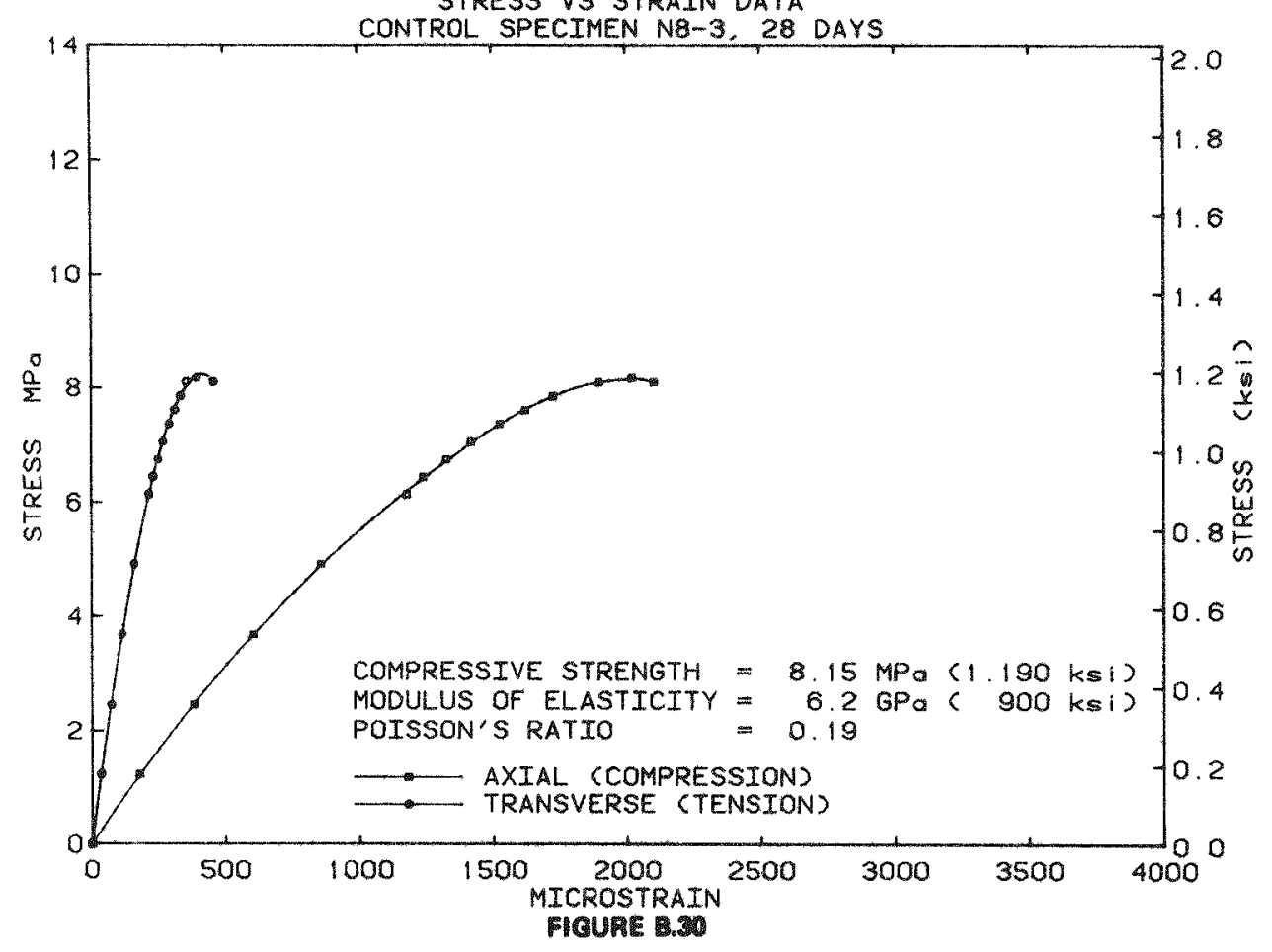



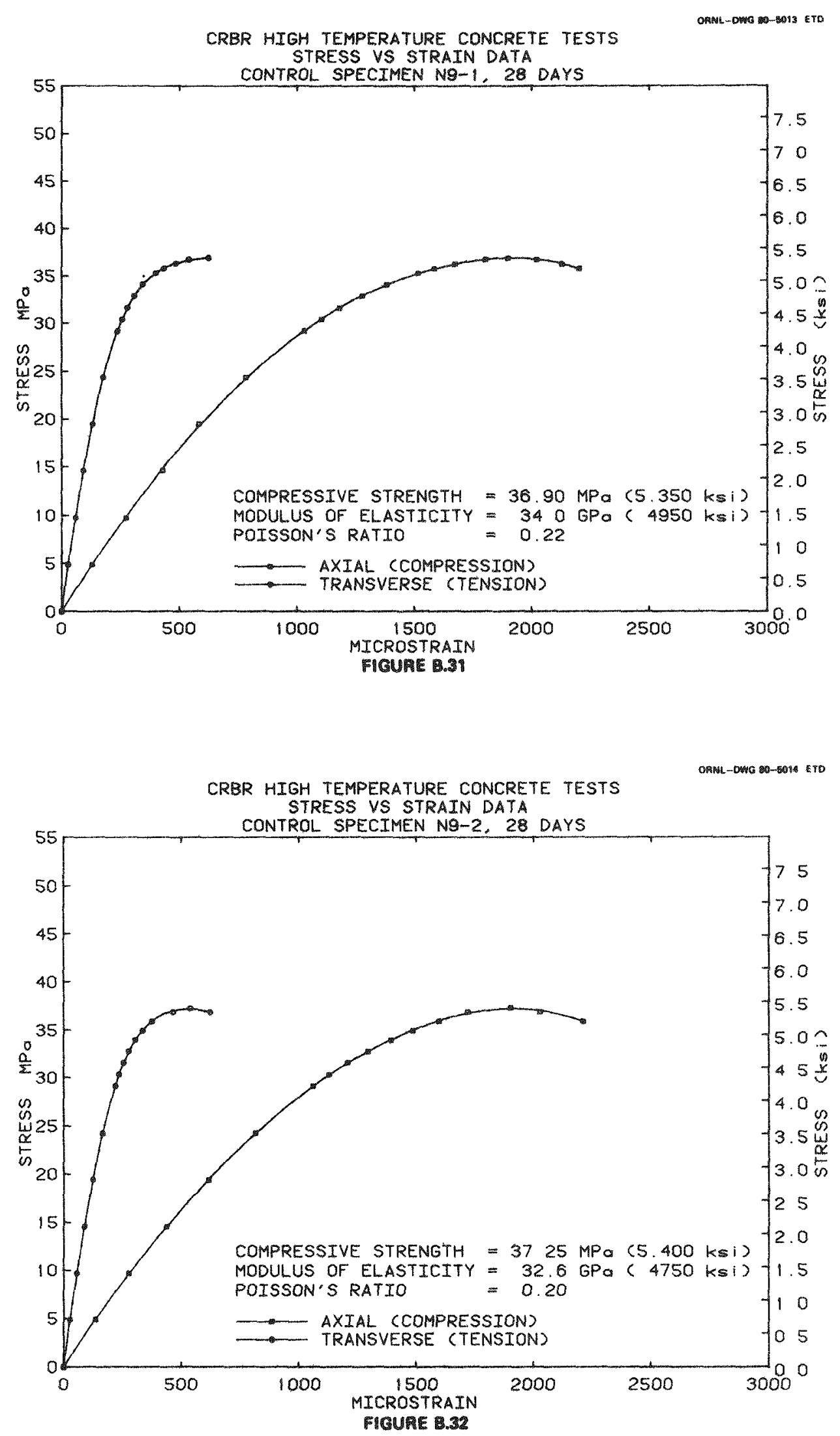
CRBR HIGH TEMPERATURE CONCRETE TESTS

STRESS VS STRAIN DATA

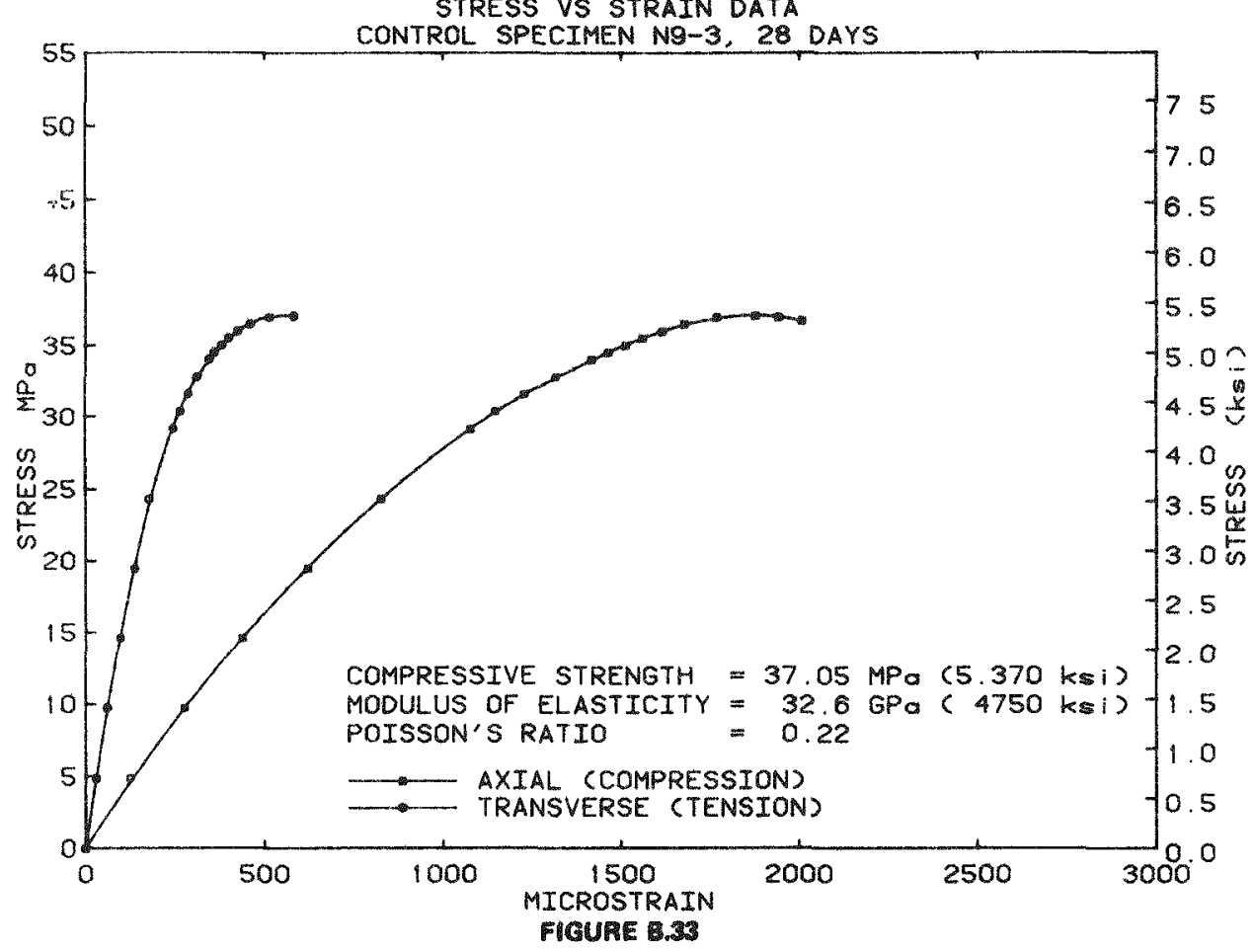

ORAL DDW DO-SOIE ETD

CRBR HIGH TEMPERATURE CONCRETE TESTS STRESS VS STRAIN DATA

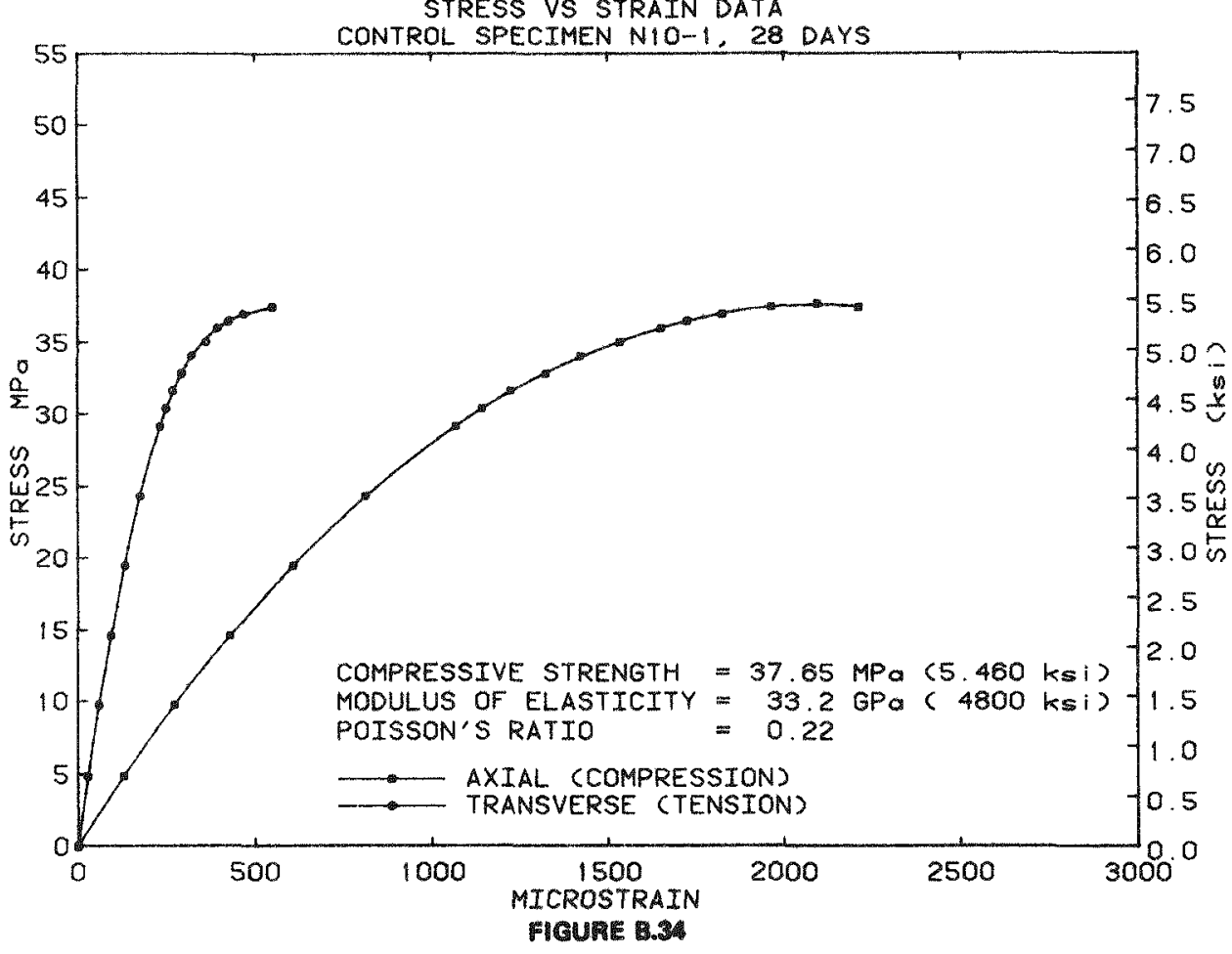


CRBR HIGH TEMPERATURE CONCRETE TESTS

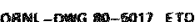
STRESS VS STRAIN DATA

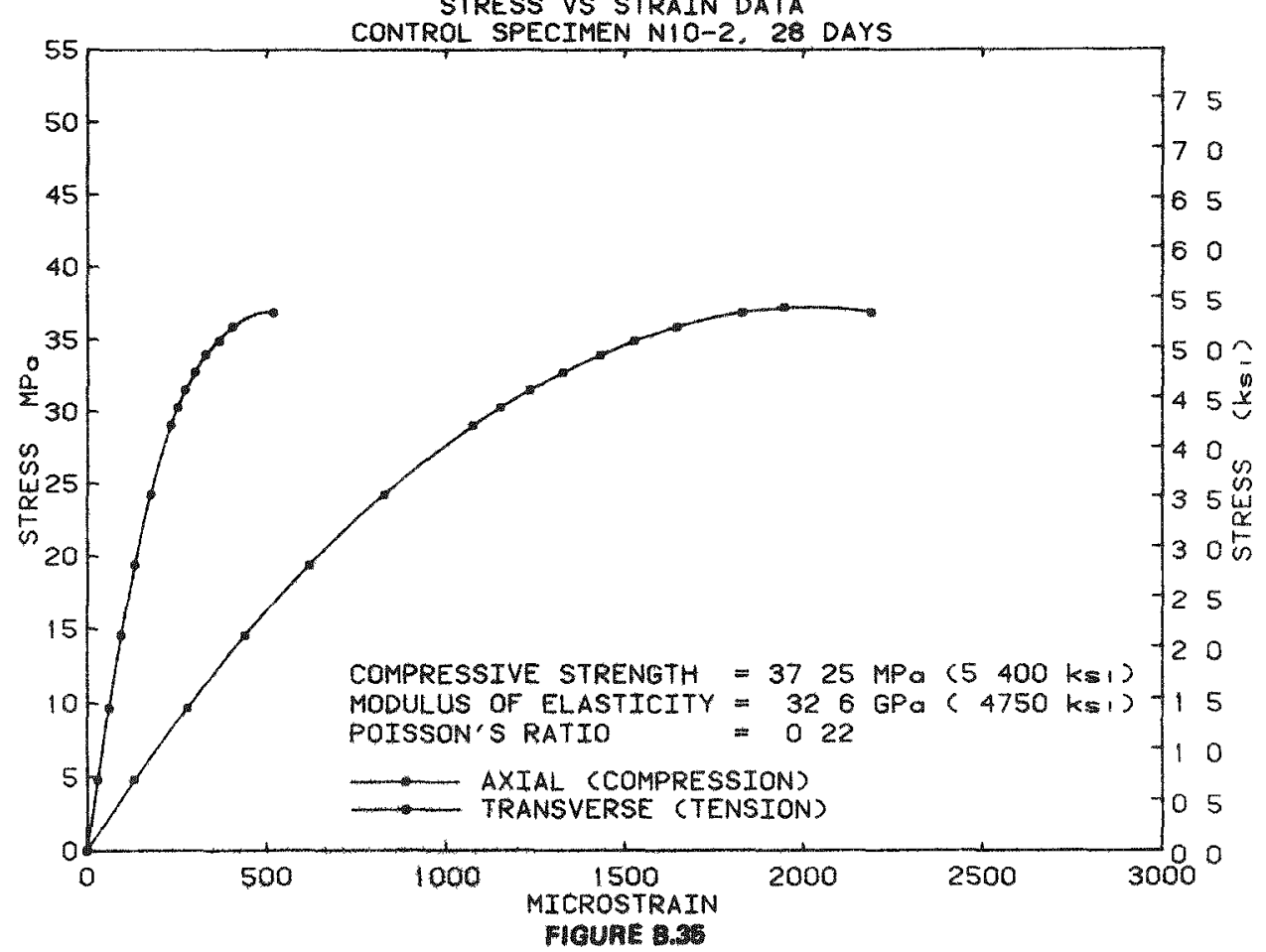

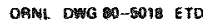

CRBR HIGH TEMPERATURE CONCRETE TESTS STRESS VS STRAIN DATA

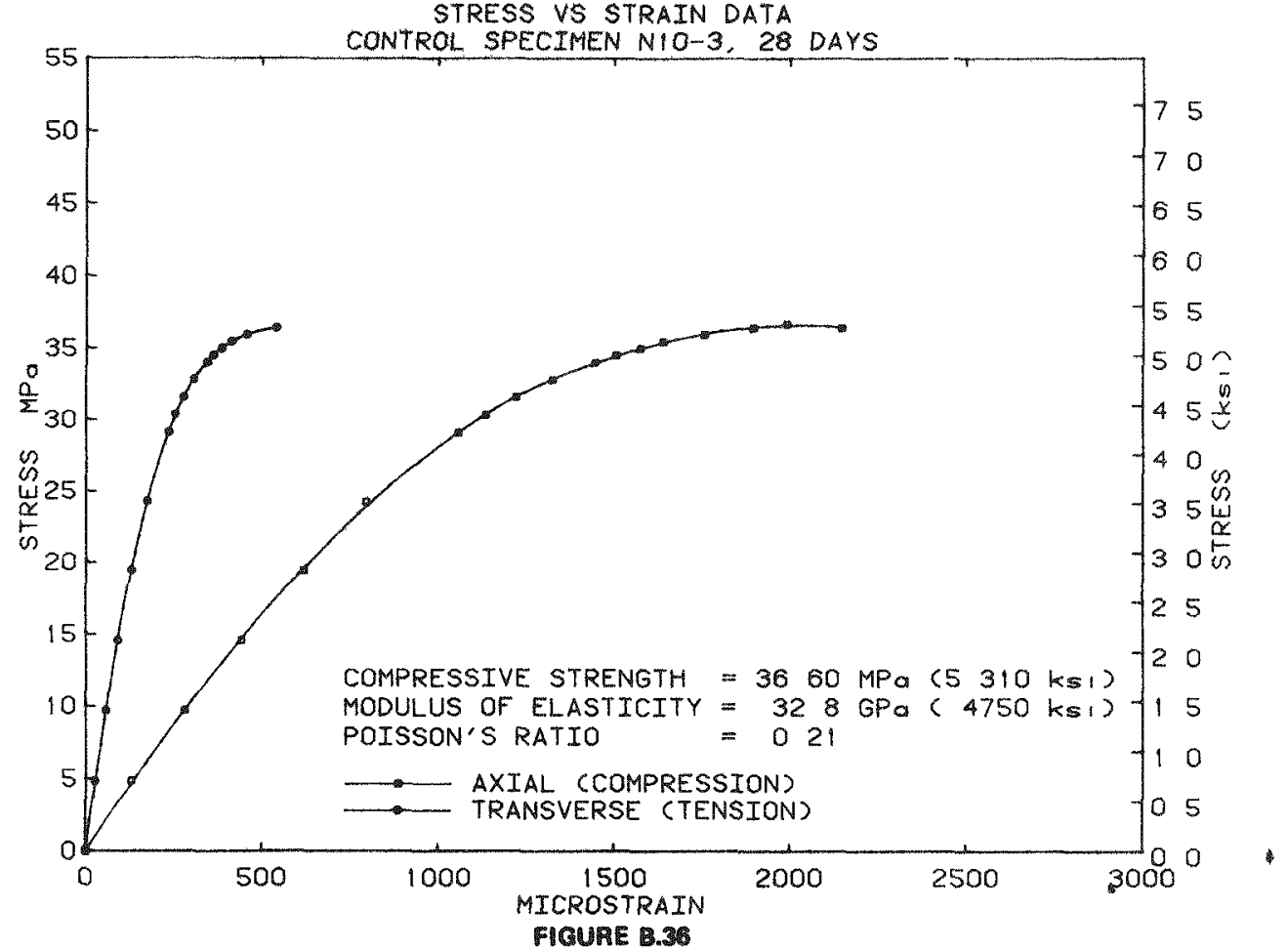


CRBR HIGH TEMPERATURE CONCRETE TESTS

STRESS VS STRAIN DATA

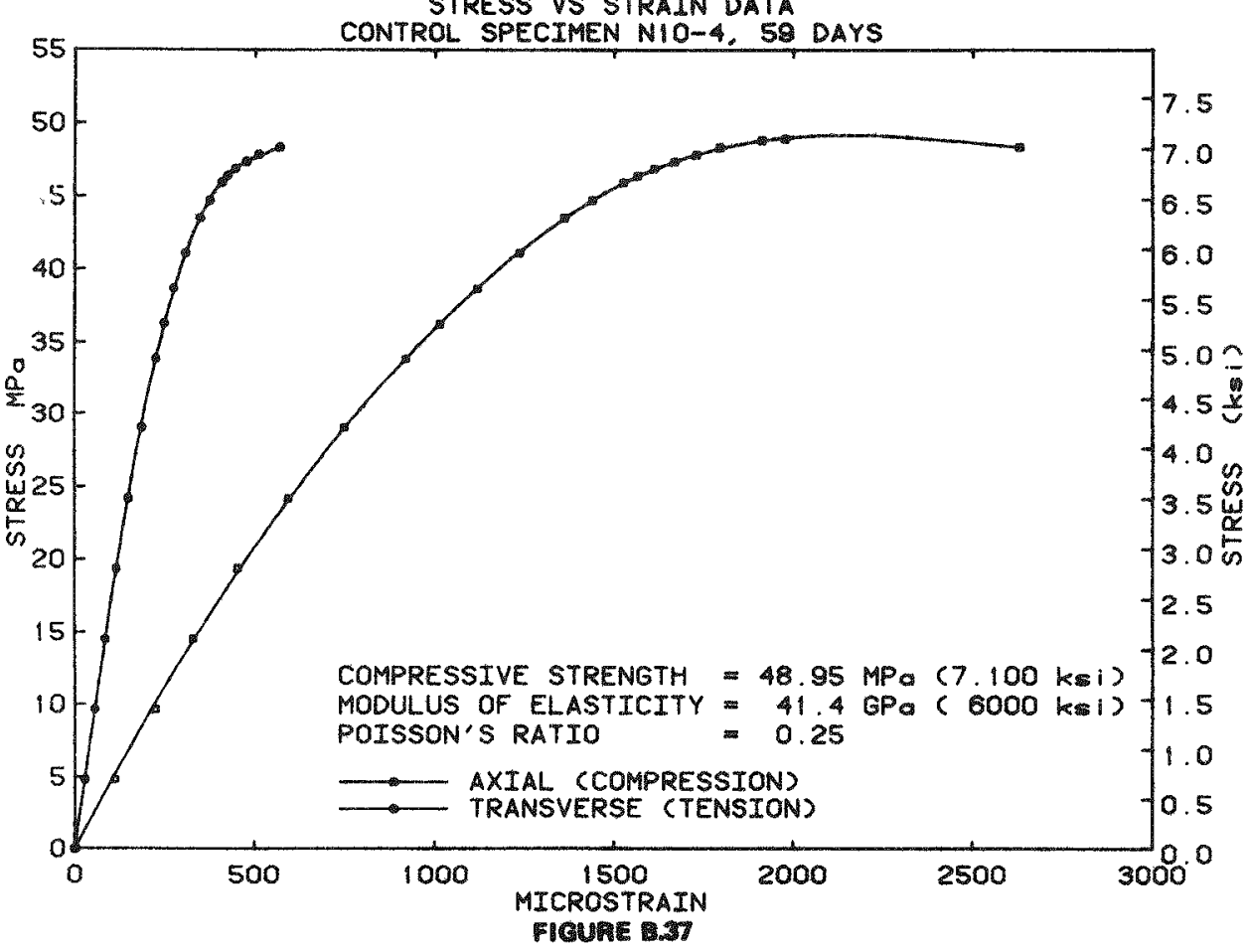

CRBR HIGH TEMPERATURE CONCRETE TESTS STRESS VS STRAIN DATA

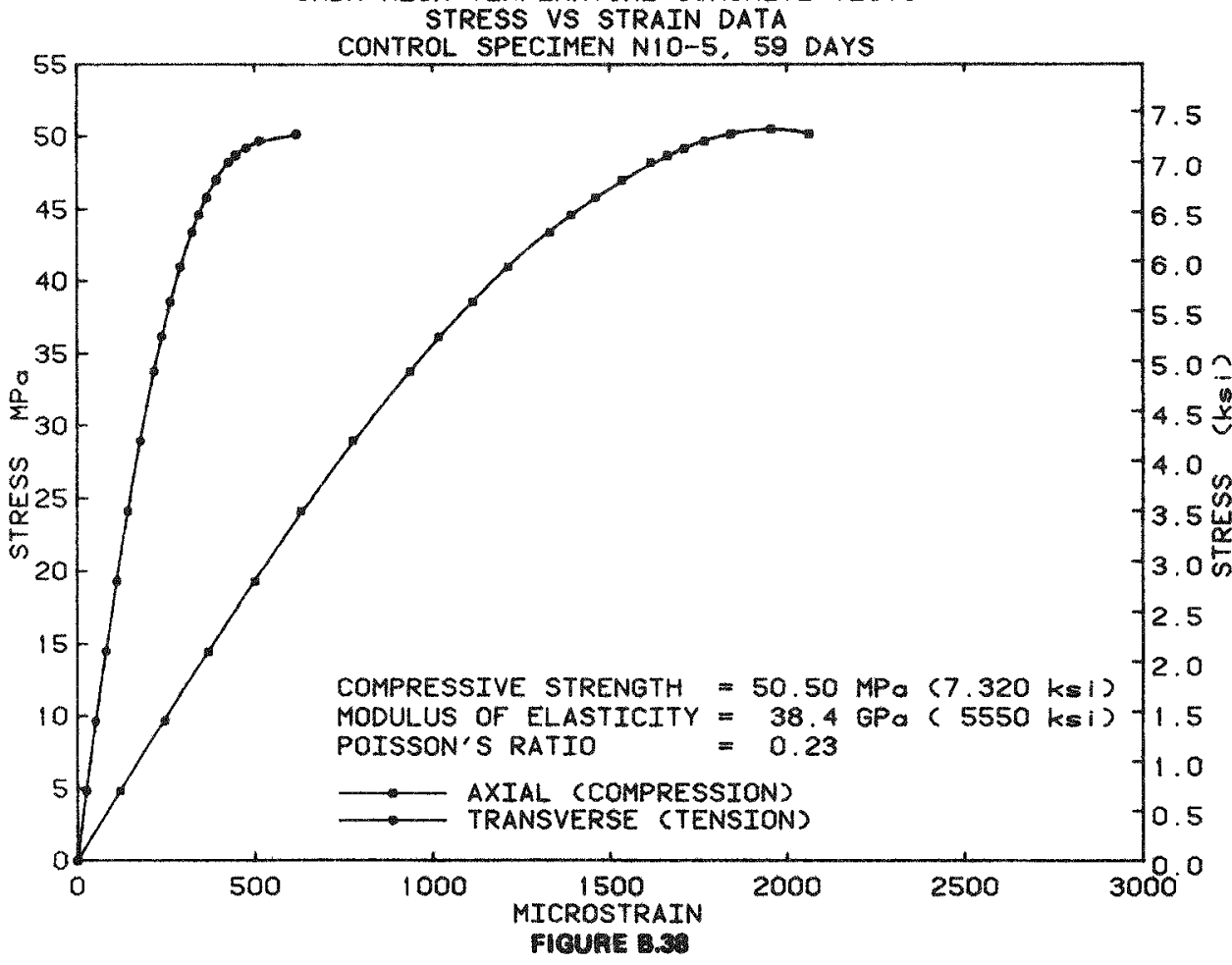


CRBR MIGH TEMPERATURE CONCRETE TESTS

STRESS VS STRAIN DATA

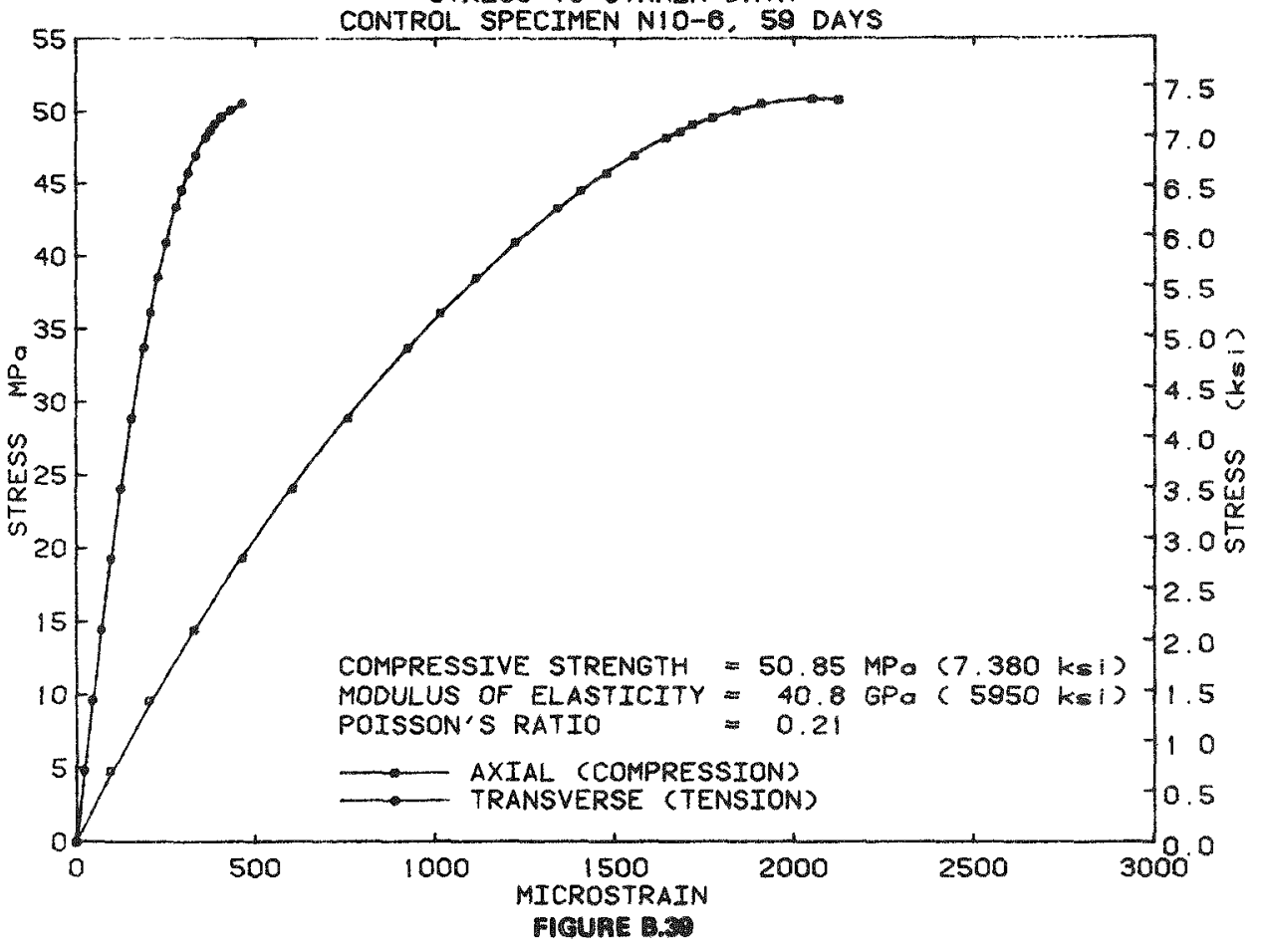

ORAL-OWO 20-TR2Z ETO

CRBR HIGH TEMPERATURE CONCRETE TESTS STRESS VS STRAIN DATA

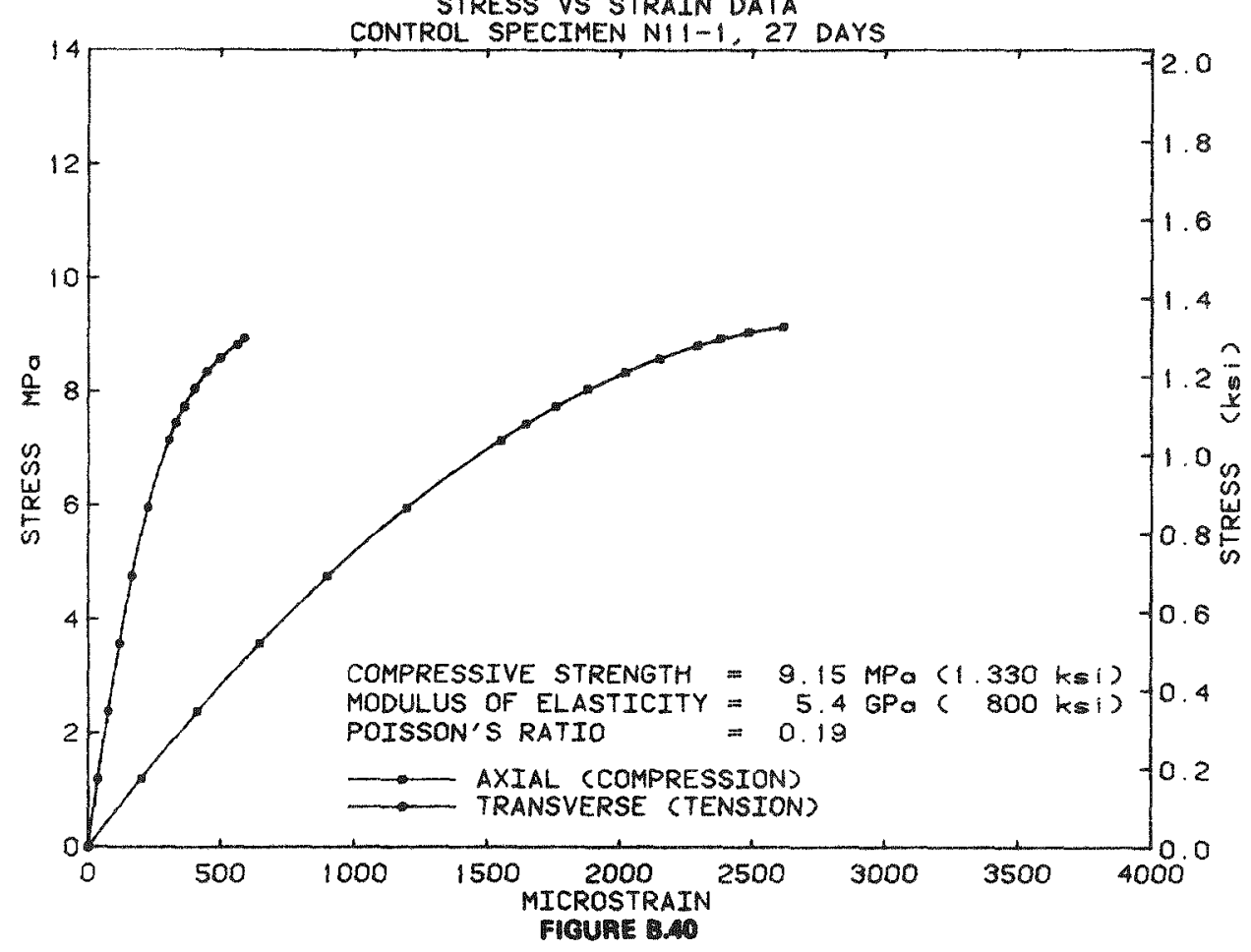


CRBR HIGH TEMPERATURE CONCRETE TESTS

STRESS VS STRAIN DATA

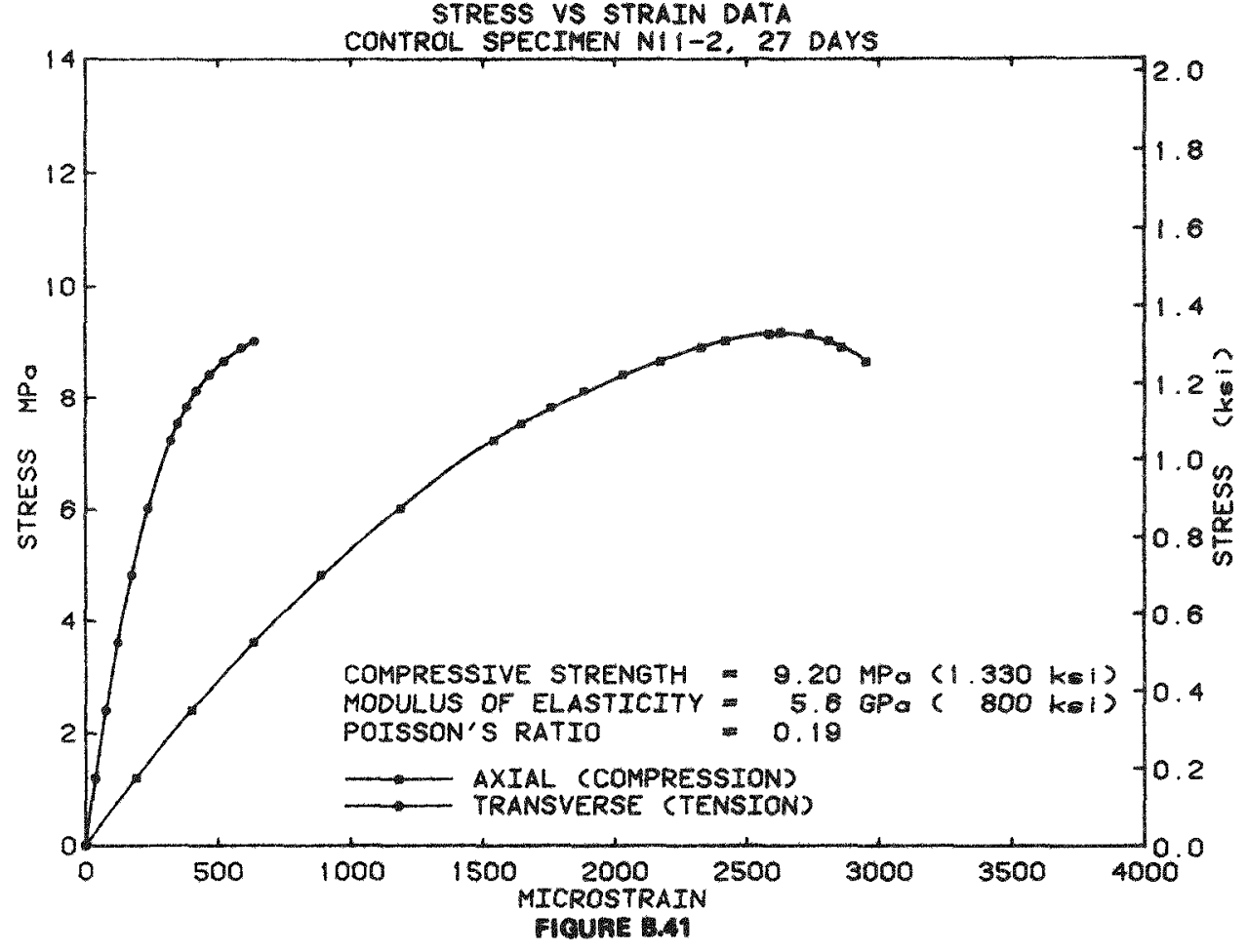

ORN1-DW

CRBR HIGH TEMPERATURE CONCRETE TESTS

STRESS VS STRATN DATA

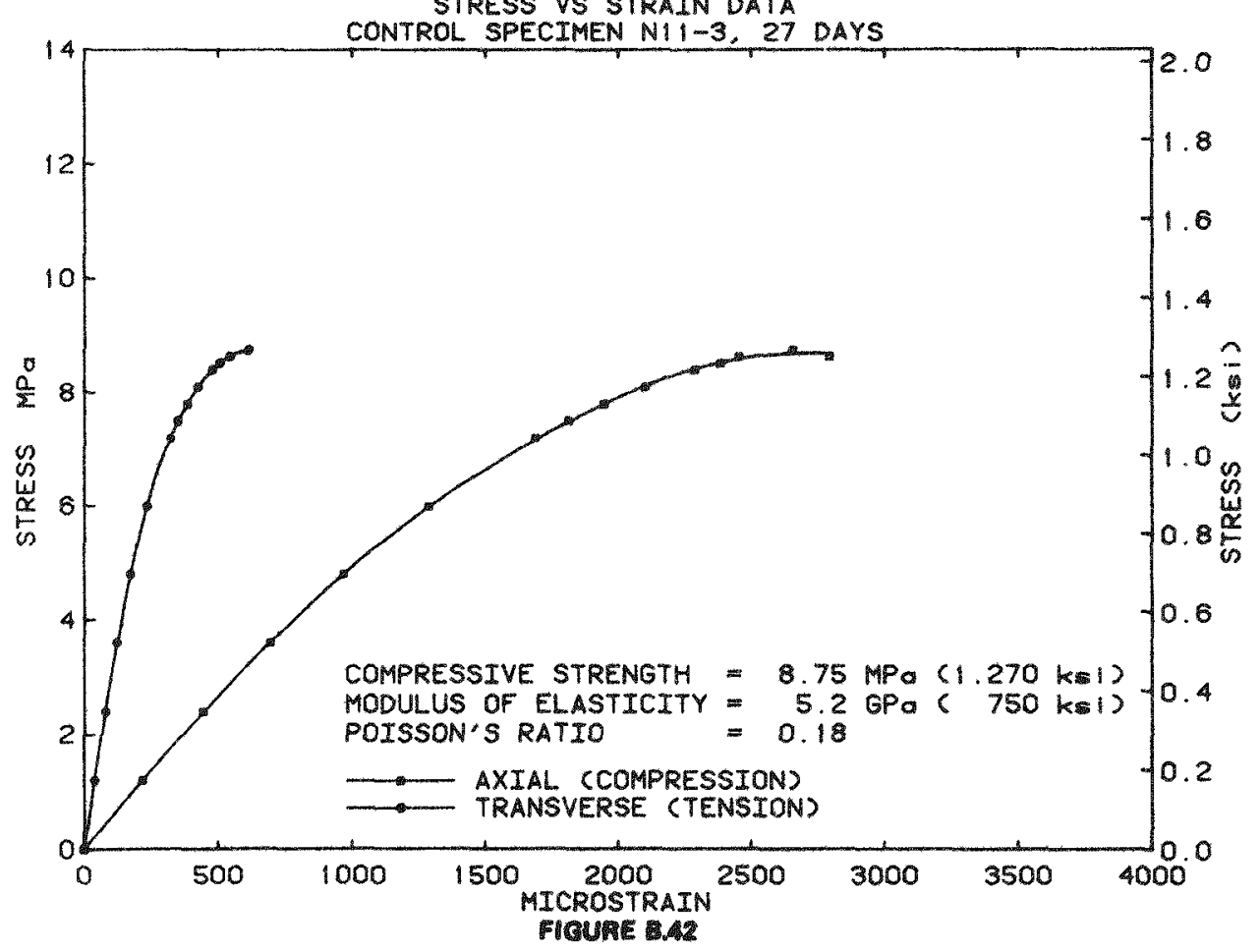




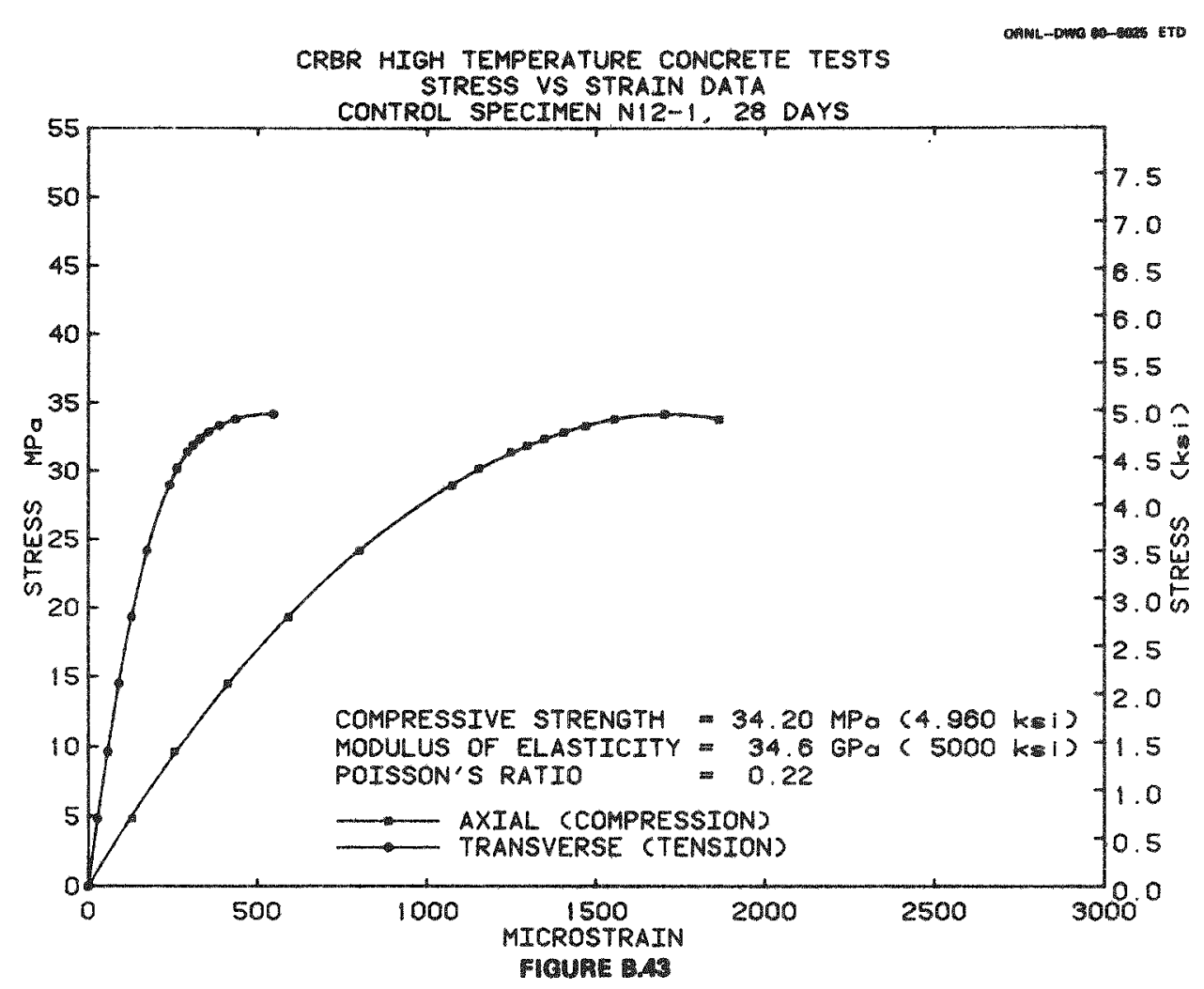

CRBR HTGH TEMPERATURE CONCRETE TESTS

STRESS VS STRAIN DATA

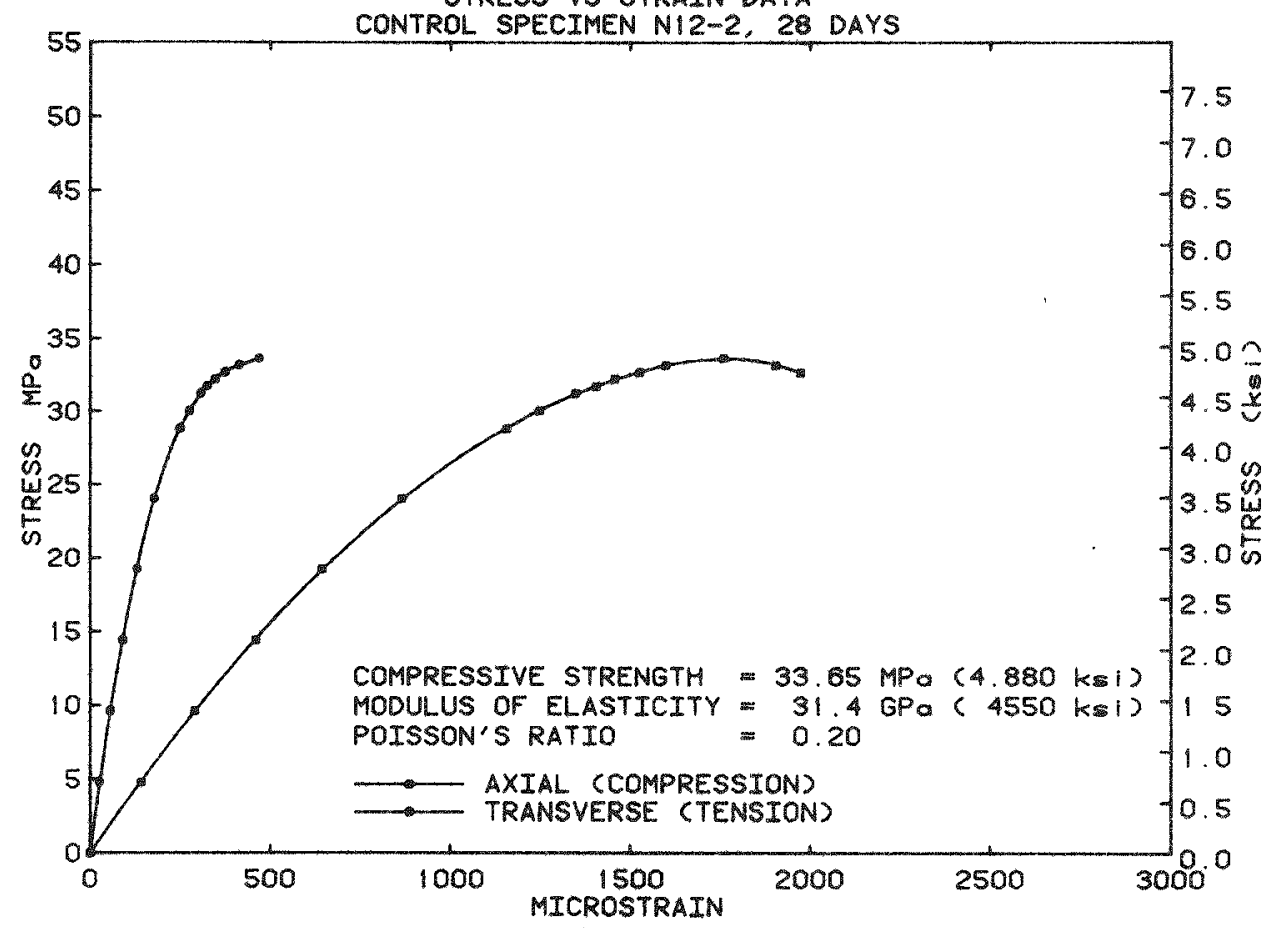

FIOURE BA 
CRBR HIGH TEMPERATURE CONCRETE TESTS

15 STRESS VS STRAIN DATA

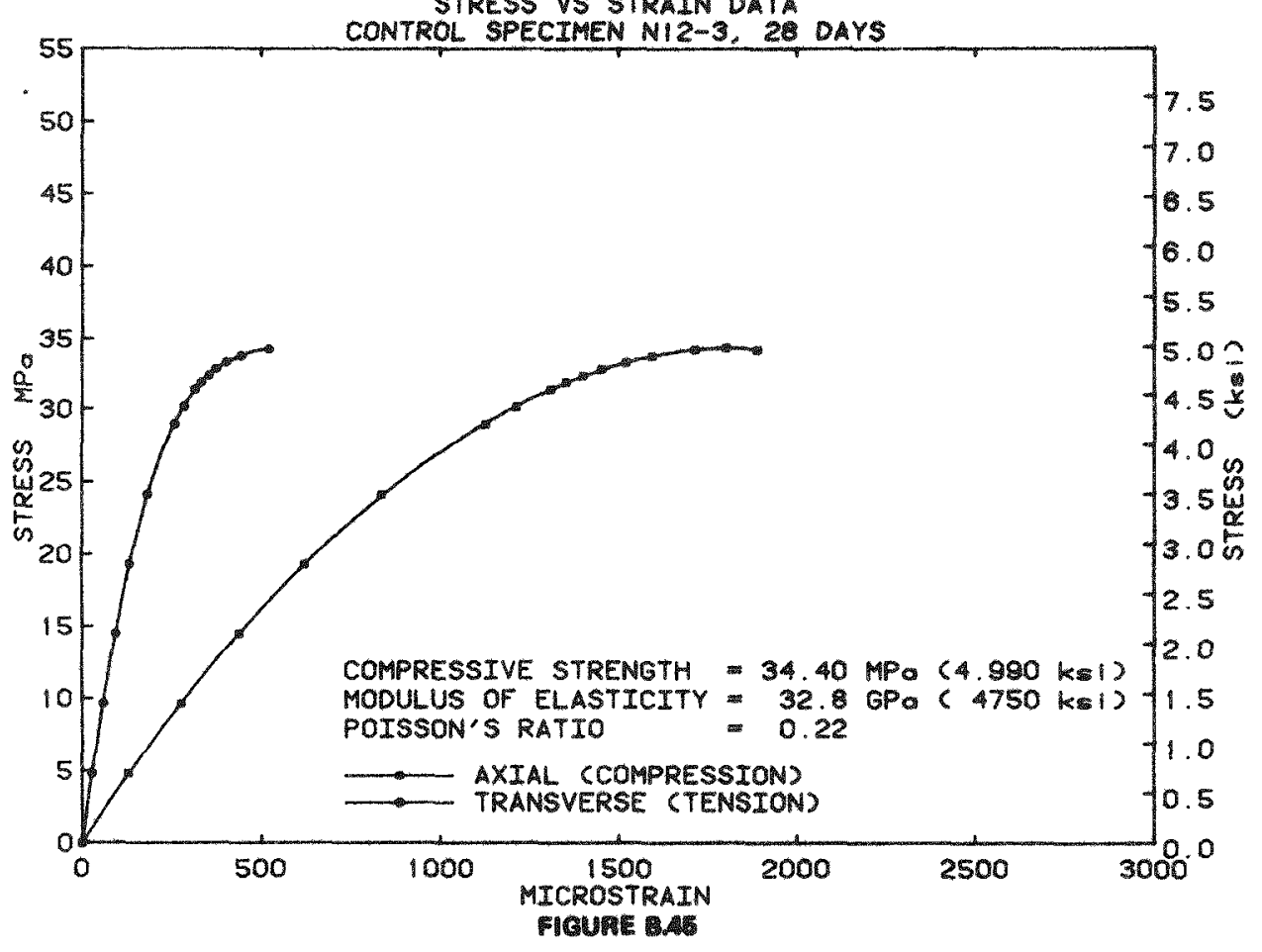

CRBR HIGH TEMPERATURE CONCRETE TESTS

STRESS VS STRAIN DATA

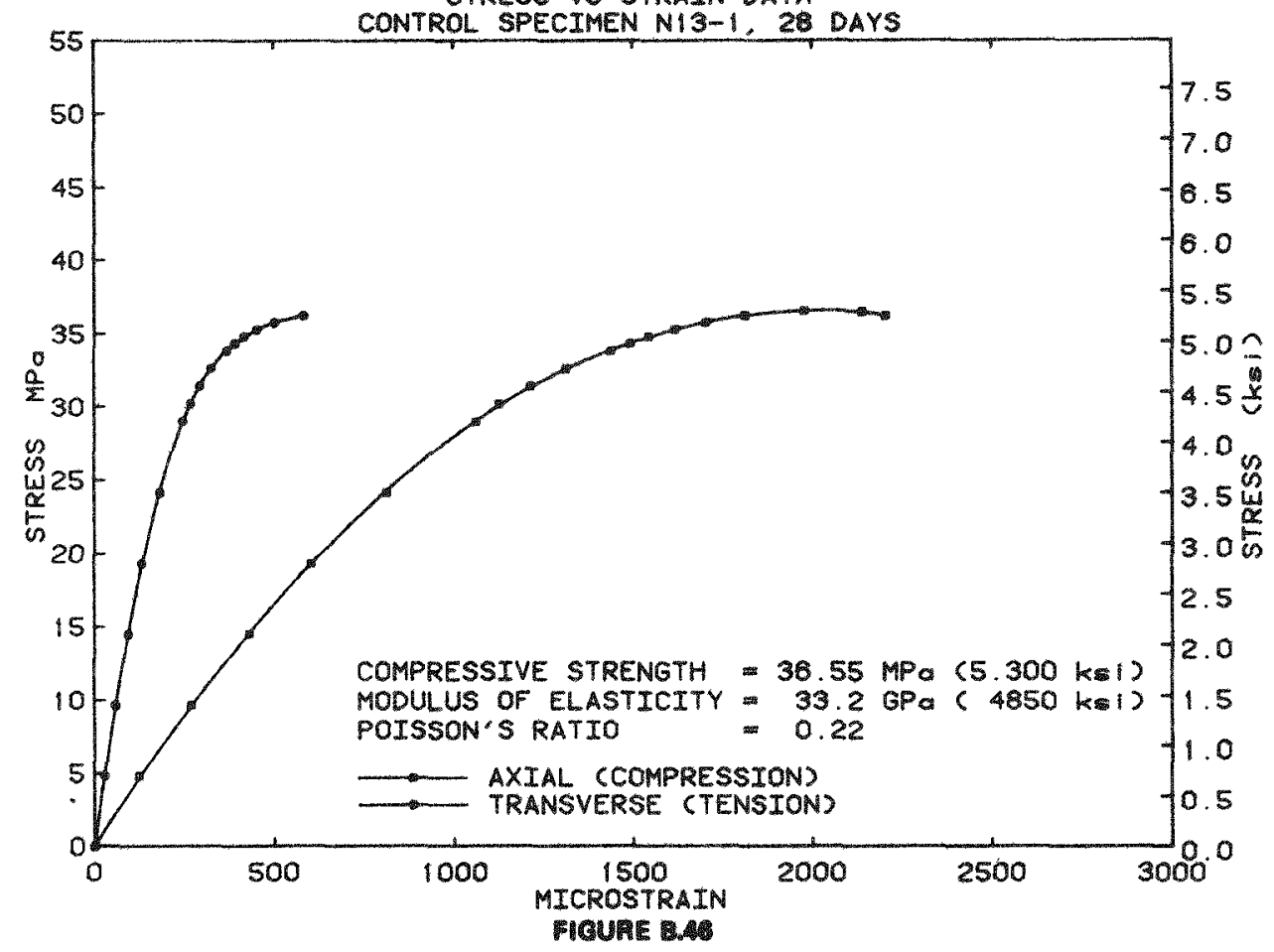




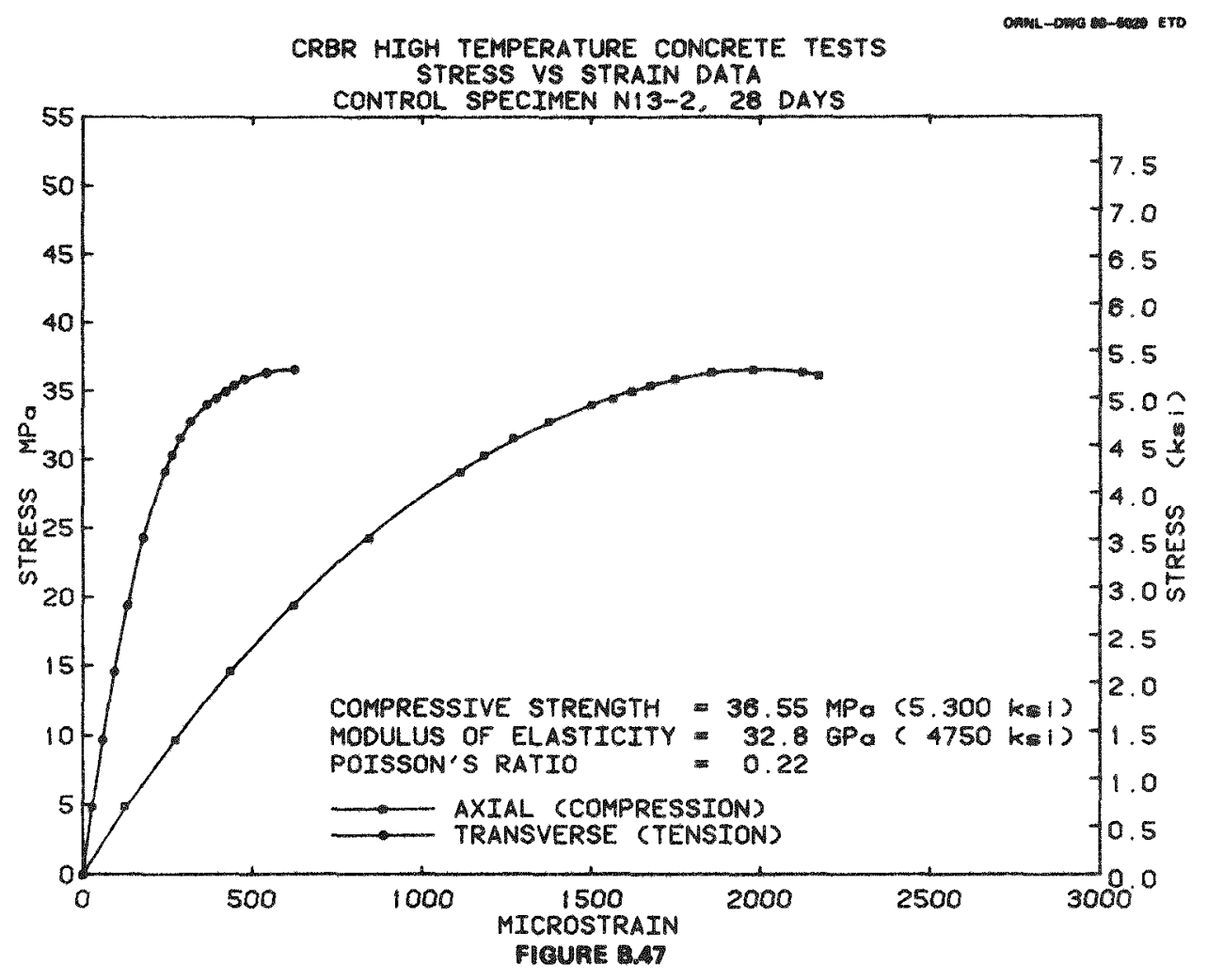

ดศดล -

CRBR HIGH TEMPERATURE CONCRETE TESTS

STRESS VS STRAIN DATA

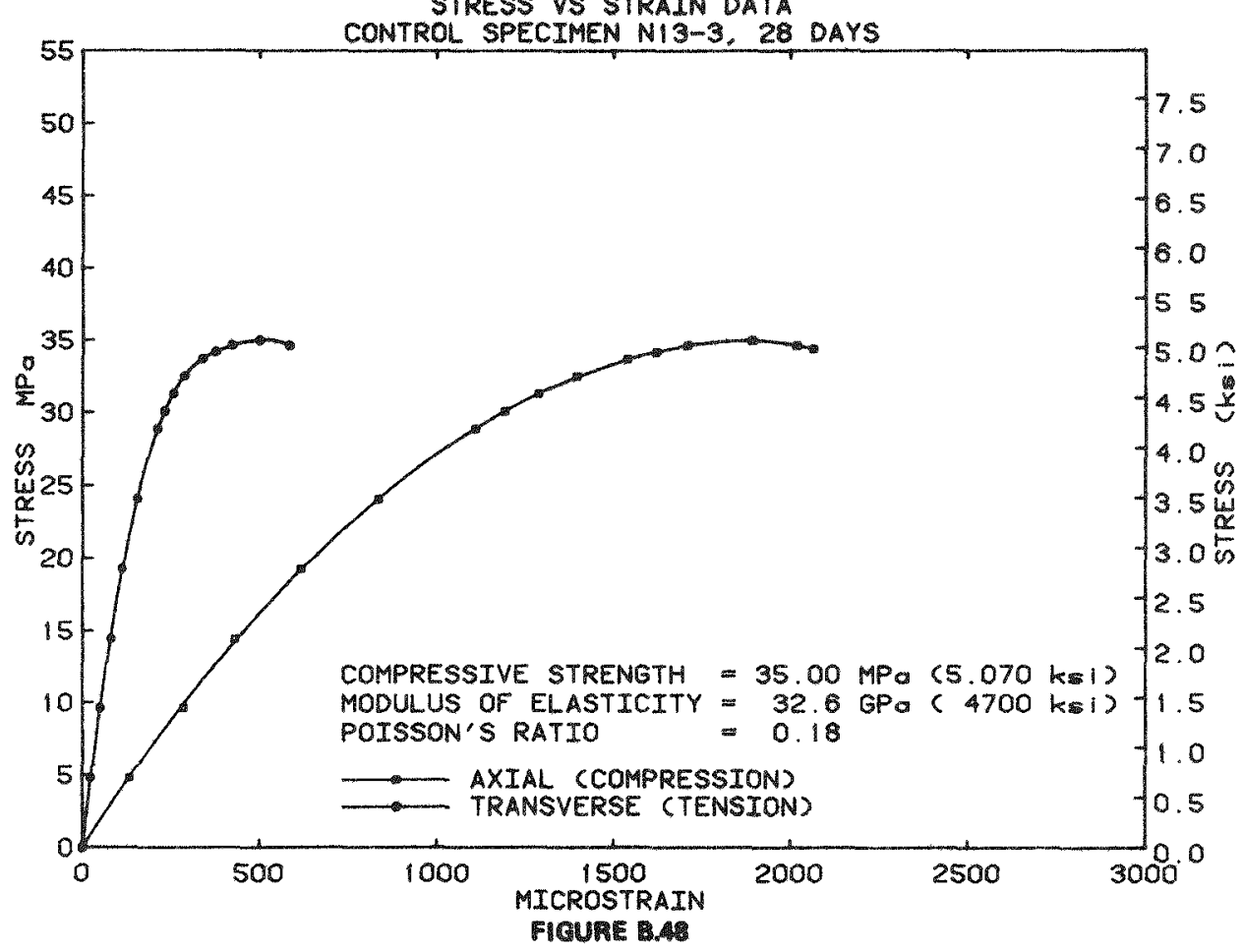



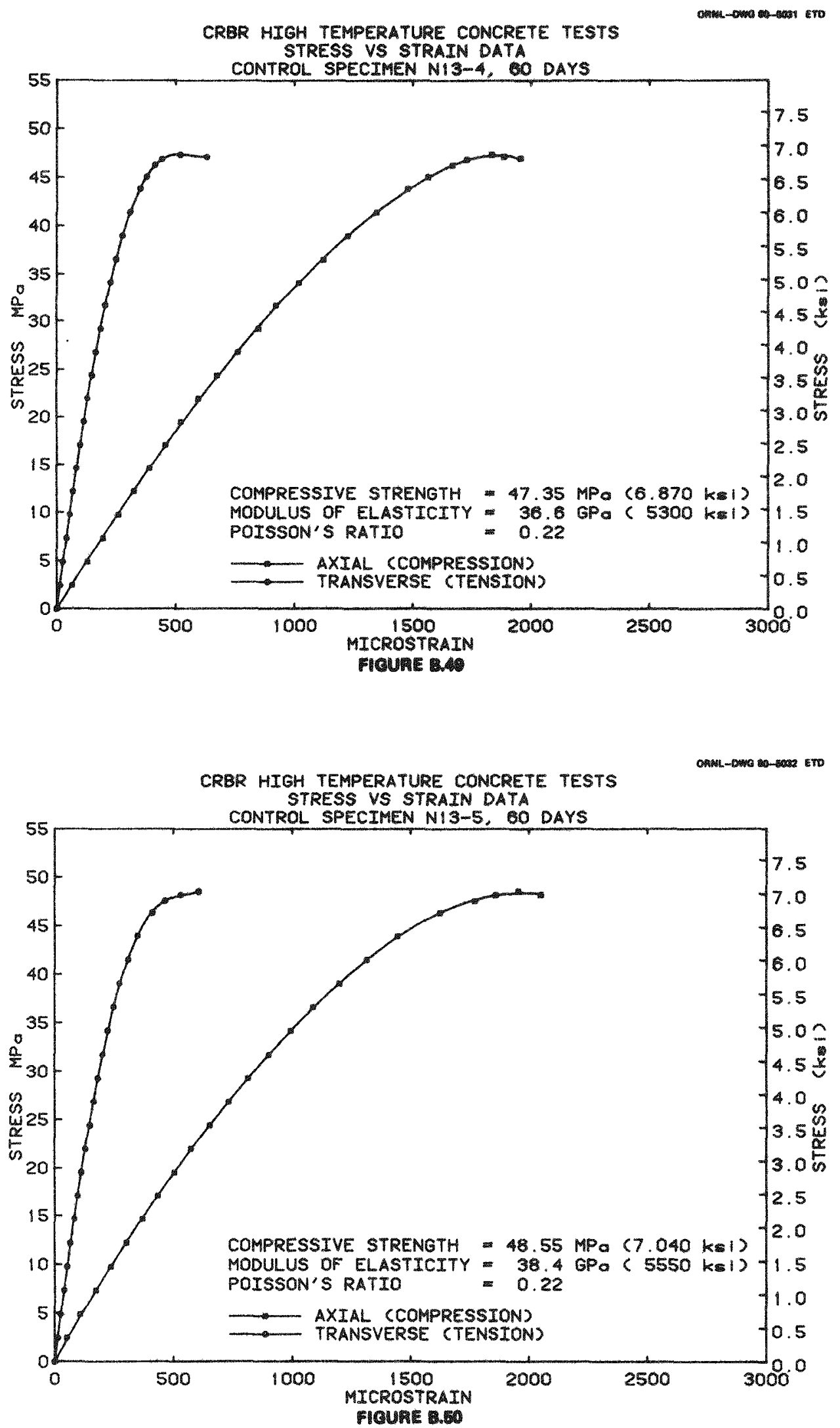


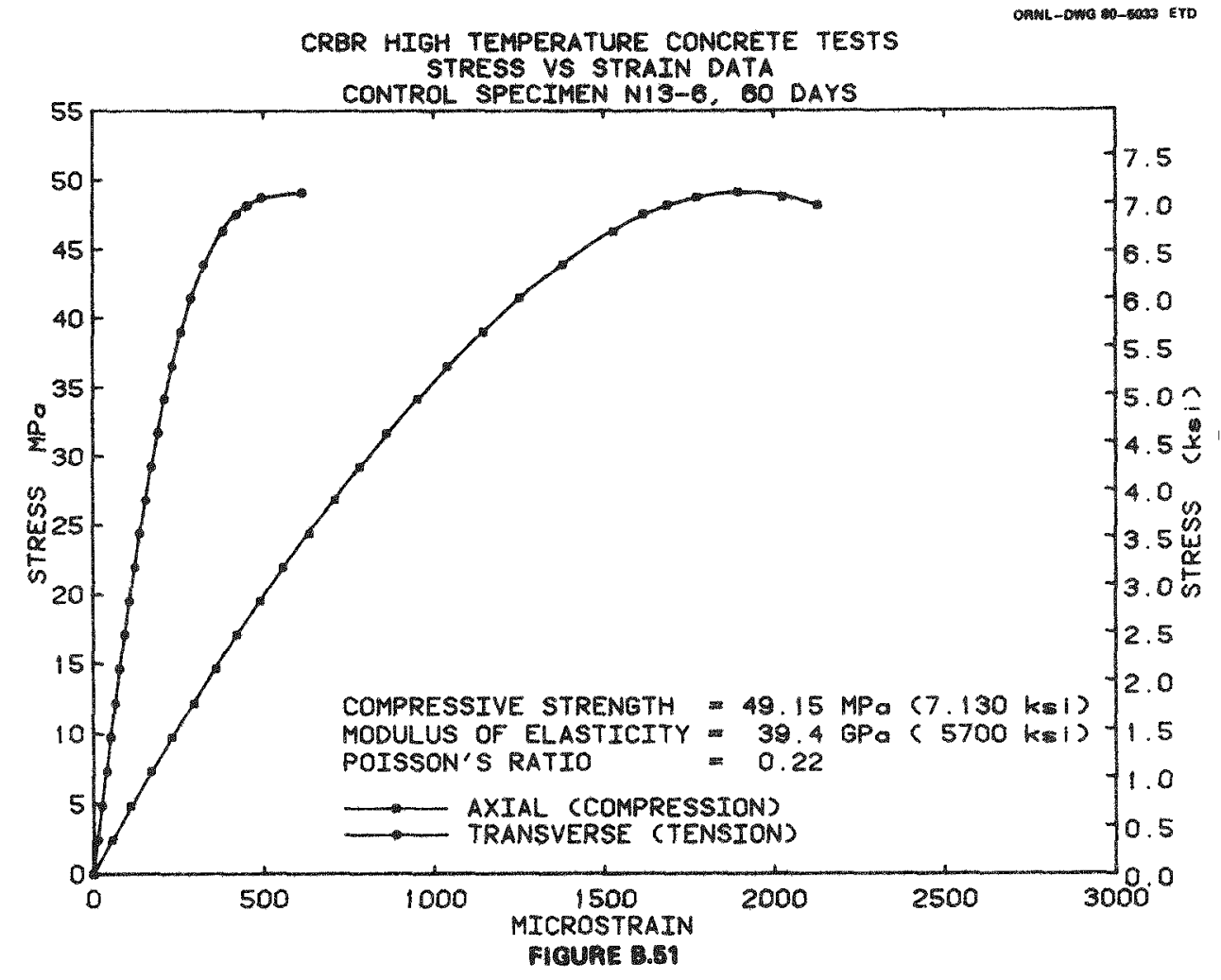

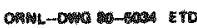

CRBR HIGH TEMPERATURE CONCRETE TESTS STRESS VS STRATN DATA

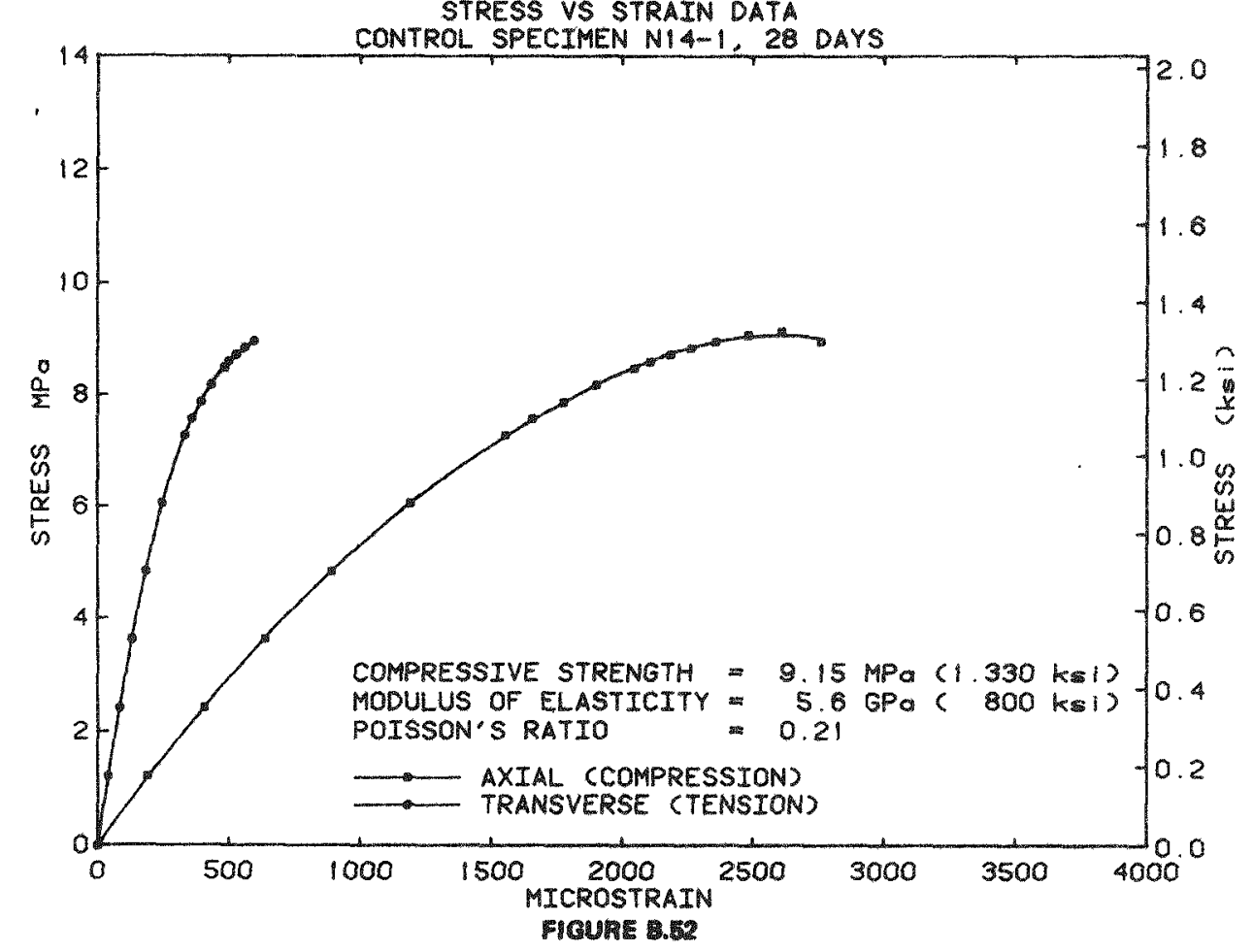




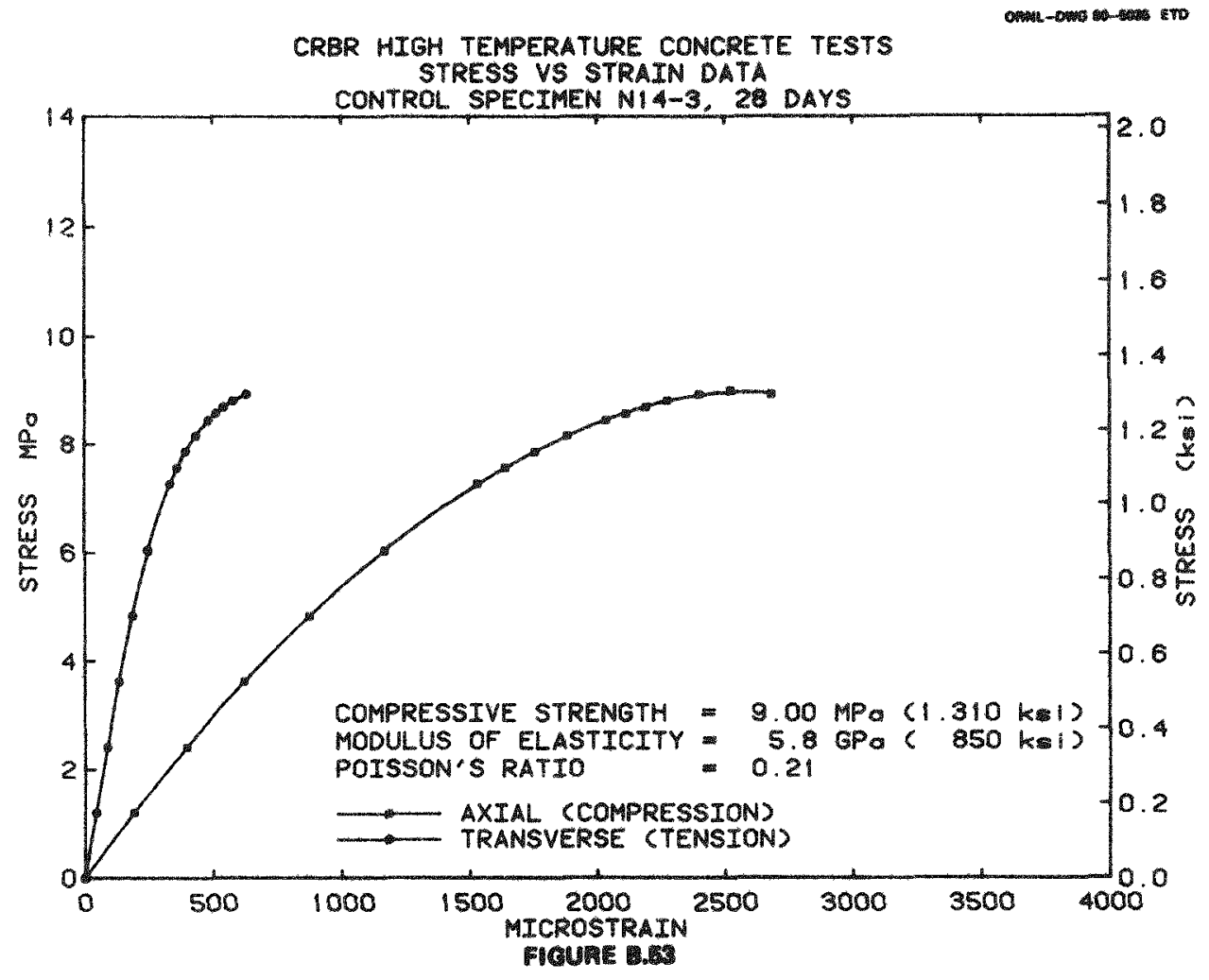

OANL- ETR

CRBR HIGH TEMPERATURE CONCRETE TESTS

STRESS VS STRAIN DATA

CONTROL SPECIMEN N14-4, 28 DAYS

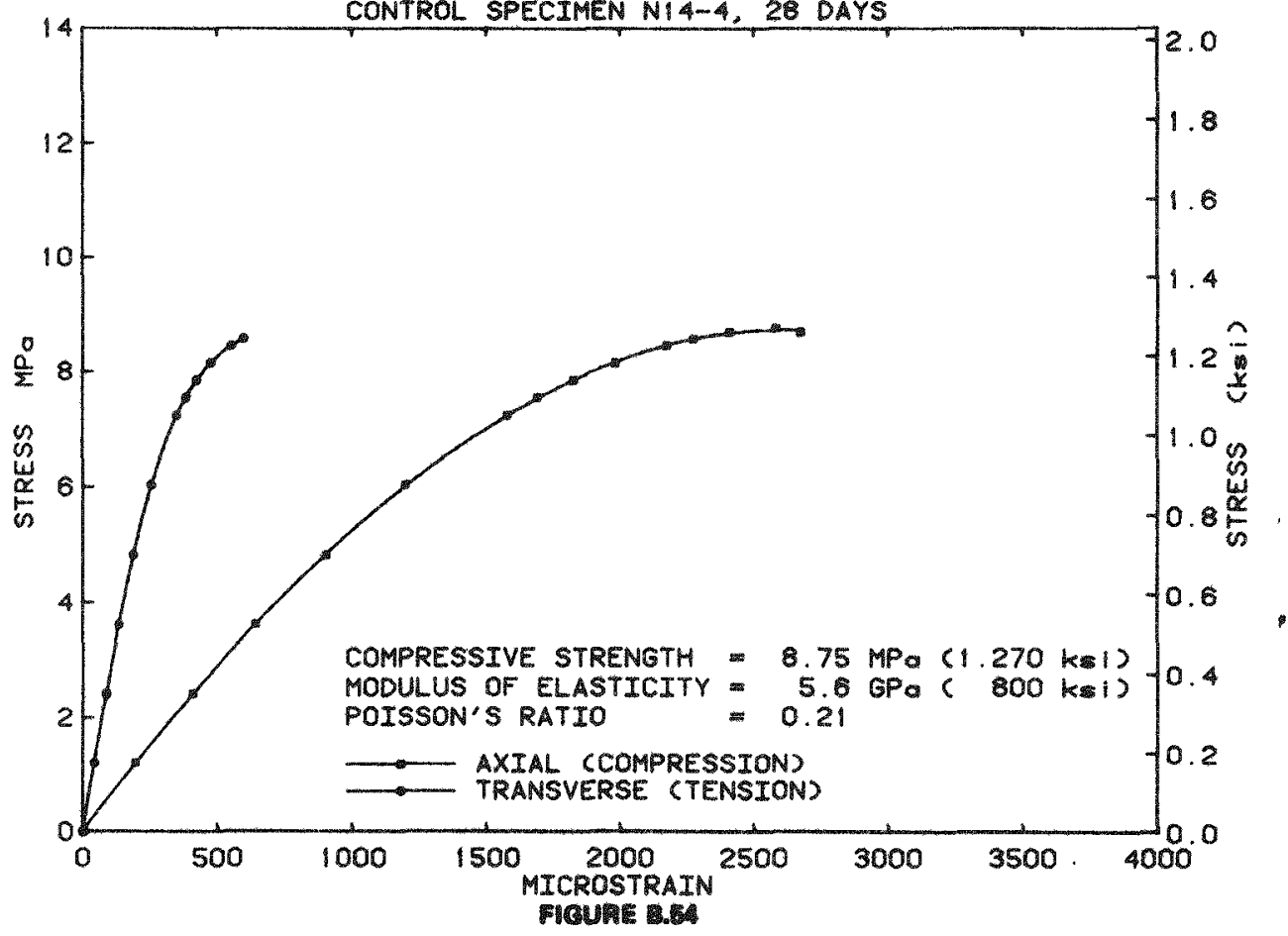




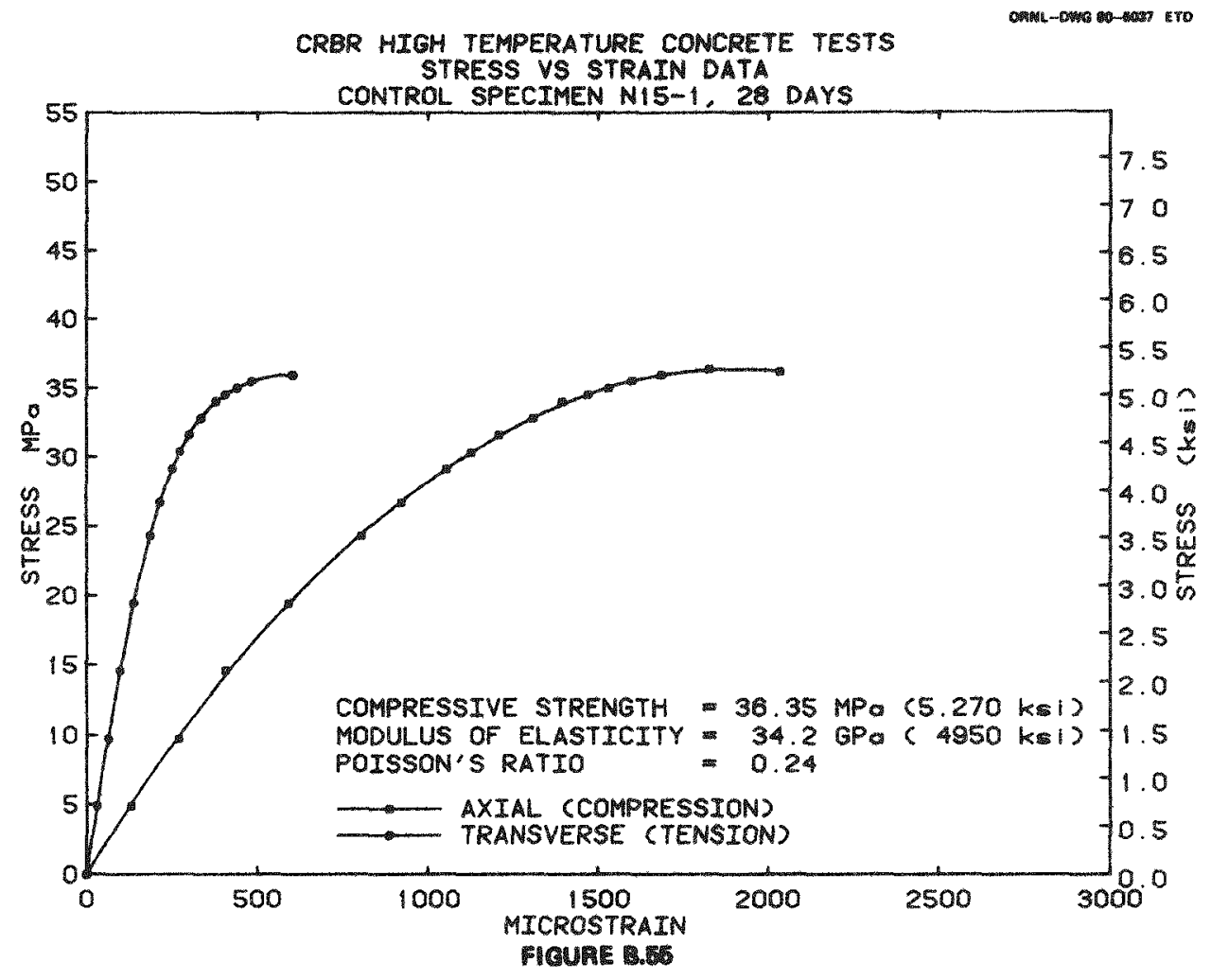

CRBR HIGH TEMPERATURE CONCRETE TESTS

OANE-D ETO

STRESS VS STRAIN DATA

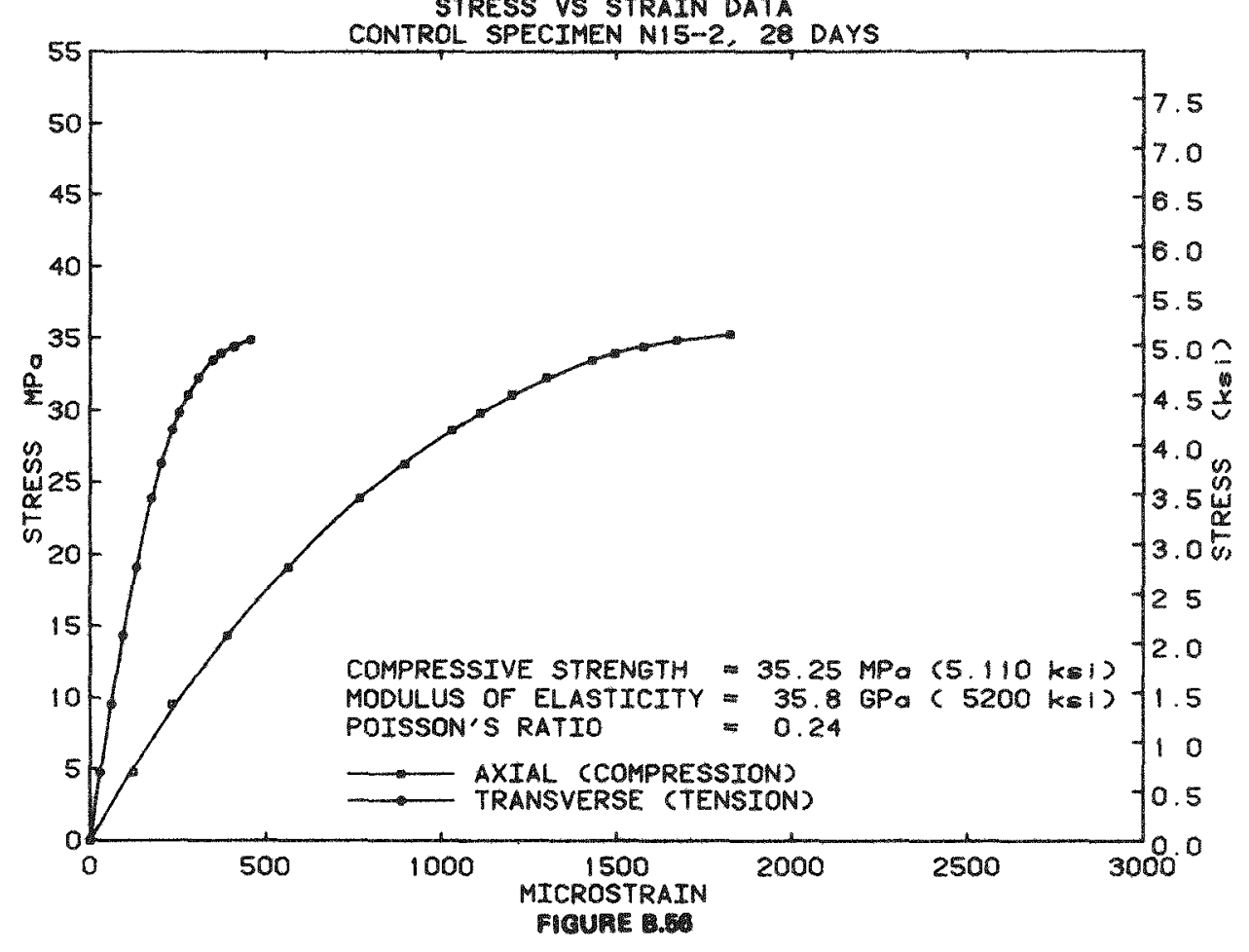




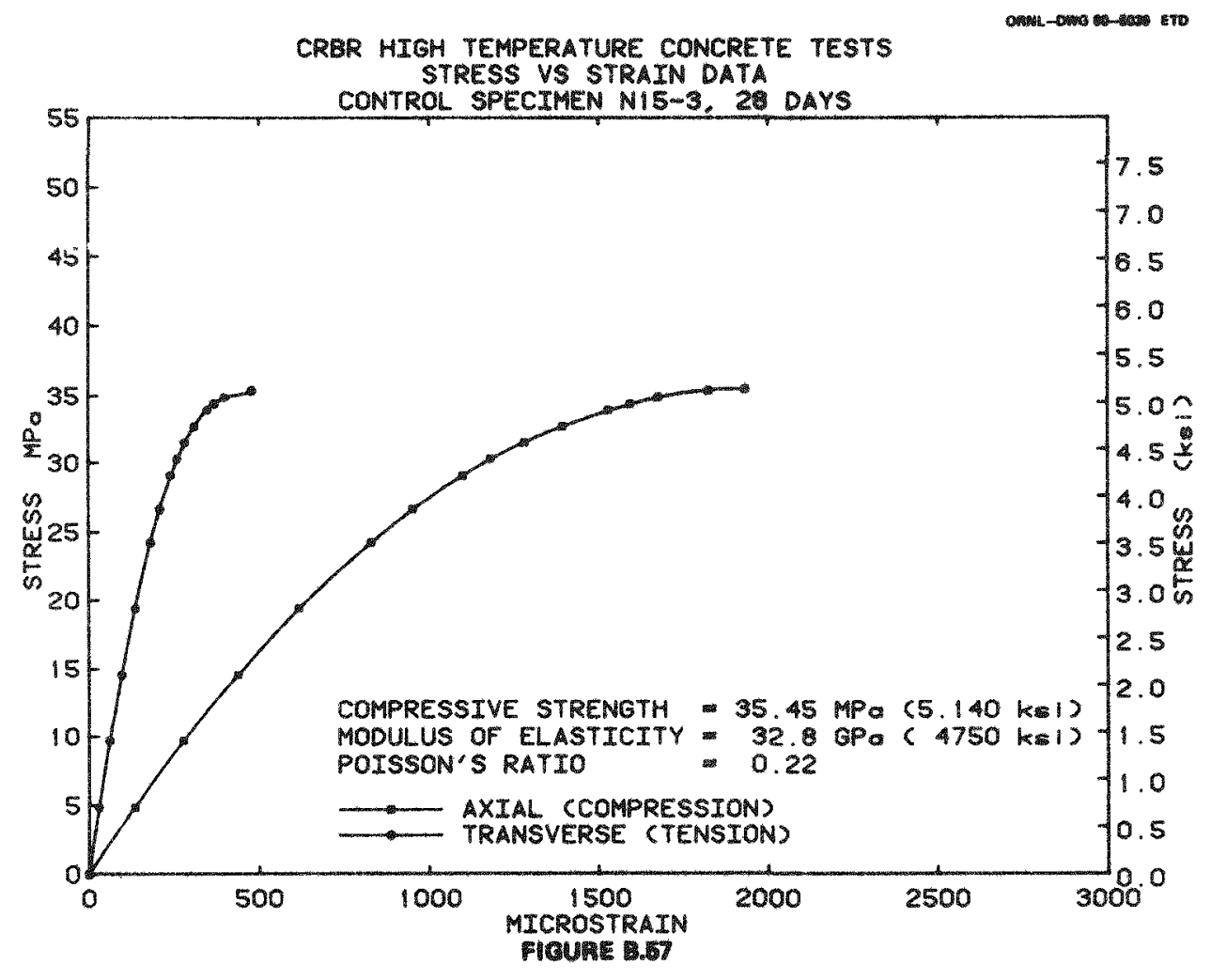

CRBR HIGH TEMPERATURE CONCRETE TESTS

Oram-10 STRESS VS STRAIN DATA

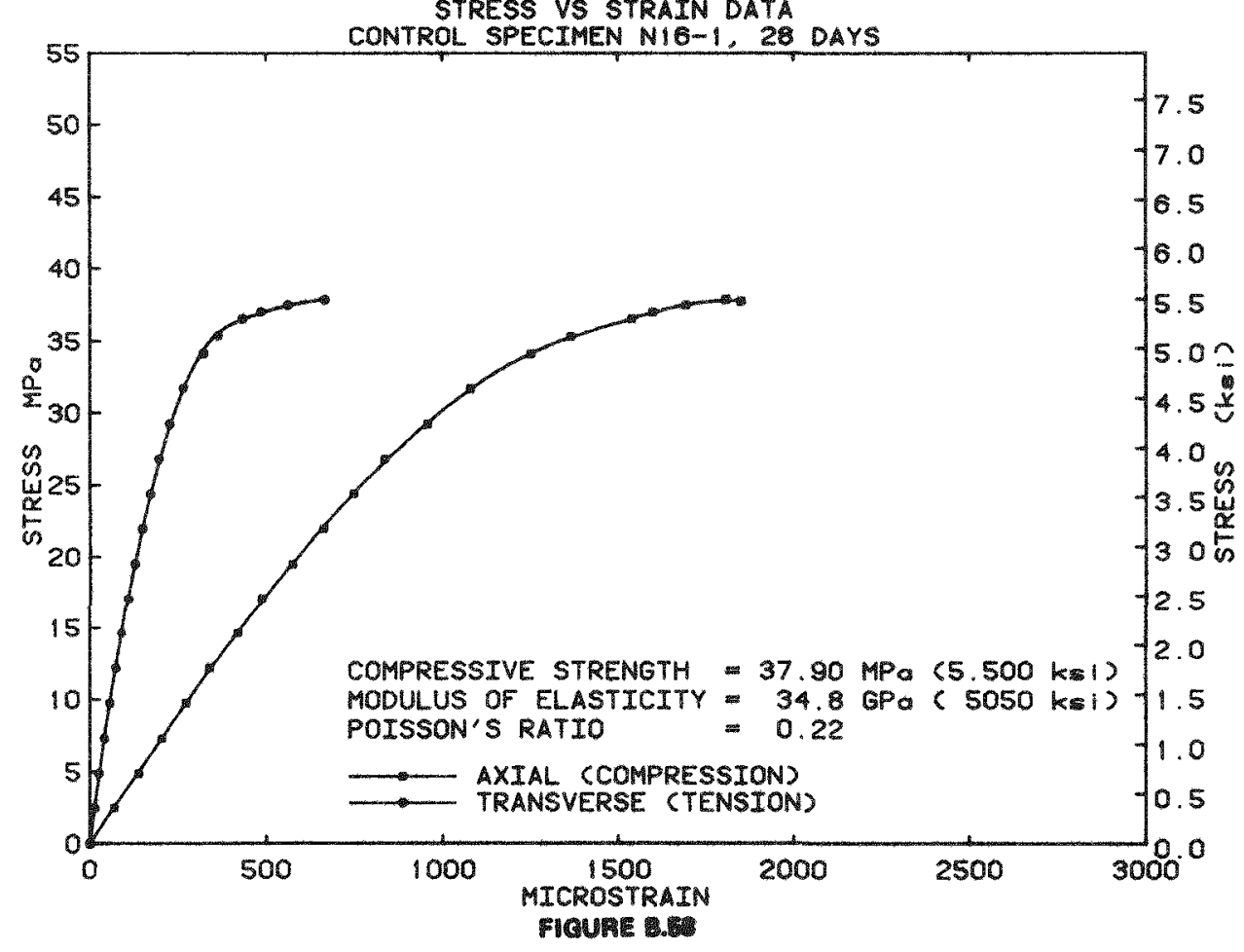


CRBR HIGH TEMPERATURE CONCRETE TESTS

STRESS VS STRATN DATA

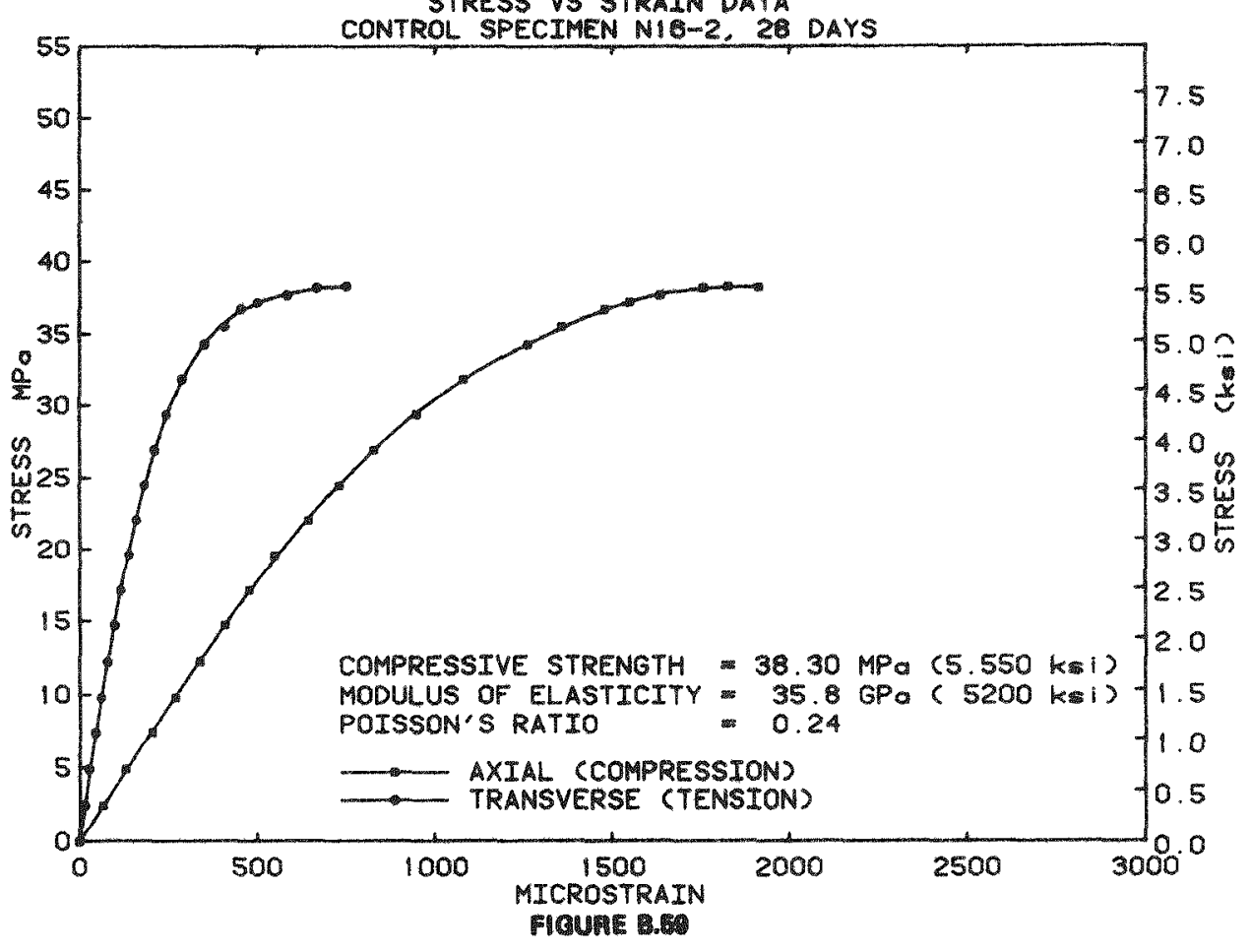

CRBR HIGH TEMPERATURE CONCRETE TESTS

STRESS VS STRAIN DATA

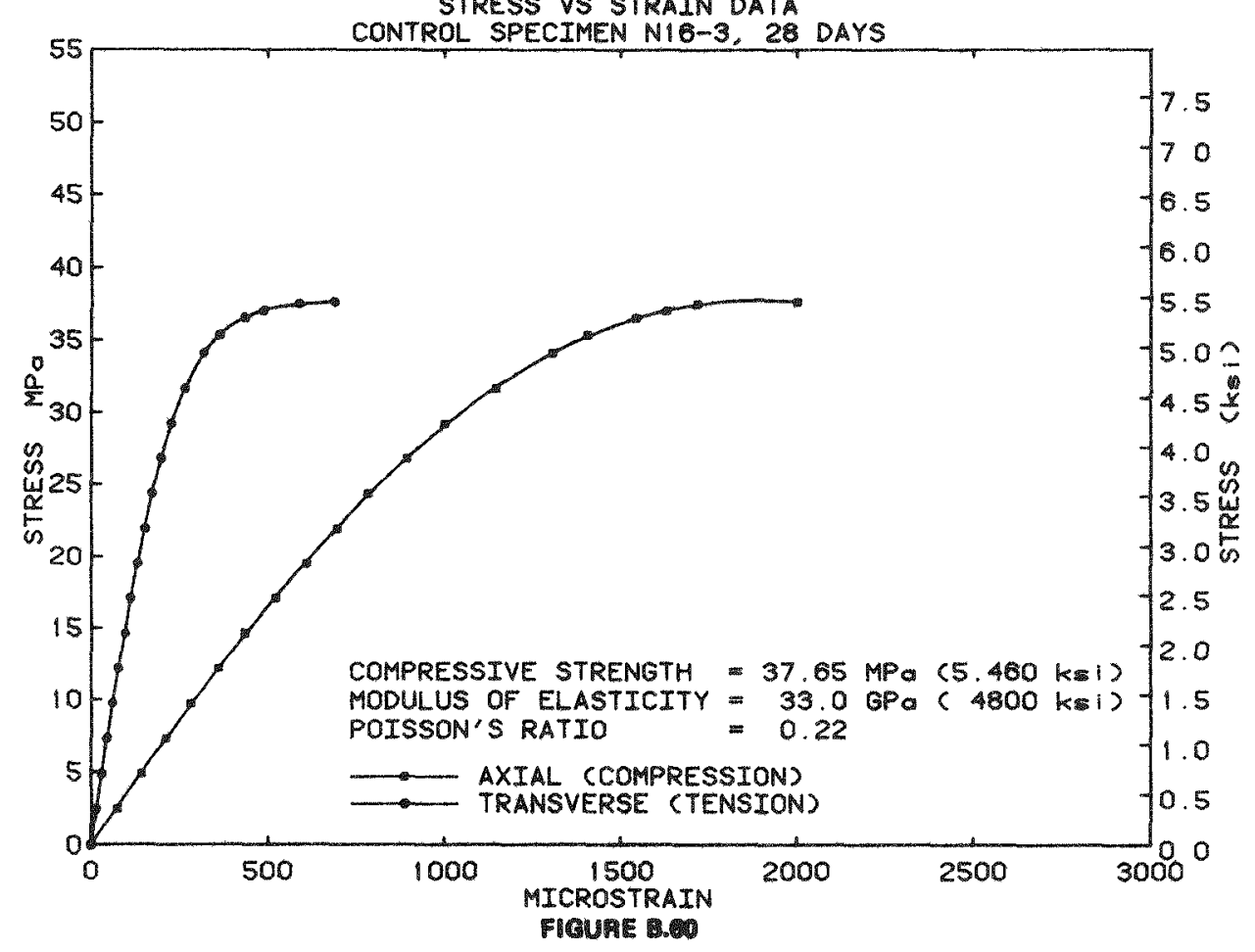


CRBR HIGH TEMPERATURE CONCRETE TESTS

STRESS VS STRAIN DATA

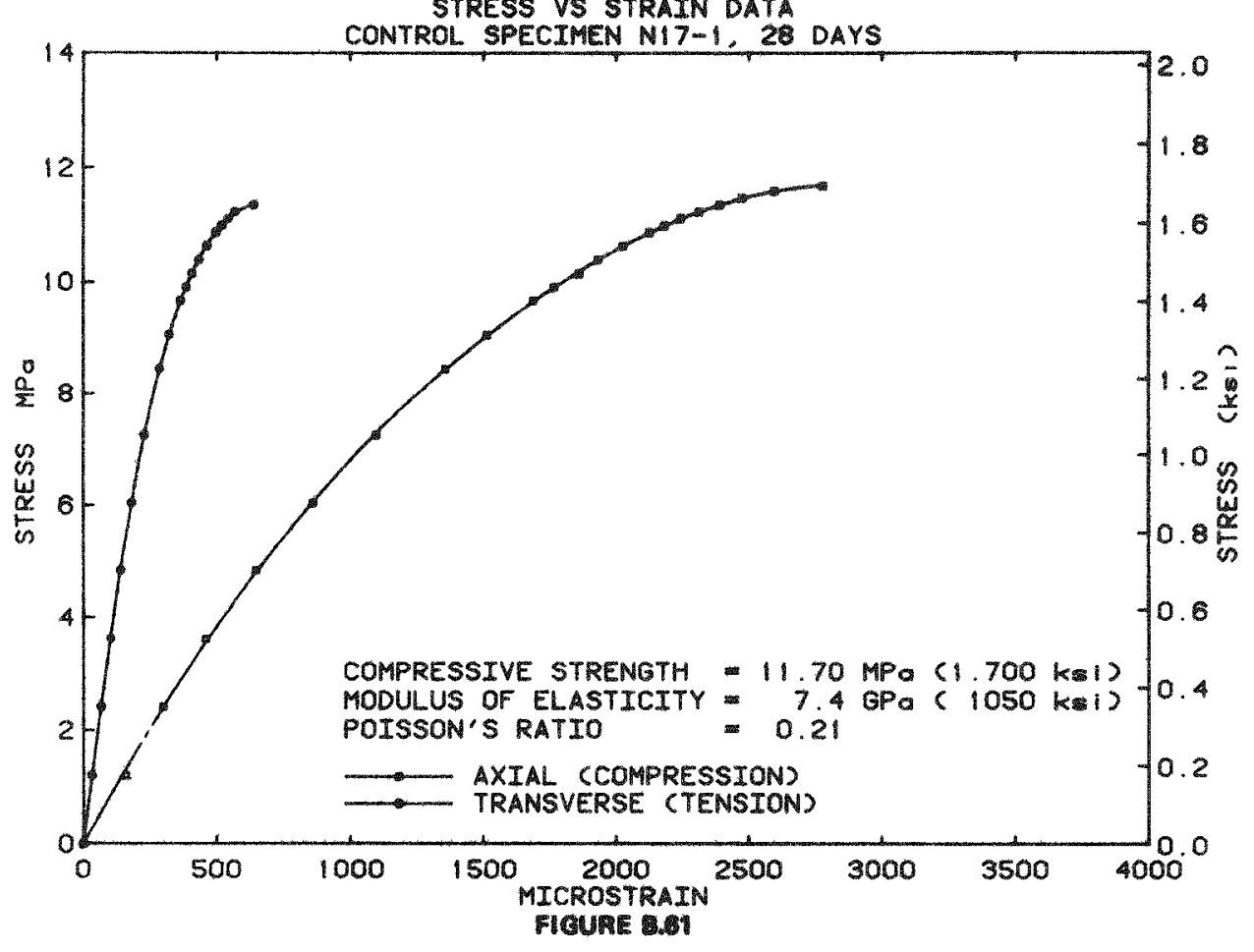

2) ETO

CRBR HIGH TEMPERATURE CONCRETE TESTS STRESS VS STRAIN DATA

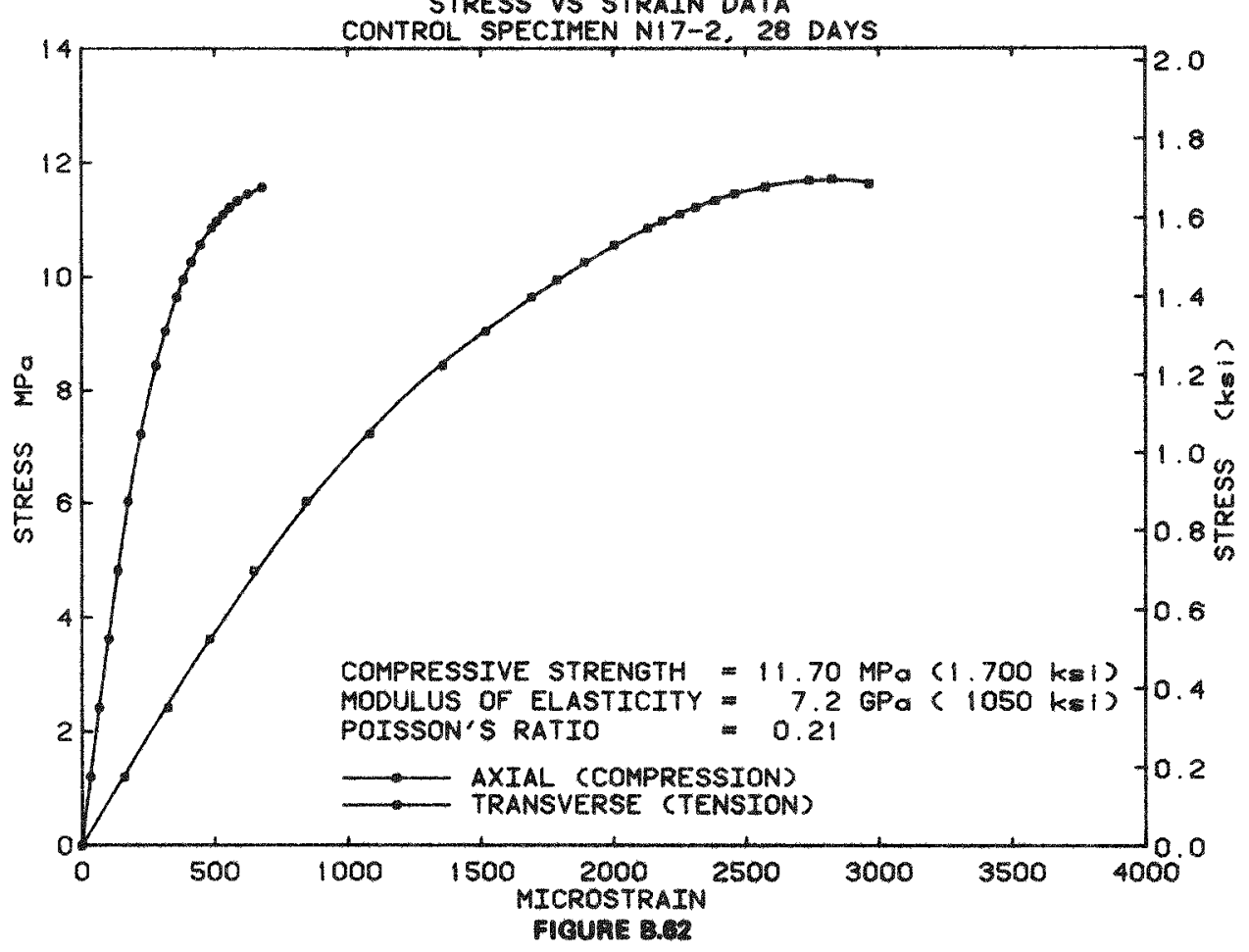




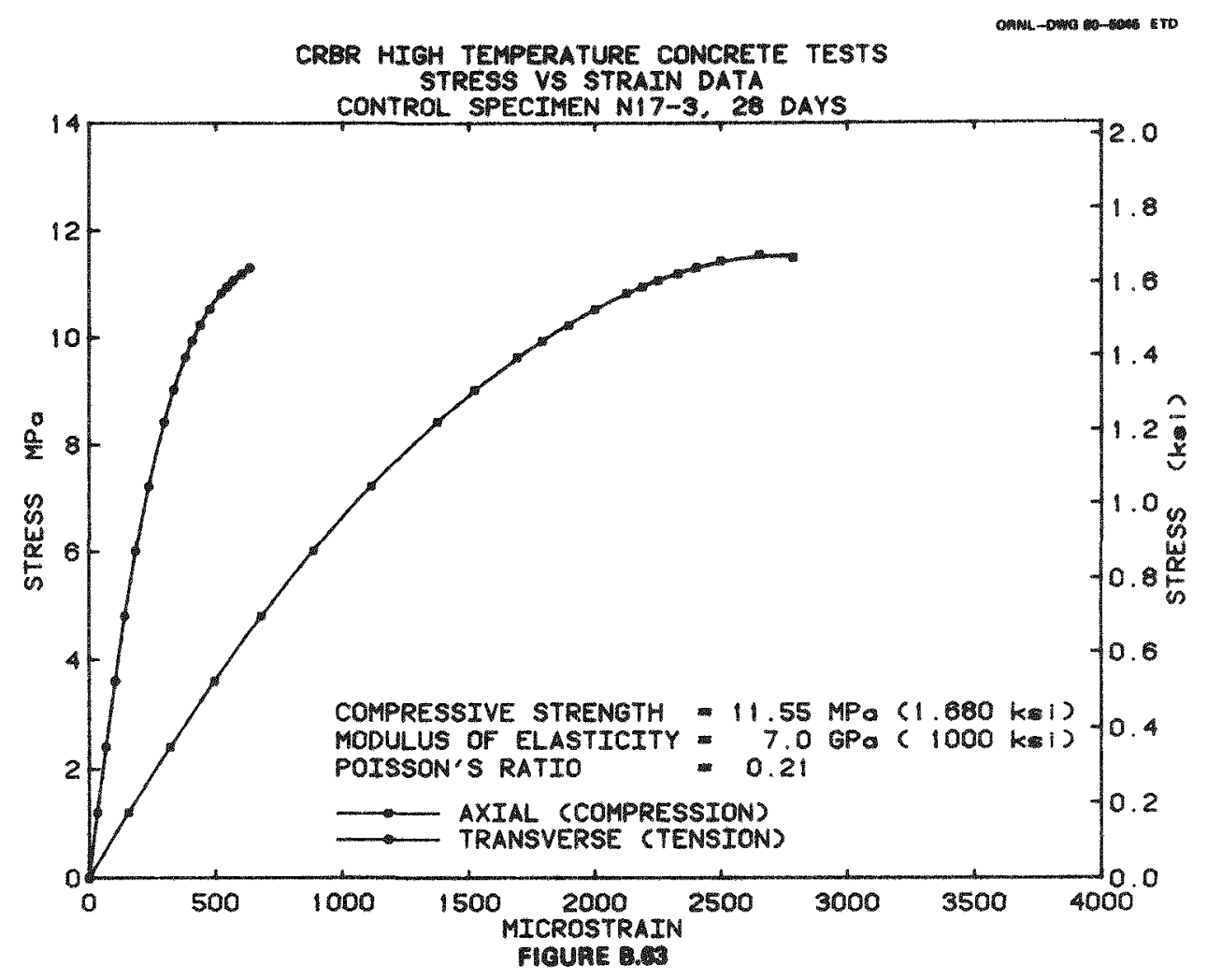

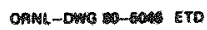

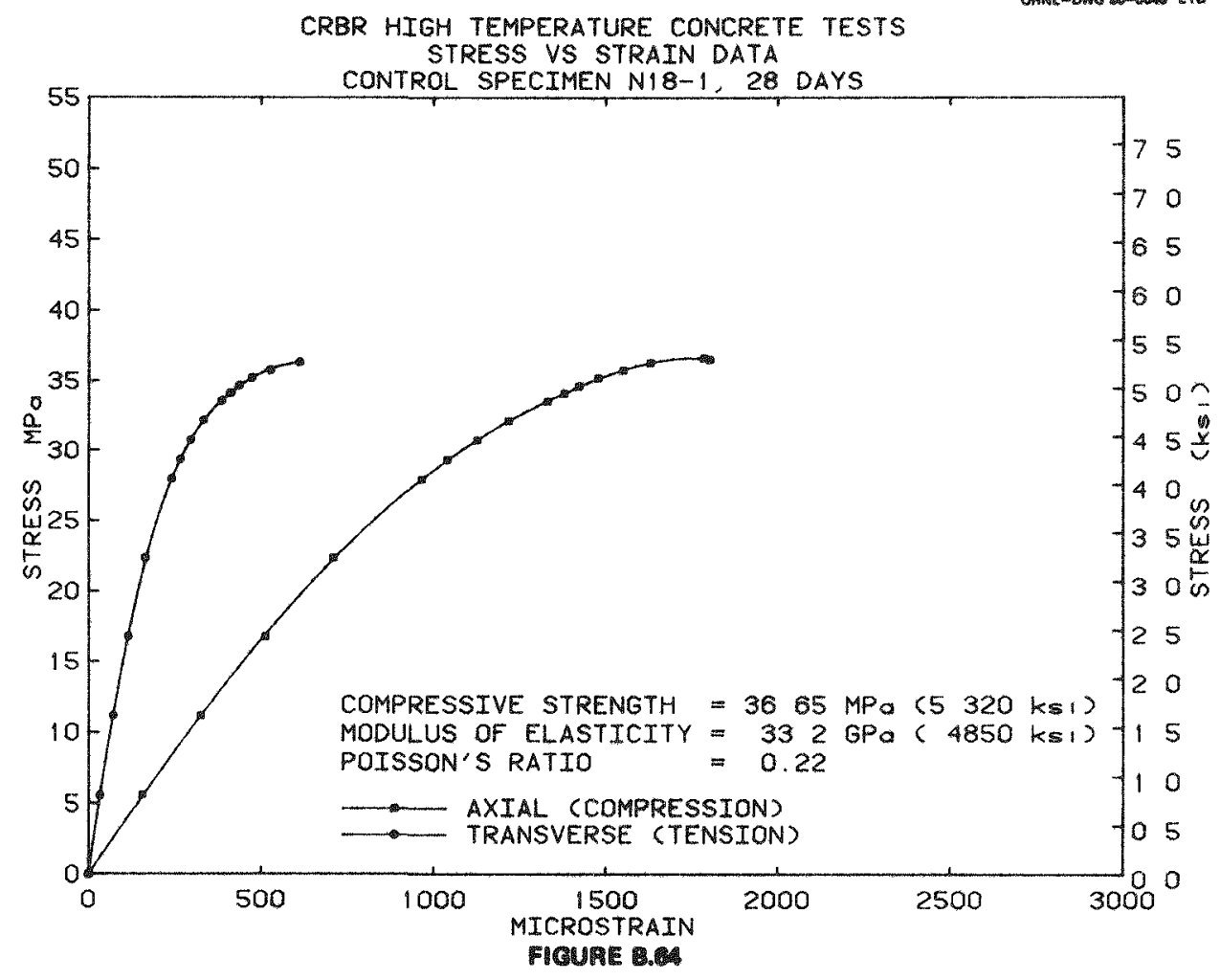




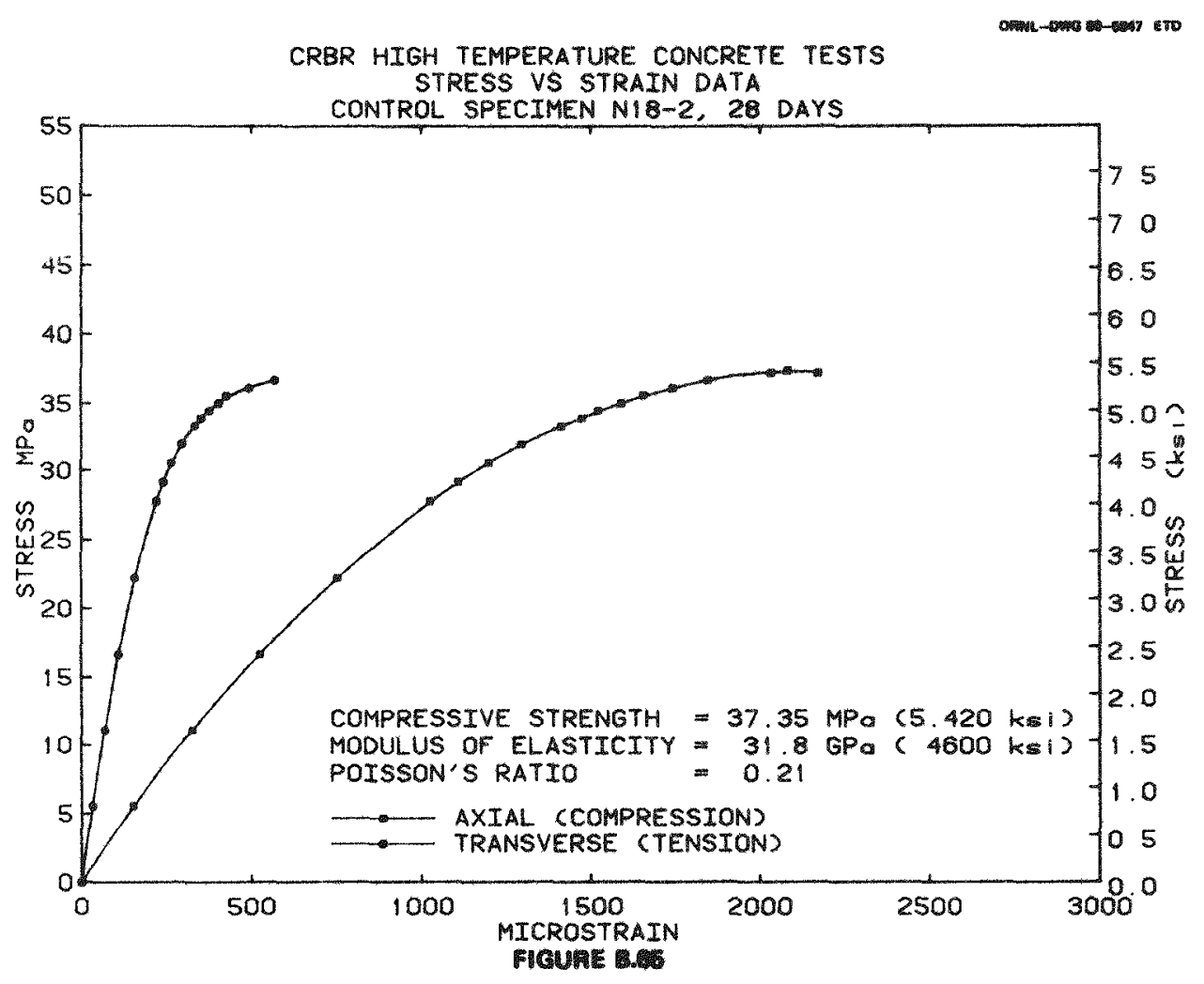

CRBR HIGH TEMPERATURE CONCRETE TESTS

20athSTRESS VS STRAIN DATA

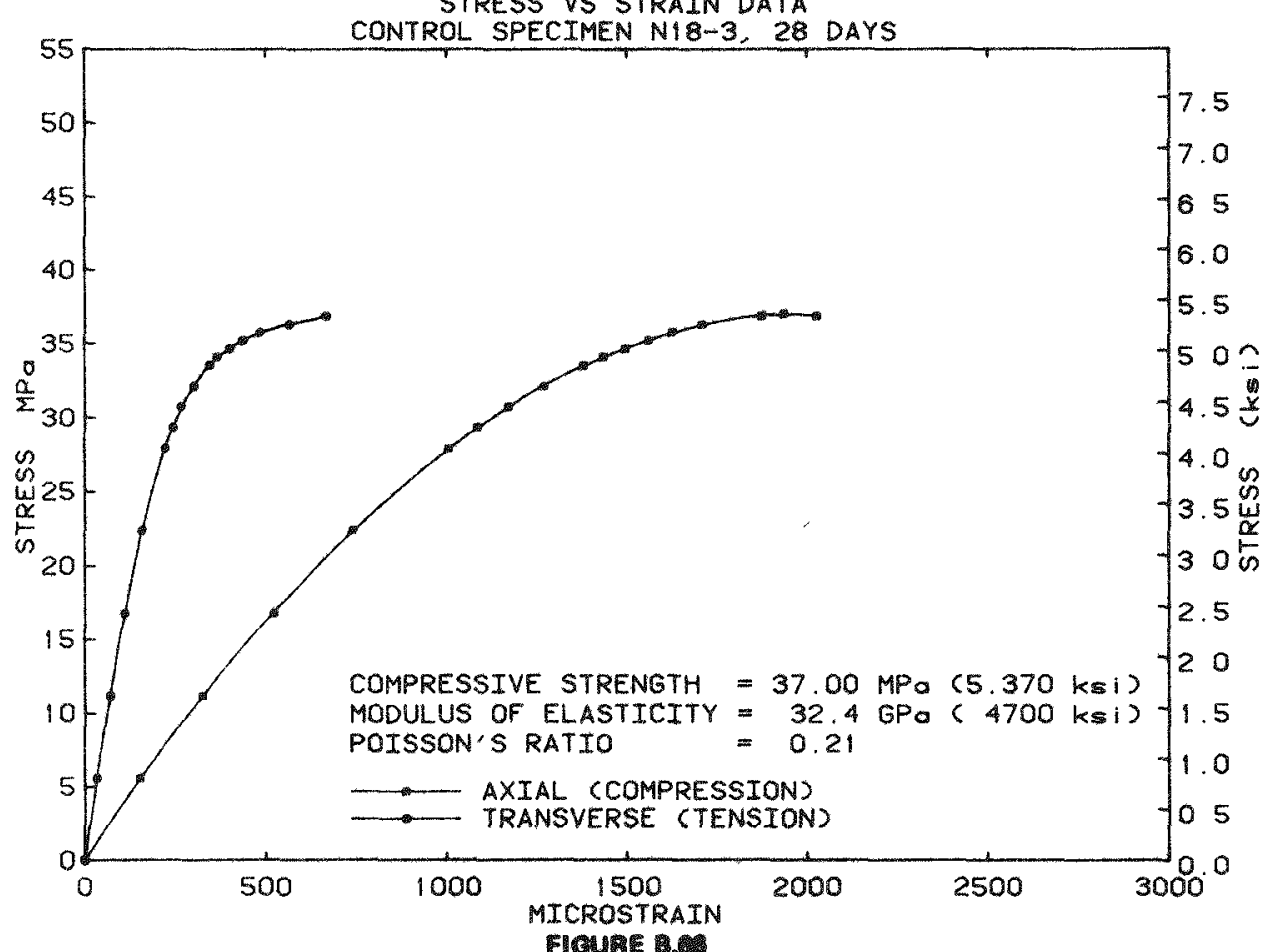




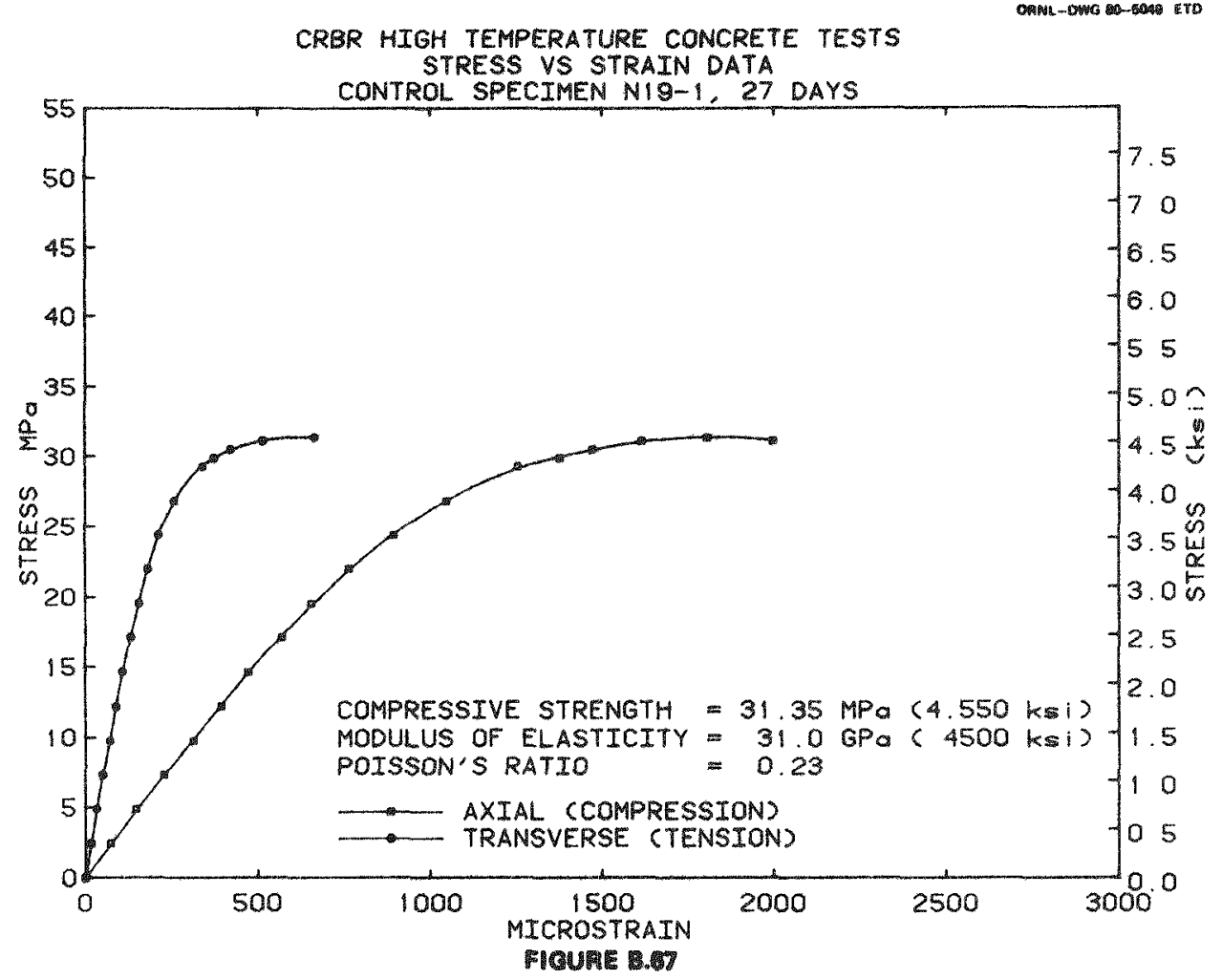

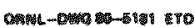

CRBR HIGH TEMPERATURE CONCRETE TESTS STRESS VS STRAIN DATA

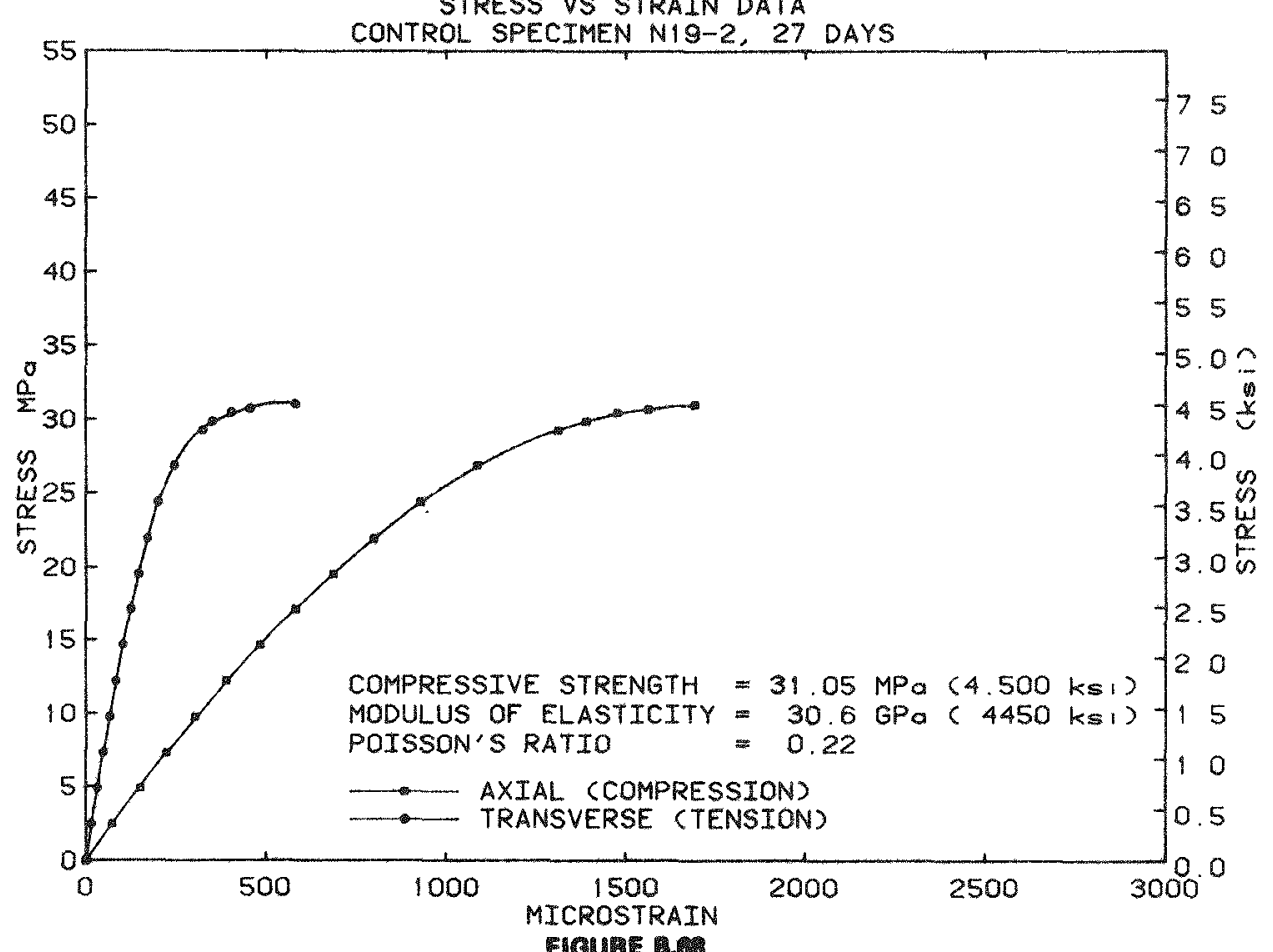



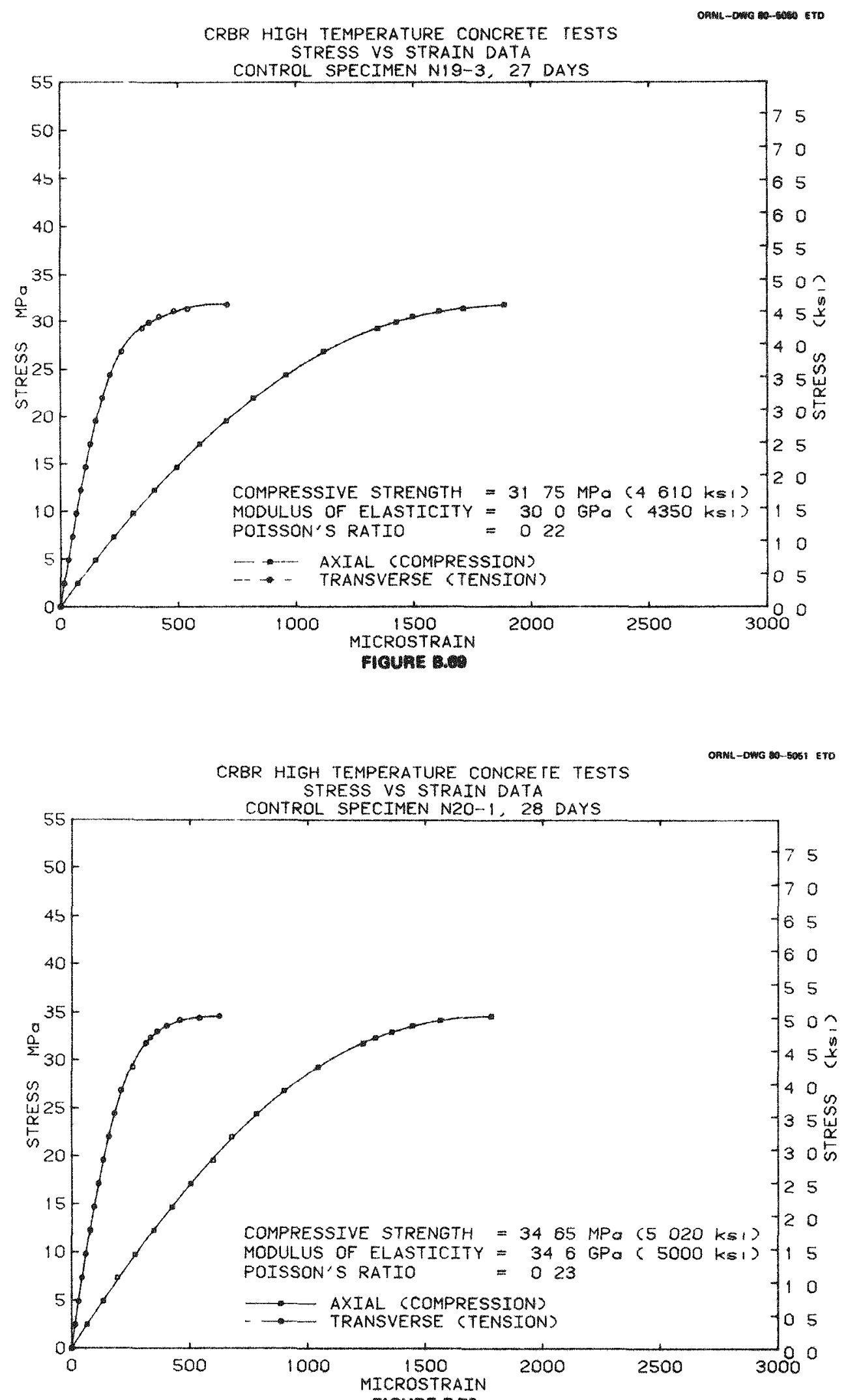
CRBR HIGH TEMPERATURE CONCRETE TESTS

STRESS VS STRAIN DATA

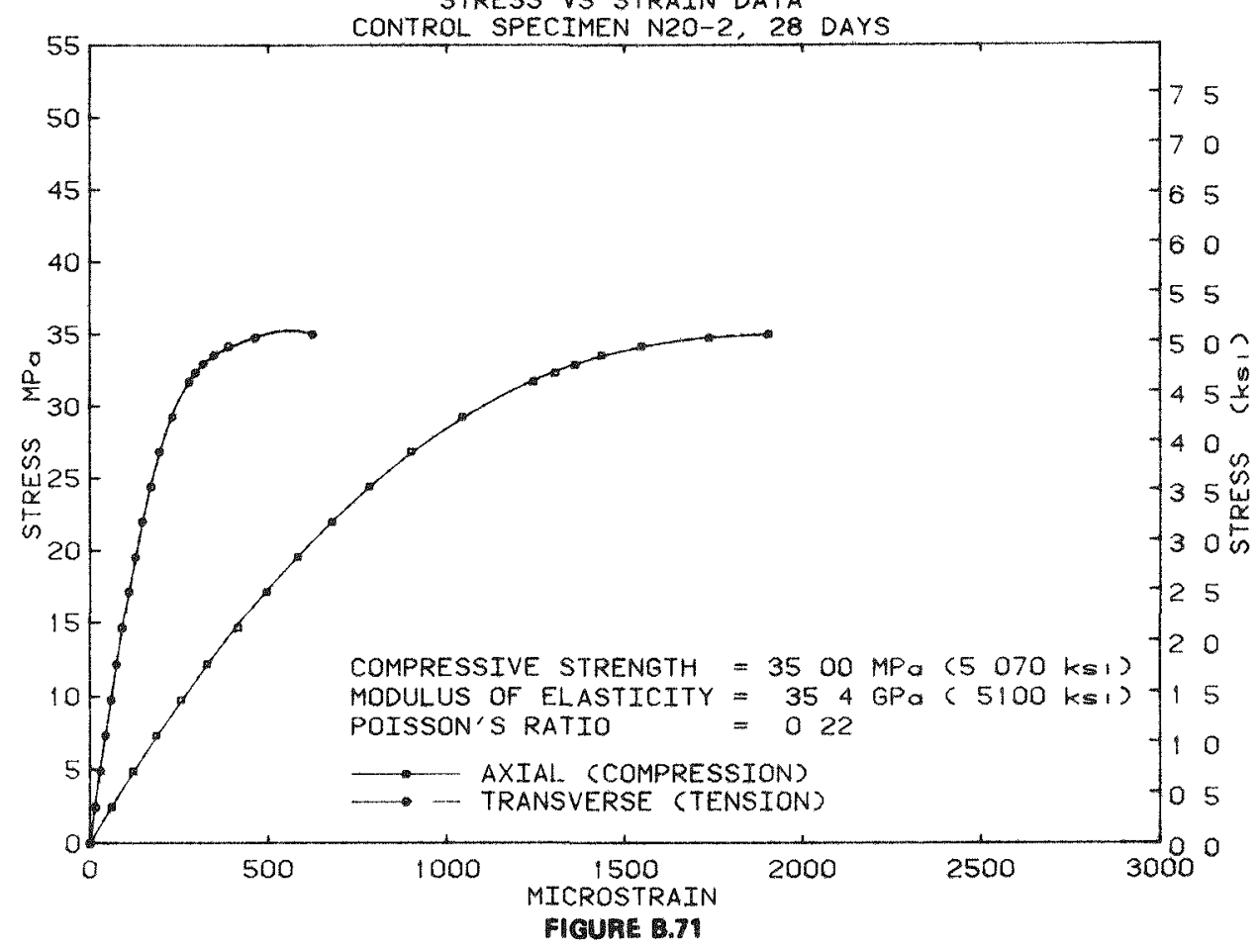

CRBR HIGH TEMPERATURE CONCRETE TESTS

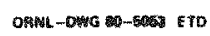

STRESS VS STRAIN DATA

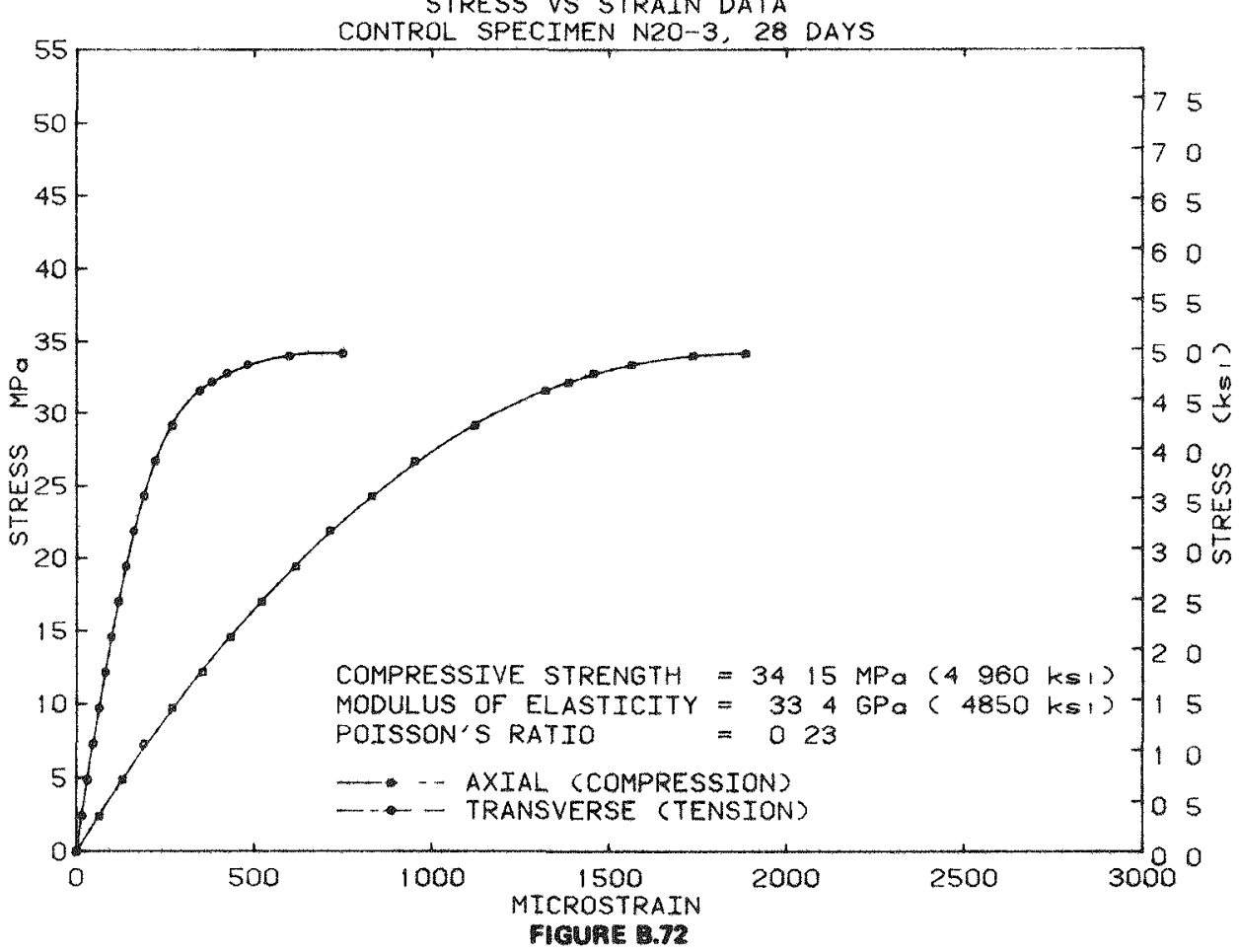




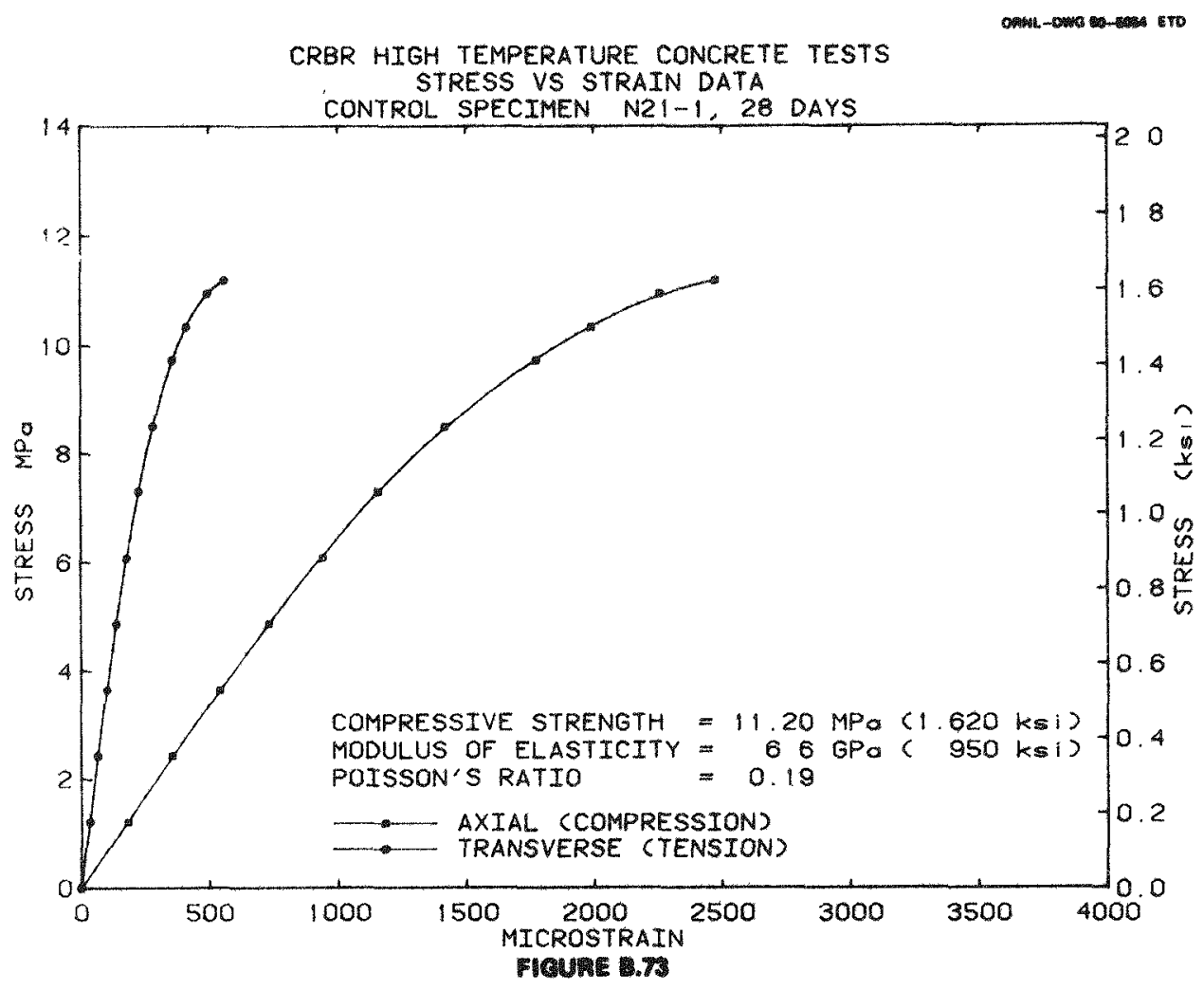

ORAB-DOWG HO- BOSS ETO

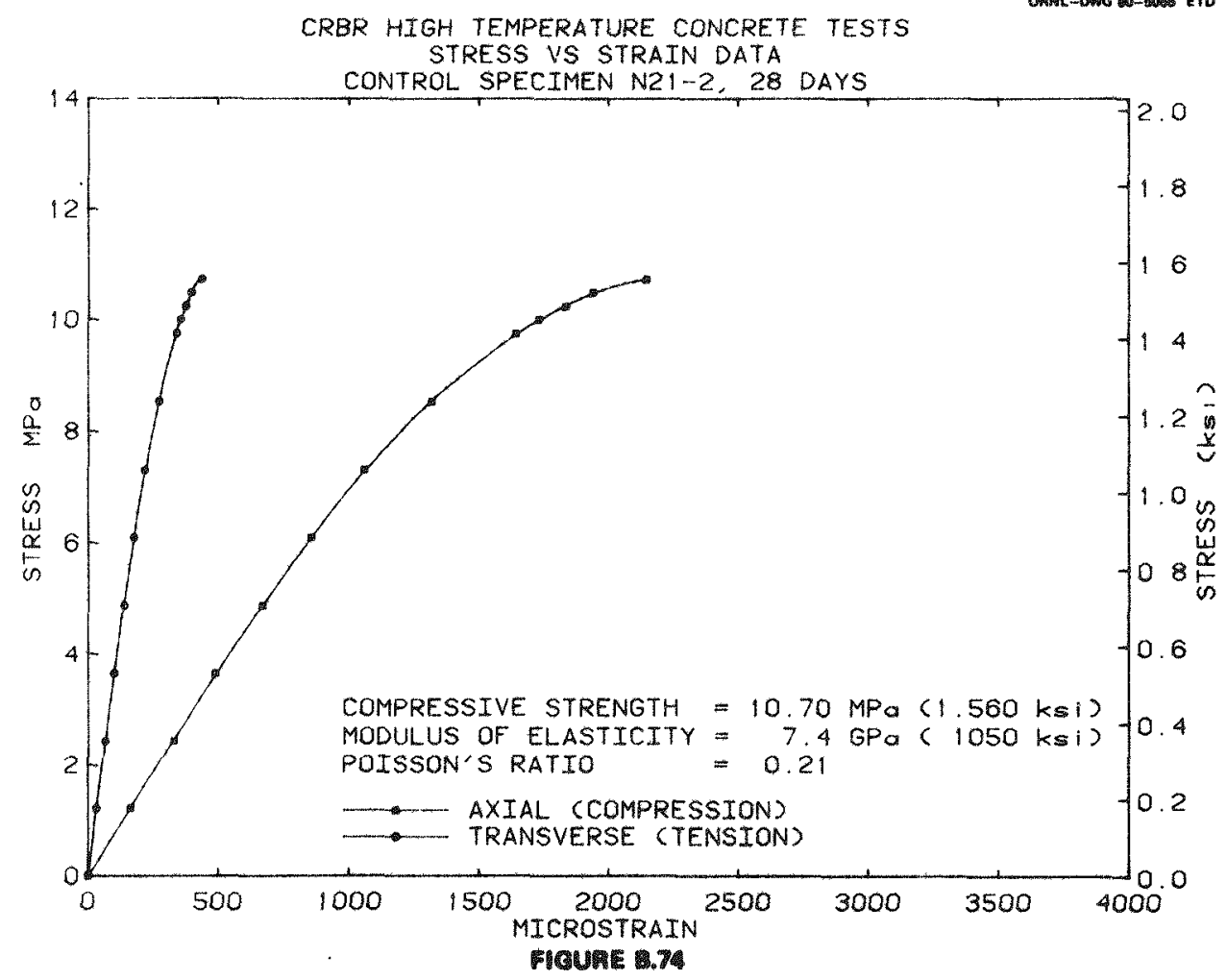




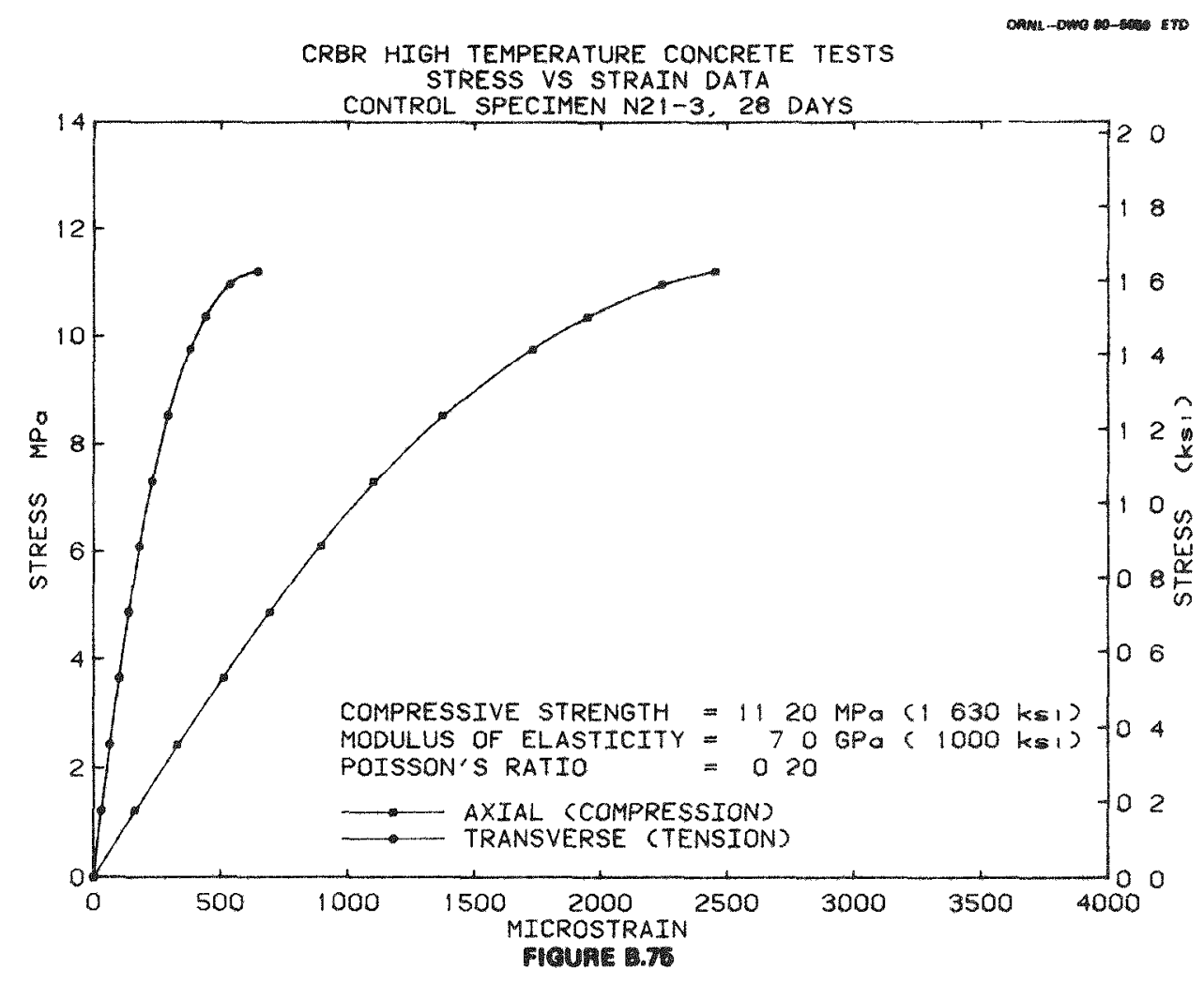


Appendix C

ELEVATED TEMPERATURE SPECIMEN'S TEMPERATURE HISTORY AND UNCONF INED COMPRESSION STRESS-STRAIN RESULTS 
140

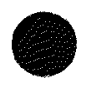

.

-

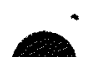

. 

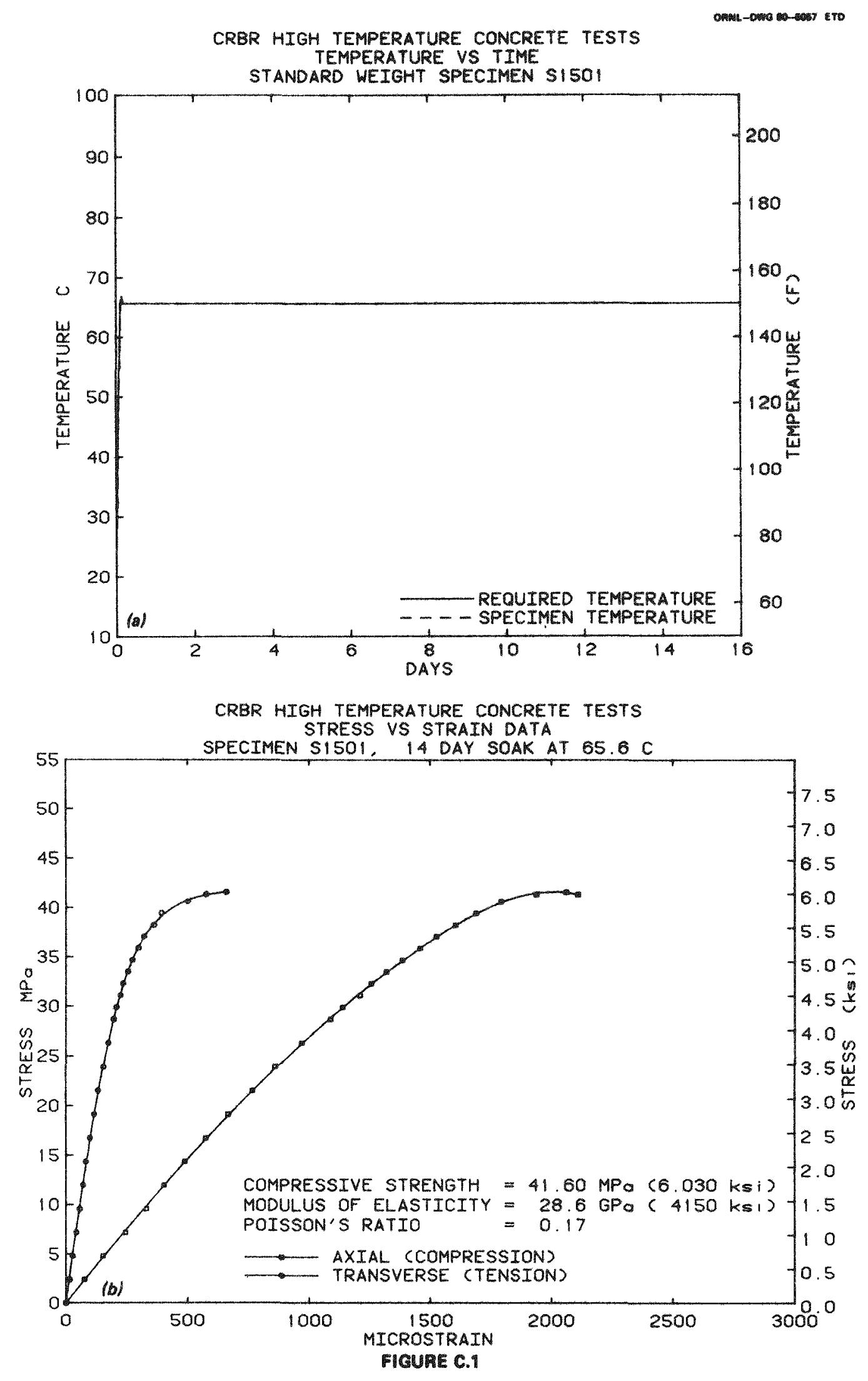

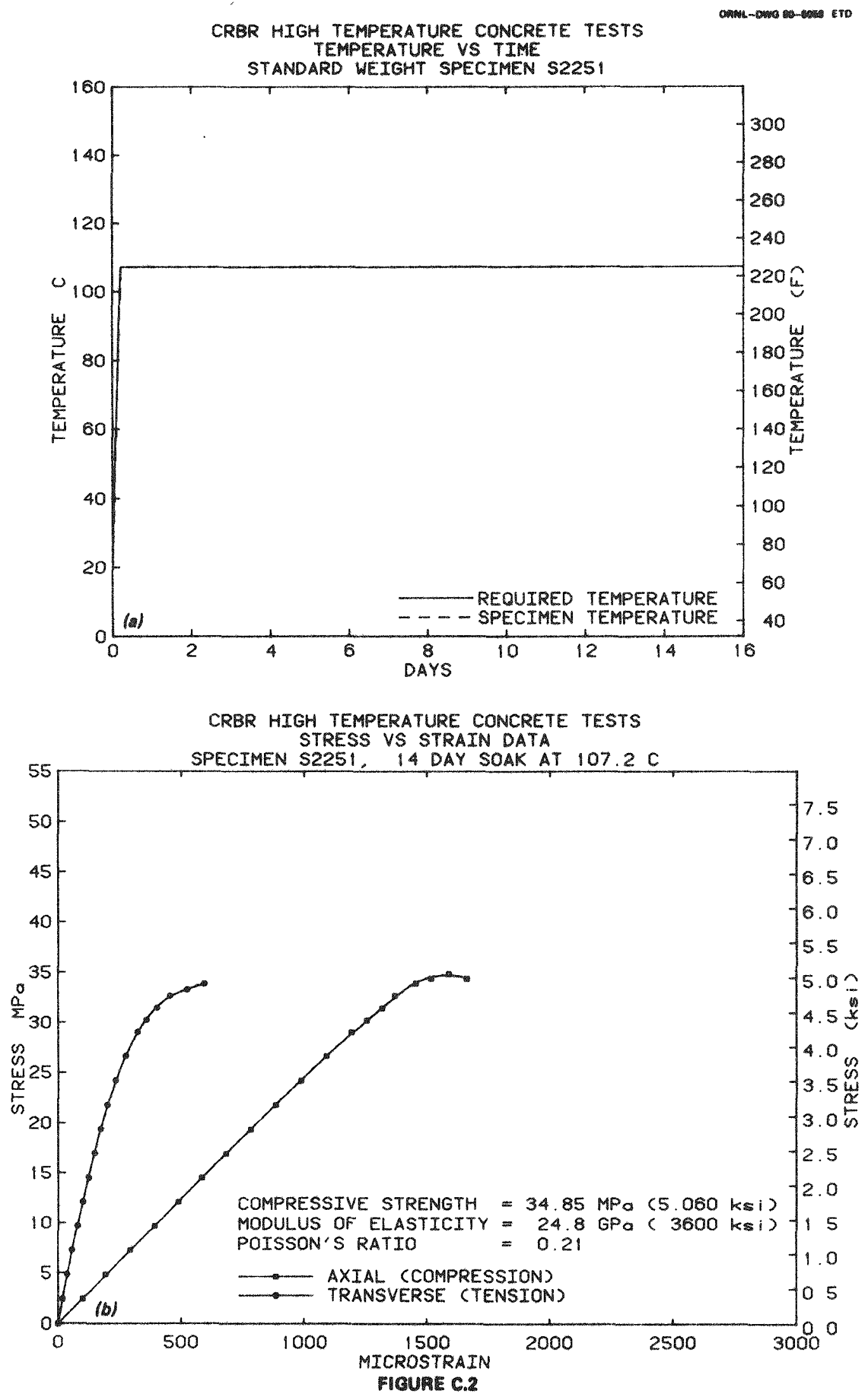
CRBR HIGH TEMPERATURE CONCRETE TESTS

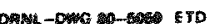
TEMPERATURE VS TIME

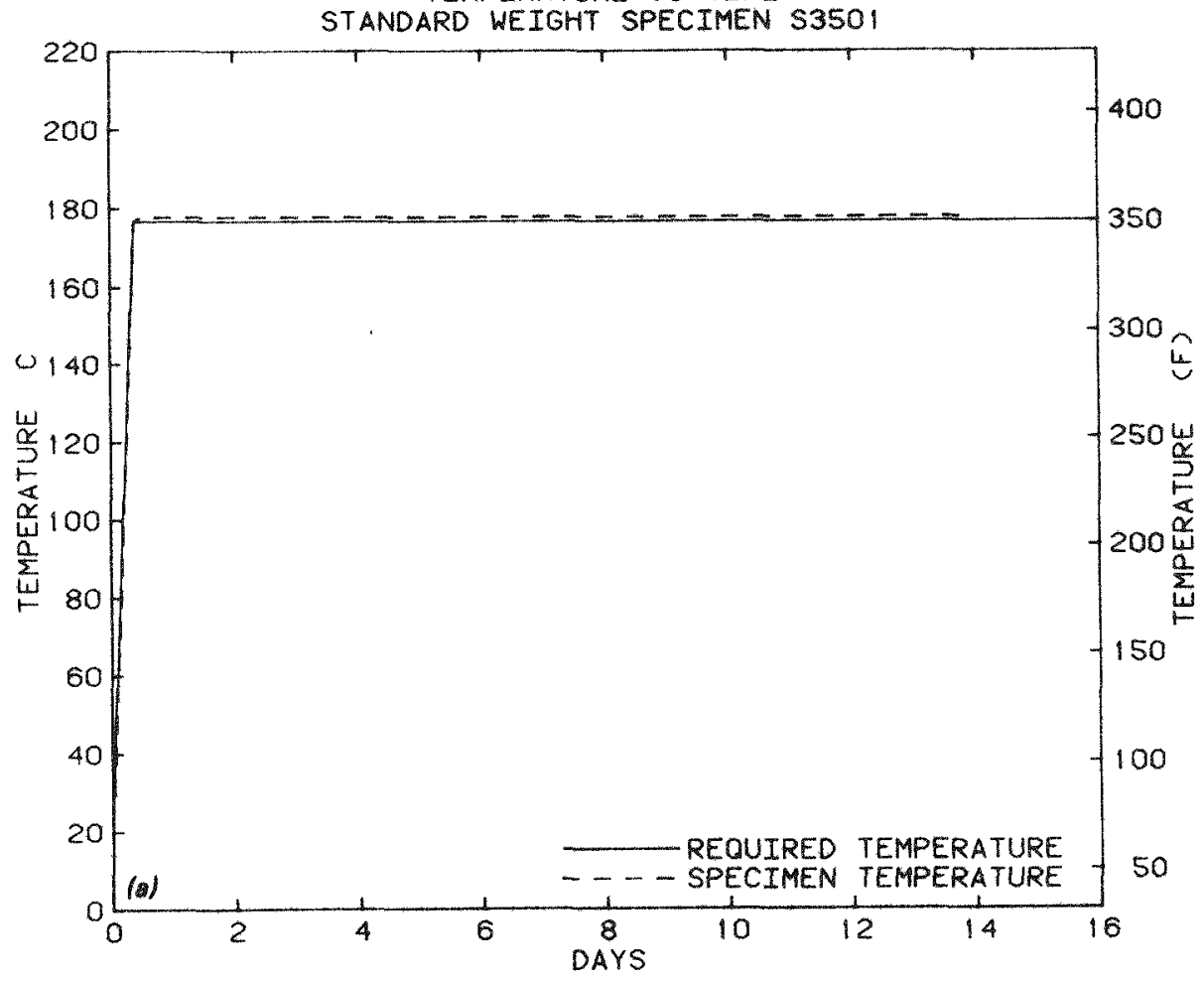

CRBR HIGH TEMPERATURE CONCRETE TESTS STRESS VS STRAIN DATA

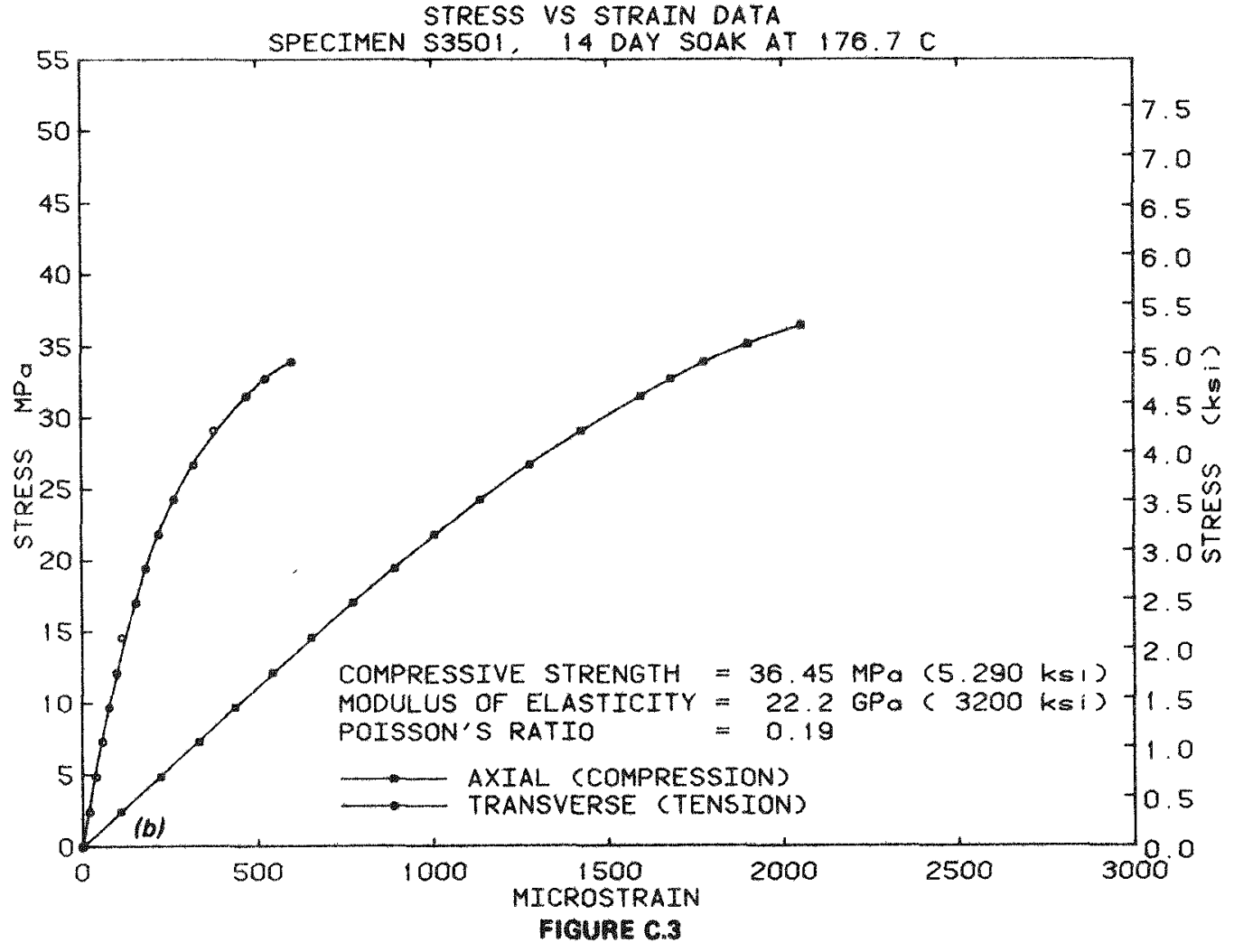



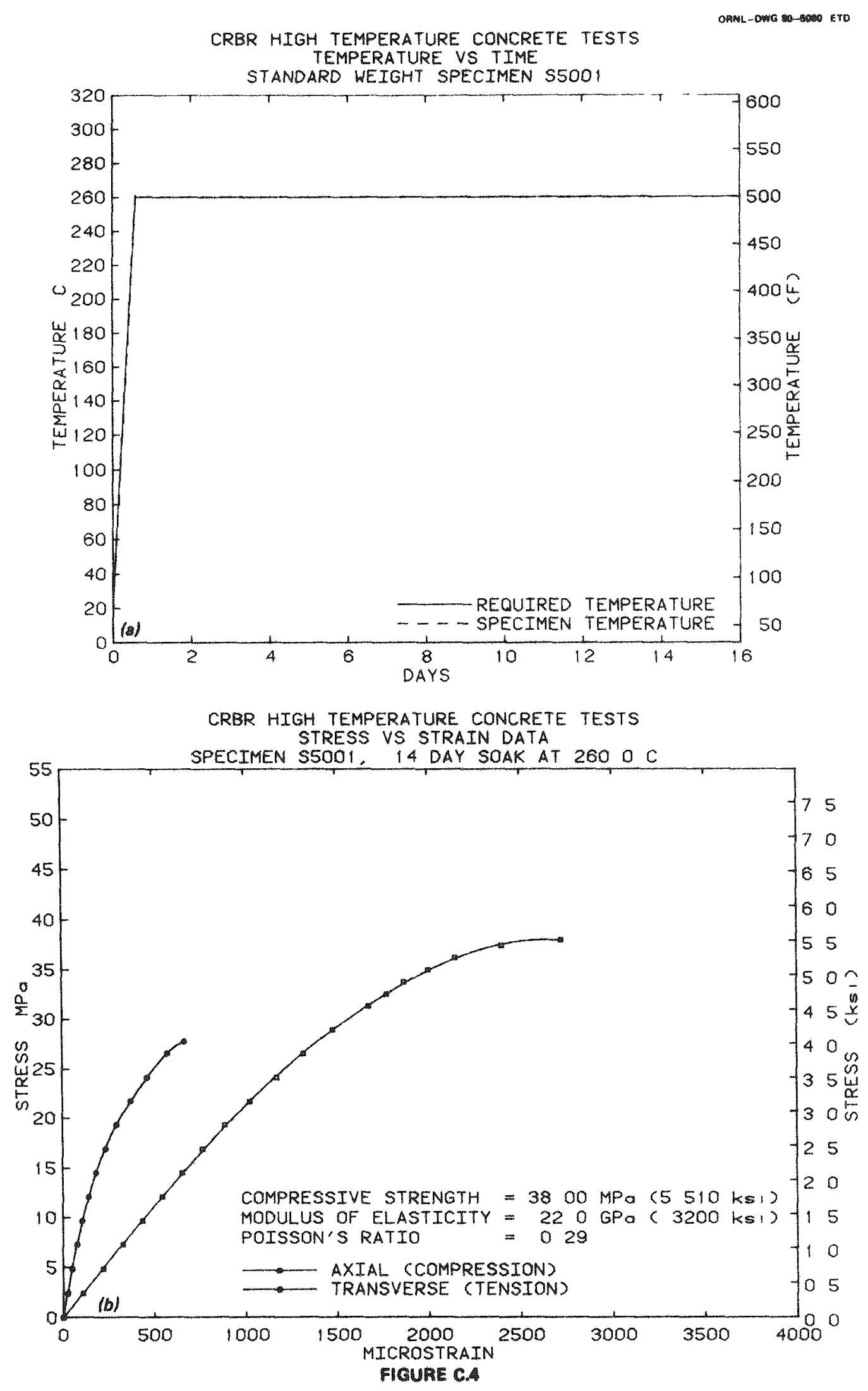

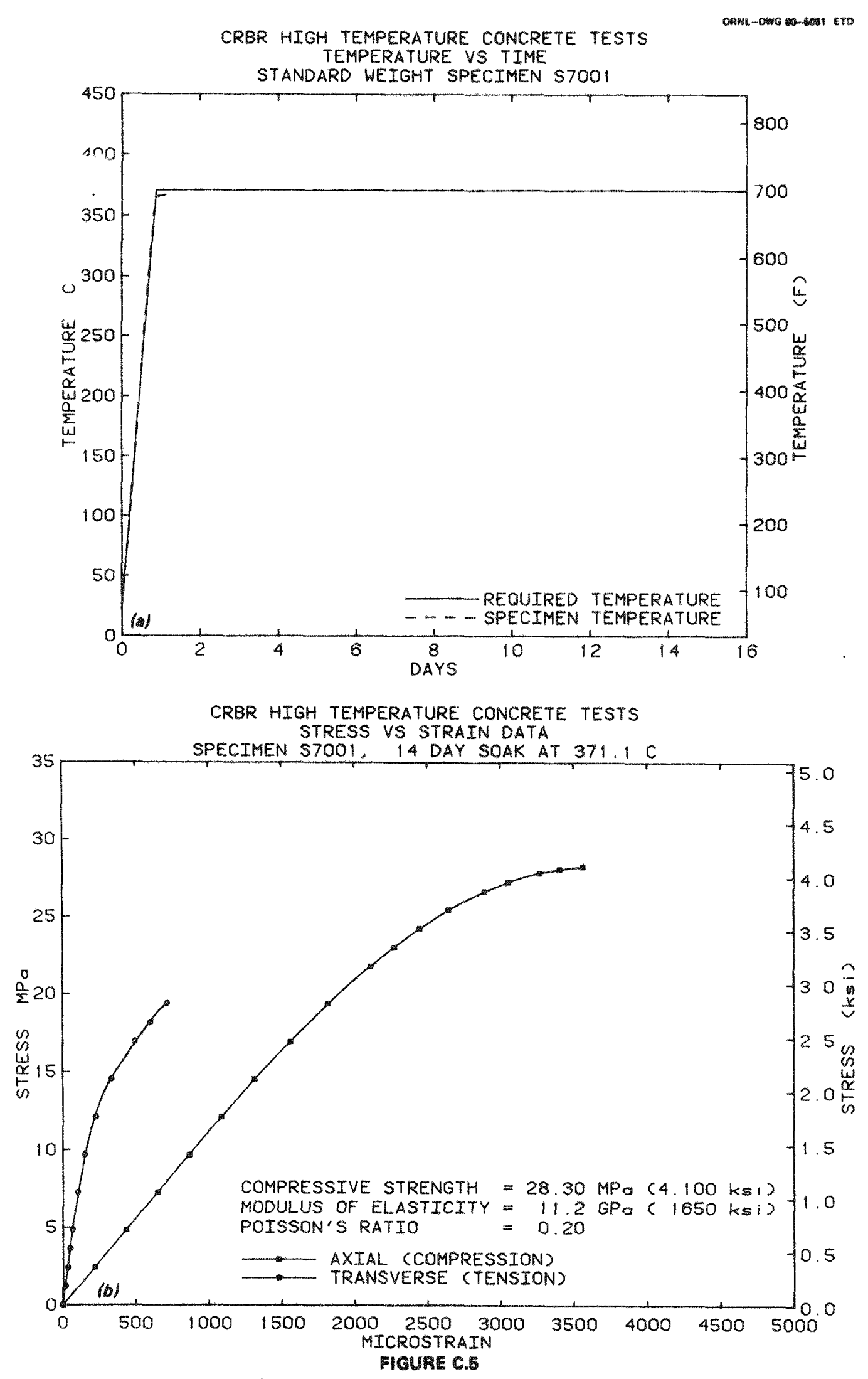

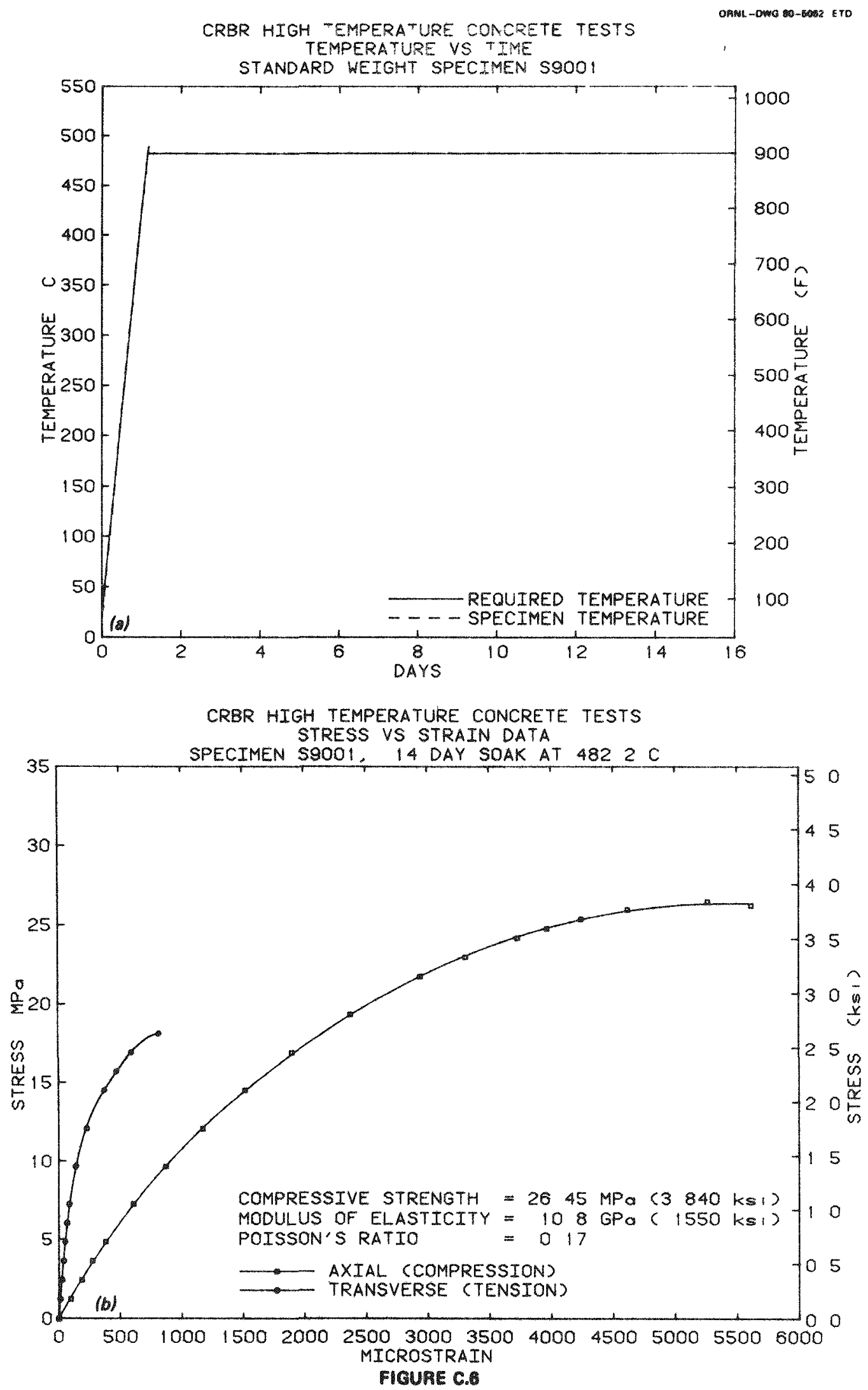

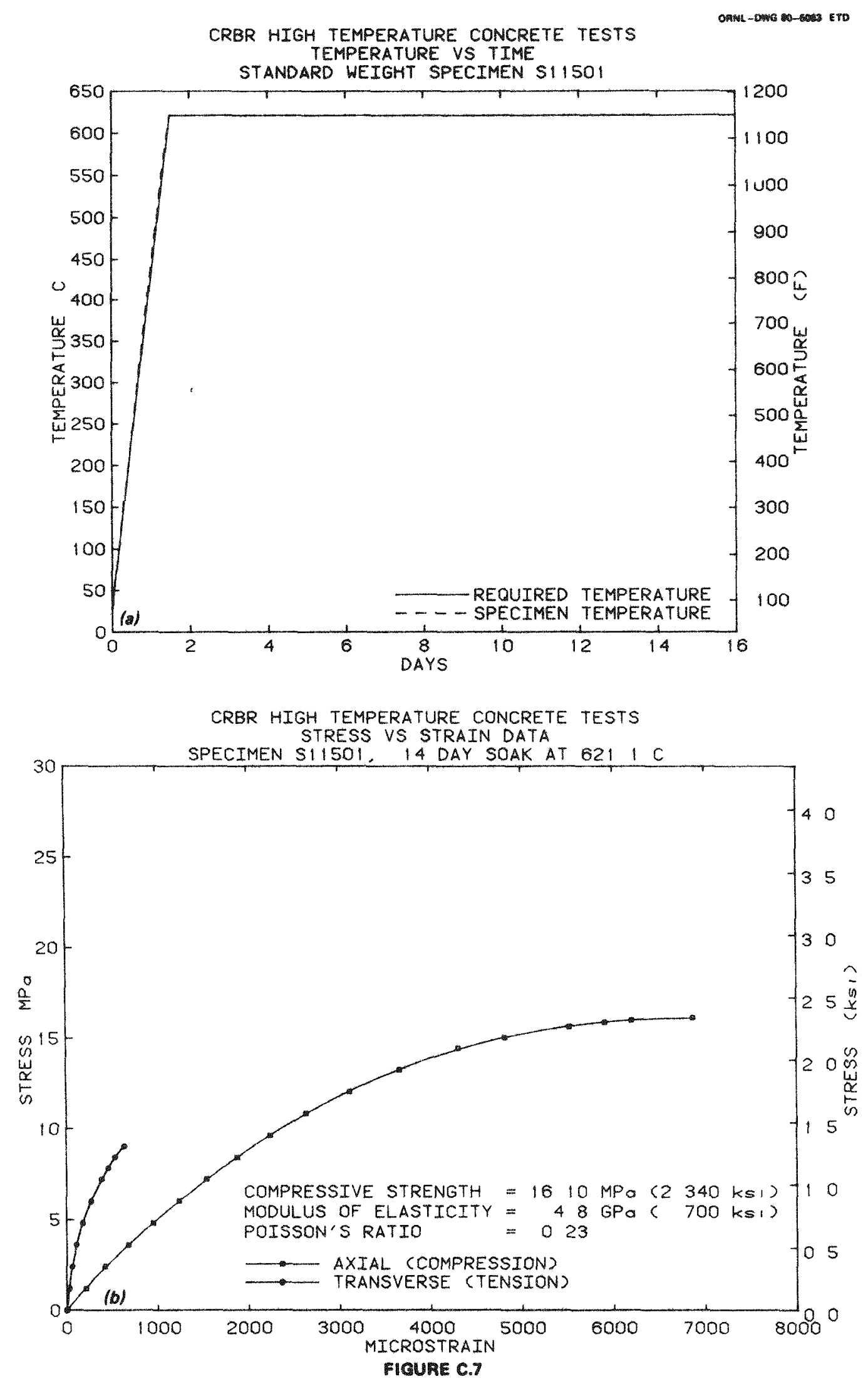
CRBR HIGH TEMPERATURE CONCRETE TESTS

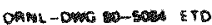
TEMPERATURE VS TIME

STANDARD WEIGHT SPECIMEN TISO:

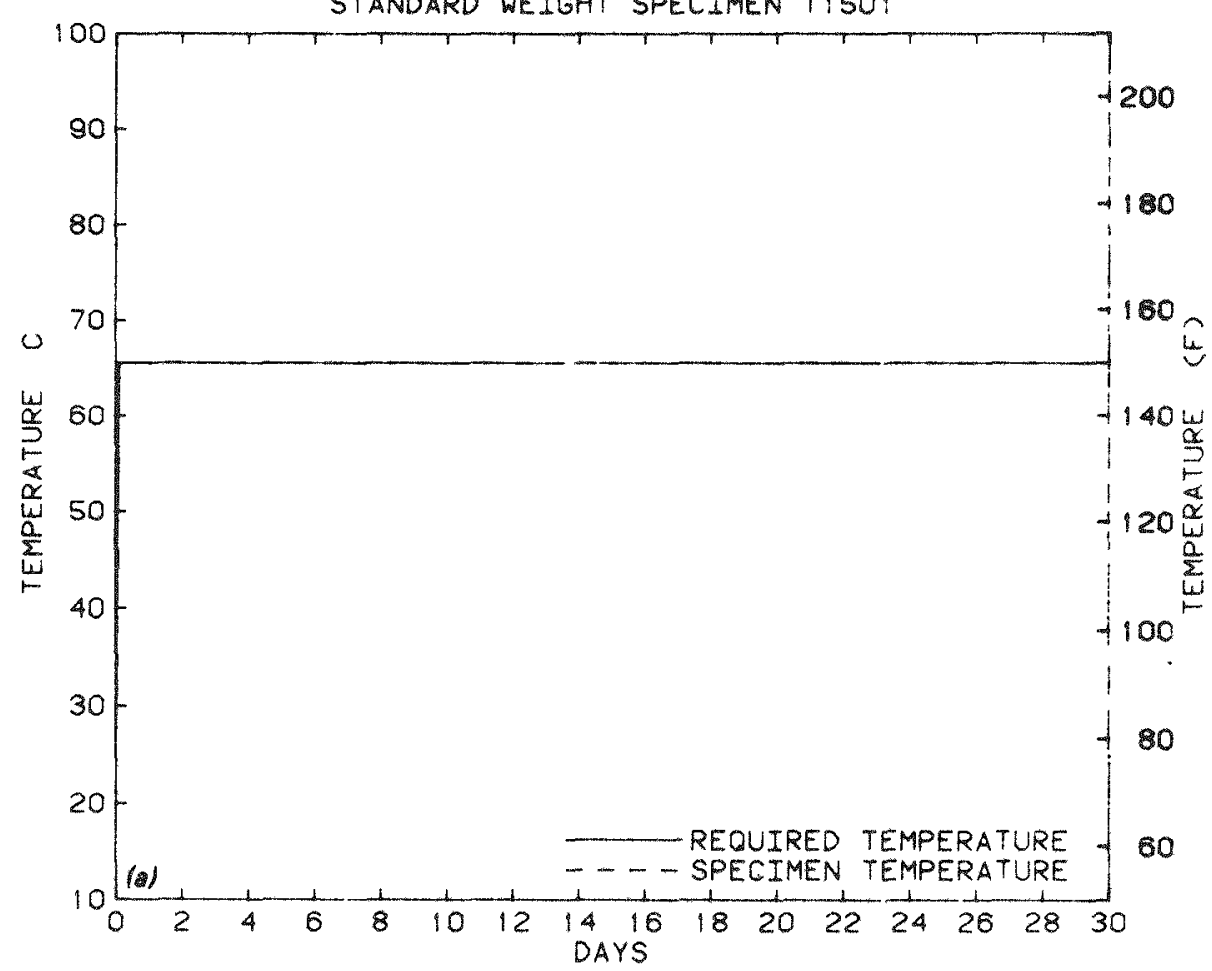

CRBR HIGH TEMPERATURE CONCRETE TESTS STRESS VS STRAIN DATA

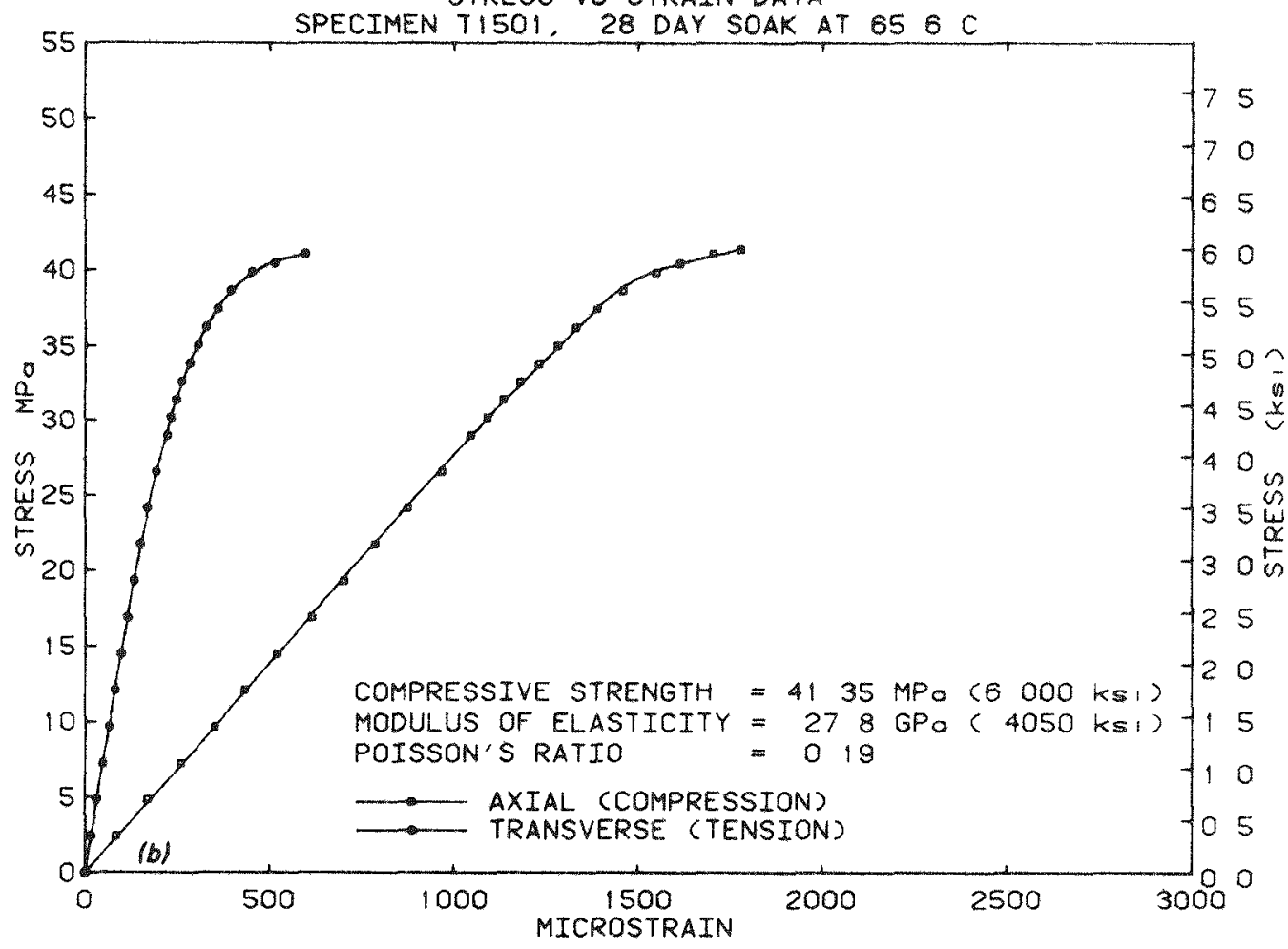

FIGURE C.8 

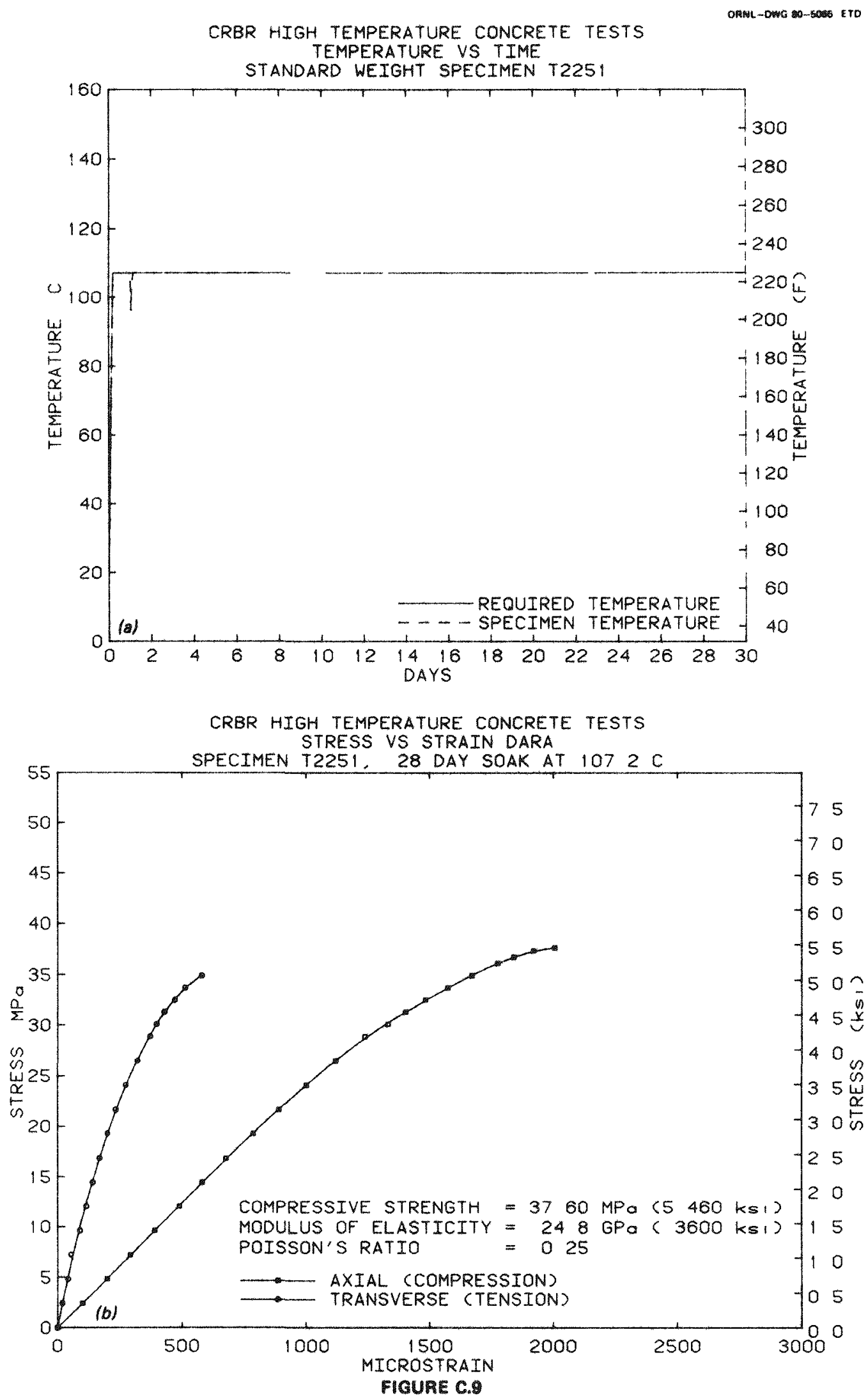

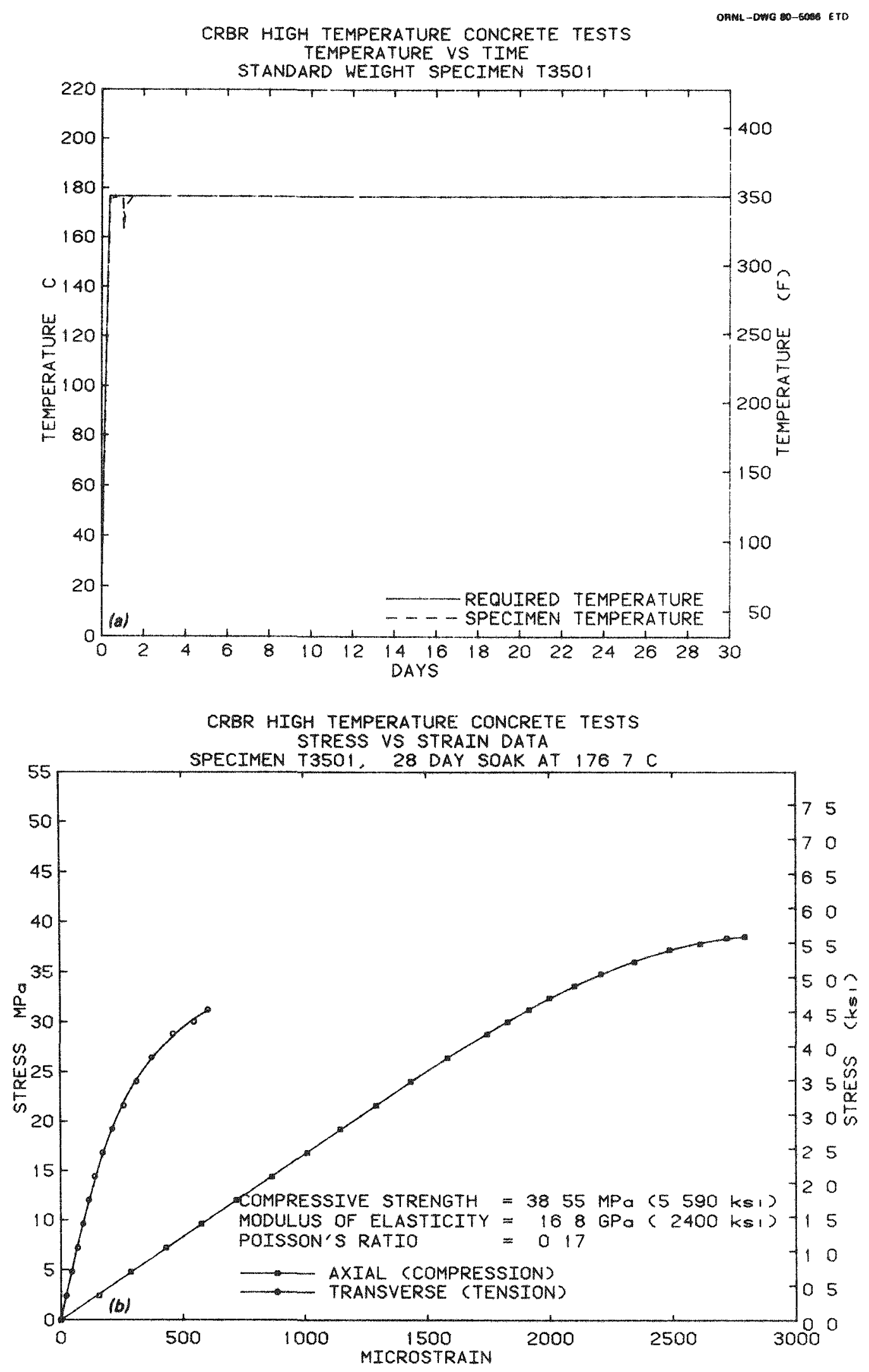

FICURE C. 10 

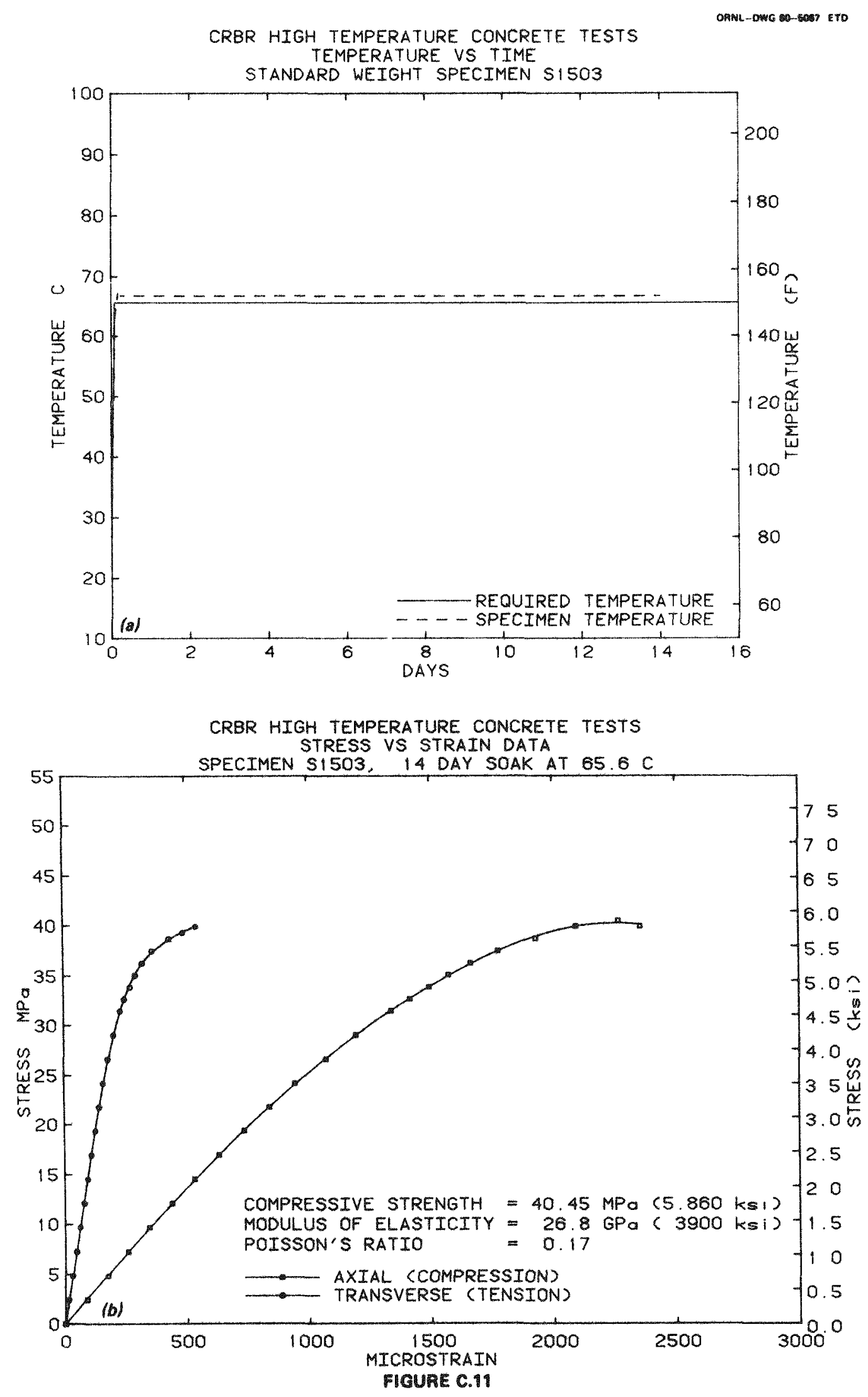


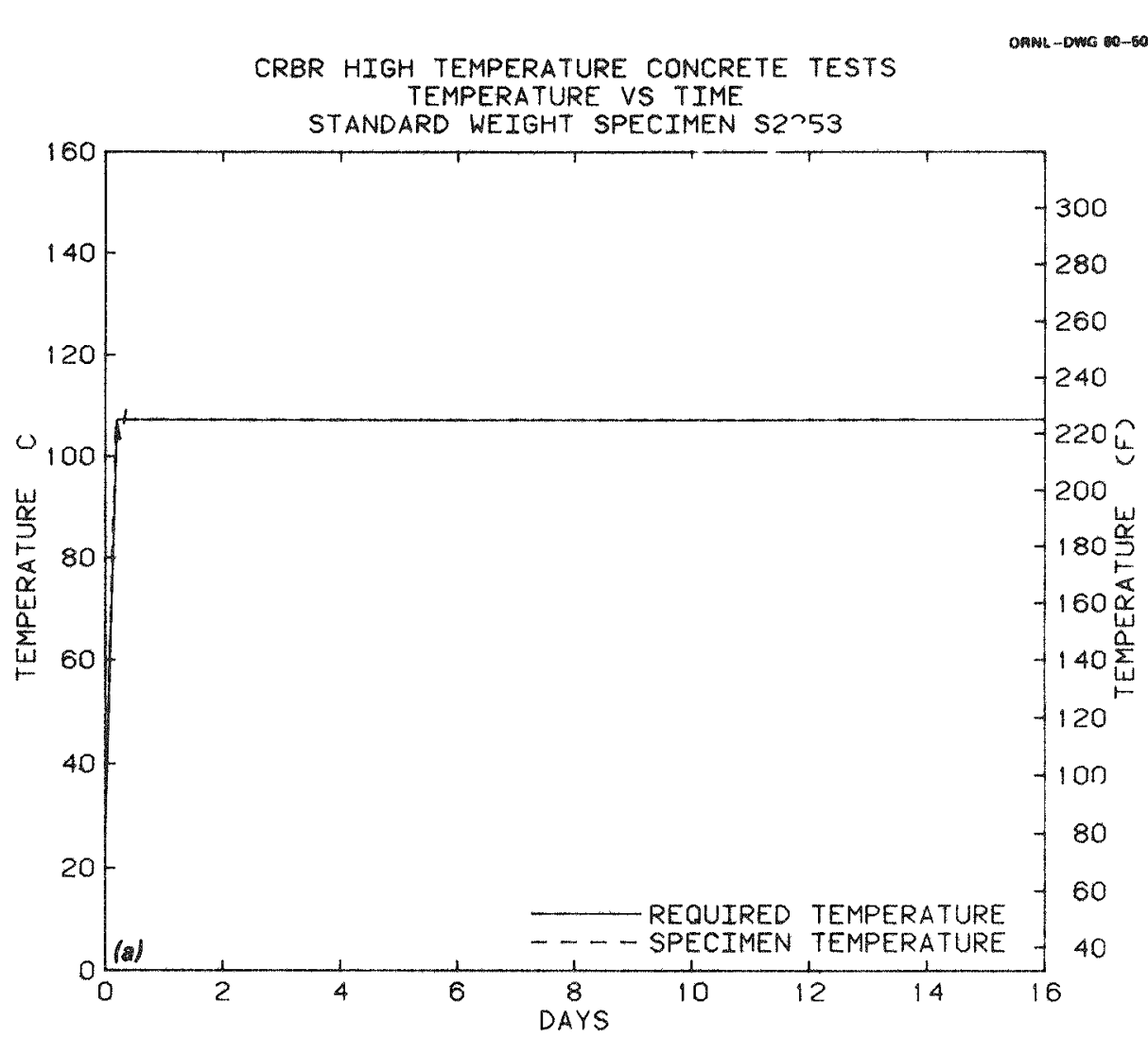

CRBR HIGH TEMPERATURE CONCRETE TESTS

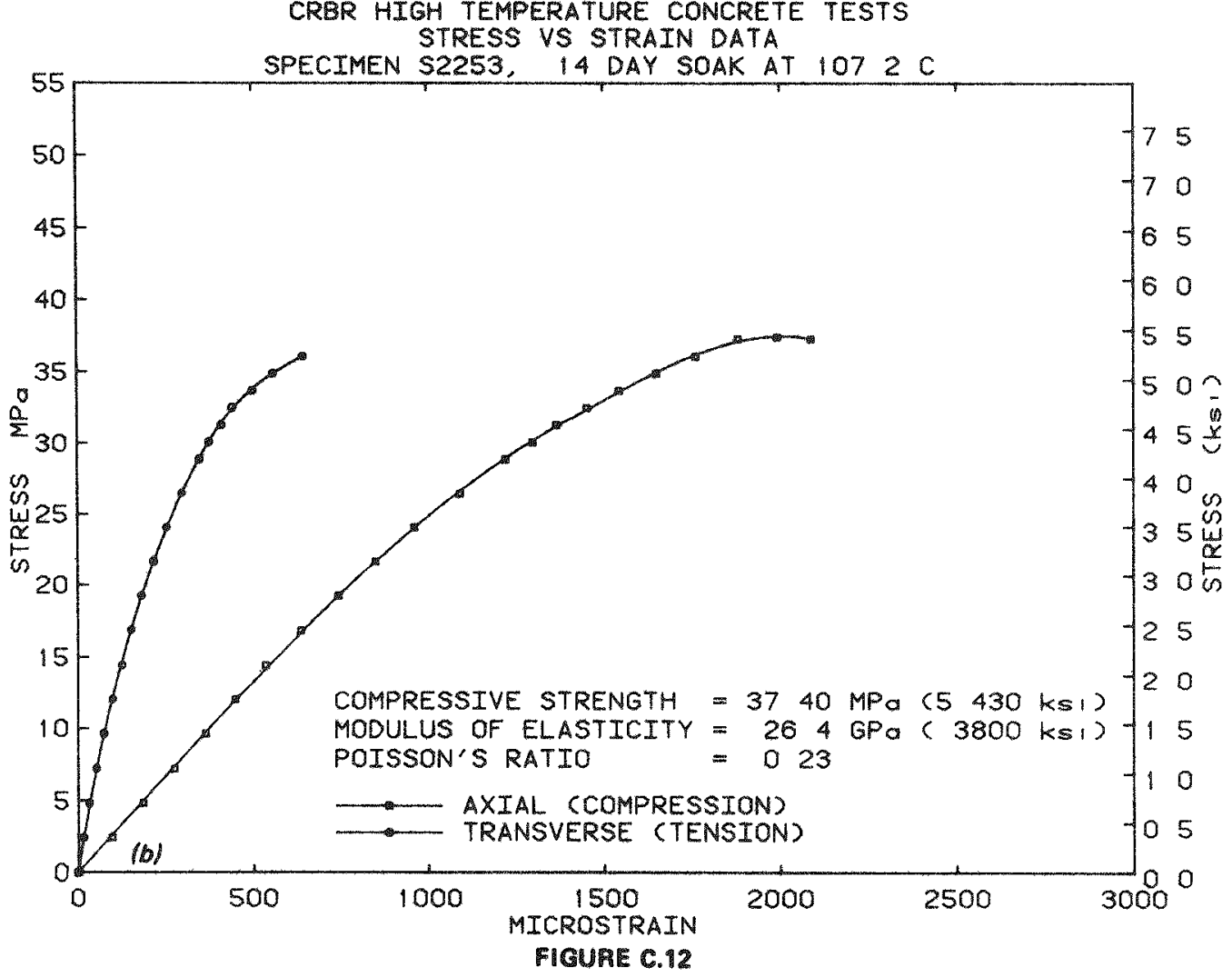


CRBR HIGH TEMPERATURE CONCRETE TESTS

DRAL -OWG ETO TEMPERATURE VS TIME

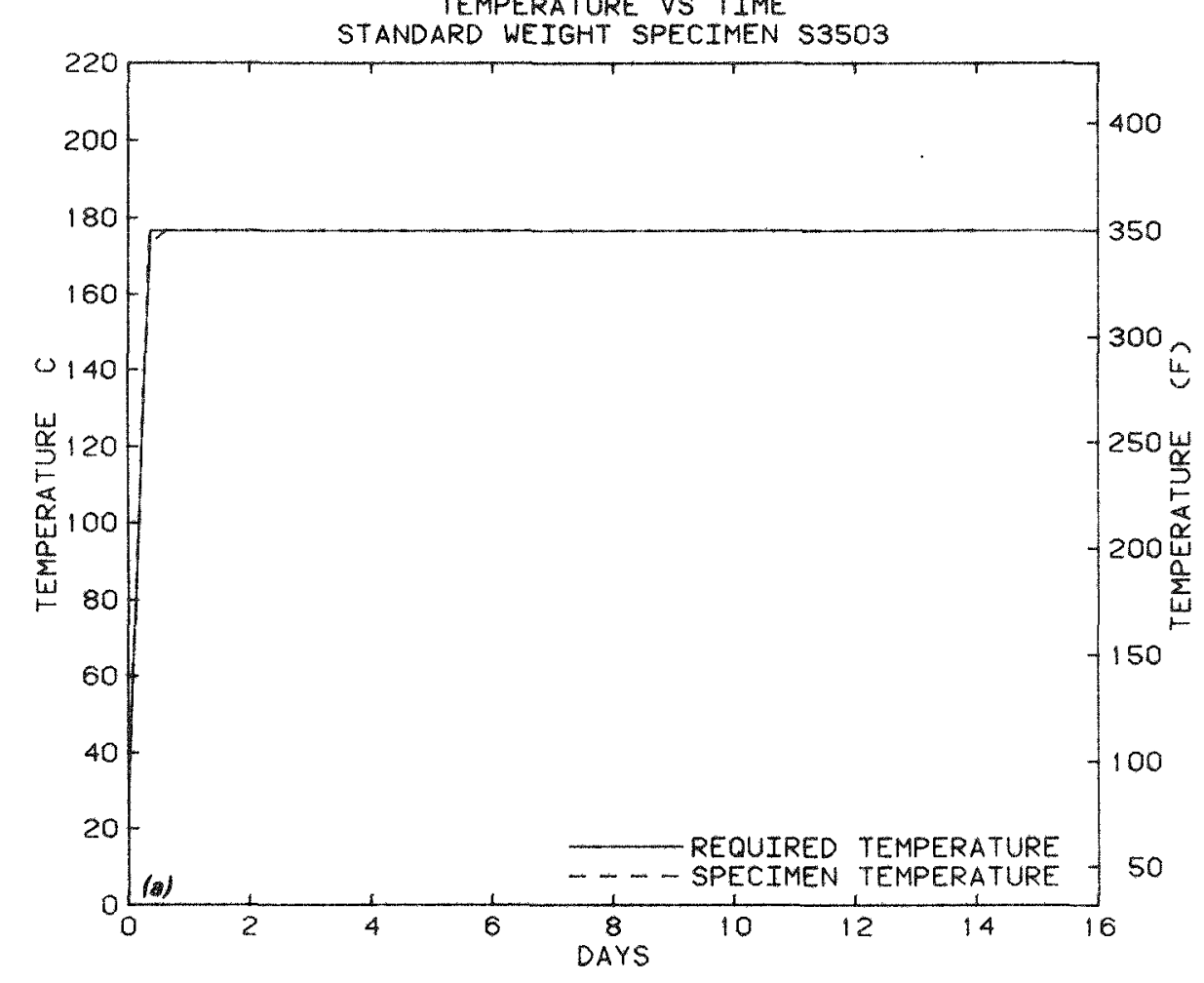

CRBR HIGH TEMPERATURE CONCRETE TESTS

STRESS VS STRAIN DATA

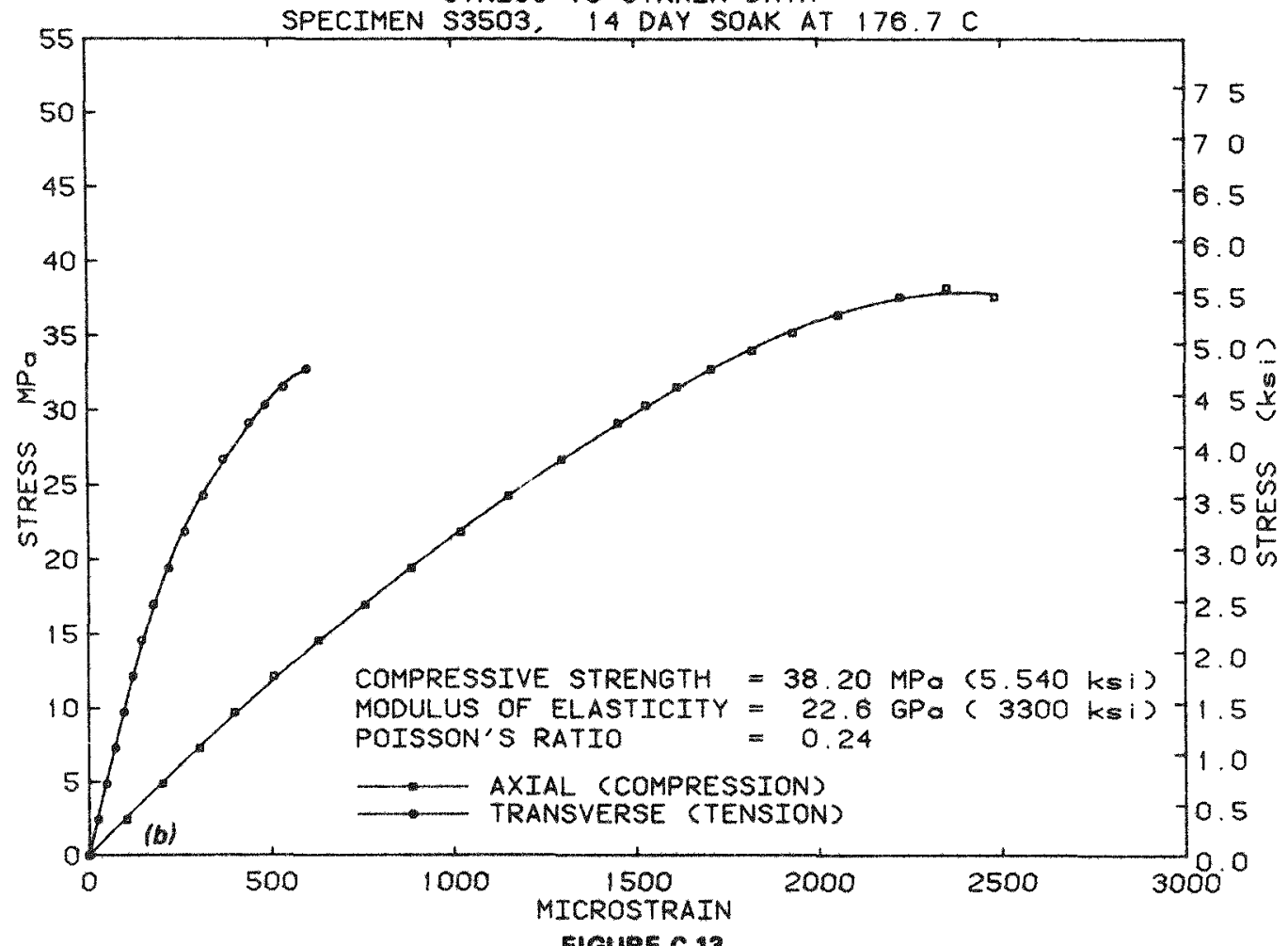

FIGURE C.13 

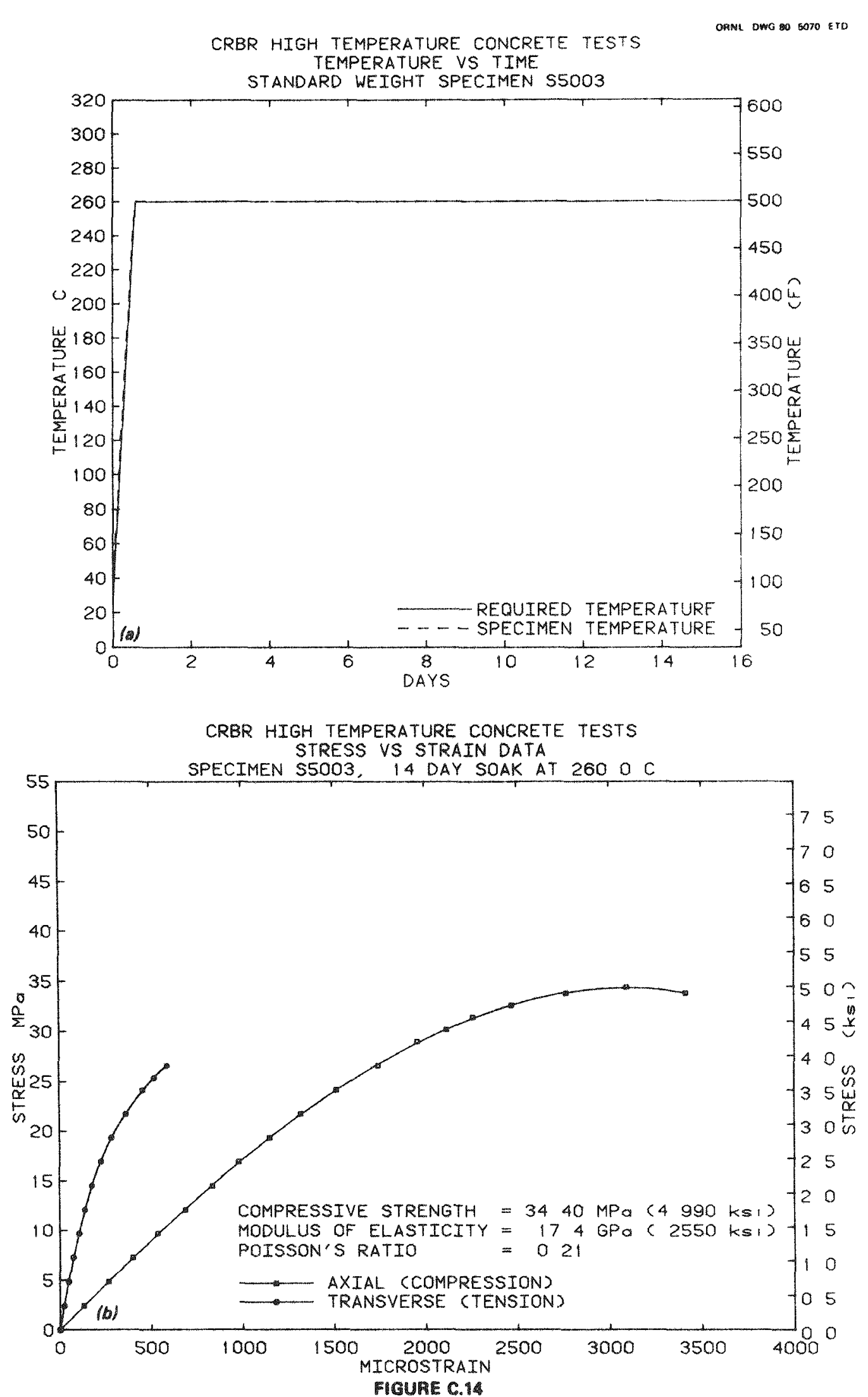
ORAL-ONG $0-\operatorname{son} 1$ हTO TEMPERATURE VS TTME

STANDARD WEIGHT SPECIMEN $\$ 7003$

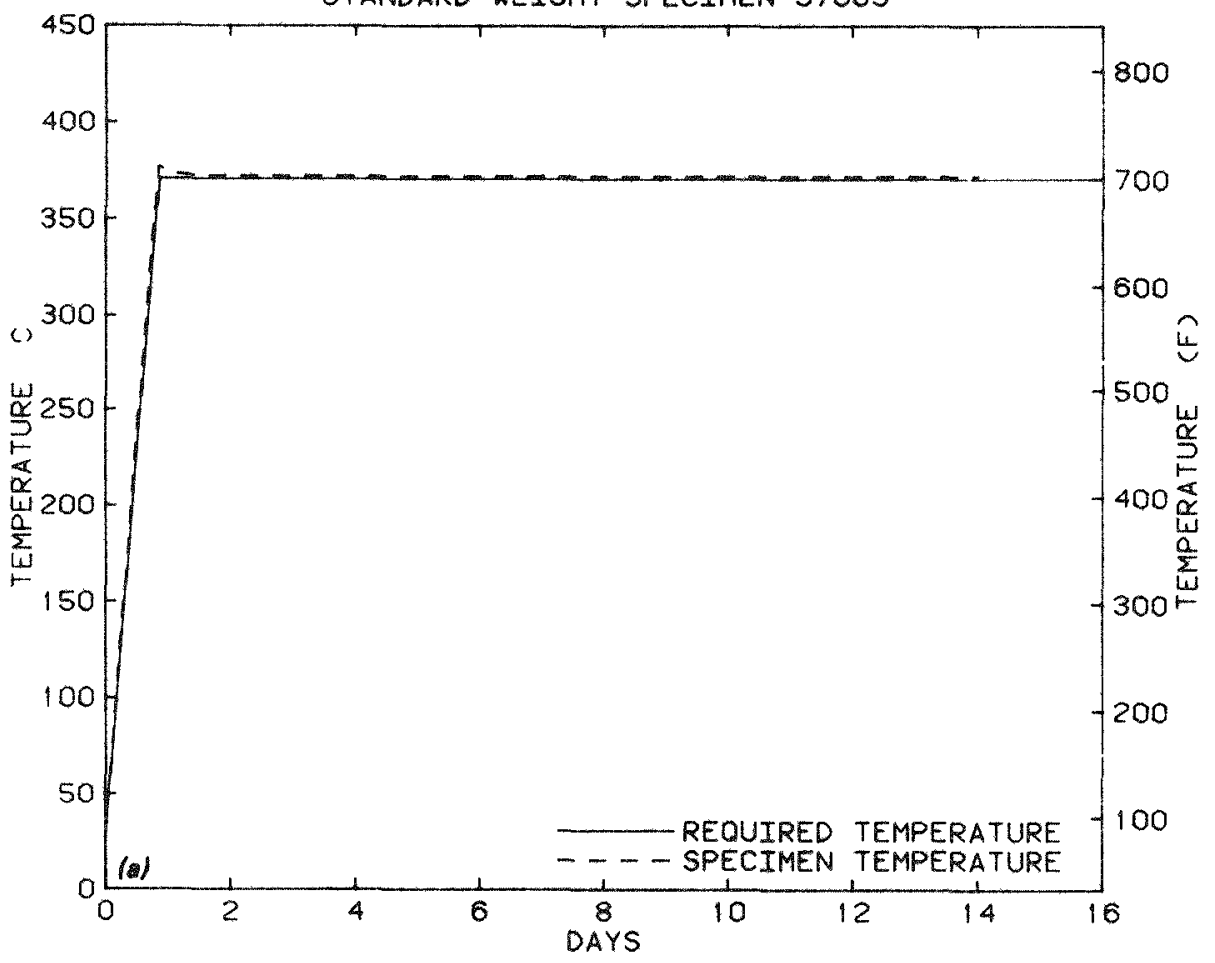

CRBR HIGH TEMPERATURE CONCRETE TESTS

STRESS VS STRAIN DATA

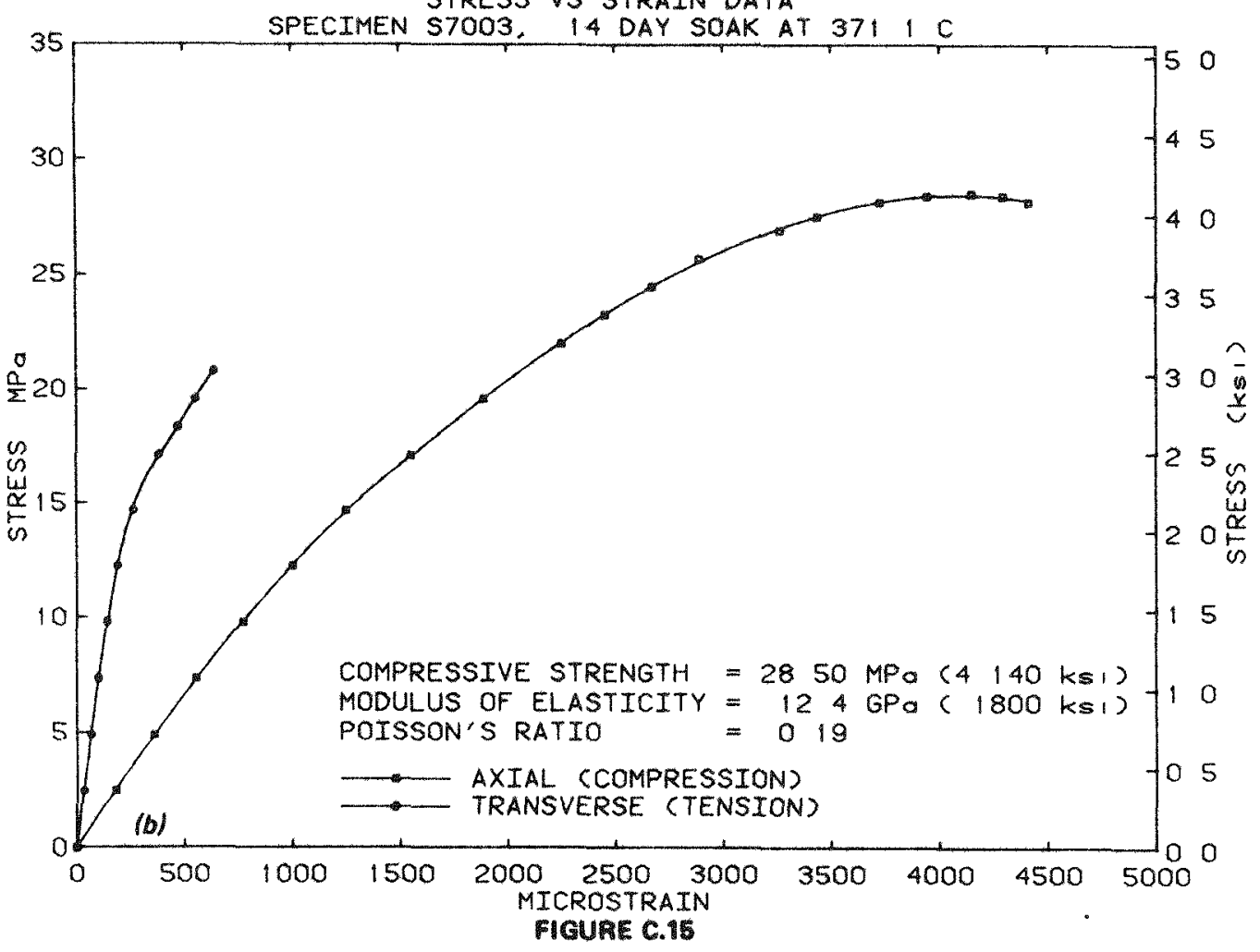


CRBR HIGH TEMPERATURE CONCRETE TESTS

OANL-OWG TEMPERATURE VS TIME

STANDARD WEIGHT SPECIMEN S9OD3

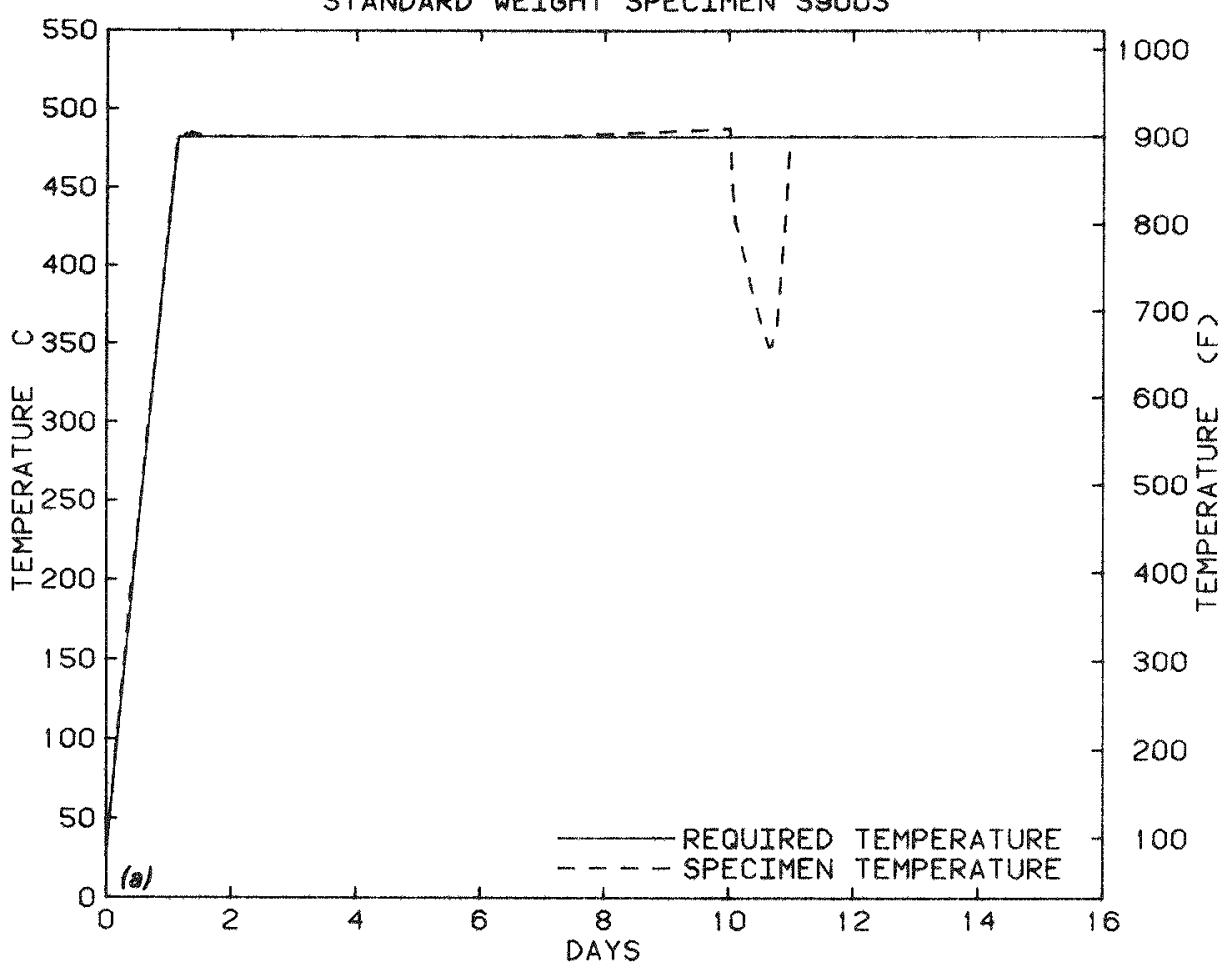

CRBR HIGH TEMPERATURE CONCRETE TESTS STRESS VS STRAIN DATA

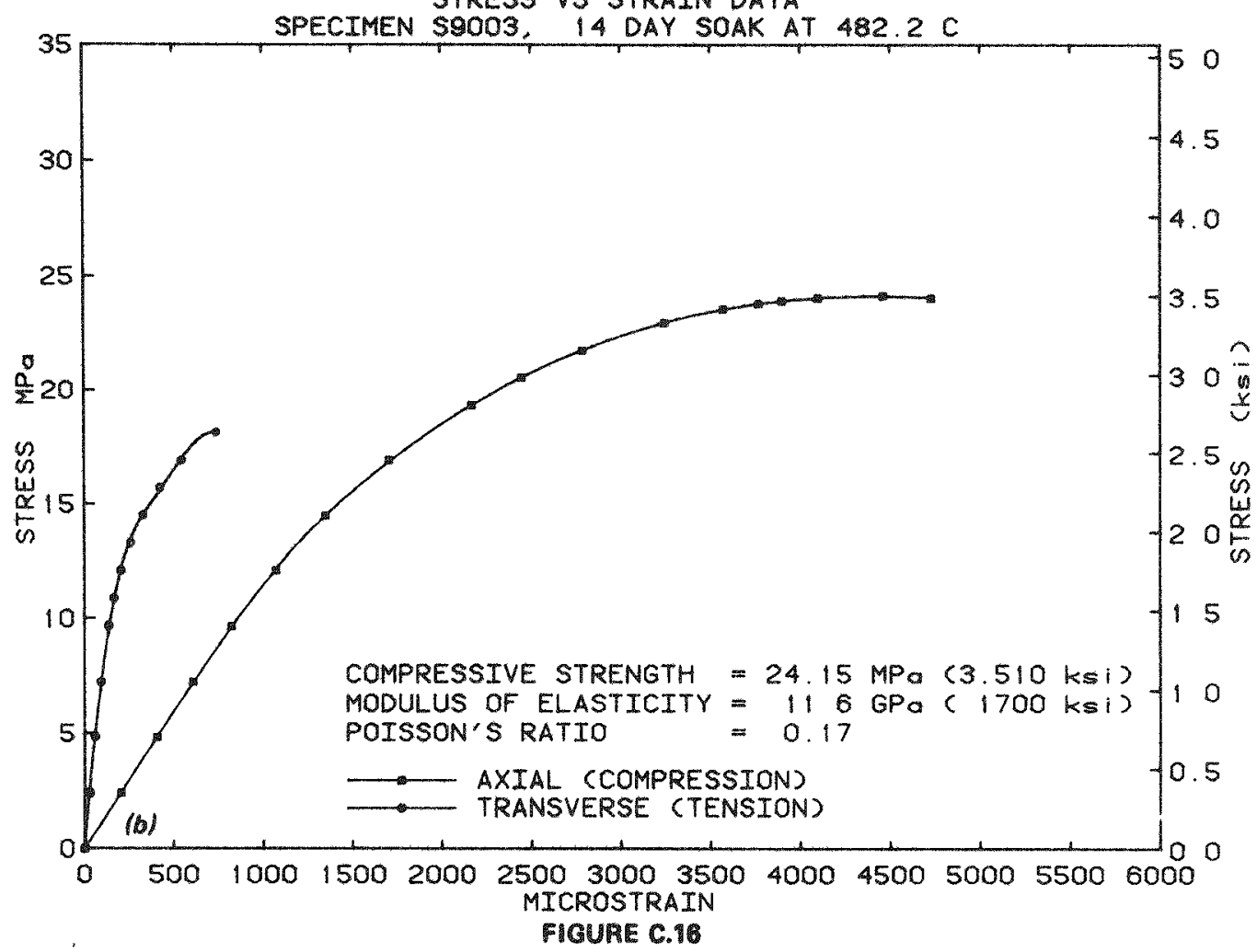


CRBR HIGH TEMPERATURE CONCRETE TESTS

OAPEL-DWC W0-5073 ETO TEMPERATURE VS TIME

STANDARD WEIGHT SPECIMEN S11503

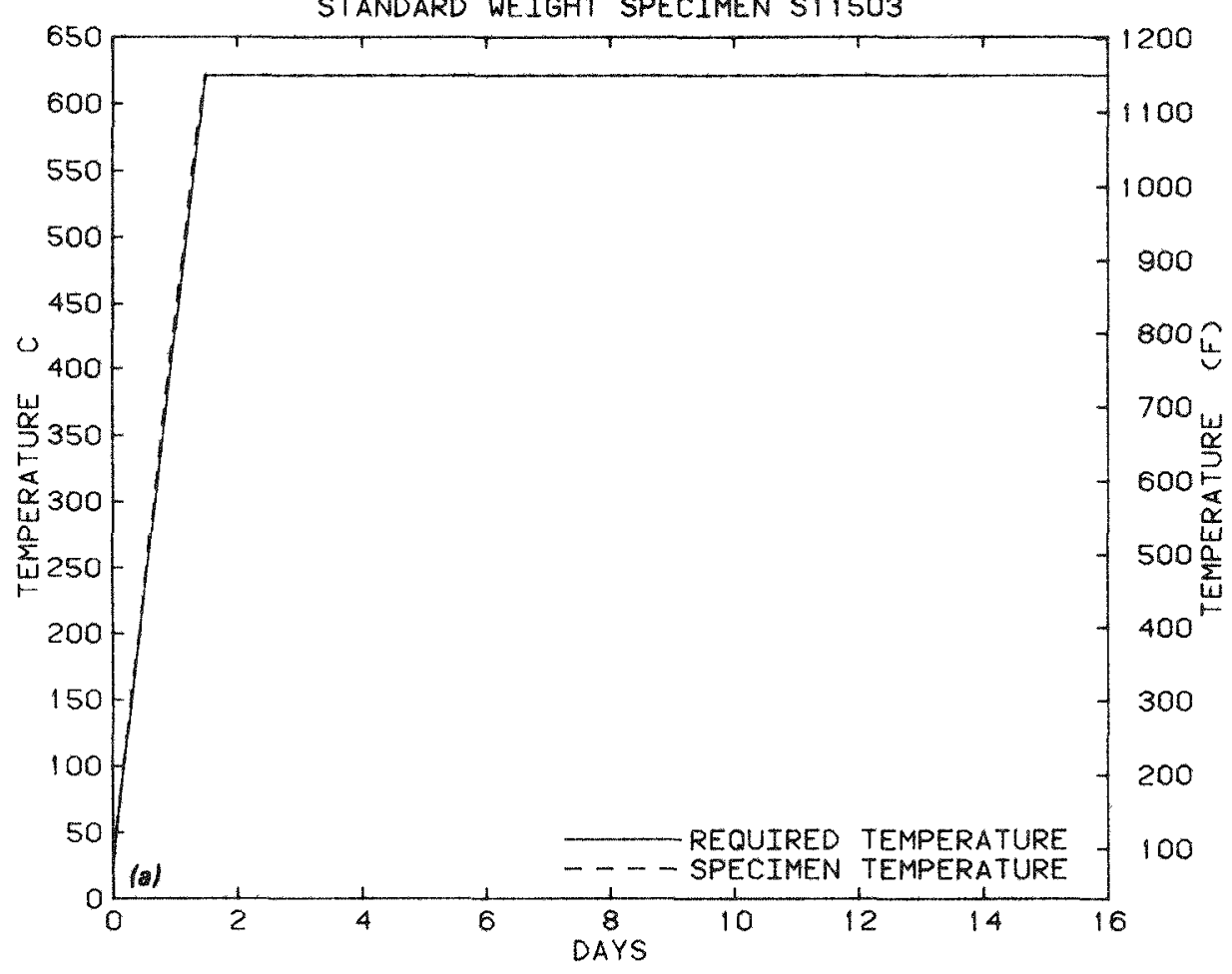

CRBR HIGH TEMPERATURE CONCRETE TESTS STRESS VS STRAIN DATA

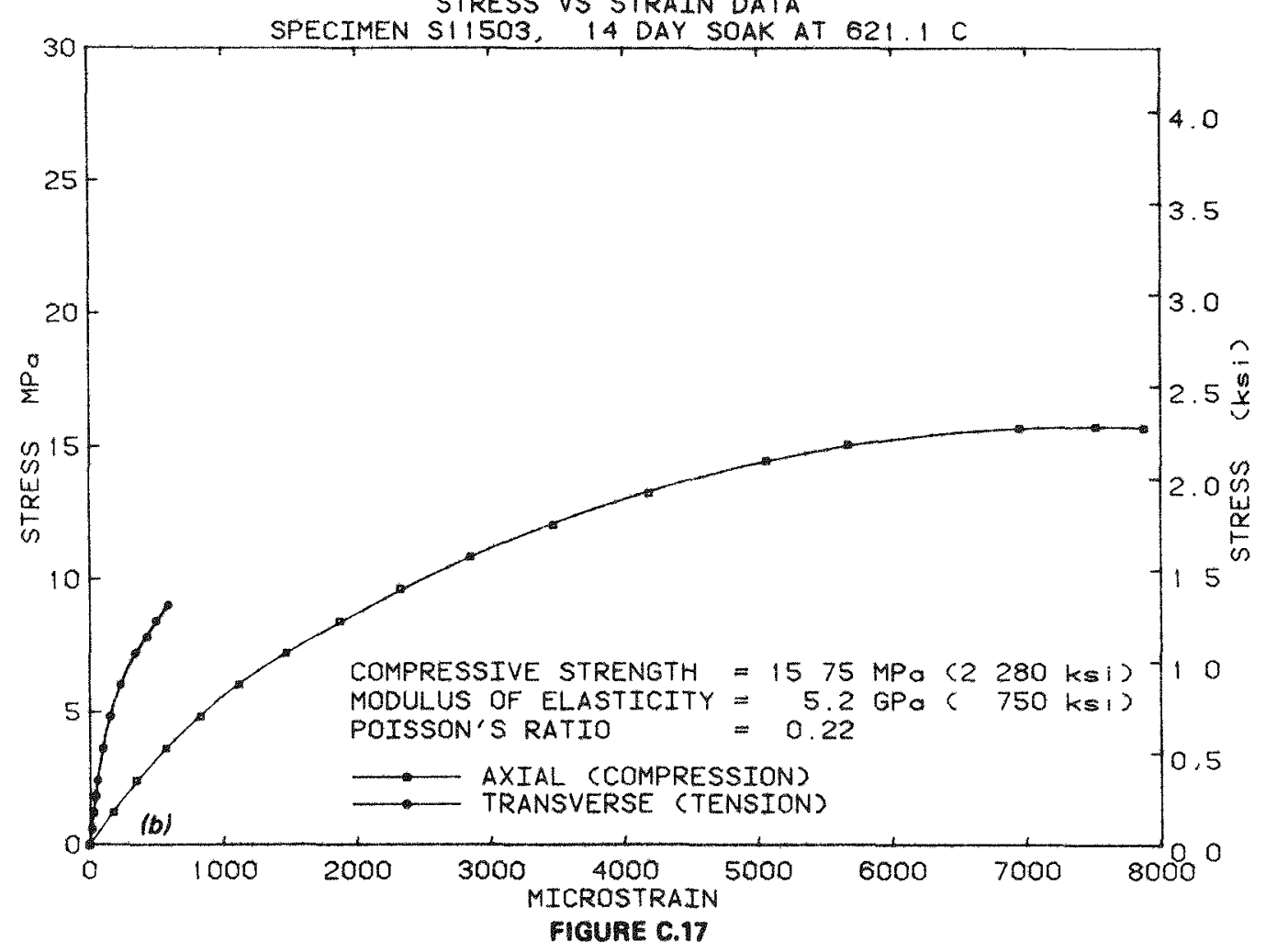


CRBR HIGH TEMPERATURE CONCRETE TESTS

ORML-DWG D-GATA ETD TEMPERATURE VS TIME STANDARD WEIGHT SPECIMEN T1503

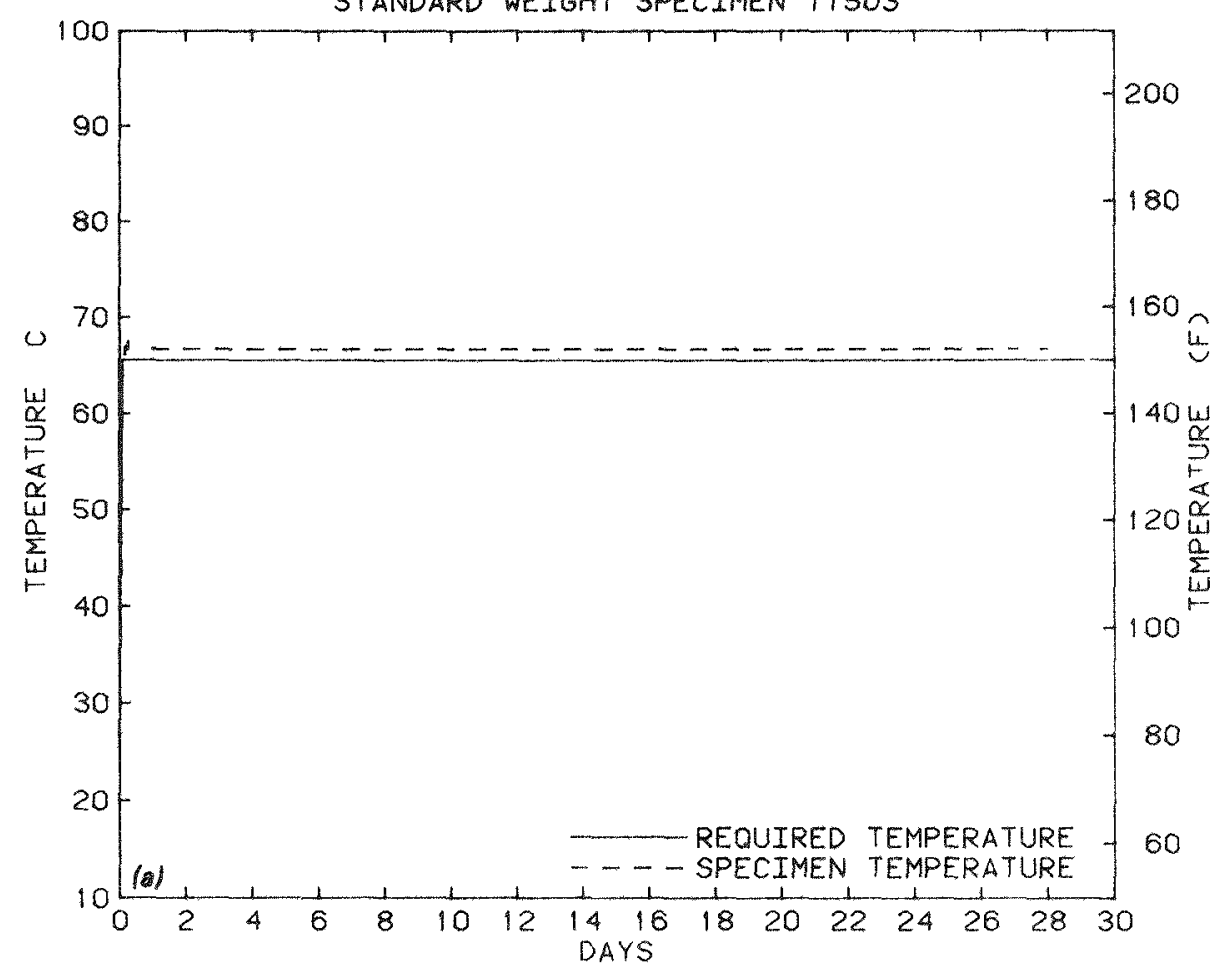

CRBR HIGH TEMPERATURE CONCRETE TESTS STRESS VS STRAIN DATA

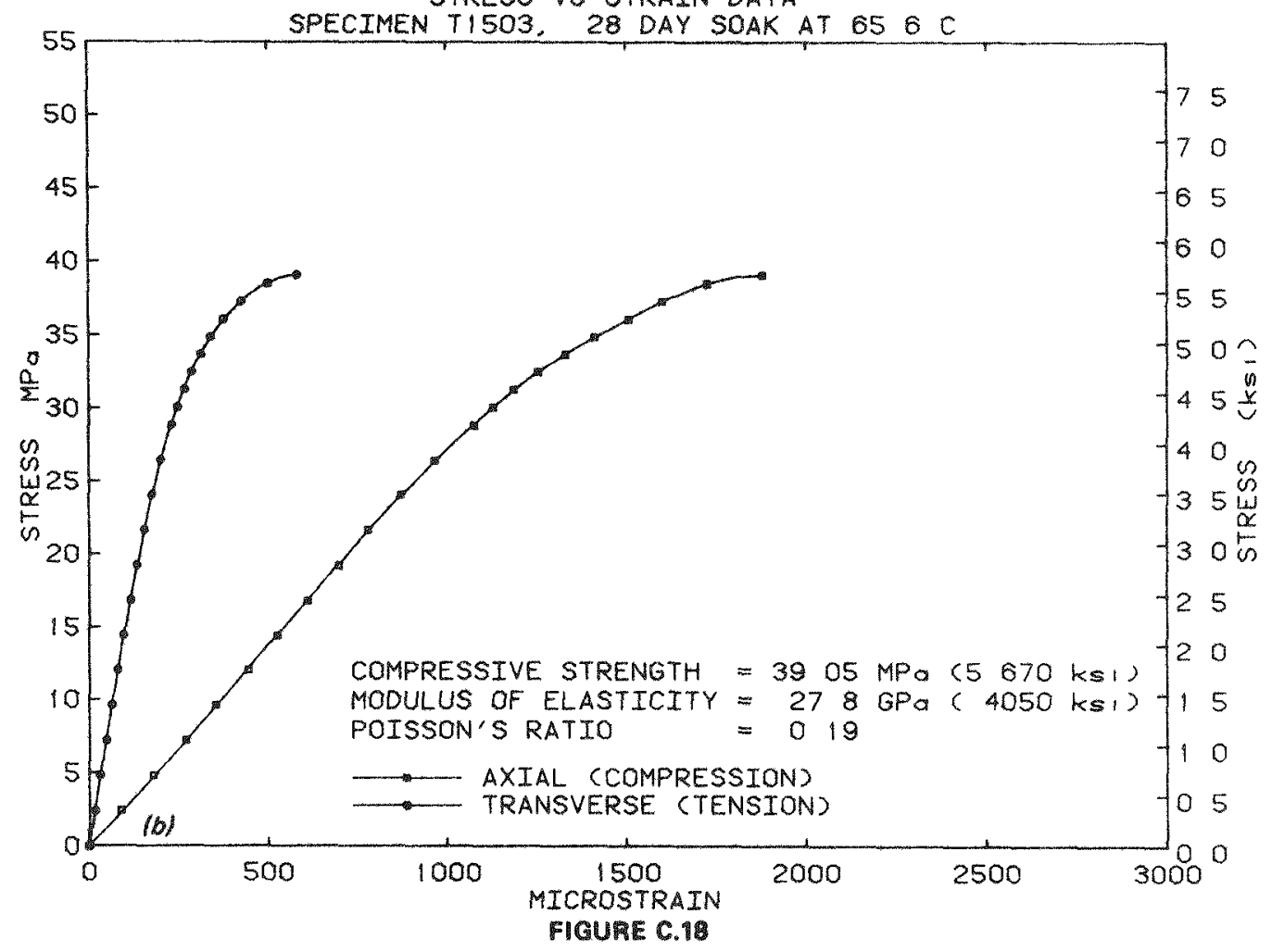


CRBR HIGH TEMPERATURE CONCRETE TESTS TEMPERATURE VS TIME

ORAL-OWG ETO ETO STANDARD WEIGHT SPECIMEN T2253
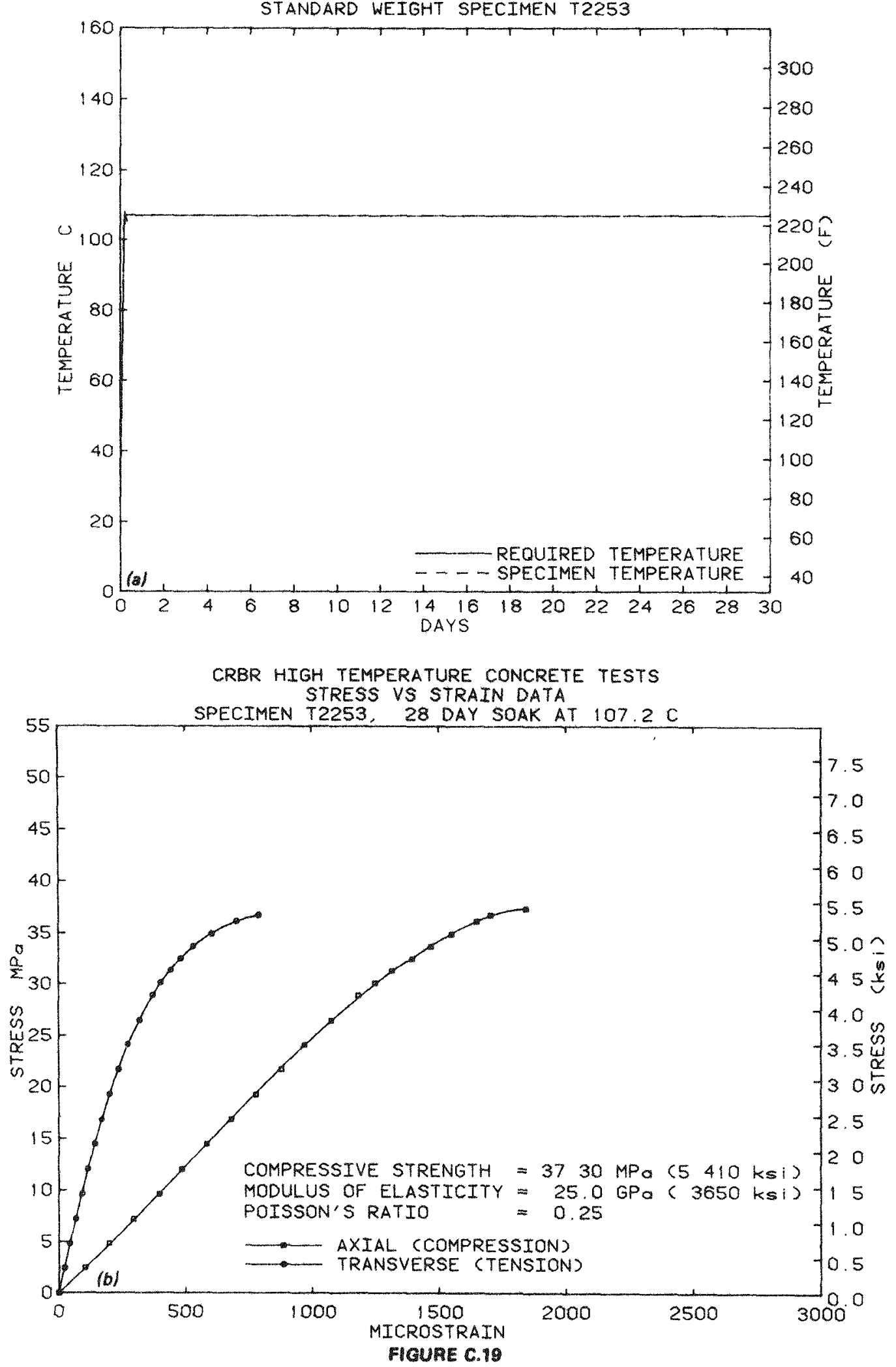


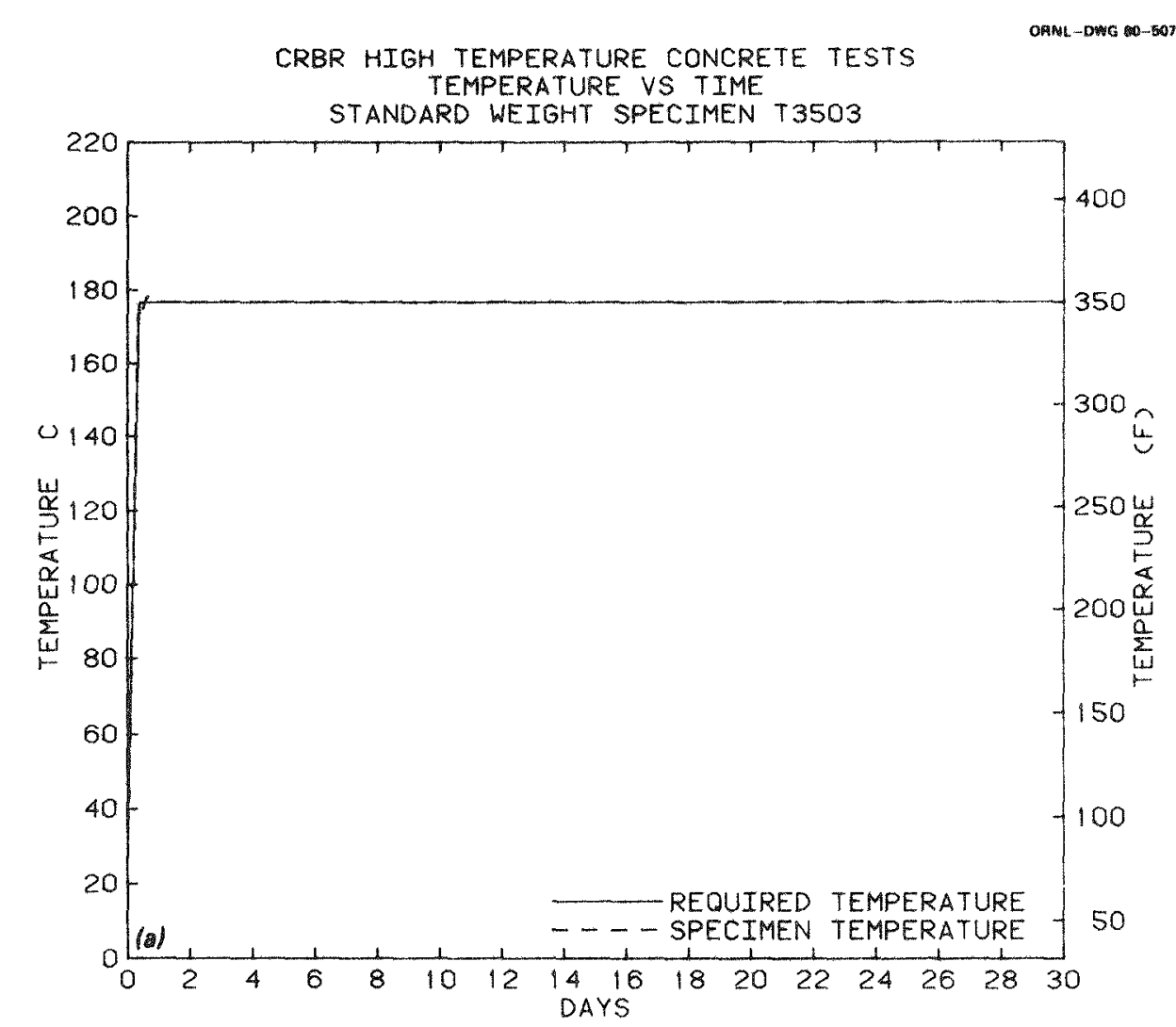

CRBR HIGH TEMPERATURE CONCRETE TESTS

STRESS VS STRAIN DATA

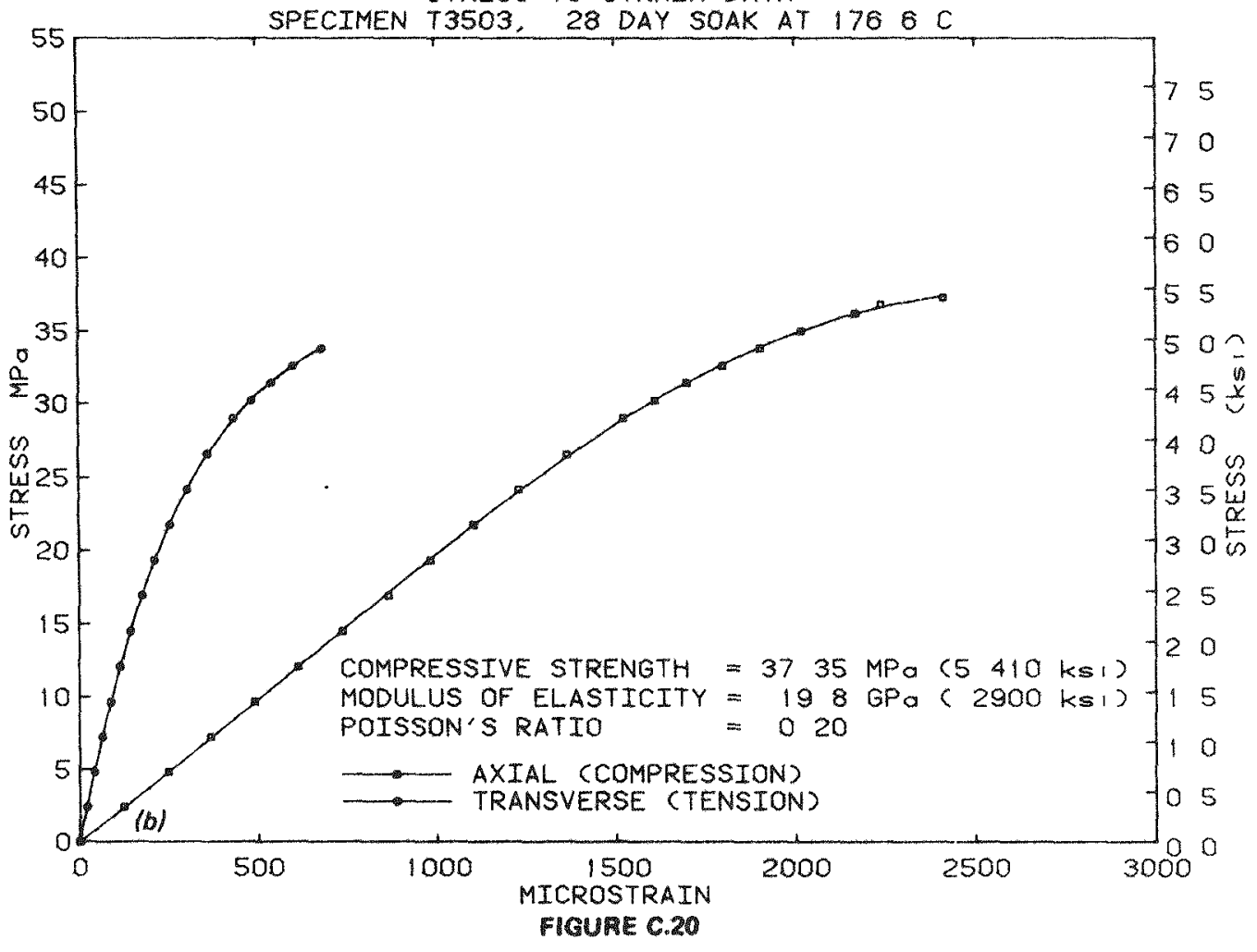




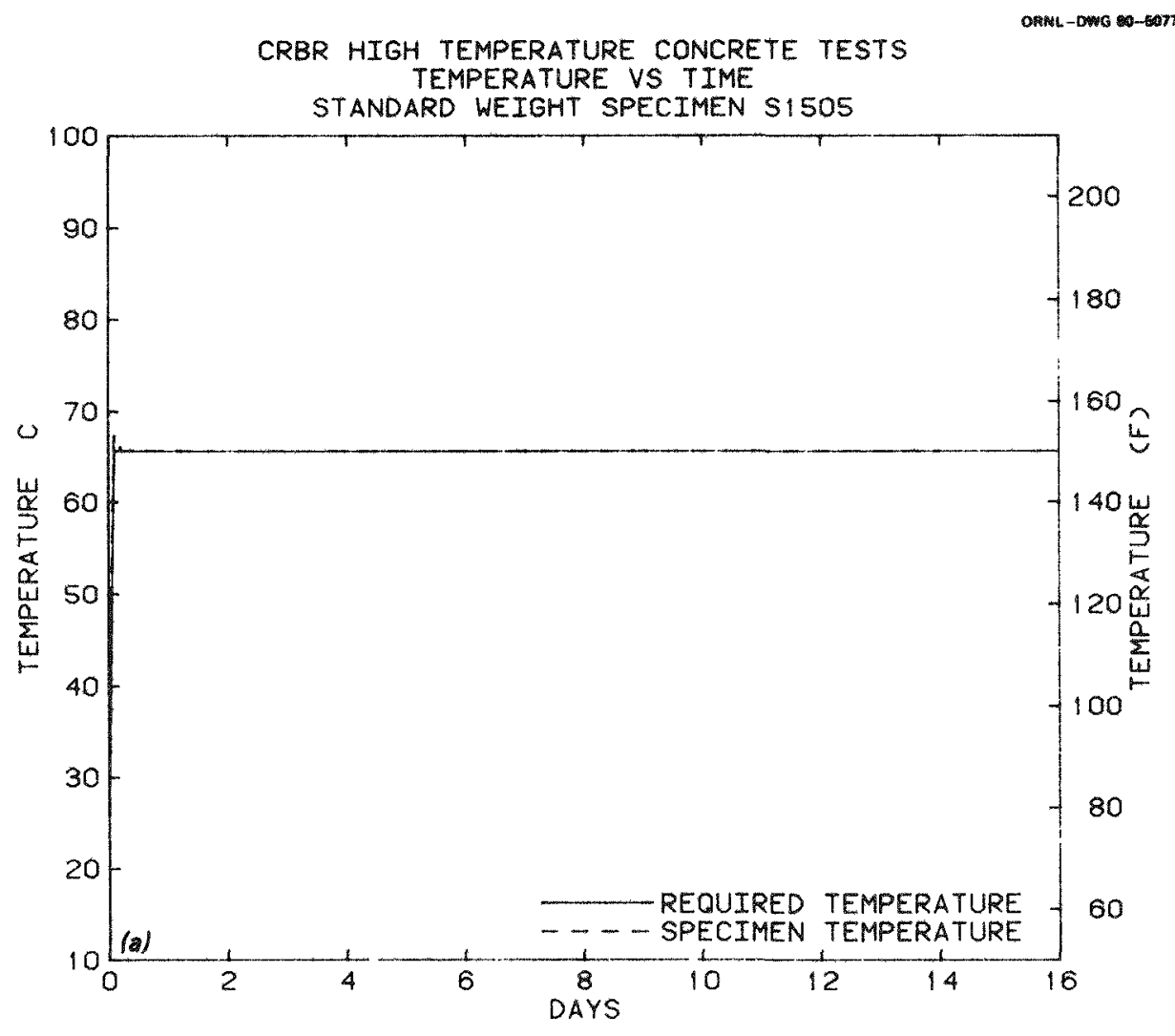

CRBR HIGH TEMPERATURE CONCRETE TESTS STRESS VS STRAIN DATA

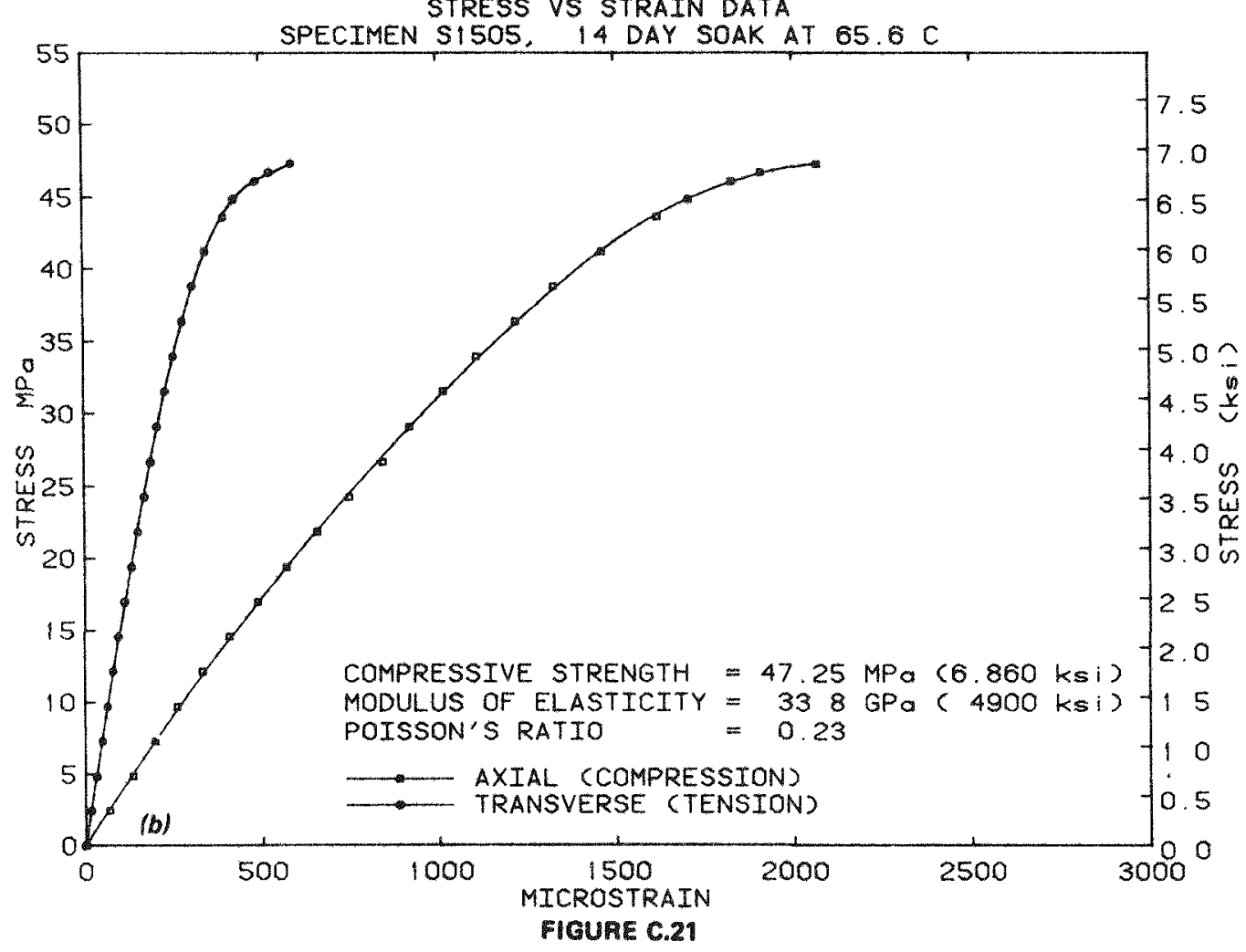




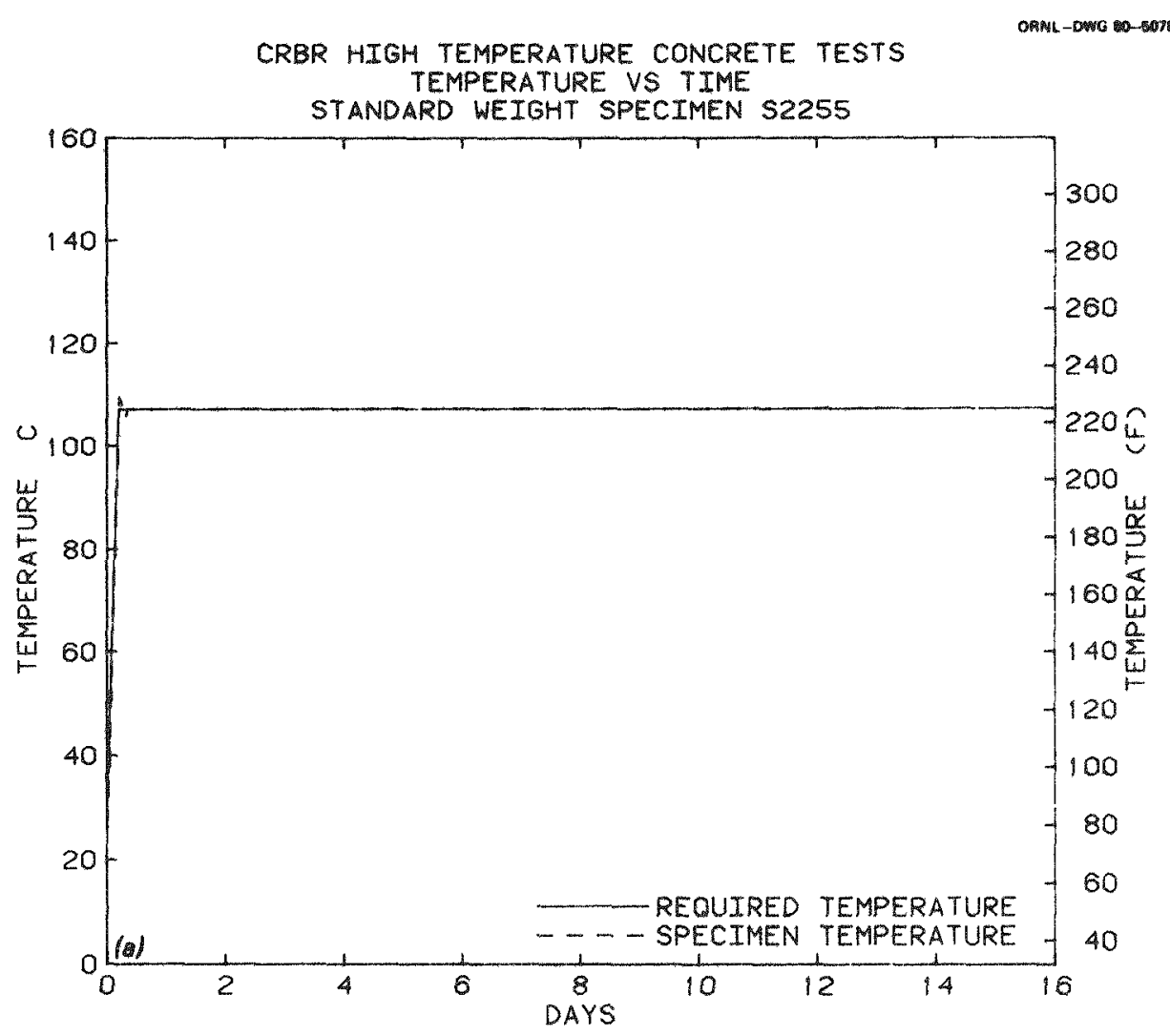

CRBR HIGH TEMPERATURE CONCKETE TESTS STRESS VS STRAIN DATA

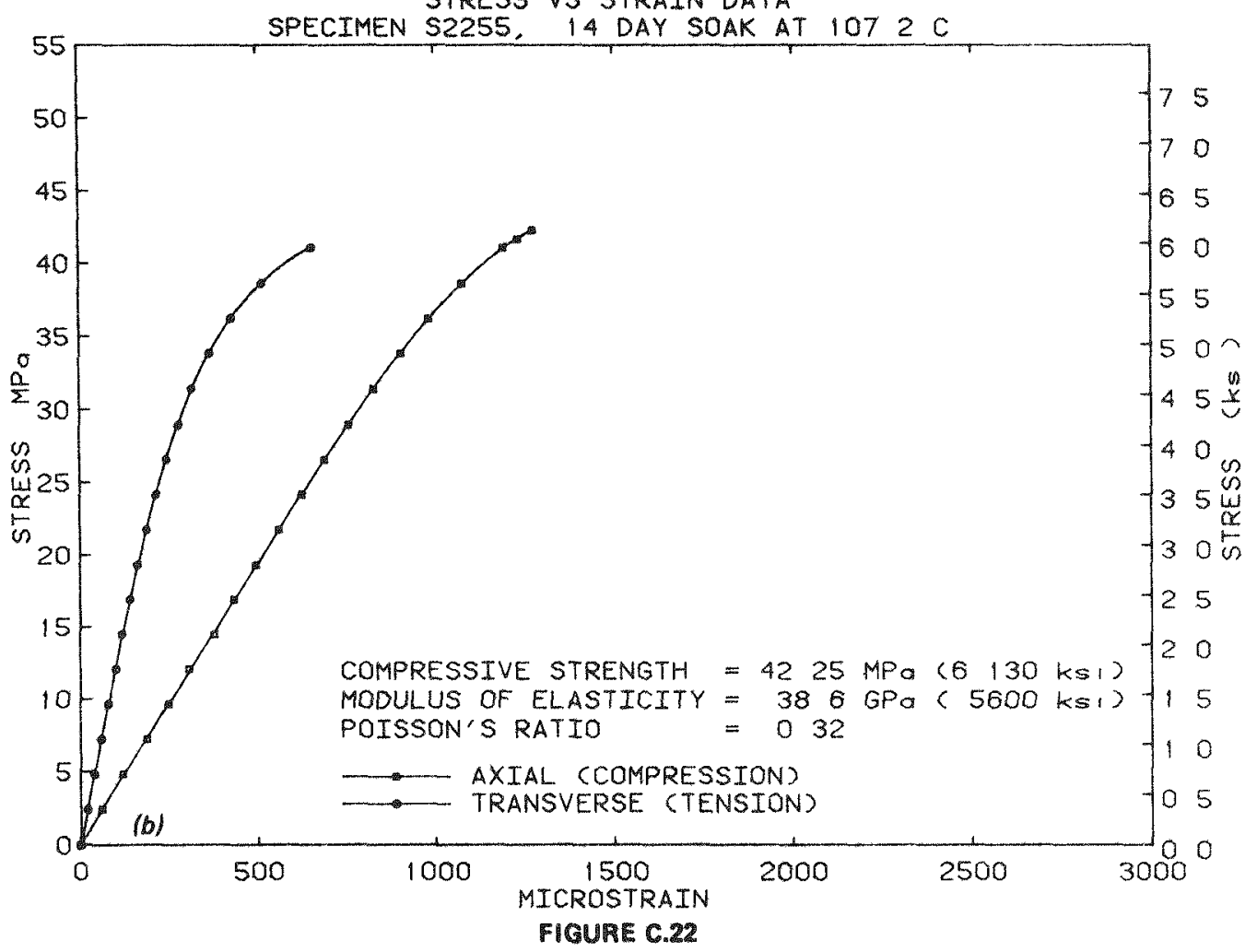



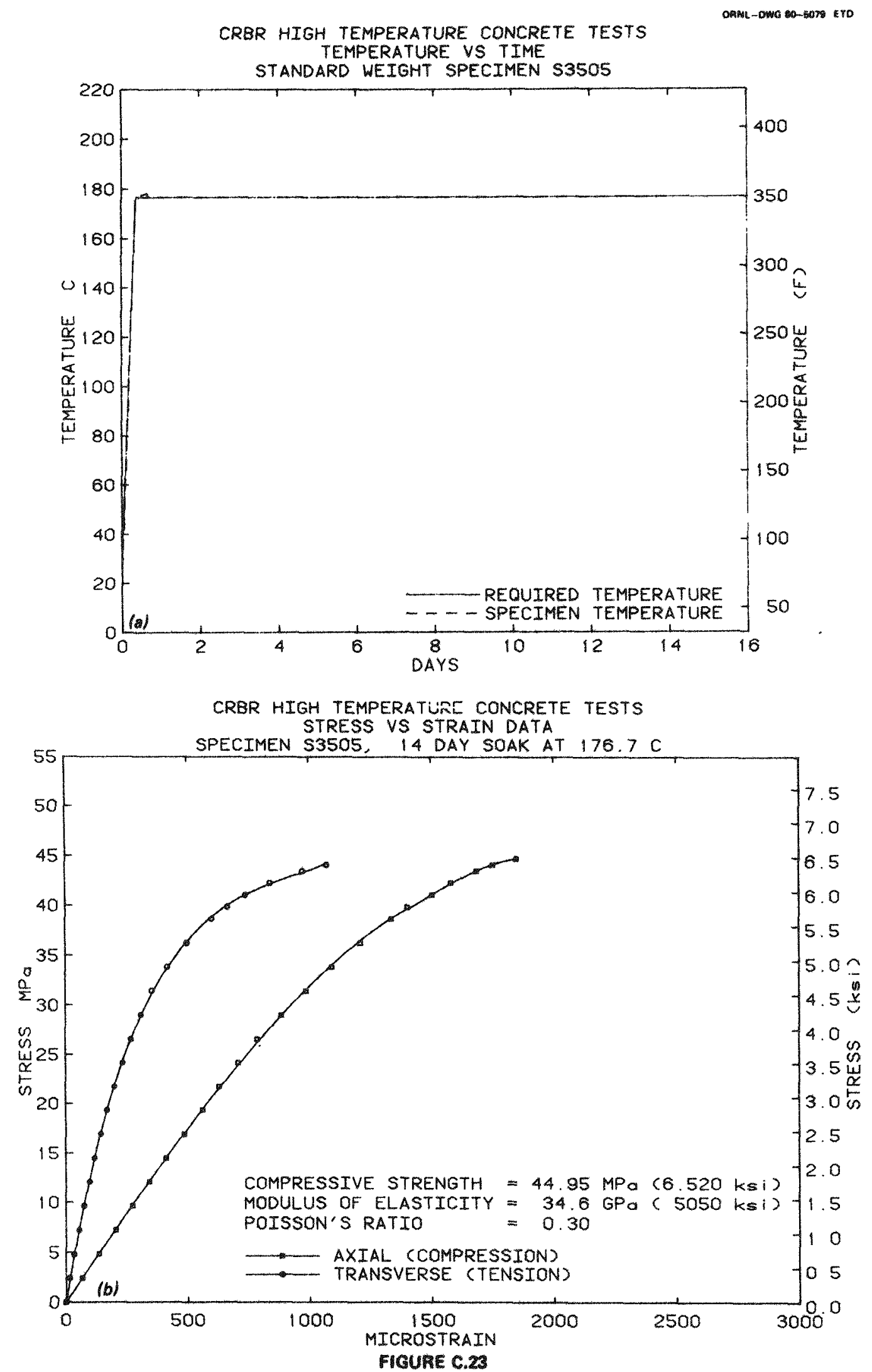


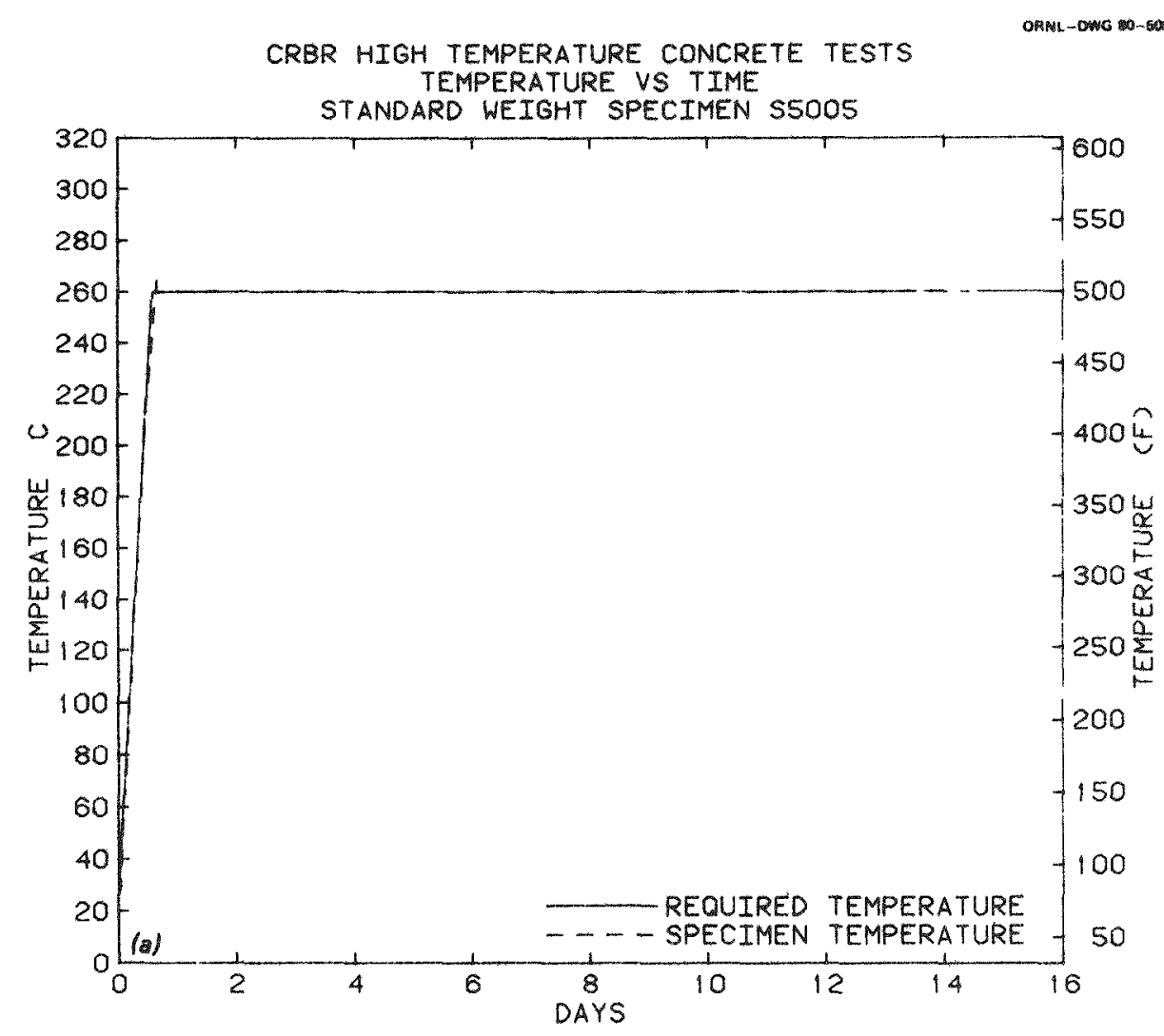

CRBR HIGH TEMPERATURE CONCRETE TESTS STRESS VS STRAIN DATA

SPECIMEN S5005, 14 DAY SOAK AT 260 O C

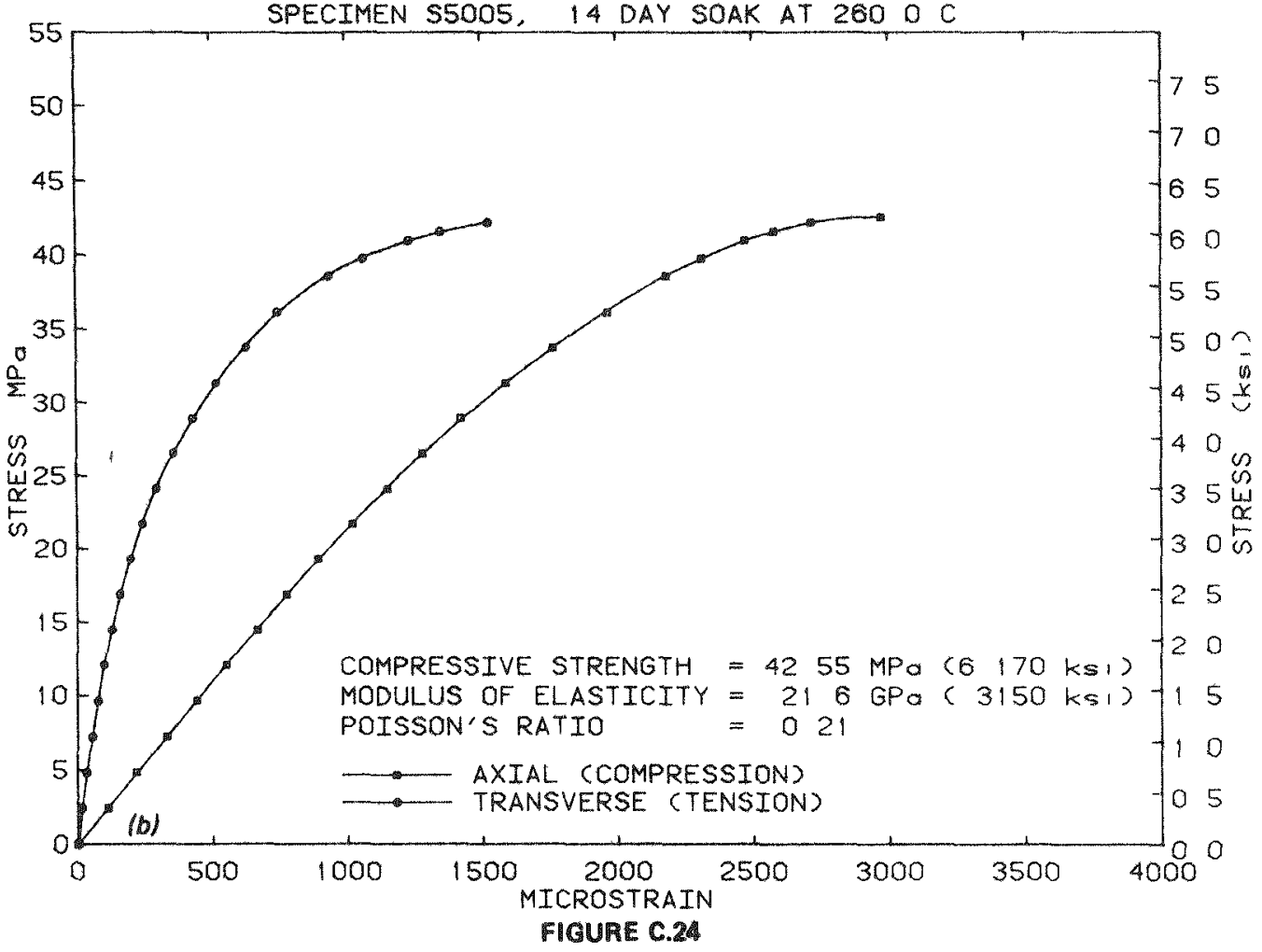



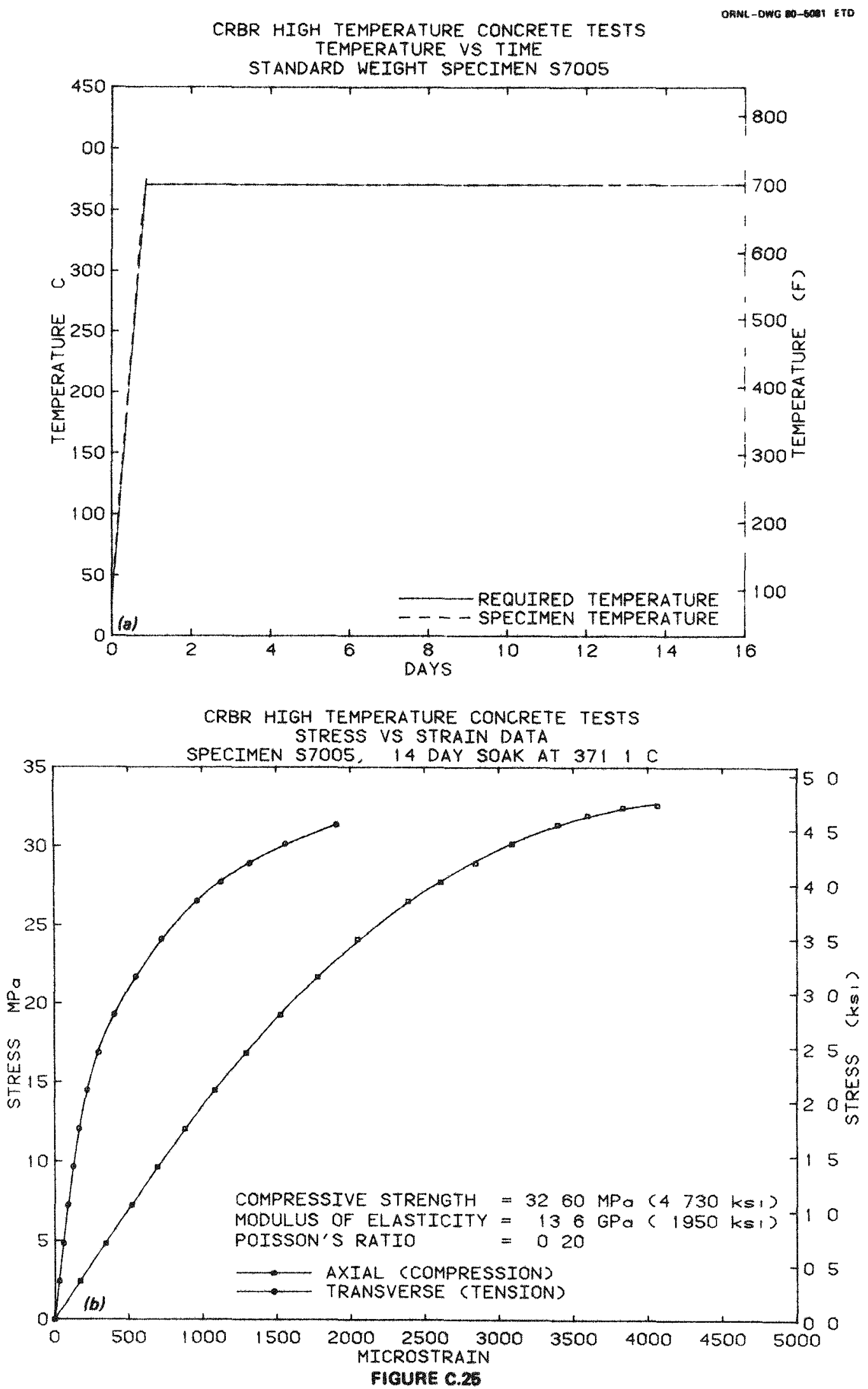
CRBR HIGH TEMPERATURE CONCRETE TESTS

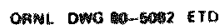
TEMPERATURE VS TIME

STANDARD WEIGHT SPECIMEN S9OOS

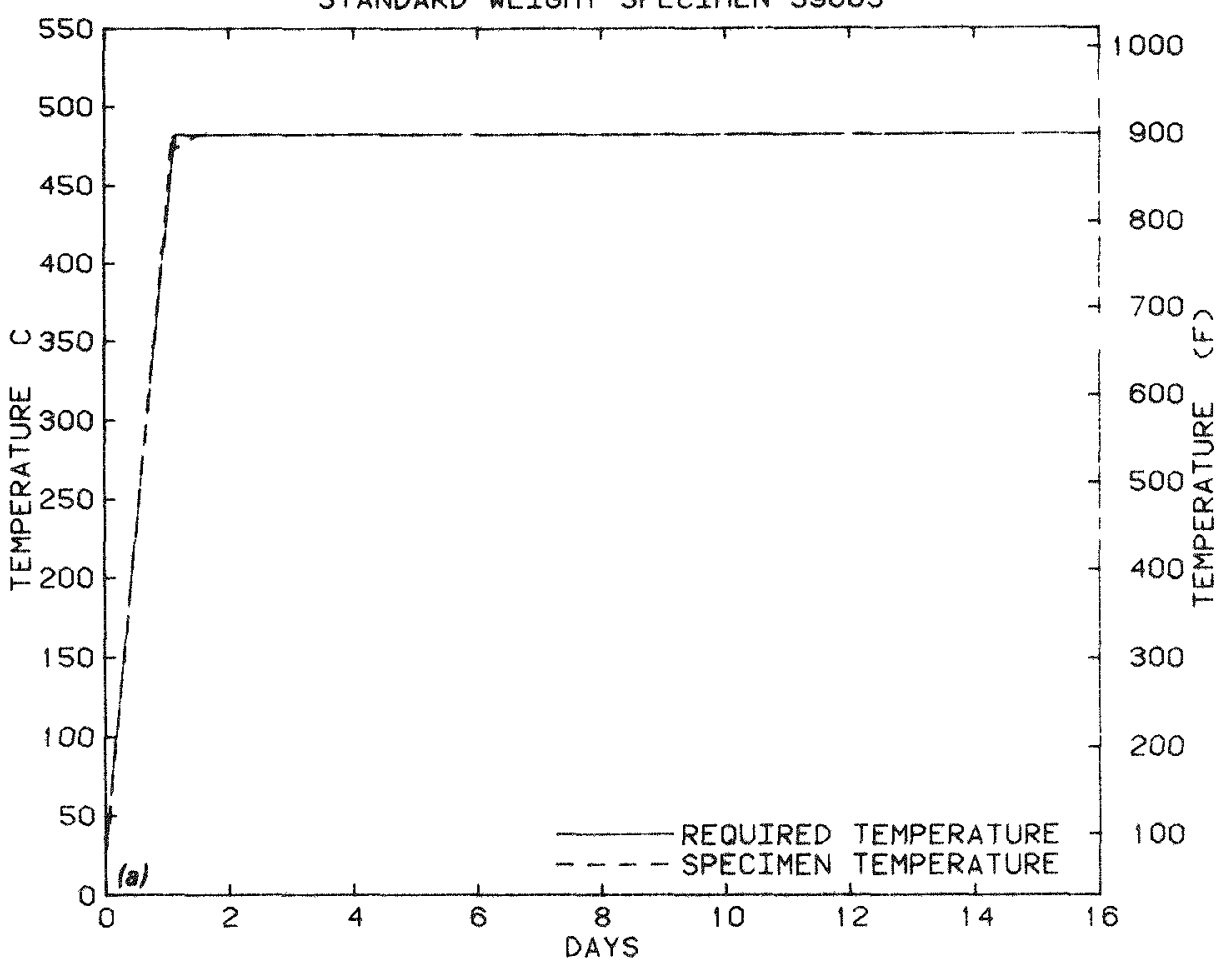

CRBR HIGH TEMPERATURE CONCRETE TESTS STRESS VS STRAIN DATA

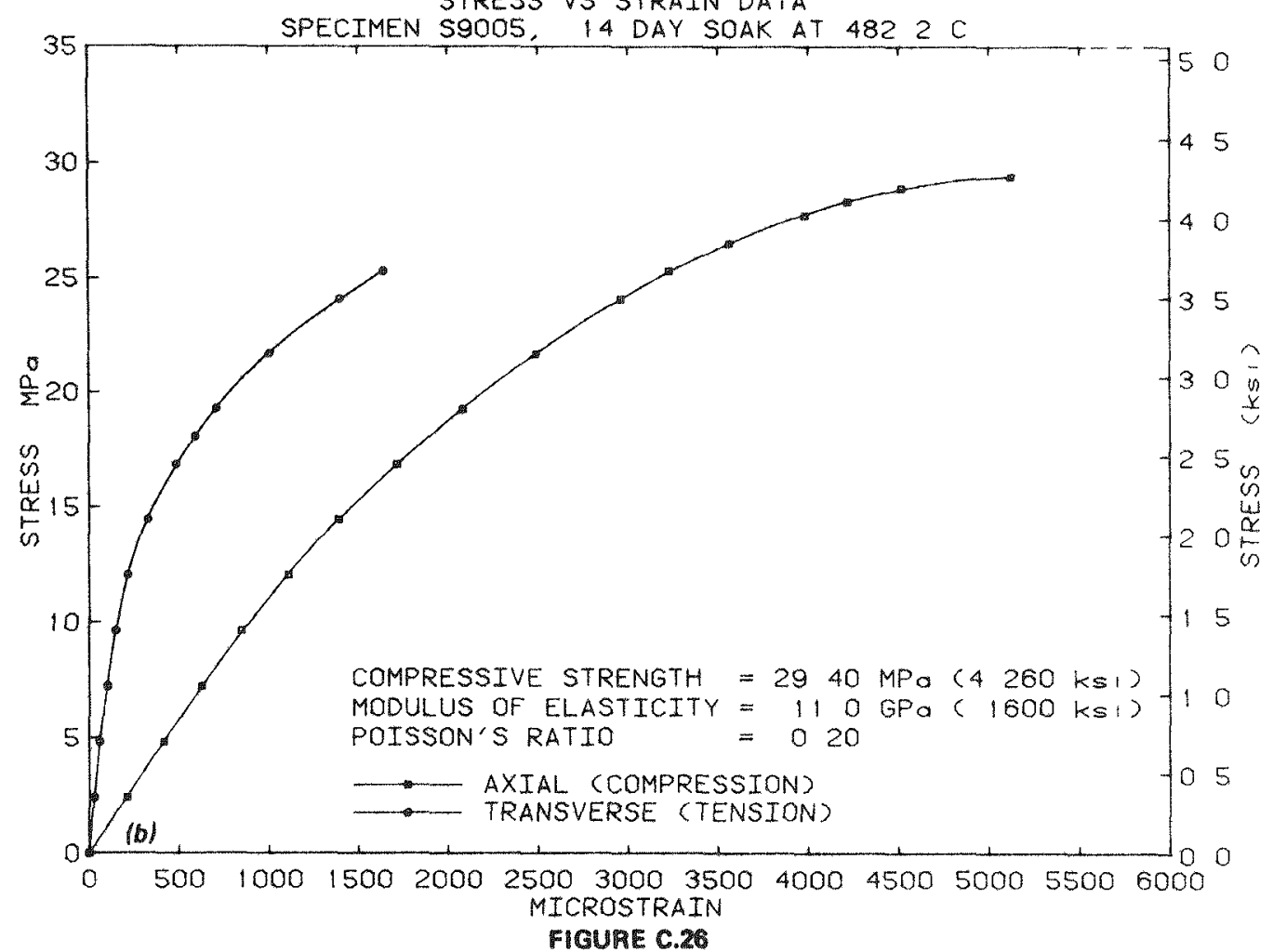




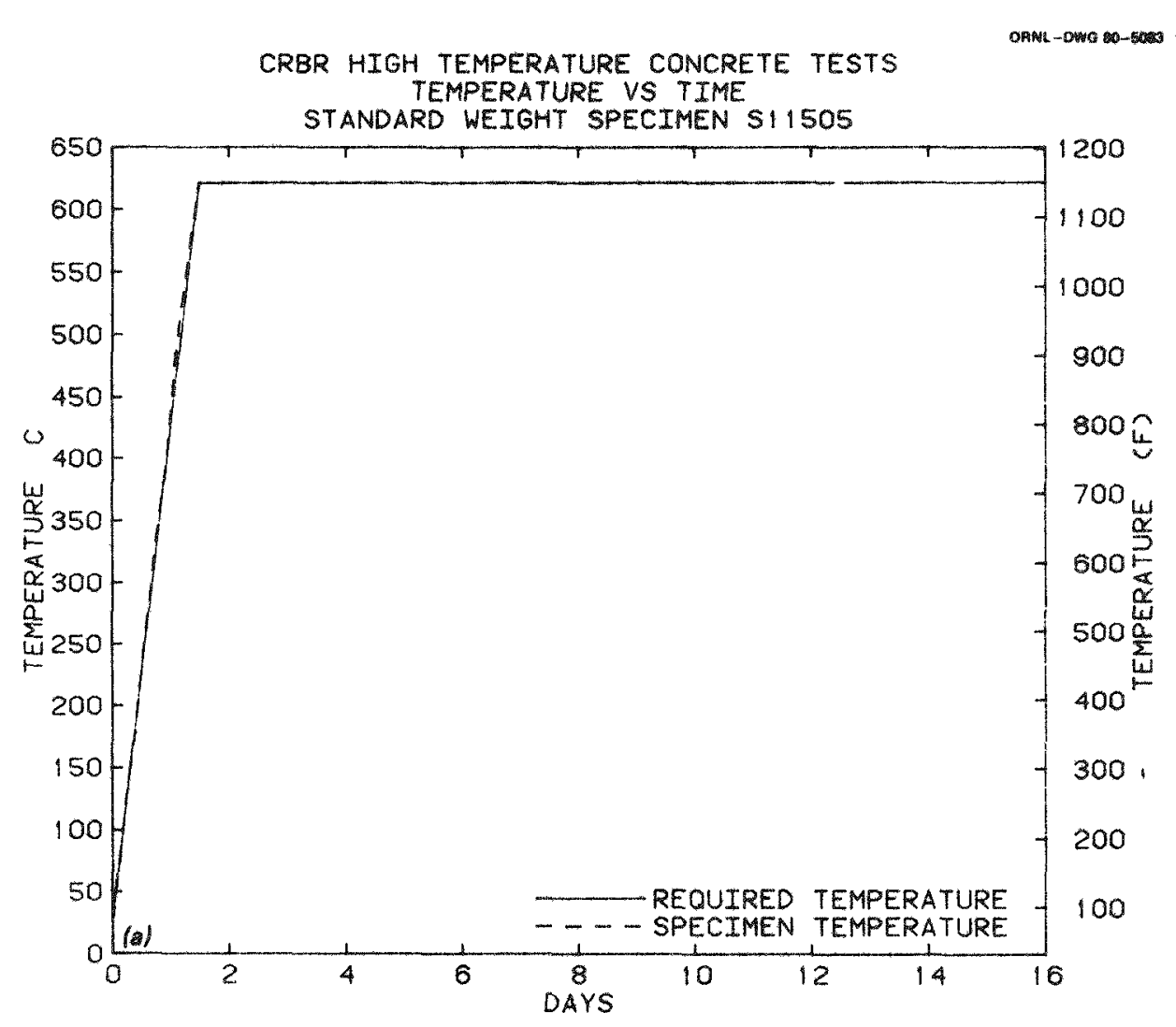

CRBR HIGH TEMPERATURE CONCRETE TESTS STRESS VS STRAIN DATA

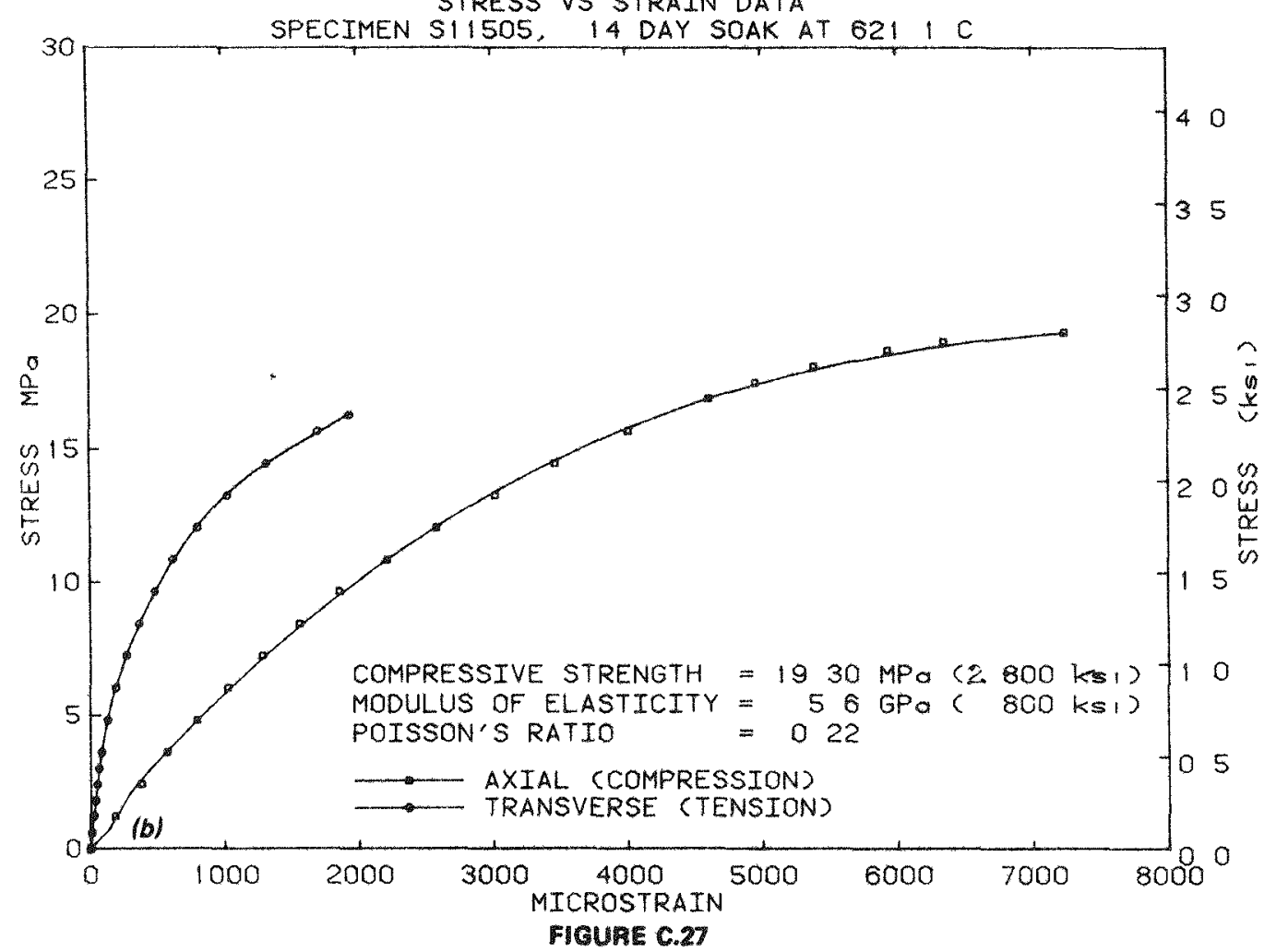



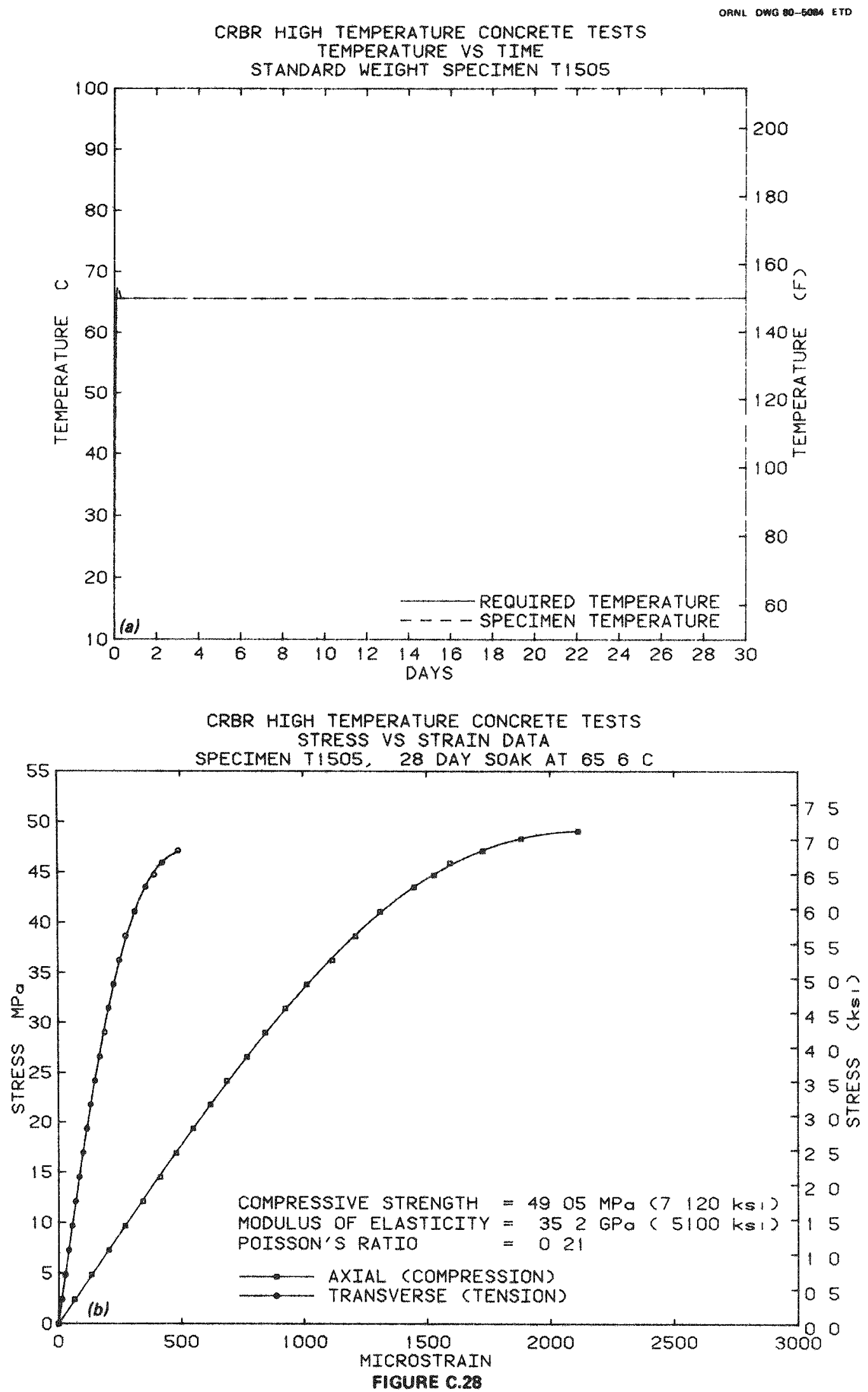
CRBR HIGH TEMPERATURE CONCRETE TESTS

OANE-DWG TEMPERATURE VS TIME

STANDARD WEIGHT SPECIMEN T2255

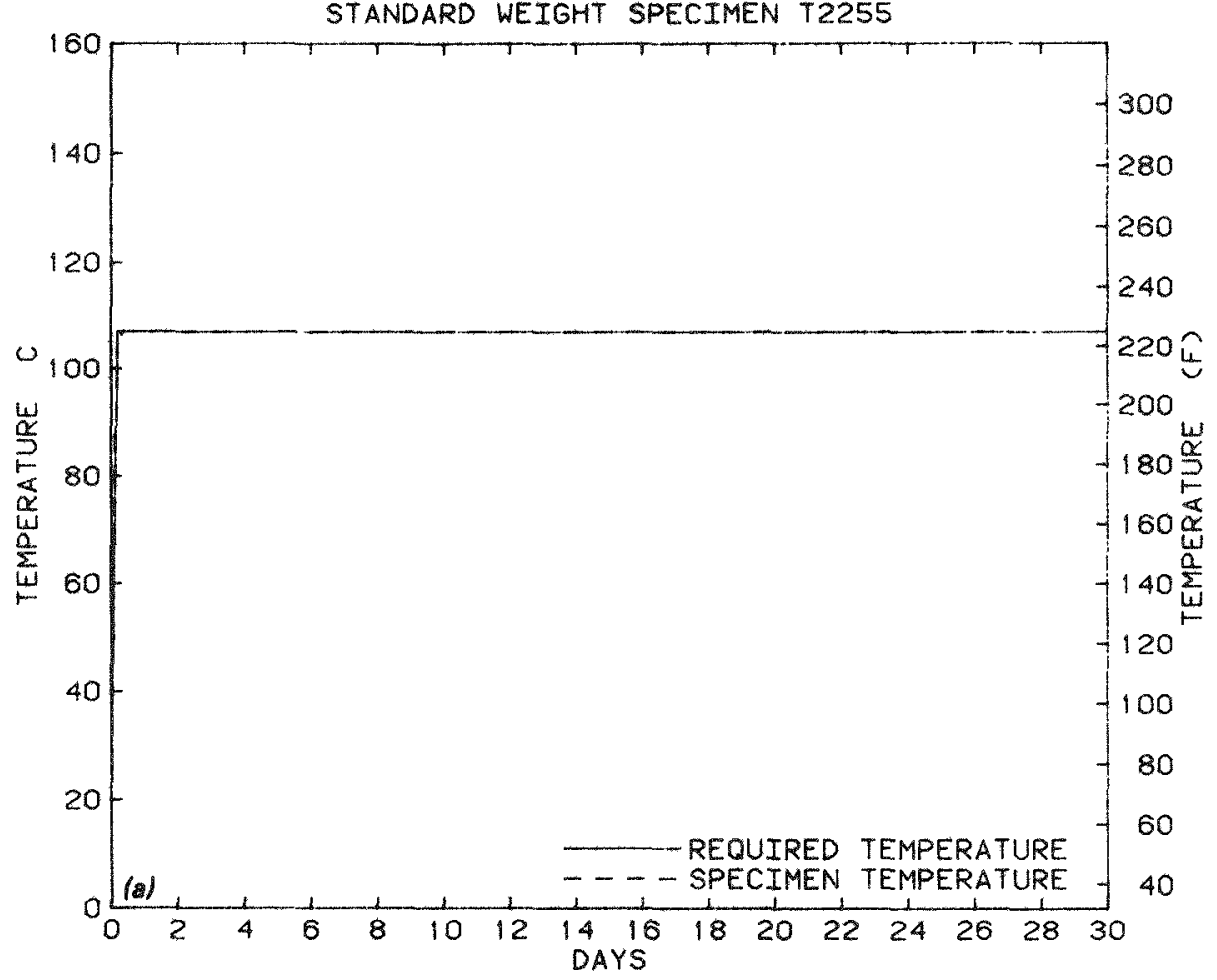

CRBR HIGH TEMPERATURE CONCRETE TESTS STRESS VS STRAIN DATA

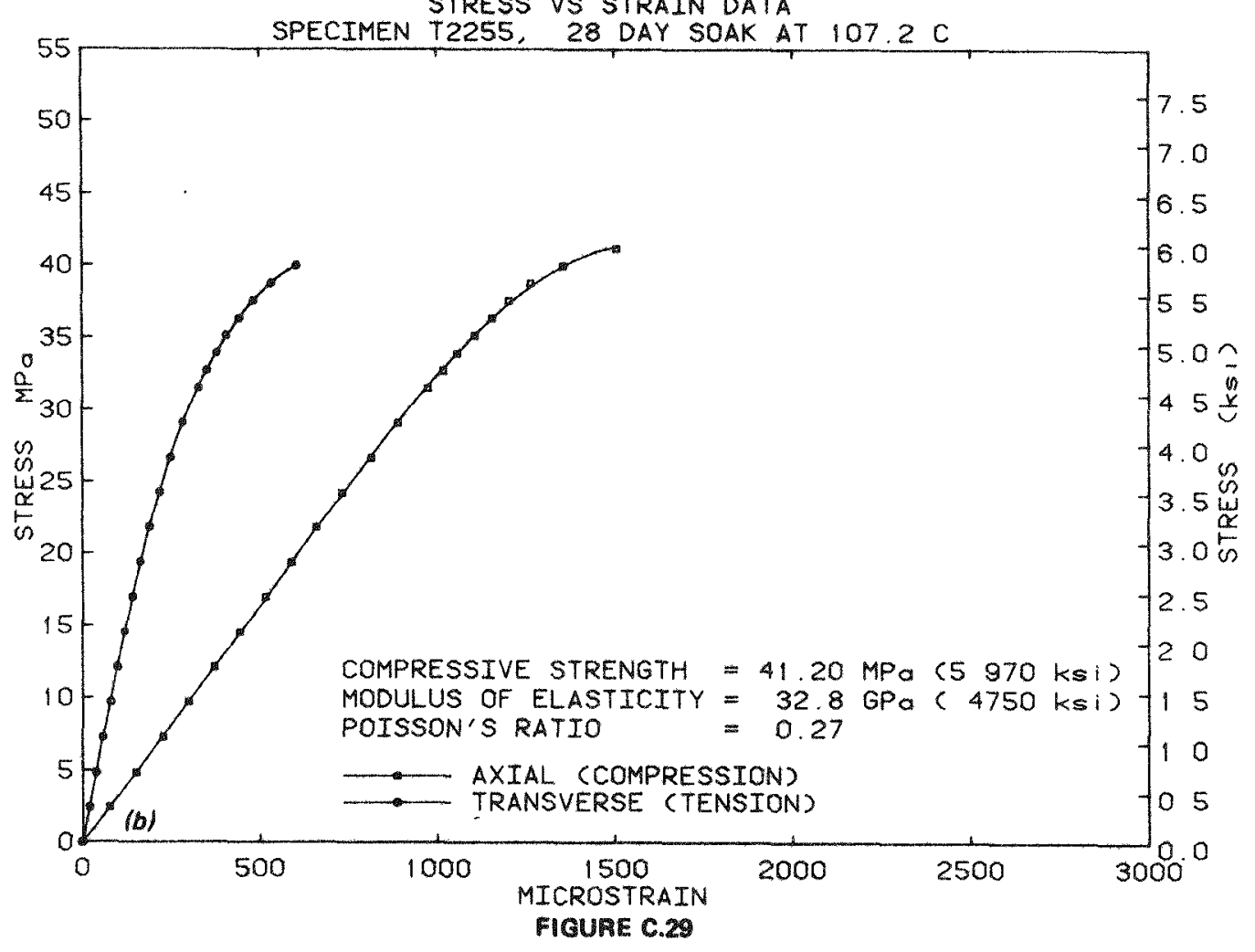



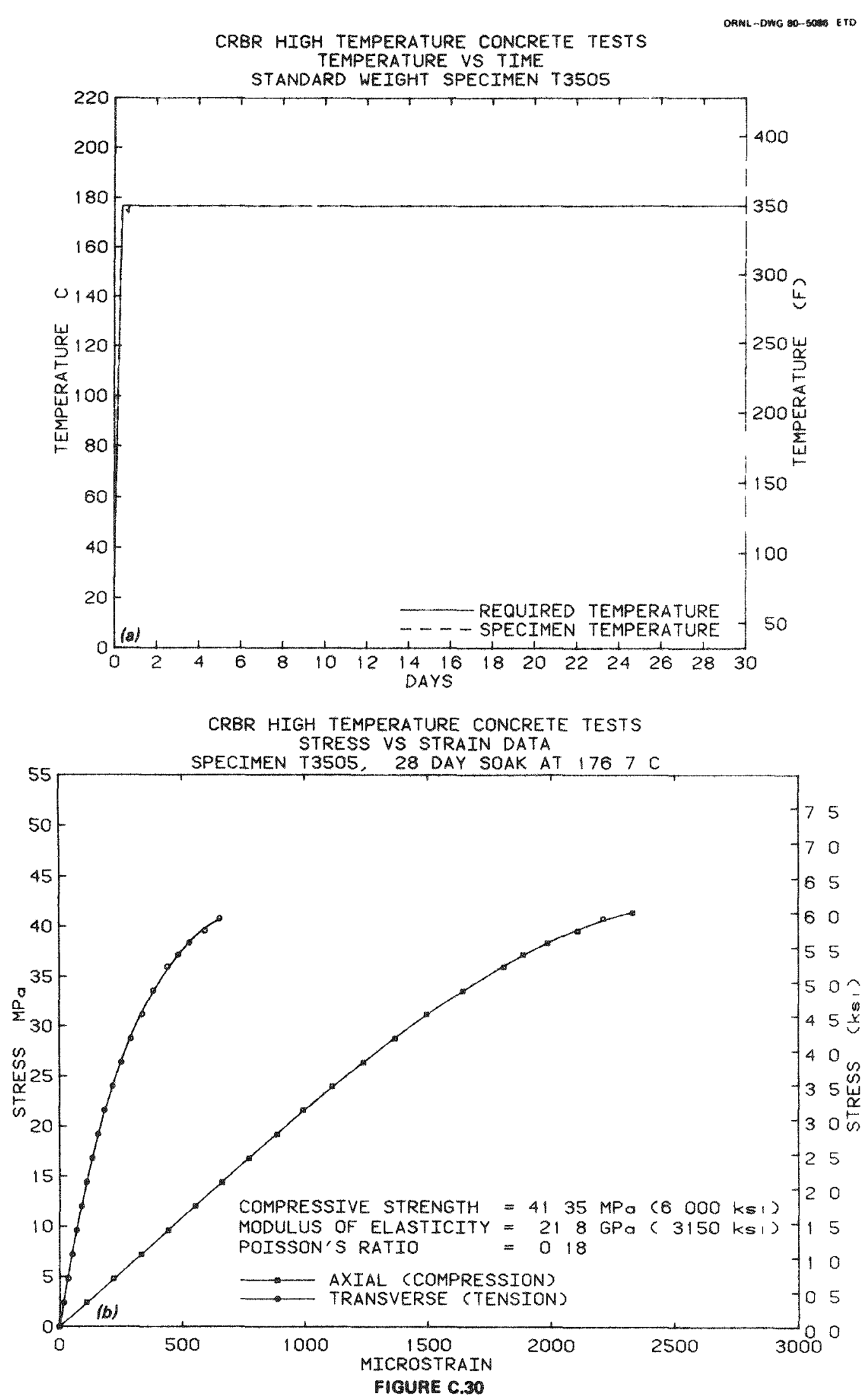
CRBR HIGH TEMPERATURE CONCRETE TESTS

TEMPERATURE VS TIME

LIGHTWEIGHT SPECIMEN L1508

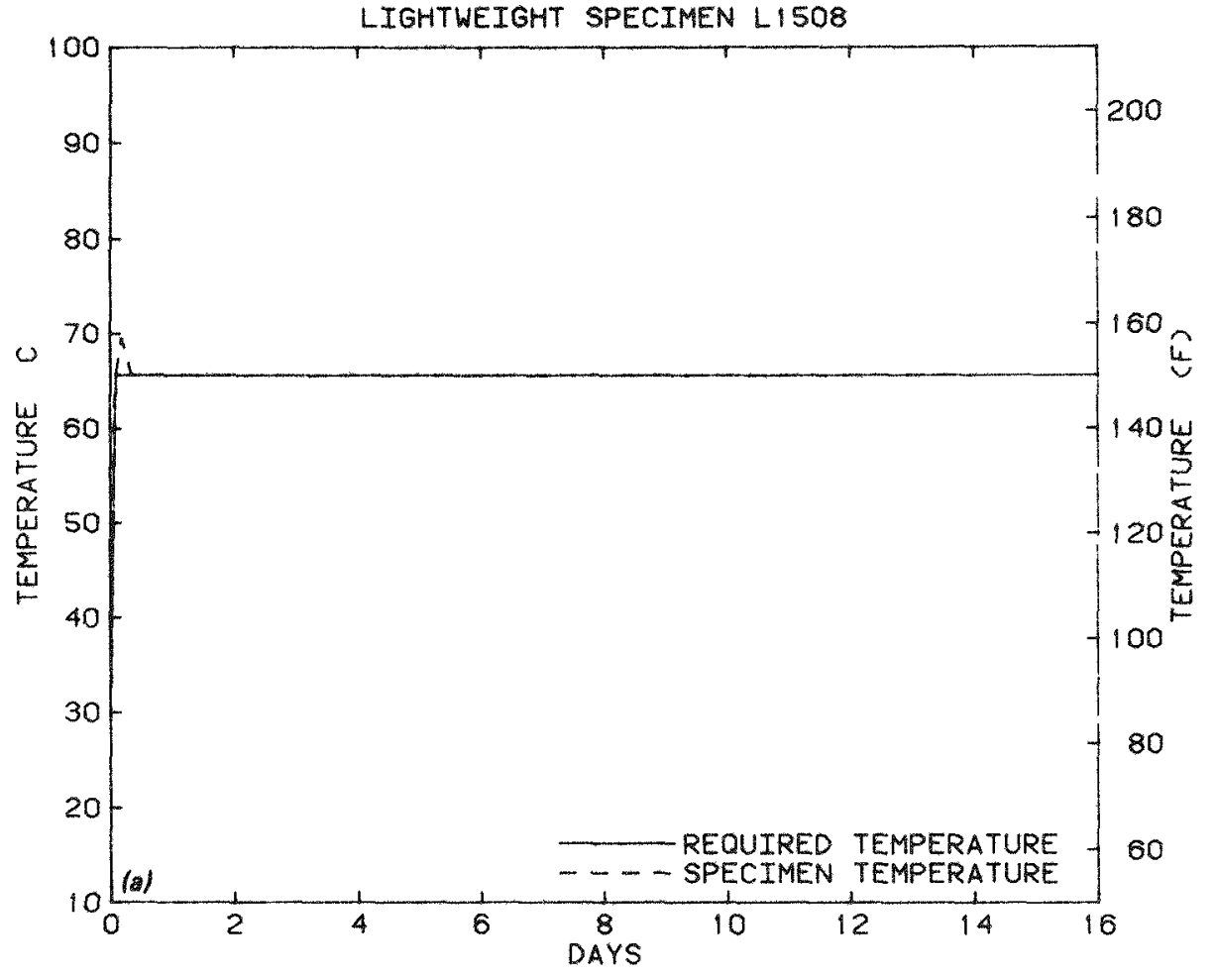

CRBR HIGH: TEMFERATURE CONCRETE TESTS

STRESS VS STRAIN DATA

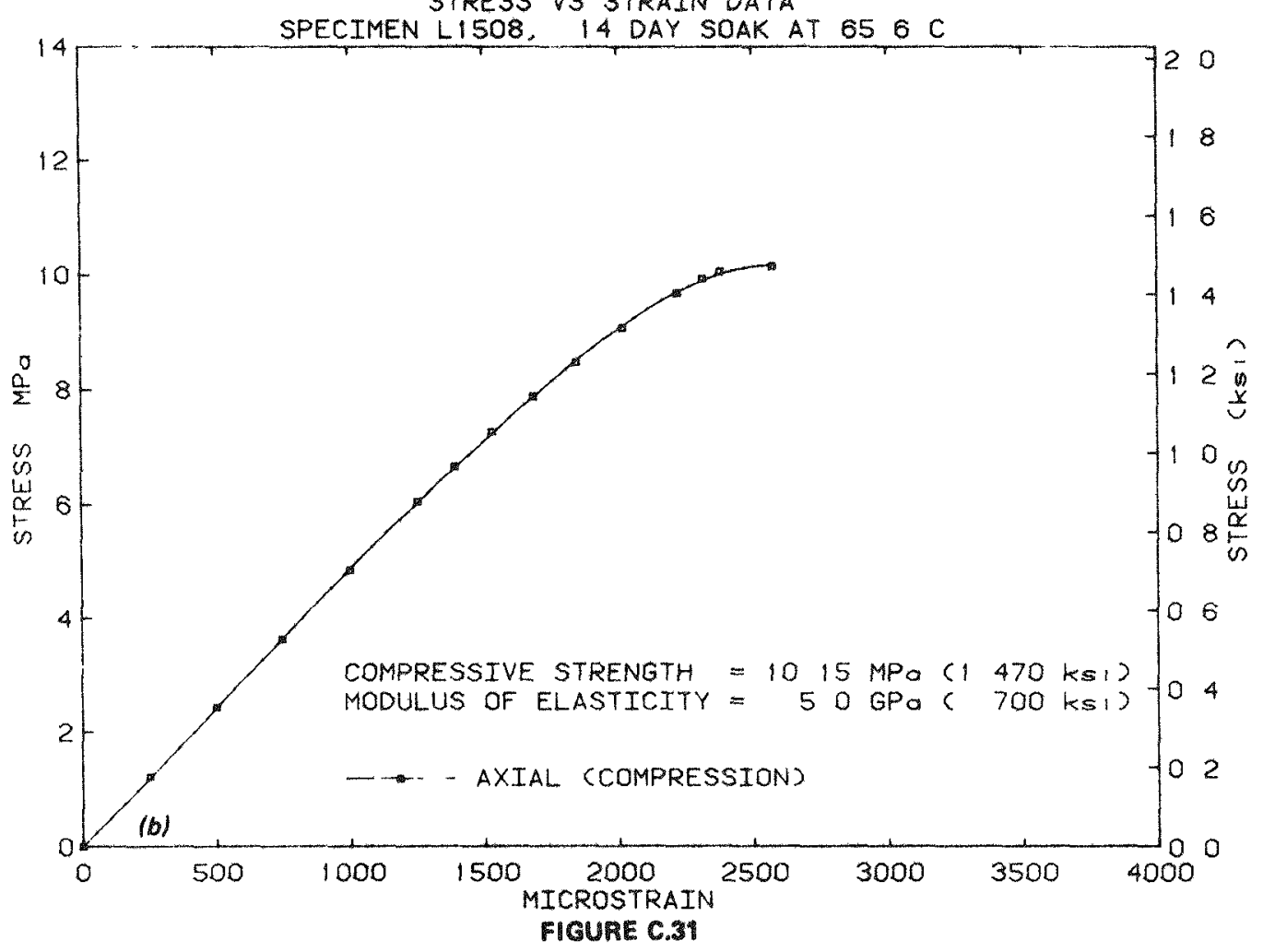




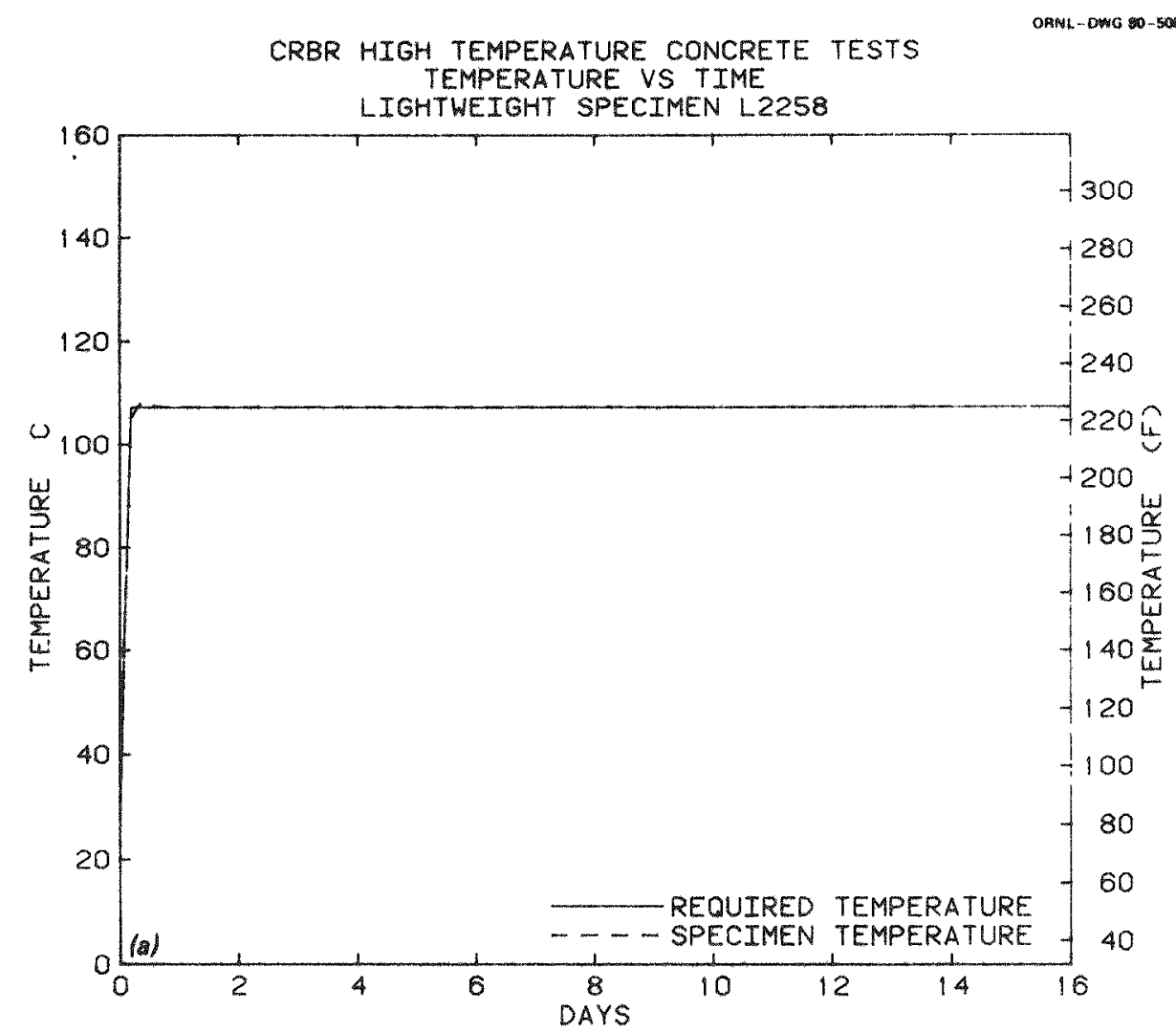

CRBR HIGH TEMPERATURE CONCRETE TESTS STRESS VS STRAIN DATA

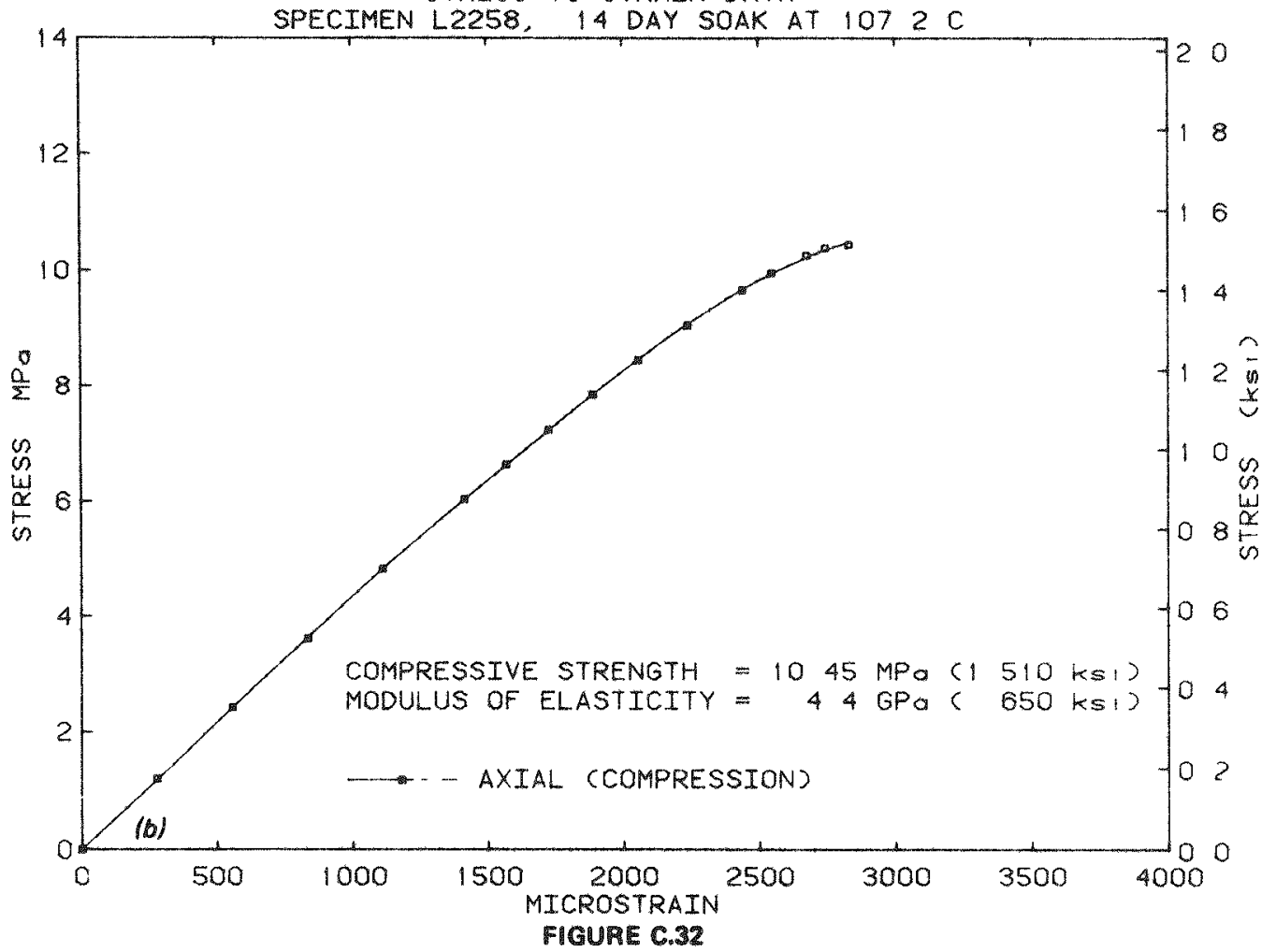




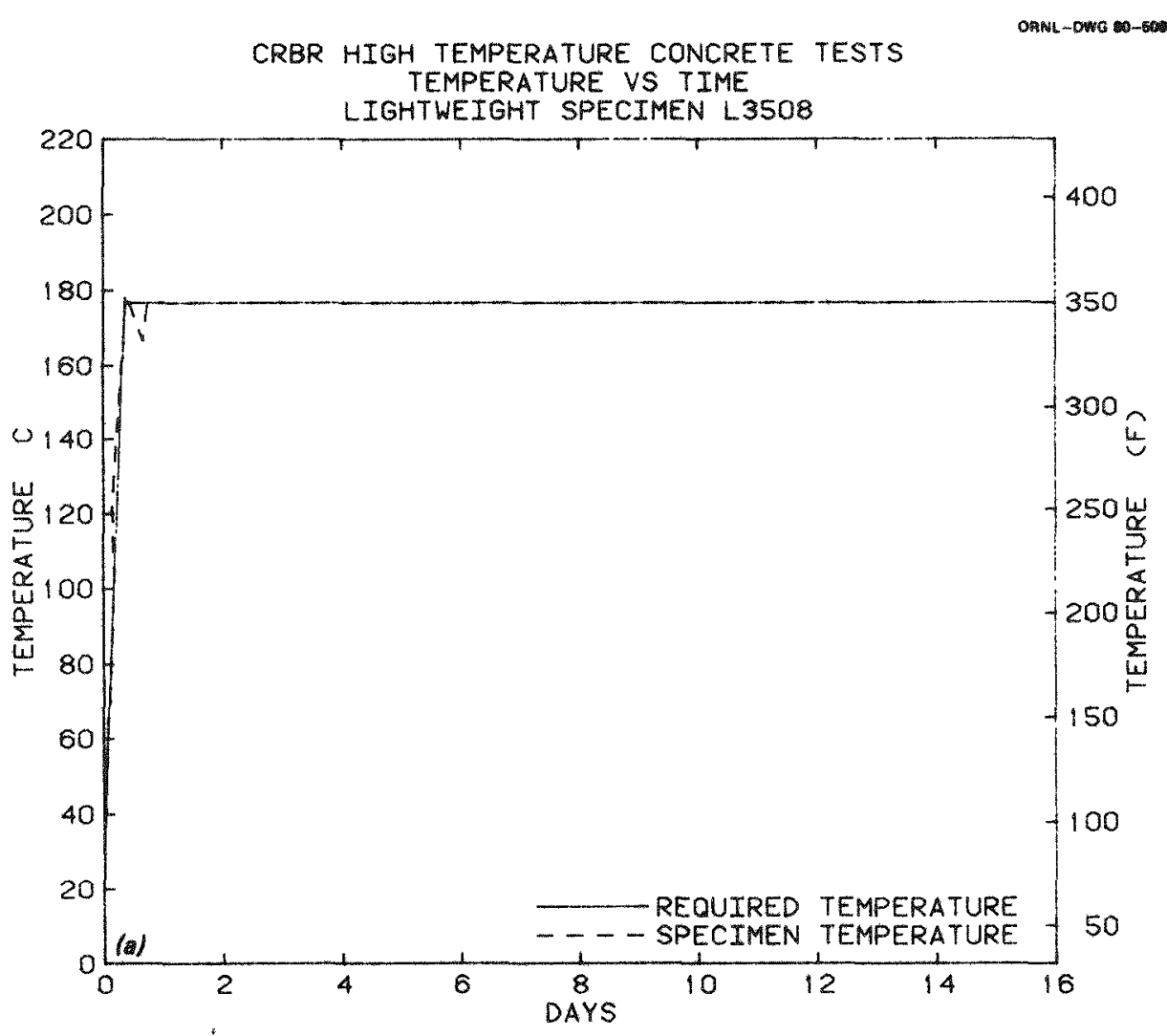

CRBR HIGH TEMPERATURE CONCRETE TESTS STRESS VS STRAIN DATA

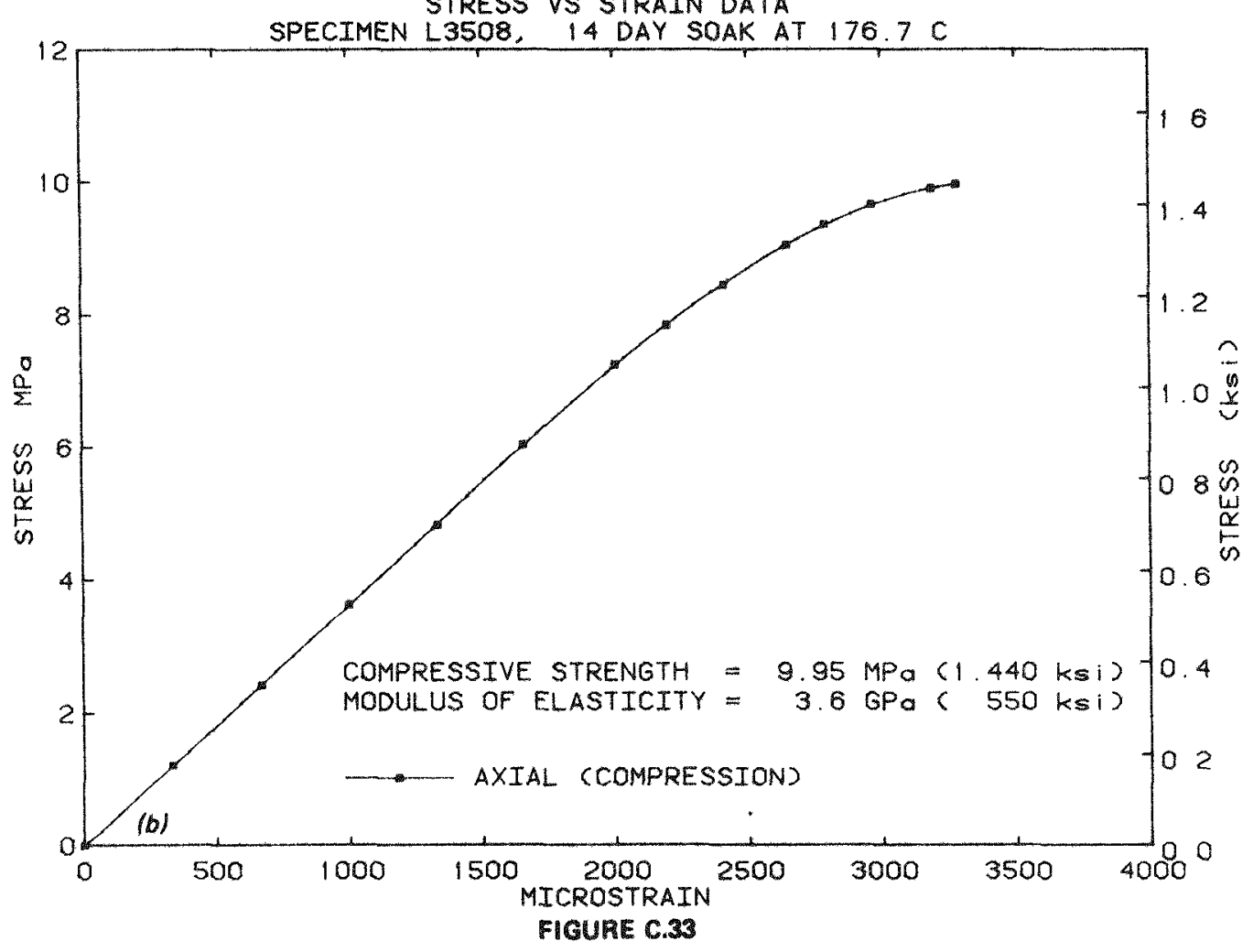


CRBR HIGH TEMPERATURE CONCRETE TESTS TEMPERATURE VS TIME

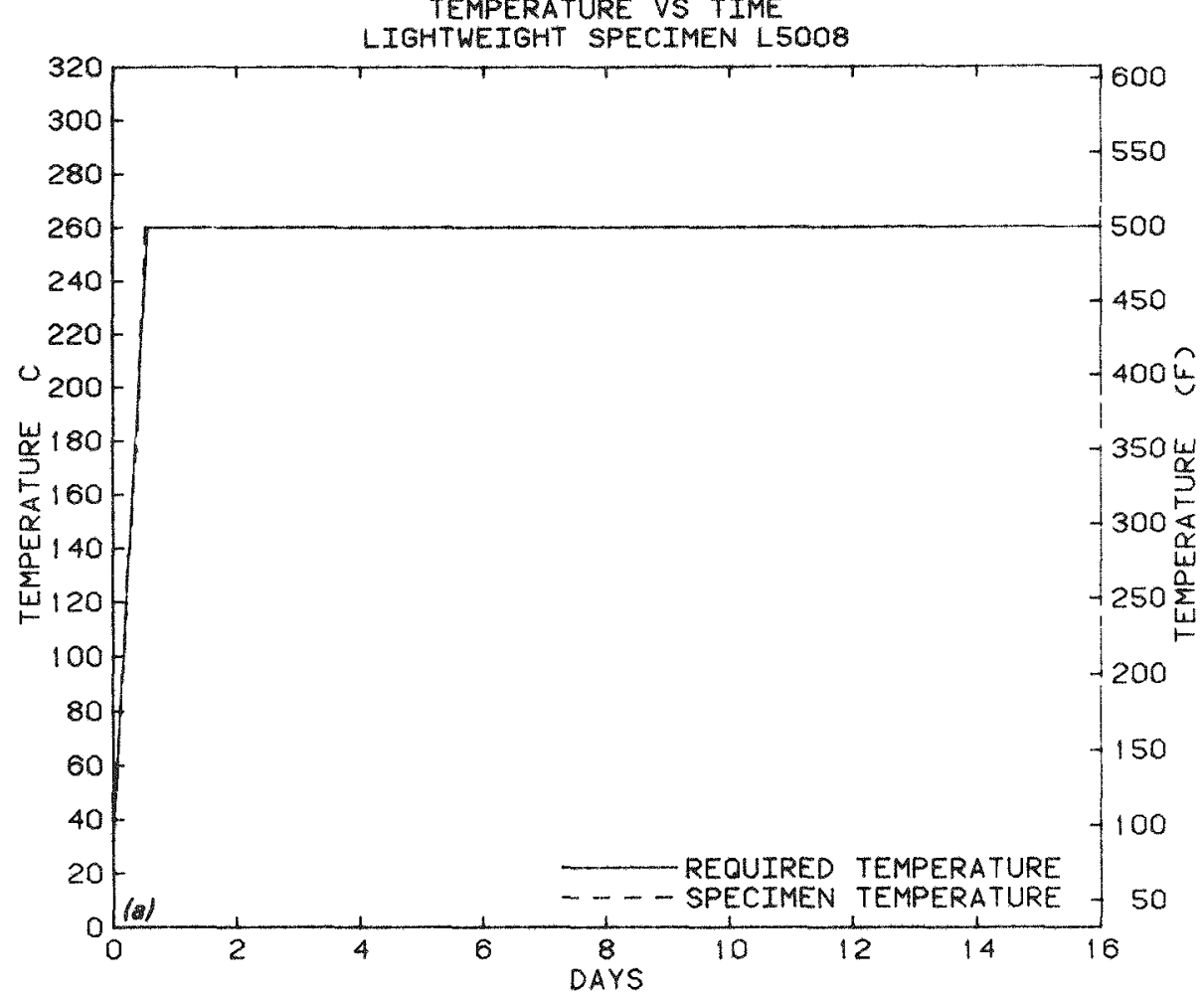

CRBR HIGH TEMPERATURE CONCRETE TESTS STRESS VS STRAIN DATA

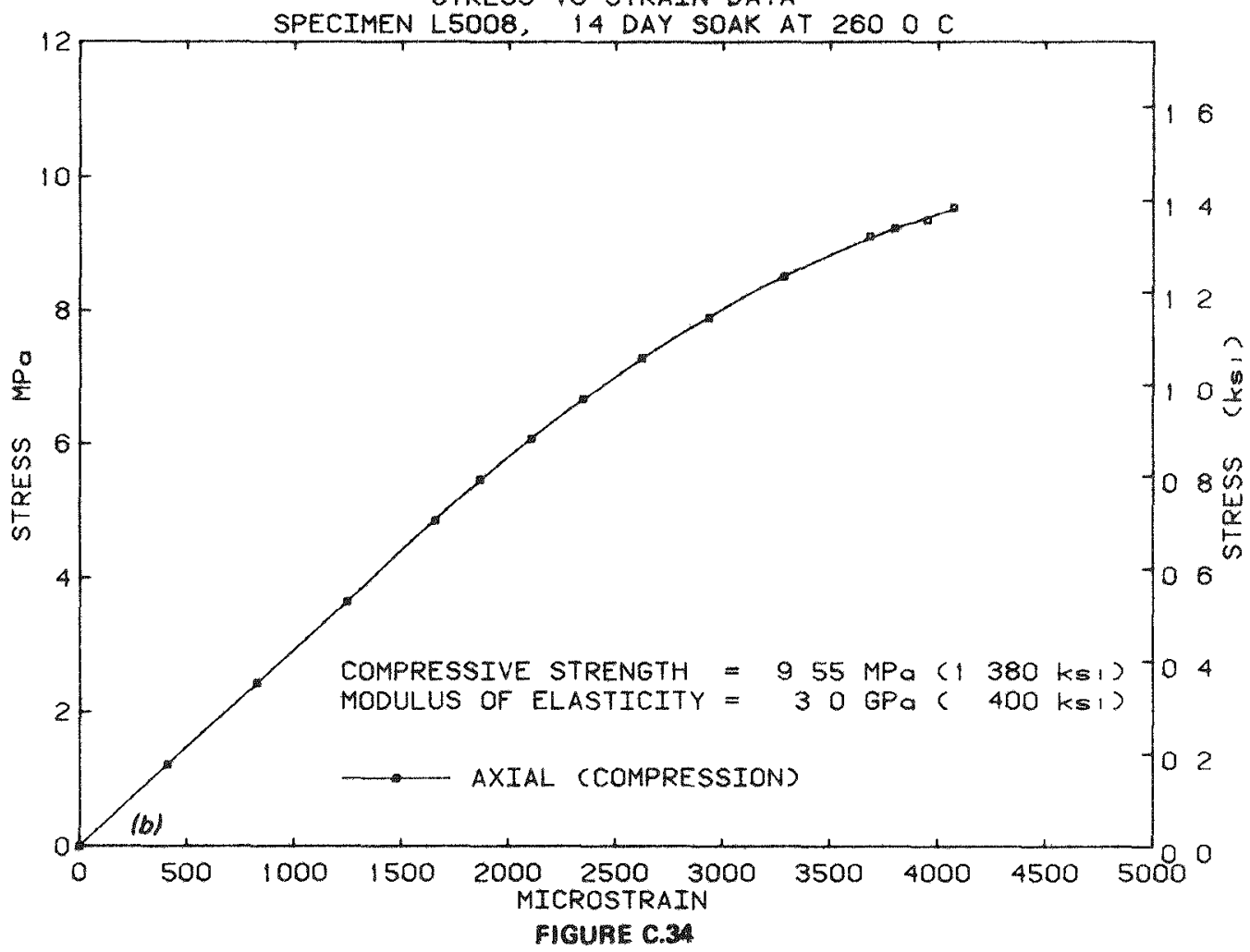




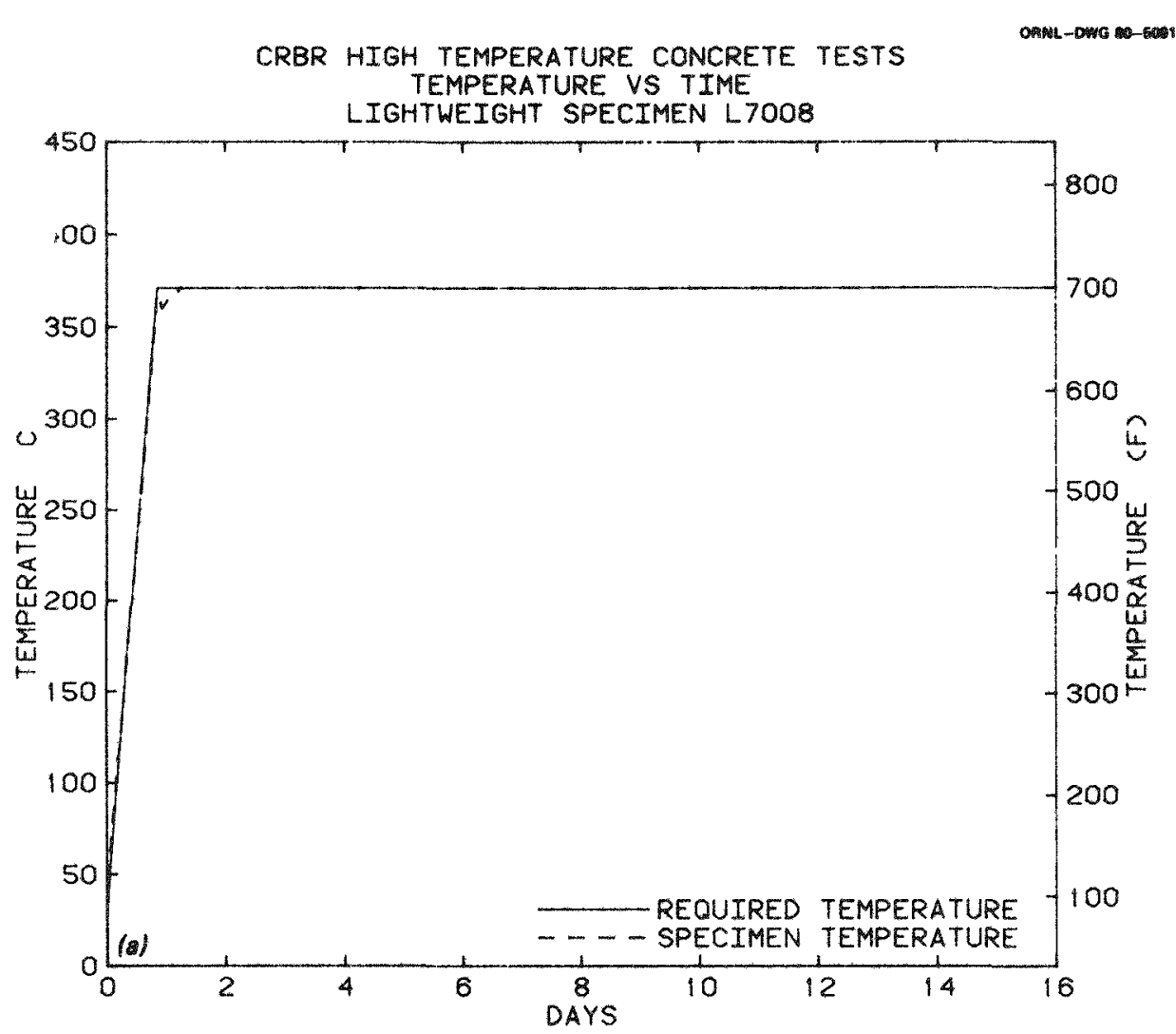

CRBR HIGH TEMPERATURE CONCRETE TESTS STRESS VS STRAIN DATA

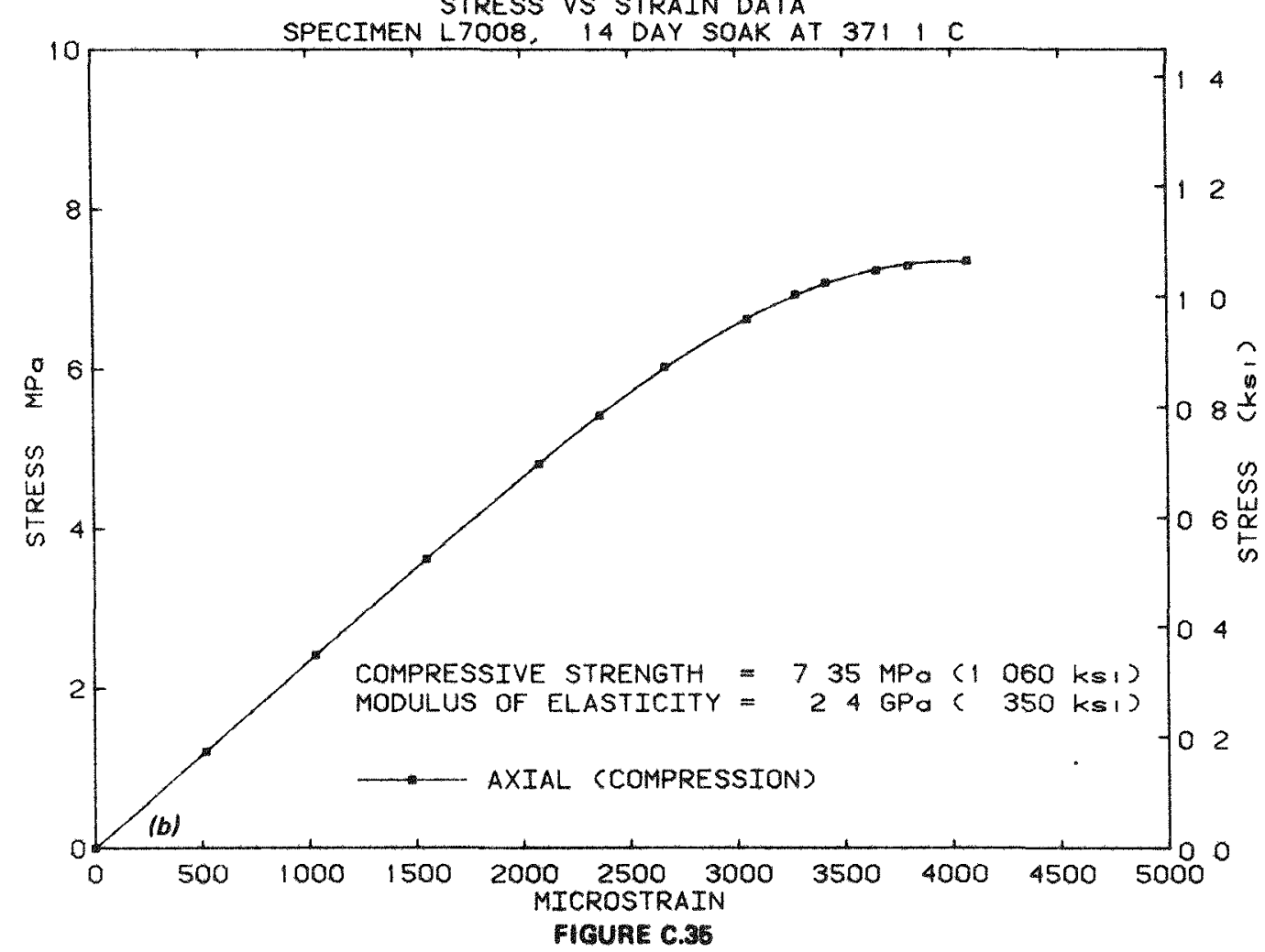



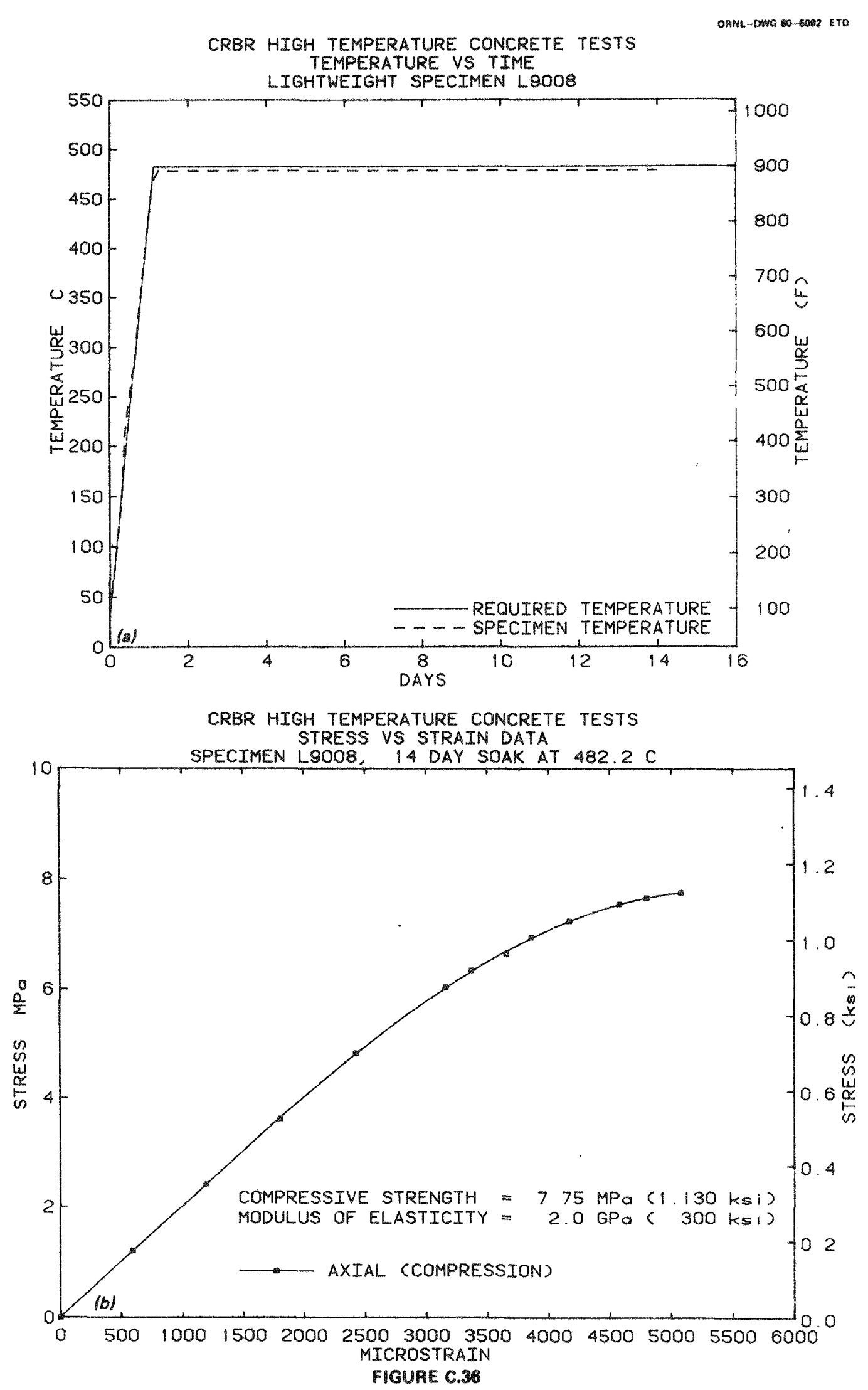


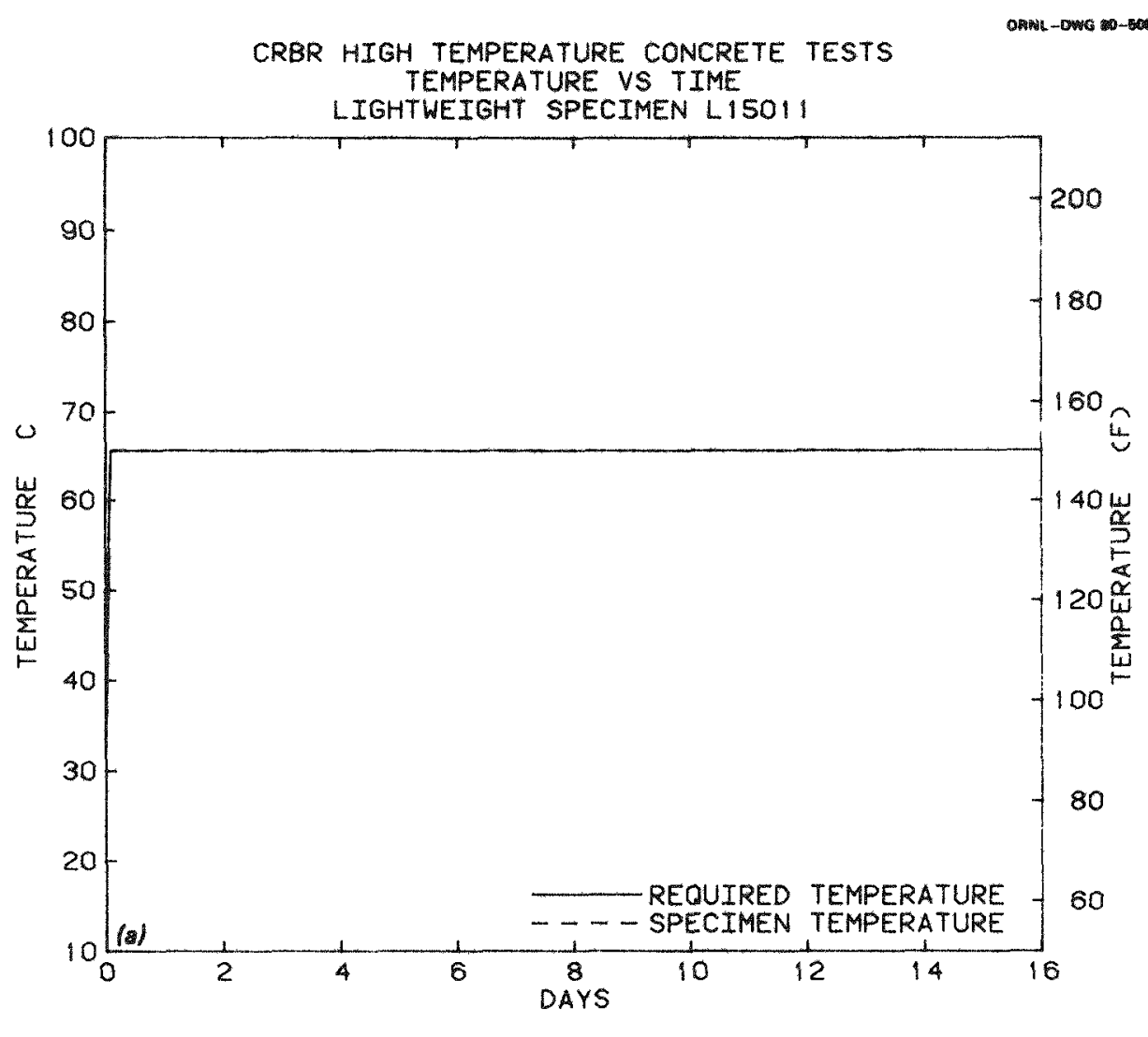

CRBR HIGH TEMPERATURE CONCRETE TESTS STRESS VS STRAIN DATA

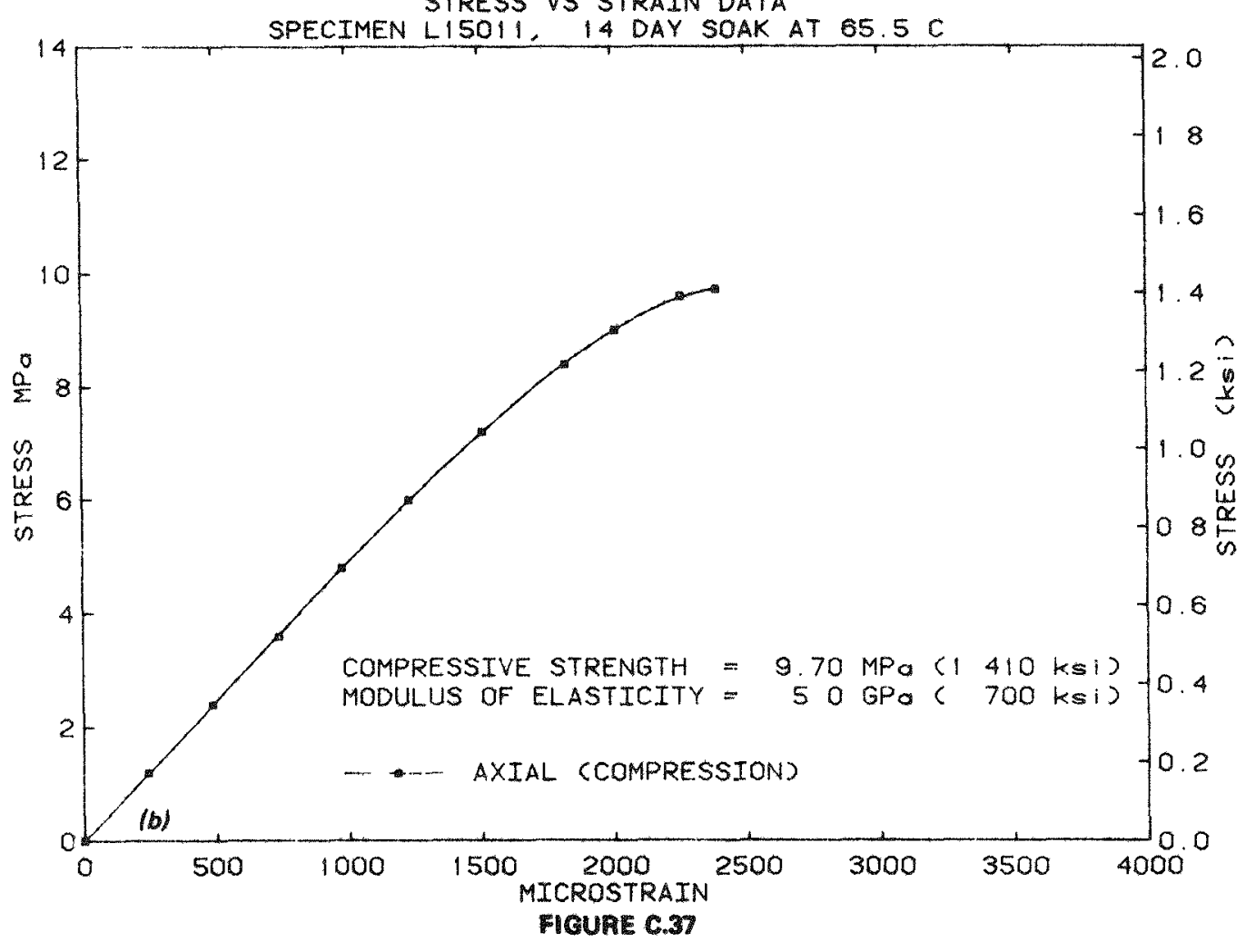




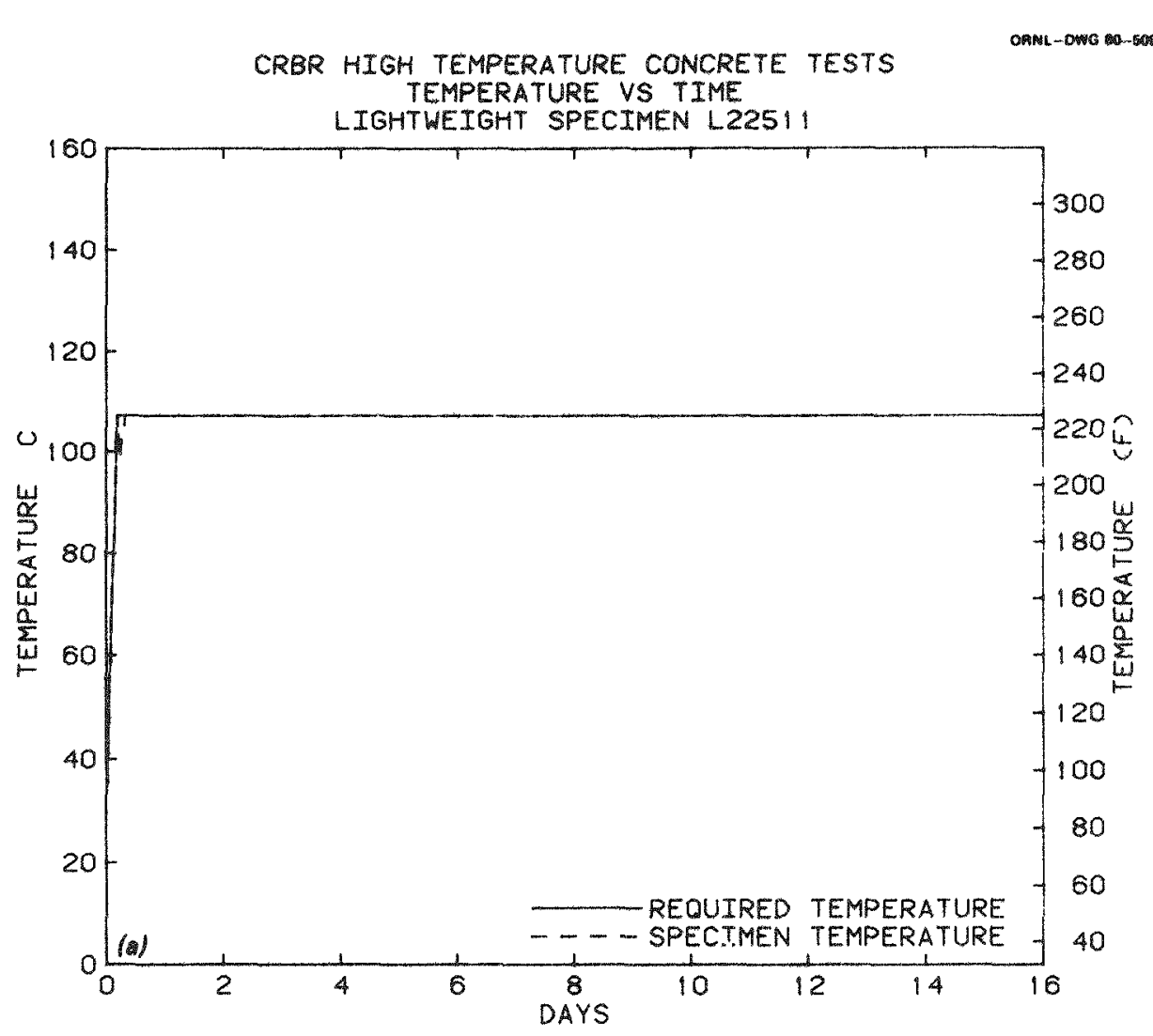

CRBR HIGH TEMPERATURE CONCRETE TESTS STRESS VS STRAIN DATA

SPECIMEN L22511, 14 DAY SOAK AT $1072 \mathrm{C}$

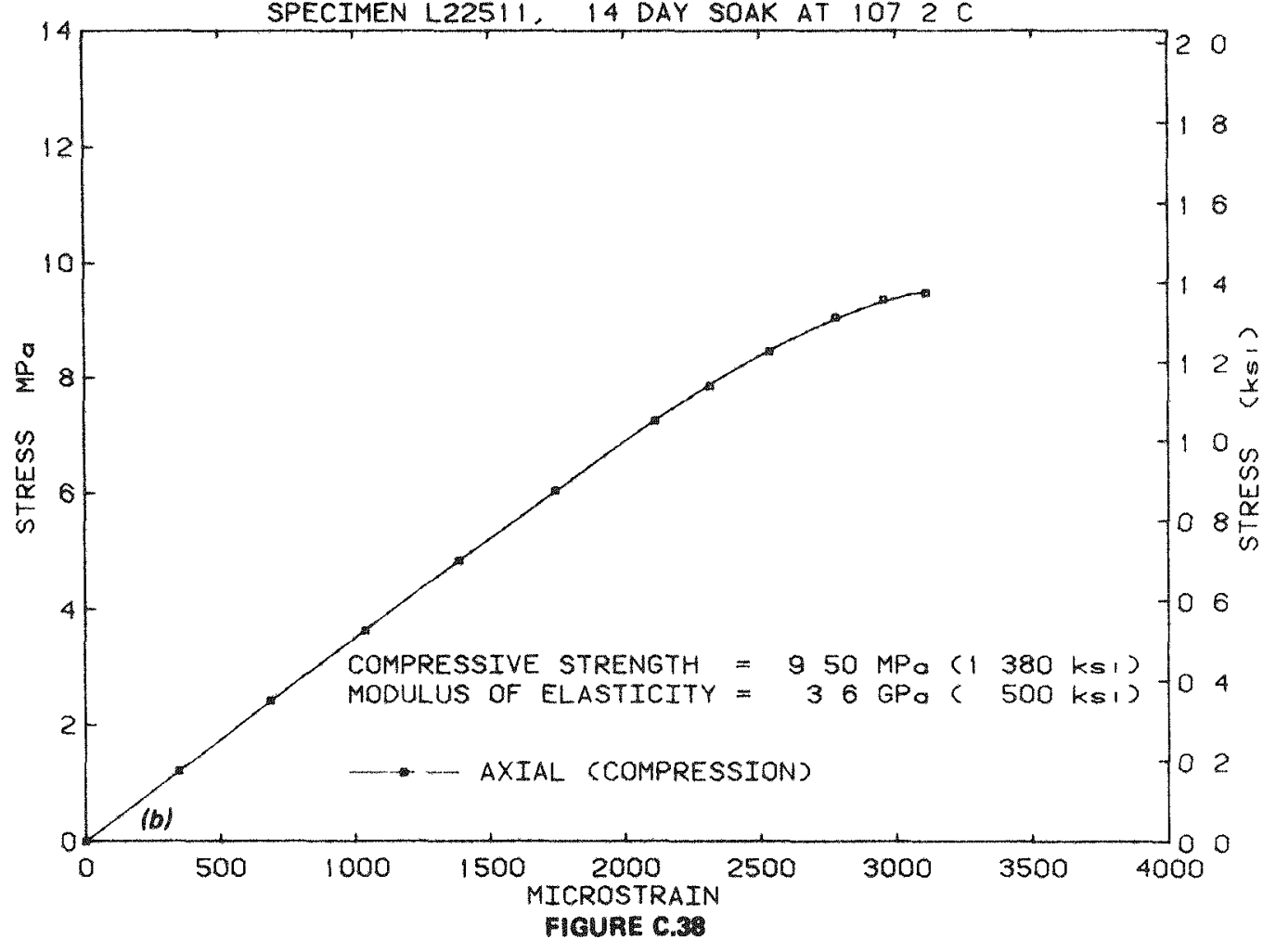




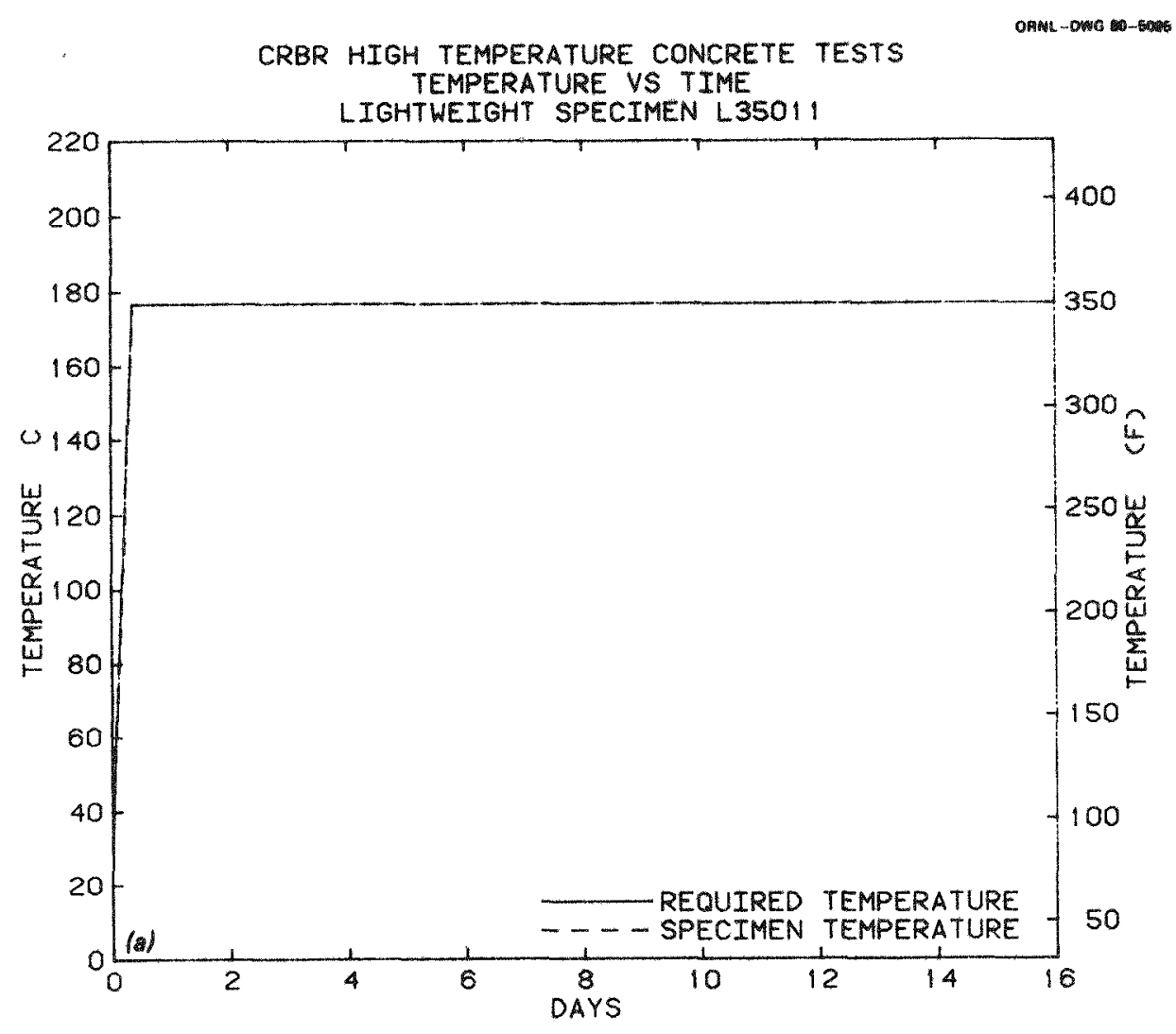

CRBR HIGH TEMPERATURE CONCRETE TESTS

STRESS VS STRAIN DATA

SPECIMEN L35011. 14 DAY SOAK AT $176.7 \mathrm{C}$

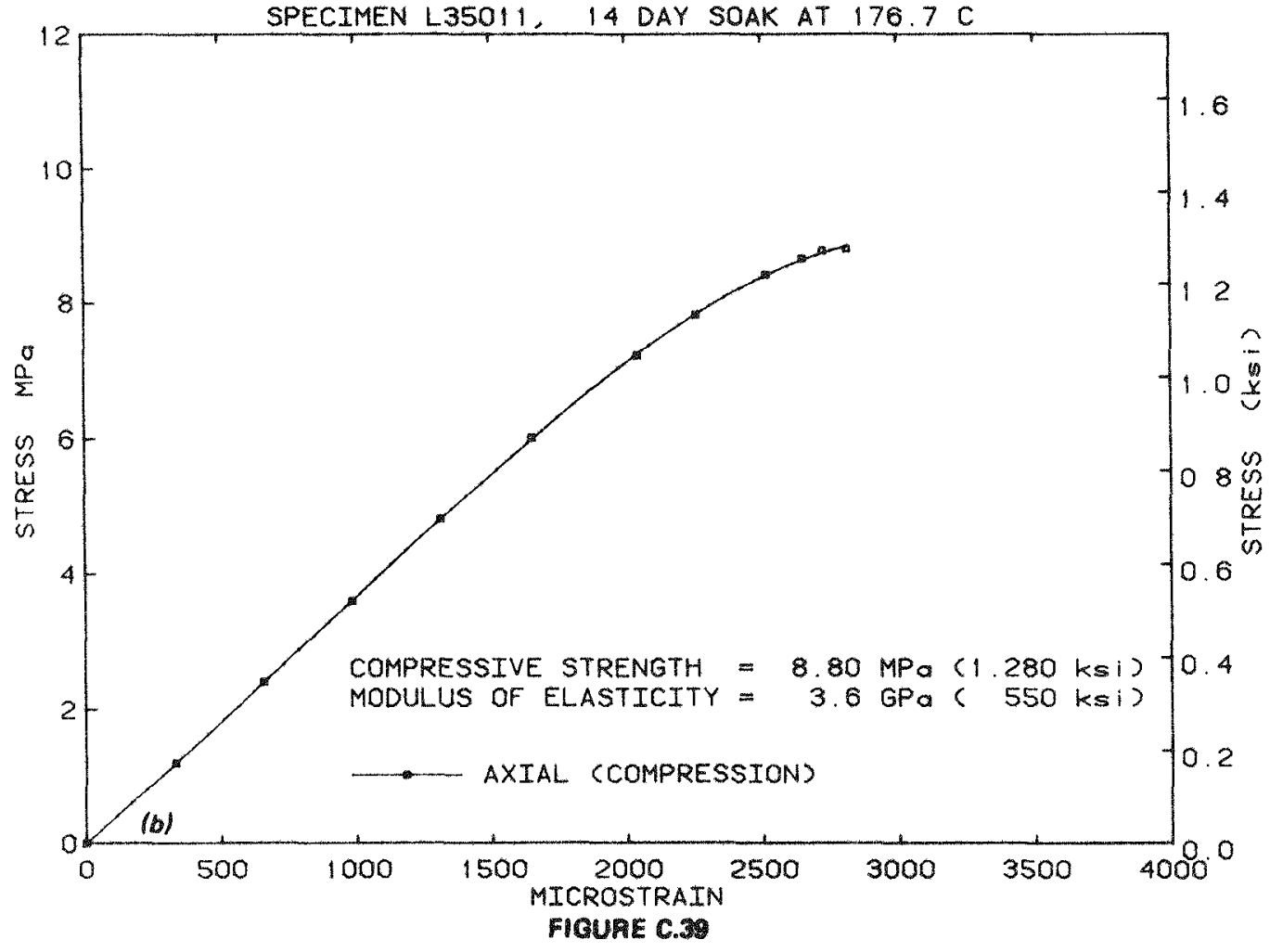


OHWL TEMPERATURE VS TIME

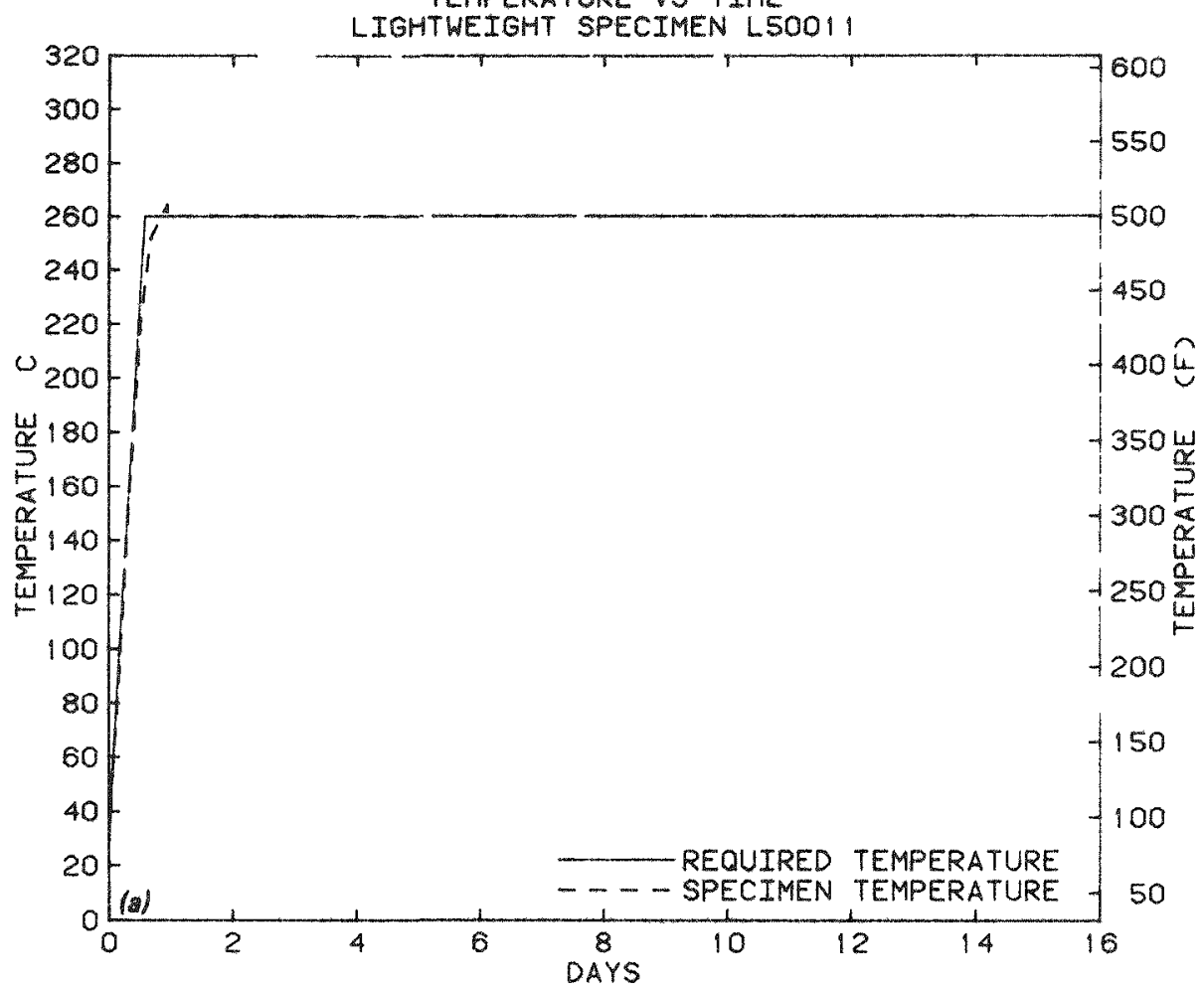

CRBR HIGH TEMPERATURE CONCRETE TESTS STRESS VS STRAIN DATA SPECIMEN L50011, 14 DAY SOAK AT $2600 \mathrm{C}$

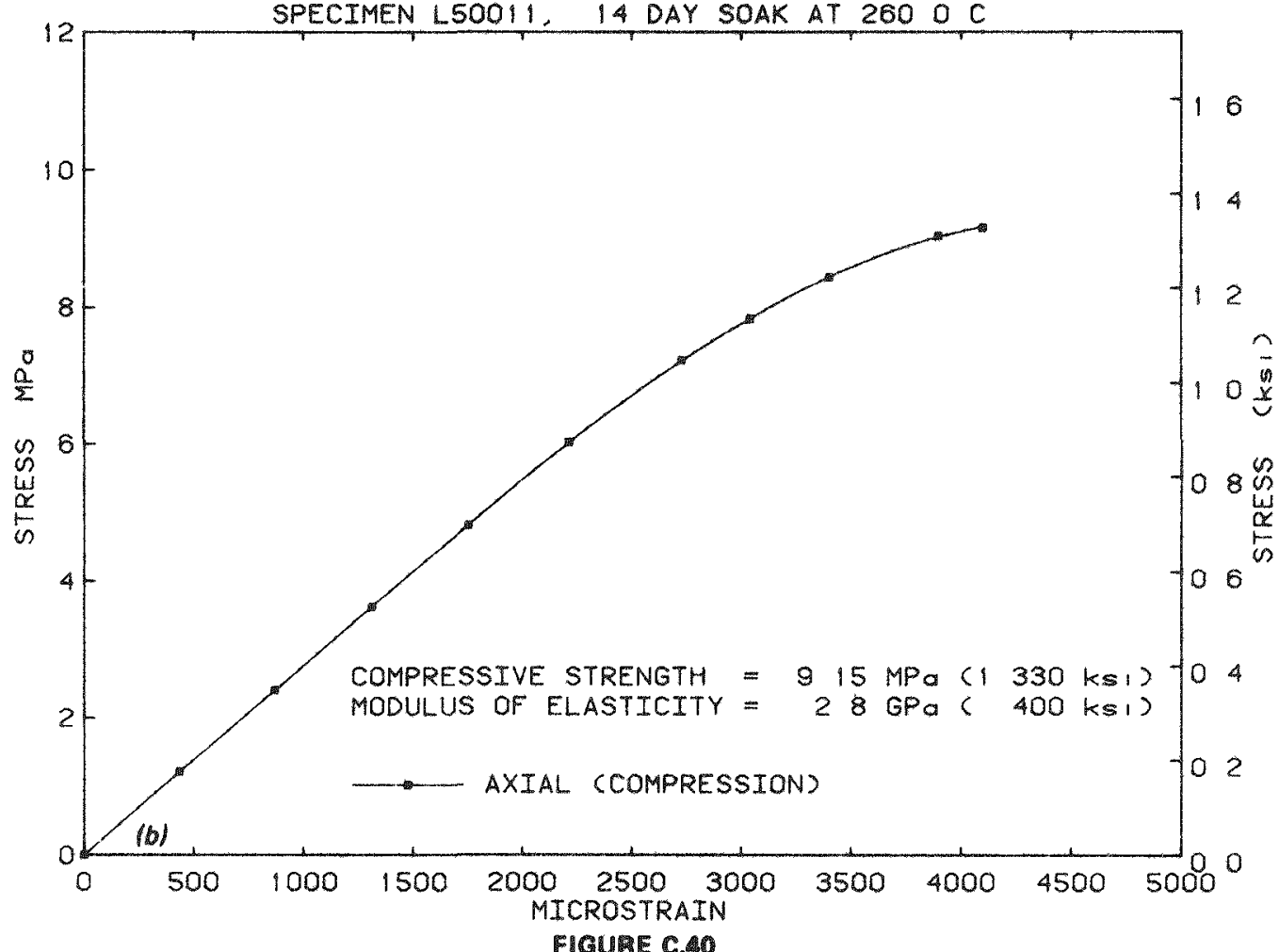



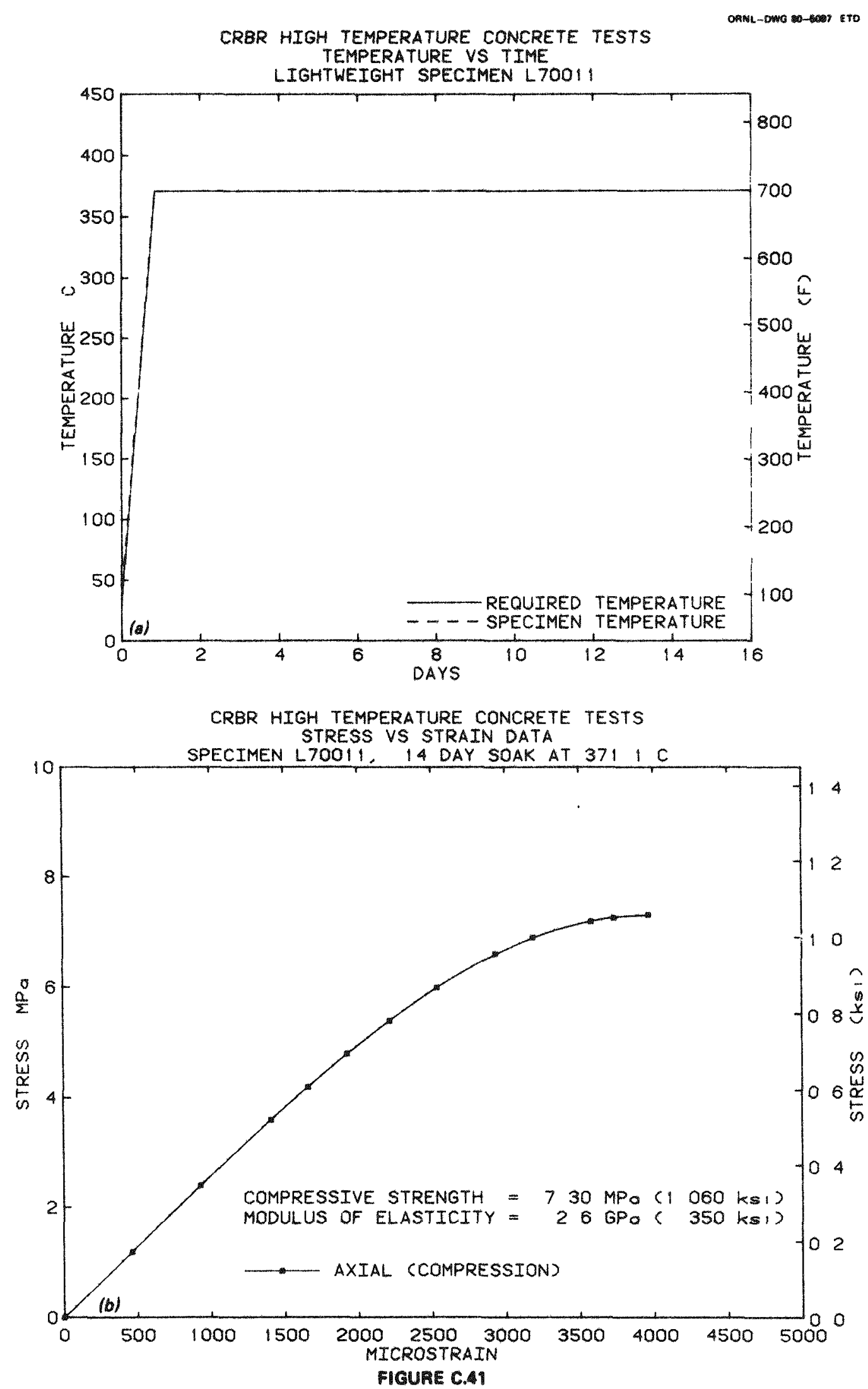


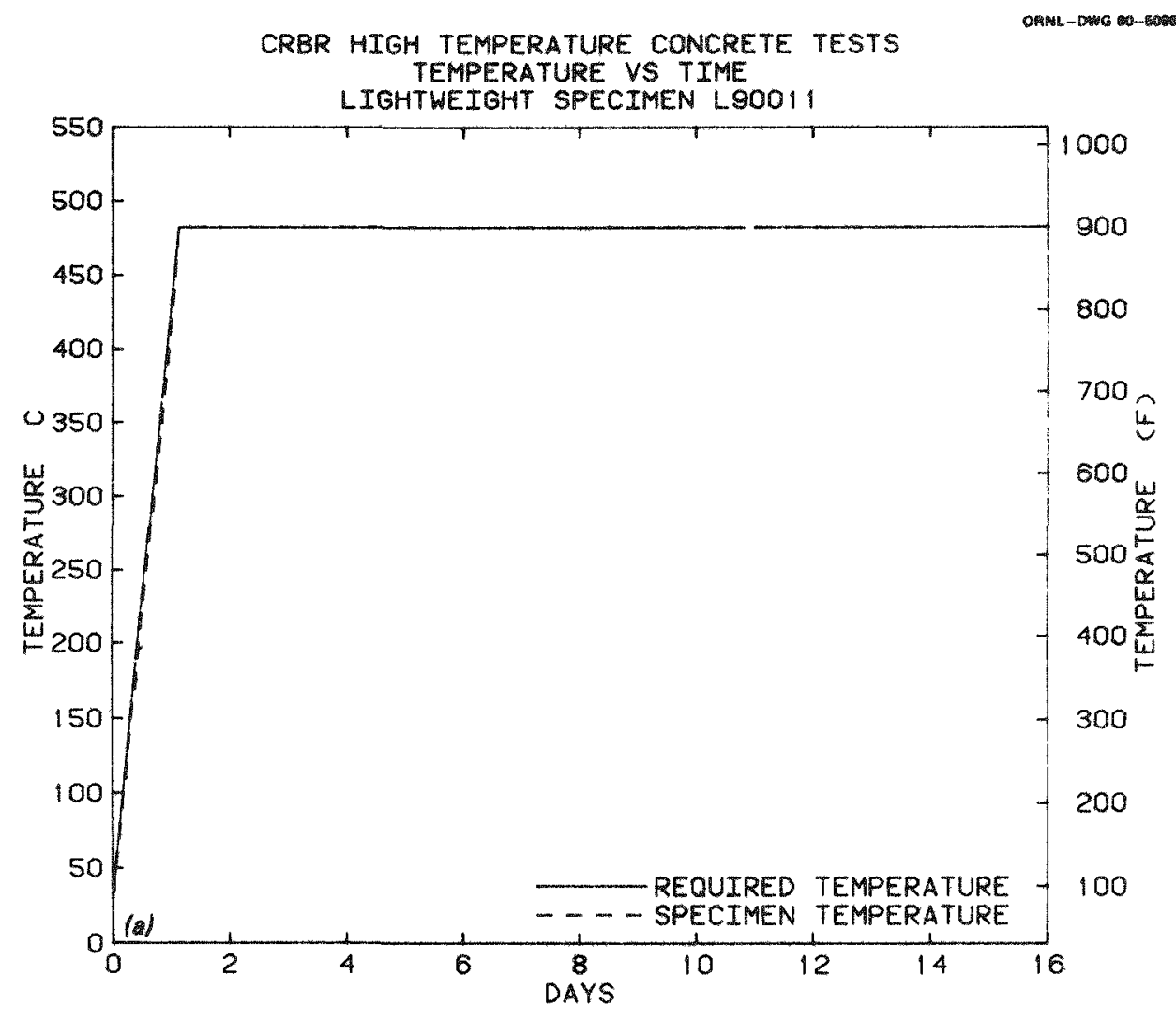

CRBR HIGH TEMPERATURE CONCRETE TESTS

STRESS VS STRAIN DATA

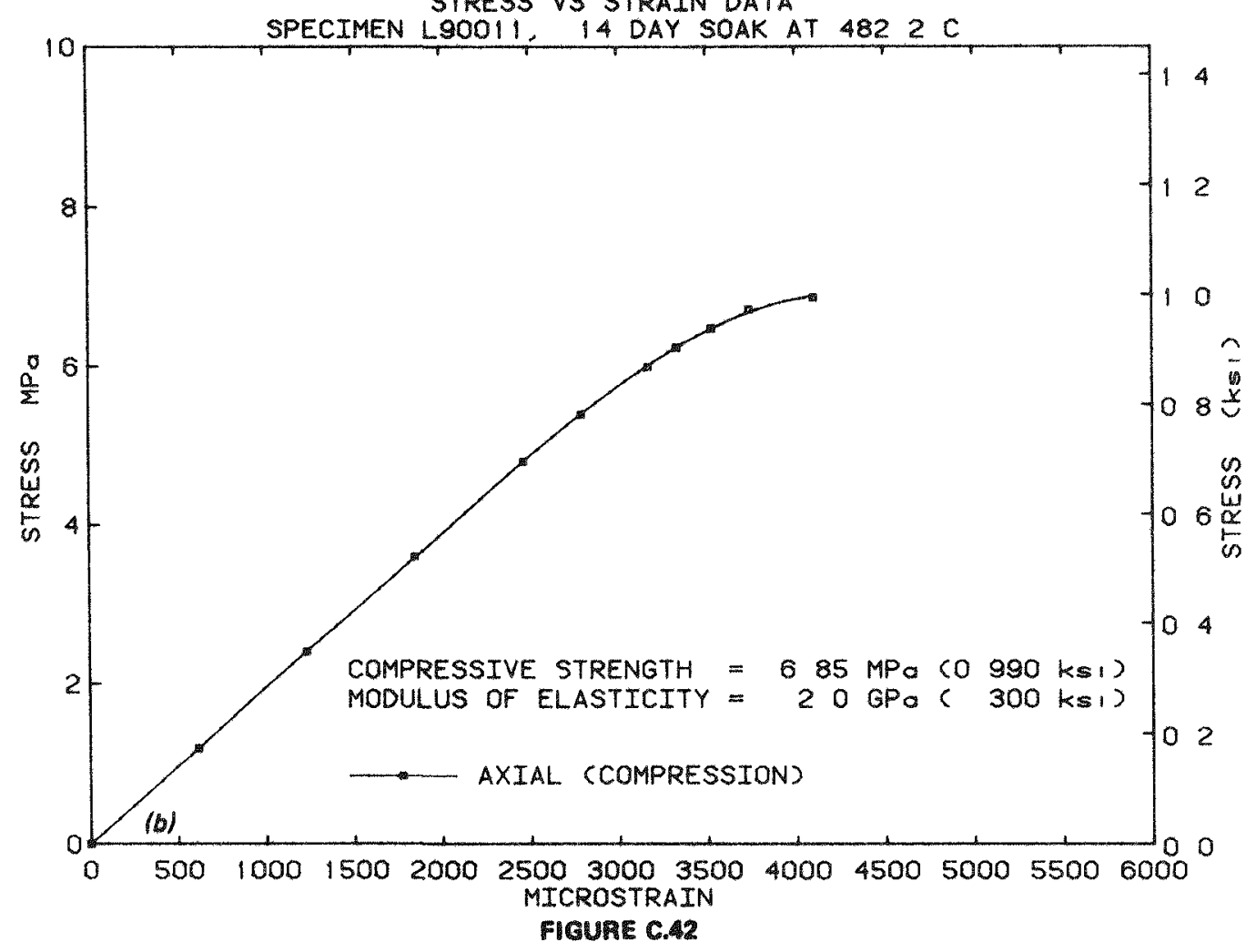




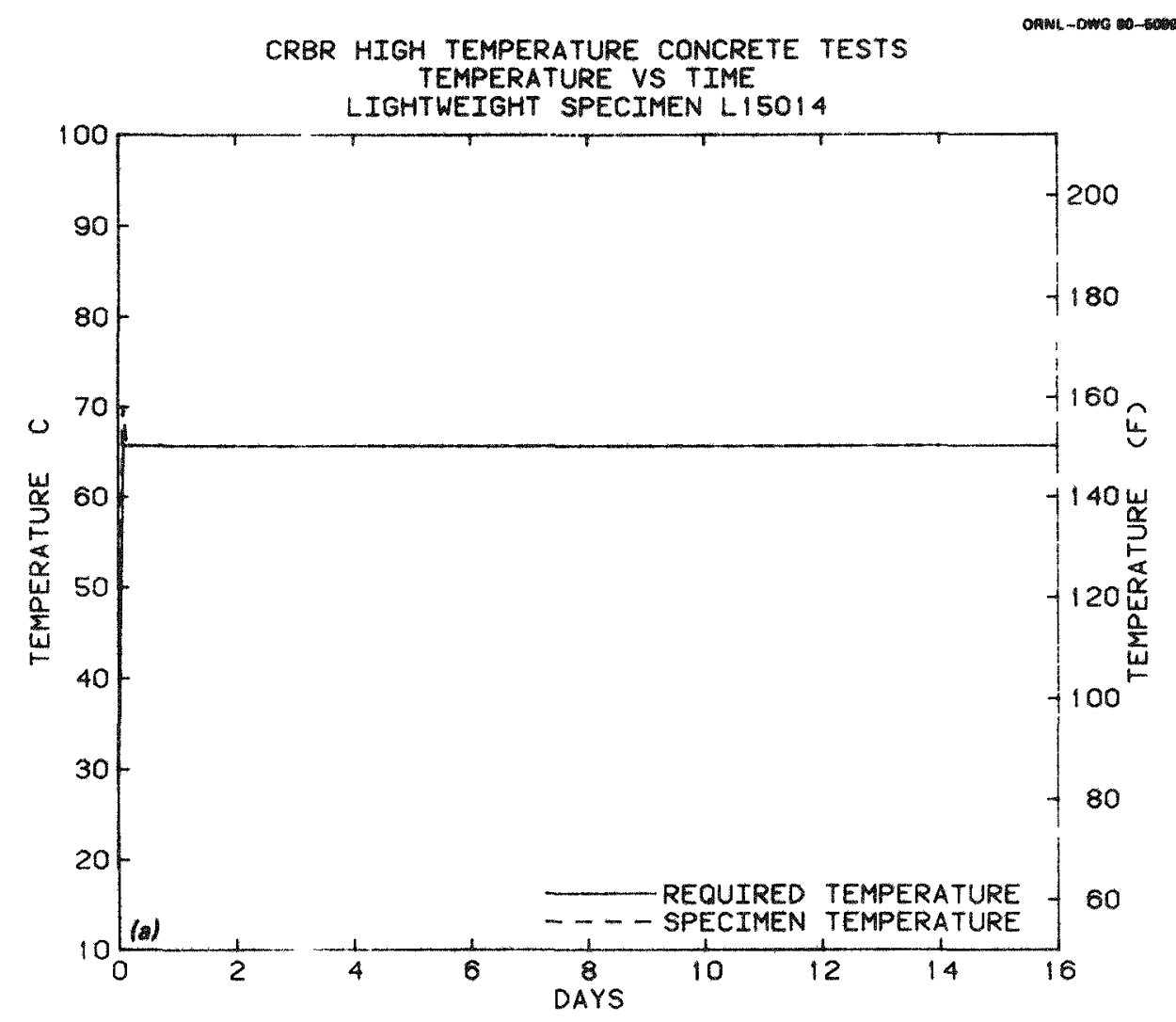

CRBR HIGH TEMPERATURE CONCRETE TESTS STRESS VS STRAIN DATA

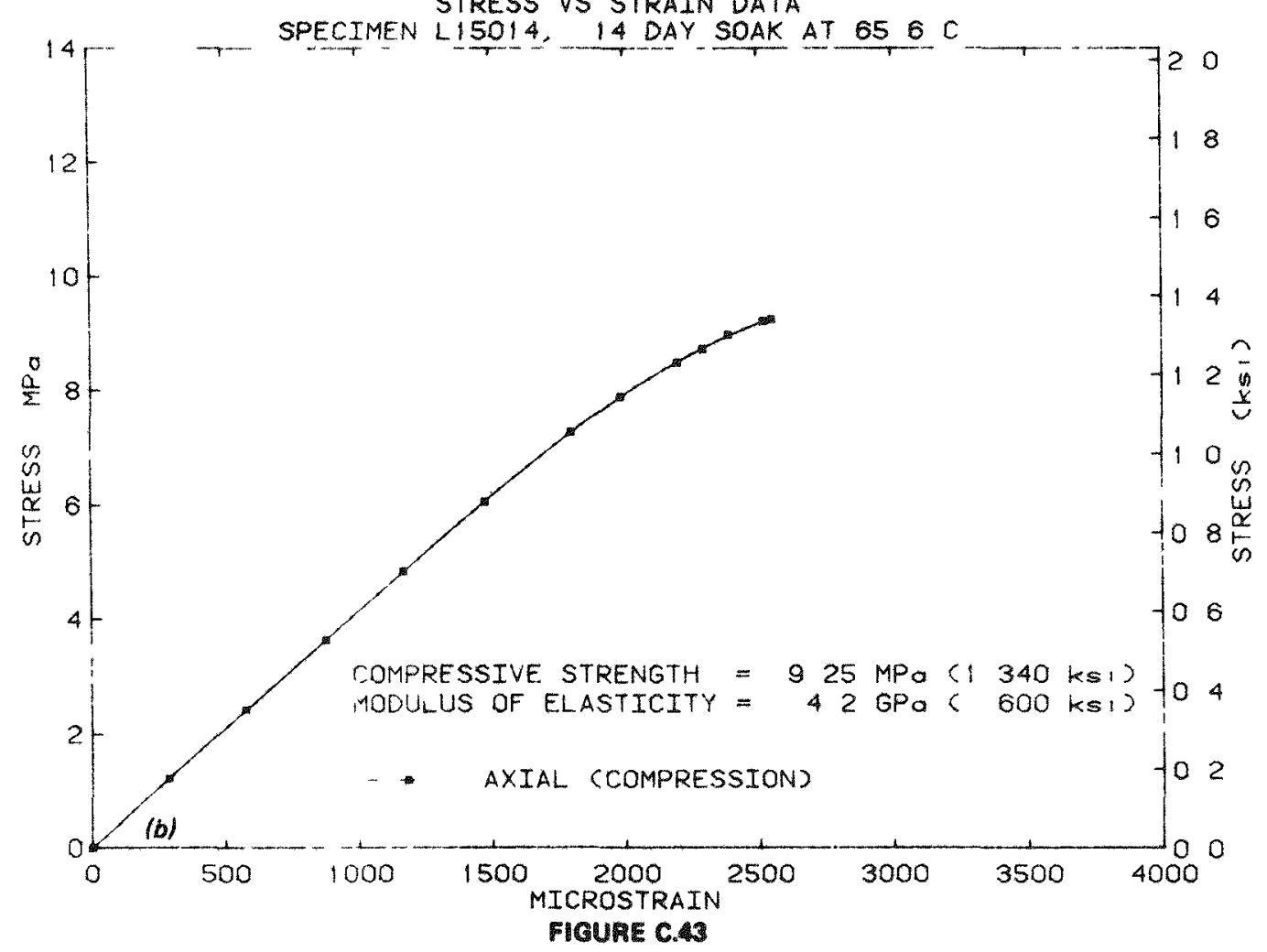



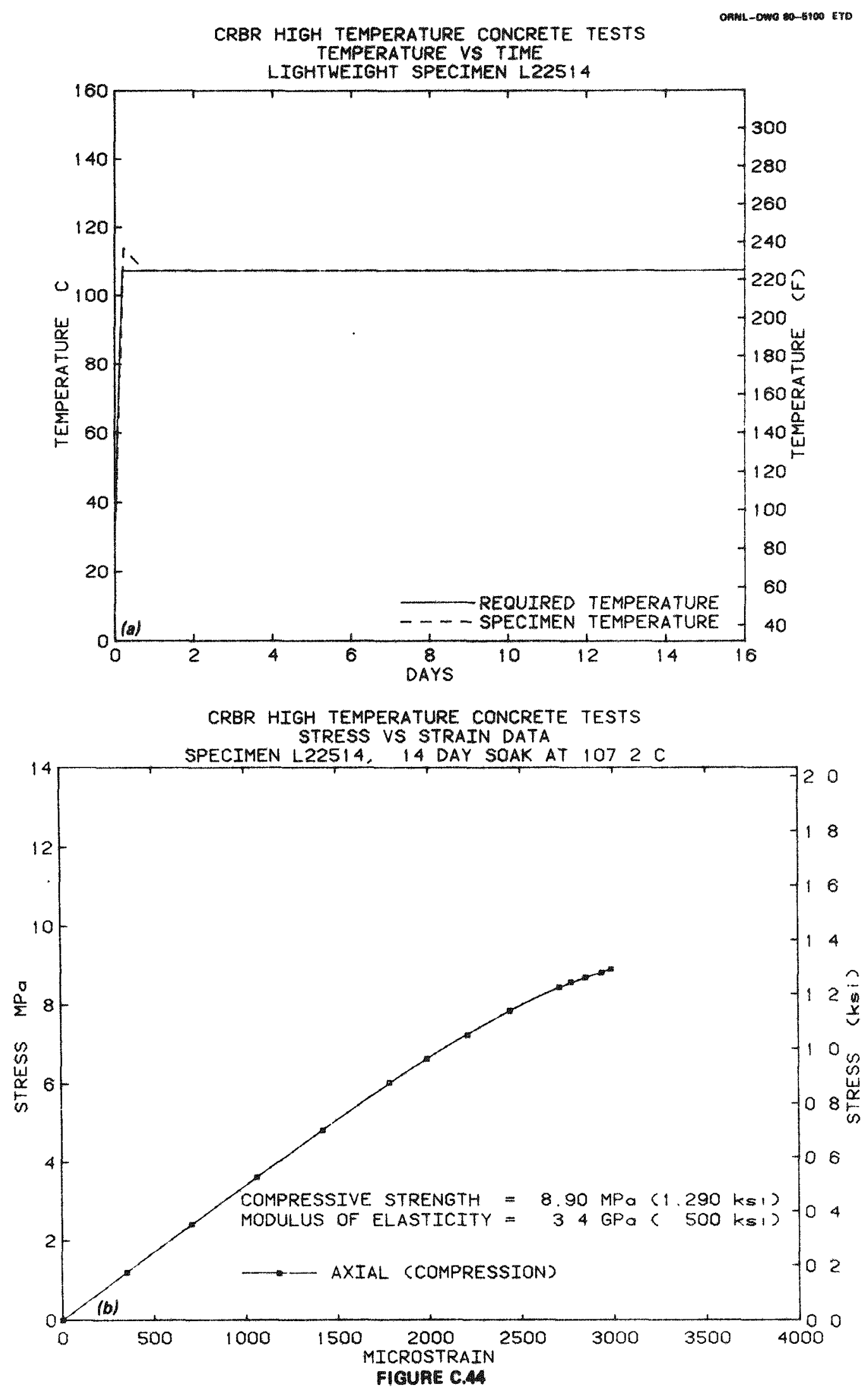

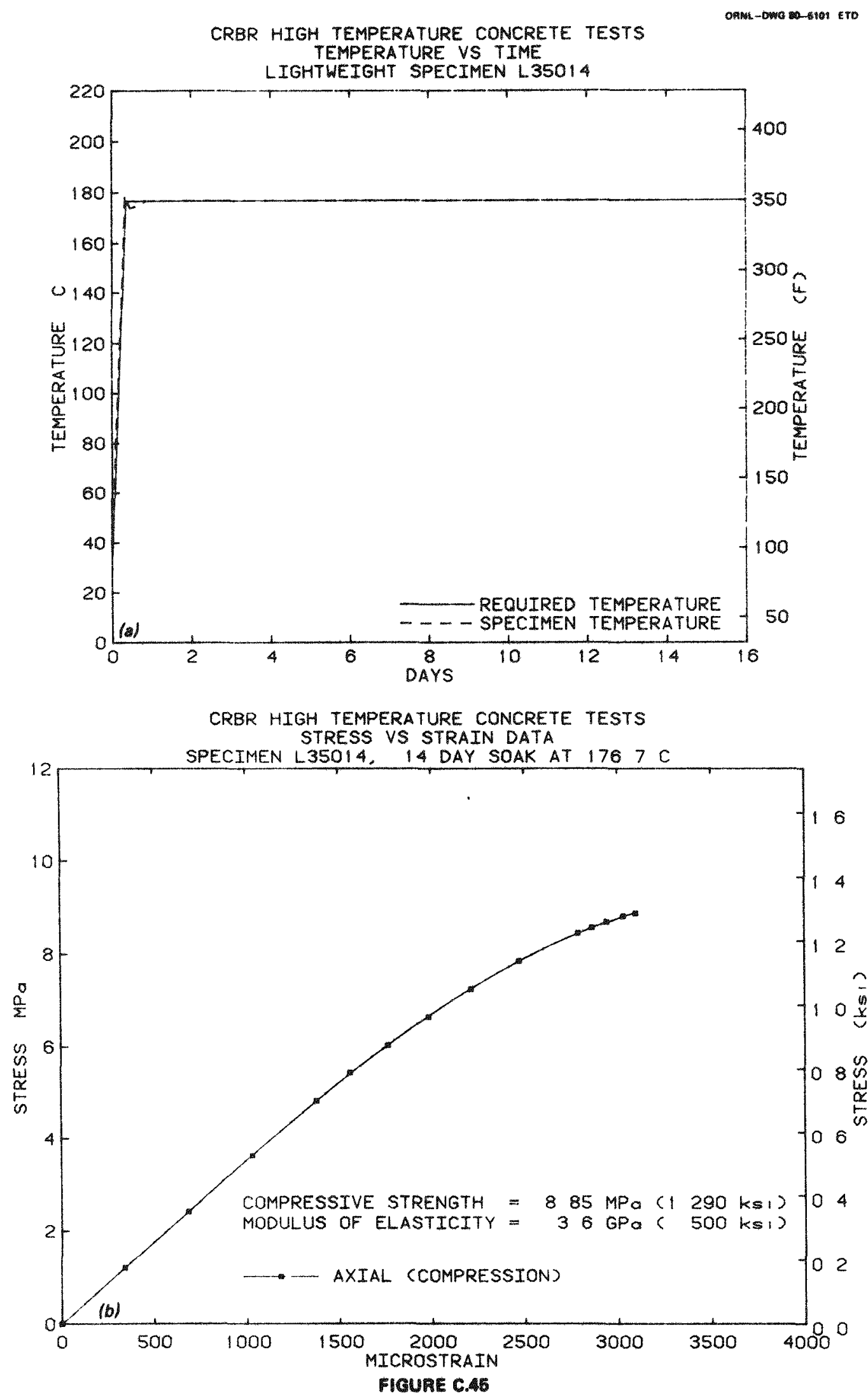
CRBR MIGH TEMPERATURE CONCRETE TESTS

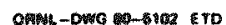
TEMPERATURE VS TTME

LIGHTWEIGHT SPECIMEN LSOO14

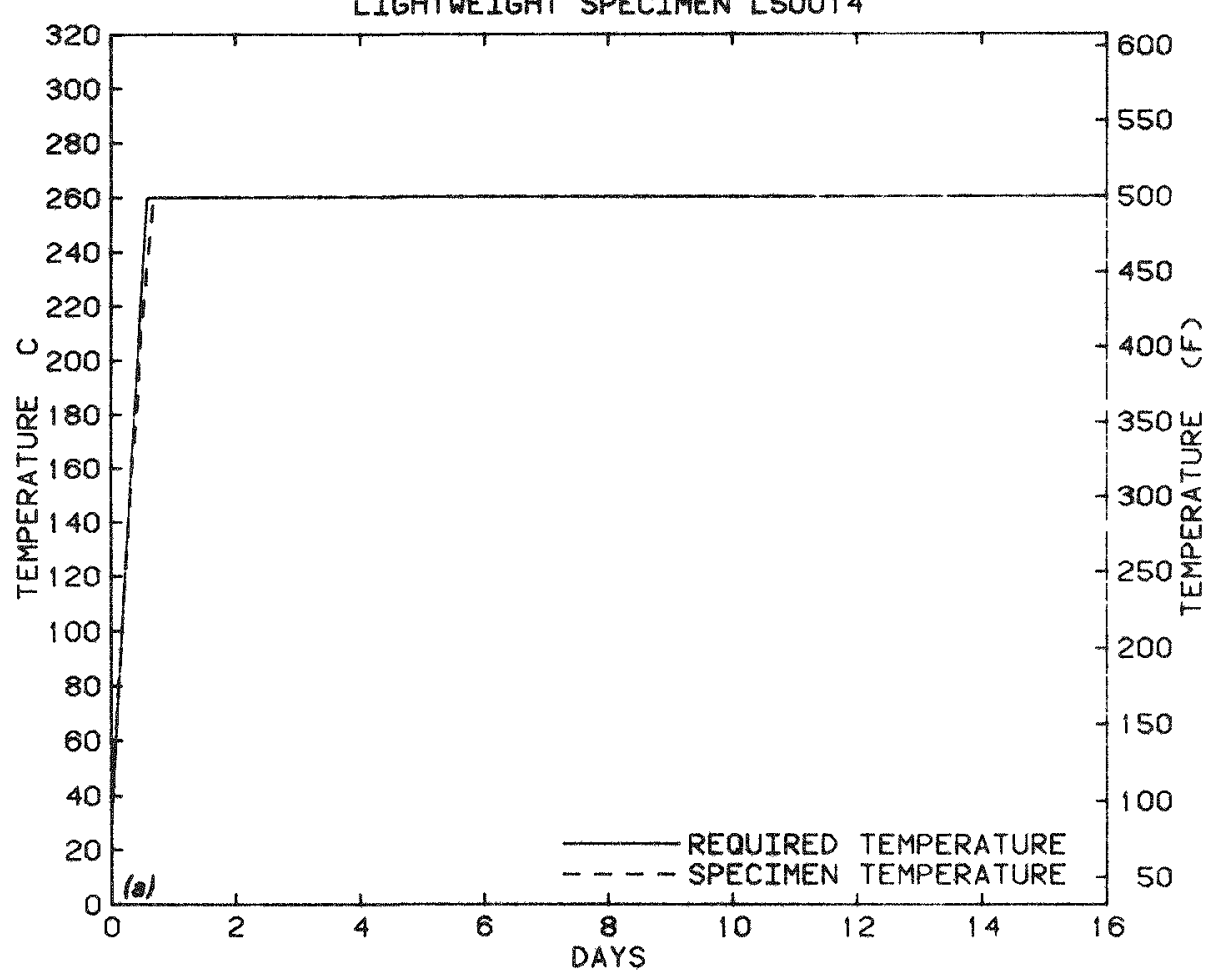

CRBR HIGH TEMPERATURE CONCRETE TESTS STRESS VS STRAIN DATA

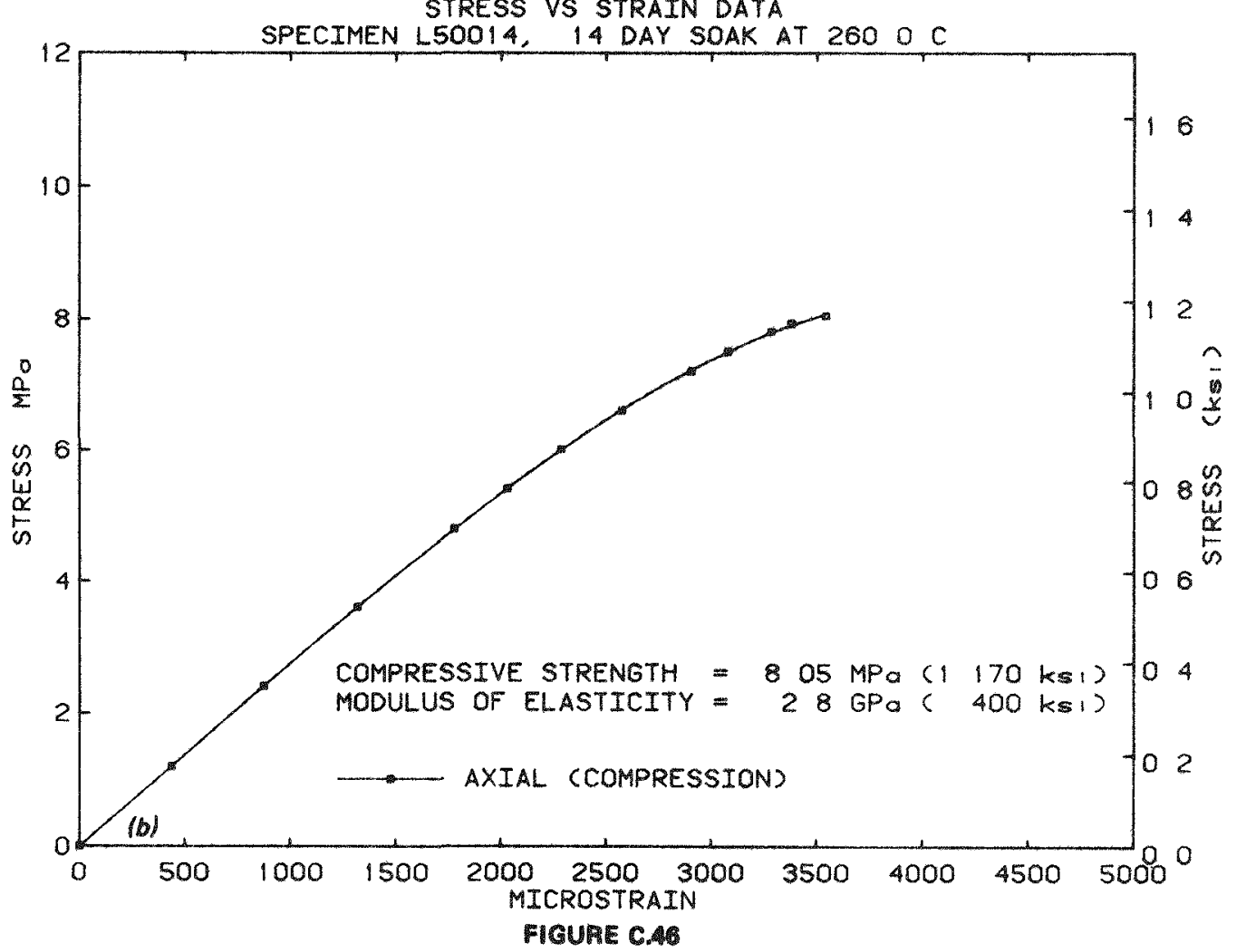



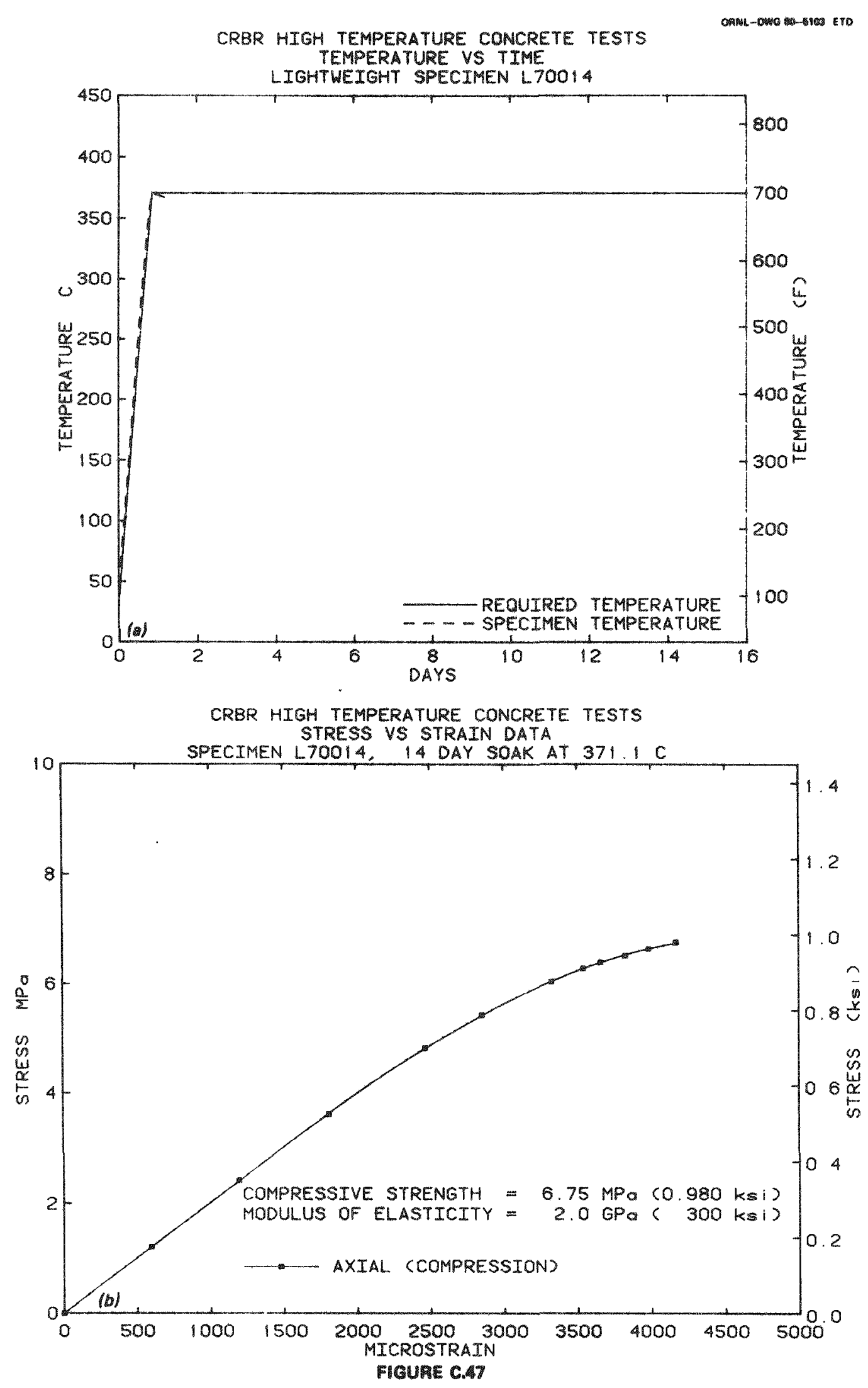
OROO UICH TEMPERATURE CONCRETE TESTS

ำนเTEMPERATURE VS TIME LIGHTWEIGHT SPECIMEN L9O014

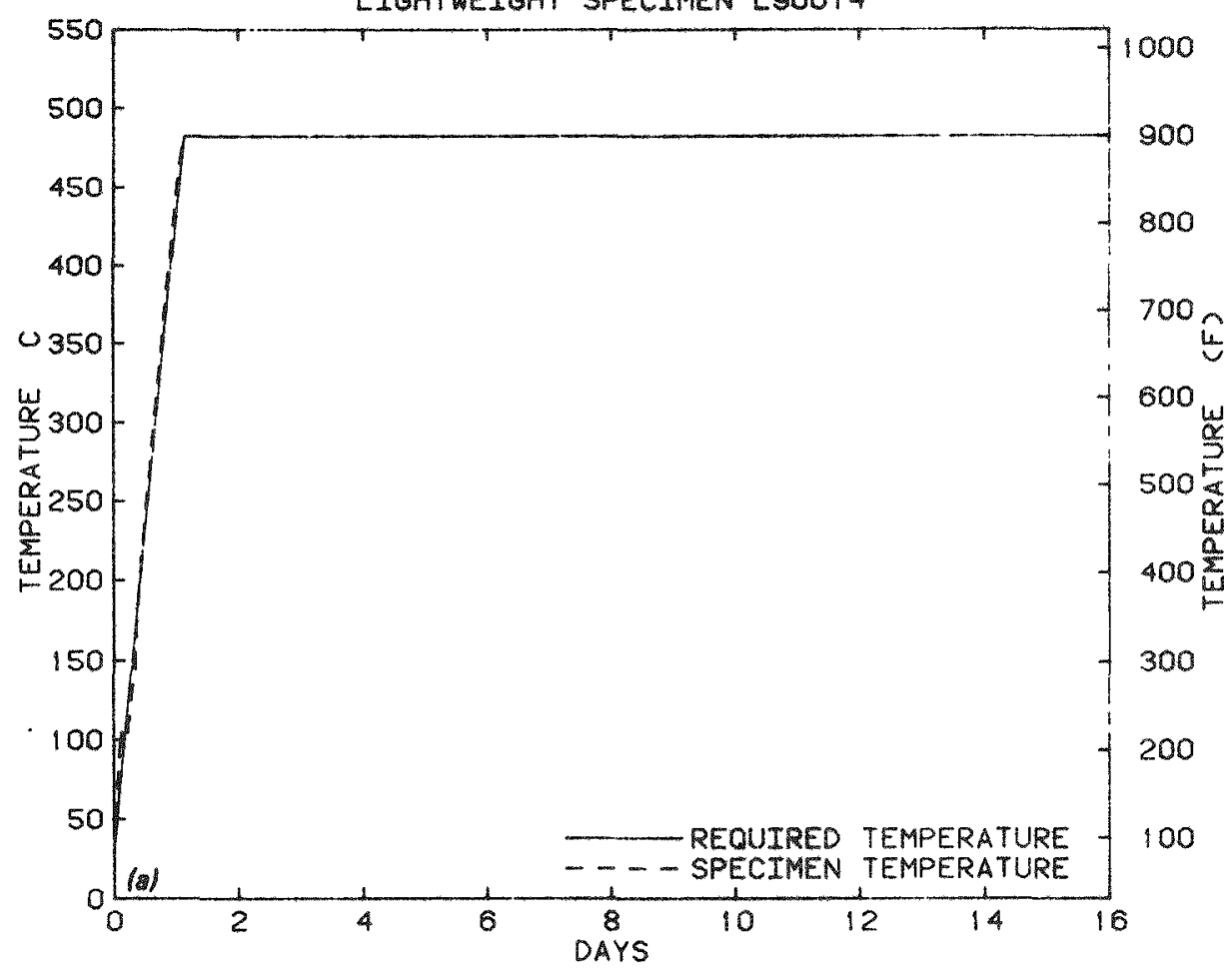

CRBR HIGH TEMPERATURE CONCRETE TESTS STRESS VS STRAIN DATA

SPECIMEN L9OO14, 14 DAY SOAK AT $4822 \mathrm{C}$

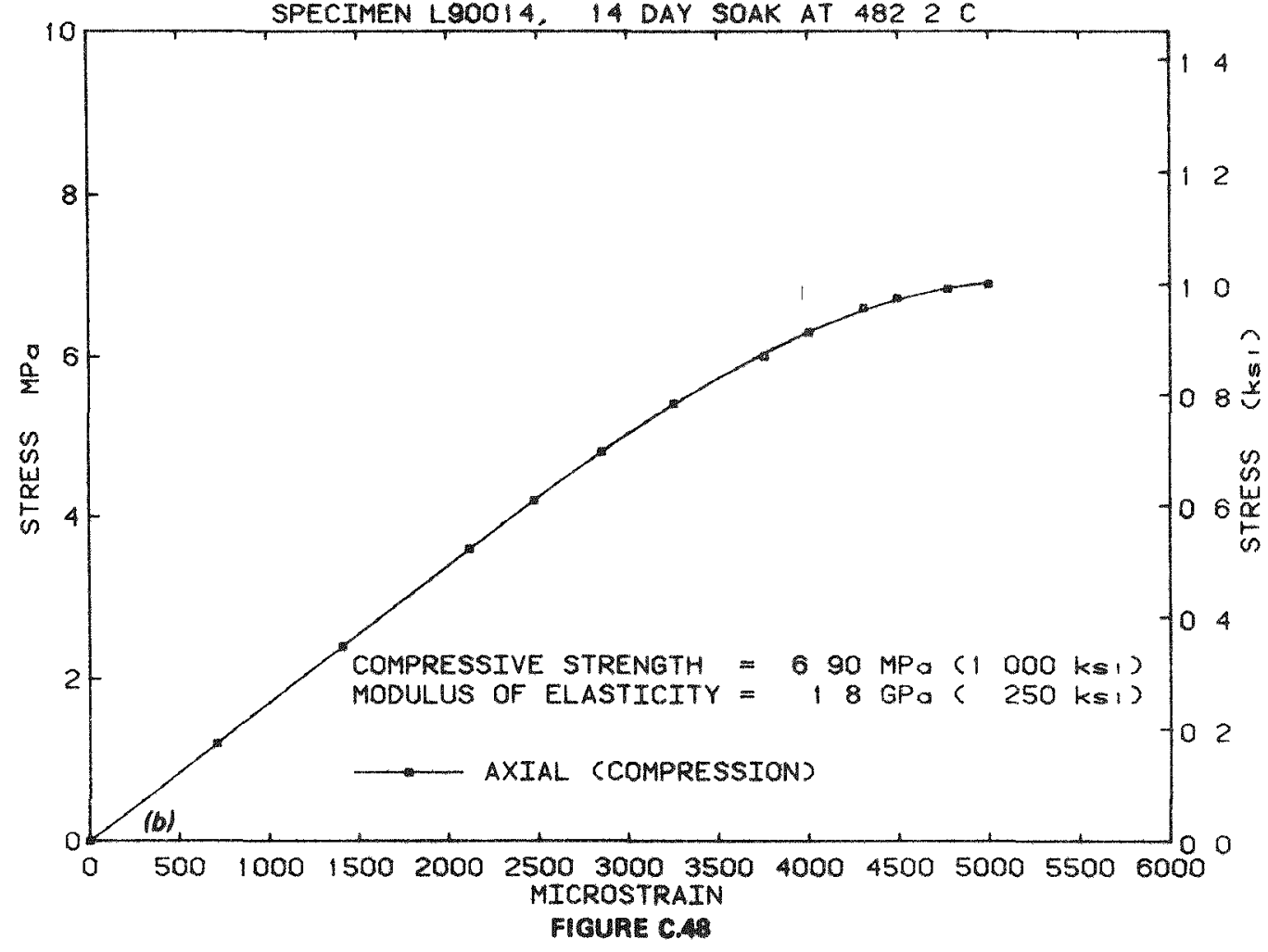




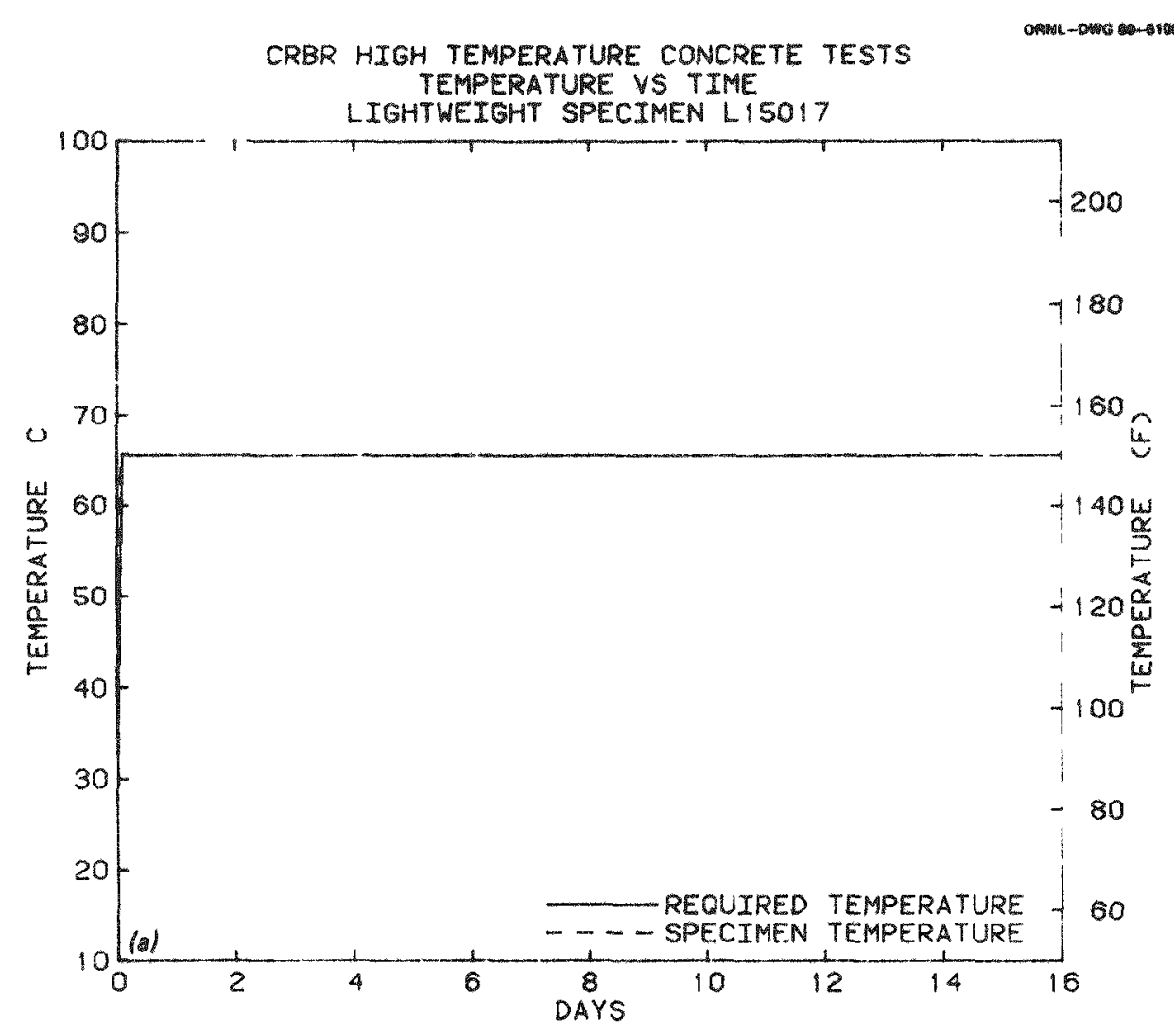

CRBR HIGH TEMPERATURE CONCRETE TESTS STRESS VS STRAIN DATA

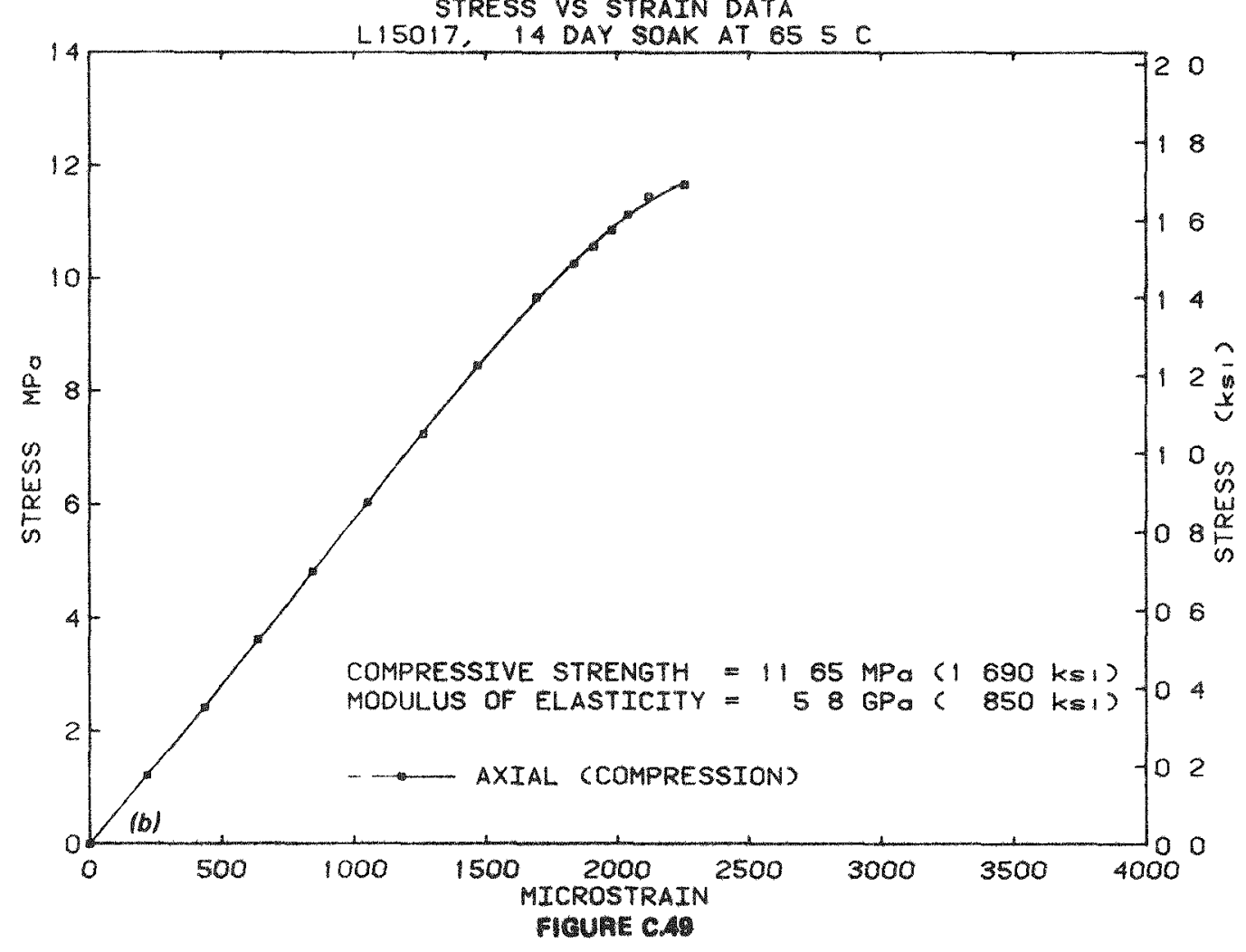




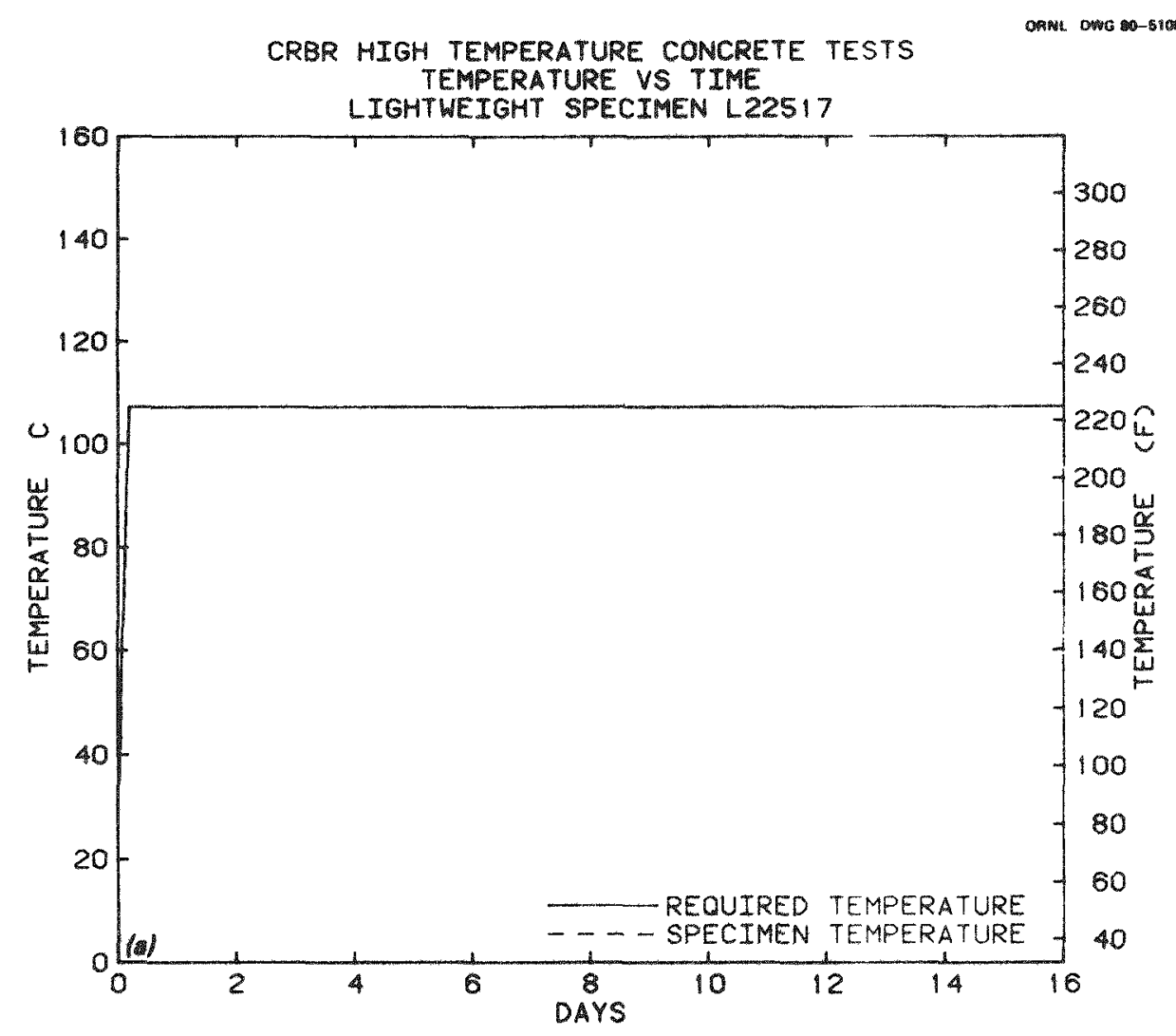

CRBR HIGH TEMPERATURE CONCRETE TESTS STRESS VS STRAIN DATA

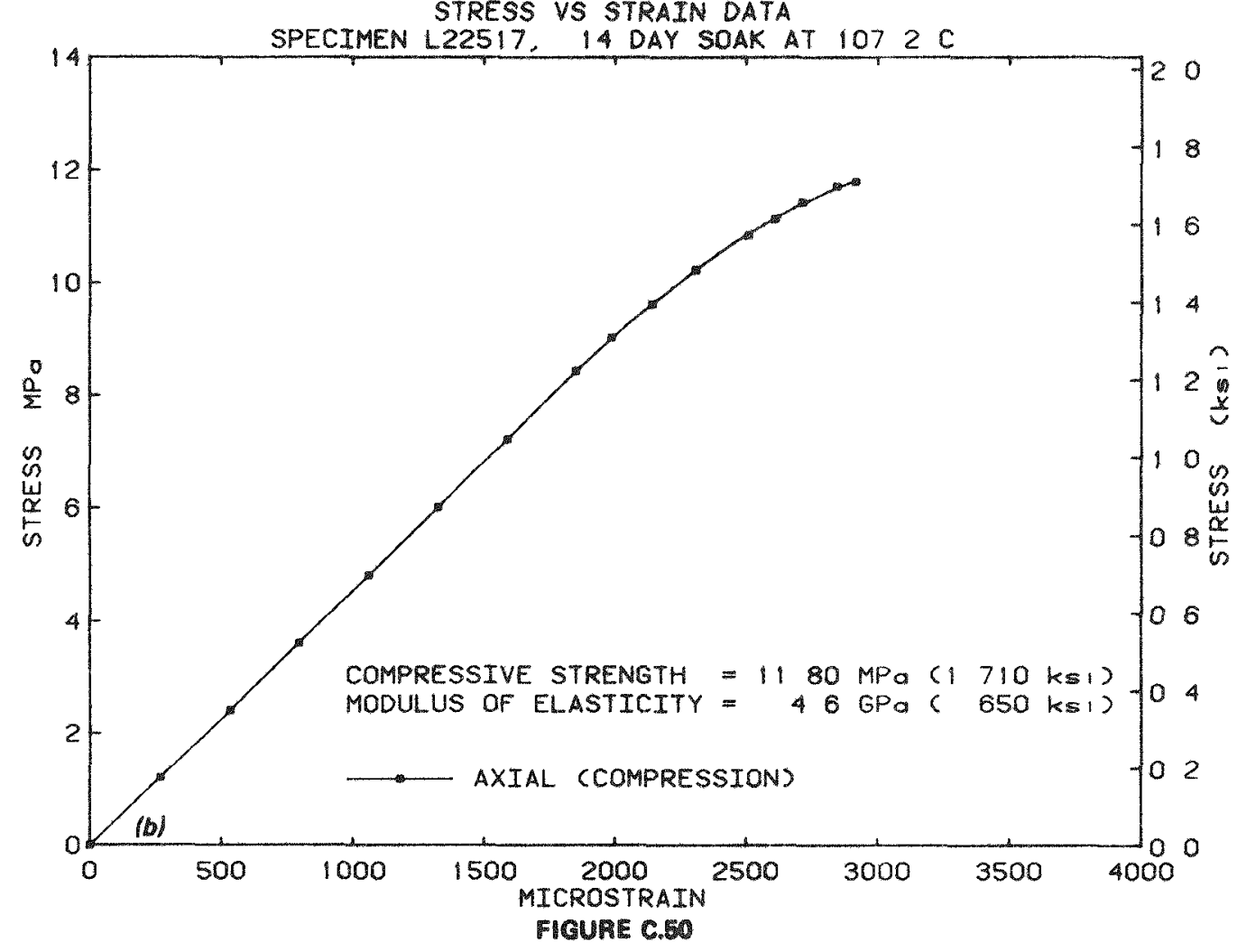



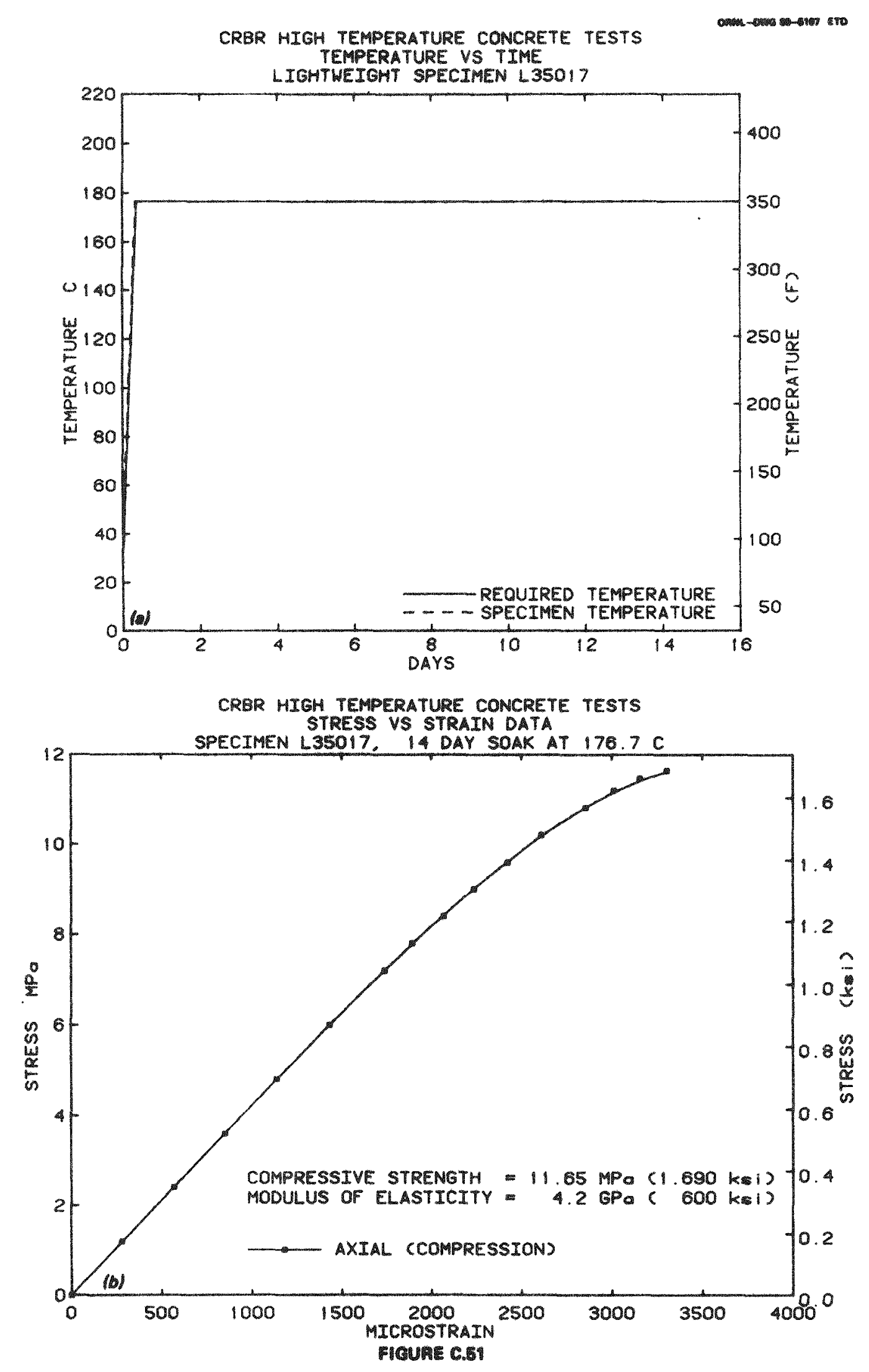


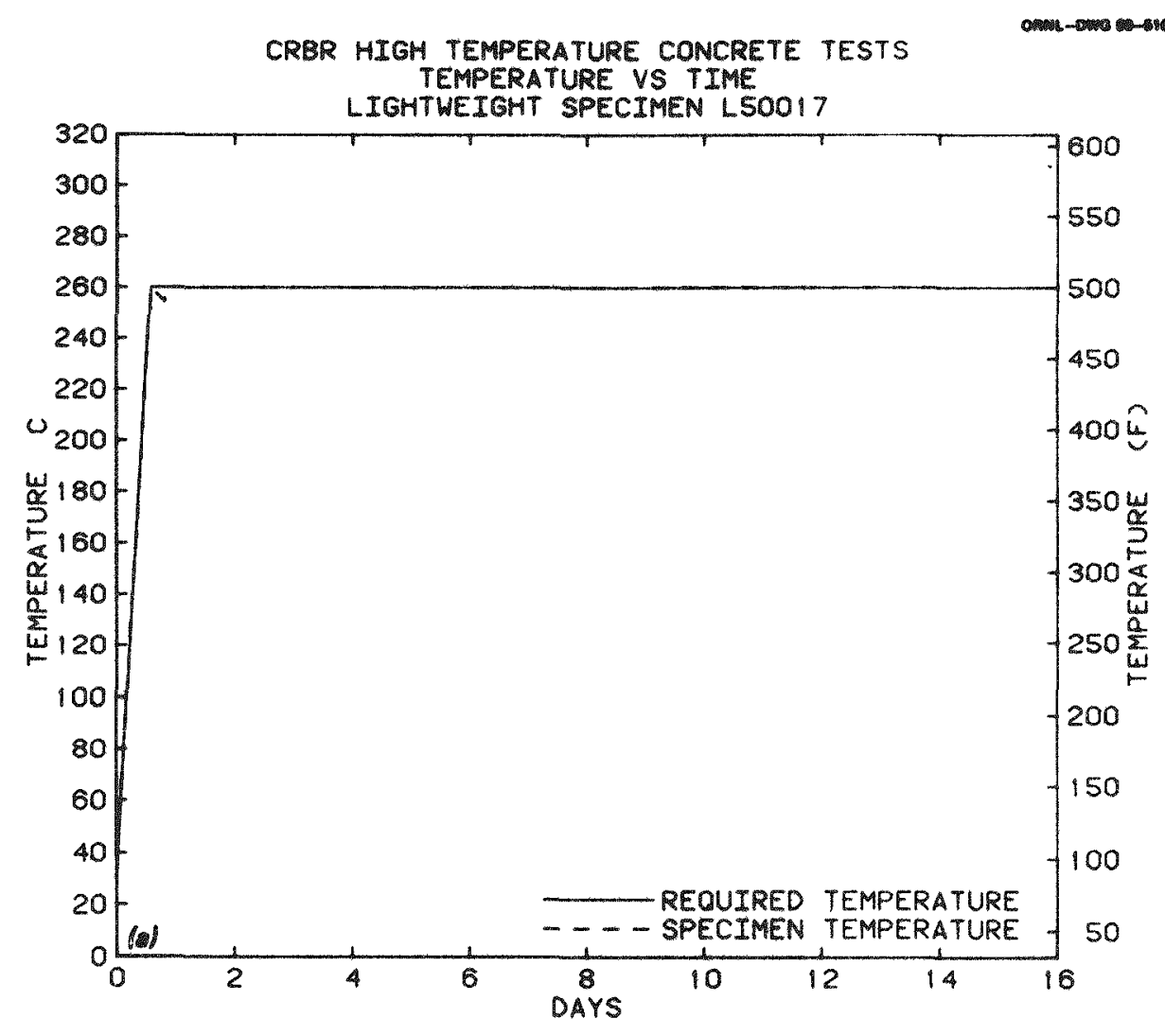

CRBR HIGH TEMPERATURE CONCRETE TESTS STRESS VS STRAIN DATA

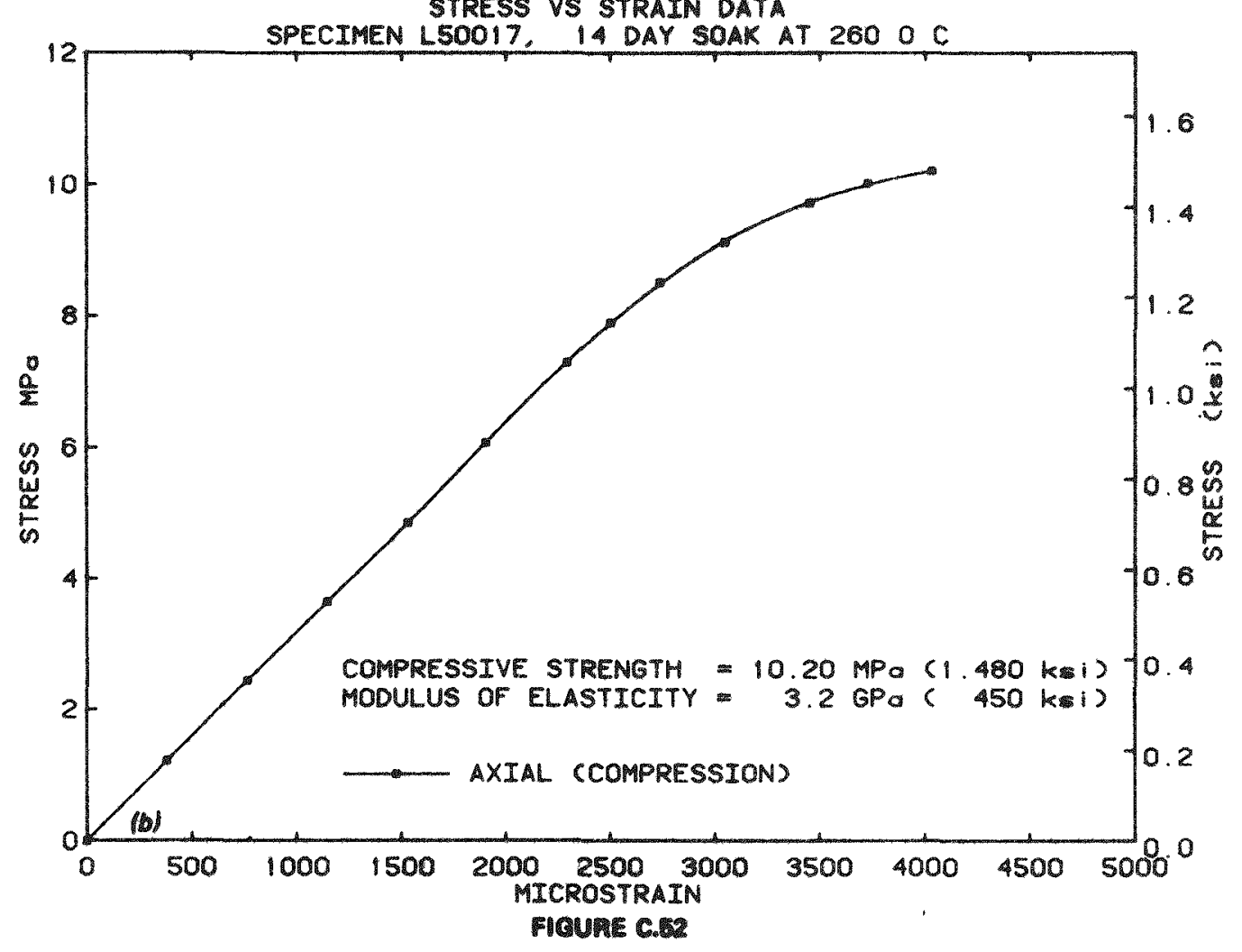




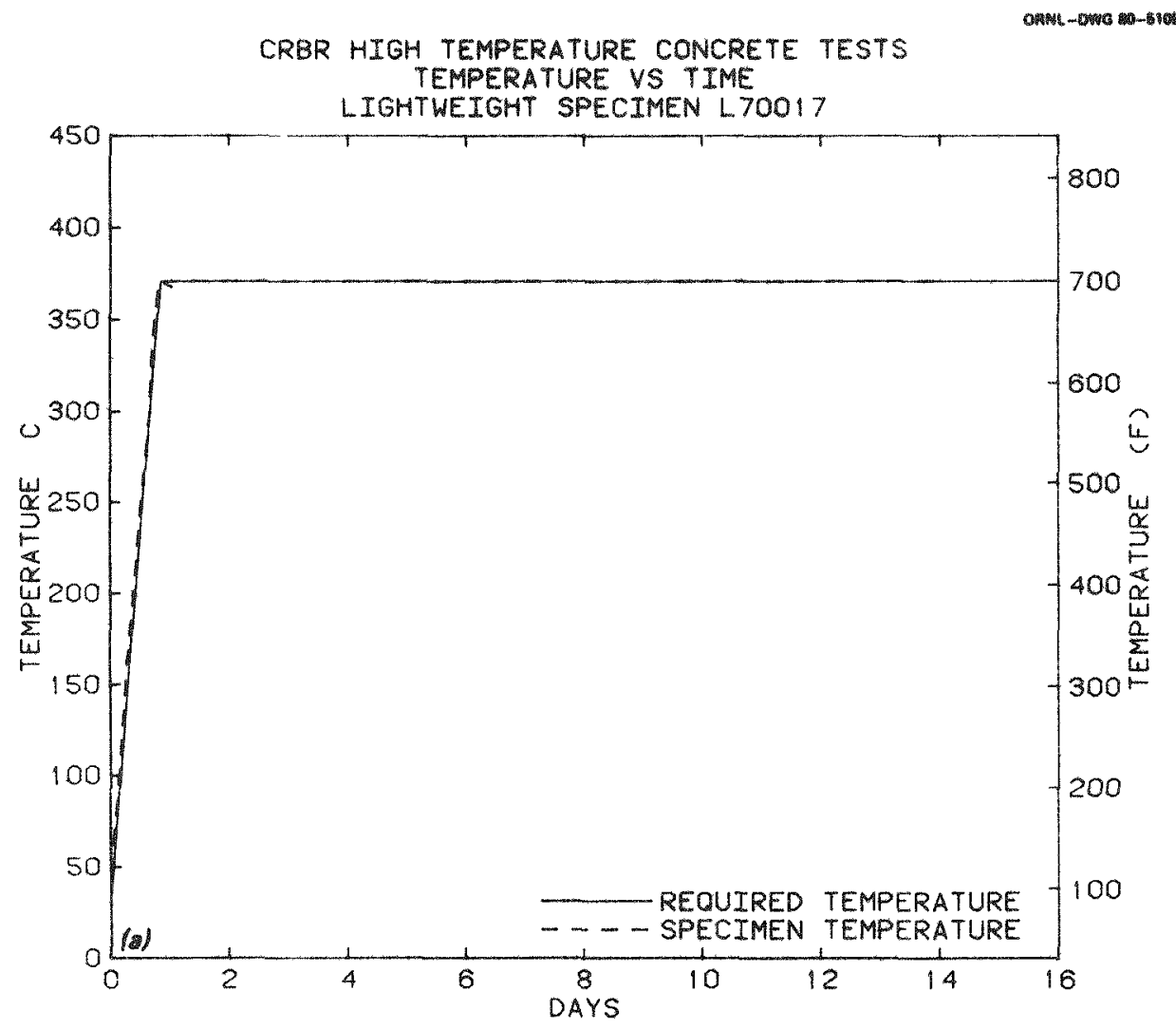

CRBR HIGH TEMPERATURE CONCRETE TESTS STRESS VS STRAIN DATA

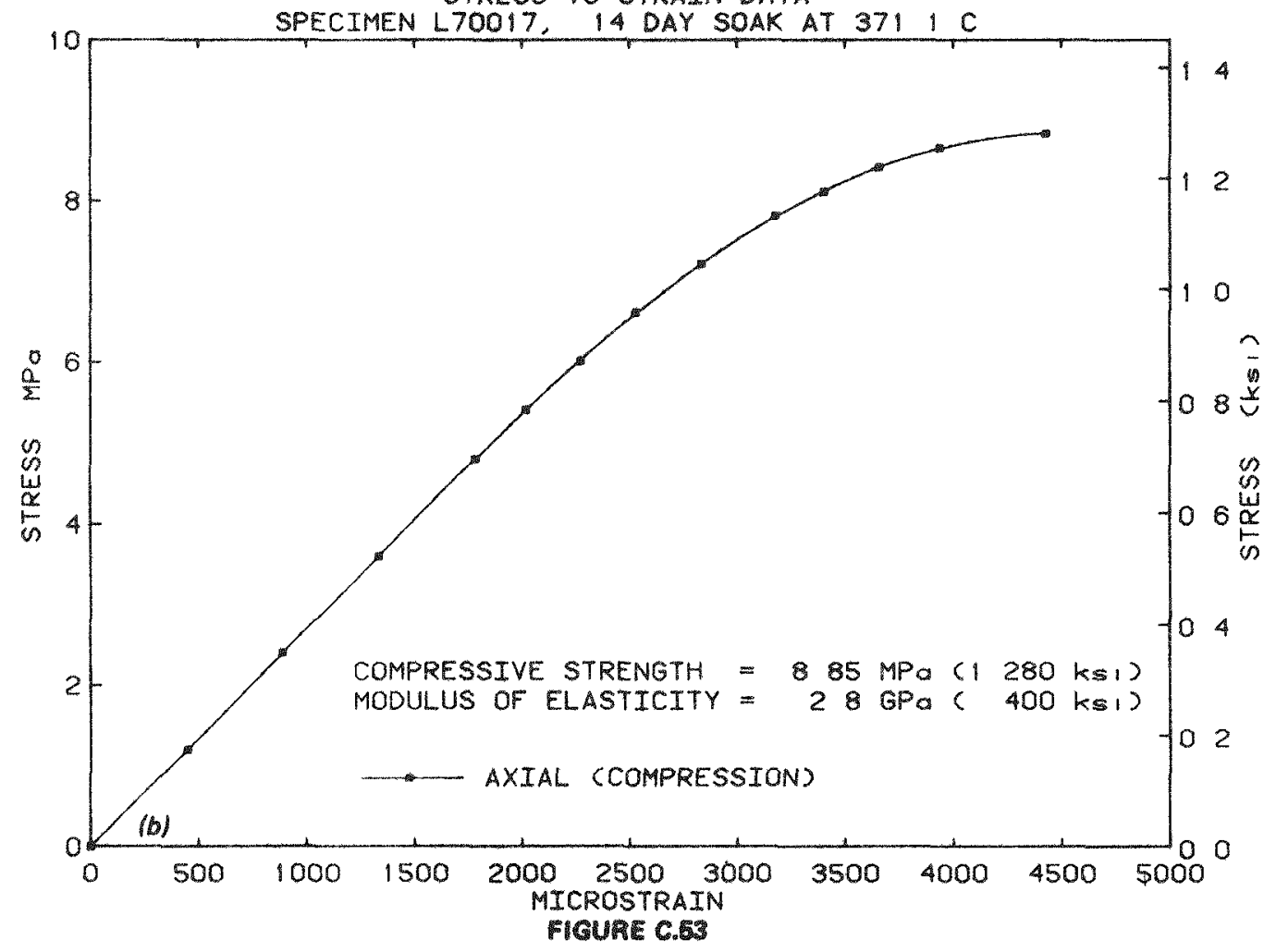


CRBR HIGH TEMPERATURE CONCRETE TESTS

1960 TEMPERATURE VS TIME

LIGHTWEIGHT SPECIMEN L\$OO 7

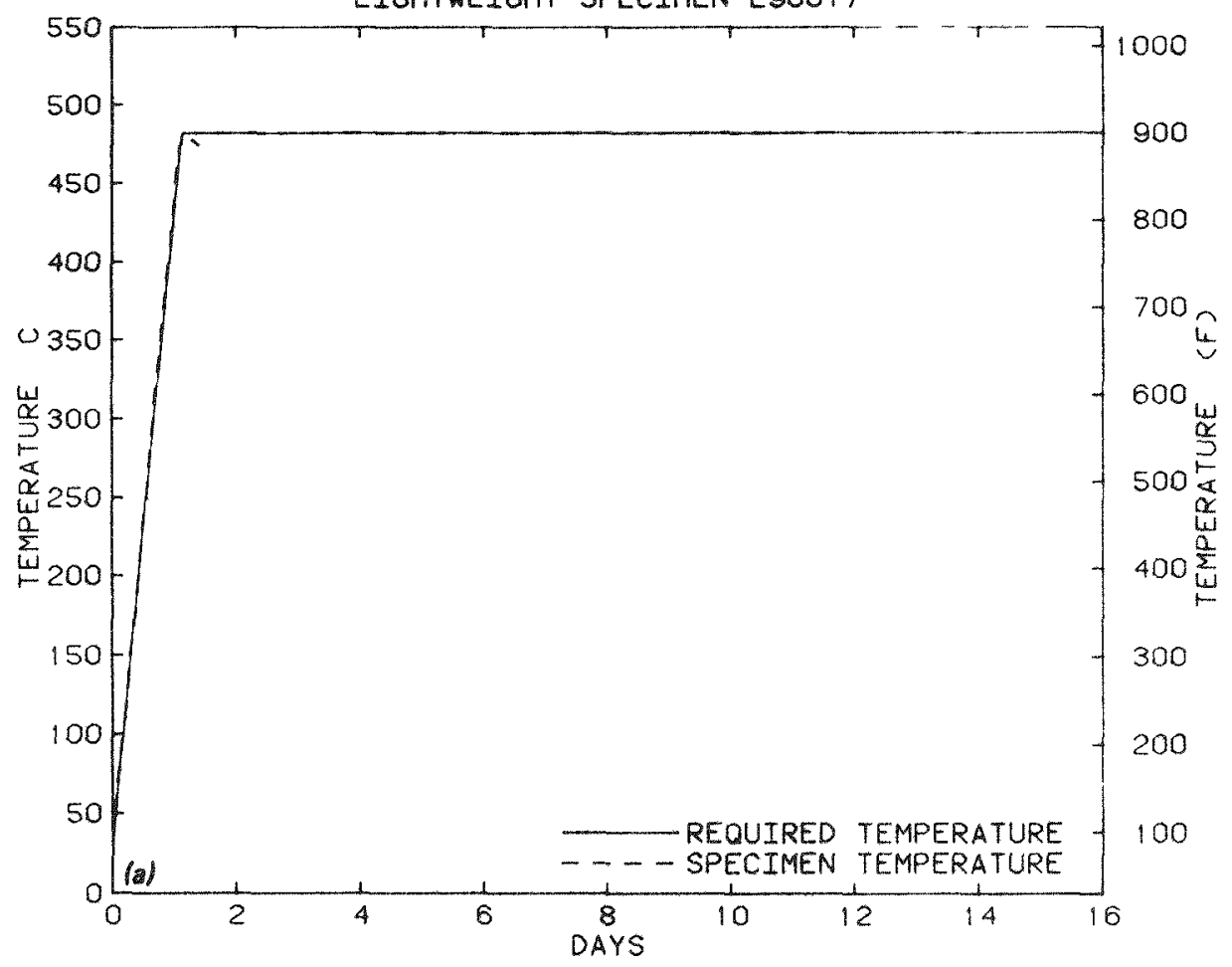

CRBR HIGH TEMPERATURE CONCRETE TESTS STRESS VS STRAIN DATA

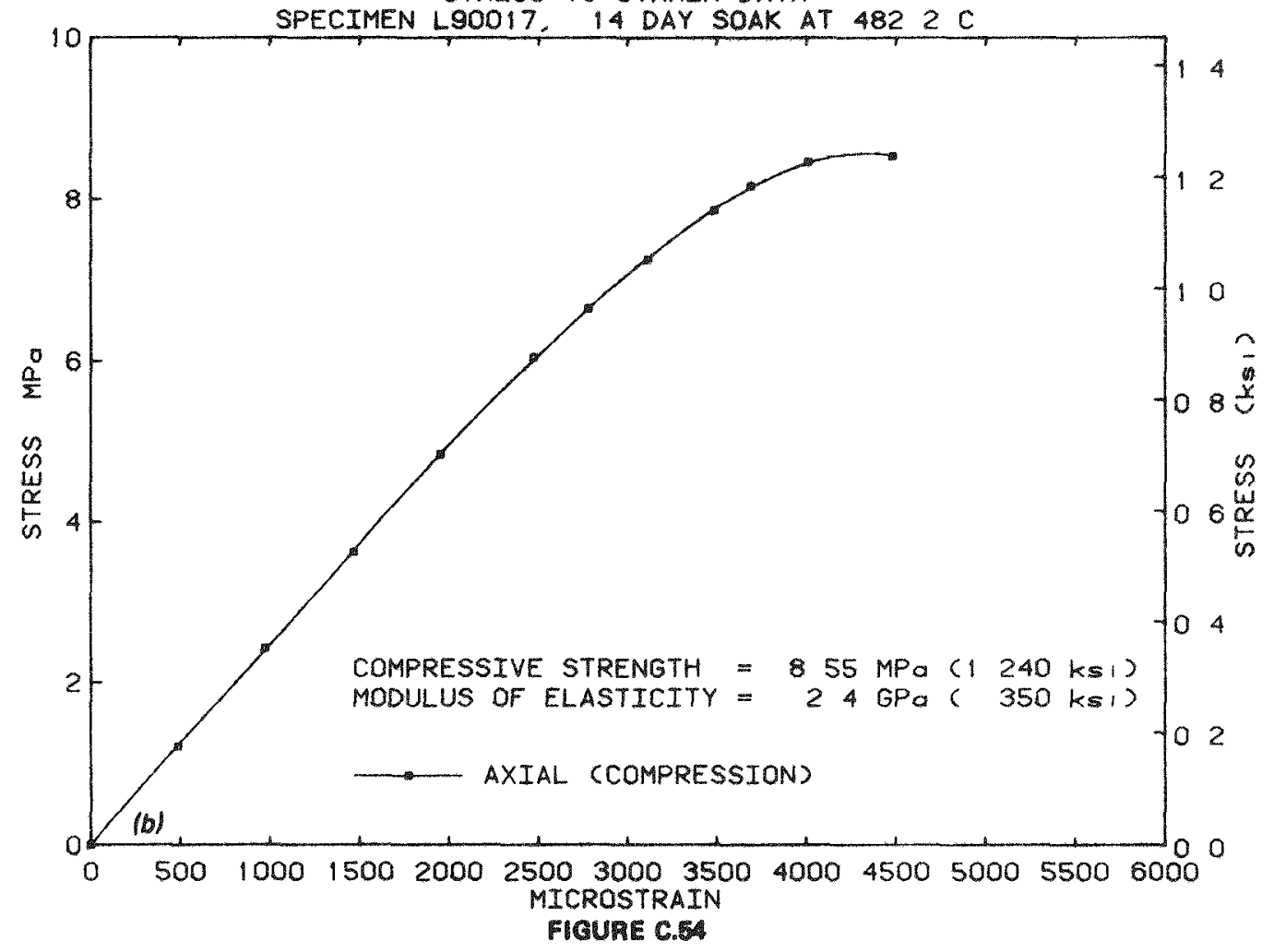


195

Appendix D

SHEAR SPECIMEN'S TEMPERATURE HISTORY 
196

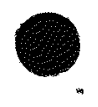

-

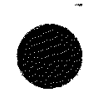



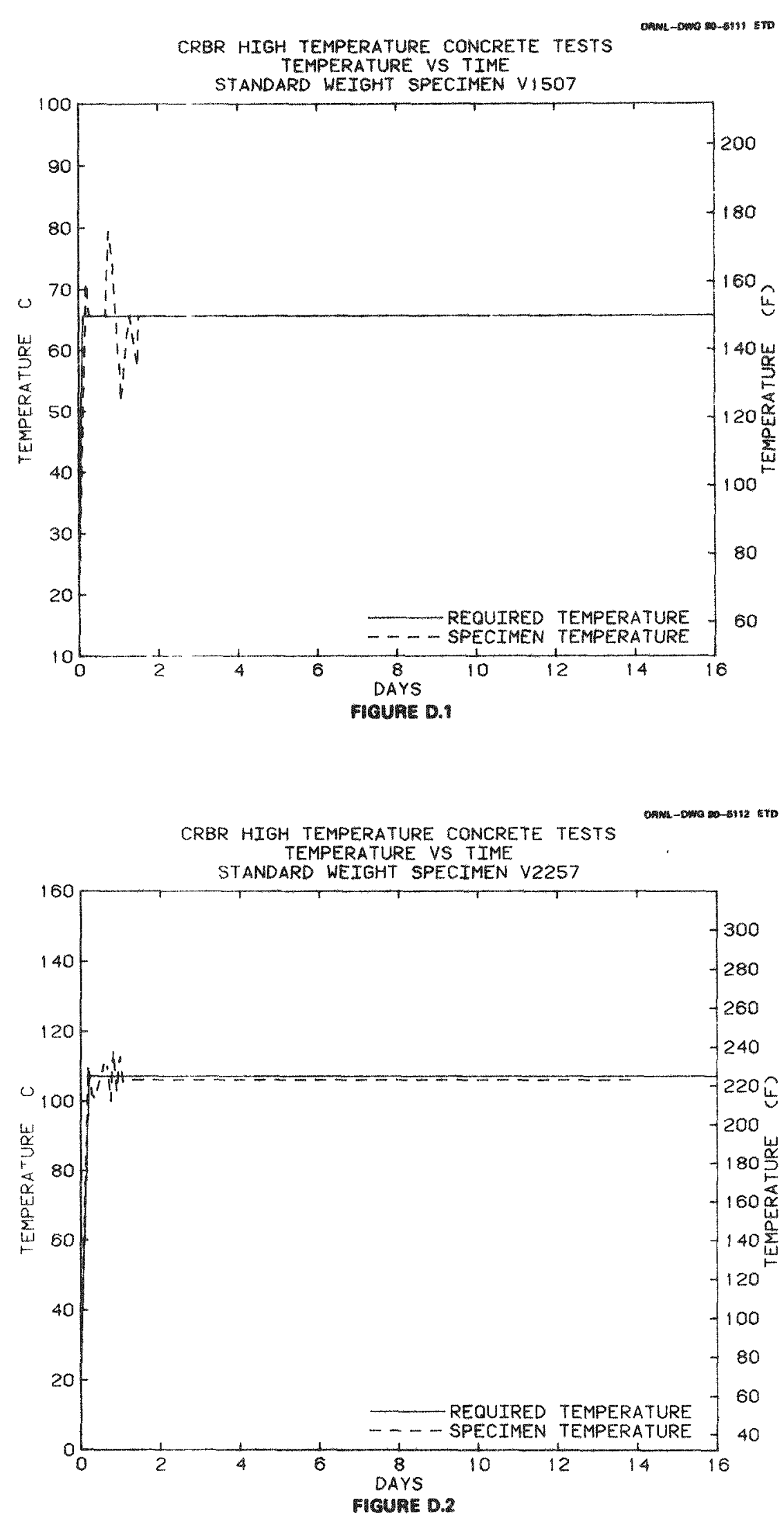

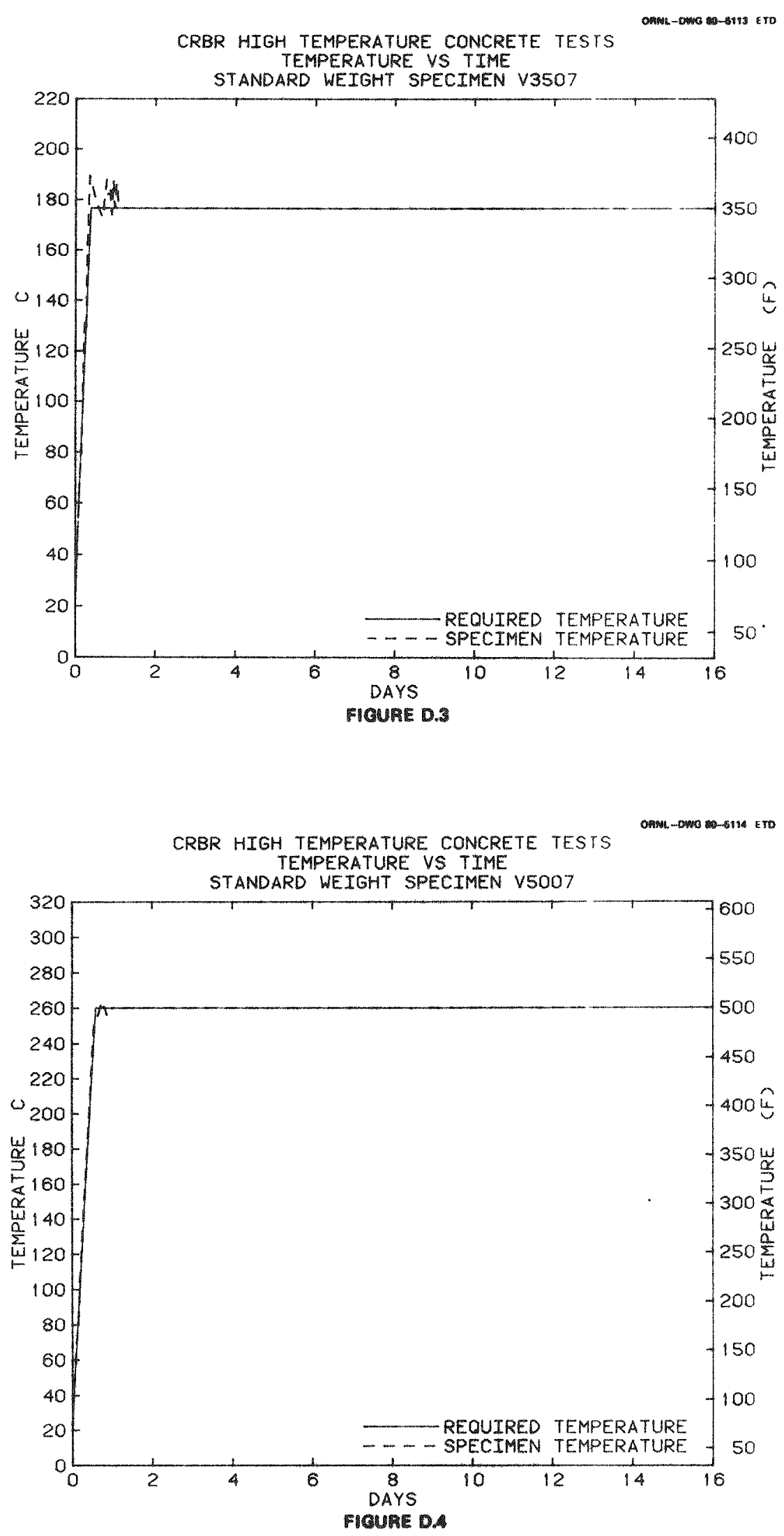

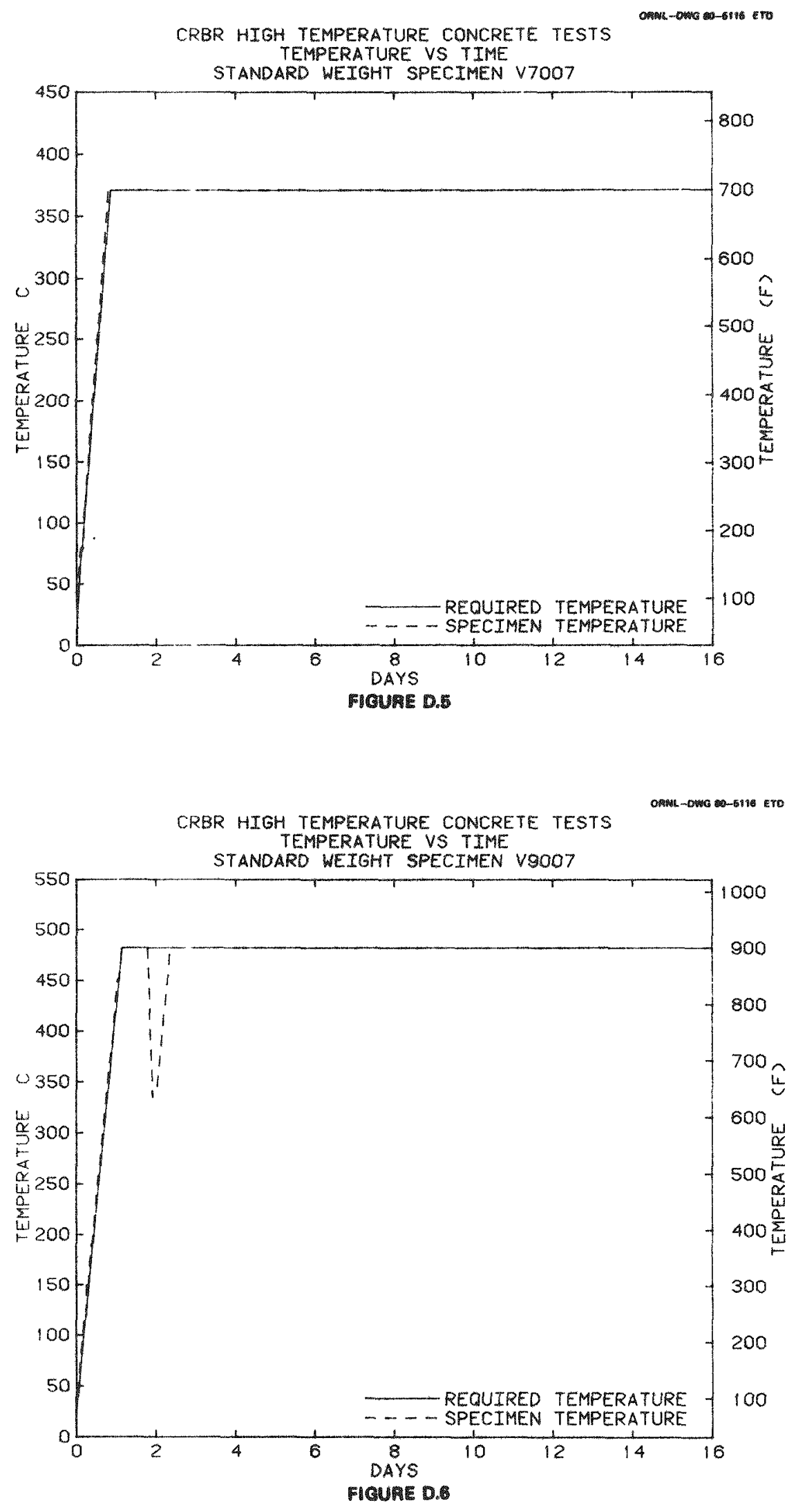

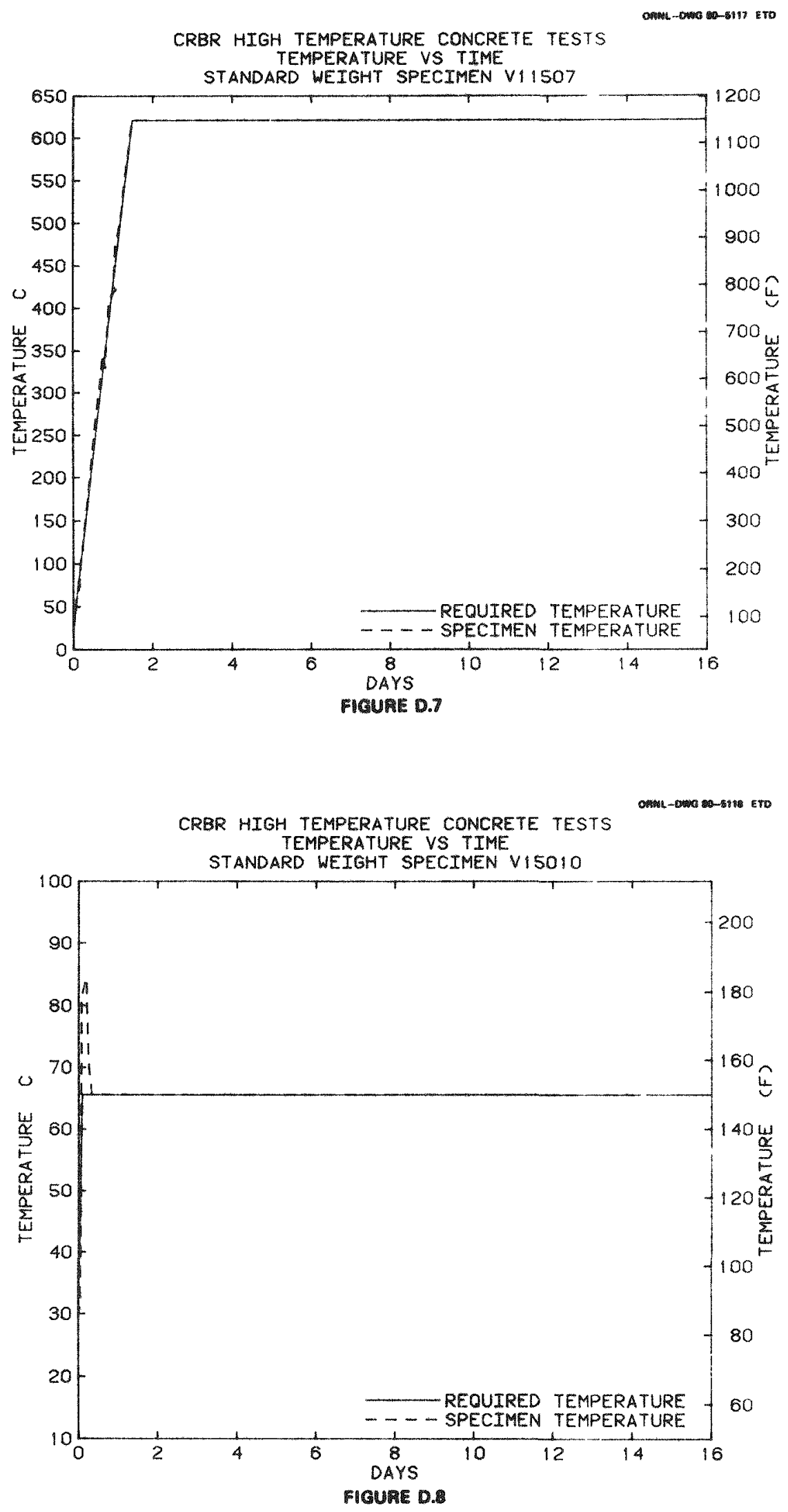

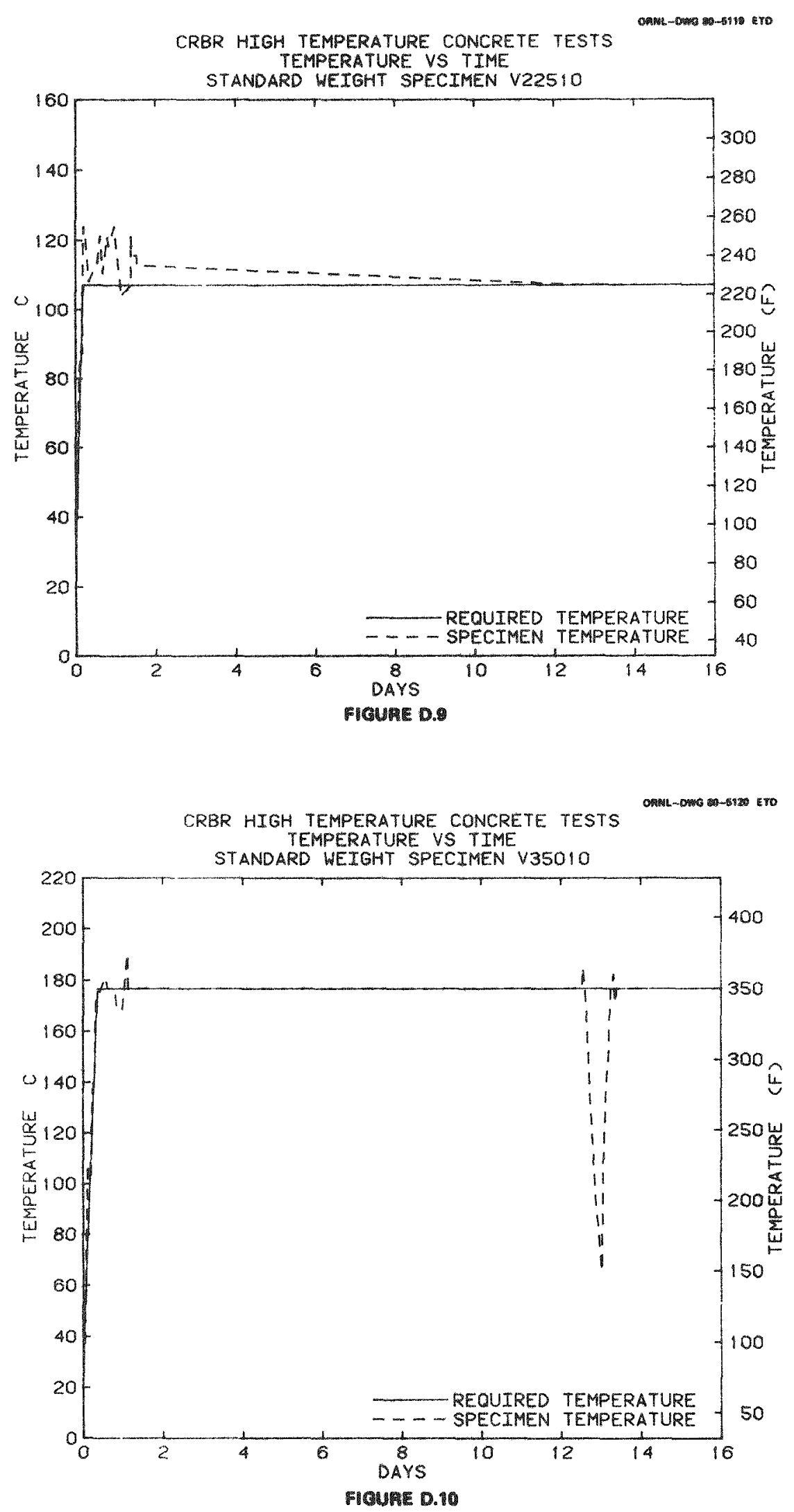

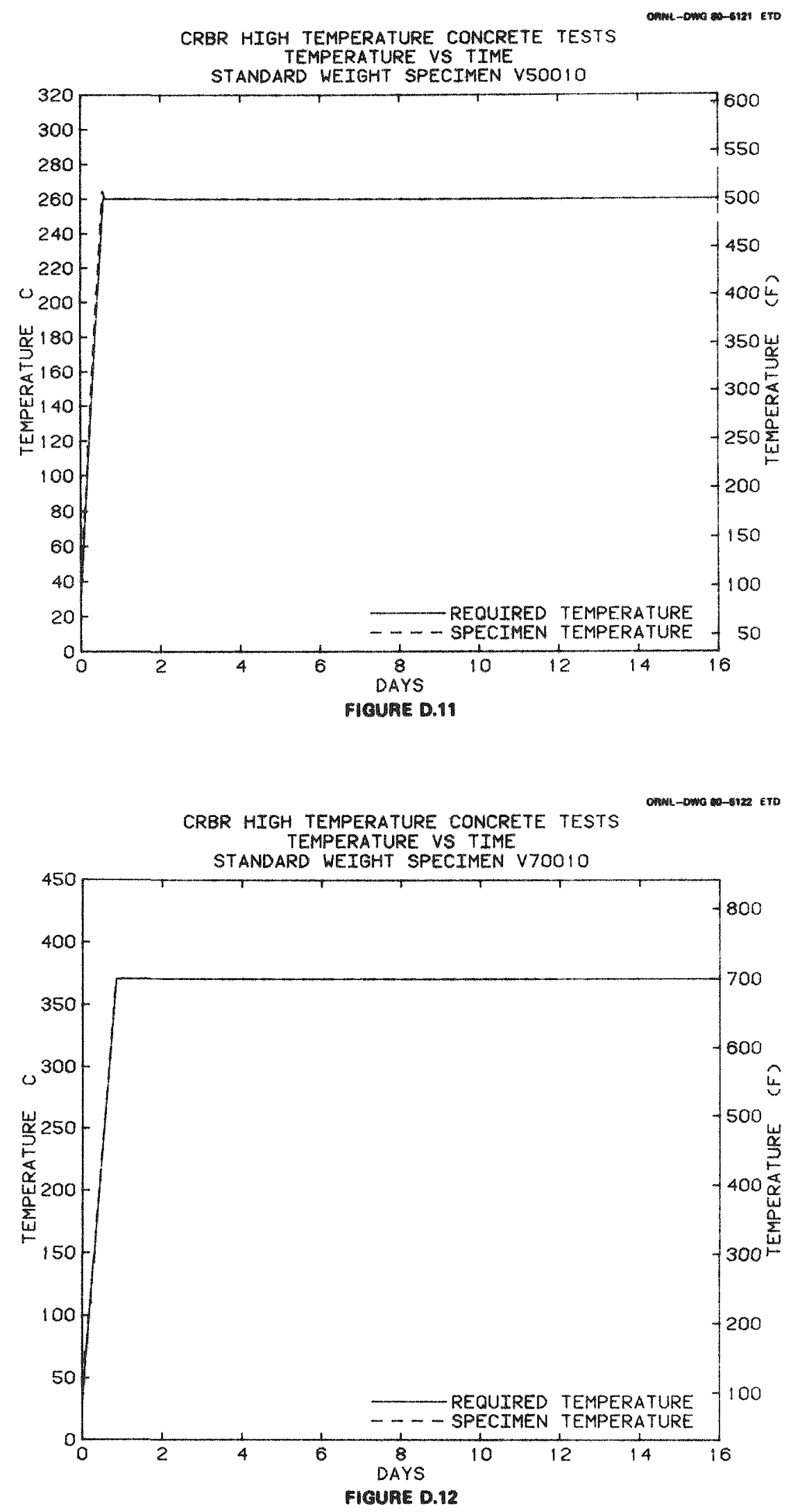


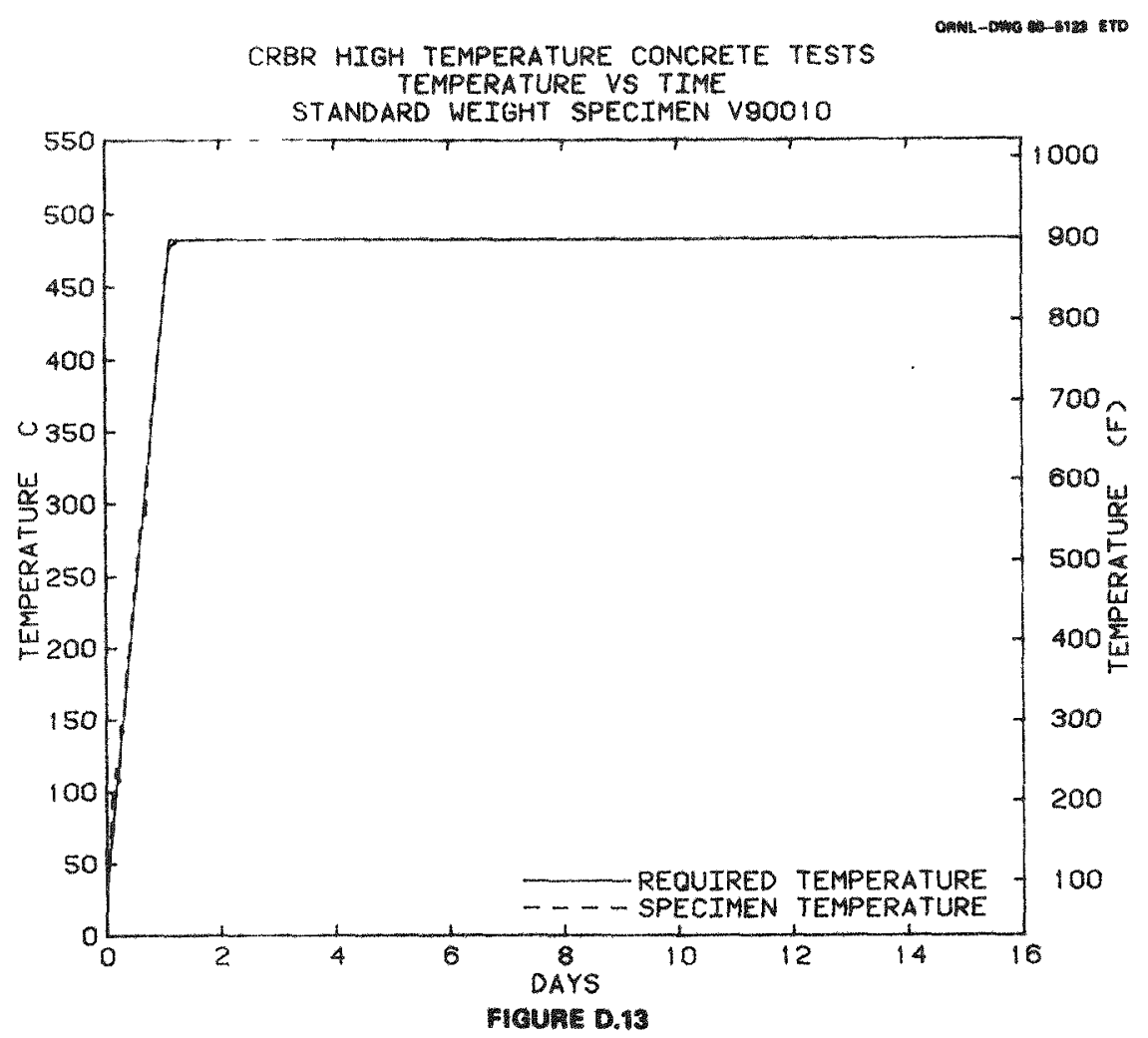

CRBR HIGH TEMPERATURE CONCRETE TESTS TEMPERATURE VS TIME

STANDARD WEIGHT SPECIMEN V 115010

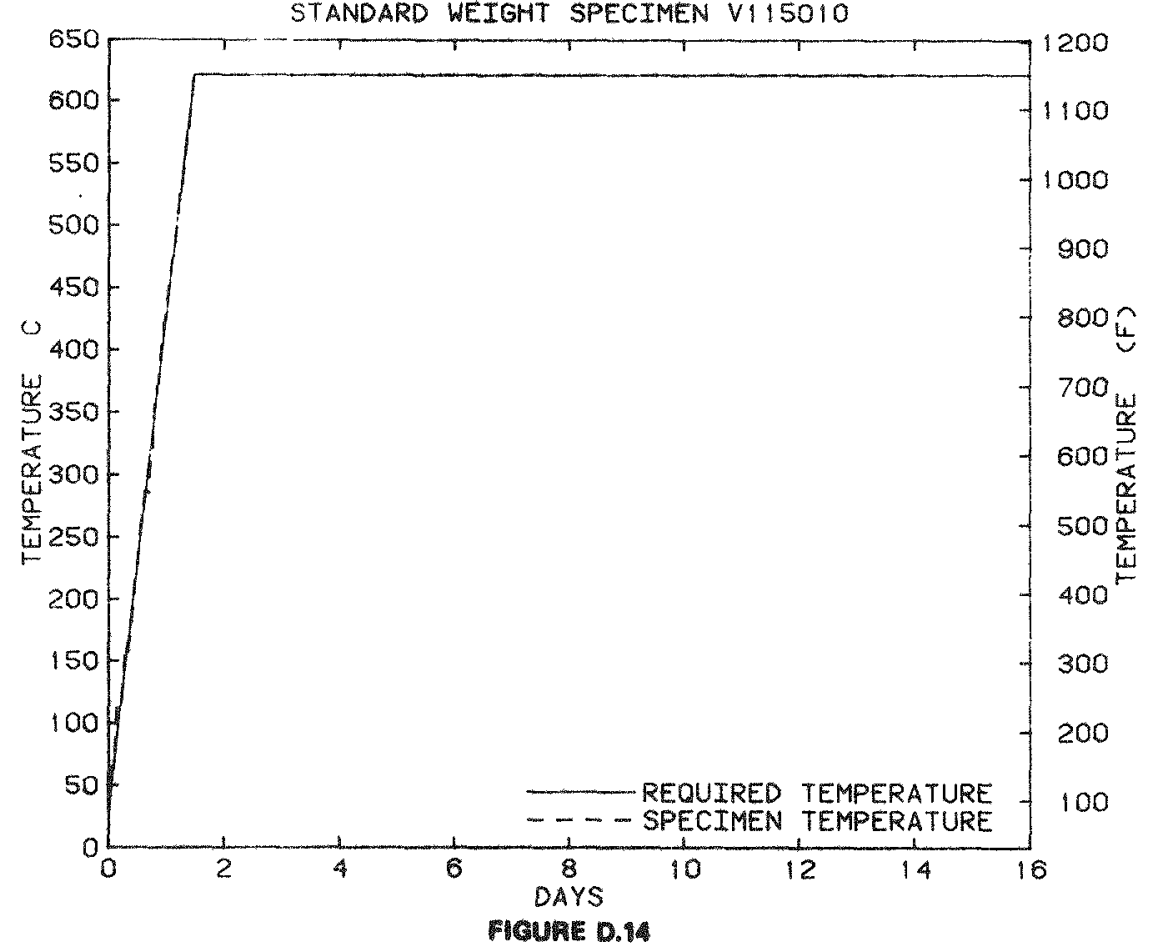




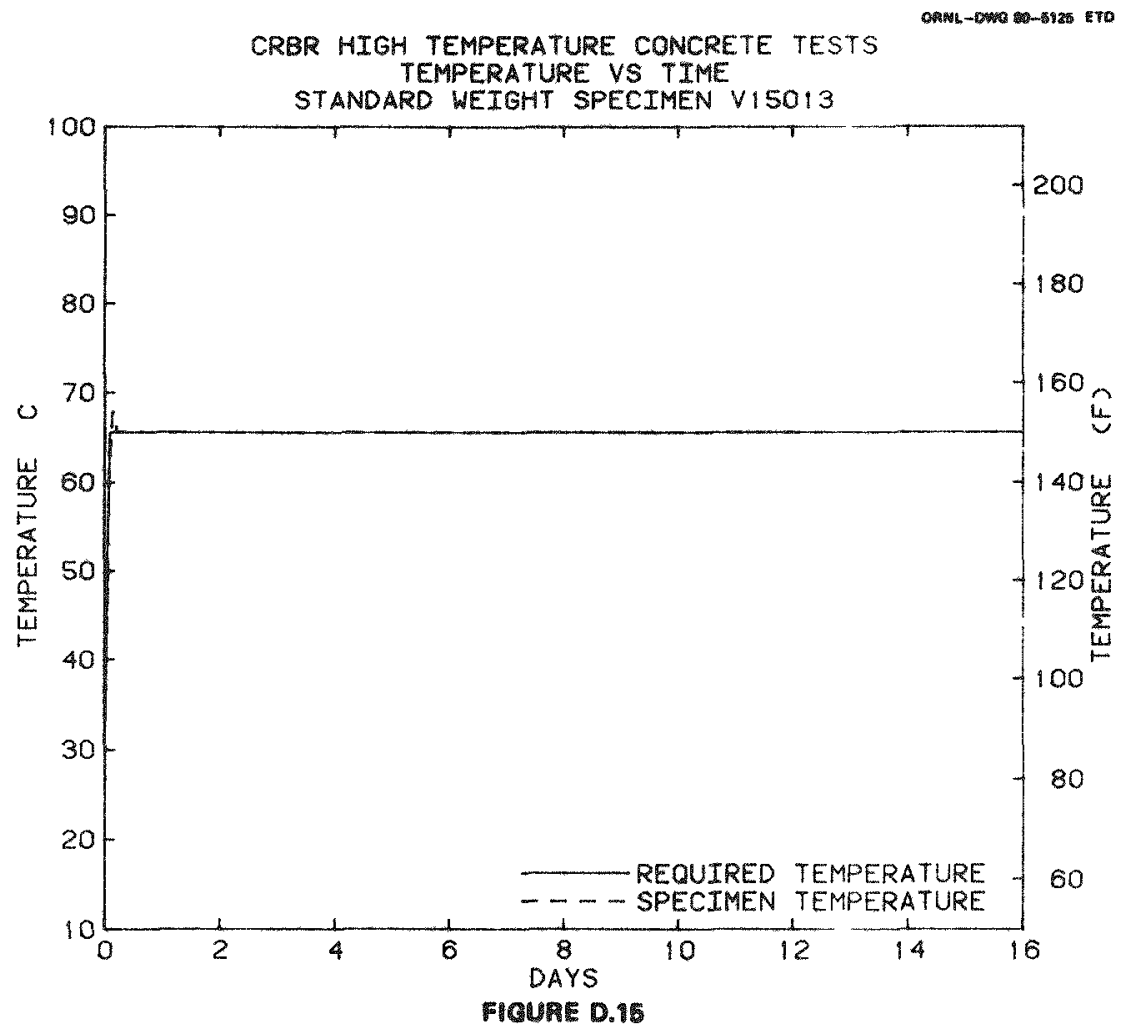

Оดคน -ONO

CRBR HIGH TEMPERATURE CONCRETE TESTS TEMPERATURE VS TIME

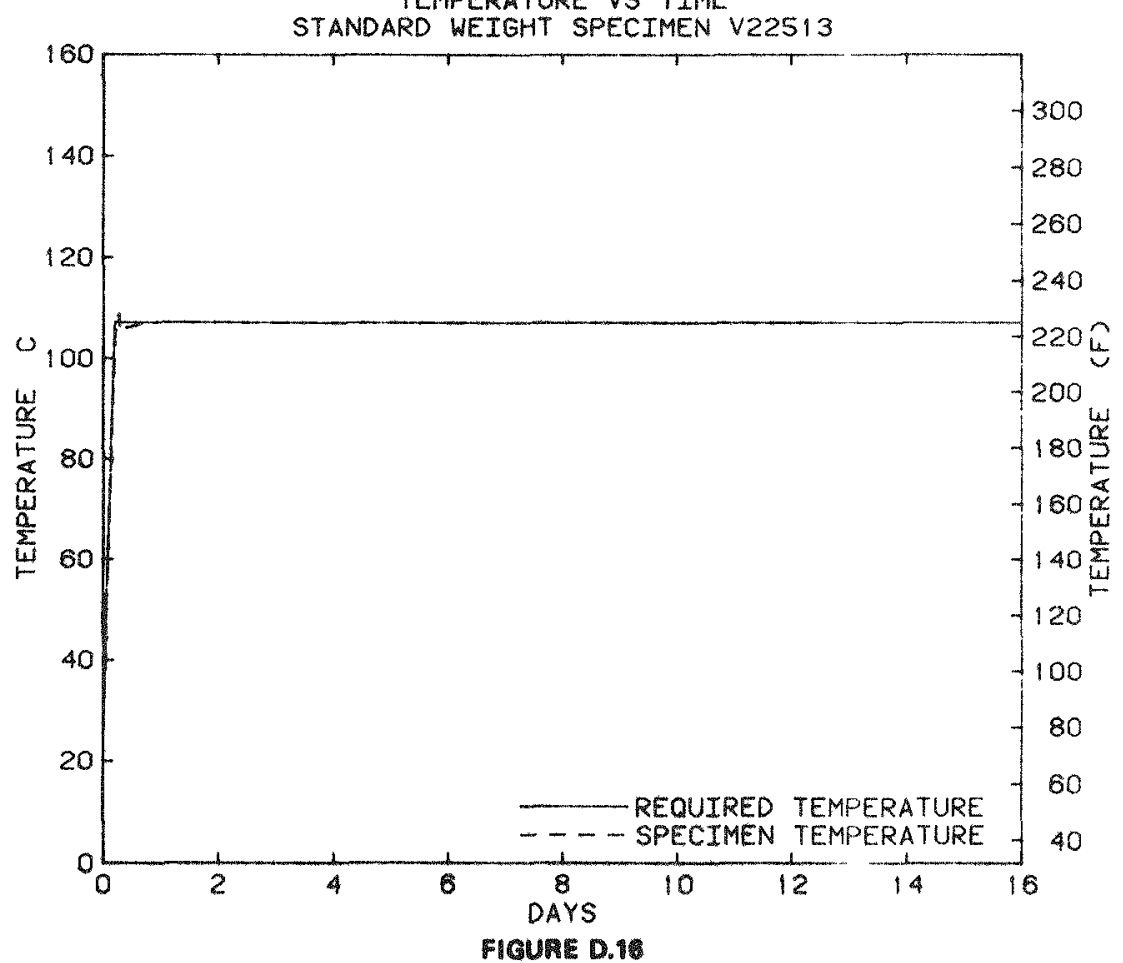




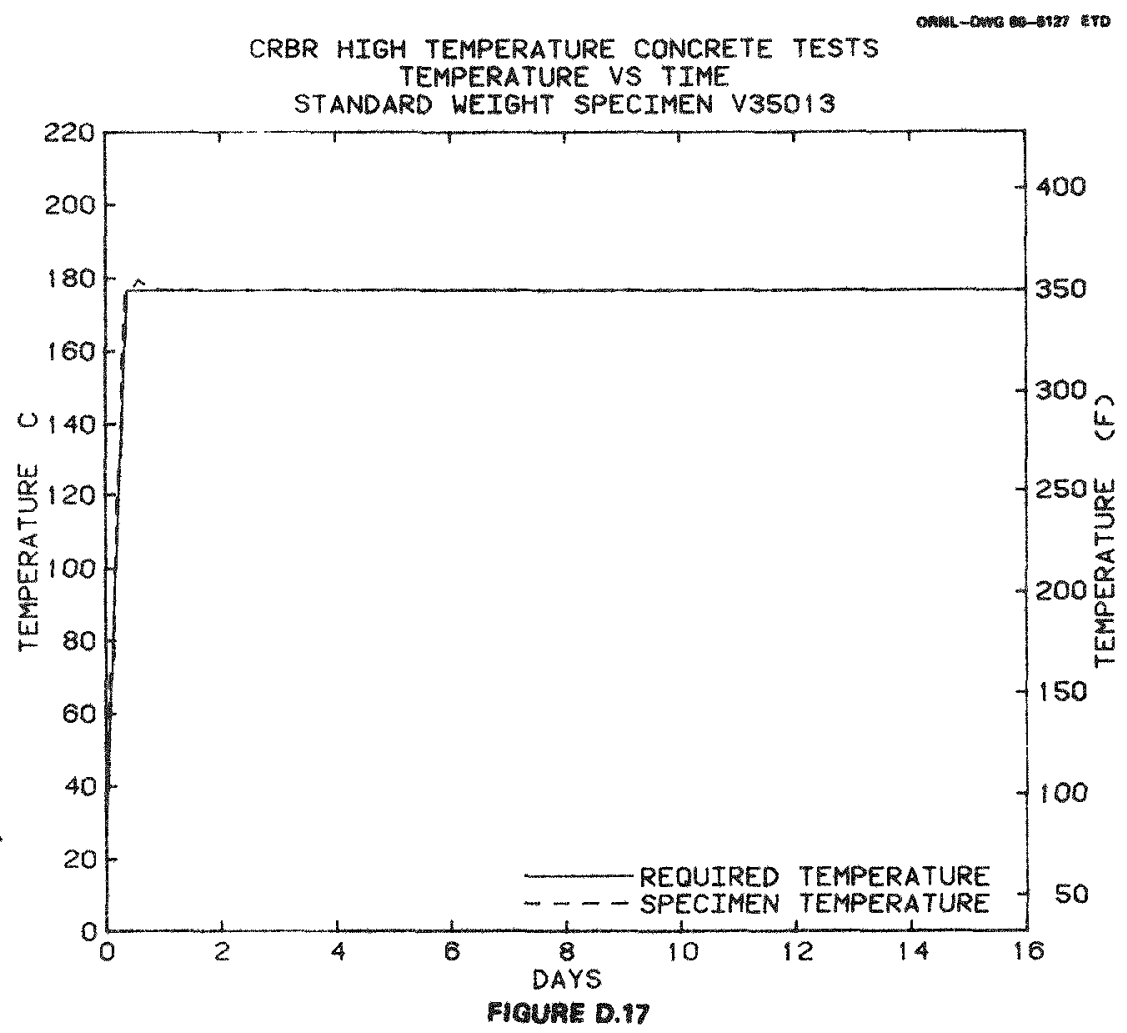

CRBR HIGH TEMPERATURE CONCRETE TESTS

CONE TEMPERATURE VS TTME

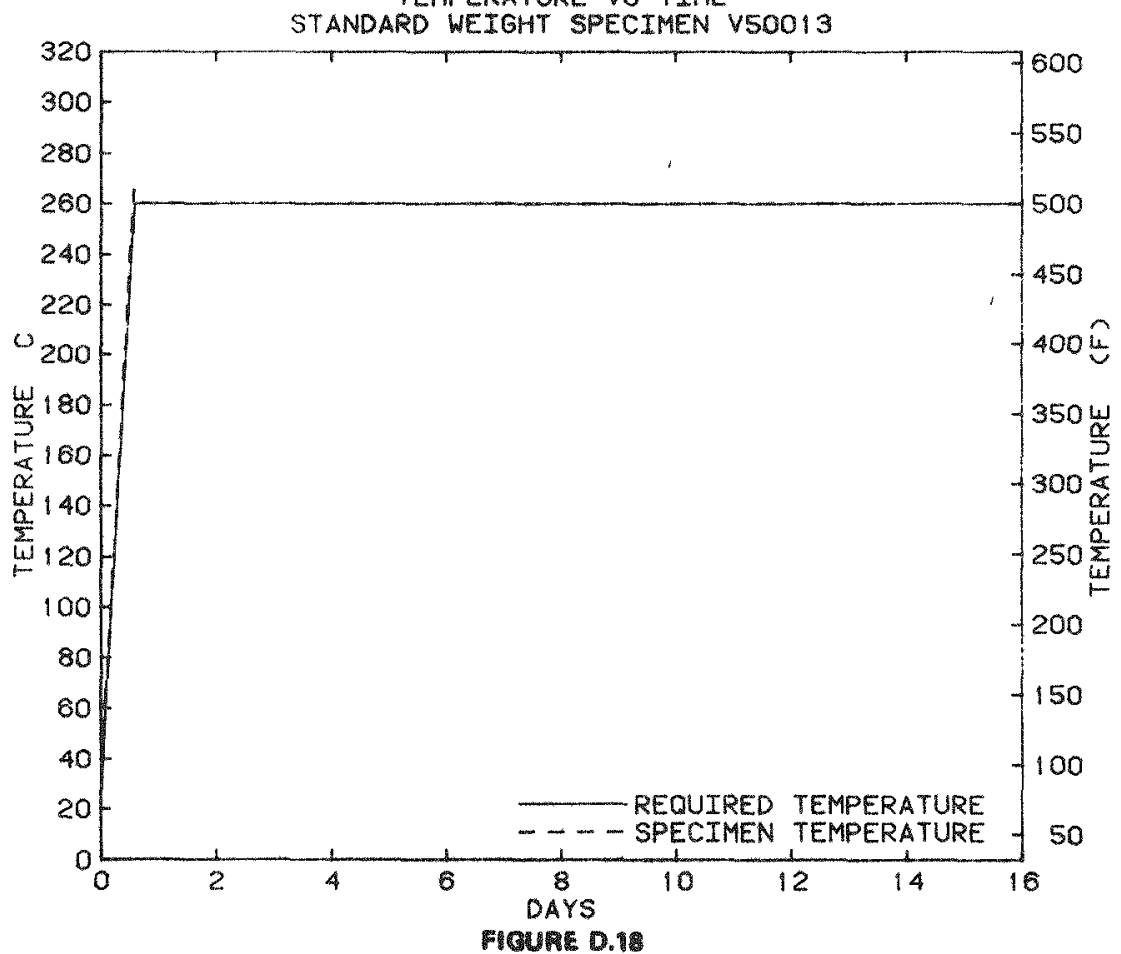



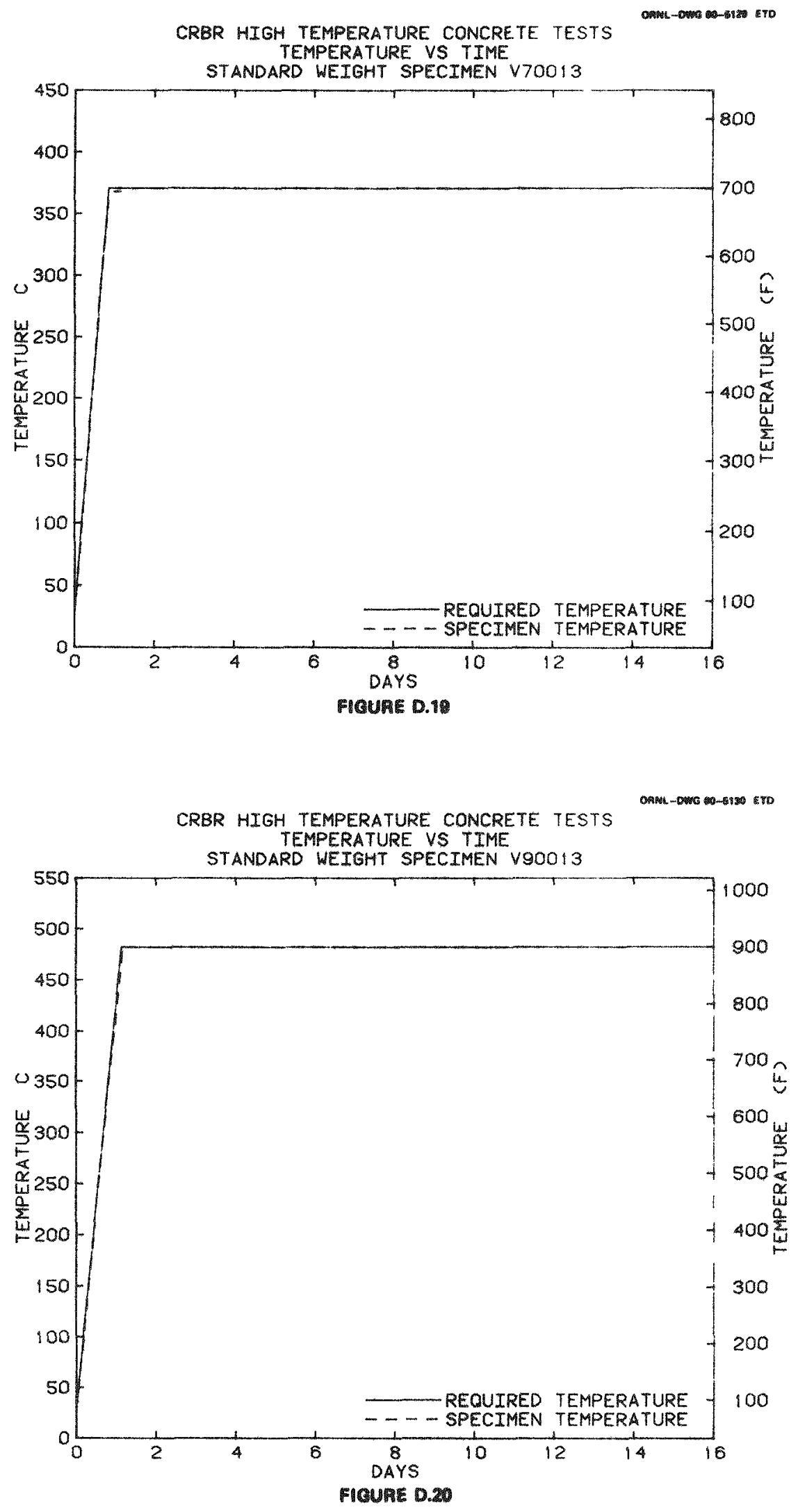


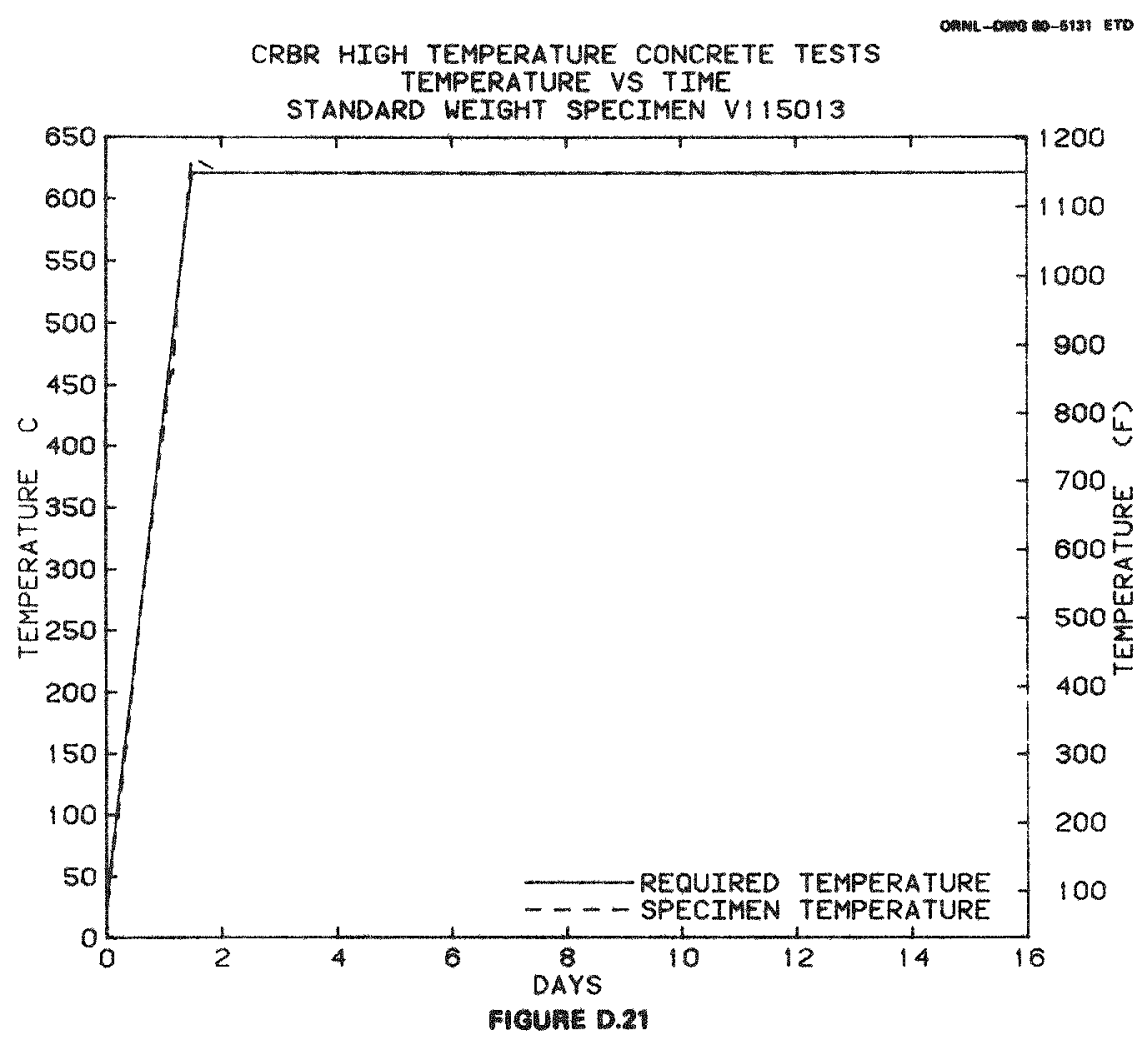


-

- 
Appendix E

CONCRETE-REBAR BOND STRESS VERSUS SLIP DATA 
-

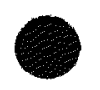



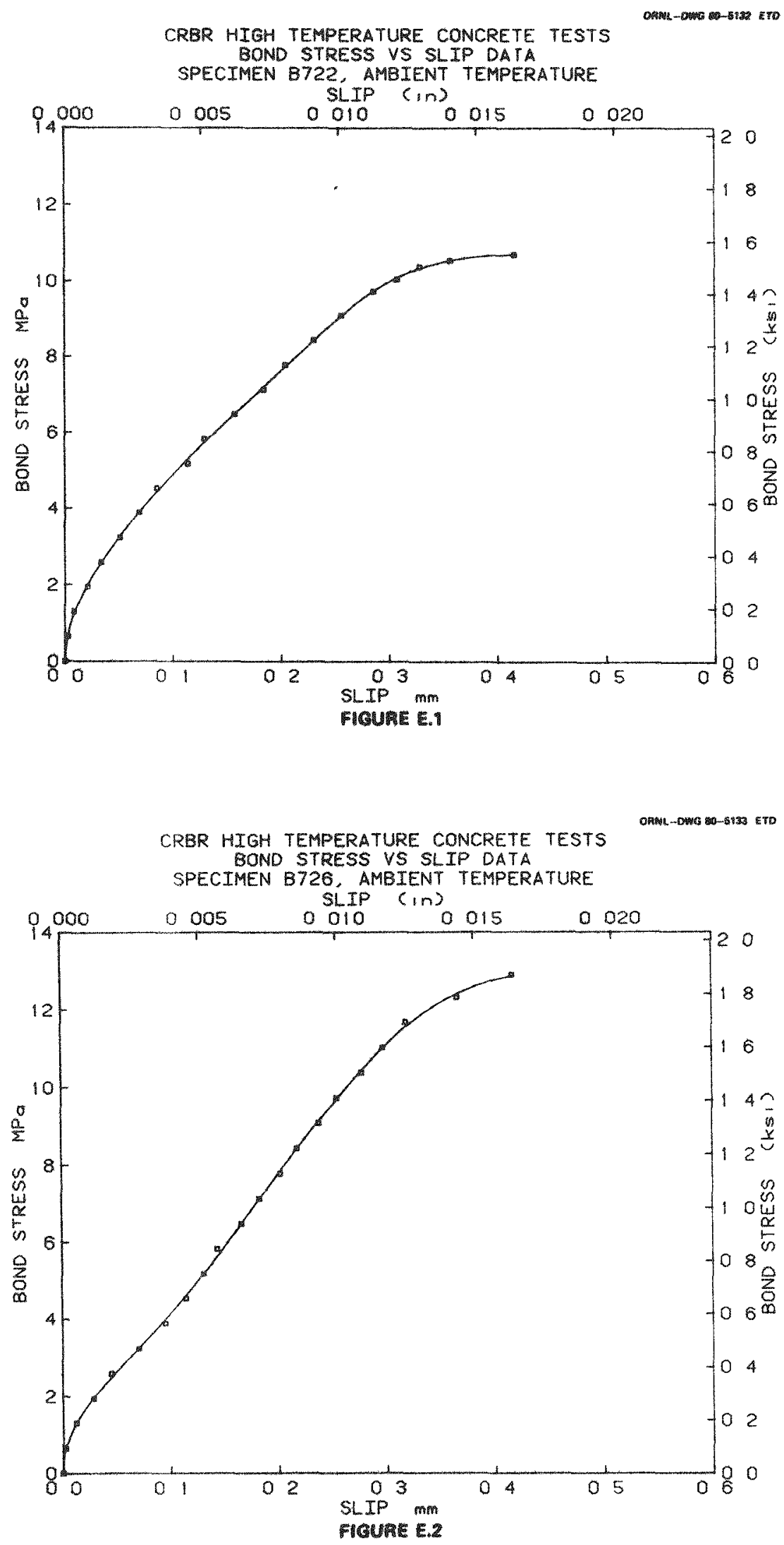


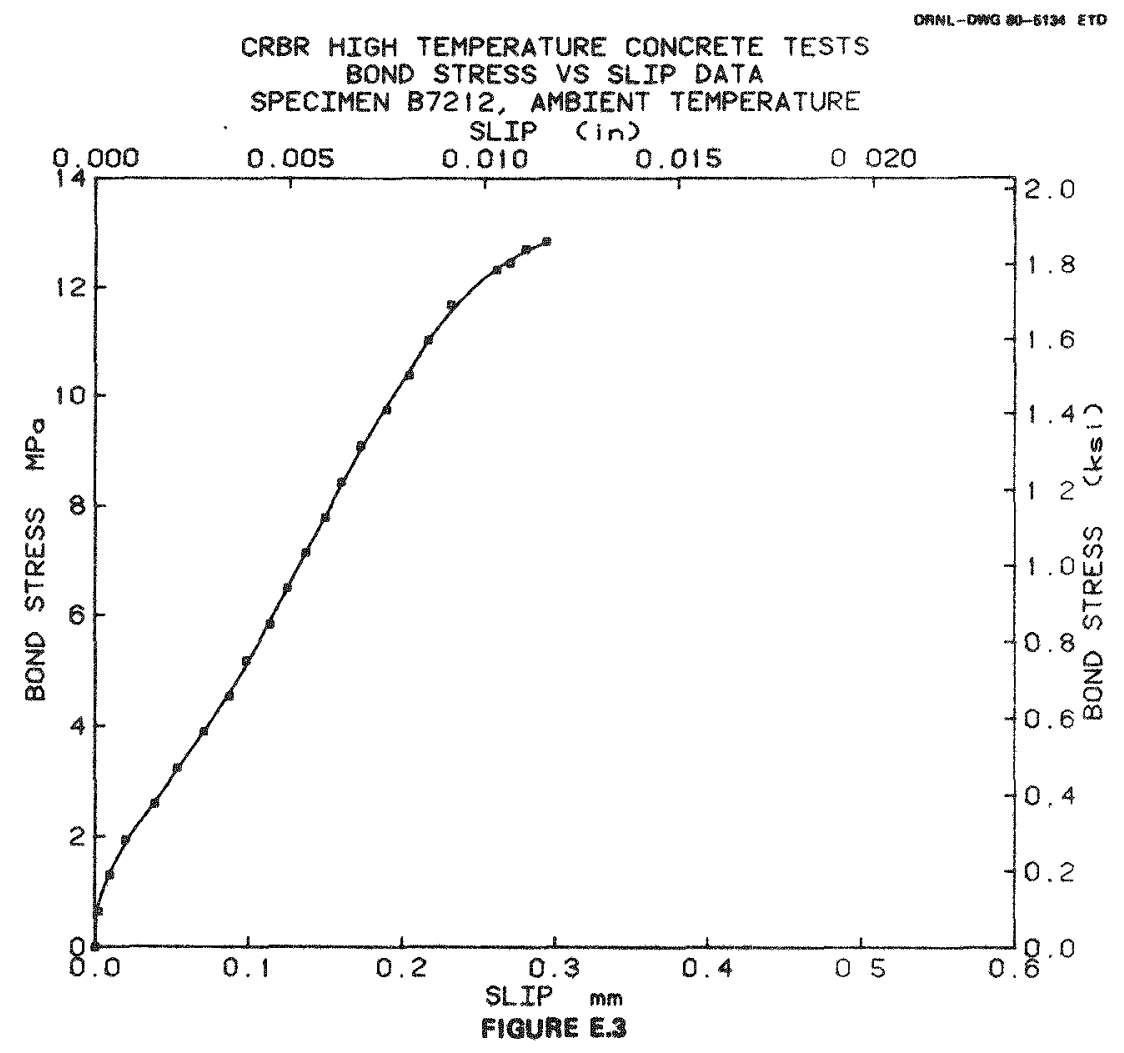



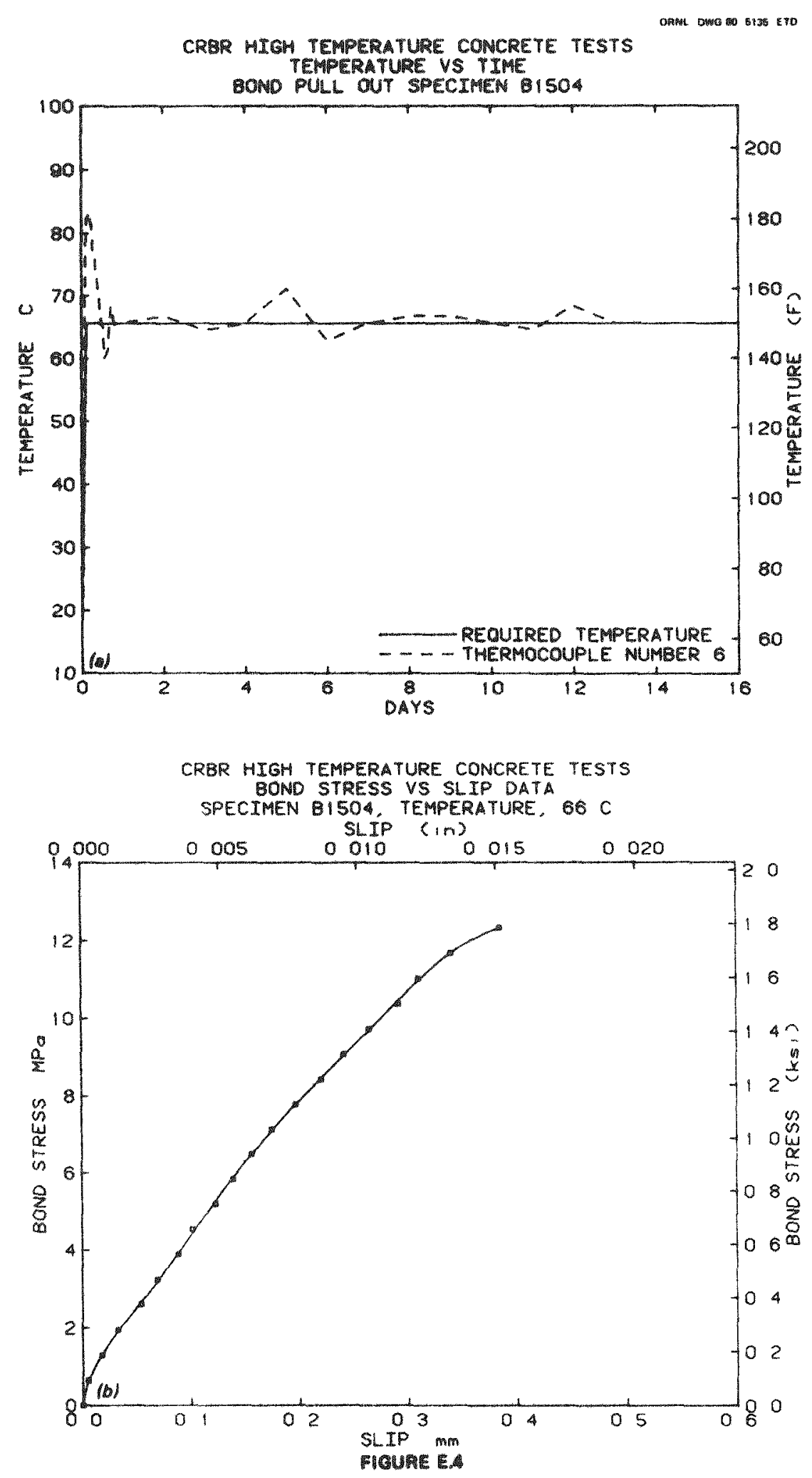

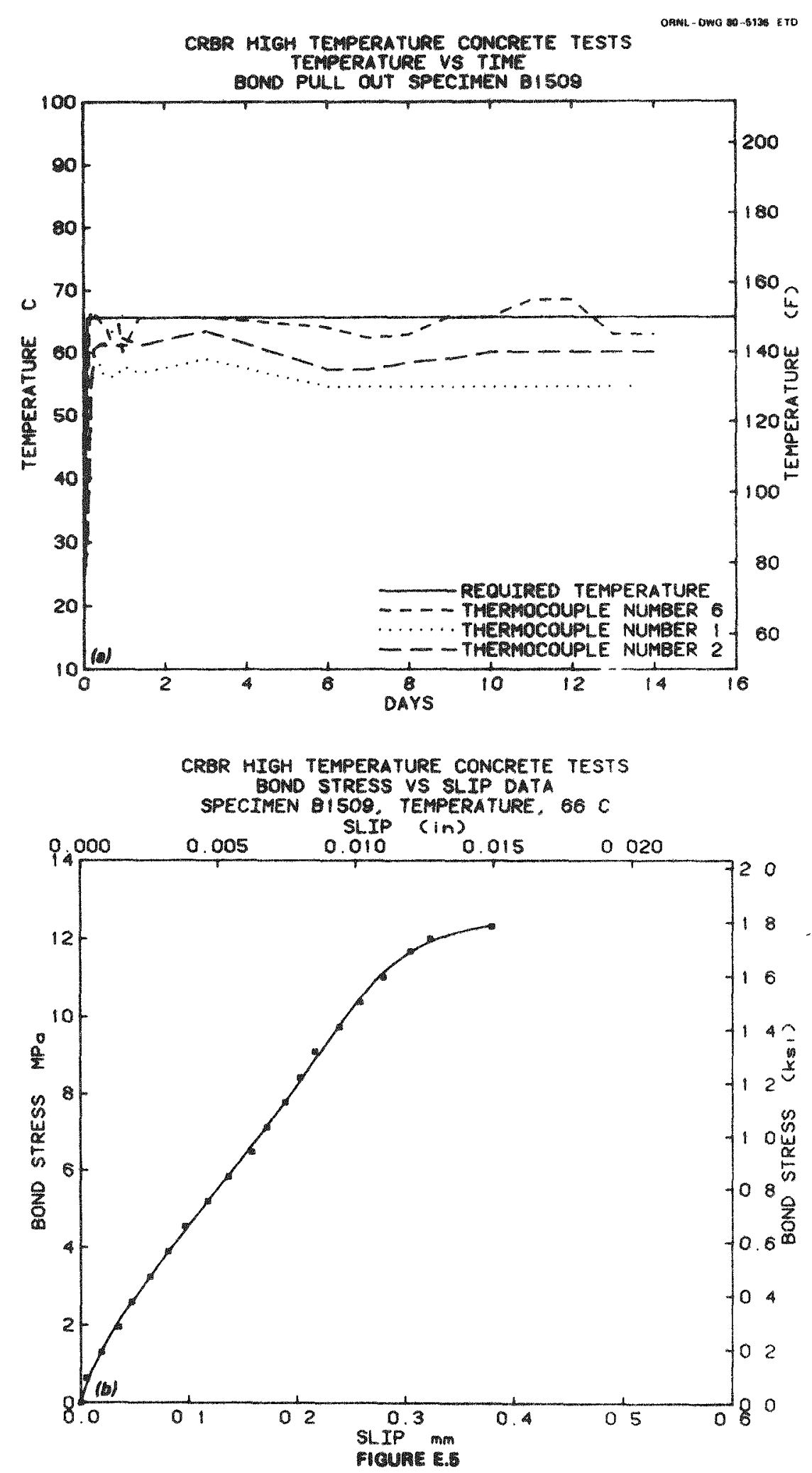

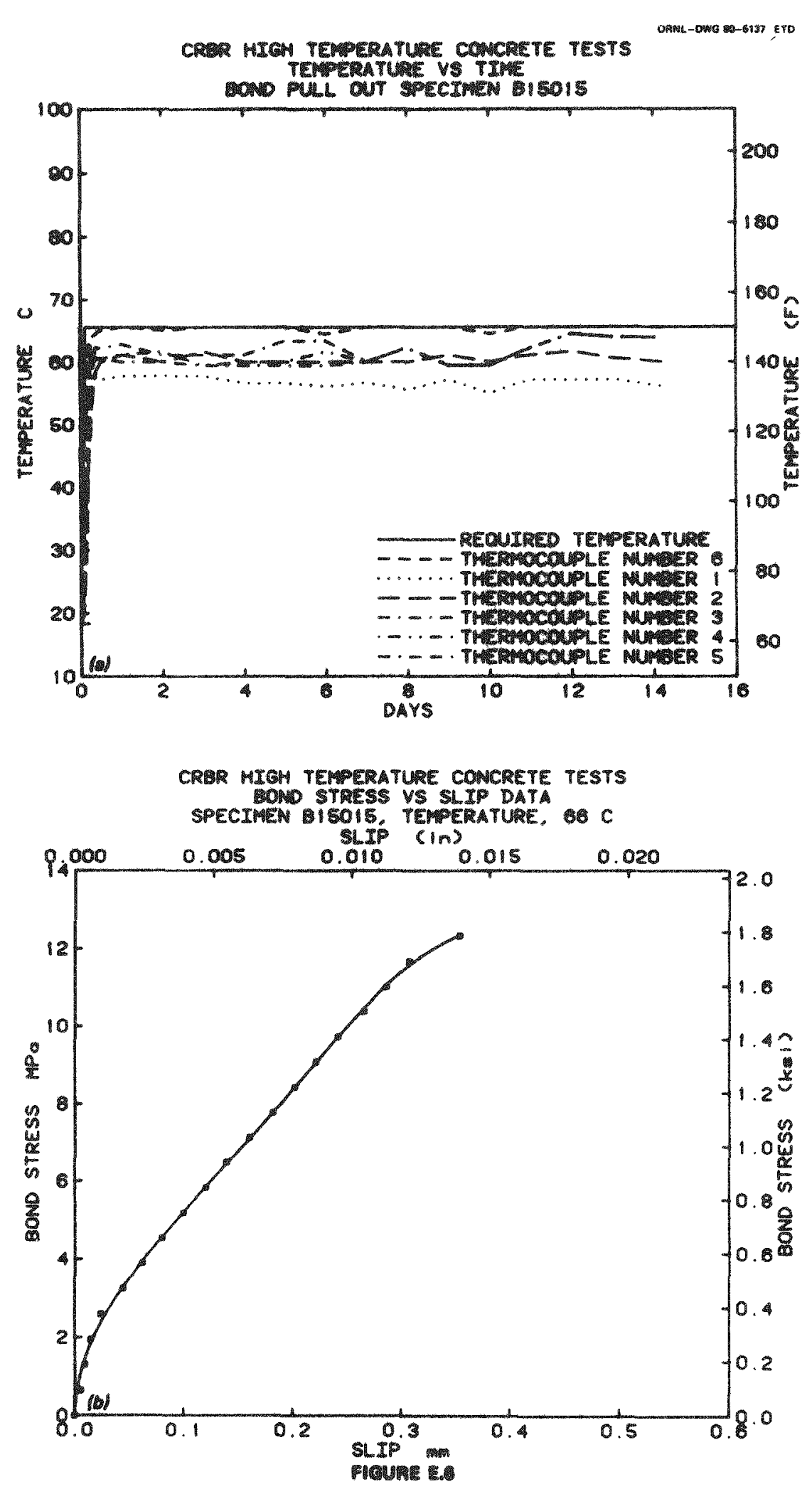

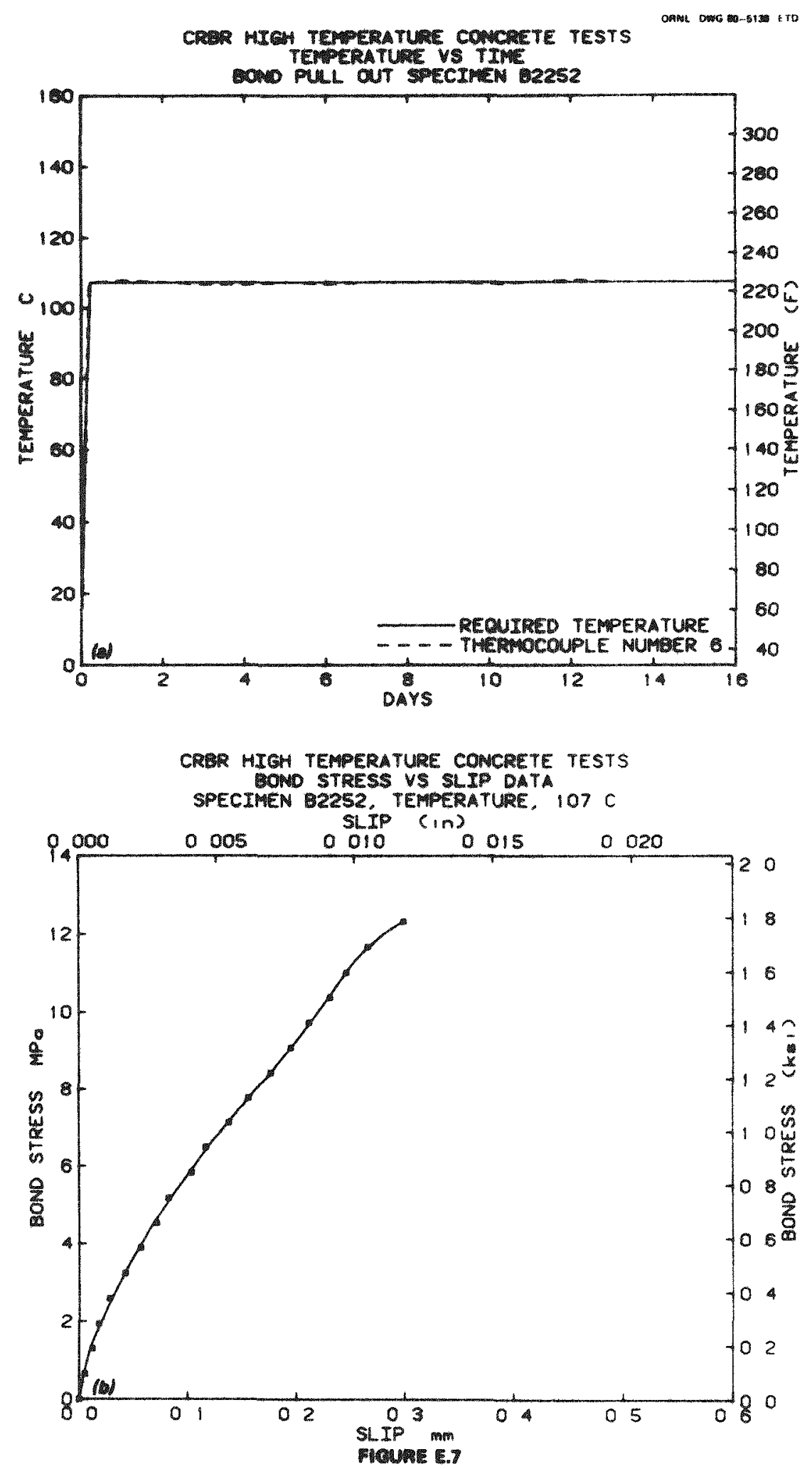

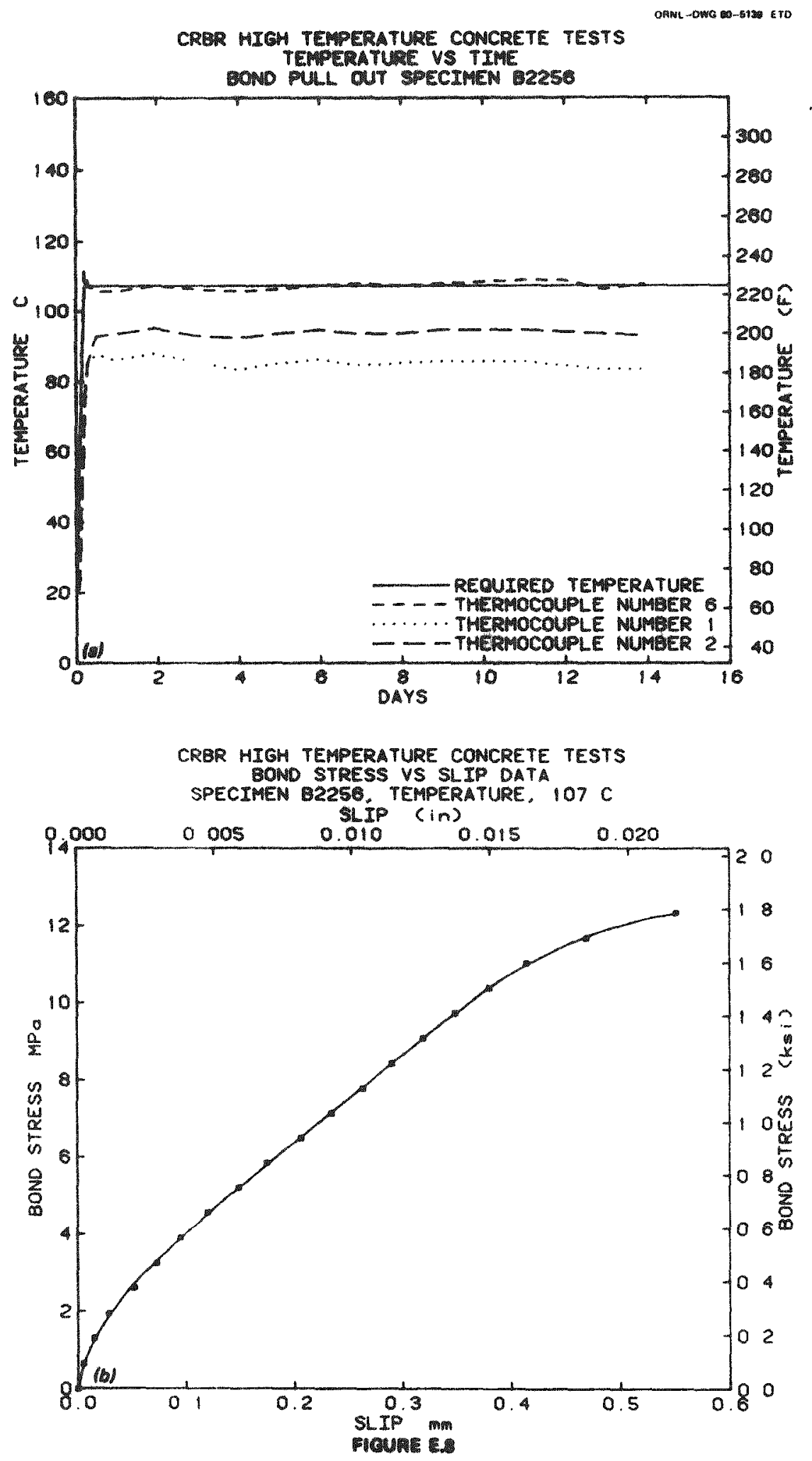

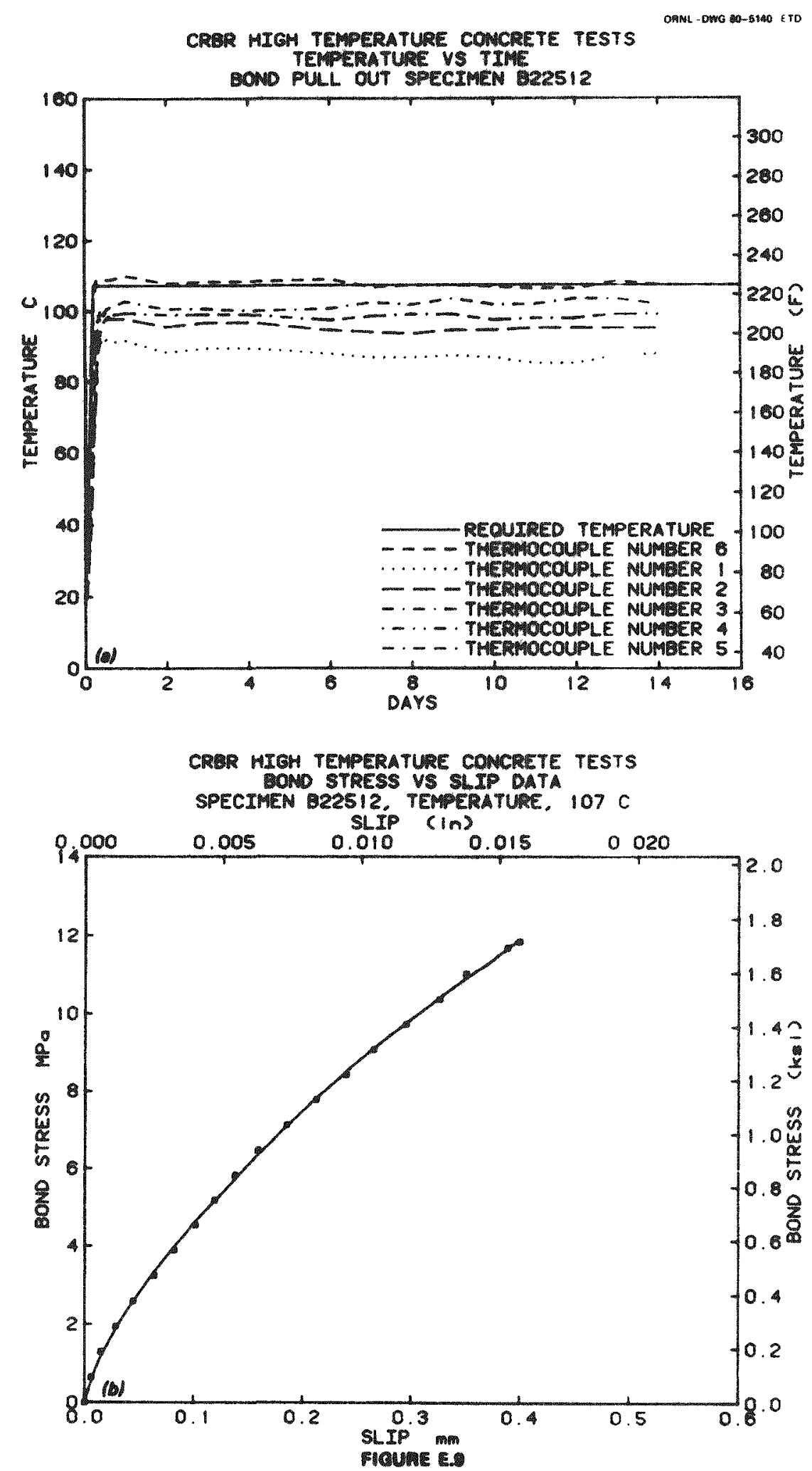

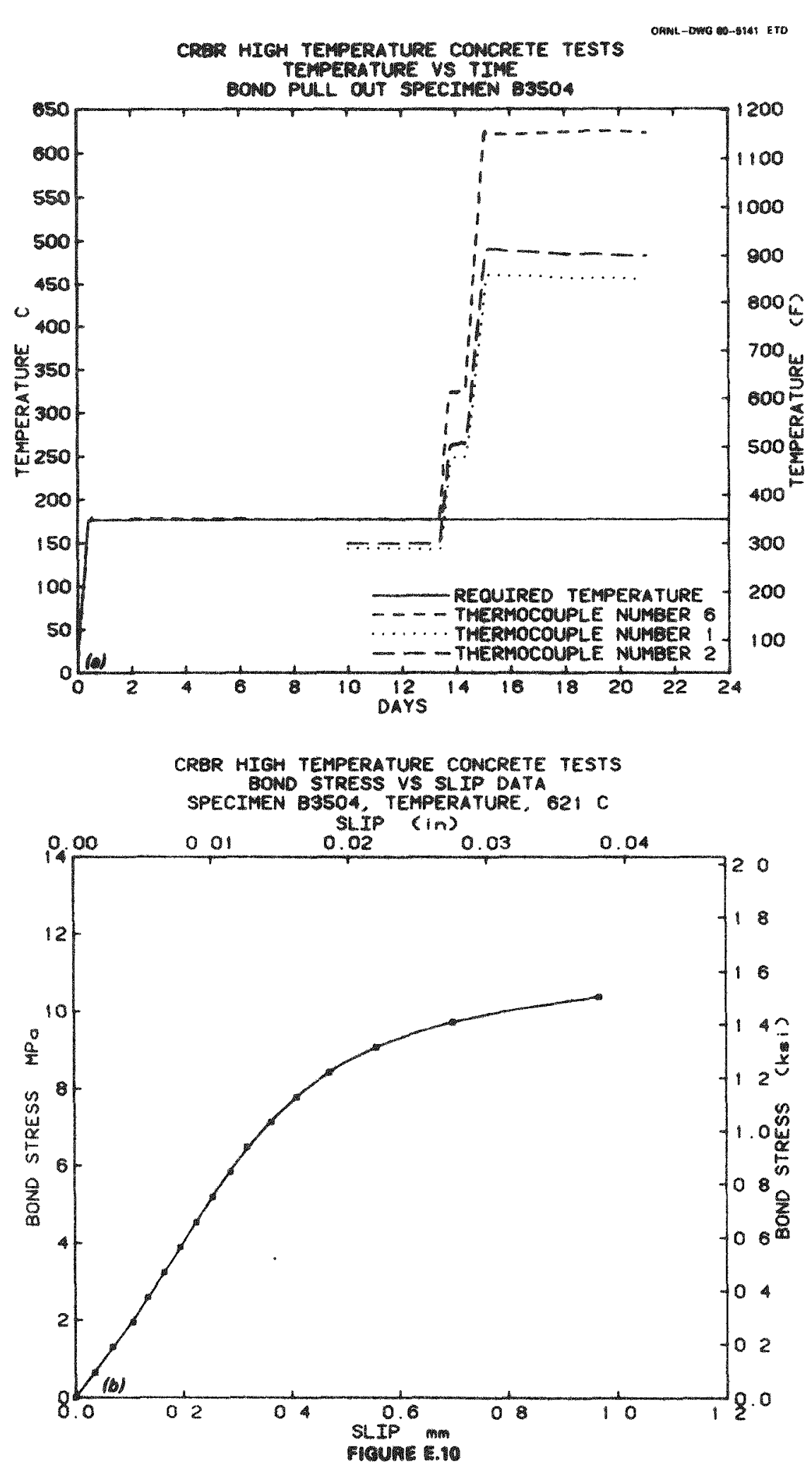
CRPR MICH TEMPEATURE CONCRETE TESTS

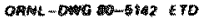

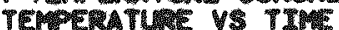

CONo PULL OUT SPCCIM

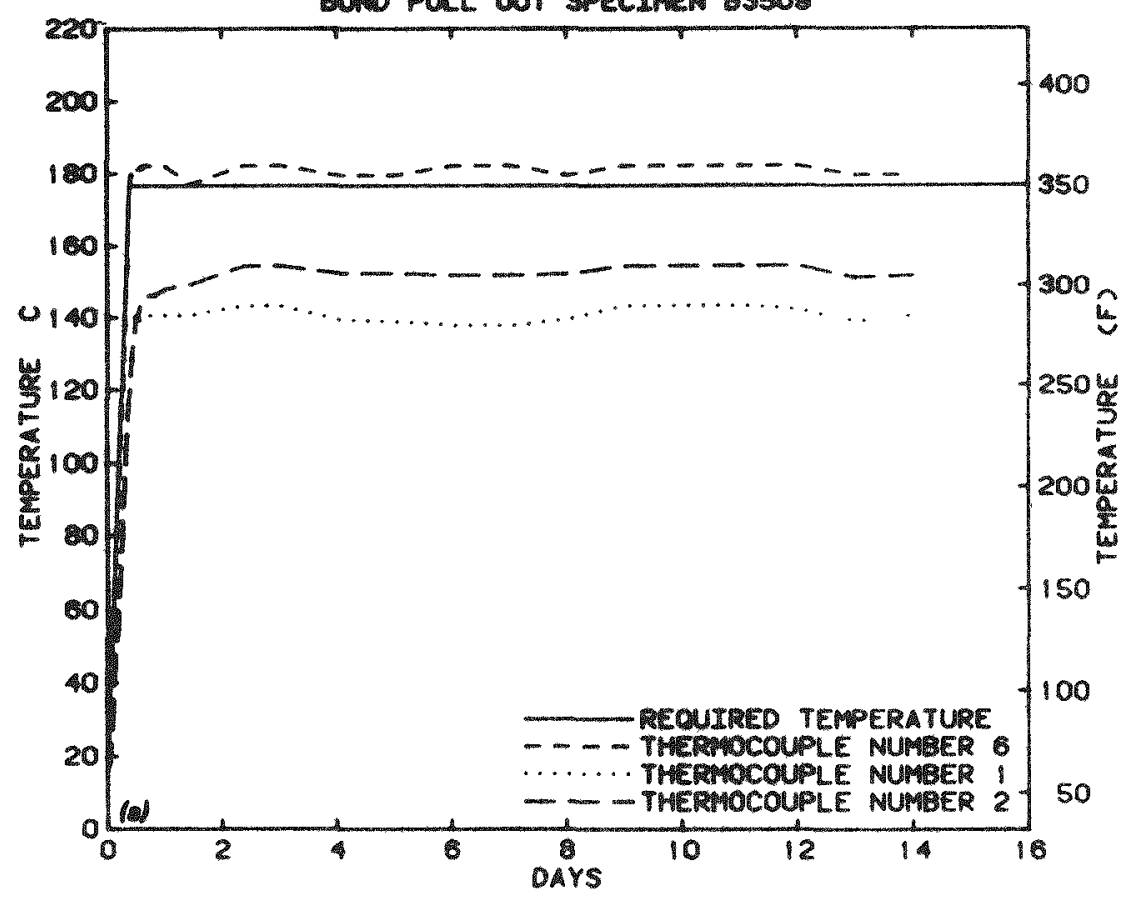

CRBR MIGH TEMPERATURE CONCRETE TESTS

BOND STRESS VS SLIP DATA

SPECIMEN SSO00. TEMPERATURE. $177 \mathrm{C}$

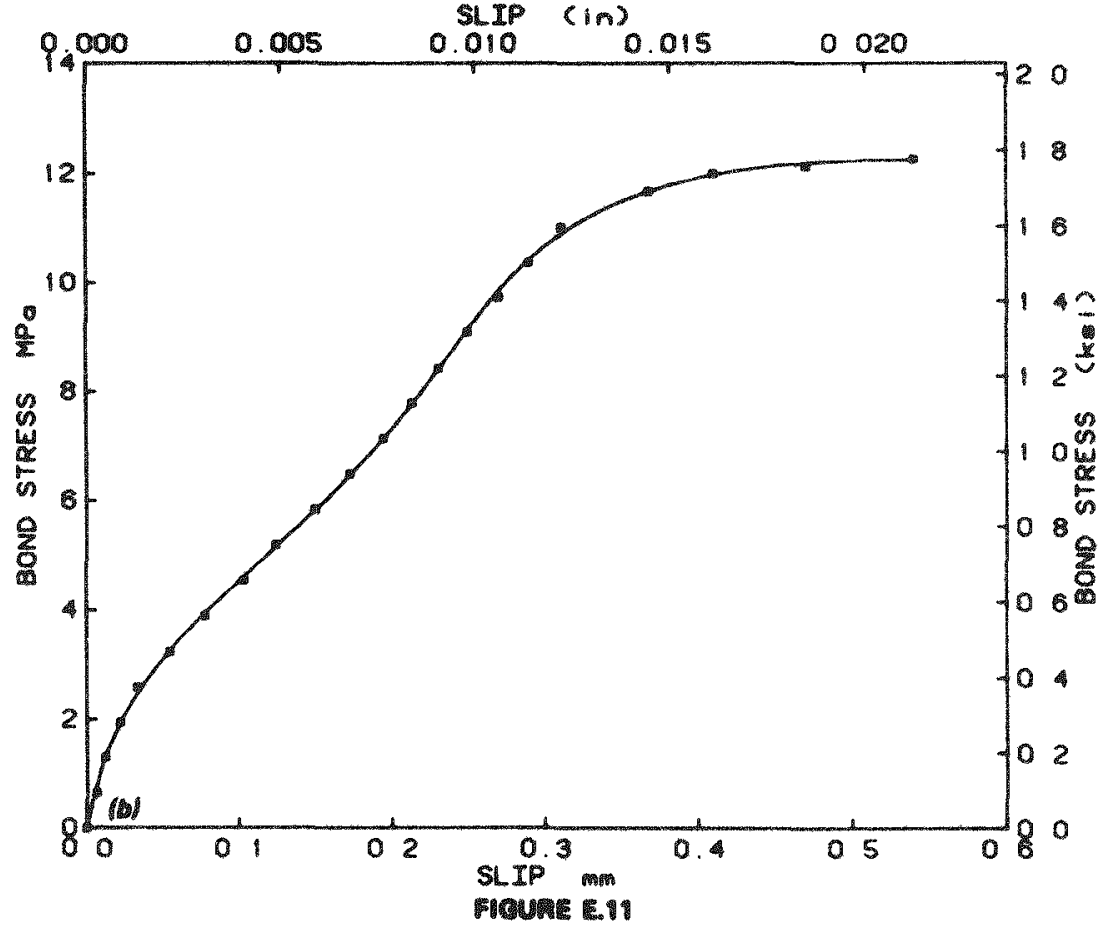


0

CRBR HIGH TEMPERATURE CONCRETE TESTS TEMPERATURE VS TIME

BOND PULL OUT SPECIMEN B3SO15

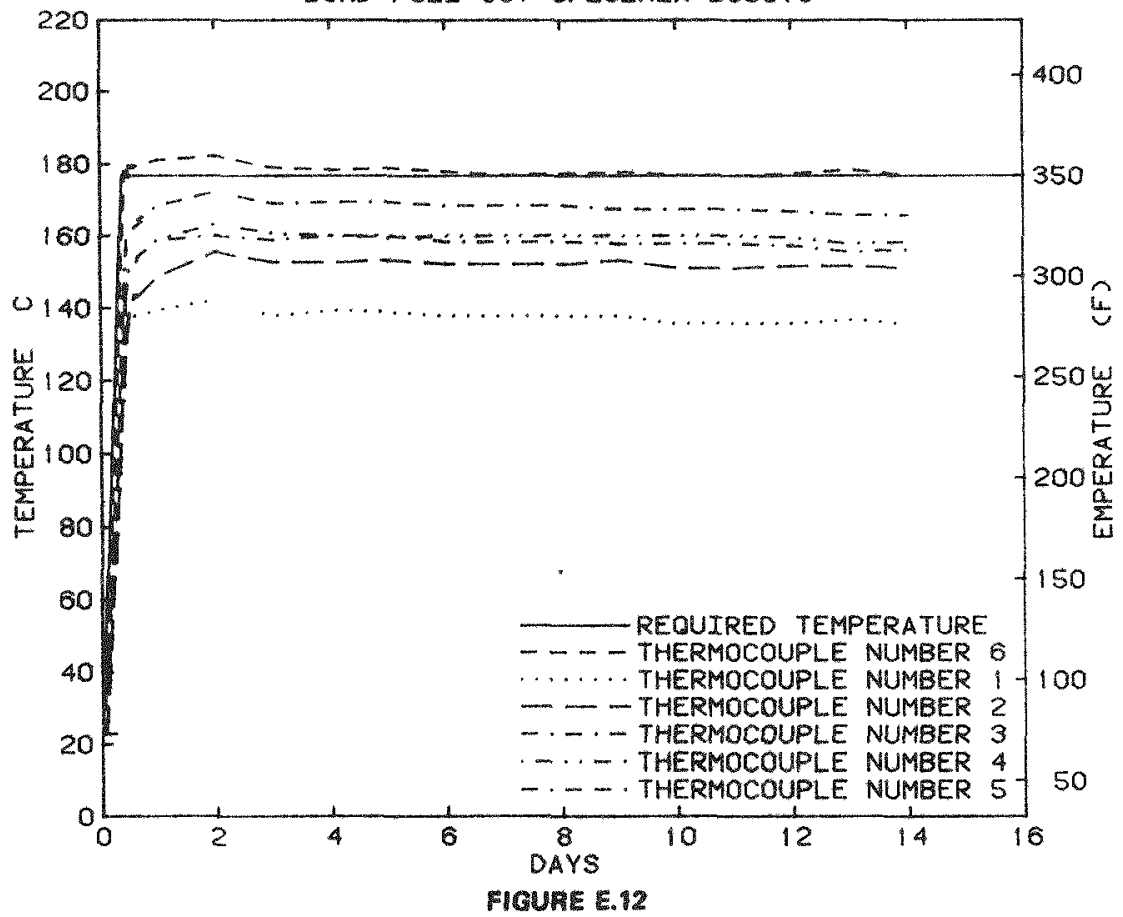


CR MIGH TEPMERTURE CONCNETE TESTS

OANG-DOUG SO-\$ISA ETO TEMPERTUR VS TIM

DOND PULL OUT SPECIMN BS5020

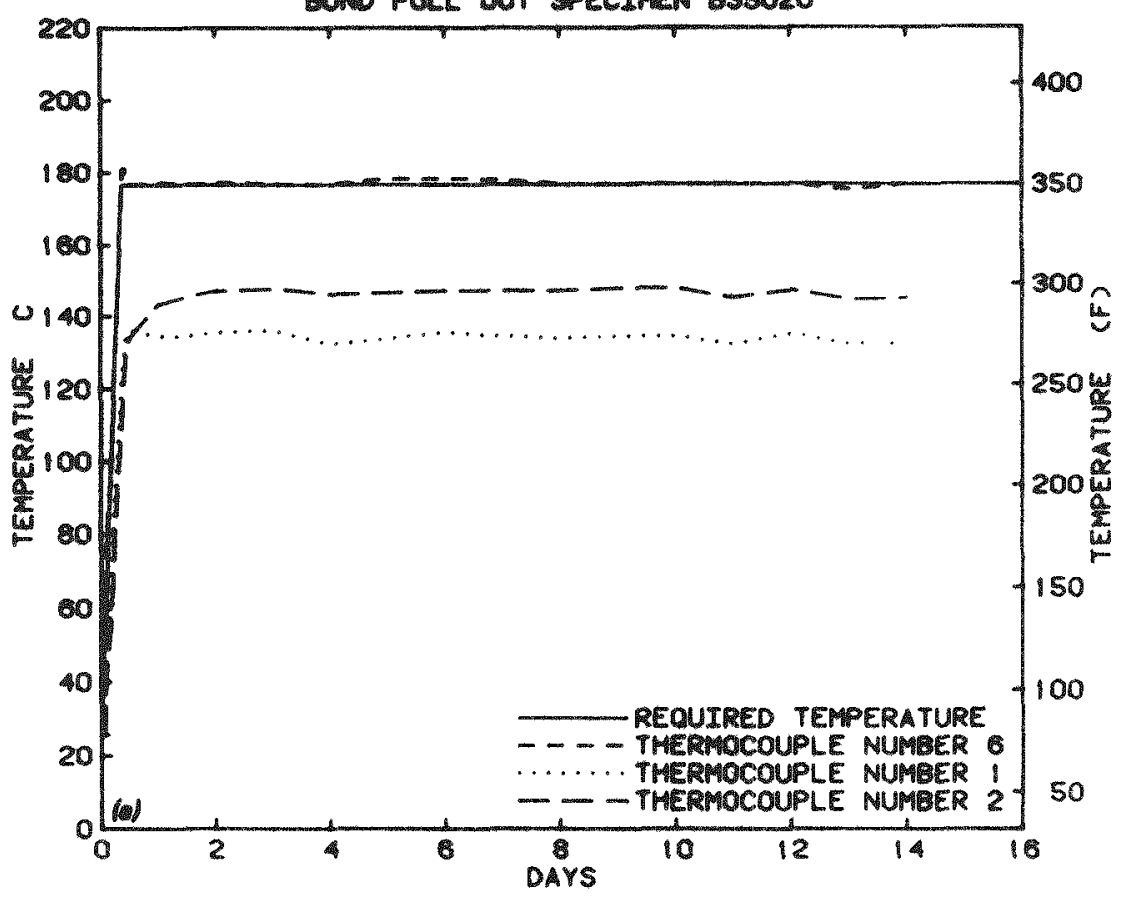

CRER MIGH TEMERATURE CONCRETE TESTS

GOND STRESS VS SLIP DATA

SPECIMEN BSS020. TEMERATURE, $177 \mathrm{C}$

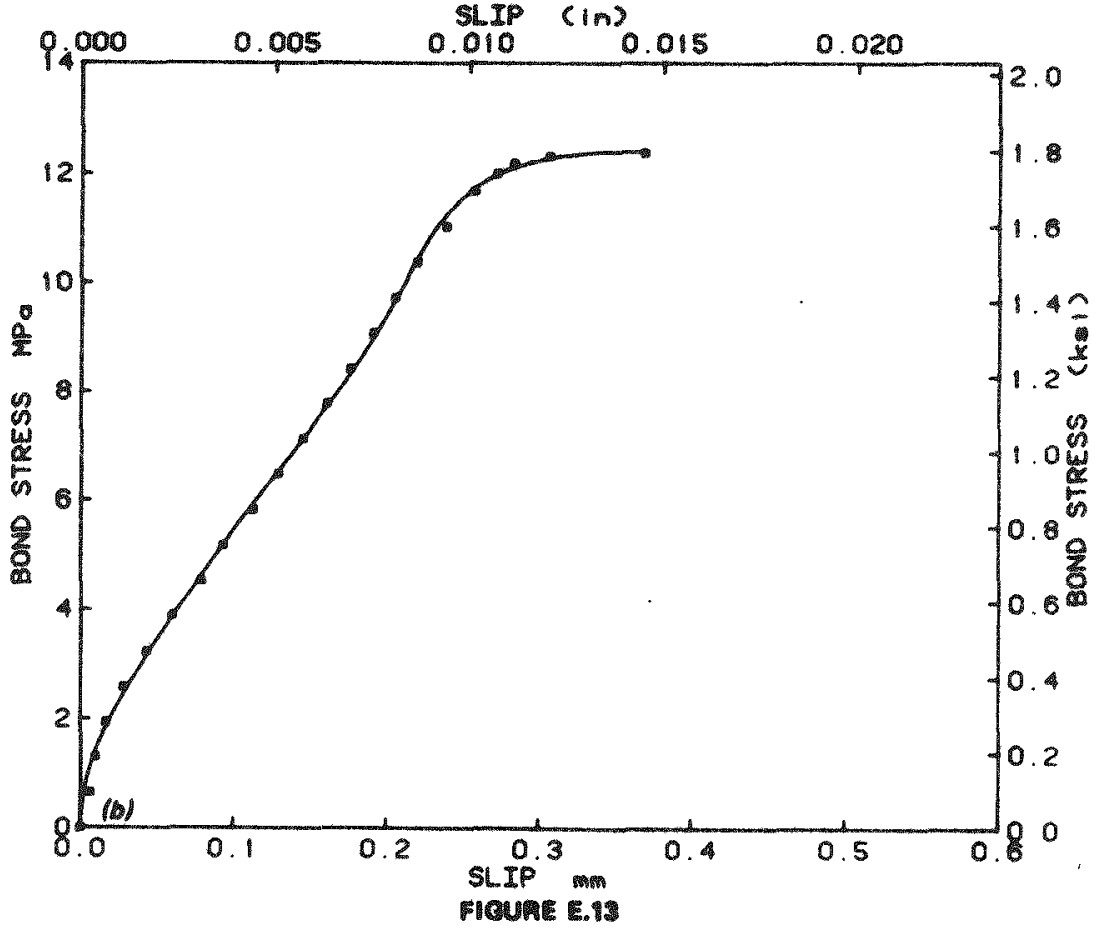



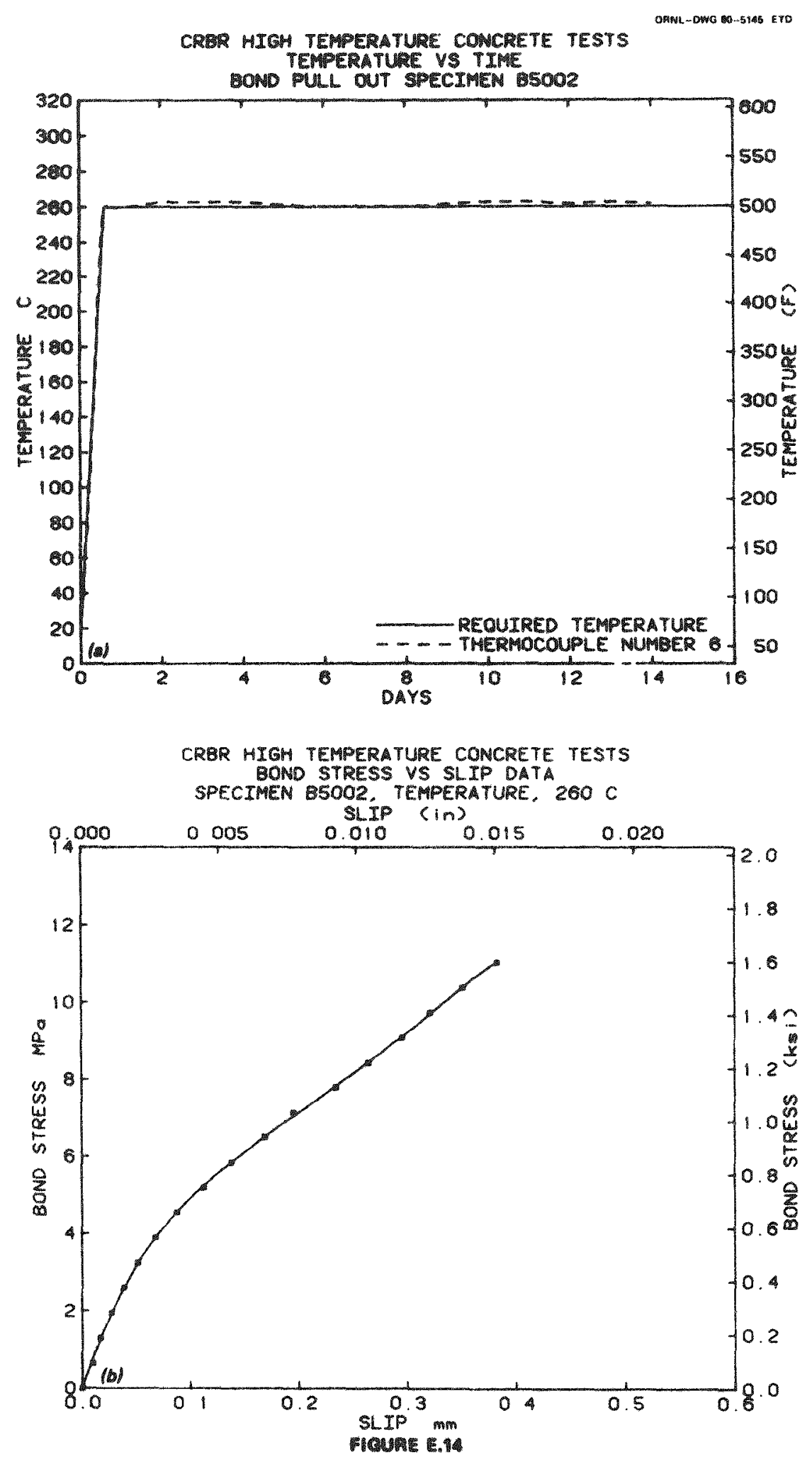

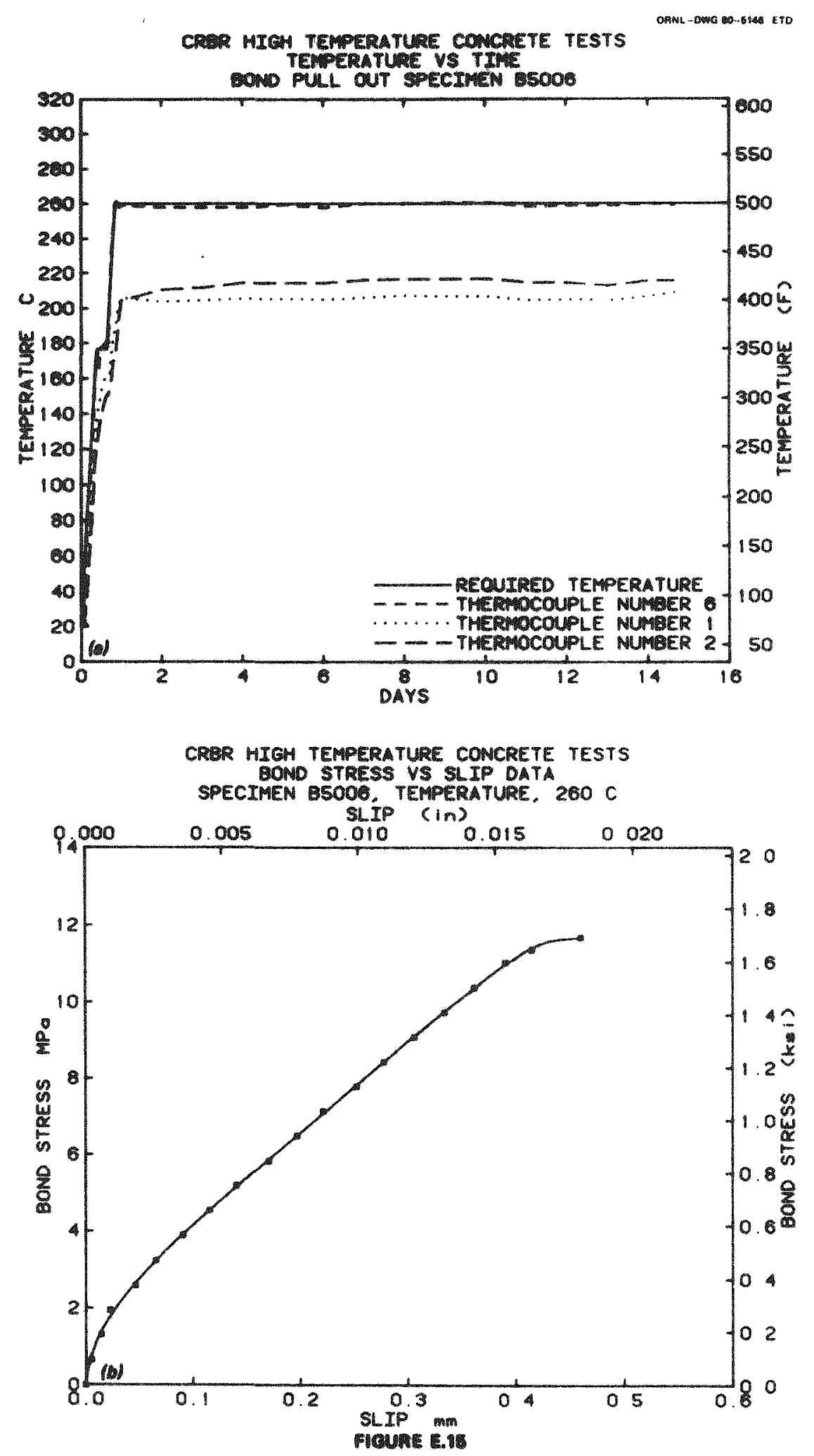
CRRR HIGH TEMPERATURE CONCRETE TESTS TEMPFRATURE US TIME

SOND FULL OUT SPECIMEN DSOOI2

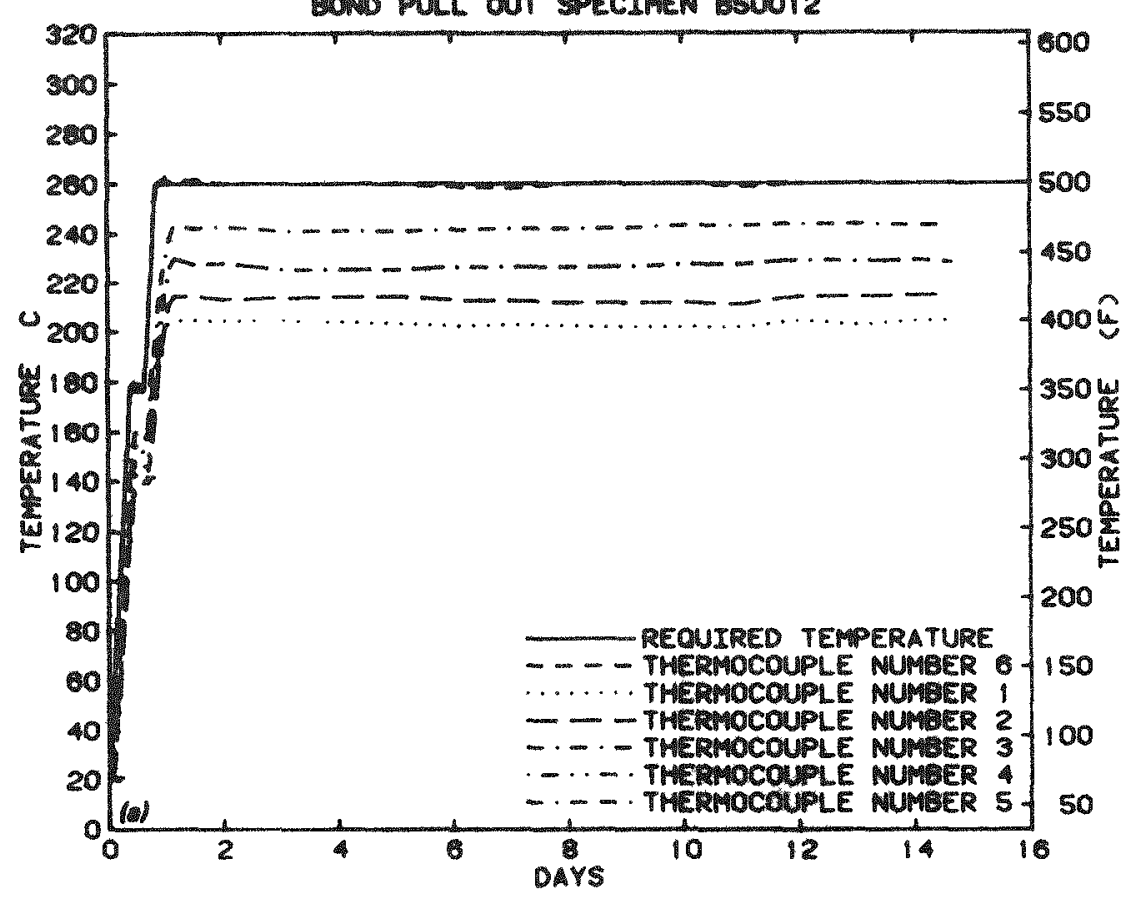

CRER MIGH TEMPERATURE CONCRETE TESTS

BOND STRESS VS SLIP DATA SPECIMEN BSO012. TEPPERATURE, $200 \mathrm{C}$

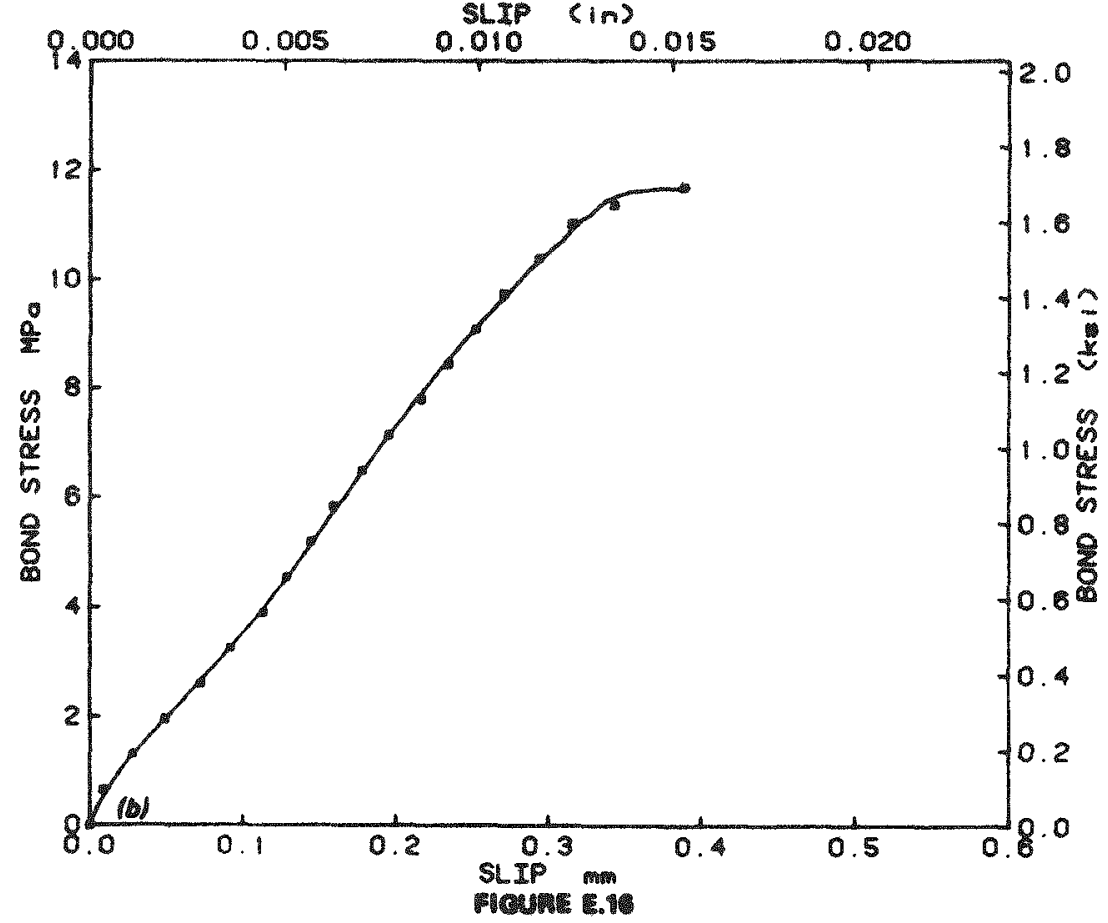




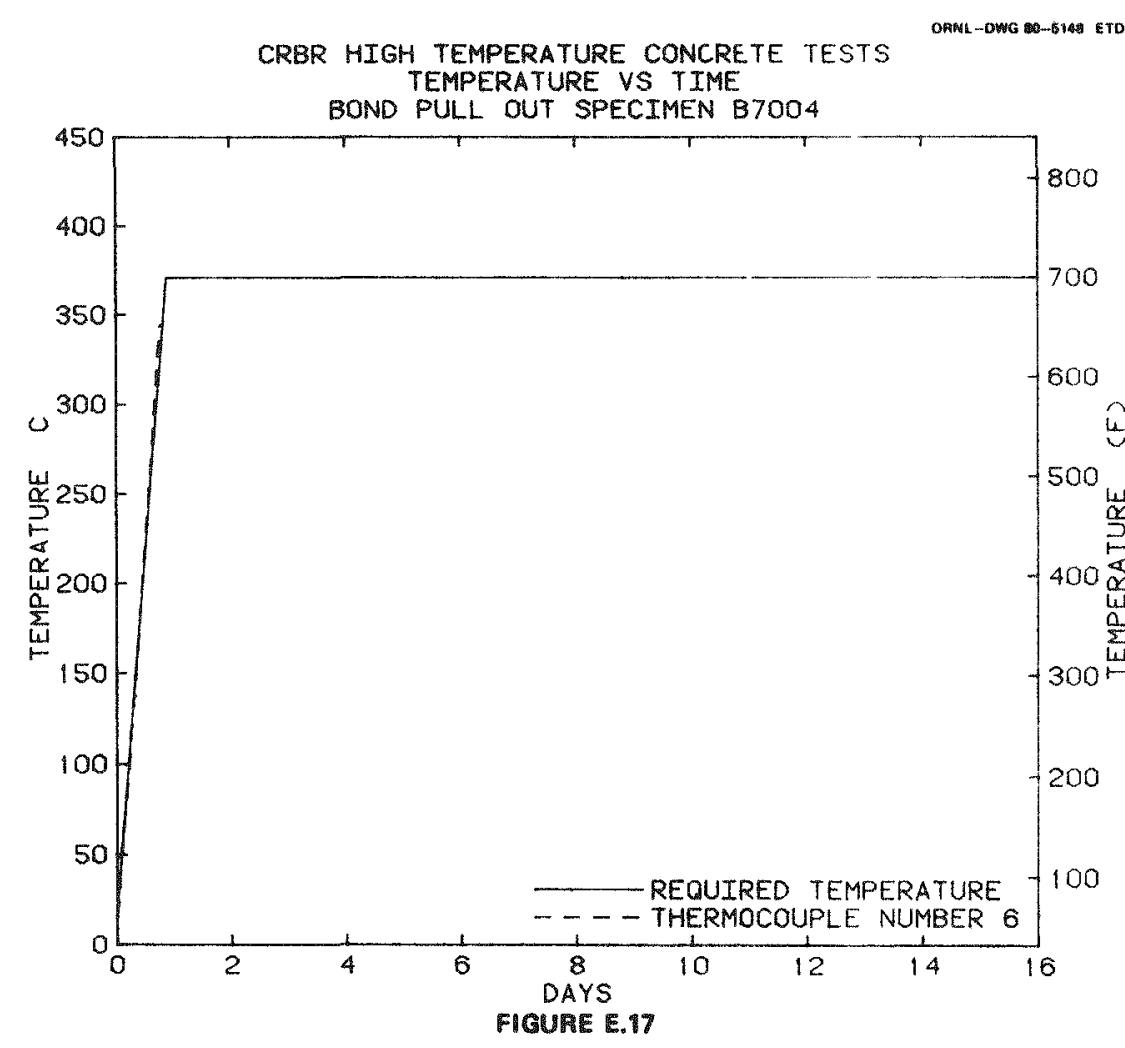


ORNL OWG 514 ETO

CRBR HICH TEMPERATURE CONCRETE TESTS TEMPERATURE VS TIME

BONO PULL OUT SPECIMEN 7009

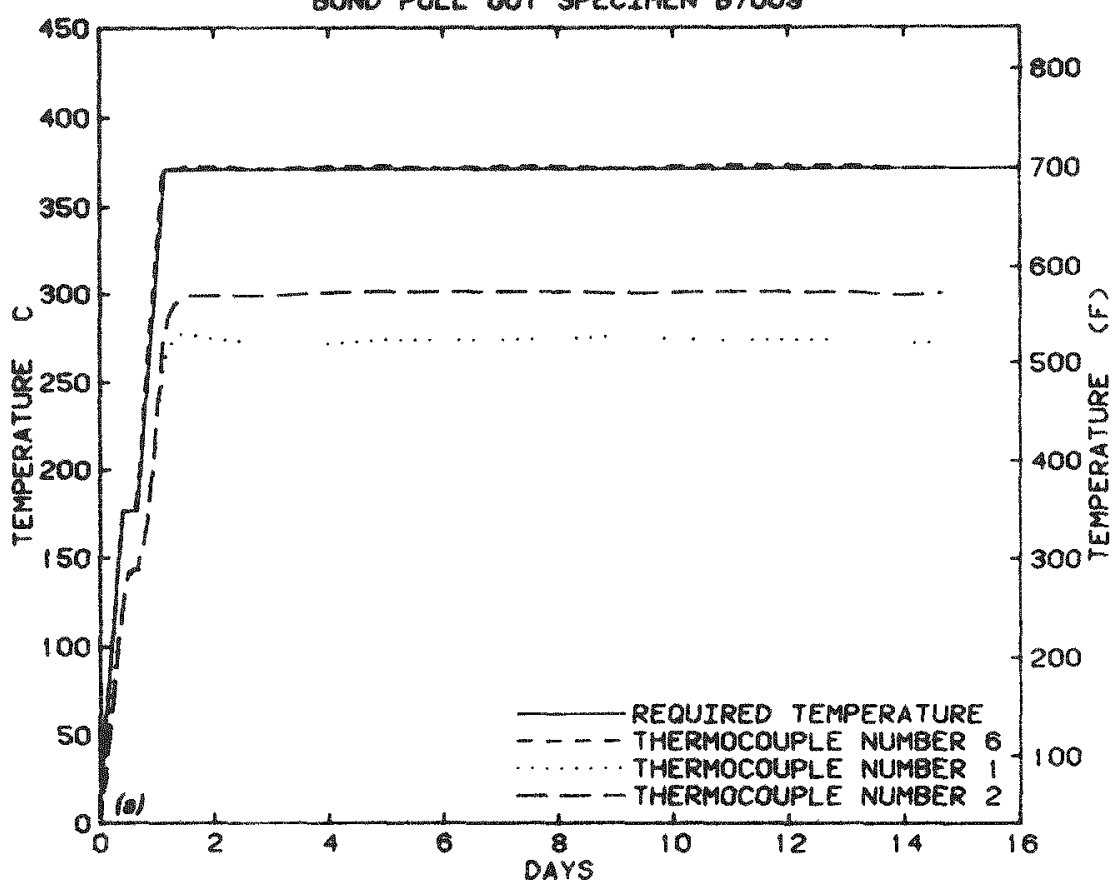

CRBR HIGH TEMPERATURE CONCRETE TESTS

BOND STRESS VS SLIP DATA

SPECIMEN B7009. TEMPERATURE, $371 \mathrm{C}$

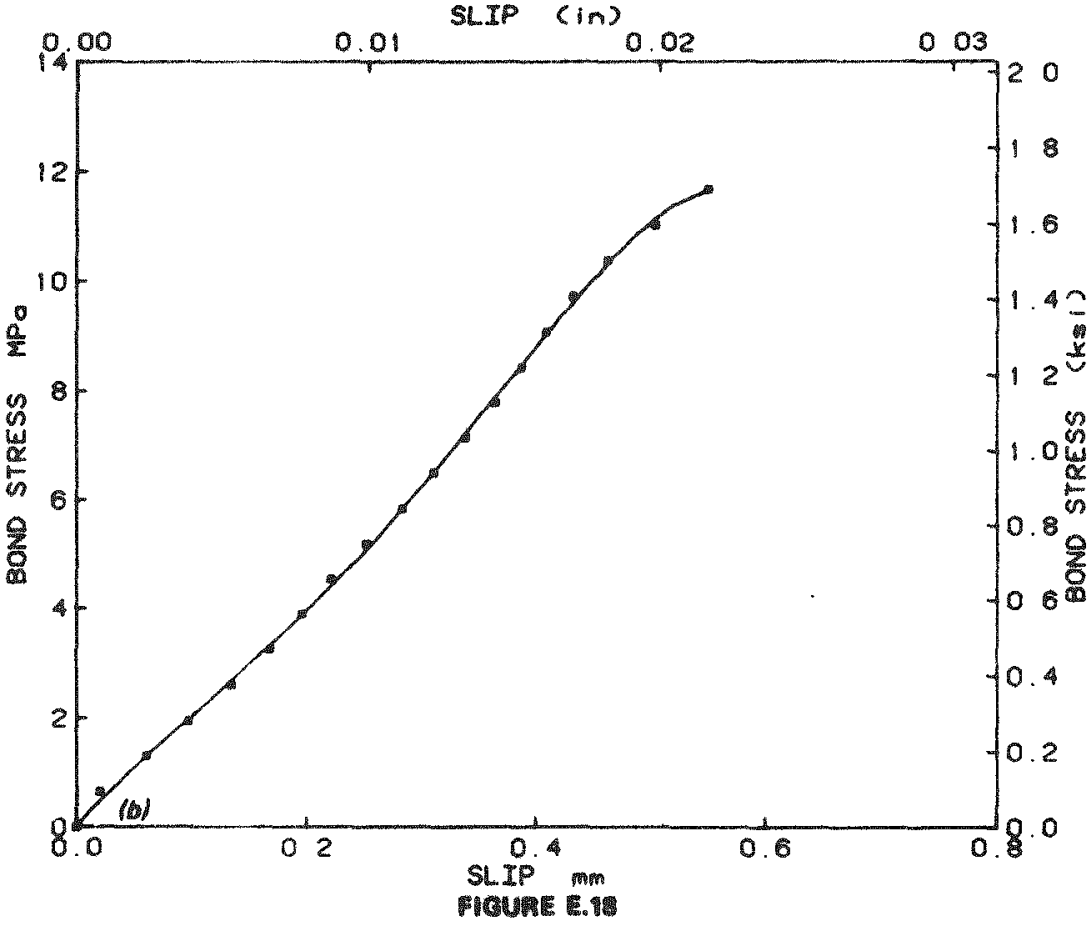


OANL OMOG -5960 ETD

CRER HICH TEMPERATURE CONCAETE TESTS TENPERATUTE VS TTR

20ND PULL OUT SPECIPAEN TOOIS

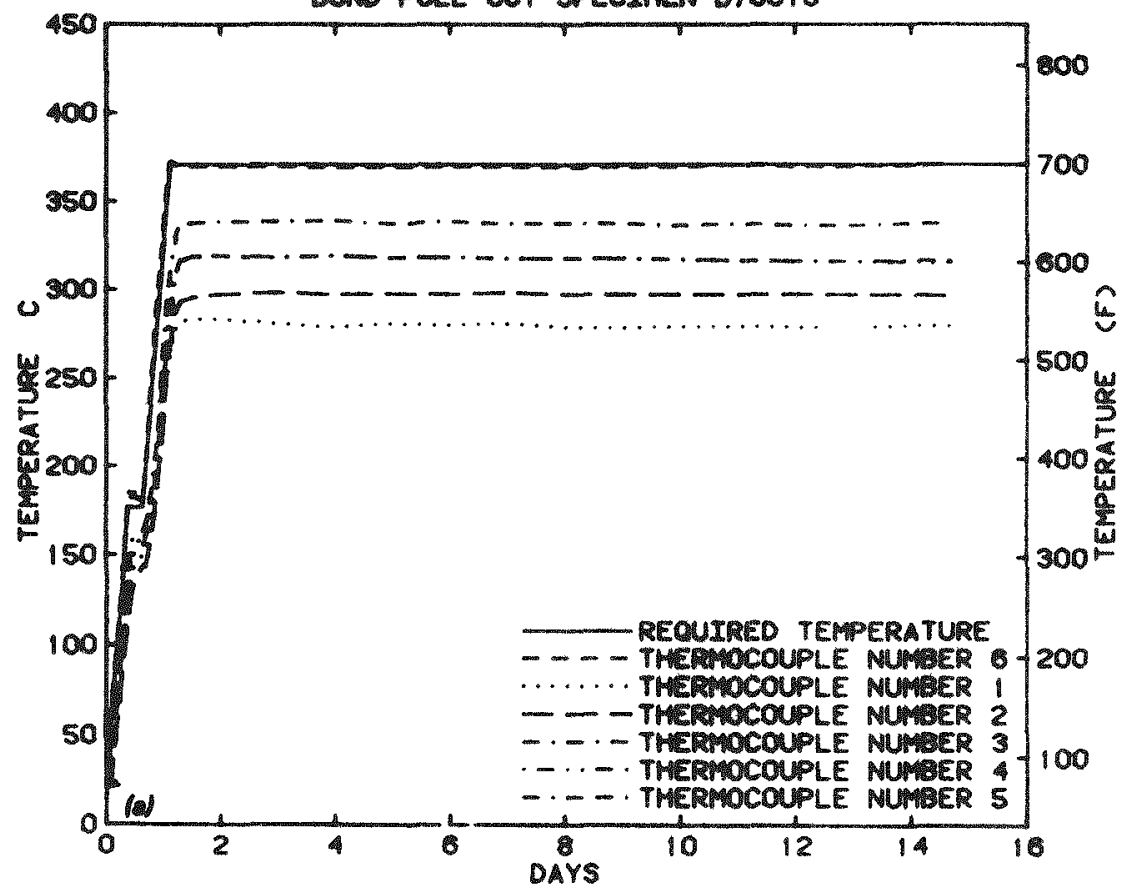

CRER HIGH TEMPERATURE CONCRETE TESTS

OONO STRESS VS SLIP DATA

SPECIMEN B70015. TEMPERATURE, $371 \mathrm{C}$

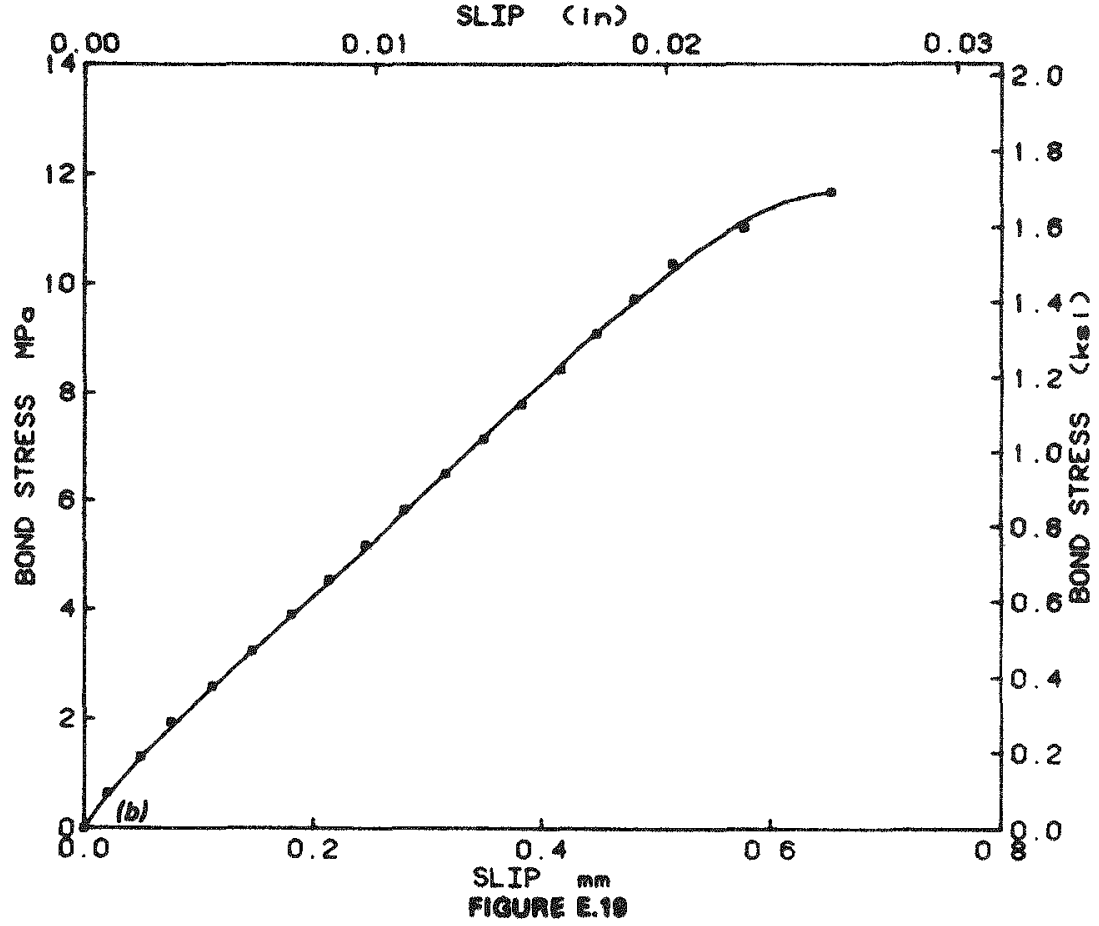



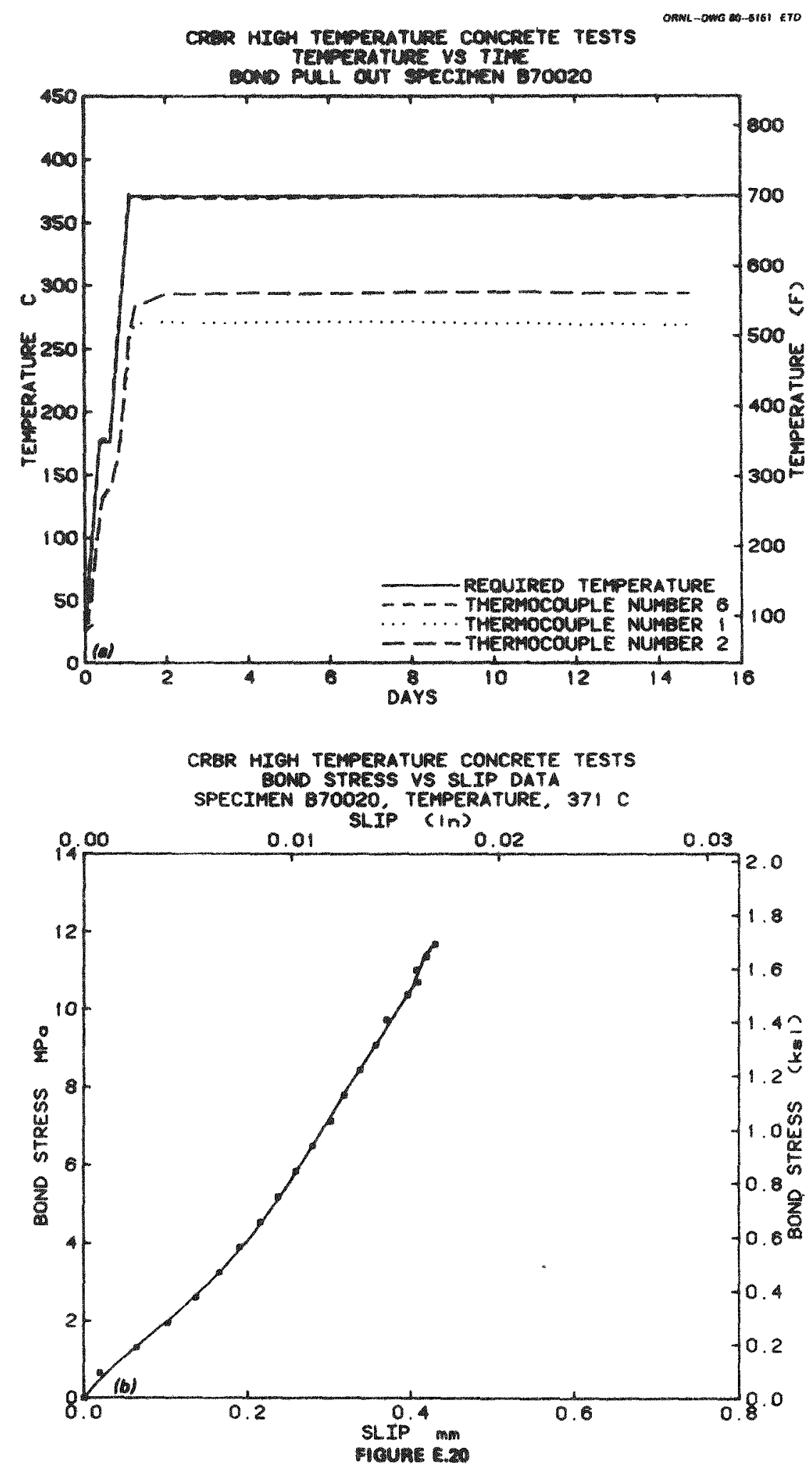


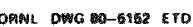

CROR MIEH TEMPERATURE CONCRETE TESTS TEMPERATURE VS TIME

20NO PUL OUT SPECINEN DOON2

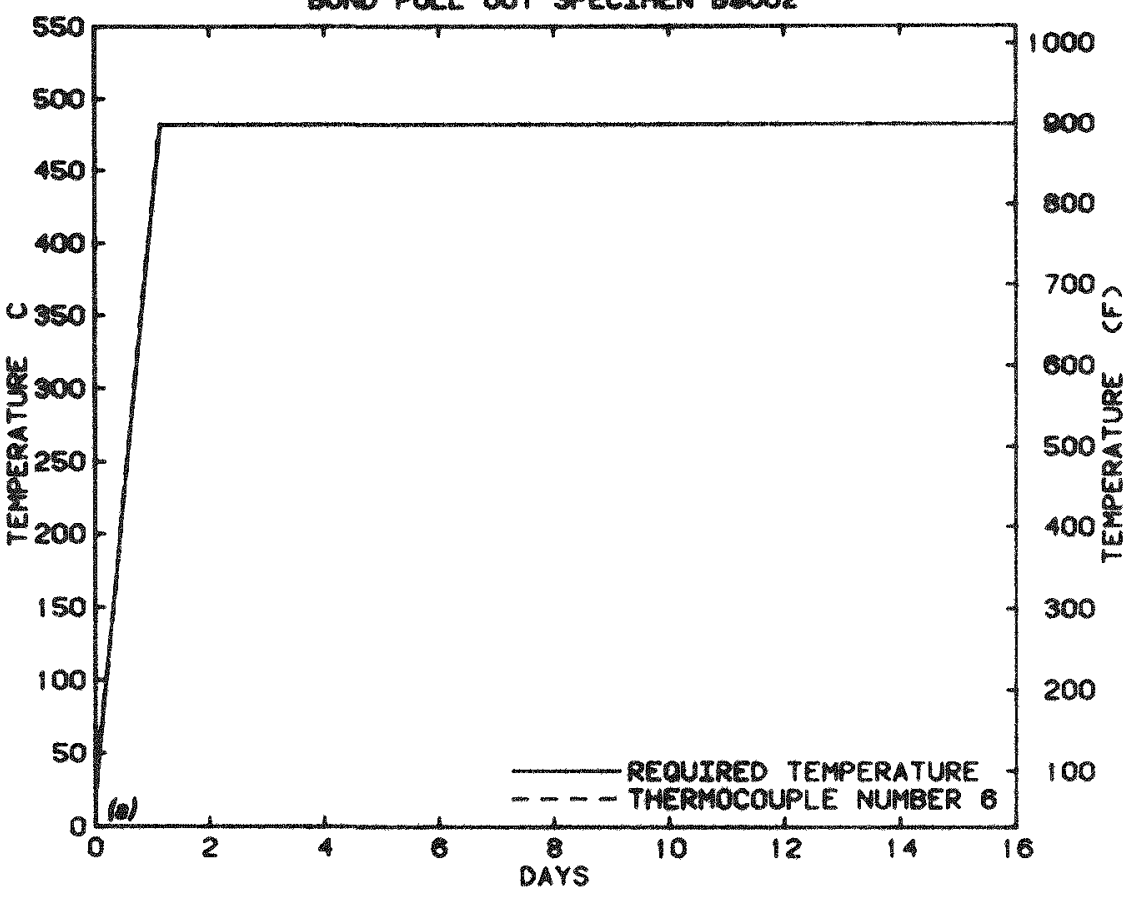

CRBR MIGH TEMPERATURE CONCRETE TESTS BOND STRESS VS SLIP DATA

SPECIMEN BQOO2. TEMPERATURE, $402 \mathrm{C}$

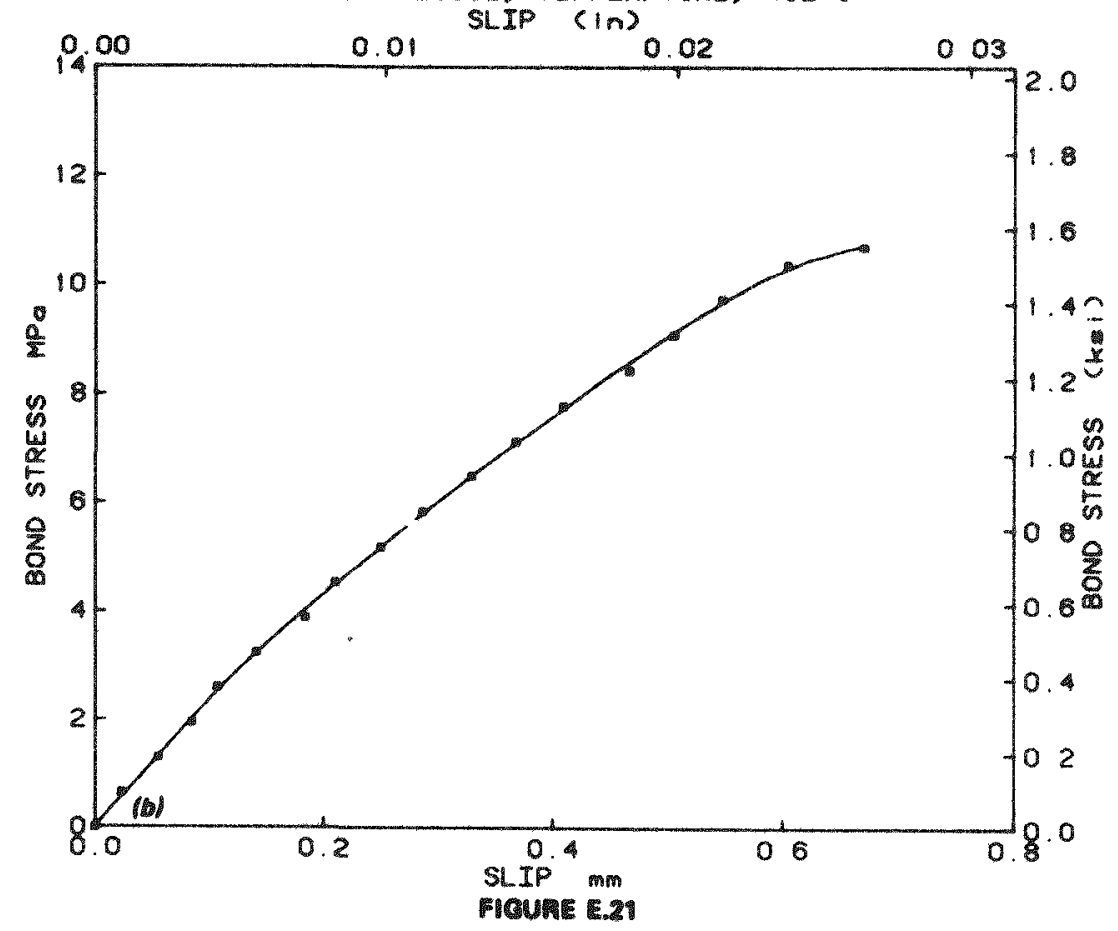




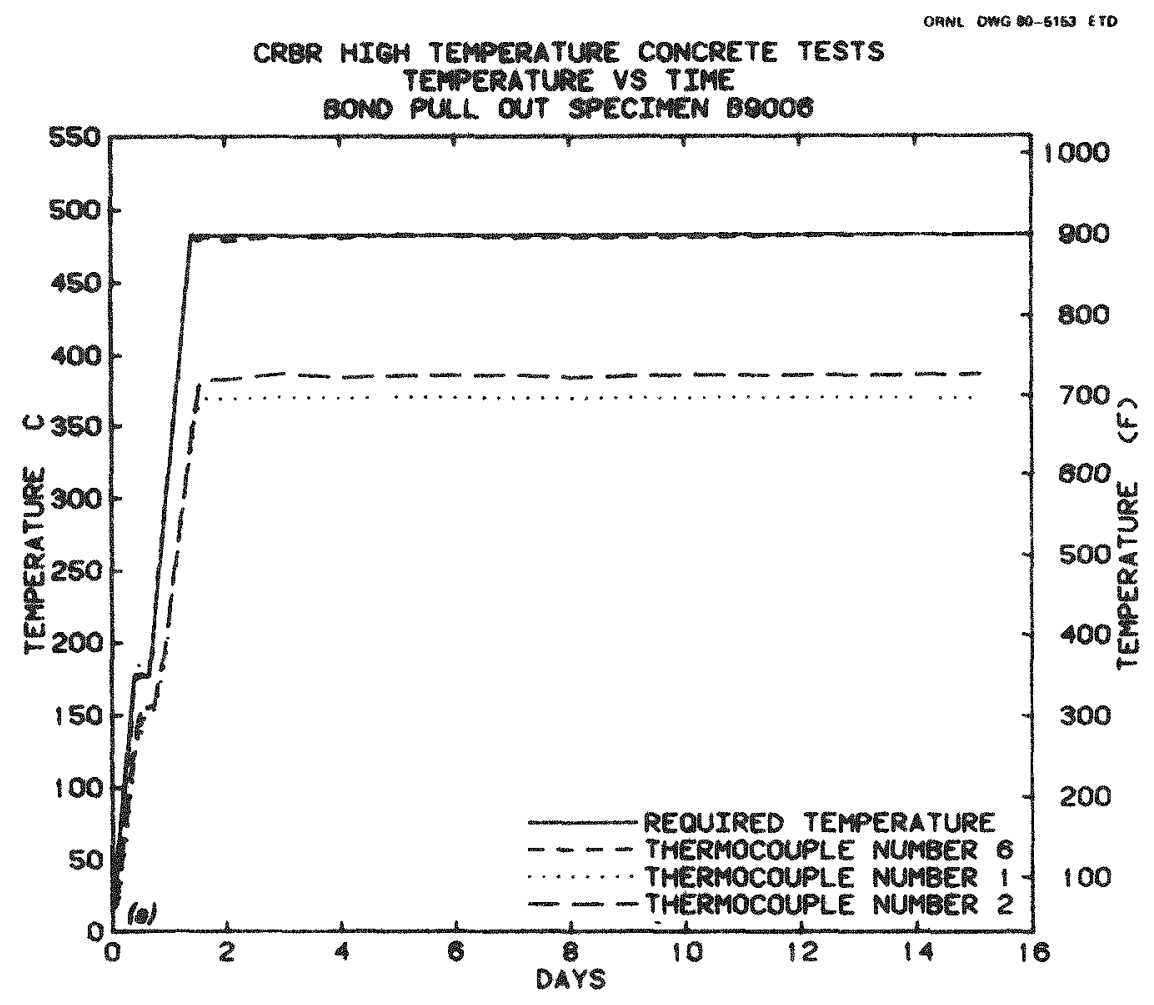

CRBR MIGH TEMPERATURE CONCRETE TESTS BOND STRESS VS SLIP DATA SPECIMEN BQO06. TEMPERATURE, $482 \mathrm{C}$

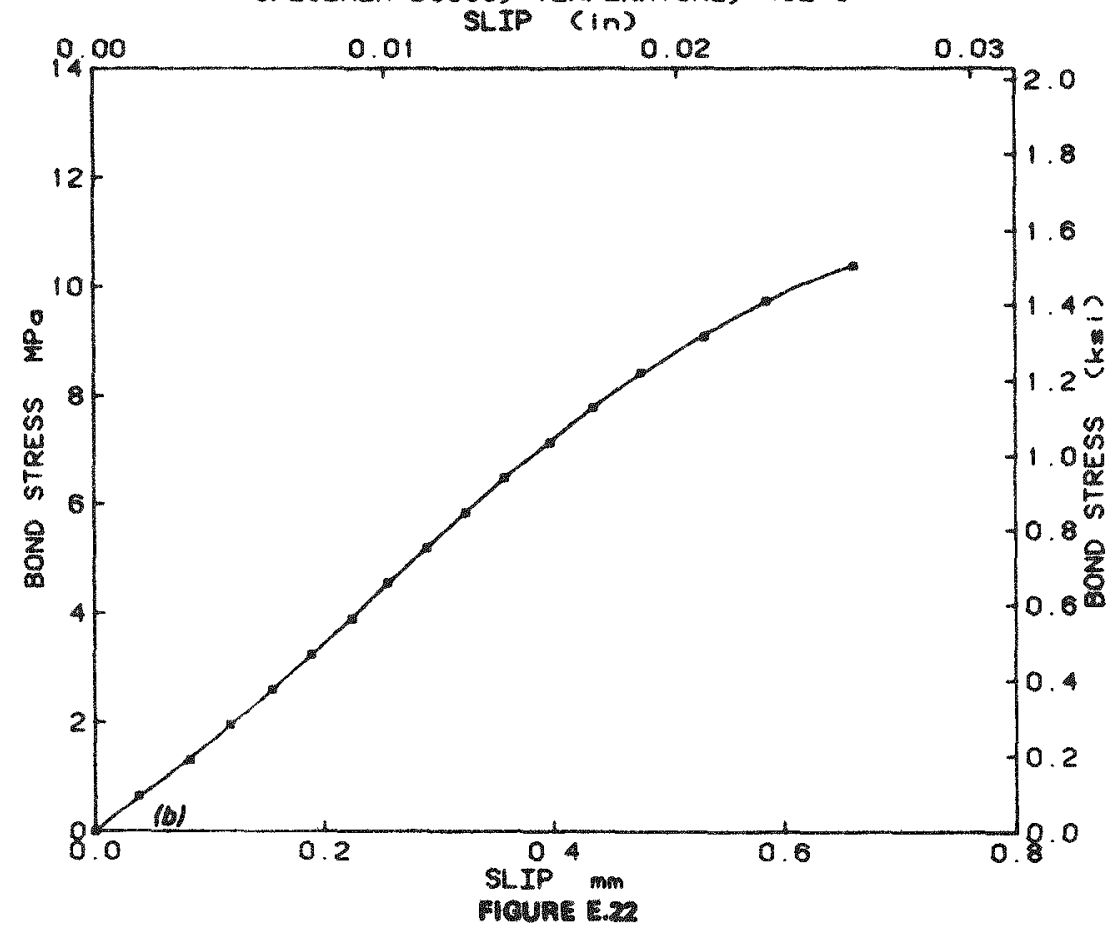


ORNL IOWG BO-515A ETD

CRBR HIOH TEMPERATURE CONCRETE TESTS TEMPERATU VS TIME

QOND PULL OUT SPECIMEN EOO12

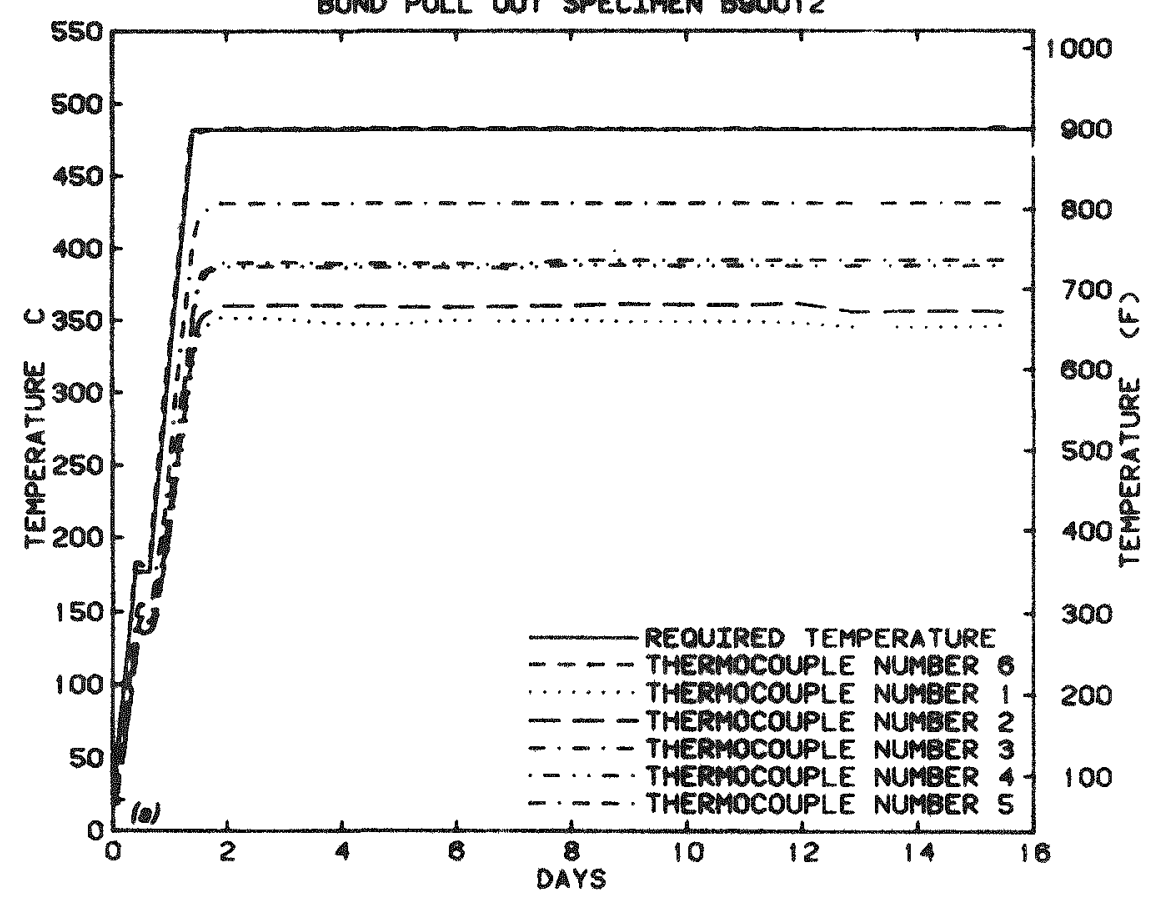

CRBR HIGH TEMPERATURE CONCRETE TESTS

BOND STRESS VS SLIP OATA SPECIMEN BOOOI2, TEMPERATURE, $482 \mathrm{C}$

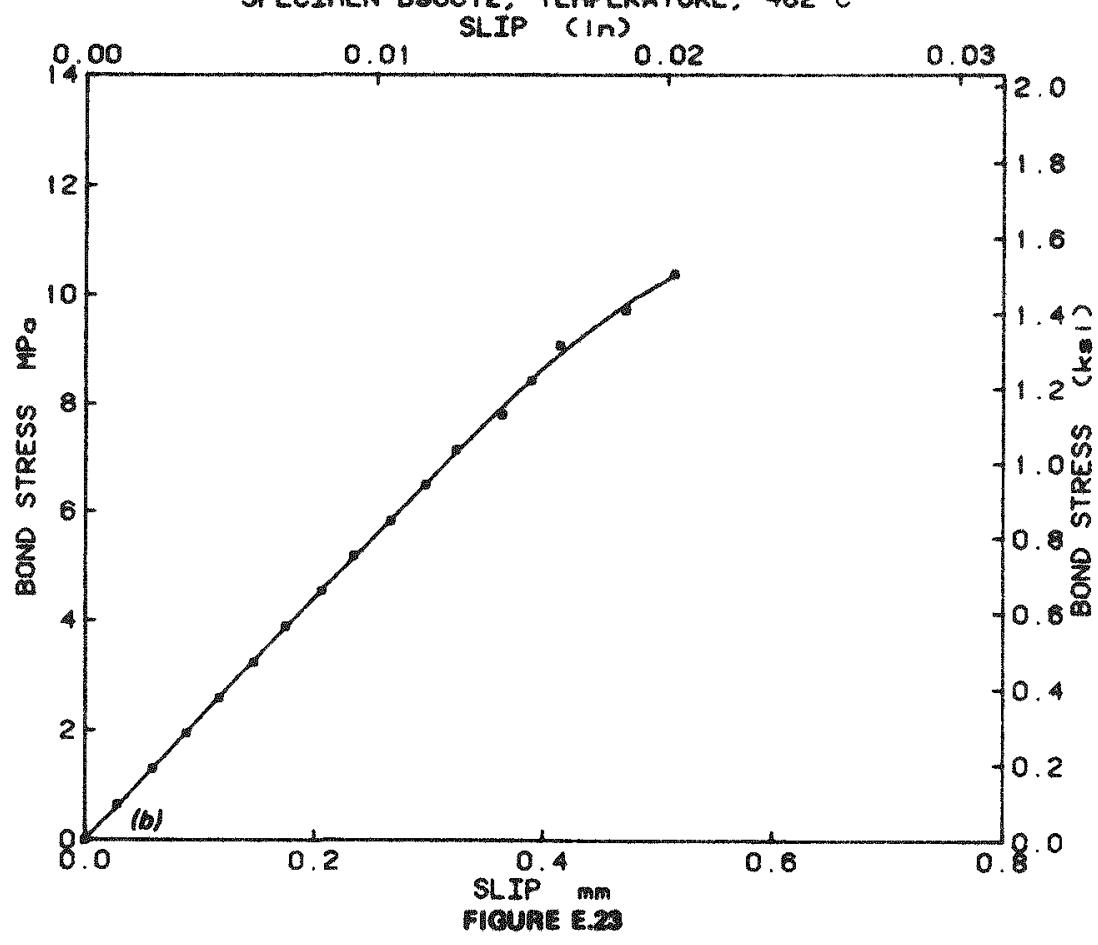




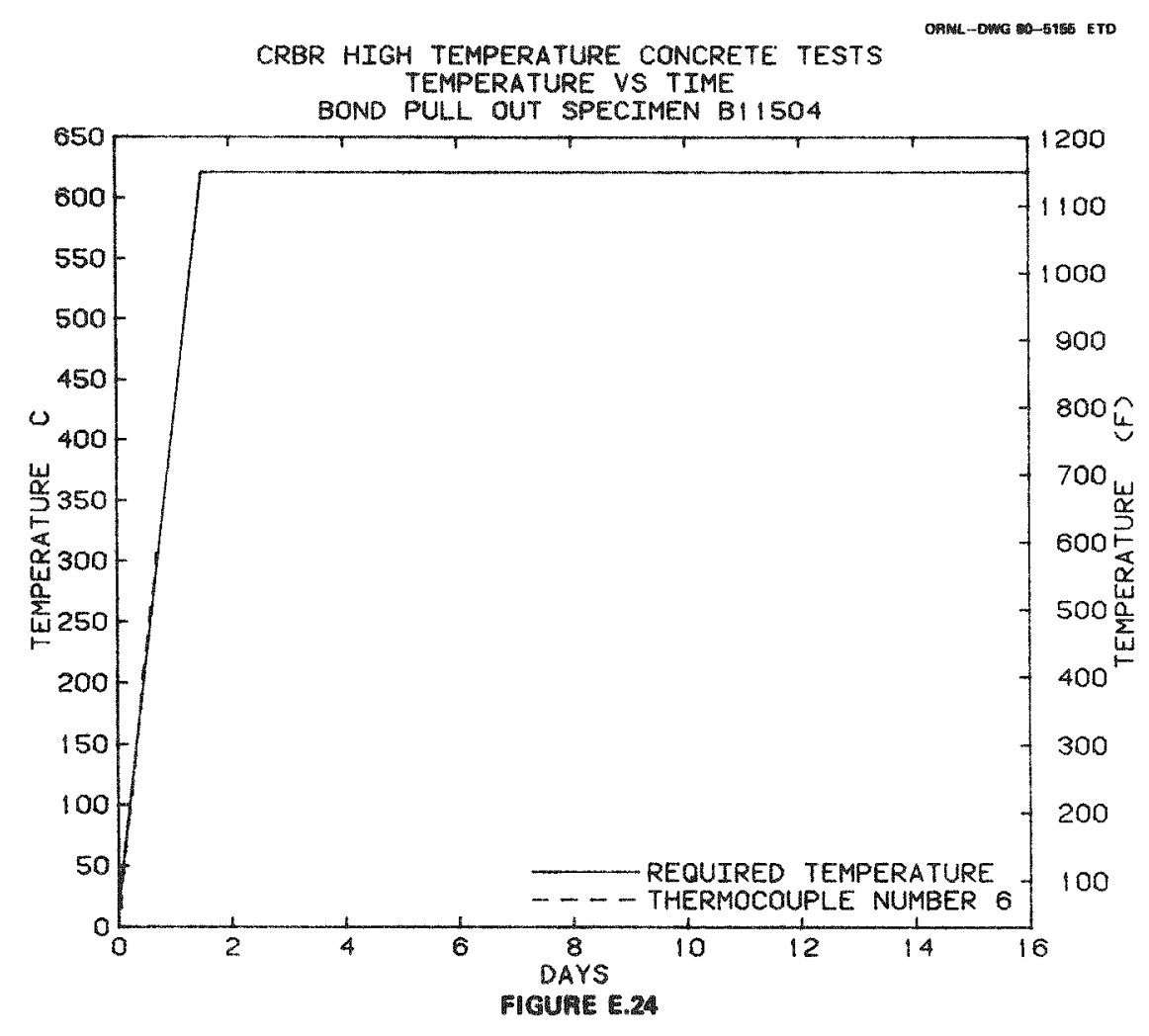


ORARL-DOWG

CRER HIGH TEPPERATURE CONCRETE TESTS TEMPERATURE VS TTME

ROND PULL OUT SPECIMEN B 1500

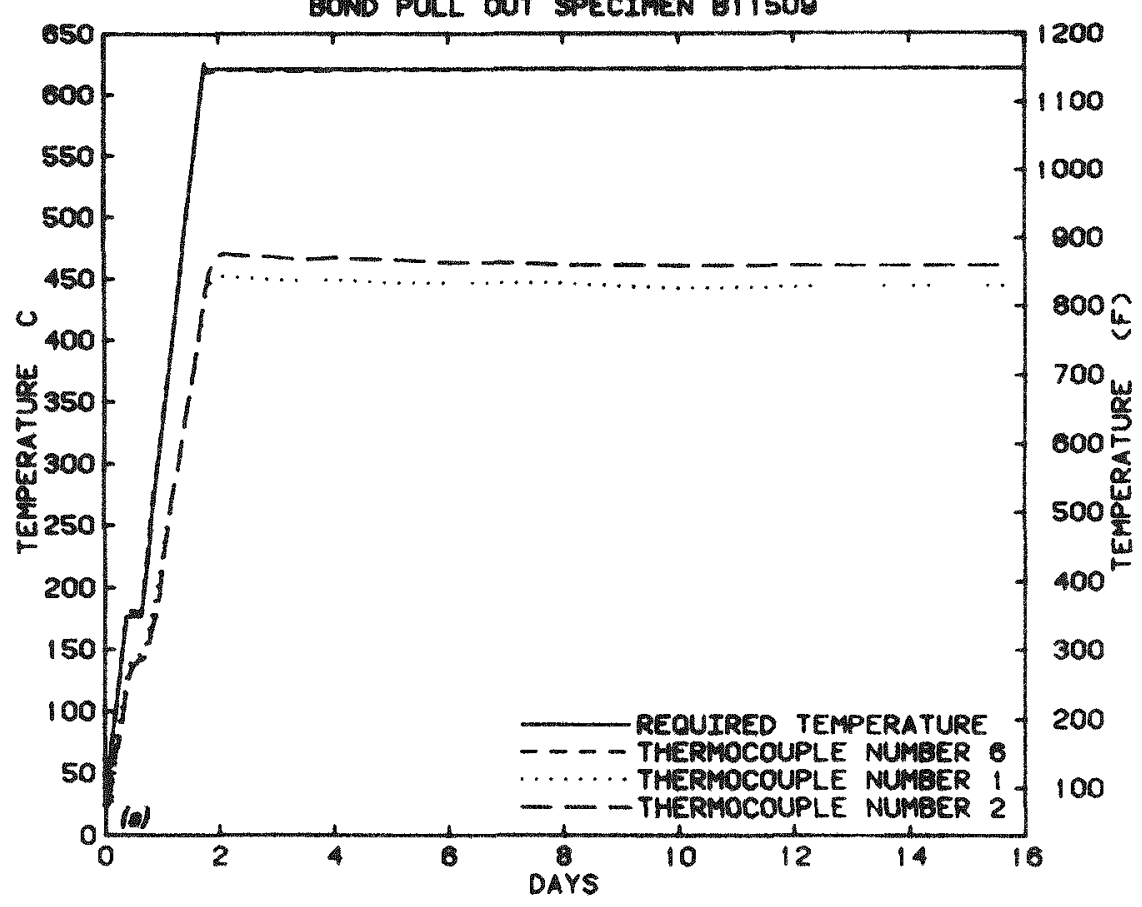

CRBR MIGH TEMPERATURE CONCRETE TESTS BOND STRESS VS SLIP DATA SPECIMEN B11509. TEMPERATURE, 621 C

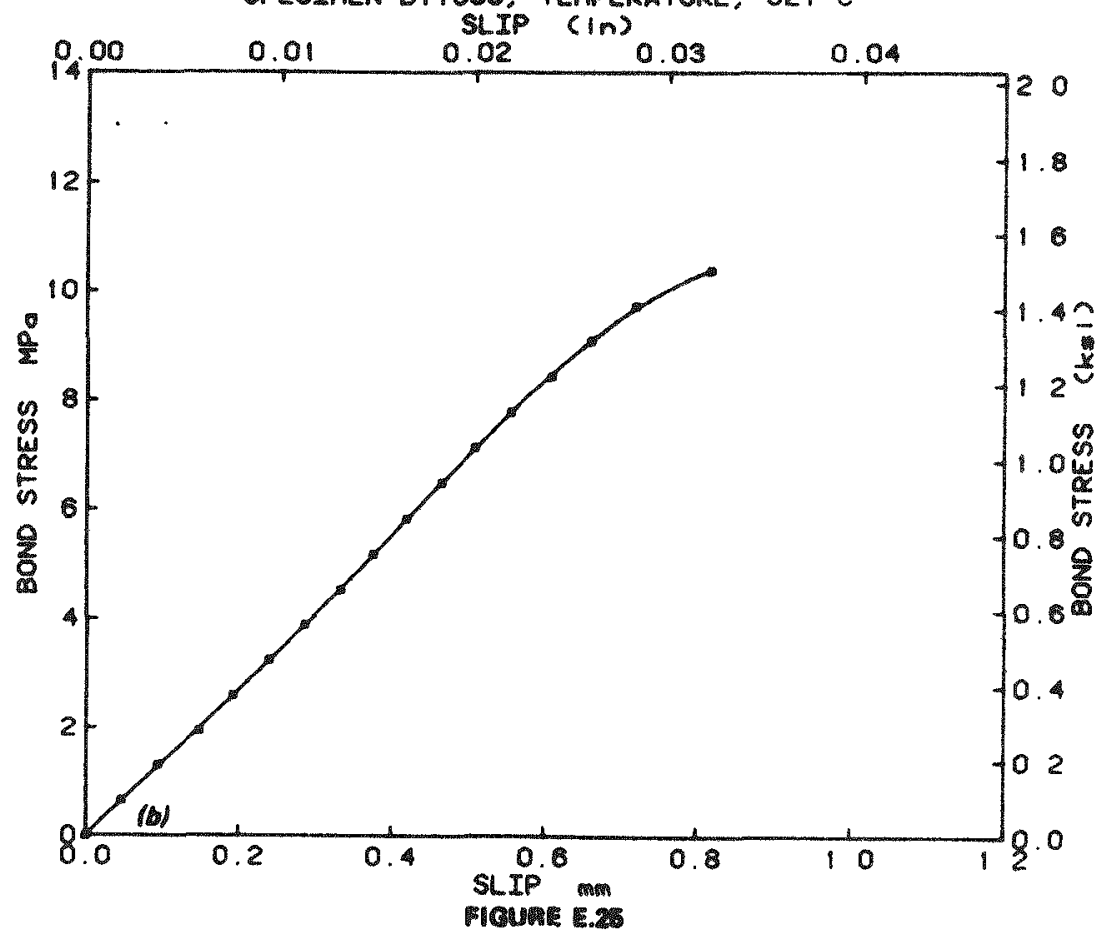



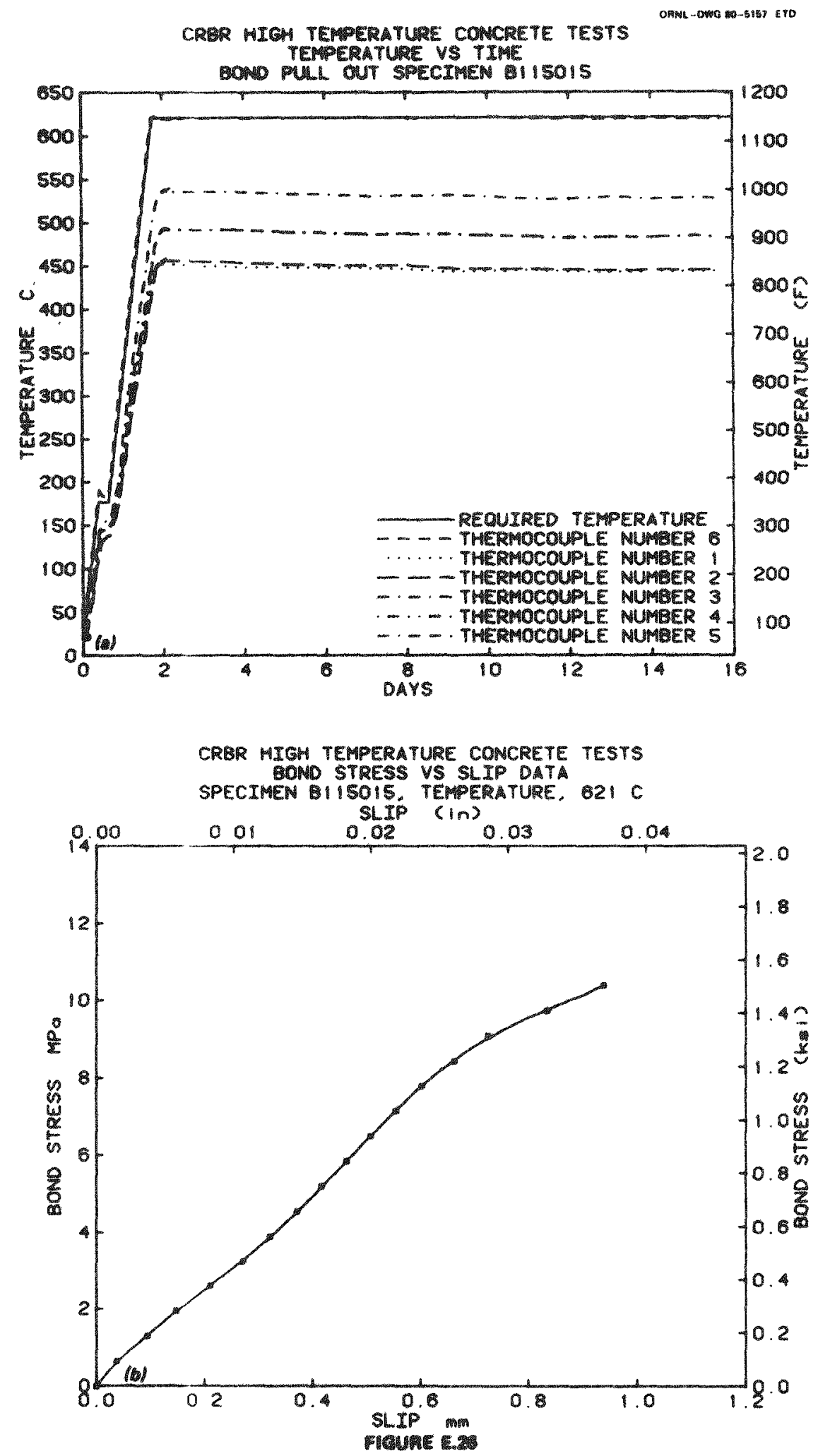
CRBR HIGH TEMPERATURE CONCRETE TESTS

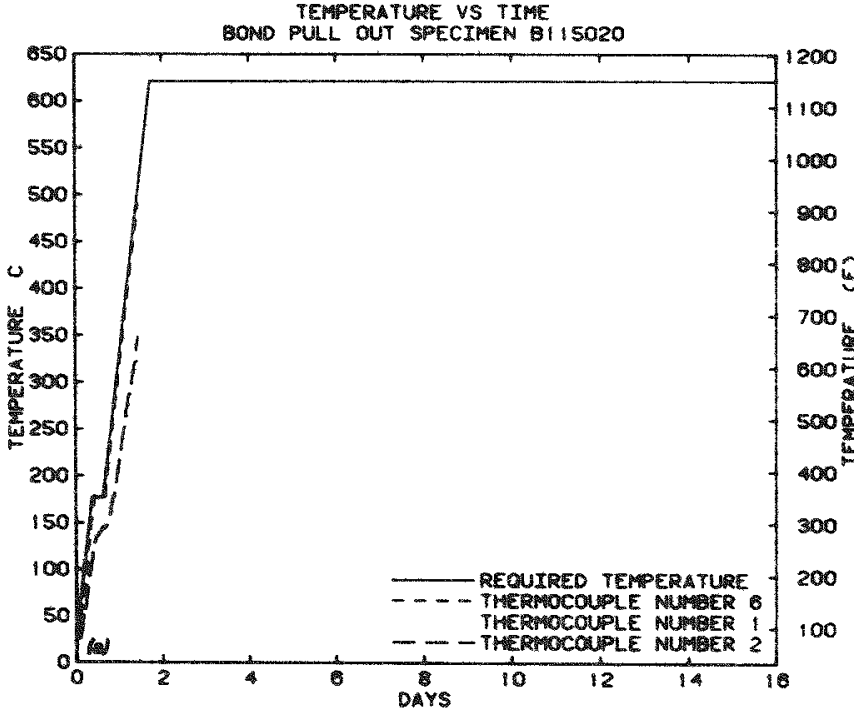

CRBR HIGH TEMPERATURE CONCRETE TESTS BOND PULL OUT SPECIMEN B115020

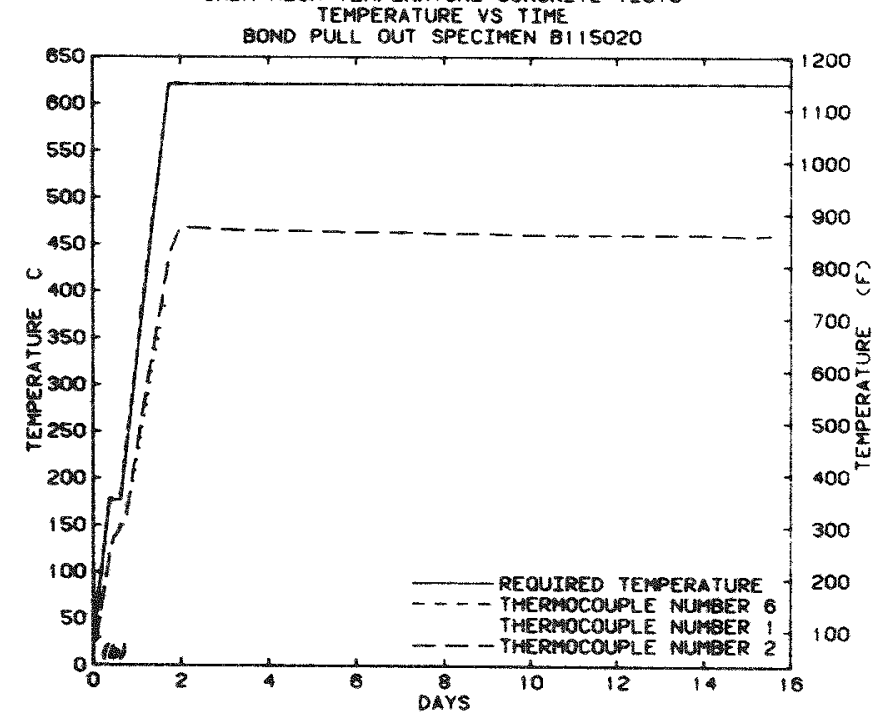

CRSR HIGH TEMPERATURE CONCRETE TESTS

SPECTMEA BII5O20. TEMPERATLRE $621 \mathrm{C}$

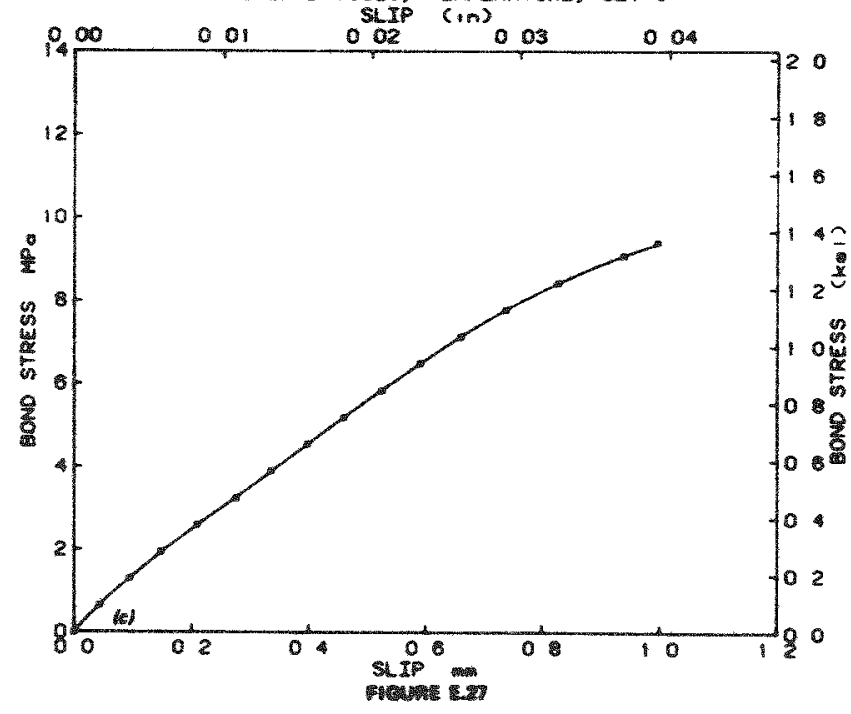



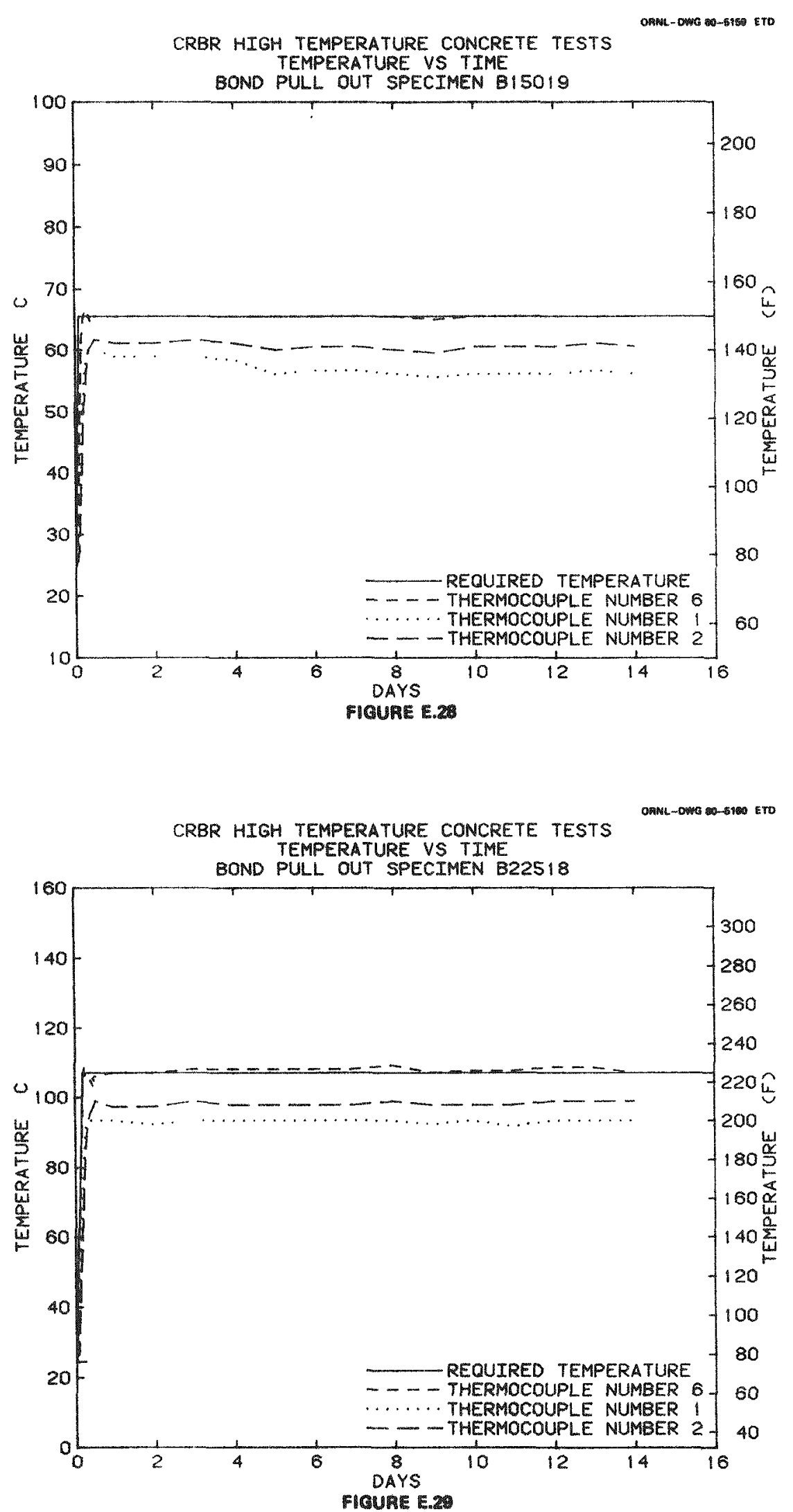


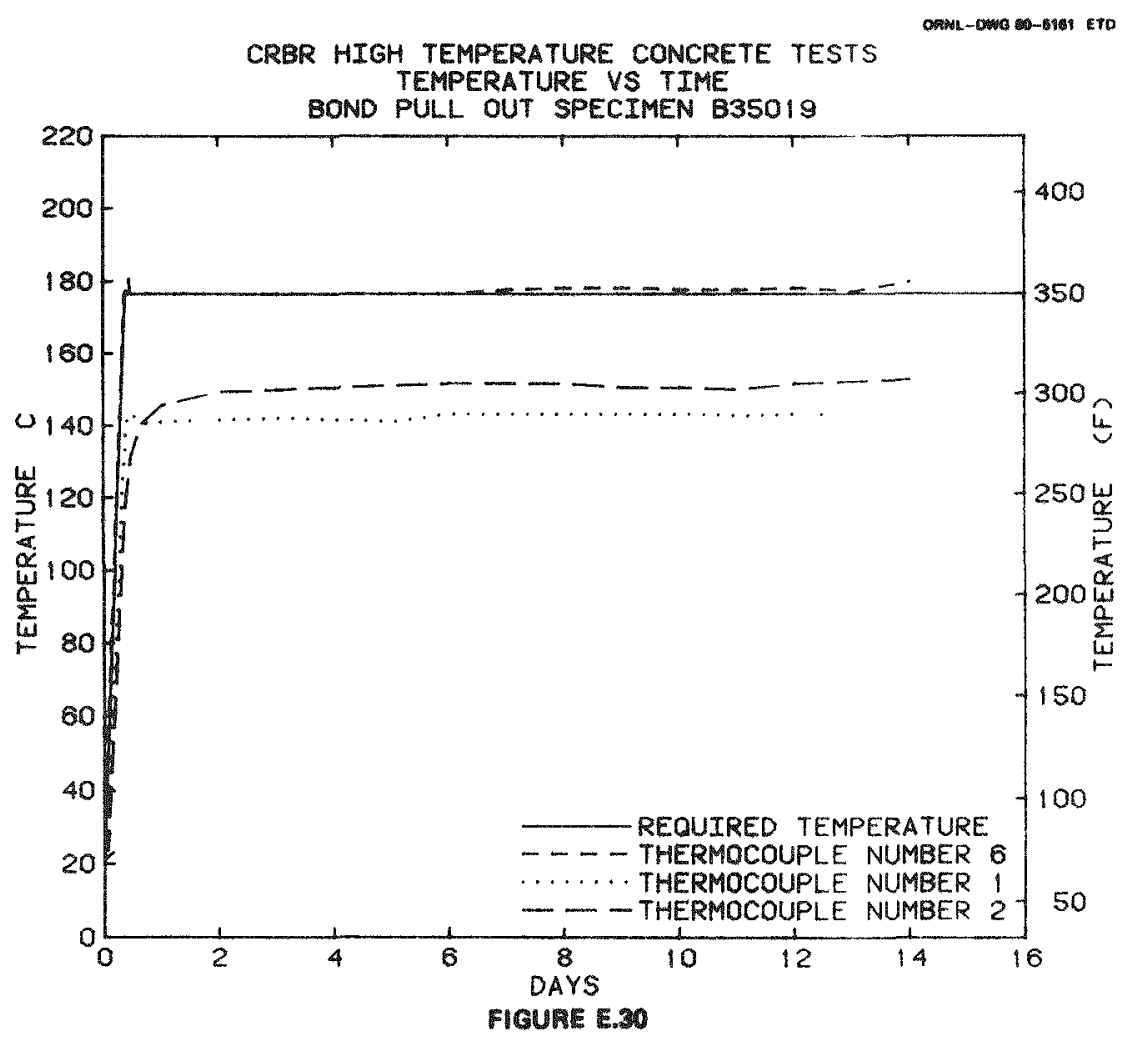

ORML-.WWG OO-6TEZ LTO

CRBR HIGH TEMPERATURE CONCRETE TESTS TEMPERATURE VS TIME

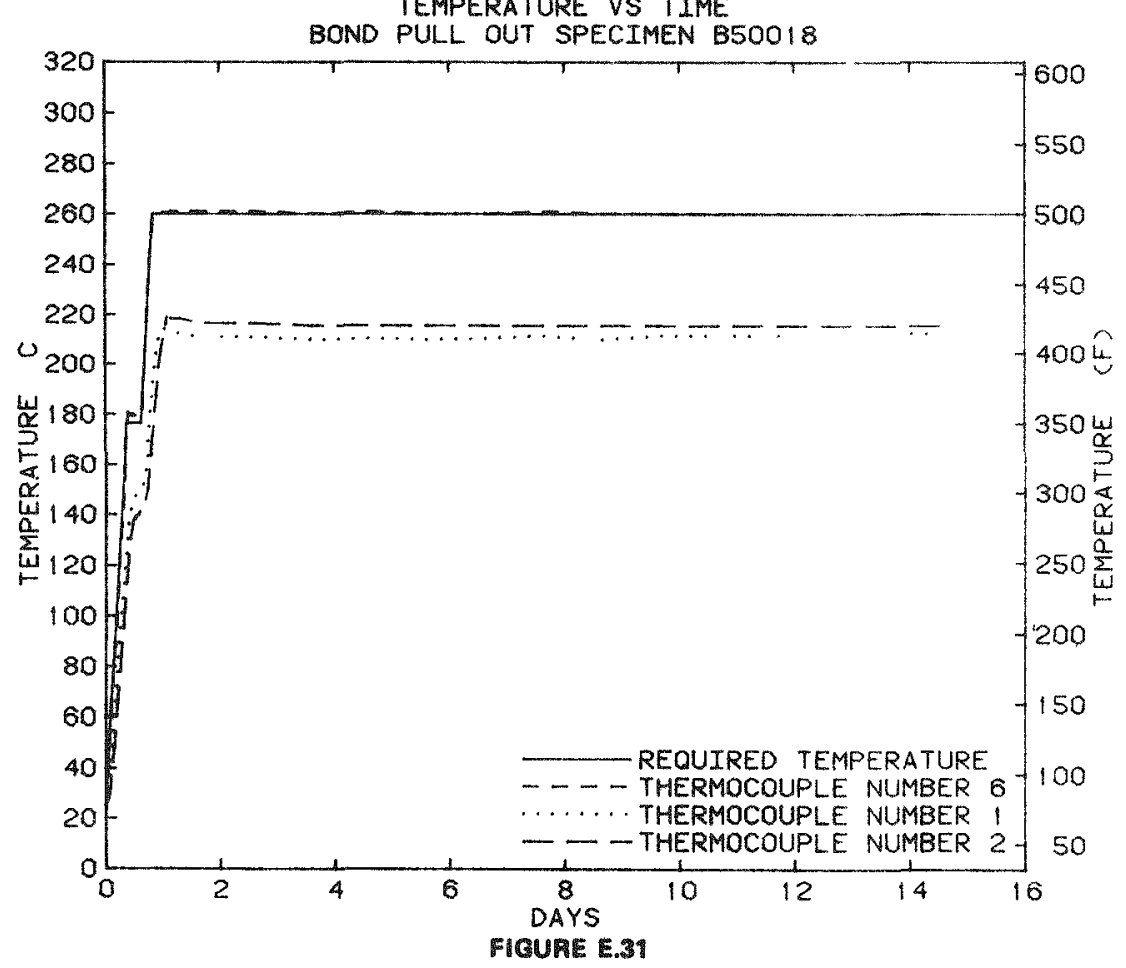




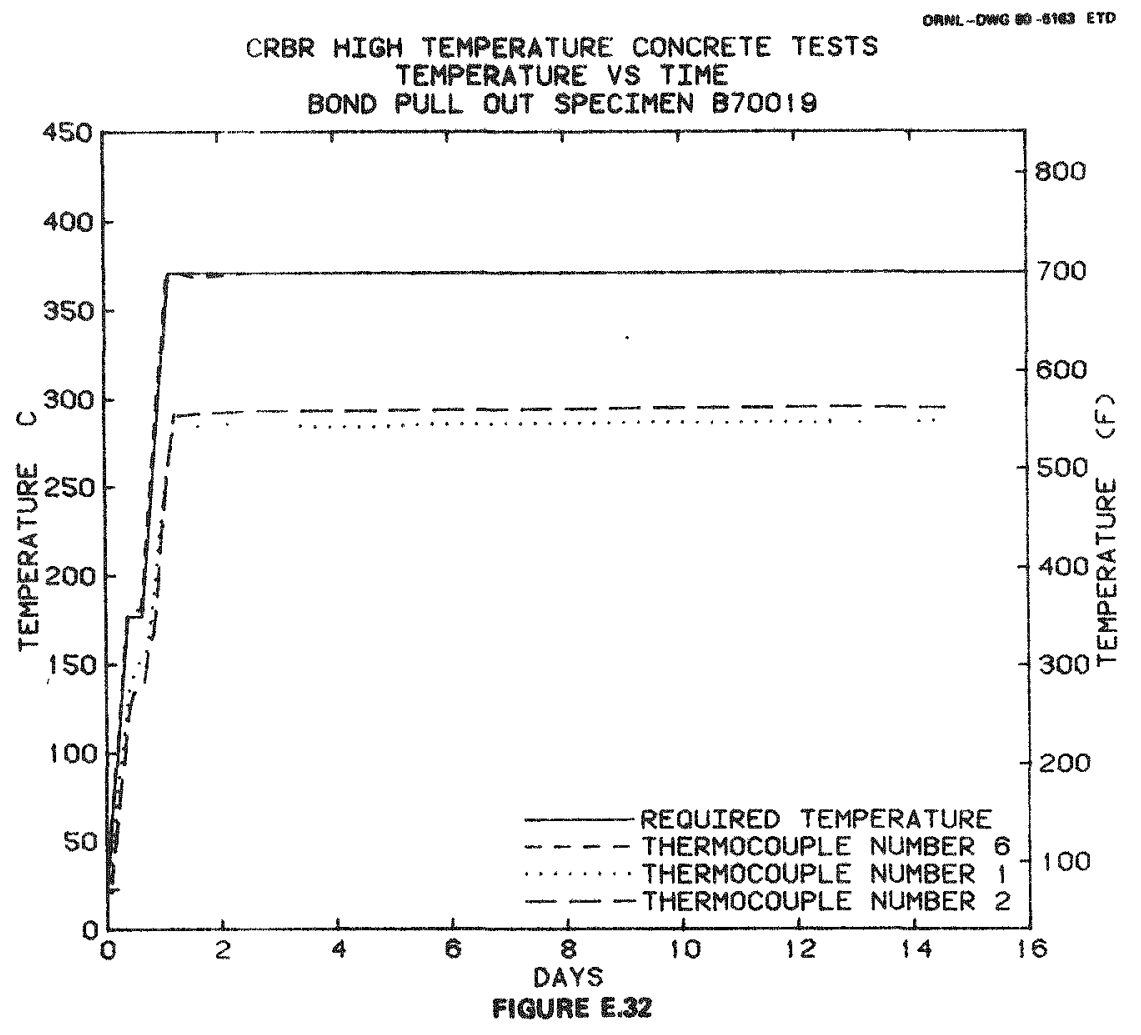

CRBR HIGH TEMPERATURE CONCRETE TESTS

OคAบL-OWอ TEMPERATURE VS TIME

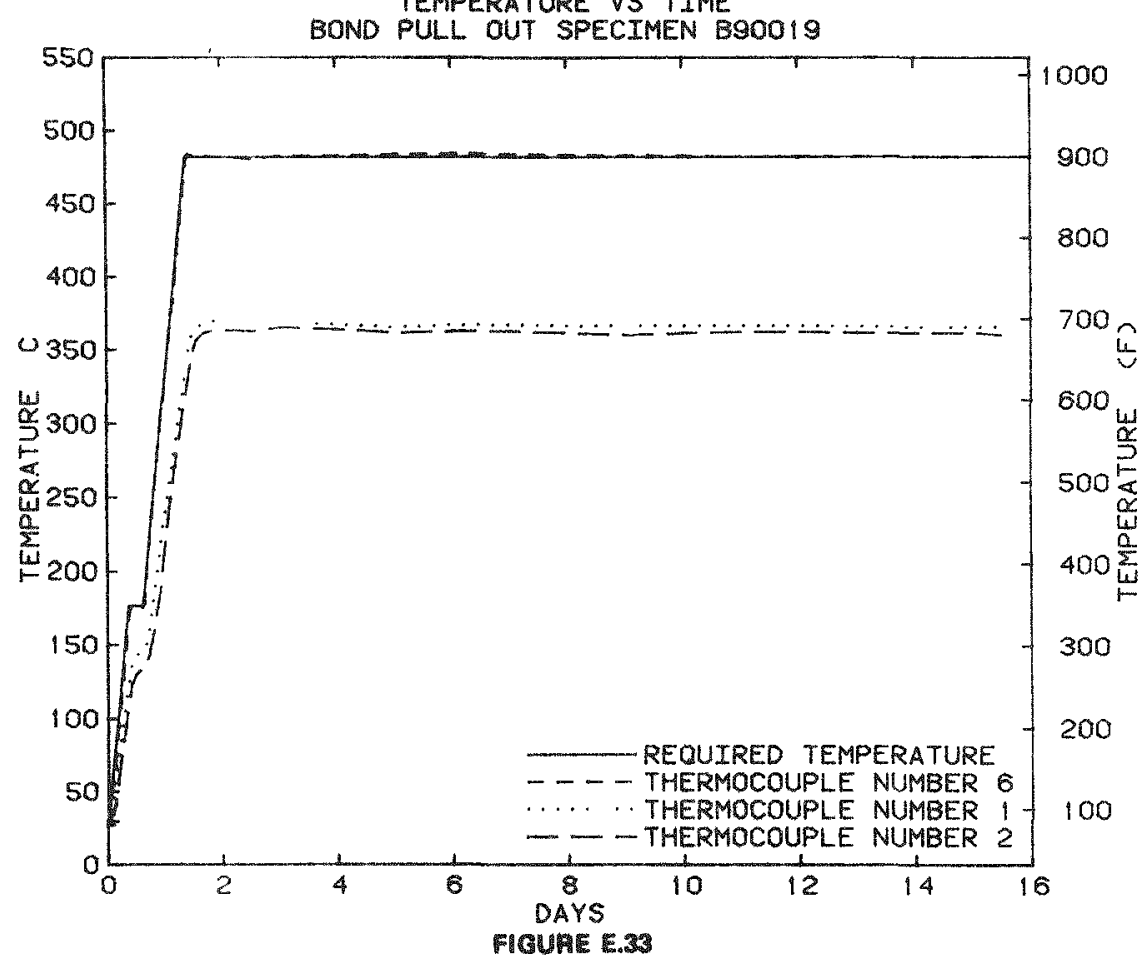




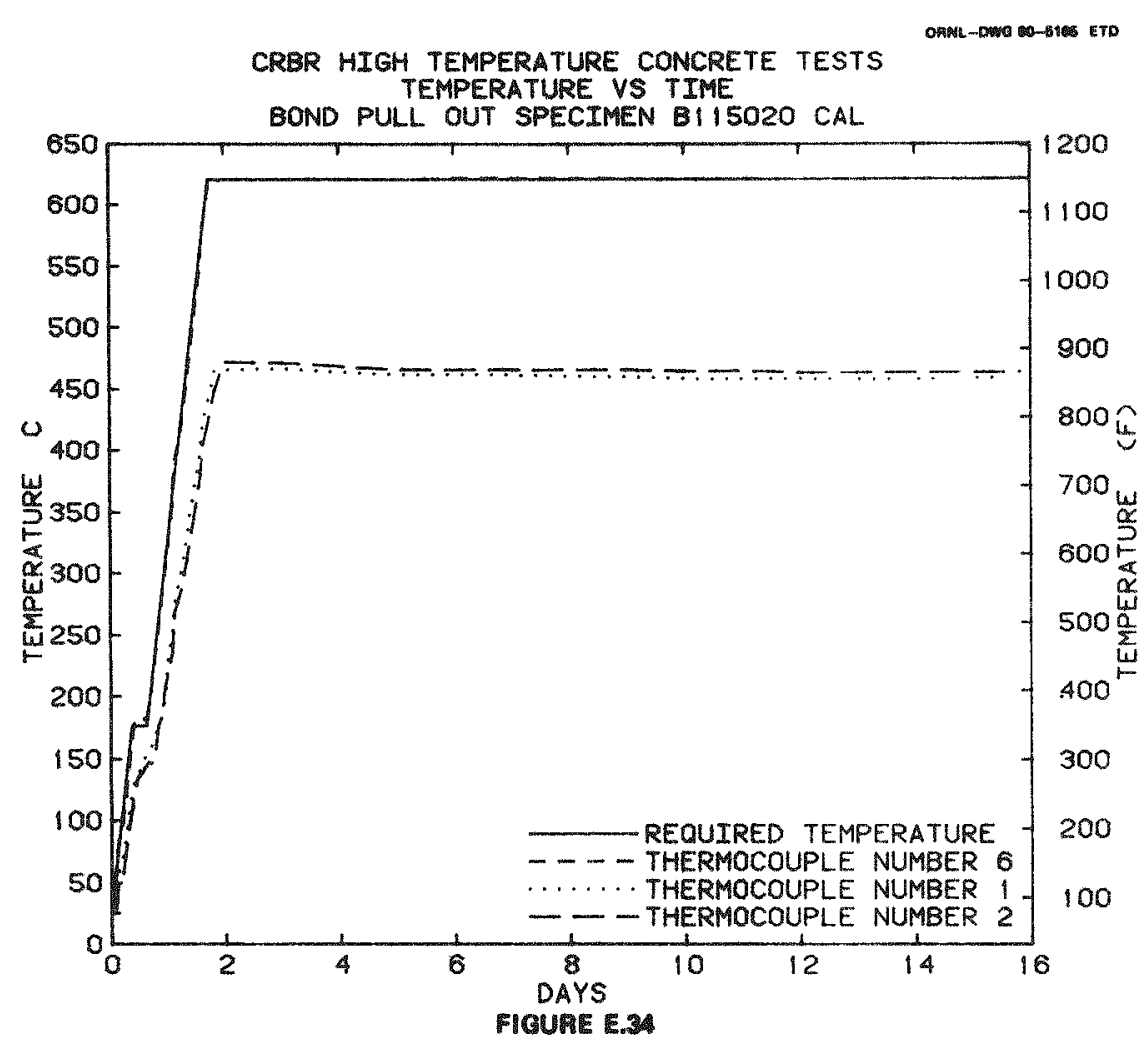


Appendix $F$

SUSTAINED LOAD SPECIMEN'S LOAD, STRAIN, AND TEMPERATURE HISTORIES 
242 

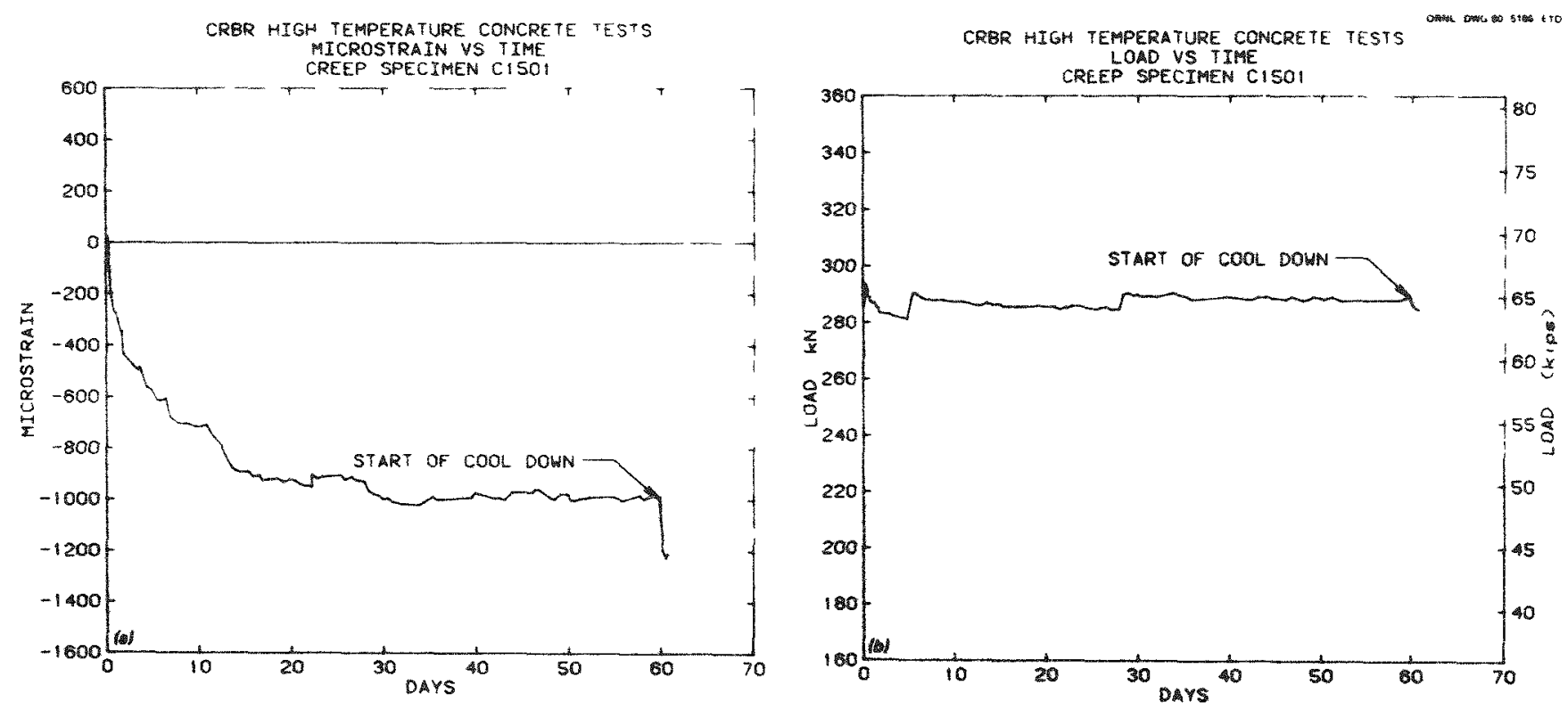

CRBR HIGH TEMPERATURE CONCRETE TESTS

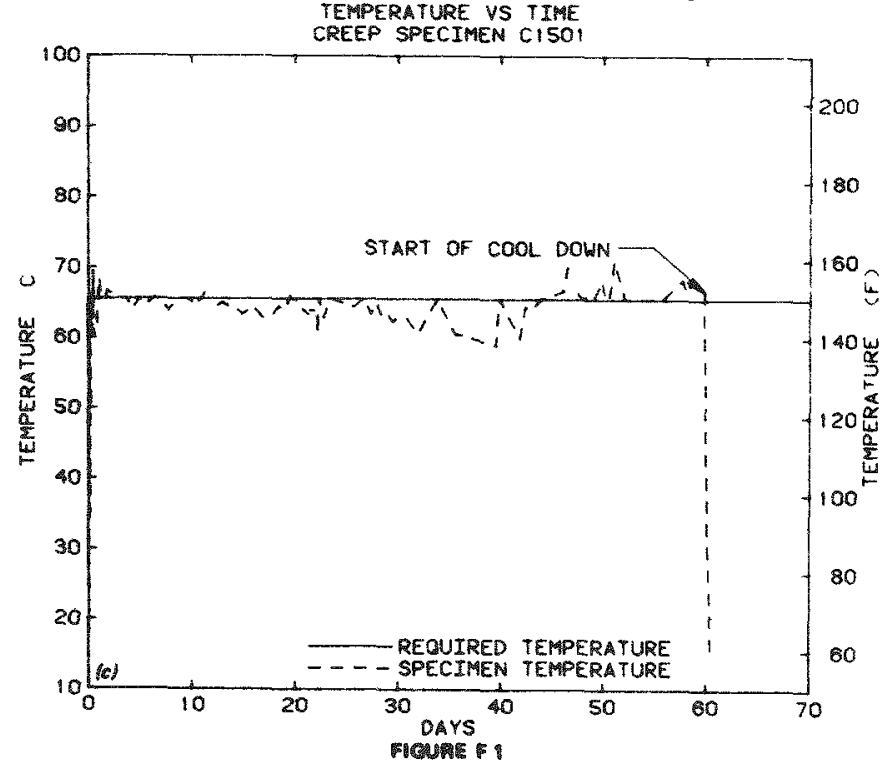



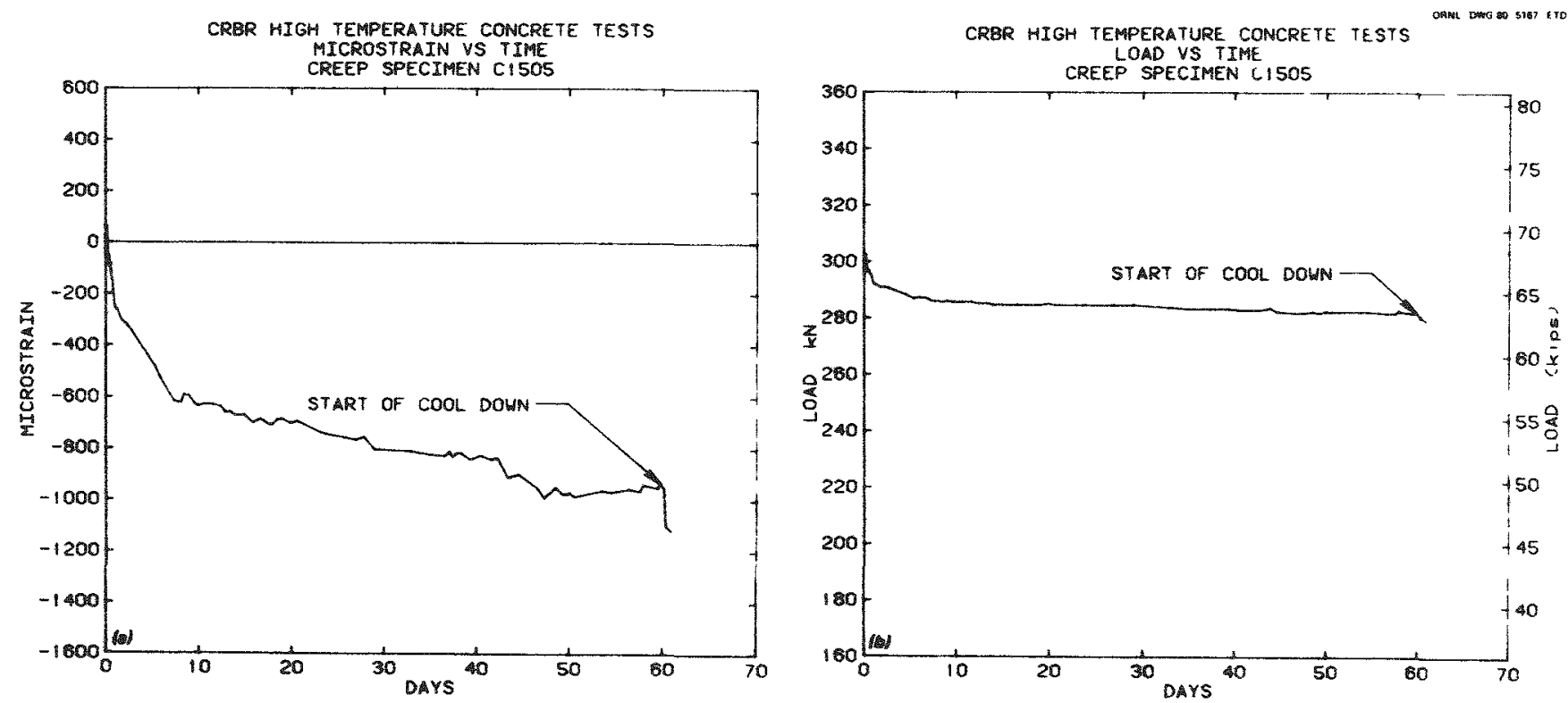

CRER HIGH TEAPERATURE CONCRETE TESTS

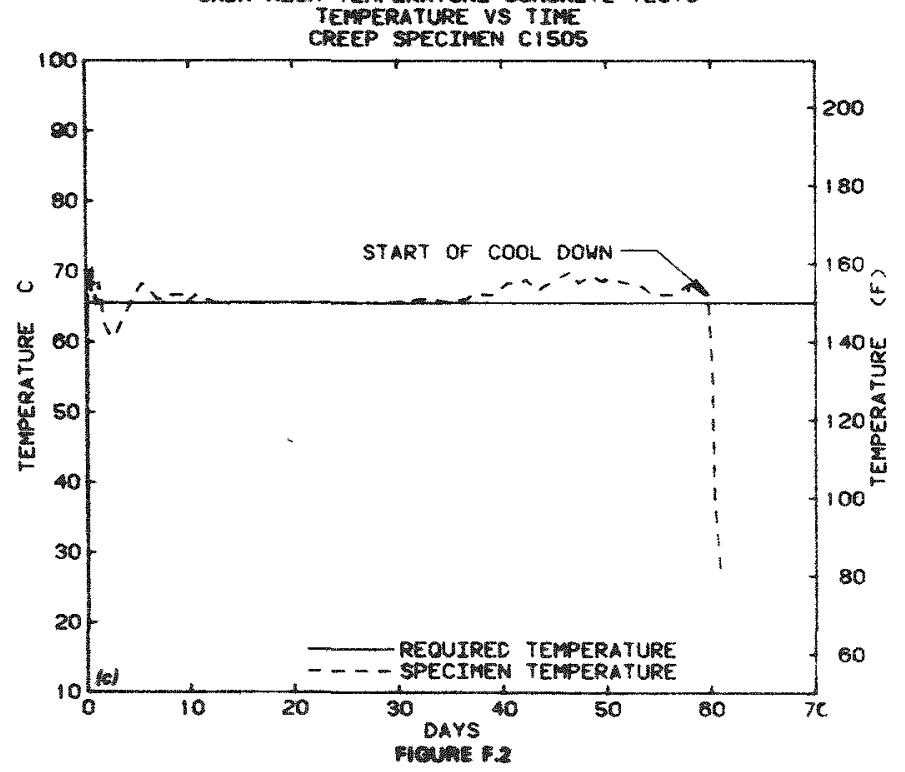


CRER HIGH TEMPERATURE CONCRETE TESTS MICROSTRAIN VS TIME
CREEP SPECIMEN CISO10

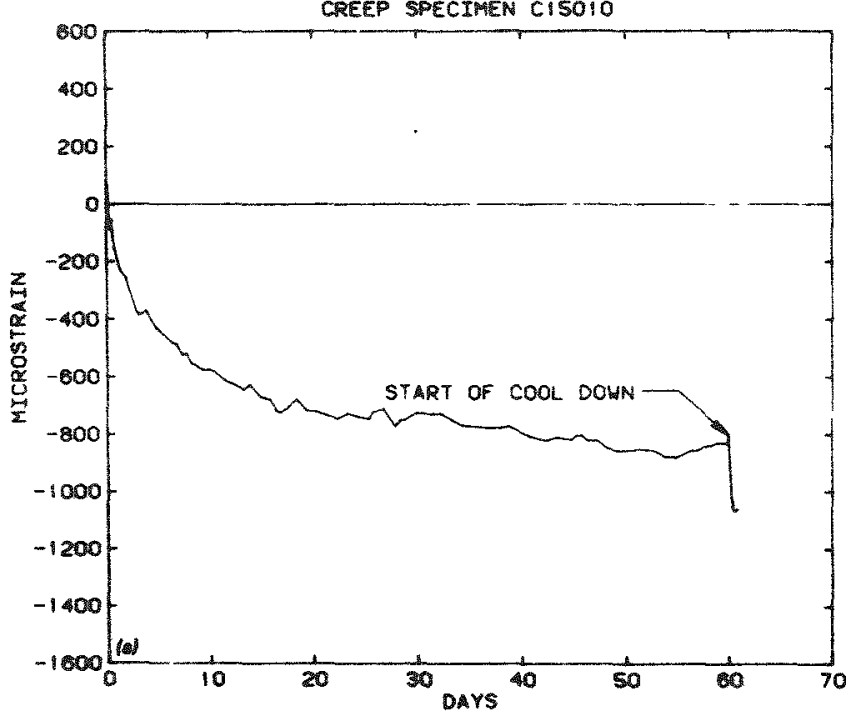

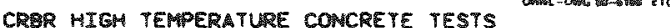
CREEP SPECIMEN CISOIO

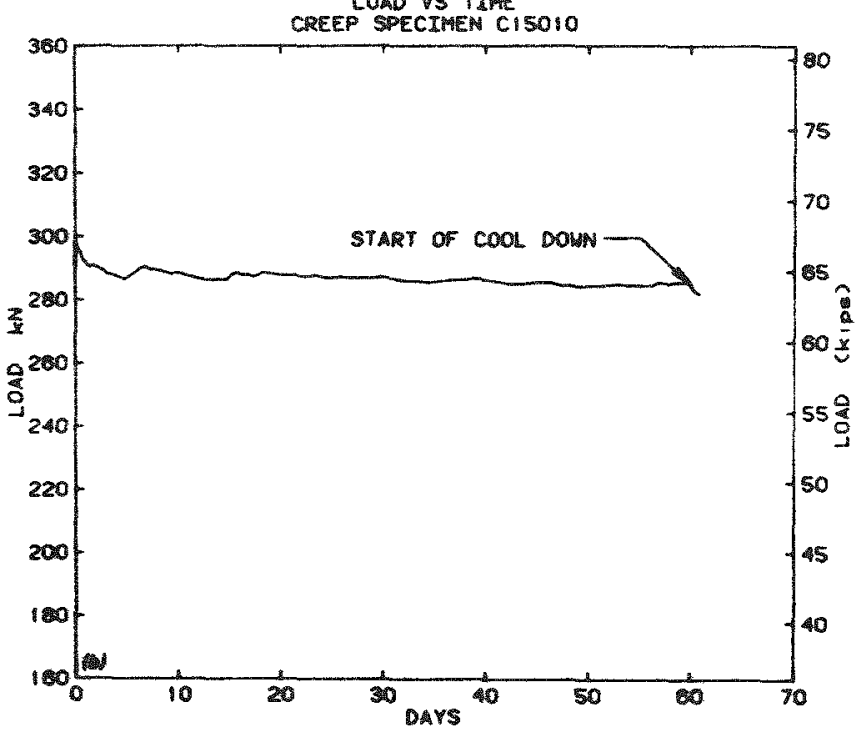

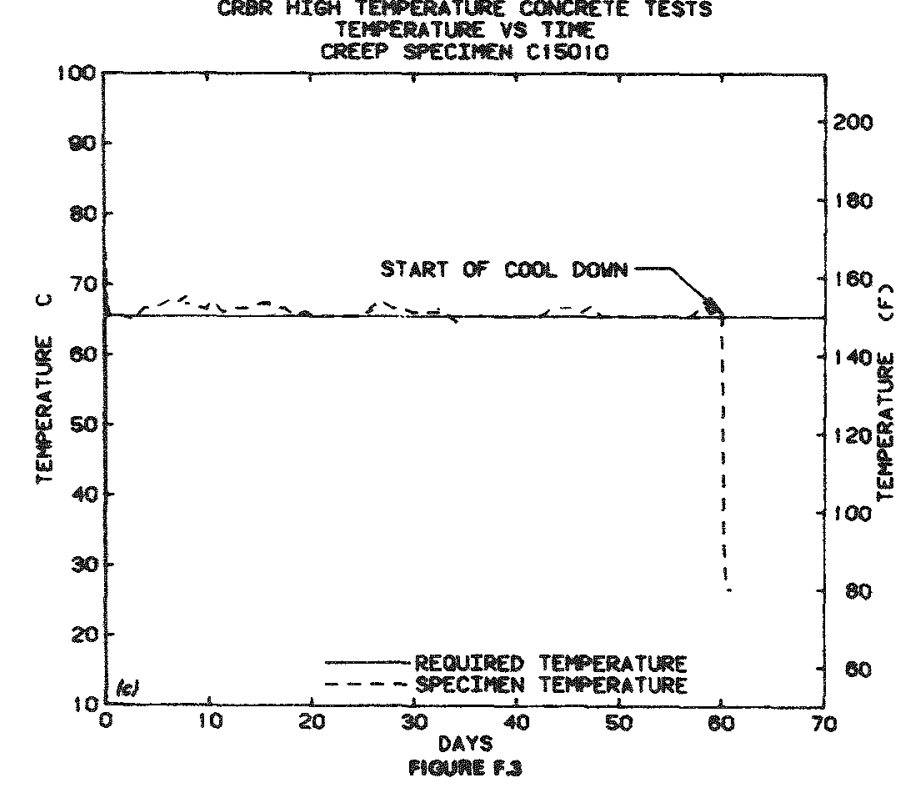




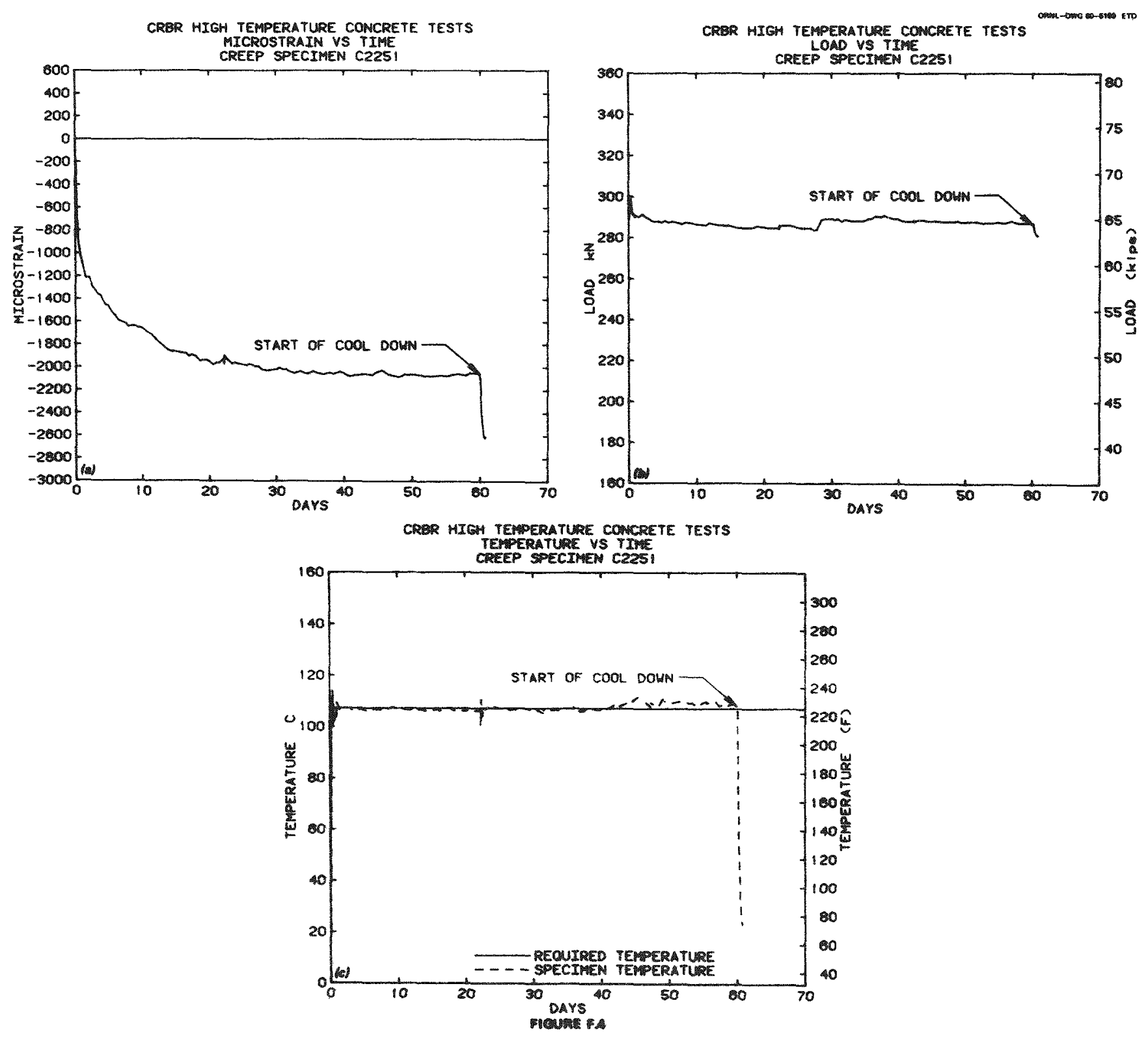




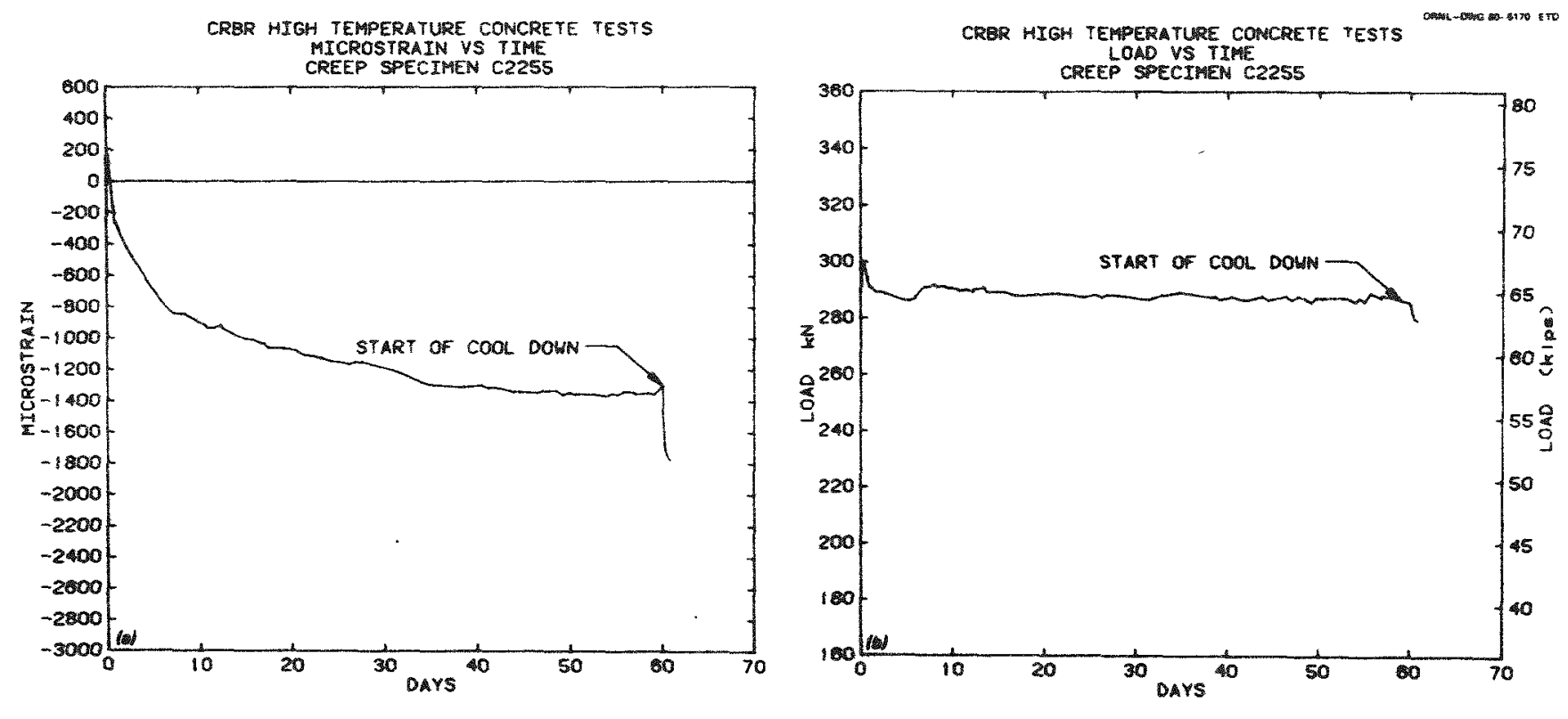

CROR HIGH TEMPERATURE CONCRETE TESTS

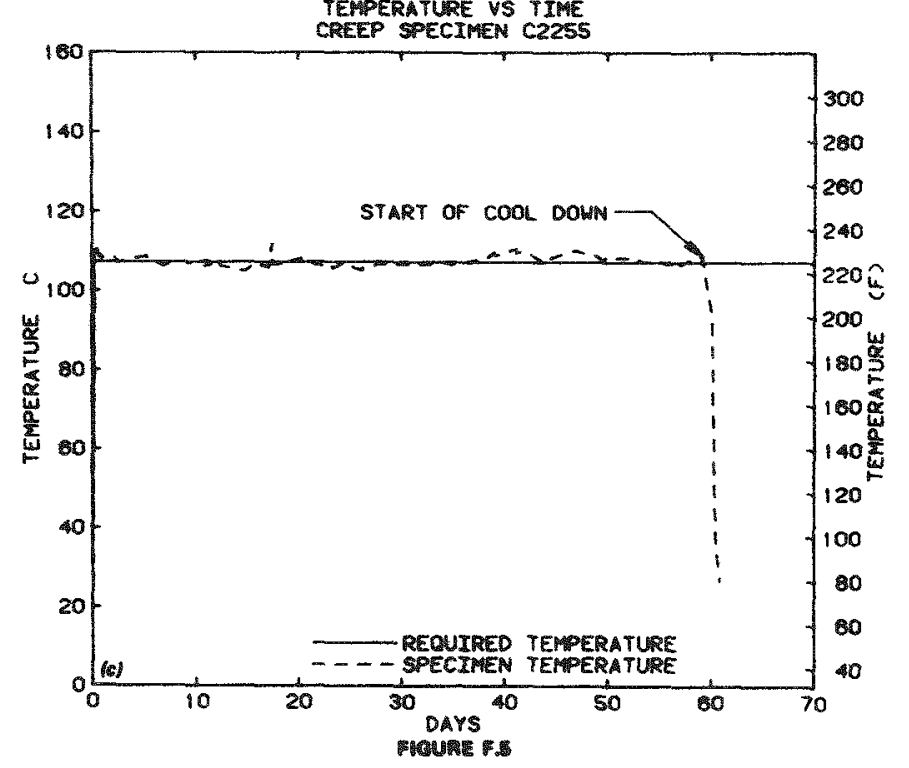



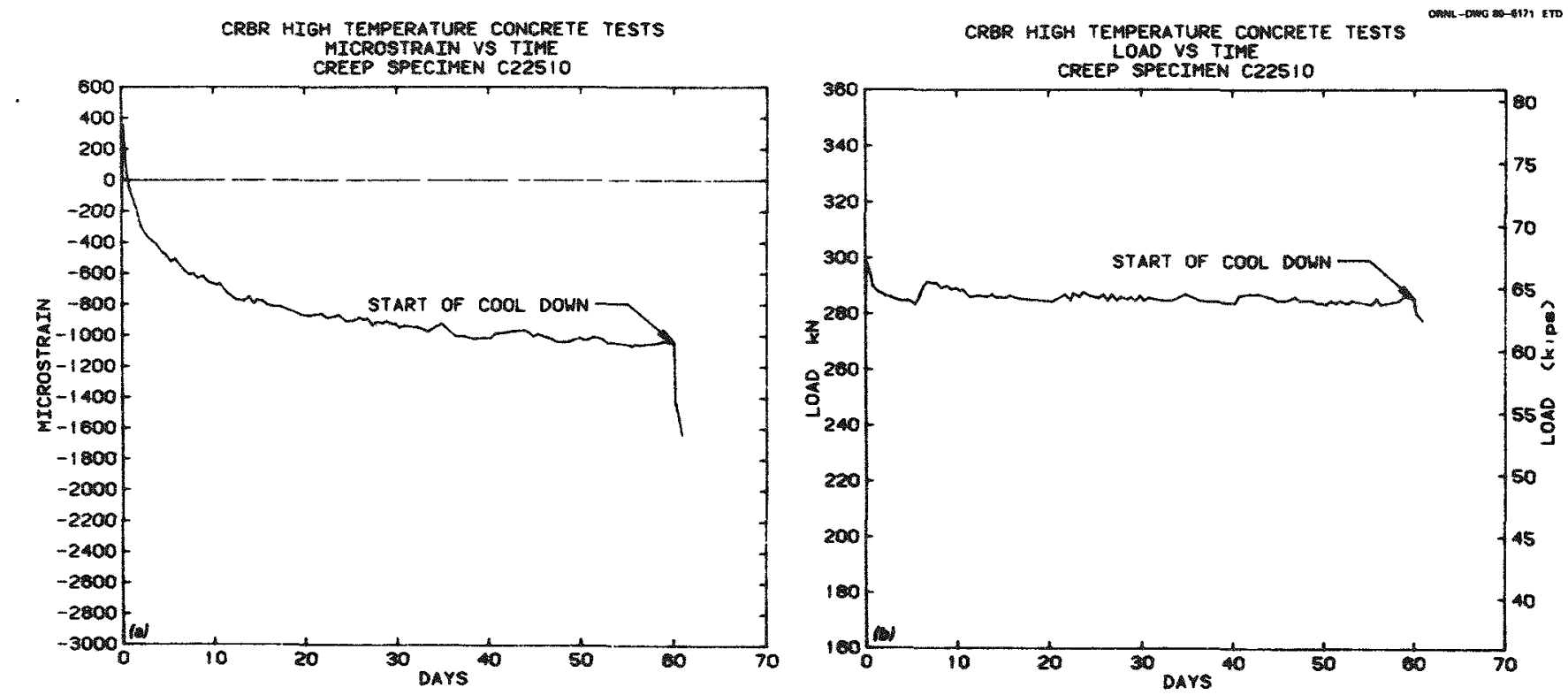

CRBR HIGH TEMPERATURE CONCRETE TESTS

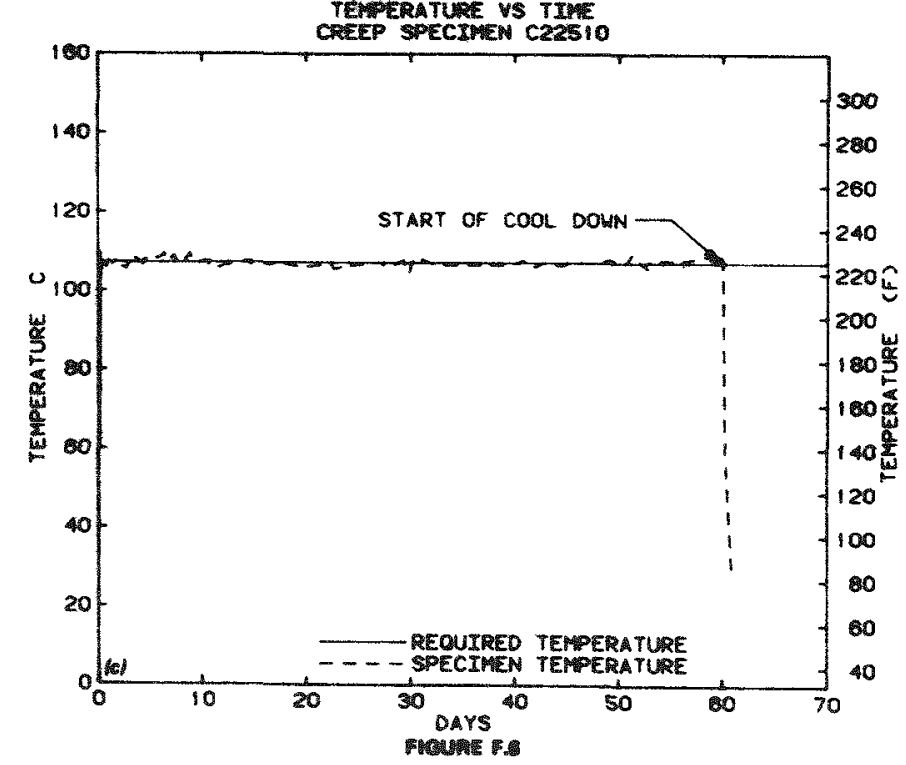



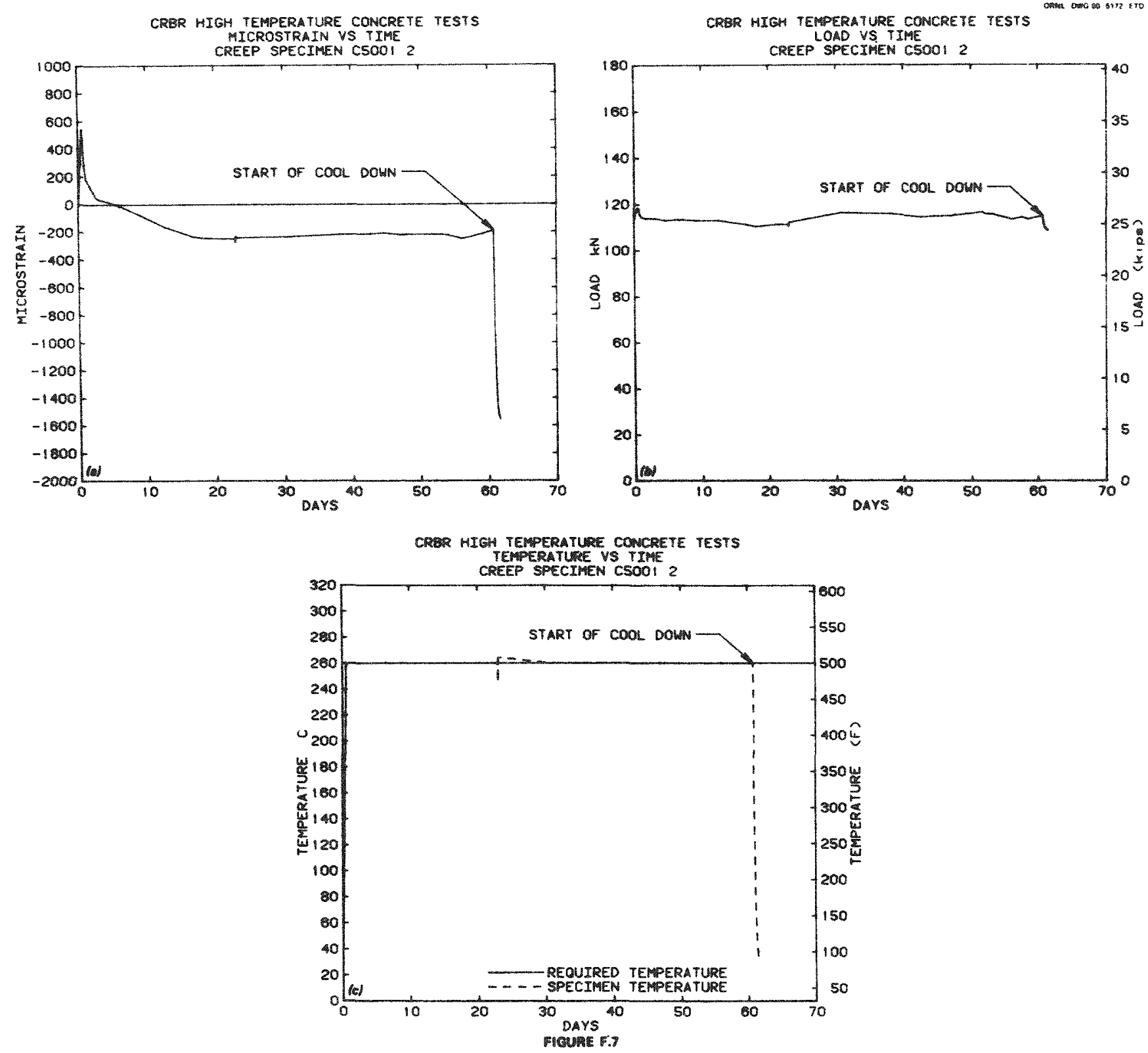


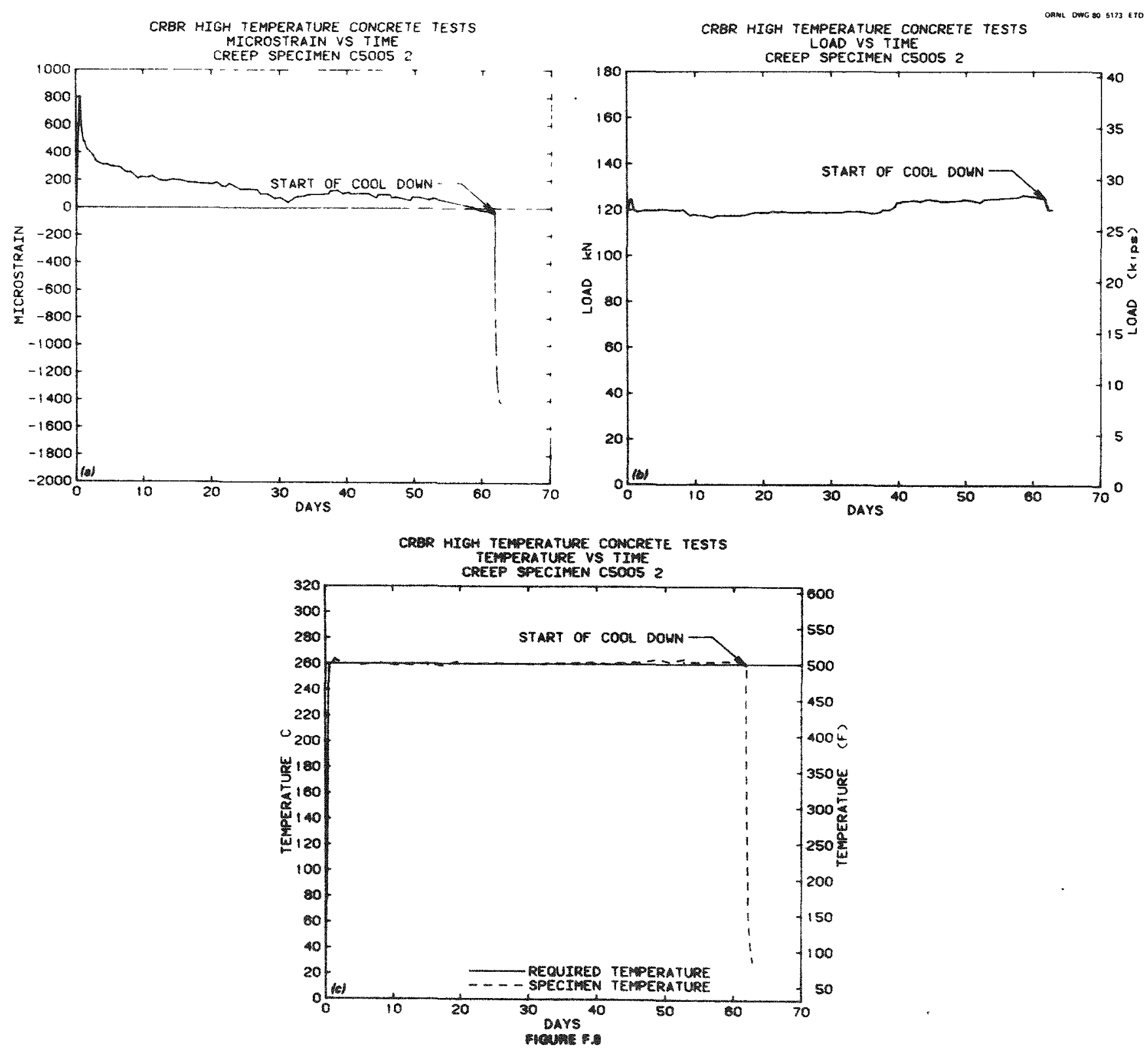




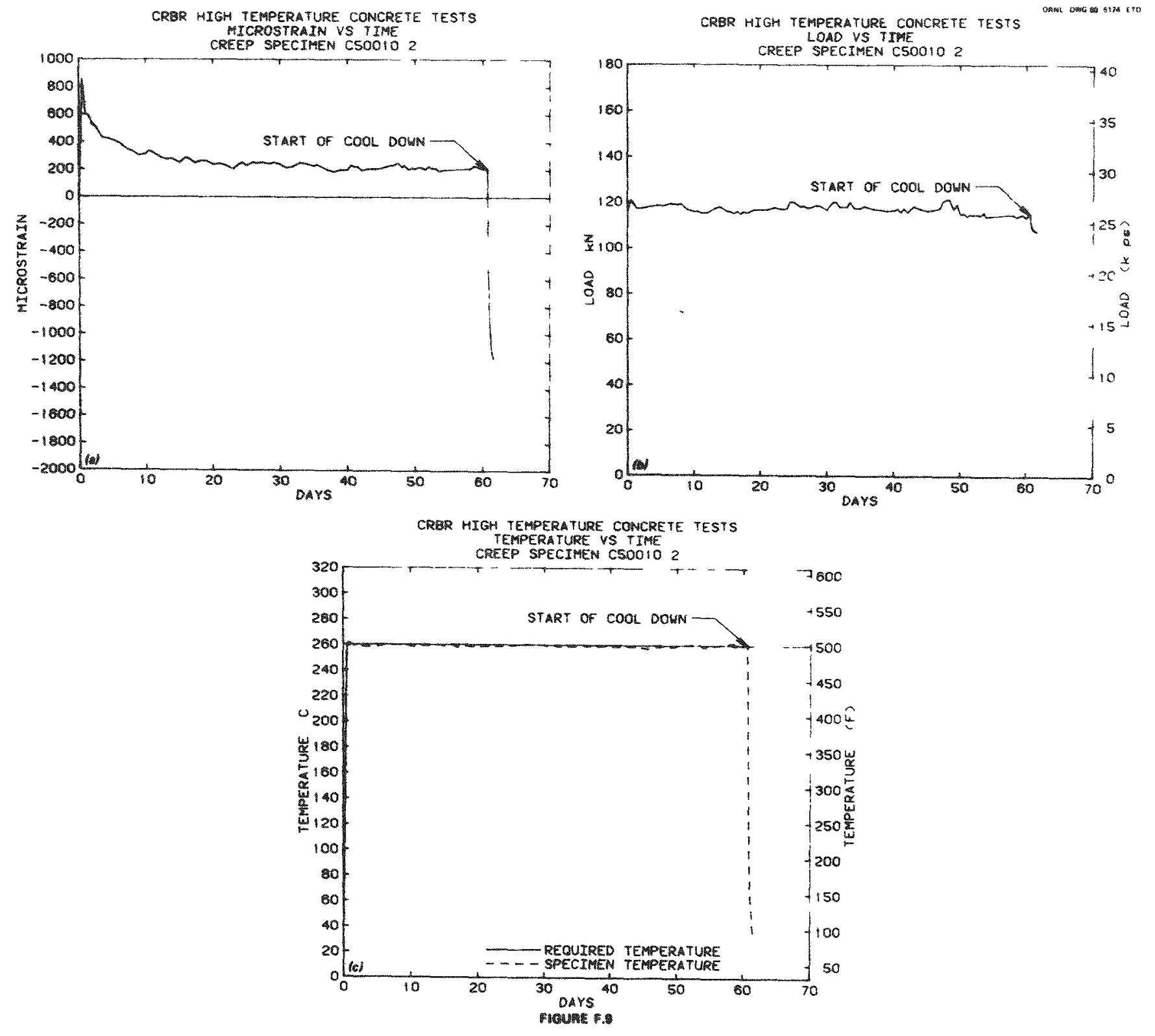



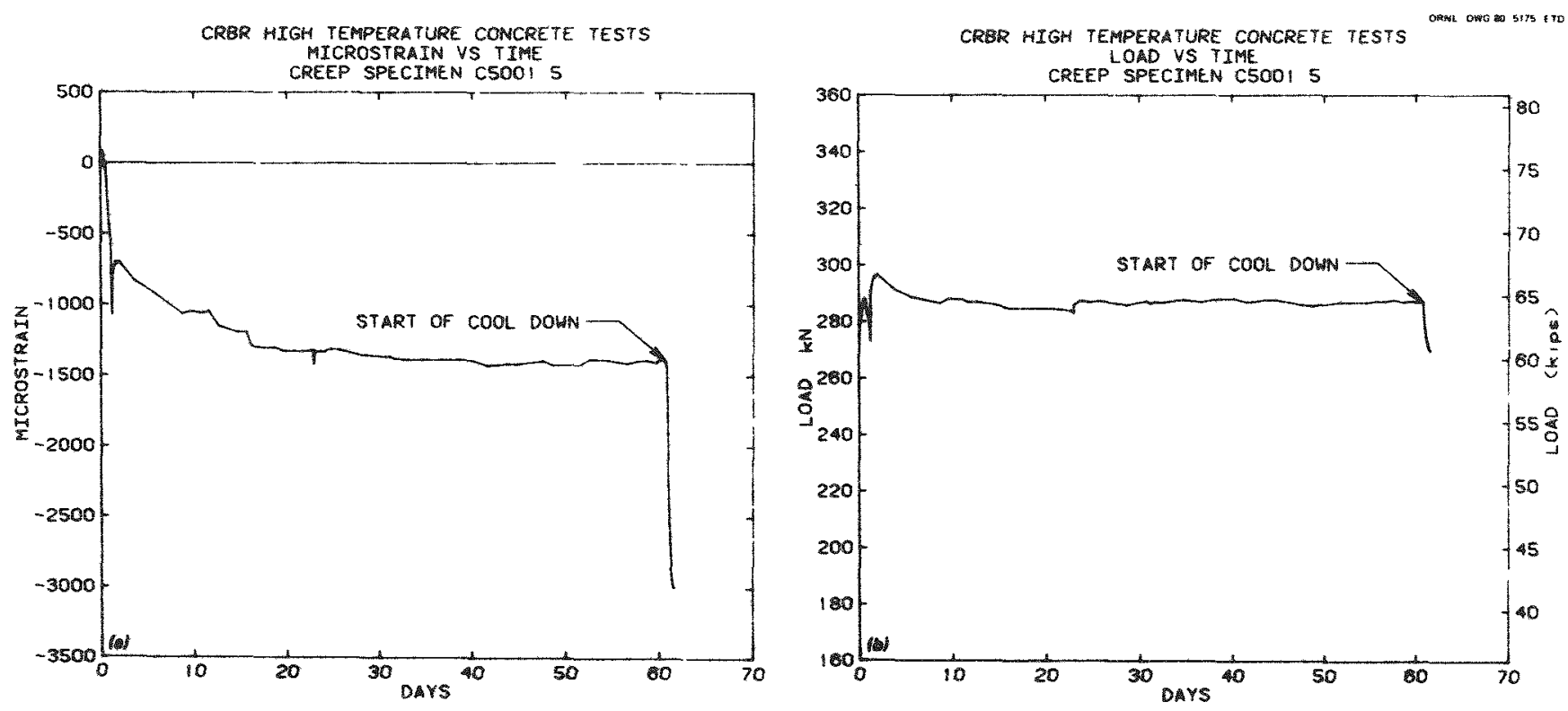

CRER HIGH TEMPERATURE CONCRETE TESTS

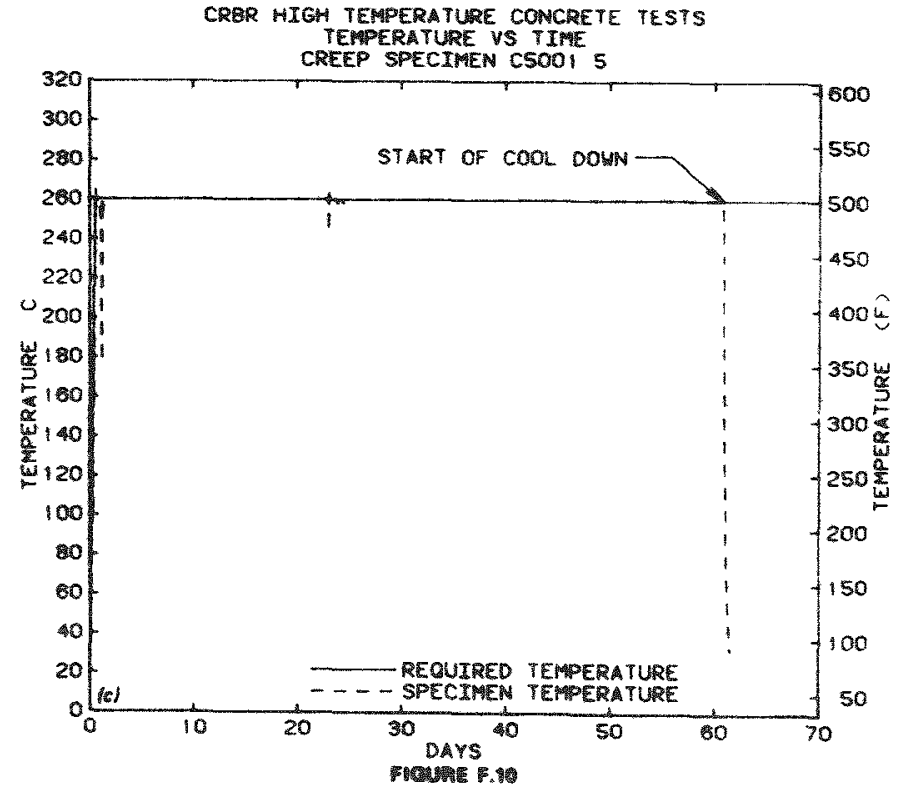



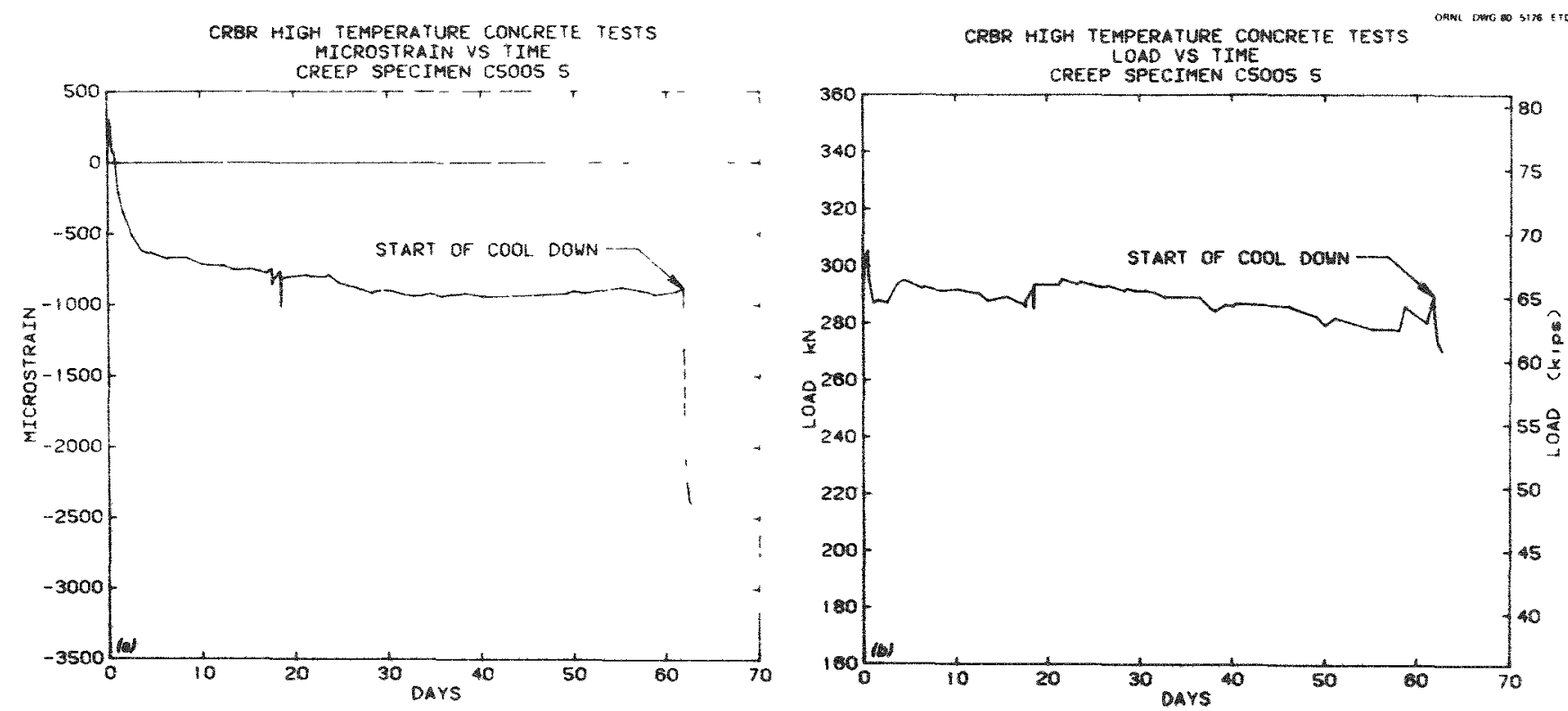

CRRR HIGH TEMPERATURE CONCRETE TESTS

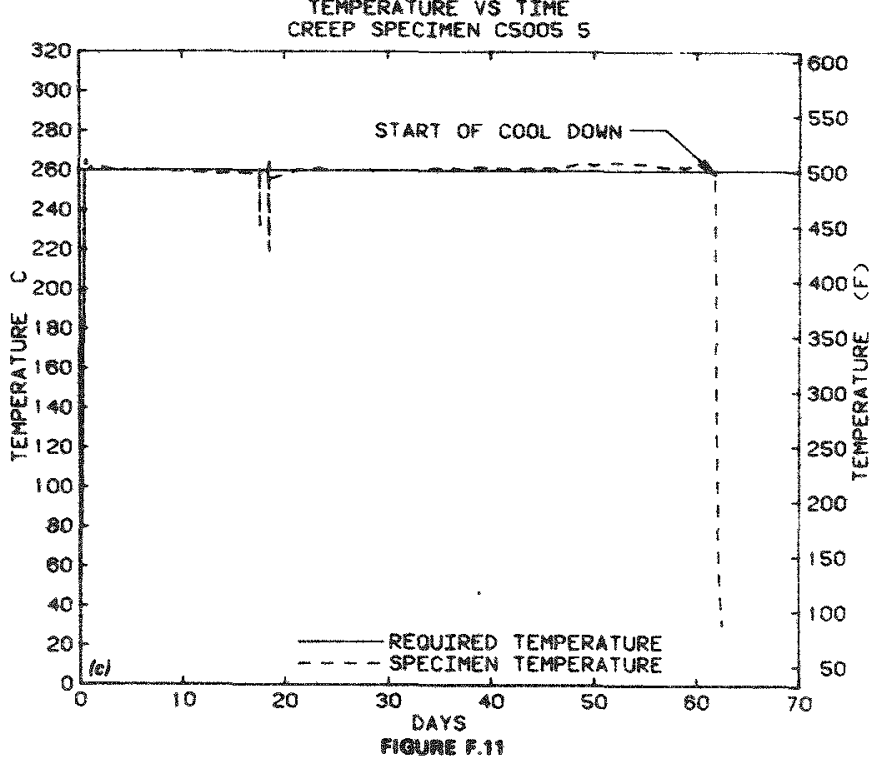



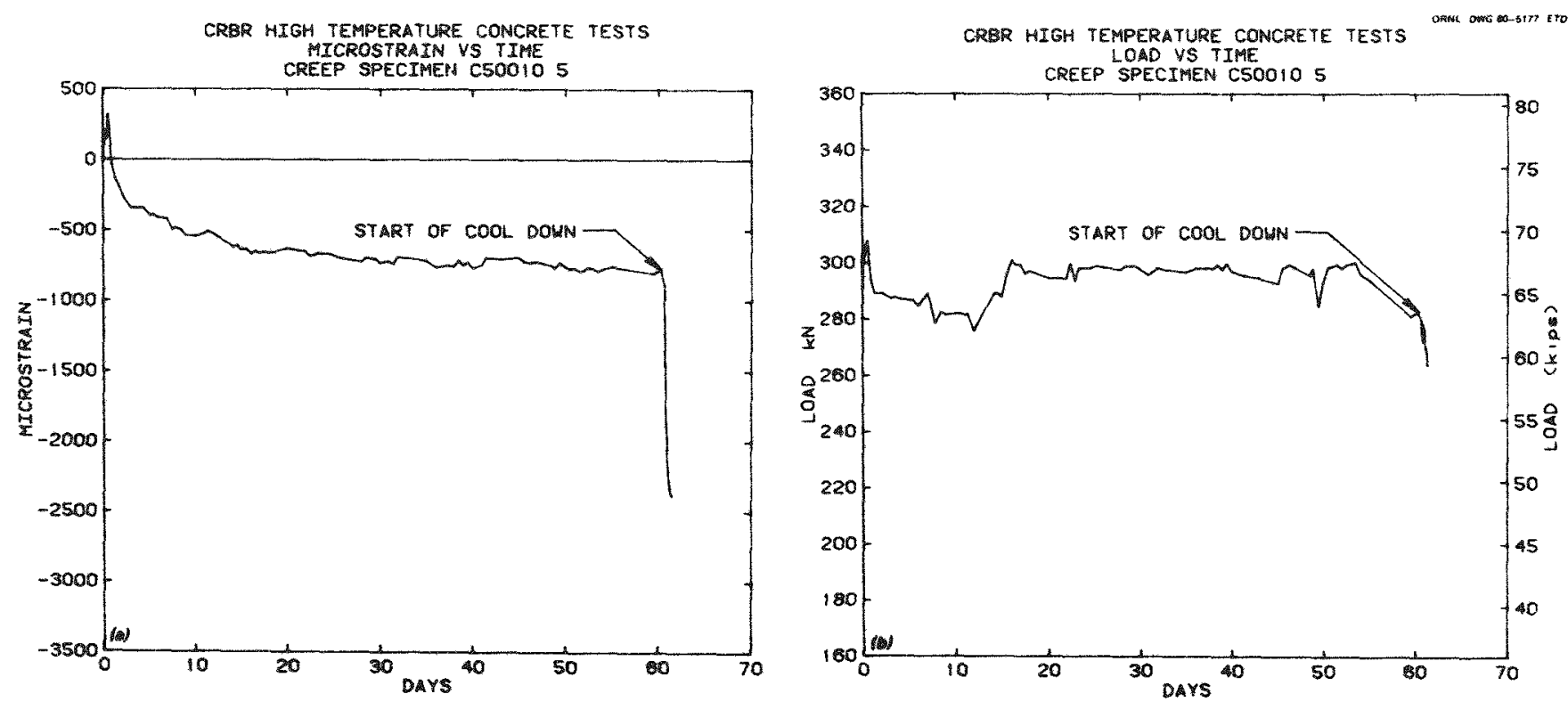

CRBR HIGH TEMPERATURE CONCRETE TESTS

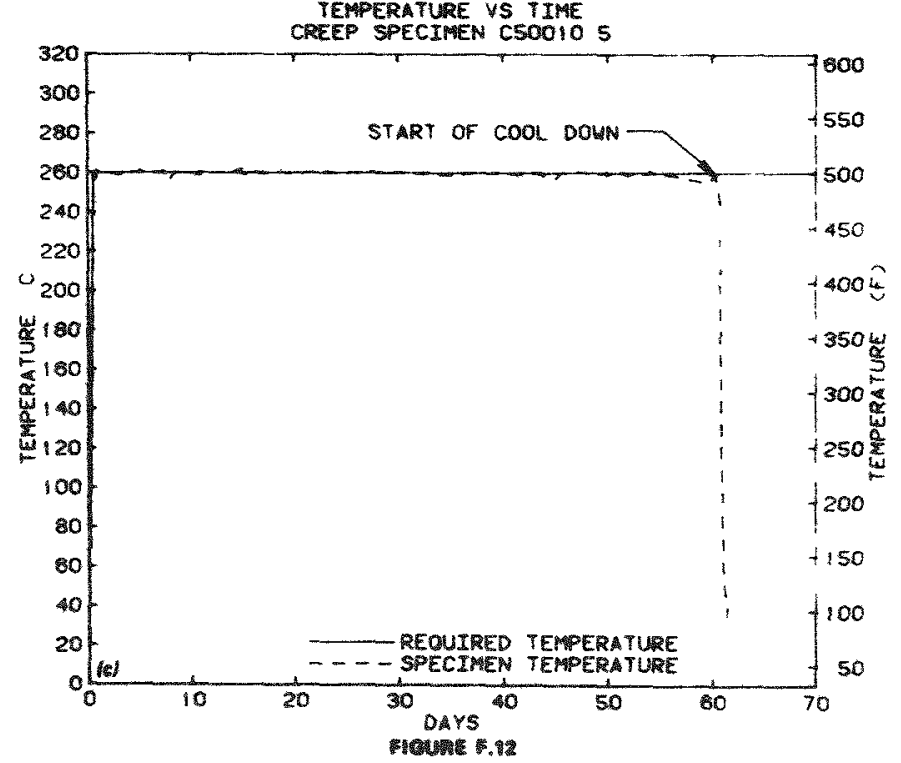



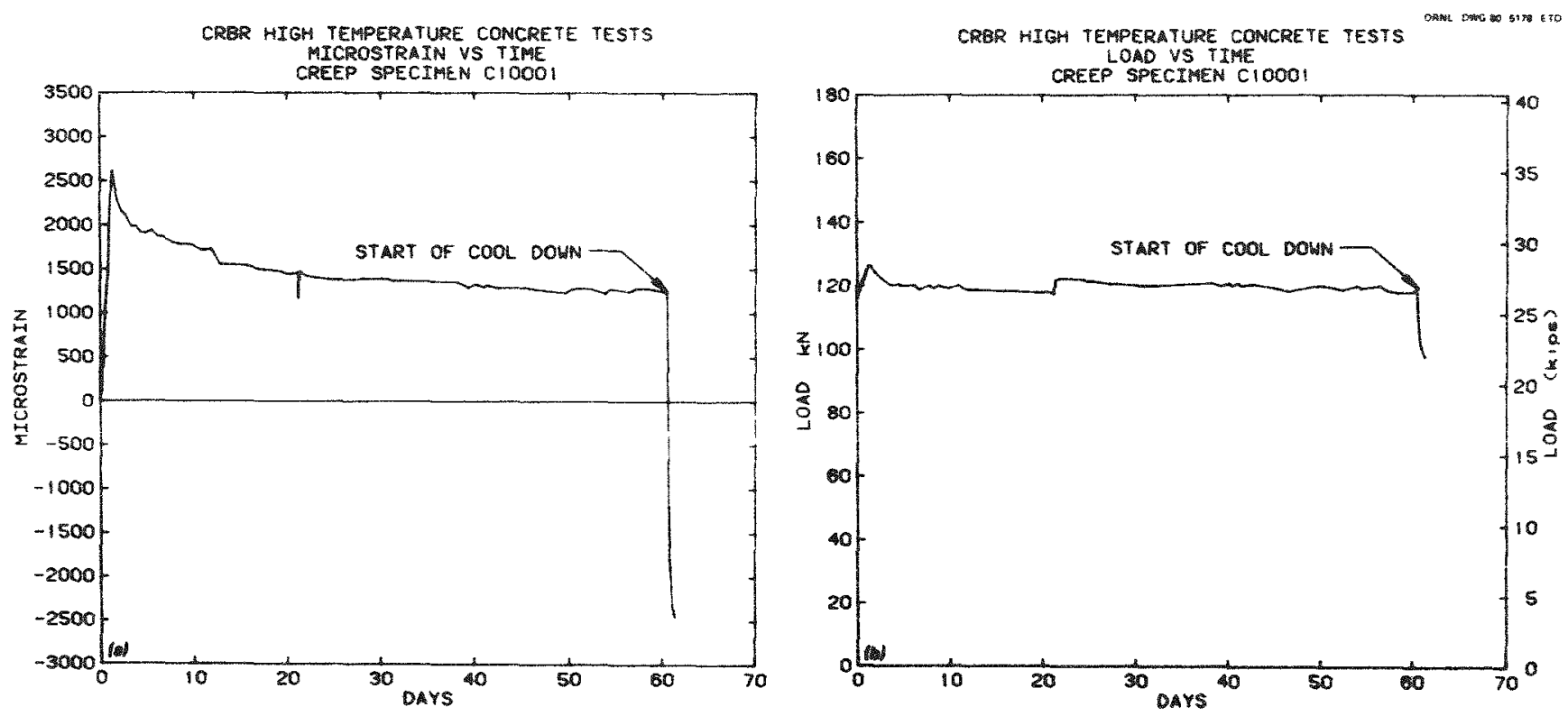

CRBR HIGH TEMPERATURE CONCRETE TESTS

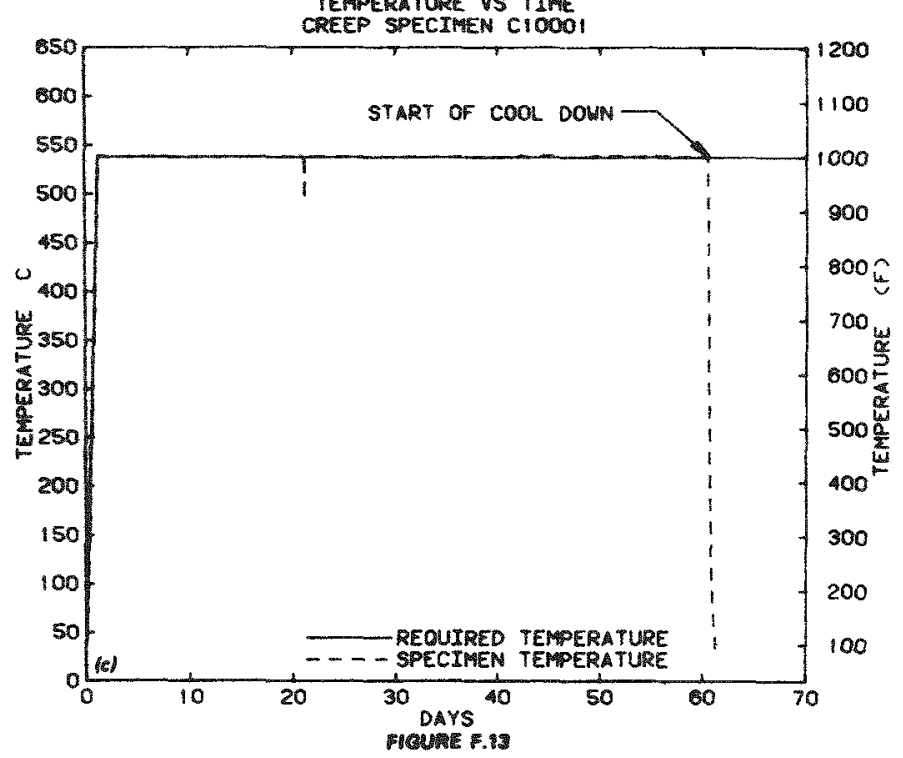



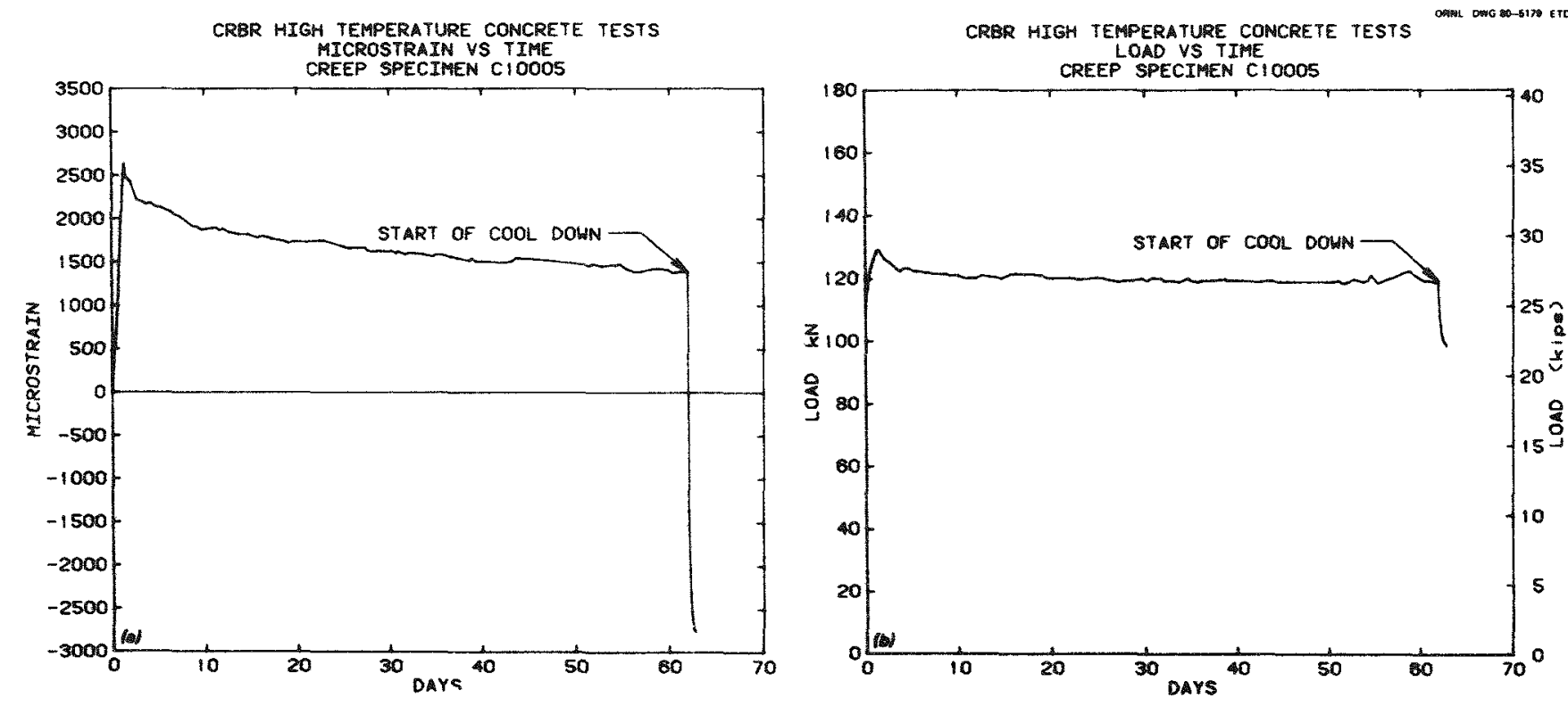

CRBR HIGH TEMPERATURE CONCRETE TESTS

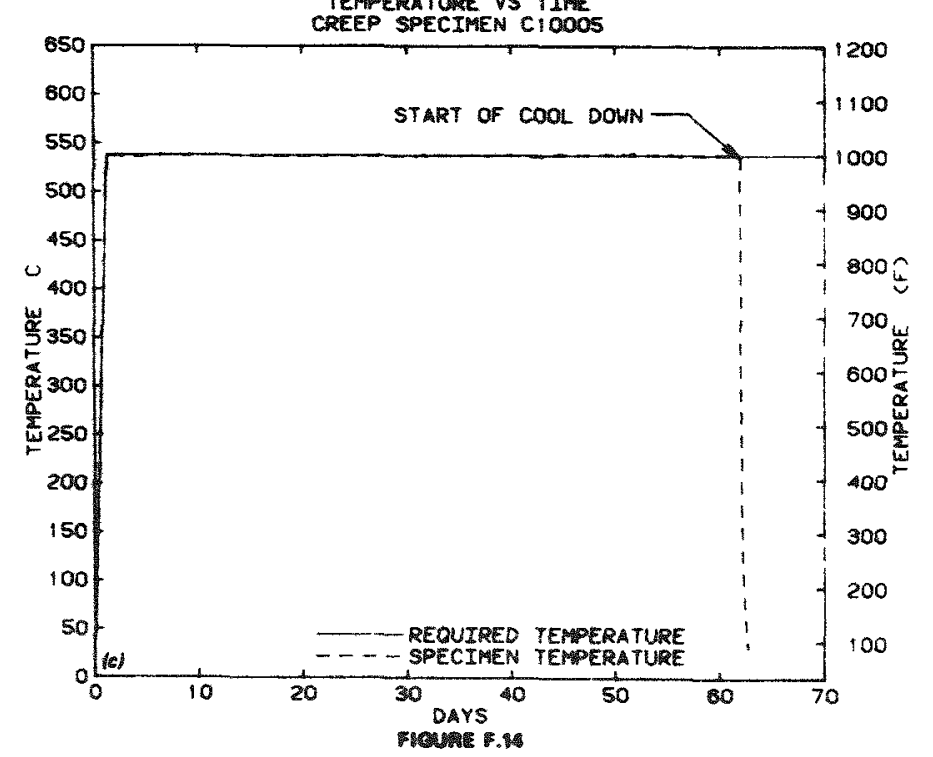



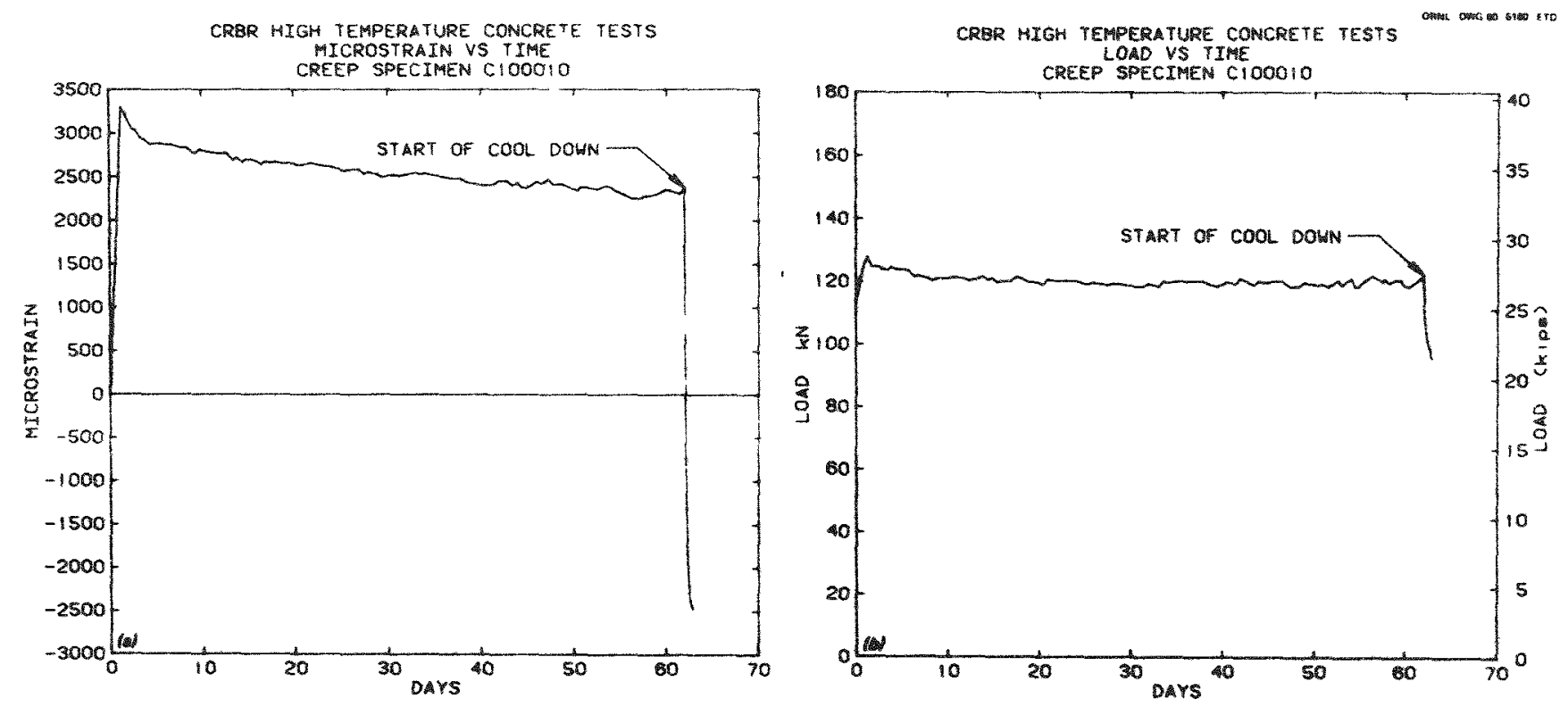

CRBR HIGM TEMPERATURE CONCRETE TESTS

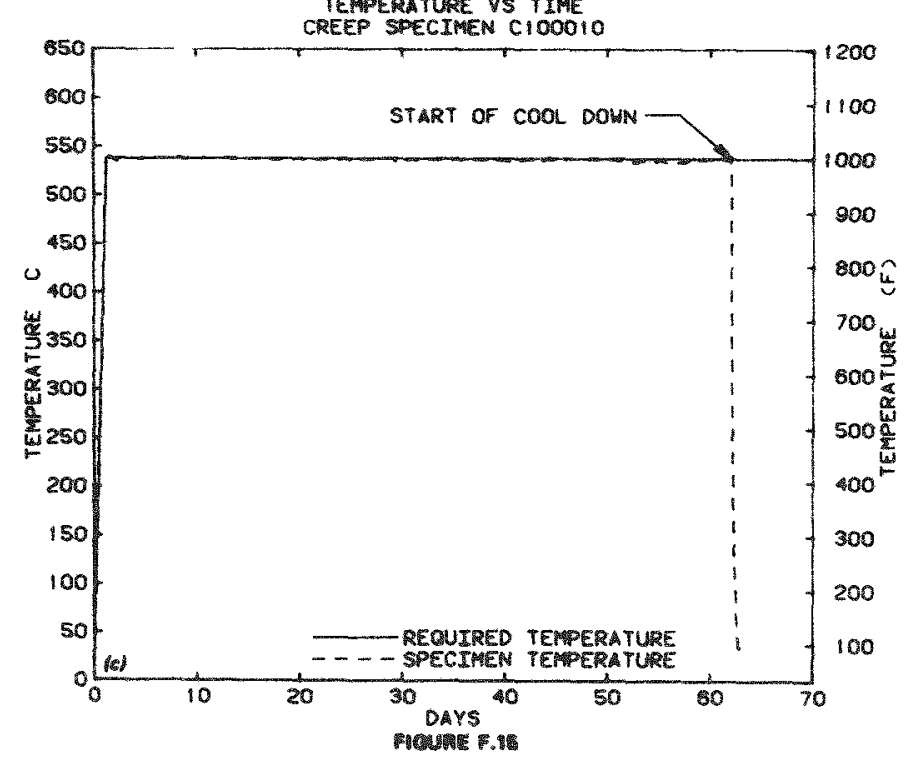


-

- 
ORNL/BRP $-80 / 5$

Limited Distribution

INTERNAL DISTRIBUTION

1. S. E. Bolt

2. J. M. Corum

3. J.R. Dougan

4. U. Gat

5. C. C. Hurtt

6. J. G. Merkle

7-11. D. J. Naus

12-16. C. B. Oland
17. J. L. RIch

18-22. G. C. Robinson

23. R. Smith, Jr.

24. H. E. Tramme11

25. G. D. Whitman

26-27. Laboratory Records Department

28. Laboratory Records - RC

29. Patent Section

EXIERNAL DISTRIBUTION

30. Office of Assistant Manager for Energy Research and Development, DOE-ORO, P.O. BOX E, Oak Ridge, TN 37830

31-32. Technical Information Center, P.0. Box 62, Oak Ridge, TN 37830 